\title{
Iron-Catalyzed $\mathrm{C}-\mathrm{H} / \mathrm{N}-\mathrm{H}$ Activations for Annulation of Allenes, Alkynes, and Bicyclopropylidenes
}

\author{
Dissertation \\ for the award of the degree \\ "Doctor rerum naturalium" \\ of the Georg-August-University of Göttingen

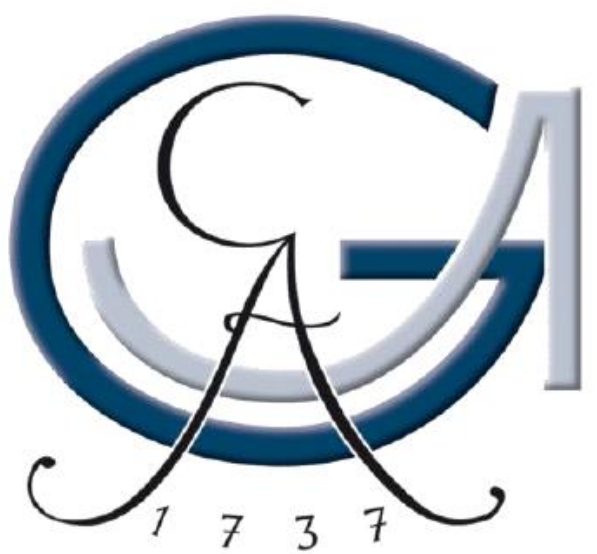

within the doctoral program of chemistry

of the Georg-August-University School of Science (GAUSS)

submitted by

Jiayu Mo

from Liuzhou, Guangxi Province, China

Göttingen, 2020 



\section{Thesis Committee}

Prof. Dr. Lutz Ackermann, Institute of Organic and Biomolecular Chemistry, University of Göttingen

Prof. Dr. Alexander Breder, Institute of Organic Chemistry, University of Regensburg

\section{Examination Board}

Reviewer: Prof. Dr. Lutz Ackermann, Institute of Organic and Biomolecular Chemistry, University of Göttingen

Second Reviewer: Prof. Dr. Alexander Breder, Institute of Organic and Biomolecular Chemistry, University of Regensburg

\section{Further Members of the Examination Board}

Prof. Dr. Dr. h.c.mult. Lutz F. Tietze, Institute of Organic and Biomolecular Chemistry, University of Göttingen

Prof. Dr. Marina Bennati, Institute of Organic and Biomolecular Chemistry, University of Göttingen; Max Planck Institute for Biophysical Chemistry, Göttingen

Prof. Dr. Ricardo Mata, Institute of Physical Chemistry, University of Göttingen Jun.-Prof. Dr. Johannes C. L. Walker, Institute of Organic and Biomolecular Chemistry, University of Göttingen

Date of the Oral Examination: 26.10.2020 



\section{Acknowledgements}

I would like to express the deepest appreciation to my supervisor Prof. Dr. Lutz Ackermann, who gave me constant encouragement, excellent guidance and patience during my Ph.D. study. Without his persistent help this dissertation would not have been possible.

I also want to express my sincere appreciation to China Scholarship Council (CSC) for the financial support of my doctoral research in Germany.

I am grateful to Prof. Dr. Alexander Breder for accepting to be my second supervisor. I also would like to thank Prof. Dr. Dr. h.c.mult. Lutz F. Tietze, Prof. Dr. Marina Bennati, Prof. Dr. Ricardo Mata, and Jun.-Prof. Dr. Johannes C. L. Walker for agreeing to take part in my defense.

I would like to thank people who I have the opportunity to cooperate in our group: Dr. Thomas Müller, Dr. Joao Carlos Agostinho de Oliveira, Dr. Antonis Messinis, Dr. Gianpiero Cera, Dr. Gandeepan Parthasarathy. My deepest thanks also go to Dr. Serhiy Demeshko and Prof. Dr. Franc Meyer for their invaluable contributions of our collaboration on iron chemistry. I also thank Dr. Torben Rogge, Julia Struwe, Dr. Julian Koeller, Ralf Alexander Steinbock, Nikolaos Kaplaneris, Uttam Dhawa and Dr. Svenja Warratz for their helpful suggestions concerning several instruments.

I deeply thank Dr. Torben Rogge, Alexej Scheremetjew, Leonardo Massignan, Nate Ang, Long Yang, Jun $\mathrm{Wu}$, and Shou-Kun Zhang for their patience and time to proofread this thesis. My sincere thanks also go to Dr. Joachim Loup, Dr. Torben Rogge, Long Yang, Julia Struwe, Nikolaos Kaplaneris, Dr. Lars Finger, Wei Wang, Dr. Xuefeng Tan, and Shou-Kun Zhang to correct supporting information and manuscripts of my projects.

I thank Dr. Gianpiero Cera, Dr. Joachim Loup, Dr. Youai Qiu, Dr. Yulei Wang, Dr. Holm Frauendorf and Dr. Michael John for their suggestion on my projects. 
I would also like to thank Dr. Christopher Golz for his assistance with X-ray diffraction analysis, as well as to all the members of the analytical departments (NMR and mass spectrometry) at the IOBC for their continuous support to our research work.

Me deeply thanks also go to Ms. Gabriele Keil-Knepel and Ms. Bianca Spitalieri for for their kindly assistance with administrative tasks. I thank Mr. Stefan Beußhausen for the technical assistance with instruments and Mr. Karsten Rauch for his support to our lab work.

I thank all the group members in Ackermann Group, particularly the past and current members in Lab 302, 308 and 123: Dr. Santhi Vardhana Yetra, Dr. Lars Finger, Dr. Thomas Müller, Dr. Julian Koeller, Dr. Joachim Loup, Zhigao Shen, Dr. Gandeepan Parthasarathy, Dr. Qingqing Bu, Dr. Alexandra Schischko, Dr. Gianpiero Cera, Dr. Wei Wang, Shou-Kun Zhang, Alexej Scheremetjew, Prof. Dr. Yan Zhang, Prof. Dr. Huawen Huang and Dr. Samaresh Chandra Sau. Last but not the least, I want to express my special thanks to my family and my friends for their continuous support and encouragement. 


\section{Contents}

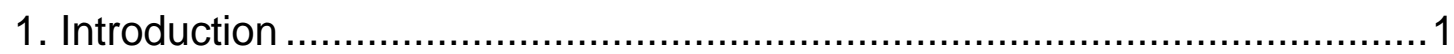

1.1 Transition Metal-Catalyzed C-H Activation........................................

1.1.1 The Concept of Transition Metal-Catalyzed C-H Activation................2

1.1.2 Advantages of Transition Metal-Catalyzed C-H Activation .................2

1.1.3 Mechanisms of Transition Metal-Catalyzed C-H Activation ................4

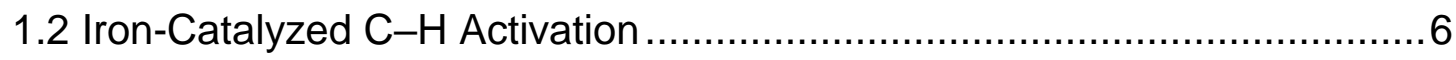

1.2.1 Early Reports on Iron-Catalyzed C-H Activation .............................

1.2.2 Iron-Catalyzed C-H Activation with Organometallic Reagents..........10

1.2.3 Iron-Catalyzed C-H Activation with Organic Electrophiles ................12

1.2.4 Iron-Catalyzed C-H Annulation Reactions ....................................17

1.3 Transition Metal-Catalyzed C-H/C-C Activation...................................21

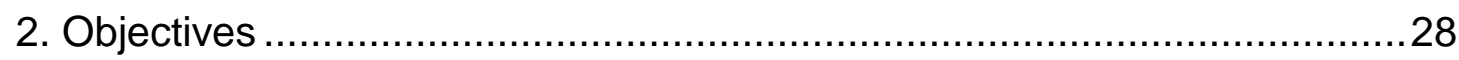

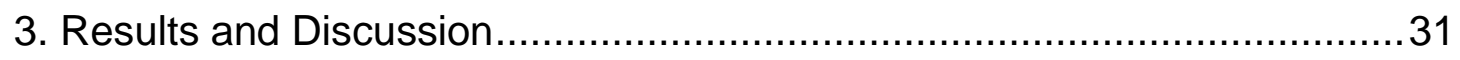

3.1 Iron-Catalyzed C-H/N-H Allene Annulation ..........................................

3.1.1 Optimization Studies ………...................................................

3.1.2. Impact of Directing Group on C-H Functionalization........................34

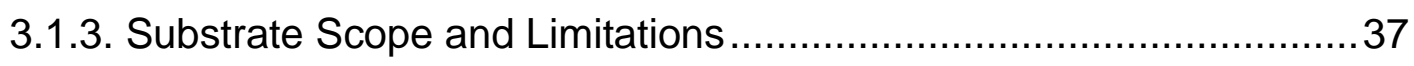

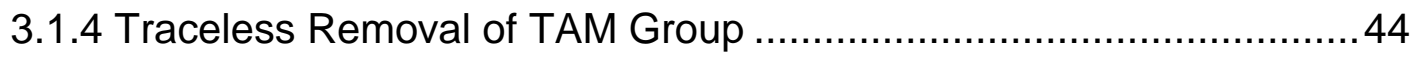

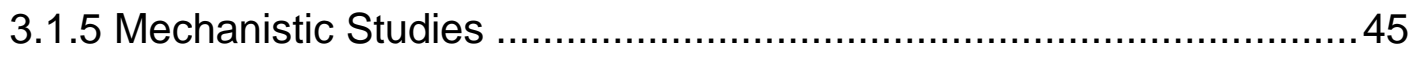

3.1.6 Proposed Mechanism ....................................................................

3.2 Iron-Catalyzed C-H/N-H Propargyl Acetate Annulation .........................52 
3.2.1 Optimization Study and Substrate Scope ……….........................52

3.2.2 Traceless Electrochemical Removal of TAH Group .........................53

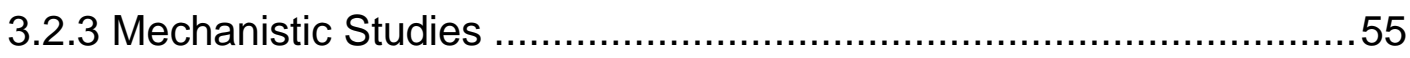

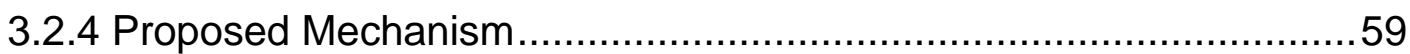

3.3 Iron-Catalyzed C-H/C-C Activation with Bicyclopropylidenes ................60

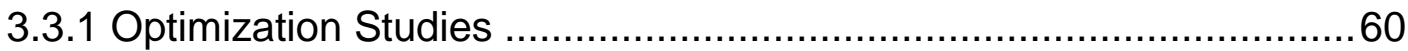

3.3.2 Impact of the N-Substituent on the $\mathrm{C}-\mathrm{H} / \mathrm{C}-\mathrm{C}$ Activation ...................64

3.3.3 Substrate Scope and Limitations ................................................66

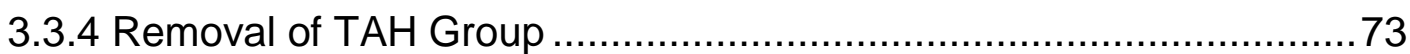

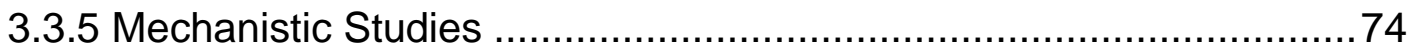

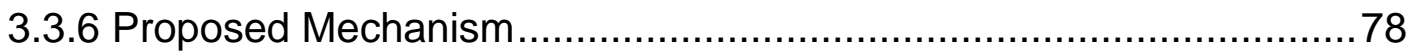

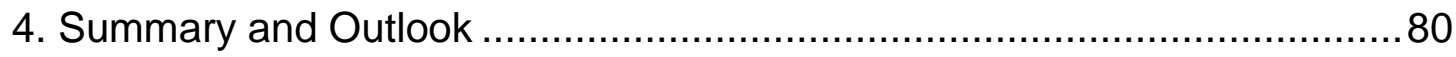

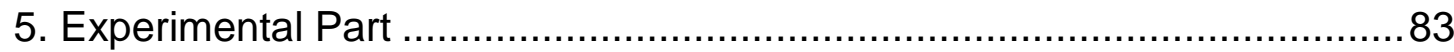

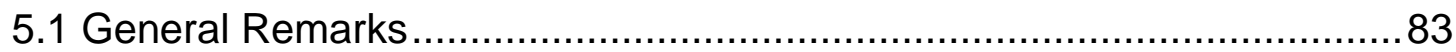

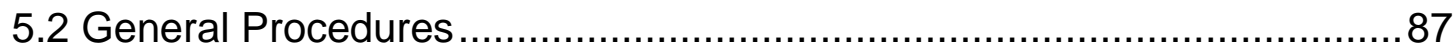

5.3 Iron-Catalyzed $\mathrm{C}-\mathrm{H} / \mathrm{N}-\mathrm{H}$ Annulation with Allenes .................................90

5.3.1 Analytical Data - Products with Different N-Substituted Triazolyl

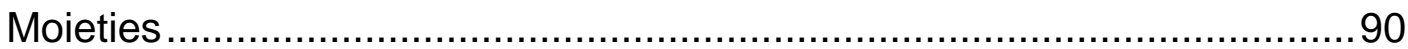

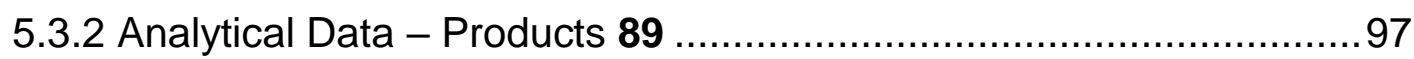

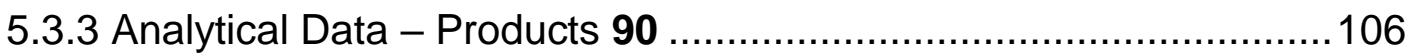

5.3.4 Analytical Data - Products of TAM Benzamide Annulation with Different

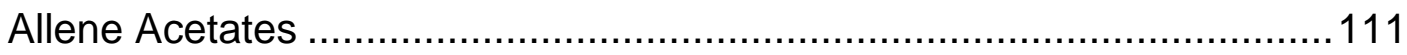

5.3.5 Traceless Removal of TAM Group ….......................................115

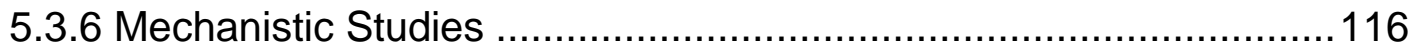


5.4 Iron-Catalyzed $\mathrm{C}-\mathrm{H} / \mathrm{N}-\mathrm{H}$ Annulation with Propargyl Acetates

5.4.1 Analytical Data - Products 92

5.4.2 Traceless Removal of TAH Group...........................................128

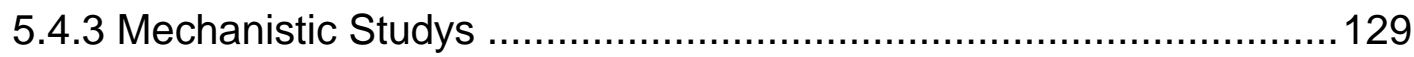

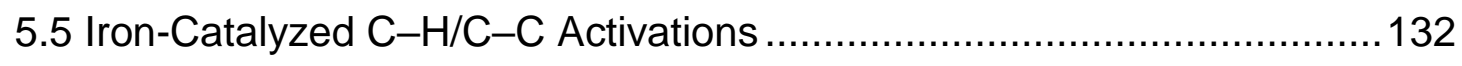

5.5.1 Analytical Data - Products with Different N-Substituted Triazolyl Moieties 132

5.5.2 Analytical Data - Isoquinolone 95 138

5.5.3 Analytical Data - Impact of $\mathrm{CF}_{3}$-Substitution of Benzamide 145

5.5.4 Analytical Data - Substrate Scope with BCP 94 150

5.5.5 Analytical Data - Bispiro-Fused Isoquinolone 96 152

5.5.6 Removal of TAH Group 161

5.5.7 Mechanistic Studies 162

5.6 Mössbauer Measurement 170

5.7 X-Ray Crystallographic Analysis 176

5.7.1 Data Analysis for Crystal Structure of 89la 176

5.7.2 Data Analysis for Crystal Structure of $\mathbf{1 2 0}$ 180

6. References 186

NMR Spectra 200 


\section{List of Abbreviations}

\begin{tabular}{|c|c|}
\hline Ac & acetyl \\
\hline acac & acetyl acetonate \\
\hline Alk & alkyl \\
\hline AMLA & ambiphilic metal ligand activation \\
\hline aq & aqueous \\
\hline $\operatorname{Ar}$ & aryl \\
\hline atm & atmosphere \\
\hline $\mathrm{BHT}$ & 2,6-di-tert-butyl-4-methylphenol \\
\hline BIES & base-assisted internal electrophilic substitution \\
\hline $\mathrm{Bn}$ & benzyl \\
\hline $\mathrm{Bu}$ & butyl \\
\hline calc. & calculated \\
\hline cat. & catalytic \\
\hline CMD & concerted metalation deprotonation \\
\hline Cy & cyclohexyl \\
\hline$\delta$ & Chemical shift \\
\hline d & doublet \\
\hline $\mathrm{dbm}$ & 1,3-diphenyl-1,3-propanedione \\
\hline dd & doublet of doublets \\
\hline DCB & dichlorobenzene \\
\hline DCE & dichloroethane \\
\hline DCP & Dicumyl peroxide \\
\hline DCIB & dichloroisobutane \\
\hline DME & dimethoxyethane \\
\hline DMSO & dimethylsulfoxide \\
\hline dppbz & 1,2-bis(diphenylphosphino)benzene \\
\hline dppe & 1,2-bis(diphenylphosphino)ethane \\
\hline dppen & 1,2-bis(diphenylphosphino)ethene \\
\hline $\mathrm{dt}$ & doublet of triplets \\
\hline DG & directing group \\
\hline
\end{tabular}




\begin{tabular}{|c|c|}
\hline EWG & electron withdrawing group \\
\hline El & electron ionization \\
\hline equiv & equivalent \\
\hline ESI & electronspray ionization \\
\hline Et & ethyl \\
\hline g & gram \\
\hline GC & gas chromatography \\
\hline h & hour \\
\hline hept & heptyl \\
\hline hex & hexyl \\
\hline HRMS & high resolution mass spectrometry \\
\hline $\mathrm{Hz}$ & Hertz \\
\hline$i$ & iso \\
\hline IMes & 1,3-bis(2,4,6-trimethylphenyl)imidazole-2-ylidene \\
\hline $\operatorname{IPr}$ & 1,3-bis(2,6-iso-propylphenyl)imidazole-2-ylidene \\
\hline IR & infrared spectroscopy \\
\hline$J$ & coupling constant \\
\hline KIE & kinetic isotope effect \\
\hline $\mathrm{L}$ & ligand \\
\hline LDA & lithium diisopropylamide \\
\hline$m$ & meta \\
\hline $\mathrm{m}$ & multiplet \\
\hline M & molar \\
\hline$[\mathrm{M}]^{+}$ & molecular ion peak \\
\hline $\mathrm{Me}$ & methyl \\
\hline Mes & mesityl \\
\hline $\mathrm{mg}$ & miligram \\
\hline $\mathrm{MHz}$ & megahertz \\
\hline $\min$ & minute \\
\hline $\mathrm{mL}$ & mililiter \\
\hline $\mathrm{mmol}$ & milimole \\
\hline M. p. & melting point \\
\hline
\end{tabular}




\begin{tabular}{ll} 
MS & mass spectrometry \\
m/z & mass to charge ratio \\
NMR & nuclear magnetic resonance \\
0 & ortho \\
Oct & octyl \\
OLED & organic light emitting diode \\
$p$ & para \\
Pent & pentyl \\
Ph & phenyl \\
phen & 1,10-phenanthroline \\
PMB & para-methoxybenzyl \\
PMP & para-methoxyphenyl \\
Piv & pivaloyl \\
ppm & parts per million \\
Pr & propyl \\
q & quartett \\
Q & 8-aminoquinoline \\
RT & room temperature \\
RL & large substituent \\
$\mathrm{S}$ & singlet and second \\
SET & single electron transfer \\
SPS & solvent purification system \\
$t$ & tert \\
t & triplet \\
$T$ & temperature \\
TAH & triazolylmethyl \\
TAM & triazolyldimethylmethyl \\
TEMPO & $2,2,6,6$-tetramethylpiperidine- $N$-oxide \\
TFA & Trifluoroacetic acid \\
THF & tetrahydrofuran \\
THP & tetrahydropyranyl \\
TLC & thin layer chromatography \\
& \\
\hline &
\end{tabular}




$\begin{array}{ll}\text { TM } & \text { transition metal } \\ \text { TMEDA } & N, N, N^{\prime}, N^{\prime} \text {-tetramethylethylenediamine } \\ \text { TMS } & \text { trimethylsilyl } \\ \text { TS } & \text { transition state } \\ \mathrm{X} & \text { (pseudo-)halide }\end{array}$




\section{Introduction}

\section{Introduction}

Organic synthesis is a powerful tool for molecular construction with notable applications to material sciences, ${ }^{[1]}$ natural product syntheses ${ }^{[2]}$ and life-saving pharmaceuticals. ${ }^{[3]}$ In light of these transformative advantages, tremendous efforts have been devoted to the development of novel methods for molecular syntheses, which has resulted in diverse applications with countless benefits for society. ${ }^{[4]}$ However, despite indisputable progress, organic syntheses, which has been dominated by the transformation of functional groups ${ }^{[5]}$ continues to be perceived as a polluting science due to inter alia waste generation, resource and energy consumption, and the use of often toxic and dangerous chemicals.

In 1988, Warner and Anastas included catalysis as one of the "12 Principles of Green Chemistry". ${ }^{[6]}$ During the past century, catalysis has been recognized as a foundation of the chemical industries with significant achievements in developing economically, environmentally and technologically beneficial transformations. ${ }^{[7]}$

A significant stimulus in organic synthesis was made by the emergence of direct functionalizations of omnipresent $\mathrm{C}-\mathrm{H}$ bonds. ${ }^{[8]} \mathrm{C}-\mathrm{H}$ functionalizations are environmentally-benign and economically-attractive, since they prevent lengthy synthetic operations and reduce waste generation by activating the inert $\mathrm{C}-\mathrm{H}$ bonds directly instead of using pre-functionalized substrates (Scheme 1).

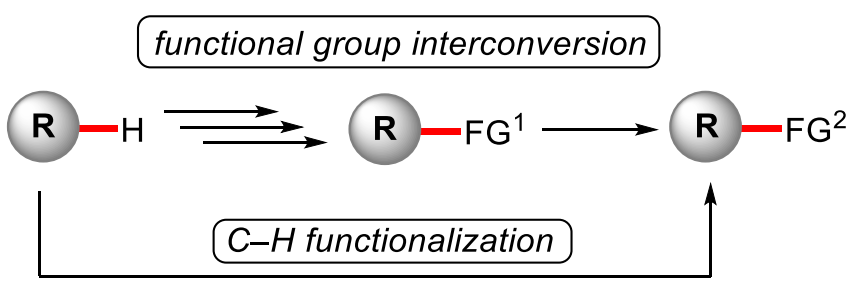

Scheme 1 Traditional functional group interconversion versus $\mathrm{C}-\mathrm{H}$ functionalization. 


\subsection{Transition Metal-Catalyzed C-H Activation}

\subsubsection{The Concept of Transition Metal-Catalyzed C-H Activation}

Transition metal-catalyzed $\mathrm{C}-\mathrm{H}$ activation involves the transformation of otherwise inert $\mathrm{C}-\mathrm{H}$ bonds into $\mathrm{C}-$ Met bonds. ${ }^{[9]}$ In this concept, the formation of an organometallic complex through $\mathrm{C}-\mathrm{H}$ coordination of the inner-sphere of a metal is often important. ${ }^{[10]}$ The intermediate produced by $\mathrm{C}-\mathrm{H}$ activation can further undergo subsequent reactions to afford the functionalized products (Scheme 1.1).

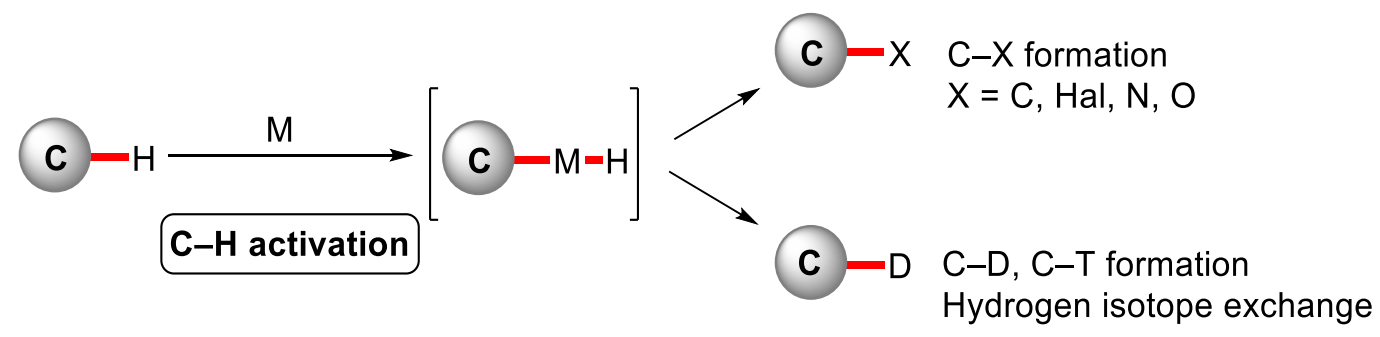

Scheme $1.1 \mathrm{C}-\mathrm{H}$ activation.

\subsubsection{Advantages of Transition Metal-Catalyzed C-H Activation}

Transition metal-catalyzed cross-couplings, such as the Suzuki-Miyaura, Negishi and Mizoroki-Heck reactions, are an important tool in organic synthesis for the formation of C-C bonds, which have been awarded the 2010 Nobel Prize in chemistry. ${ }^{[11]}$ However, despite indisputable progress, cross-coupling reactions continue to be severely limited, due to inter alia the requirement of pre-functionalized substrates and organometallic compounds, which signifycantly decrease the user-friendliness, sustainability and step-economy. From this point of view, the direct activation of omnipresent $\mathrm{C}-\mathrm{H}$ bonds would be a highly desirable alternative to conventional cross-couplings due to the avoidance of pre-functionalized substrates (Scheme 1.2). 


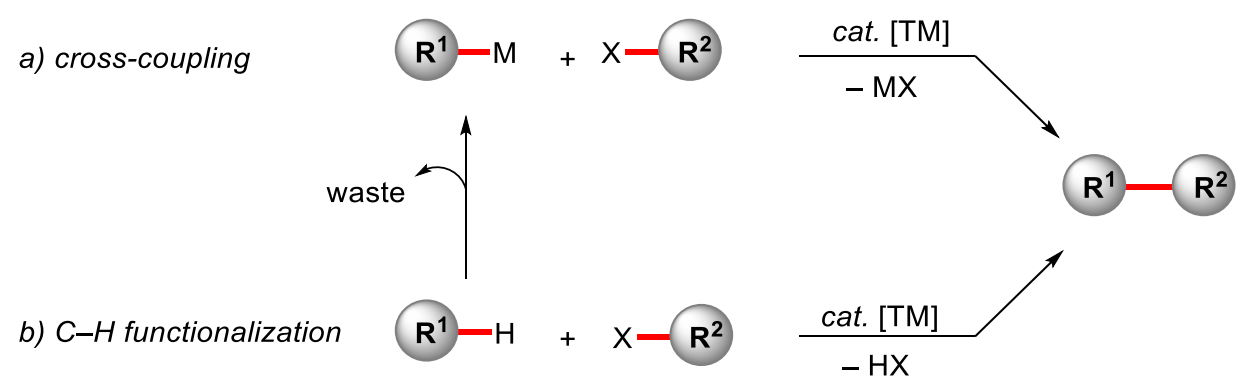

Scheme 1.2 Comparison of cross-coupling and $\mathrm{C}-\mathrm{H}$ functionalization.

In order to achieve an efficient direct $\mathrm{C}-\mathrm{H}$ functionalization, a transition metal catalyst, which can directly react with a $\mathrm{C}-\mathrm{H}$ bond to generate a $\mathrm{C}-\mathrm{M}$ bond under mild conditions, is highly desirable. Partially, due to the high dissociation energy of $\mathrm{C}-\mathrm{H}$ bonds $\left(\sim 110 \mathrm{kcal} \mathrm{mol}^{-1}\right.$ for $\mathrm{C}($ aryl $)-\mathrm{H}$ and $\sim 105 \mathrm{kcal} \mathrm{mol}^{-1}$ for alkanes), ${ }^{[12]}$ harsh conditions would be required to cleave the bond directly, thus resulting in a narrow substrate scope. ${ }^{[13]}$ Additionally, the metallated intermediates can easily react with a number of different chemicals thereby allowing for a range of applications. ${ }^{[14]}$

The fact that $\mathrm{C}-\mathrm{H}$ bonds are omnipresent in organic molecules and have comparable dissociation energies represents a challenge for controlling the selectivity in direct $\mathrm{C}-\mathrm{H}$ activation. To tackle this issue, various strategies have been developed based on the transition metal catalyst's mode of action, for example 1) electronic bias, ${ }^{[15]}$ 2) steric control,[16] and 3) directing groupassisted $\mathrm{C}-\mathrm{H}$ activation ${ }^{[17]}$ (Scheme 1.3a). Since approaches based on electronic and steric biases highly depend on the nature of the substrates, this strategy is typically limited in terms of viable scope. In sharp contrast, by a directing group (DG) which coordinates to the metal center of the catalyst and directs the catalyst to a proximal position, selective $\mathrm{C}-\mathrm{H}$ activation could be achieved with a broad variety of substrates. Furthermore, considerable attention has been devoted to the development of weakly coordinating, ${ }^{[18]}$ removable ${ }^{[19,17 c]}$ or transient ${ }^{[20]}$ directing groups (Scheme 1.3b). 
a) approaches for selective $\mathrm{C}-\mathrm{H}$ activation
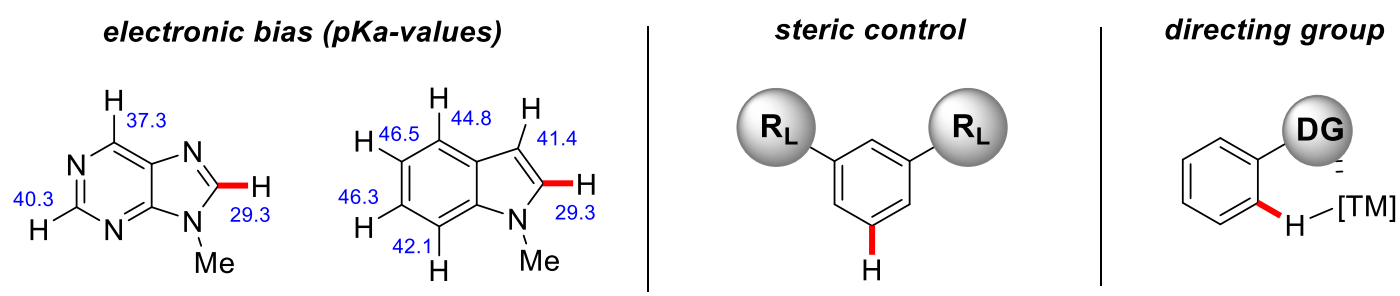

b) selected examples of directing groups
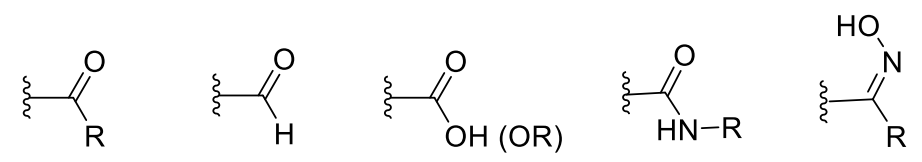<smiles>CC(C)(C)c1ccccn1</smiles><smiles></smiles>

Scheme 1.3 Positional selectivity in $\mathrm{C}-\mathrm{H}$ activation.

\subsubsection{Mechanisms of Transition Metal-Catalyzed C-H Activation}

As a better understanding of the elementary $\mathrm{C}-\mathrm{H}$ cleavage step would allow for the design of more efficient catalytic $\mathrm{C}-\mathrm{H}$ functionalizations, intensive studies have been devoted to elucidate various $\mathrm{C}-\mathrm{H}$ activation modes. ${ }^{[21]}$ Depending on the metal fragment, $\mathrm{C}-\mathrm{H}$ metalation can proceed via several distinct reaction pathways:[21a] a) oxidative addition with electron-rich, low-valent complexes of late transition metals, b) electrophilic substitution with late transition metals in higher oxidation states where the metal acts as a Lewis acid, c) $\sigma$-bond metathesis with early transition metals, typically involving an alkyl- or hydridemetal complex, as well as lanthanides and actinides, ${ }^{[21 b]}$ d) 1,2-addition with unsaturated $\mathrm{M}=\mathrm{X}$ bonds, such as metal imido, oxo and alkylidene complexes, and e) base-assisted metalation most commonly with carboxylate ligands (Scheme 1.4). [21a] 
a) oxidative addition

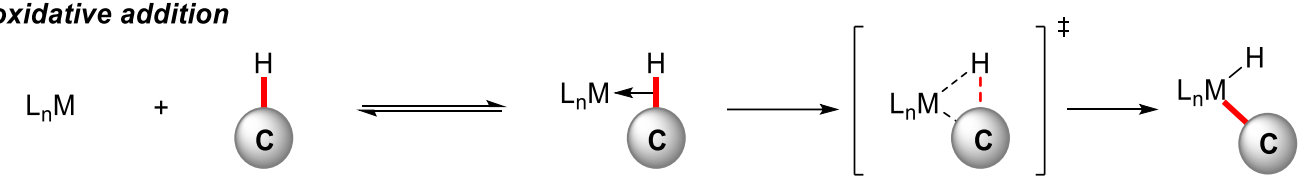

b) electrophilic substitution

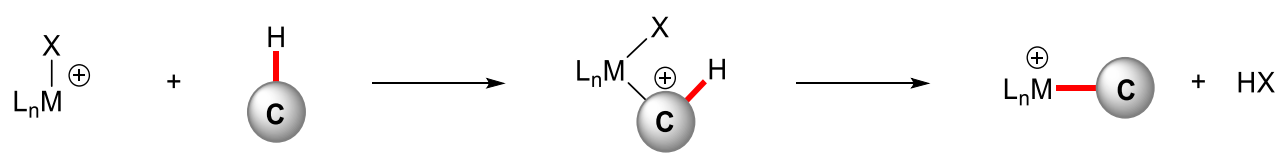

c) $\sigma$-bond metathesis

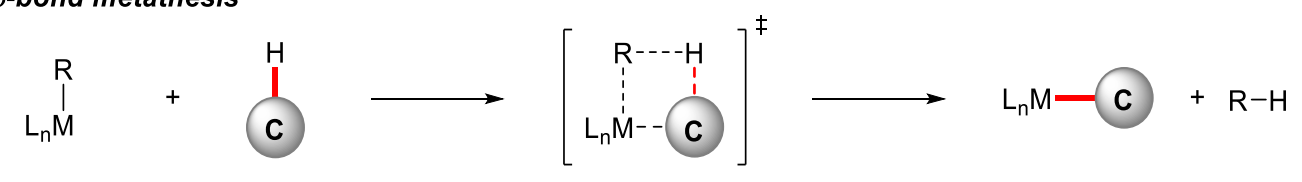

d) 1,2-addition

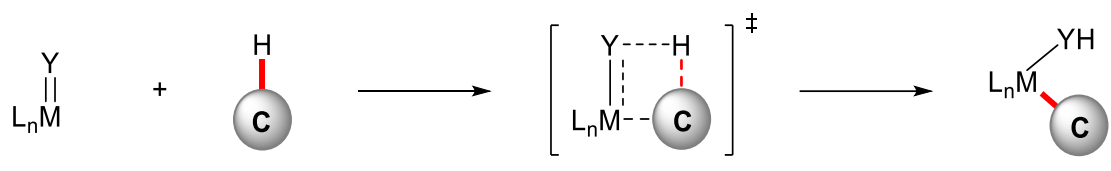

e) base-assisted metalation

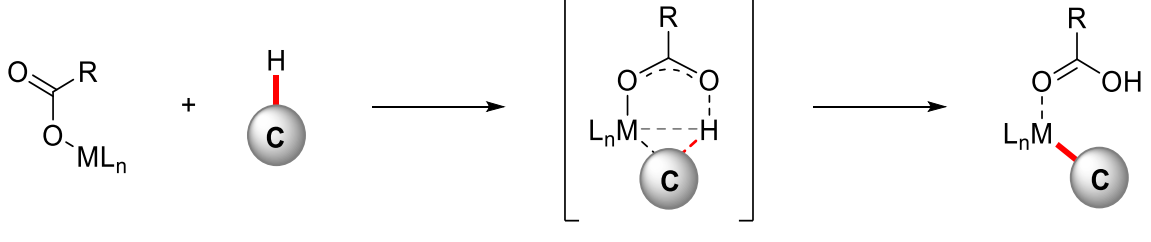

Scheme 1.4 Viable modes of organometallic C-H activation.

Over the past few years, several transition states of base-assisted $\mathrm{C}-\mathrm{H}$ metalation were proposed (Scheme 1.5).[21a] The concerted metalationdeprotonation $(\mathrm{CMD})^{[22]}$ describes the synergistic interaction between the metal center, the carboxylate-ligand and the $\mathrm{C}-\mathrm{H}$ bond via a six-membered transition state. For the ambiphilic metal-ligand activation (AMLA), ${ }^{[23]}$ a similar transition state has been proposed. Both transition states are characterized by a preference for kinetically $\mathrm{C}-\mathrm{H}$-acidic substrates. As an explanation for the preference of electron-rich substrates in several catalytic transformations, the concept of base-assisted internal electrophilic substitution (BIES) has been 
proposed by Ackermann ${ }^{[24]}$ In contrast to the six-membered transition states, the term internal electrophilic substitution (IES $)^{[25]}$ which was proposed for the reaction involving alkoxide bases featured a transition state with a highly strained four-membered ring, basically a $\sigma$-bond metathesis. Based on Ackermann's BIES, Carrow coined this mechanistic manifold very recently as e-CMD. ${ }^{[26]}$

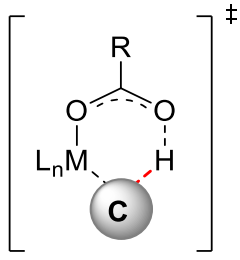

CMD

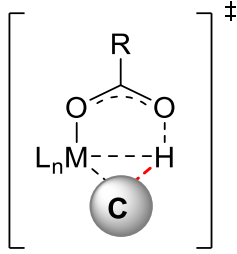

AMLA

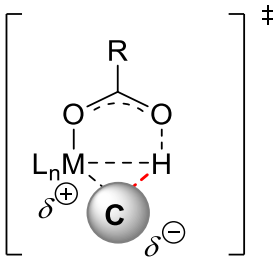

BIES

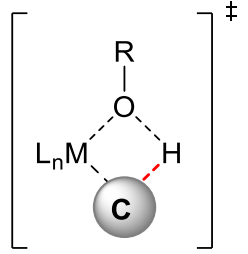

IES

Scheme 1.5 Proposed transition states for base-assisted C-H metalations.

\subsection{Iron-Catalyzed C-H Activation}

Transition metal-catalyzed $\mathrm{C}-\mathrm{H}$ functionalization has been recognized as a powerful tool for molecular syntheses. ${ }^{[9,14,17 a]}$ Thus far, $\mathrm{C}-\mathrm{H}$ functionalizations were often achieved with precious transition metal catalysts, for instance, palladium, iridium, rhodium and ruthenium. However, these noble late transition metals normally feature high costs, ${ }^{[27]}$ a low natural abundance ${ }^{[28]}$ and a high toxicity, ${ }^{[29]}$ which highly decreases the sustainability and economic efficiency of the approach. As a direct consequence, the development of transformations under $3 \mathrm{~d}$ transition metal catalysis, ${ }^{[30]}$ and especially iron, ${ }^{[31]}$ has attracted considerable attention due to their high Earth-abundance, cost-efficiency, and low toxicity. ${ }^{[32]}$

Owing to the electron configuration of iron, iron catalysts can access various oxidation from -2 to +6 and spin states and can easily undergo single electron transfer (SET) processes. These properties enable iron catalysts to be employed in a wide range of transformations. ${ }^{[33]}$ 


\section{Introduction}

In general, iron in low oxidation states exhibits nucleophilic properties, which enables a number of organic transformations, such as nucleophilic substitutions, reductions, cycloisomerizations, or cross coupling reactions, ${ }^{[34]}$ while in higher oxidation states, iron behaves as a Lewis acid, thus activating unsaturated bonds. ${ }^{[35]}$

Inspired by early studies of catalytic C-C bond formations, ${ }^{[36]}$ the scientific community focused their attention on the development of efficient iron catalysts systems for sustainable $\mathrm{C}-\mathrm{H}$ activation strategies. Indeed, low-valent iron species were found to be effective for the activation of $\mathrm{C}\left(\mathrm{sp}^{2}\right)-\mathrm{H}$ as well as $\mathrm{C}\left(\mathrm{sp}^{3}\right)-\mathrm{H}$ bonds under mild reaction conditions, providing an environmentally benign and atom-economical alternative for the construction of novel $\mathrm{C}-\mathrm{C}$ and C-Het bonds. [31]

\subsubsection{Early Reports on Iron-Catalyzed C-H Activation}

In 1968, an early example of stoichiometric organometallic $\mathrm{C}-\mathrm{H}$ activation was reported, in which an ortho- $\mathrm{C}-\mathrm{H}$ bond was oxidatively added to an iron(0) center to form the hydride ferracycle complex 2 through irradiation of the $\left[\mathrm{Fe}(\mathrm{dppe})_{2} \cdot \mathrm{C}_{2} \mathrm{H}_{4}\right]$ complex 1 (Scheme 1.6). ${ }^{[37]}$

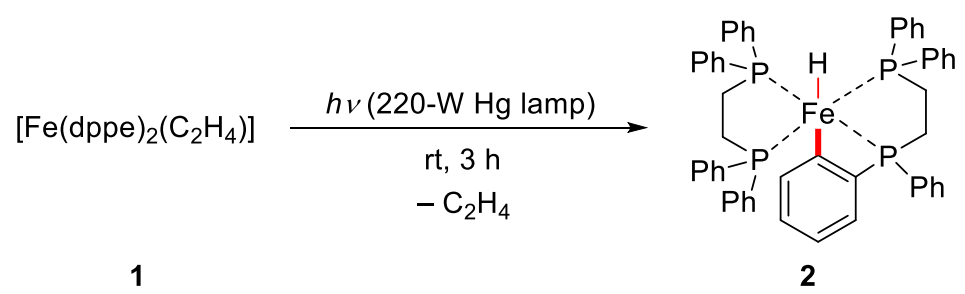

Scheme 1.6 Stoichiometric organometallic $\mathrm{C}-\mathrm{H}$ activation.

Stoichiometric cyclometallations of organic compounds with iron complexes were subsequently described. ${ }^{[38]}$ A representative example is the stoichiometric cyclometallation of aryl imines with $\mathrm{Fe}\left(\mathrm{PMe}_{3}\right)_{4}$ or $\mathrm{FeMe}_{2}\left(\mathrm{PMe}_{3}\right)_{4}$, which was reported by Klein. ${ }^{[39]} \mathrm{C}-\mathrm{H}$ activation of benzaldimine $3 \mathbf{a}$ by $\mathrm{FeMe}_{2}\left(\mathrm{PMe}_{3}\right)_{4}$ 
proceeds via $\sigma$-bond metathesis, while cyclometallation was proposed to proceed via nitrogen-assisted $\mathrm{C}-\mathrm{H}$ oxidative addition when $\mathrm{Fe}\left(\mathrm{PMe}_{3}\right)_{4}$ and ketimine $\mathbf{3 b}$ were employed (Scheme 1.7).

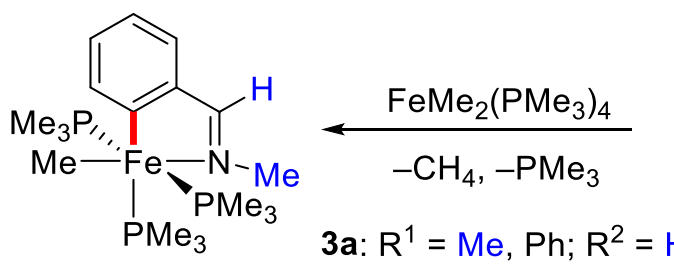

4

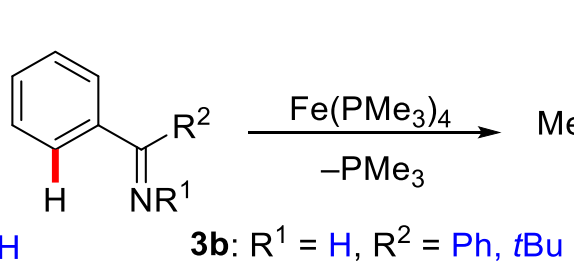

3

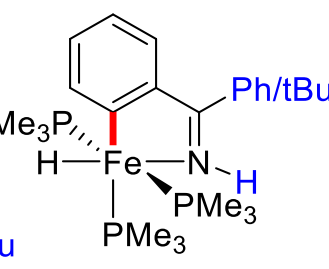

5

Scheme 1.7 Directed stoichiometric C-H activation.

Two notable aspects of this stoichiometric $\mathrm{C}-\mathrm{H}$ activation are: 1) Nitrogendirected $\mathrm{C}\left(\mathrm{sp}^{2}\right)-\mathrm{H}$ activation is possible, ideally with iron $(0)$ through oxidative addition or with a methyliron(II) species via $\sigma$-bond metathesis, and 2) the iron(0) complex displayed a higher reactivity towards $\mathrm{C}-\mathrm{H}$ bond activation as compare to $\mathrm{N}-\mathrm{H}$ bond cleavage.

In 1987, Jones disclosed the first example of iron-catalyzed $\mathrm{C}-\mathrm{H}$ functionalization. ${ }^{[40]}$ The catalyst 8 generated from $\mathrm{Fe}\left(\mathrm{PMe}_{3}\right)_{4}$ and isocyanide 7 enable the successful transformation of aldimine $\mathbf{9}$ from benzene 6 (Scheme 1.8). The key to success in this reaction was the low concentration to avoid substrate inhibition and the use of UV irradiation for the generation of active iron species.

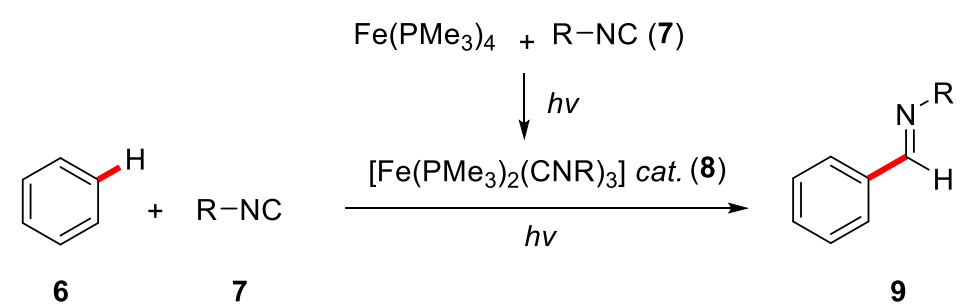

Scheme 1.8 Iron-catalyzed C-H functionalization of benzene.

In 2006, Nakamura disclosed an example of iron-catalyzed direct $\mathrm{C}-\mathrm{H}$ activation was disclosed by through a serendipitous observation during iron- 
catalyzed cross-coupling reactions (Scheme 1.9). ${ }^{[41]}$ Here, a $\mathrm{C}-\mathrm{H}$ functionalized product, 2-biphenylpyridine 12, was observed in the crosscoupling of 2-bromopyridine $\mathbf{1 0}$ and a phenylzinc reagent. In order to develop an efficient iron-catalyzed $\mathrm{C}-\mathrm{H}$ activation system, the authors analyzed the reaction, which resulted in a number of significant observations: 1) an oxidant is necessary for catalyst turnover, 2) a nitrogen-based ligand is crucial for this transformation, and 3) the coupling partner is an in situ formed organic zinc reagent rather than the Grignard reagent.

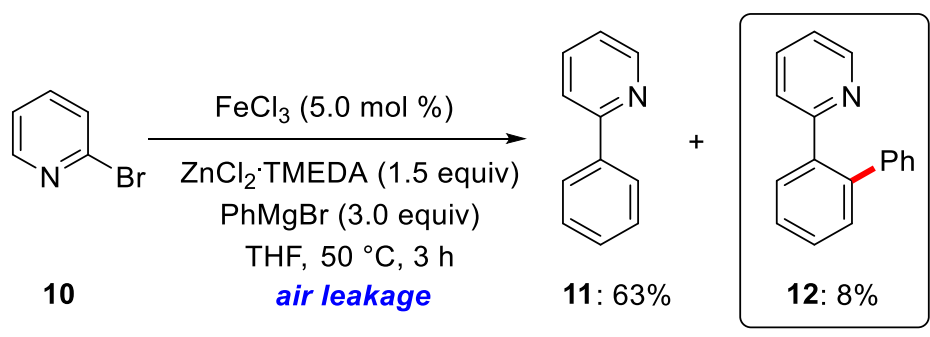

Scheme 1.9 Iron-catalyzed C-H arylation.

Two years later, Nakamura reported an iron-catalyzed direct $\mathrm{C}-\mathrm{H}$ activation with phenanthroline 14 as the ligand and dichloroisobutane 15 (DCIB) as the oxidant of choice (Scheme 1.10). ${ }^{[42]}$<smiles>C1=CC2=CC=Cc3cccc2c3C=C1</smiles>

13

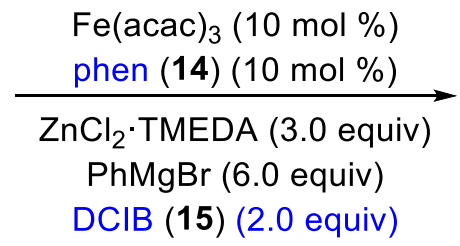

$\mathrm{THF}, 0^{\circ} \mathrm{C}, 16 \mathrm{~h}$<smiles>c1ccc(-c2cccc3ccc4cccnc4c23)cc1</smiles>

16: $99 \%$

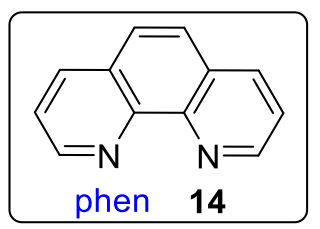<smiles>CC(C)(Cl)CCCC(C)(C)Cl</smiles>

Scheme 1.10 Iron-catalyzed direct $\mathrm{C}-\mathrm{H}$ activation.

Subsequent studies using monodentate directing groups, ${ }^{[43]}$ such as imines, amides, ketones, esters, and pyridines, led to major advancement in the field of 


\section{Introduction}

iron-catalyzed $\mathrm{C}\left(\mathrm{sp}^{2}\right)-\mathrm{H}$ arylations and alkylations. A breakthrough in ironcatalyzed $\mathrm{C}-\mathrm{H}$ functionalization was represented by the application of bidentate $\left.^{[9 a}, 9 \mathrm{~g}\right]$ directing groups, which not only provided an access to unprecedented $\mathrm{C}\left(\mathrm{sp}^{3}\right)-\mathrm{H}$ activations, but also significantly diversified possible transformations. Major progress in the field of bidentate directing groupassisted iron-catalyzed C-H functionalizations was achieved by Nakamura ${ }^{[31 a]}$ with 8-aminoquinoline (Q) group and by Ackermann ${ }^{[31 b]}$ with the easily accessible triazolyldimethylmethyl (TAM) group.

\subsubsection{Iron-Catalyzed C-H Activation with Organometallic Reagents}

At an early stage, major progress in this research field was achieved by the development of direct arylations of $\mathrm{C}\left(\mathrm{sp}^{2}\right)-\mathrm{H}$ bonds using monodentate directing groups, including: 1) functionalizations of olefinic $\mathrm{C}\left(\mathrm{sp}^{2}\right)-\mathrm{H}$ bonds, ${ }^{[43 g]}$ 2) without zinc additives, ${ }^{[43 \mathrm{~h}]}$ 3) replacing Grignard reagents with metallic magnesium, ${ }^{[43 e]}$ and 4 ) the use of synthetically useful imines ${ }^{[43 c, 43 \mathrm{~h}, 43 \mathrm{j}]}$ and amides $^{[43 f]}$ as the directing group.

$\mathrm{C}\left(\mathrm{sp}^{3}\right)-\mathrm{H}$ functionalizations were realized by bidentate directing group assistance through low-valent iron catalysis. In this context, Nakamura reported on 8-aminoquinoline group-assisted direct arylations of aliphatic amides 17 with in situ generated aryl zinc reagents (Scheme 1.11a). ${ }^{[44]}$ In contrast, Ackermann developed a powerful method employing the TAM group, a highly effective bidentate directing group, for the direct arylation of aromatic and aliphatic amides 20 and 23 (Scheme 1.11b). ${ }^{[45]}$ It is worth noting that a bidentate phosphine ligand, such as dppbz 18 or dppe 21, was necessary for these transformations, whereas nitrogen-based ligands turned out to be ineffective. Recently, Ackermann successfully used environmental friendly electricity as oxidant instead of DCIB for the iron-catalyzed C-H arylation. ${ }^{[46]}$ 


\section{Introduction}

a) Nakamura

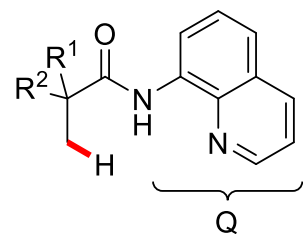

17

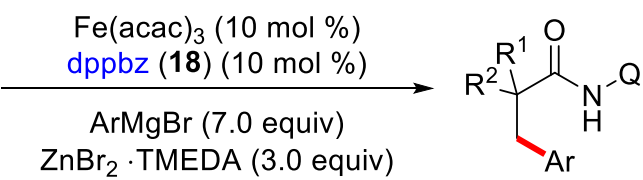

19

b) Ackermann

$C\left(s p^{2}\right)-H$ arylation
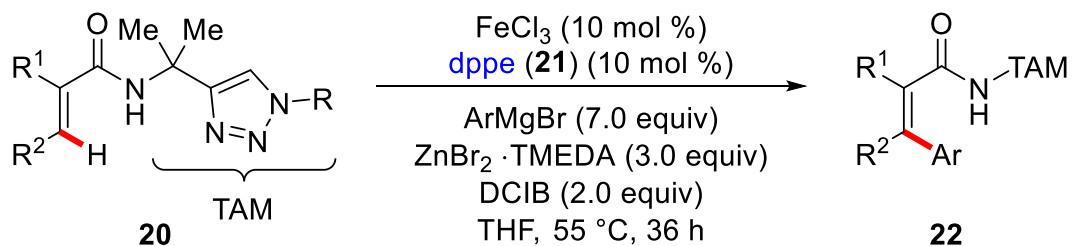

$C\left(s p^{3}\right)-H$ arylation

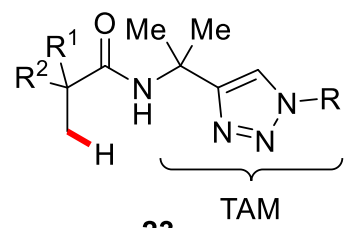

23

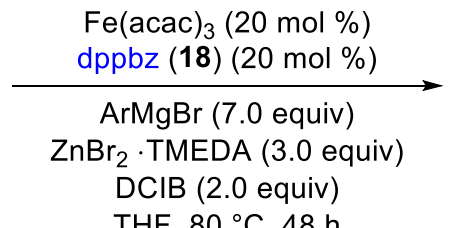

$\mathrm{THF}, 80^{\circ} \mathrm{C}, 48 \mathrm{~h}$<smiles>[R14][NH2+]C(=O)C([R])([R])C[Al]</smiles>

24
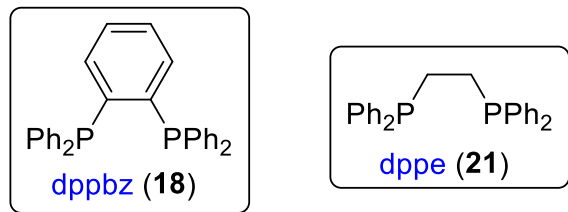

dppe (21)

Scheme 1.11 Bidentate directing group-assisted iron-catalyzed $\mathrm{C}-\mathrm{H}$ arylation.

In addition, lithium borate salts $\mathbf{2 6}$ proved to be a viable alternative to Grignard reagents for the low-valent iron-catalyzed C-H alkenylation (Scheme 1.12a). ${ }^{[47]}$ Since various alkenylboronates are easily available and the corresponding magnesium reagents are usually difficult to prepare, this transformation shows a broader substrate scope as compared to the approach using alkenylmagnesium bromide 28 (Scheme 1.12b). ${ }^{[48]}$ 
a) alkenylation with lithium borate salts

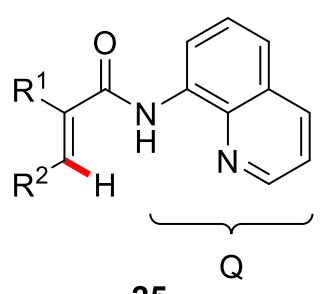

25

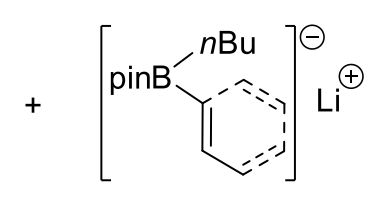

26

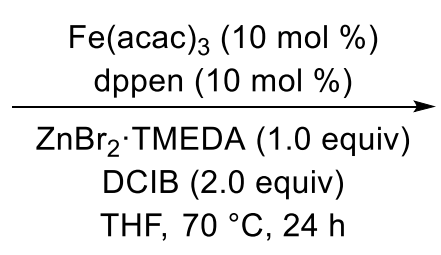

THF, $70^{\circ} \mathrm{C}, 24 \mathrm{~h}$

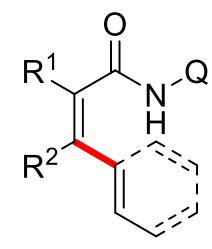

27

b) alkenylation with Grignard reagents<smiles>[R]C=C([R])C(=O)Nc1cccc2cccnc12</smiles>

25

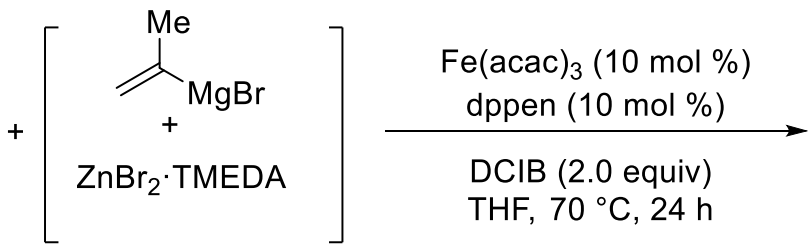

28

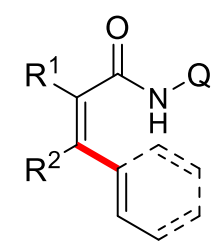

27

Scheme 1.12 Iron-catalyzed C-H alkenylation.

Apart from arylations and alkenylations, considerable achievements were also accomplished in iron-catalyzed $\mathrm{C}-\mathrm{H}$ alkylations using alkyl aluminium reagents $^{[49]}$ or in situ alkyl formed zinc reagents. ${ }^{[48,50]}$

\subsubsection{Iron-Catalyzed C-H Activation with Organic Electrophiles}

Despite indisputable progress in iron-catalyzed $\mathrm{C}-\mathrm{H}$ activations with nucleophilic coupling partners, in most of the cases, stoichiometric amounts of expensive and toxic DCIB is needed as an oxidant to guarantee an efficient transformation (Scheme 1.13, path a). Recently, a major advancement in ironcatalyzed $\mathrm{C}-\mathrm{H}$ activation was represented by reacting the in situ generated iron species with various organic electrophiles, thus avoiding the use of external oxidants (scheme 1.13, path b). In this context, $\mathrm{C}-\mathrm{H}$ transformations including alkylation, ${ }^{[51]}$ allylation ${ }^{[51 a, 52]}$ and alkynylation ${ }^{[53]}$ were accomplished, employing electrophiles in bidentate directing group-assisted low-valent iron catalysis. 


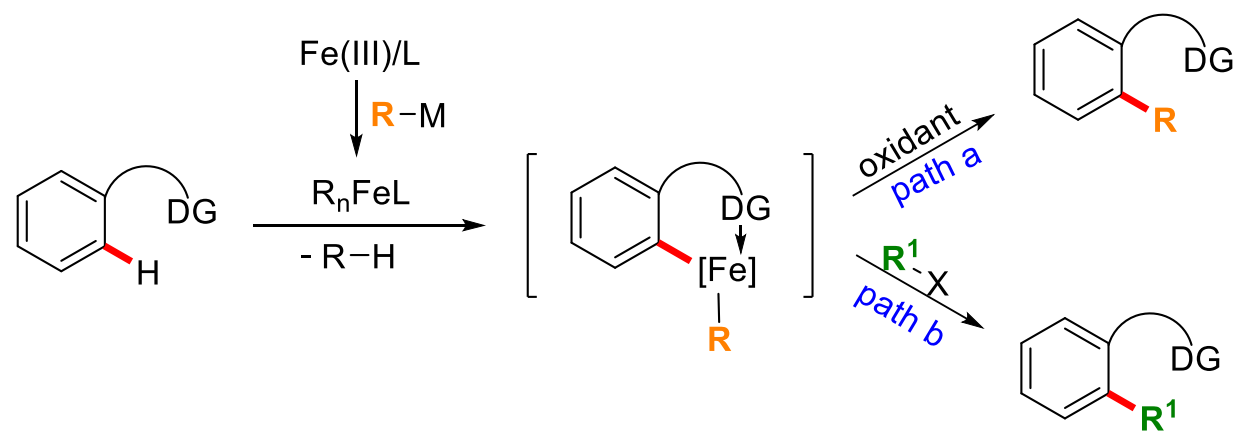

Scheme 1.13 Bidentate directing group assisted iron-catalyzed C-H arylation.

Nakamura reported iron-catalyzed $\mathrm{C}-\mathrm{H}$ allylations with allyl phenyl ethers $\mathbf{3 0}$ as the organic electrophiles (Scheme 1.14a). ${ }^{[52]}$ The fact that allyl phenyl ether 30 could be used as the electrophile in iron-catalyzed $\mathrm{C}-\mathrm{H}$ functionalizations, was serendipitously discovered during their optimization of oxidants for ironcatalyzed arylations of $\mathrm{N}$-phenylpyrazole with diarylzinc. In this approach, $\mathrm{C}-\mathrm{H}$ methylations and arylations in the presence of organozinc reagents, such as $\mathrm{Me}_{2} \mathrm{Zn}$ or $\mathrm{Ph}_{2} \mathrm{Zn}$, was observed, suggesting that an appropriate organometallic base was crucial for the transformation. To further gain insights into the catalyst's mode of action, deuterated allyl phenyl ether [D]2-30 was subjected

a) allyl phenyl ethers as electrophile<smiles>[R]#CCOc1ccccc1C(=O)NO</smiles>

29

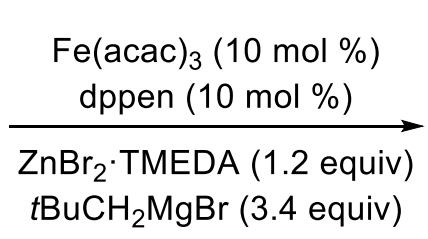

THF, $70{ }^{\circ} \mathrm{C}, 4 \mathrm{~h}$

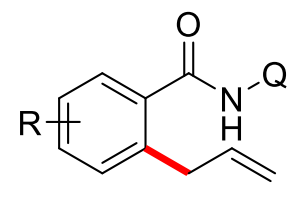

31

b) evidence for $S_{N} 2$-type mechanism<smiles>O=C(NO)c1ccccc1</smiles><smiles>[2H]C([2H])(C=C)Oc1ccccc1</smiles>
$[D]_{2}-30$

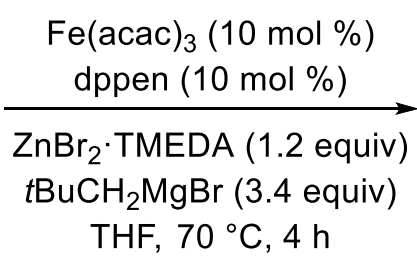
$\mathrm{THF}, 70^{\circ} \mathrm{C}, 4 \mathrm{~h}$<smiles>[2H]C([2H])(C=C)c1ccccc1C(=O)NO</smiles>
$[D]_{2}-31: 96 \%$

Scheme 1.14 Iron-catalyzed $\mathrm{C}-\mathrm{H}$ allylations with allyl phenyl ethers. 


\section{Introduction}

to the reaction. Selectively $\gamma, \gamma$-deuterated-product $[D]_{2}-31$ was observed, providing strong support for a $S_{N 2}$-type mechanism (Scheme 1.14b).

In a report by Ackermann, a widely applicable method for $\mathrm{C}-\mathrm{H}$ allylations employing the user-friendly TAM group was disclosed. ${ }^{[51 a]}$ Various aromatic, heteroaromatic and olefinic benzamides 32 were found to be applicable in the transformation (Scheme 1.15a). Notably, the branched allylated product $\mathbf{3 4 e / 3 4 f}$ was formed with comparable levels of regioselectivity with $(E)$-crotyl chloride $\mathbf{3 3 a}$ or the secondary allyl chloride $\mathbf{3 3 b}$, providing support for the formation of a $\eta^{3}$-allyl intermediate (Scheme 1.15b). ${ }^{[54]}$

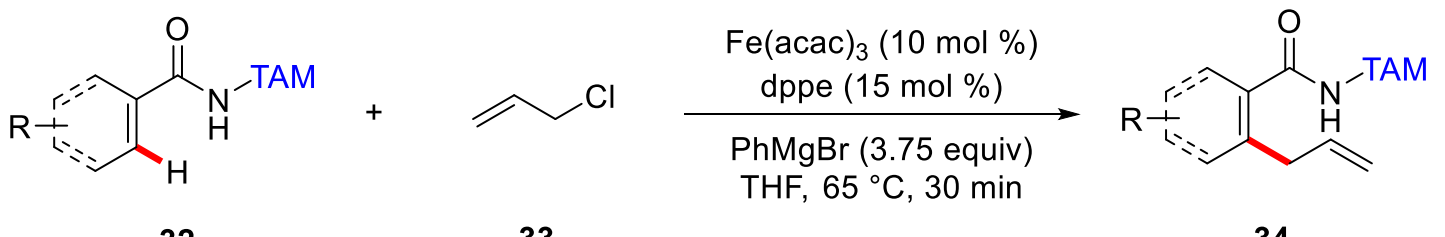

32

33

34

a) selected examples of benzamides<smiles>C=CCc1cc(Cl)c(Cl)cc1C(=O)N[Mg]</smiles>

34a: $59 \%$<smiles>C=CCc1ccsc1C(=O)N[Te]</smiles>

34b: $85 \%$<smiles>C=CC/C(C)=C(/C)C(=O)N[XeH]</smiles>

34c: $58 \%$<smiles>C=CCC1=C(C(=O)N[14CH3])CCCO1</smiles>

34d: $81 \%$

b) evidence for $\eta^{3}$-allyl-iron intermediate<smiles>[Y10]NC(=O)c1ccccc1</smiles>

32<smiles>[R]C=CC([R])CCl</smiles>

$\mathrm{R}^{1}=\mathrm{H} ; \mathrm{R}^{2}=\mathrm{Me}(\mathbf{3 3 a})$ $\mathrm{R}^{1}=\mathrm{Me} ; \mathrm{R}^{2}=\mathrm{H}(\mathbf{3} 3 \mathbf{b})$

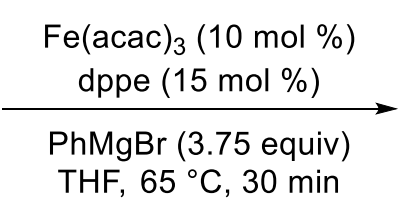<smiles>[Y14]NC(=O)c1ccccc1C([R])C=C</smiles>

34e: $\mathrm{R}=\mathrm{Me}, 80 \%(b: I=4.2: 1)$ 34f: $\quad R=M e, 75 \%(b: I=2.5: 1)$

Scheme 1.15 Iron-catalyzed C-H allylation with allyl halides.

The concept was further expanded to iron-catalyzed $\mathrm{C}-\mathrm{H}$ alkylation and benzylation using alkyl and benzyl electrophiles. 


\section{Introduction}

For the alkylation reported by Nakamura, an excess of Nal was crucial for suppressing the undesired $\mathrm{C}-\mathrm{H}$ arylation, thereby allowing for an efficient transformation (Scheme 1.16). ${ }^{[51 c]}$ Interestingly, the diastereochemical information was partially deteriorated in 36 a when using diastereochemically well-defined trans-4-tert-butylcyclohexyl tosylate 35a. In addition, the catalytic activity was completely inhibited when the radical scavenger TEMPO was added. These observations highlight the radical character of the $\mathrm{C}-\mathrm{O}$ cleavage process. [55]<smiles>O=C(NCl)c1ccccc1</smiles>

$25 / 29$ $+\quad$ Alk-OTs $\left(1^{\circ}\right.$ or $\left.2^{\circ}\right)$

35

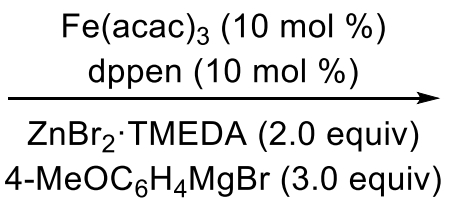

$\mathrm{Nal}$ (1.5 equiv) THF, $70{ }^{\circ} \mathrm{C}, 12 \mathrm{~h}$<smiles>O=C(NO)c1ccccc1Cl</smiles>

36<smiles>CC(C)(C)[C@H]1CC[C@H](C2=C(C(=O)NO)CCCC2)CC1</smiles>

36a: $43 \%$ $($ trans $/$ cis $=78: 22)$<smiles>CN(C)c1ccc(C2CCCC2)c(C(=O)NO)c1</smiles>

36b: $89 \%$<smiles>O=C(NO)c1sccc1CCc1ccccc1</smiles>

36c: $41 \%$

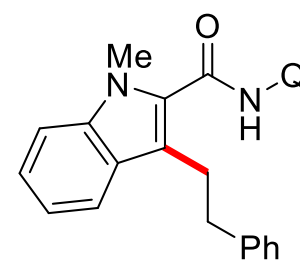

36d: $81 \%$

Scheme 1.16 Iron-catalyzed C-H alkylation with tosylates.

In a contribution by Cook, alkyl and benzyl halides were employed for alkylations and benzylations in which $\mathrm{Nal}$ or zinc salt as additives were not necessary (Scheme 1.17a). ${ }^{[51 b]}$ The key to success in this reaction was the slow addition of the Grignard reagent and the use of BHT in the transformation of secondary alky halides $\mathbf{3 8}$. In addition, based on the slow addition procedure and the short reaction time, the authors proposed that a phenyliron species formed by transmetallation from $\mathrm{PhMgBr}$, which immediately undergoes turnover-limiting coordination of the amide substrate, followed by rapid, irreversible C-H cleavage. Furthermore, Ackermann described an approach for methylation, alkylation and benzylation utilizing the modular click-triazole- 


\section{Introduction}

based TAM as the directing group (Scheme 1.17b).[51a] This powerful procedure enabled the $\mathrm{C}-\mathrm{H}$ alkylations with alkyl iodides, bromides, and even chlorides as the electrophile. Detailed studies revealed the reaction to proceed via a SETinduced C-Hal cleavage.

a) Cook<smiles>O=C(NO)c1ccccc1</smiles>

29

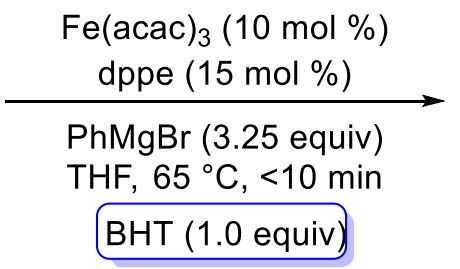

BHT (1.0 equiv)

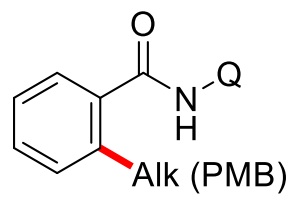

39<smiles>CSc1ccc(C(=O)NO)c([PH](=O)(=O)[O-])c1</smiles>

$39 a: 80 \%$<smiles>Cn1ccc(P)c1C(=O)NO</smiles>

39b: $61 \%$<smiles>O=C(NO)c1ccccc1C1CCCC1</smiles>

39c: $73 \%$

b) Ackermann

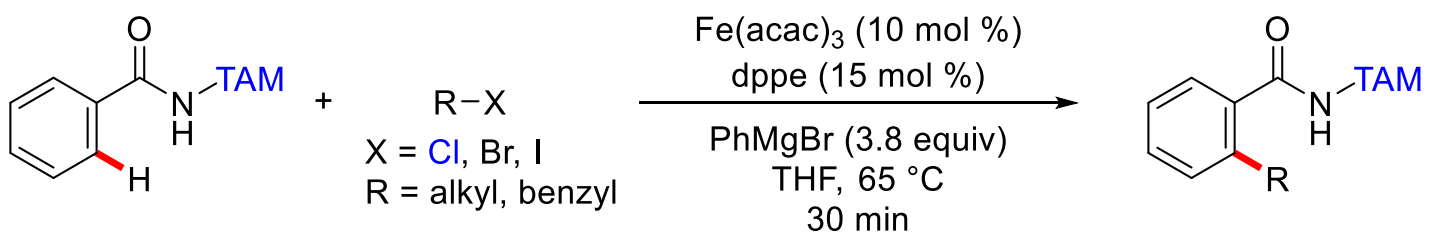

32

40

41<smiles>[Y10][AlH2]NC(=O)c1ccccc1[AlH2]</smiles>

Alk $=$ Me, $X=I(41 a): 75 \%$ Alk $=\mathrm{Bn}, \mathrm{X}=\mathrm{Cl}$ (41b): $76 \%$<smiles>CCOC(=O)CCCc1ccccc1C(=O)N[Te]</smiles>

41c: $60 \%$<smiles>[Y10][AlH2]NC(=O)c1ccsc1C1CCCC1</smiles>

41d: $53 \%$

Scheme 1.17 Iron-catalyzed alkylation and benzylation of amides with halides. 


\section{Introduction}

\subsubsection{Iron-Catalyzed C-H Annulation Reactions}

Apart from their application to $\mathrm{C}-\mathrm{H}$ alkylation, arylation and allylation reactions, low-valent iron species, which can be coordinated by the $\pi$-systems of alkynes, ${ }^{[56]}$ can promote $\mathrm{C}-\mathrm{H}$ annulation reactions.

Thus, Nakamura reported the iron-catalyzed oxidative [4 +2$]$ annulation of 2biaryl Grignard reagents $\mathbf{4 2}$ with alkynes $\mathbf{4 3}$ for the synthesis of phenanthrene derivatives 44 (Scheme 1.18a). ${ }^{[57]}$ Notably, not only internal alkynes but also terminal alkynes could be transformed. In addition, a similar approach for ironcatalyzed oxidative [2+2+2] annulations of aryl Grignard reagents 45 with two molecules of an internal alkyne $43 \mathbf{a}$ was achieved by the authors. ${ }^{[58]}$ Mechanistically, the reaction was proposed to proceed through iron-catalyzed carbometalation of the alkyne $43 a$ with the aryl Grignard reagent 45 , subsequent with intramolecular $\mathrm{C}-\mathrm{H}$ activation to form the five-membered ferracycle 46. Then insertion of a second molecule of alkyne 43a takes place to form intermediate $\mathbf{4 8}$, which undergoes reductive elimination and oxidation to afford the final product 49 and regenerate the active iron species (Scheme 1.18b). Furthermore, a combination of arylindium reagents with alkyl Grignard reagents was found to be a viable alternative for the synthesis of phenanthrene derivatives under redox-neutral conditions. ${ }^{[59]}$ 


\section{Introduction}

a) $[4+2]$ benzannulation<smiles>Brc1ccccc1-c1ccccc1</smiles>

42

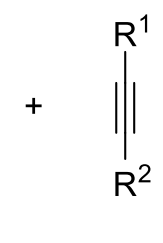

43

$$
\begin{aligned}
& \mathrm{Fe}(\mathrm{acac})_{3}(10 \mathrm{~mol} \%) \\
& \begin{array}{c}
\underset{\mathrm{DCIB}}{\mathrm{dtbpy}(10 \mathrm{~mol} \%)} \\
\underset{\mathrm{THF} / \mathrm{Et}_{2} \mathrm{O}, 25^{\circ} \mathrm{C}, 1 \mathrm{~h}}{\longrightarrow}
\end{array}
\end{aligned}
$$<smiles>[R]c1c([R])c2ccccc2c2ccccc12</smiles>

44: $96 \%$<smiles>c1ccc(-c2c(-c3ccccc3)c3ccccc3c3ccccc23)cc1</smiles>

44a: $96 \%$<smiles>c1ccc(-c2cc3ccccc3c3ccccc23)cc1</smiles>

44b: $44 \%$<smiles>Cc1c(C)c2ccccc2c2ccccc12</smiles>

44c: $59 \%$<smiles>CCCc1c(C(C)C)c2ccccc2c2ccccc12</smiles>

44d: $91 \%$<smiles>c1ccc(C2=C(c3ccccc3)C3CCCCC3c3ccccc32)cc1</smiles>

44e: $85 \%$

b) oxidative $[2+2+2]$ annulation<smiles></smiles>

45

$43 a$

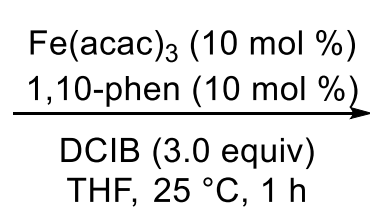

THF, $25^{\circ} \mathrm{C}, 1 \mathrm{~h}$<smiles>c1ccc(-c2c(-c3ccccc3)c(-c3ccccc3)c3ccccc3c2-c2ccccc2)cc1</smiles>

49: $73 \%$<smiles>FC(F)(F)[Mg][Mg]</smiles><smiles>[Al]C(=[Te])C(=C(c1ccccc1)c1ccccc1)c1ccccc1</smiles>

46

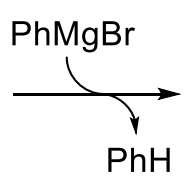

$\mathrm{PhH}$<smiles>Cl[Te]1(c2ccccc2)[Te]C(c2ccccc2)=C1c1ccccc1</smiles>

47<smiles>CC(=C[C+](C)(C)C(C)C)C(C)C(C)CCl</smiles><smiles>FC(F)(F)C(C(=C(c1ccccc1)c1ccccc1)c1ccccc1)=C(c1ccccc1)c1ccccc1</smiles>

48

Scheme 1.18 Iron-catalyzed annulation of alkynes with aryl Grignard reagents.

Nakamura ${ }^{[60]}$ and Ackermann ${ }^{[61]}$ reported iron-catalyzed formations of pyridone 50 and isoquinolone derivatives 52 by assistance of the well-established $Q$ and the modular triazolylmethyl (TAH) groups, respectively (Scheme 1.19). In contrast to iron-catalyzed transformations using organometallic reagents ${ }^{[45]}$ or organic electrophiles, ${ }^{[51 \mathrm{a}]}$ which prefer the bulky TAM group, the TAH group was shown to be more suitable for oxidative annulations. 


\section{Introduction}

a) Nakamura<smiles>[R]/C(=C/[C@H](C)C(C)C)C(=O)NO</smiles>

50a: $87 \%$<smiles>Cc1cc(C)c(=O)n(O)c1C#CC#N</smiles>

50b: $98 \%$<smiles>CC(C)c1c(C(C)C)n(O)c(=O)c2ccccc12</smiles>

50c: $98 \%$

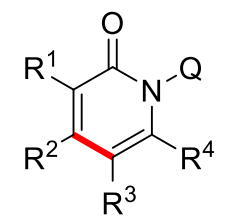

50

b) Ackermann<smiles>[R][CH][In]NC(=O)c1ccccc1</smiles>

51

43

$$
\begin{gathered}
\begin{array}{c}
\mathrm{Fe}(\mathrm{acac})_{3}(10 \mathrm{~mol} \%) \\
\text { dppe }(15 \mathrm{~mol} \%)
\end{array} \\
\begin{array}{c}
\mathrm{PrMgBr} \\
\mathrm{ZnBr}_{2} \cdot \mathrm{TMEDA}^{2}, \mathrm{DCIB}
\end{array}
\end{gathered}
$$$$
\mathrm{THF}, 60^{\circ} \mathrm{C}, 16 \mathrm{~h}
$$<smiles>[R]c1c([R])n([AlH2])c(=O)c2ccccc12</smiles>

52<smiles>CCCCc1c(CCCC)n([TlH])c(=O)c2ccccc12</smiles>

52a: $84 \%$<smiles>O=c1c2ccccc2c([N+](=O)[O-])c(-c2ccccc2)n1[TlH]</smiles>

52b: $74 \%$<smiles>Cc1sccc1-c1c(C)c2ccccc2c(=O)n1[AlH2]</smiles>

52c: $68 \%$<smiles>Cc1c(-c2ccccc2)c(-c2ccccc2)n(O)c(=O)c1C</smiles>

50d: $99 \%$

\section{Scheme 1.19 Iron-catalyzed $\mathrm{C}-\mathrm{H}$ annulations.}

Inspired by the work of Reed on iron(0)-mediated imine cyclometallations, ${ }^{[62]}$ Wang developed $\mathrm{Fe}_{3}(\mathrm{CO})_{12}$ catalyzed redox-neutral cyclizations of internal alkynes $\mathbf{4 3}$ with imines $\mathbf{5 3}$ for the synthesis of 3,4-dihydroisoquinolines 54 (Scheme 1.20). ${ }^{[63]}$ Despite this transformation featured neat reaction conditions, the coupling partners were limited in diarylethynes and poor regio-selectivity was observed when asymmetric alkyne was employed. 
<smiles>[R][X]C#C[R]</smiles>

$\mathrm{R}=$ aryl, alkyl

53

43

$$
\underset{\mathrm{Et}_{2} \mathrm{O}, 120^{\circ} \mathrm{C}, 12 \mathrm{~h}}{\stackrel{\mathrm{Fe}_{3}(\mathrm{CO})_{12}(10 \mathrm{~mol} \%)}{\longrightarrow}}
$$<smiles>[R2][C]1N=C([R])c2ccccc2[C@H]1[R1]</smiles>

54<smiles>PC1=CC=C[C@H](c2ccccc2)c2ccccc21</smiles>

54a: $60 \%$<smiles>CCCCC1=N[C@@H](c2ccccc2)[C@H](c2ccccc2)c2ccccc21</smiles>

54b: $46 \%$

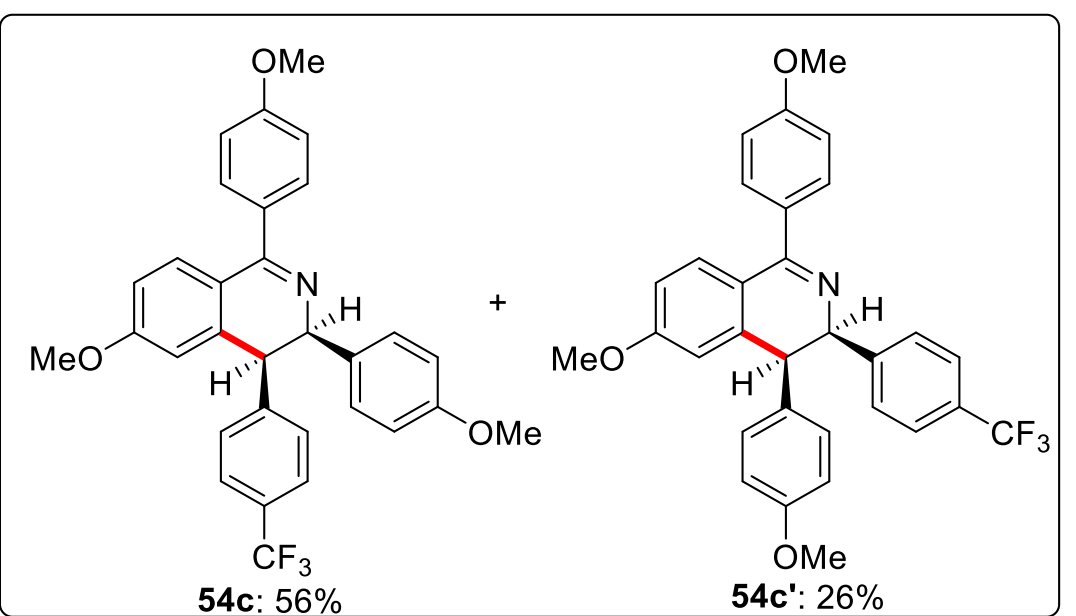

54c: $56 \%$

Scheme 1.20 Iron-catalyzed $\mathrm{C}-\mathrm{H}$ redox-neutral [4+2] cyclization.

Despite considerable progress, iron-catalyzed $\mathrm{C}-\mathrm{H}$ annulation reactions, thus far limited to alkynes as coupling partners, employing unsaturated coupling partners such as allenes and BCPs have not been developed.

Allenes have been recognized as increasingly useful building blocks in modern synthetic chemistry, ${ }^{[64]}$ due to inter alia their transformative utility, ${ }^{[65]}$ and various bioactive compounds and functional materials containing an allene moiety. ${ }^{[66]}$ However, compared to alkyne and alkene transformations, ${ }^{[67]}$ the application of allenes in catalyzed $\mathrm{C}-\mathrm{H}$ activation remains underdeveloped, and thus far dominated by precious $4 \mathrm{~d}$ and $5 \mathrm{~d}$ transition metals. ${ }^{[68]}$

Bicyclopropylidenes (BCPs) featuring two cyclopropane rings were identified as a useful structural motif for six membered ring formation. ${ }^{[69]}$ However, their applications in $\mathrm{C}-\mathrm{H}$ activation are narrow with three ruthenium-catalyzed $\mathrm{C}-\mathrm{H}$ hydroarylations being reported, in which the cyclopropane rings are conserved. [70] 


\section{Introduction}

\subsection{Transition Metal-Catalyzed C-H/C-C Activation}

Transition metal-catalyzed $\mathrm{C}-\mathrm{H}$ activation has gained significant attention for efficient $\mathrm{C}-\mathrm{C}$ and $\mathrm{C}-\mathrm{Het}$ formations. The past decade has witnessed the emergence of selective $\mathrm{C}-\mathrm{C}$ cleavages as a powerful tool for the construction of increasingly complex molecules, ${ }^{[71]}$ despite $\mathrm{C}-\mathrm{C}$ bonds usually being less sterically accessible and having less favorable orbital interactions with transition metal catalyst compared to $\mathrm{C}-\mathrm{H}$ bonds. ${ }^{[72]}$ Significant progress in this field was recently made by merging $\mathrm{C}-\mathrm{H}$ activation with challenging $\mathrm{C}-\mathrm{C}$ activation, ${ }^{[73]}$ which provided a new strategy for overcoming synthetic challenges and a method for the convenient preparation of novel molecules (Scheme 1.21).

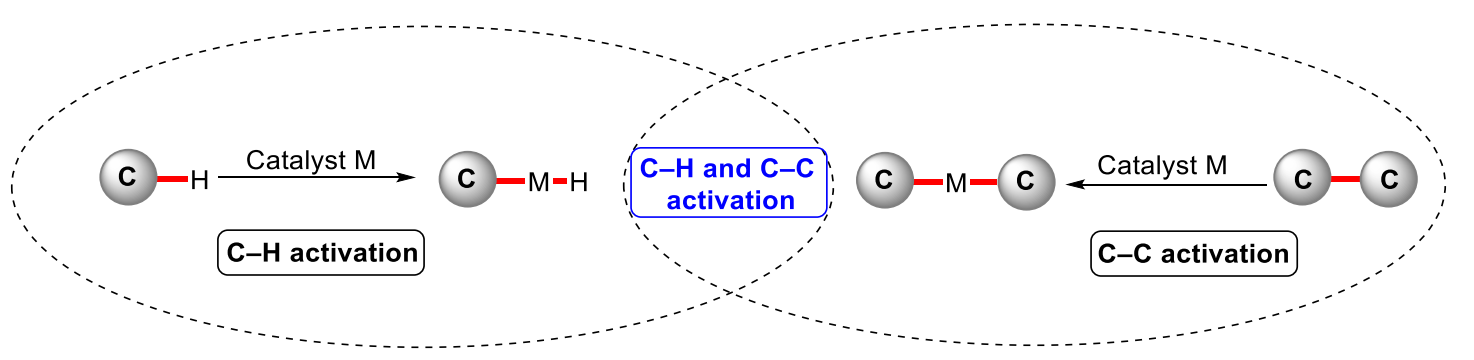

Scheme 1.21 Merging $\mathrm{C}-\mathrm{H}$ activation with $\mathrm{C}-\mathrm{C}$ activation.

To date, several mode of actions have been suggested for this novel strategy depending on the different kinds of substrates, including mainly: 1) combination of decarboxylation and $\mathrm{C}-\mathrm{H}$ activation, ${ }^{[74]}{ }^{2)}$ merging decarbonylation with $\mathrm{C}-$ $\mathrm{H}$ activation, ${ }^{[75]}$ and 3) functionalization of strained carbocycles ${ }^{[76]}$ (Scheme 1.22). The tandem reactions of decarboxylation and concomitant $\mathrm{C}-\mathrm{H}$ activation is highly desirable, due to the abundance and availability of aromatic carboxylic acids. For a successful transformation, a fine-tuning of the experimental conditions is required to avoid protodecarboxylation without $\mathrm{C}-\mathrm{H}$ activation as well as $\mathrm{C}-\mathrm{H}$ bond activation without decarboxylation (Scheme 1.22a). The decarbonylation of aldehydes through dual $\mathrm{C}-\mathrm{H}$ and $\mathrm{C}-\mathrm{C}$ activation became attractive to the scientific community after Wilkinson's catalyst was found to be effective for this transformation. ${ }^{75 a,}$, $\left.75 d-75 f\right]$ Typically, the 


\section{Introduction}

decarbonylation includes two elementary steps. First, $\mathrm{C}-\mathrm{H}$ activation of the aldehyde occurs, followed by $\mathrm{C}-\mathrm{C}$ cleavage and $\mathrm{CO}$ extrusion (Scheme 1.22b). The strain-release of highly strained carbocycles enabled $\mathrm{C}-\mathrm{C}$ cleavages by the assistance of transition metals (Scheme 1.22c), ${ }^{[77]}$ which provided access to novel molecules. ${ }^{[78]}$

a) decarboxylation accompanied by $\mathrm{C}-\mathrm{H}$ activation

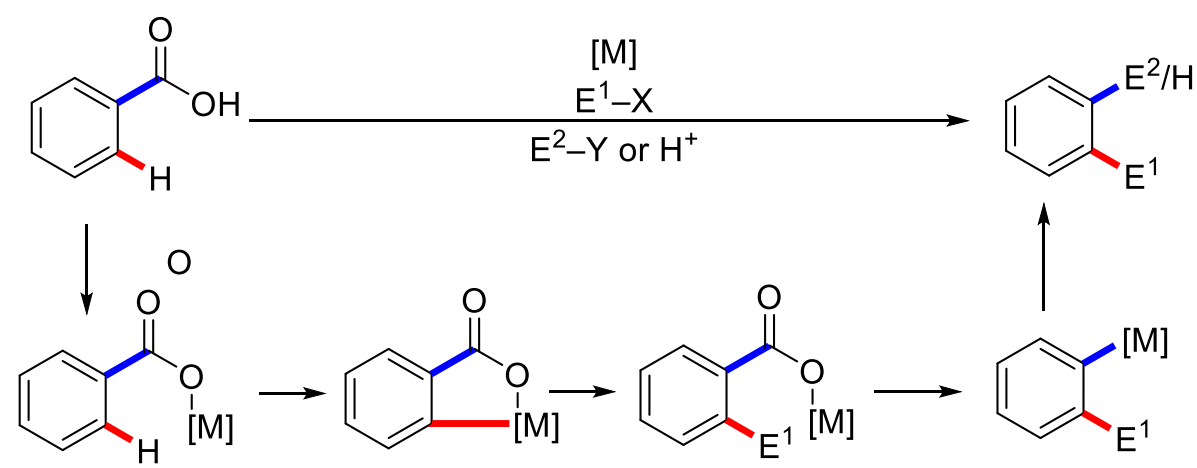

b) decarbonylation accompanied by $\mathrm{C}-\mathrm{H}$ activation

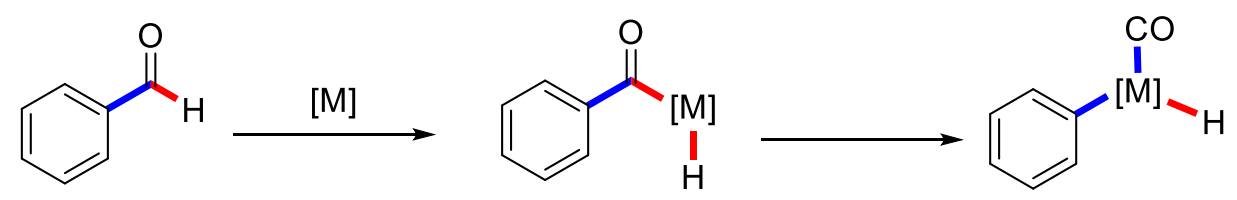

c) $\mathrm{C}-\mathrm{H}$ and $\mathrm{C}-\mathrm{C}$ activation of strained carbocycles

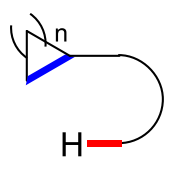<smiles>CCCC(C)C</smiles><smiles>C1CCCCCCCCCC1</smiles>

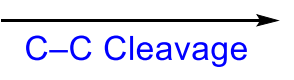<smiles>[M]C1CCCCC1</smiles>
$\mathrm{n}=0,1$
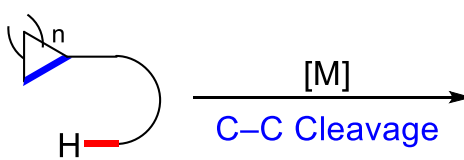

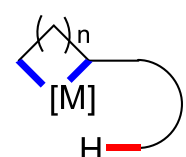

$\underset{\mathrm{C}-\mathrm{H} \text { Activation }}{\longrightarrow}$<smiles>C1=CCCCC1</smiles>
$\mathrm{n}=0,1$

Scheme 1.22 Manifolds of merging $\mathrm{C}-\mathrm{H}$ activation and $\mathrm{C}-\mathrm{C}$ cleavage.

The first example of this dual activation mode was reported by Bergman during a study on the mechanism of the formation of rhodacyclobutane 58 (Scheme 1.23). ${ }^{[79]}$ The $\mathrm{C}-\mathrm{H}$ bond of 1,1-dimethylcyclopropane 55 was activated by the rhodium species 56 at low temperature. Subsequently, by warming up the 


\section{Introduction}

reaction mixture, $\mathrm{C}-\mathrm{C}$ bond insertion took place to give the thermodynamic product 58.

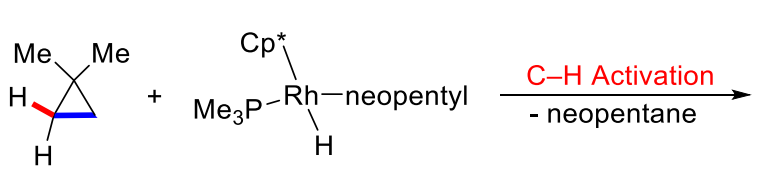

55

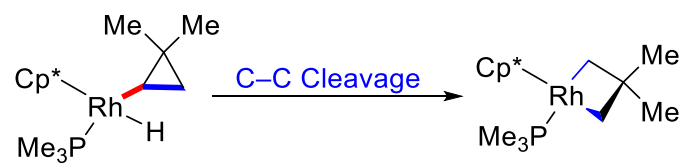

57

58: $99 \%$

Scheme 1.23 Dual activation of $\mathrm{C}-\mathrm{H}$ and $\mathrm{C}-\mathrm{C}$ bonds.

Inspired by the pioneering work of Bergman, strained ring systems for $\mathrm{C}-\mathrm{H}$ and C-C dual activations have thus been intensively studied. ${ }^{80]}$ In 2000, Shair reported the rhodium-catalyzed intramolecular $\mathrm{C}-\mathrm{H}$ activation and $\mathrm{C}-\mathrm{C}$ cleavage for the formation of cyclooctenone 63. ${ }^{[81]}$ The $\mathrm{C}-\mathrm{H}$ activation of the aldehyde moiety in 59 takes place first, then intermediate 60 undergoes intramolecular hydrometallation to form intermediate 61. After ring opening and reductive elimination, the final product 63 is obtained (Scheme 1.24). In order to avoid decarbonylation and guarantee high yields ethylene was necessary.

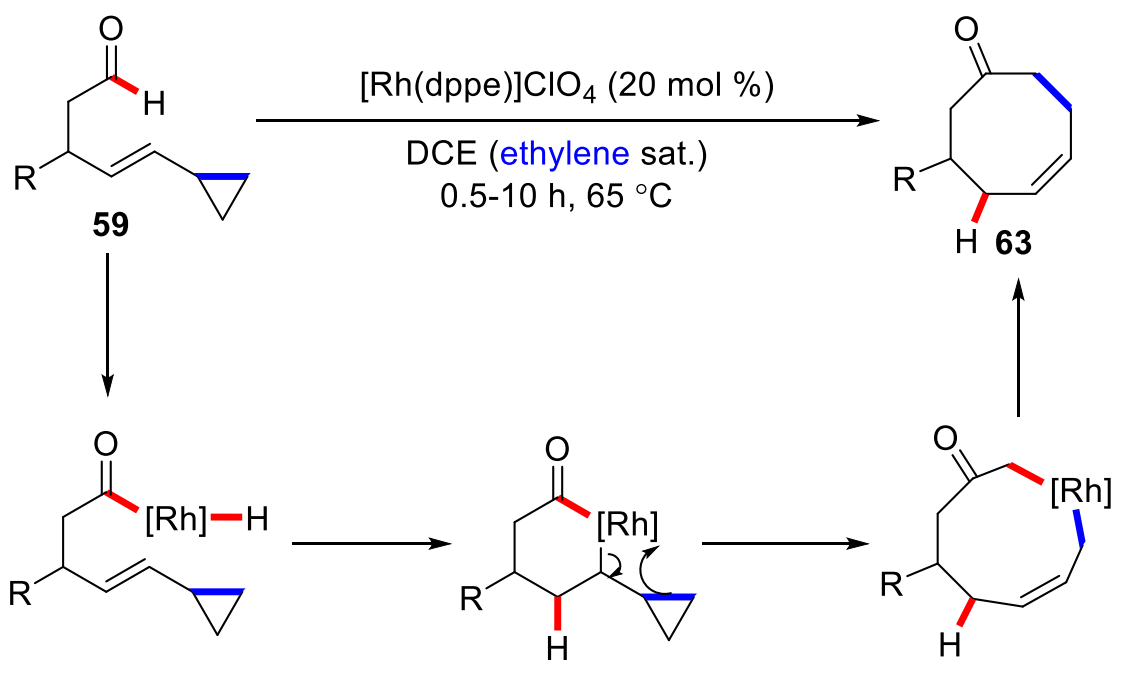

60

61

62

Scheme 1.24 Synthesis of cyclooctenone through dual C-H and C-C activation.

In 2011, Orellana disclosed the synthesis of benzodiquinanes 65 through palladium-catalyzed oxidative ring expansion of 1-vinyl-1-cyclobutanols 64 (Scheme 1.25). ${ }^{[82]}$ The generally moderate yields observed in this 


\section{Introduction}

transformation suggested the existence of other pathways, which led to several byproducts.

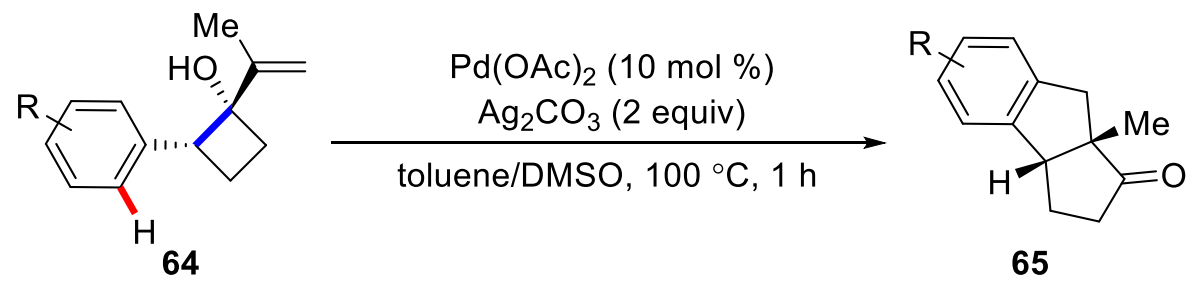

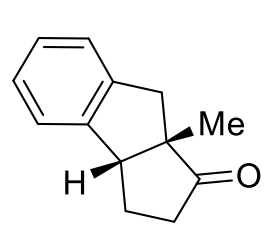

65a: $48 \%$

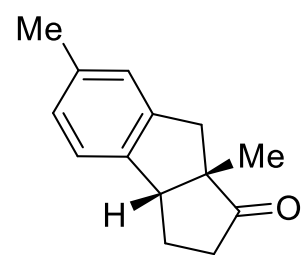

65b: $66 \%$<smiles>C[C@]12Cc3cc(Cl)cc(Cl)c3[C@H]1CCC2=O</smiles>

65c: $56 \%$<smiles>COc1cc2c(c(OC)c1OC)C[C@]1(C)C(=O)CC[C@H]21</smiles>

65d: $53 \%$

Scheme 1.25 Palladium-catalyzed oxidative ring expansion reaction.

The dual activation strategy was also viable for intermolecular reactions using rhodium or ruthenium catalysts. ${ }^{[83]}$ An early example of a dual activation manifold for intermolecular reactions was disclosed by Ackermann during their research on ruthenium-catalyzed hydroarylations of methylenecyclopropanes

a)<smiles>[CH2+]c1cccc(OC)c1-c1ccccn1</smiles>

66<smiles>[CH2+]c1cccc(OC)c1-c1ccccn1</smiles>

66<smiles>COc1cccc(-c2ccccn2)c1OC</smiles>

66<smiles>C=C1CC1c1ccccc1</smiles>

67

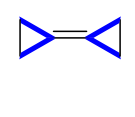

70

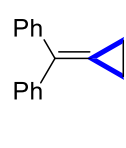

72<smiles>COc1cccc(CC2CC2Pc2ccccc2)c1C1=NCC=C1</smiles>

69: $78 \%$

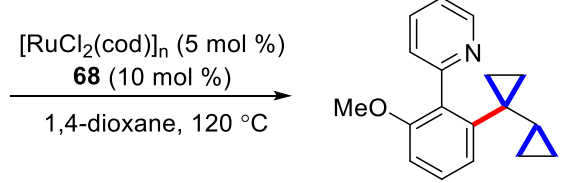

71: $85 \%$

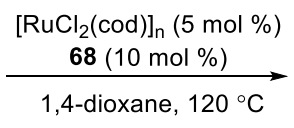<smiles>COc1cccc(CC(C)=C(c2ccccc2)c2ccccn2)c1-c1ccccc1</smiles>

73: $79 \%$

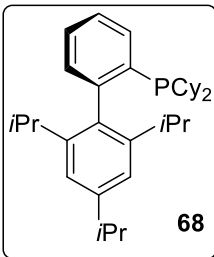<smiles>C=C(Cc1cccc(OC)c1-c1ccccn1)C(c1ccccc1)c1ccccc1</smiles>

73': $12 \%$

Scheme 1.26 Ruthenium-catalyzed hydroarylation reactions. 


\section{Introduction}

67 (Scheme 1.26a).[70b, 70c] It is worth noting that in the reactions with methylenecyclopropanes 67 or bicyclopropylidenes 70, the strained rings were conserved (Scheme 1.26a and 1.26b), while in the hydroarylation with benzhydrylidenecyclopropane 72 C-C cleavage occurred (Scheme 1.26c).

In 2013, Wu developed an intermolecular tandem $\mathrm{C}-\mathrm{H}$ and $\mathrm{C}-\mathrm{C}$ activation during their research on rhodium-catalyzed $\mathrm{C}-\mathrm{H}$ annulations of benzamide with methylenecyclopropanes (Scheme 1.27). ${ }^{[84]}$ From a mechanism perspective, $\mathrm{C}-\mathrm{H}$ activation proceeds through a concerted metalation-deprotonation sequence, followed by coordination and insertion of methylenecyclopropane 67 to furnish $\mathbf{7 5}$, the arylrhodium intermediate 76 then undergoes $\beta$-C-elimination and reductive elimination to yield product 77 .<smiles>[R]c1ccc(C(=O)NO[NH3+])o1</smiles>

74

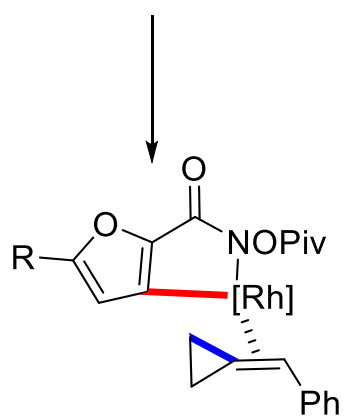

75

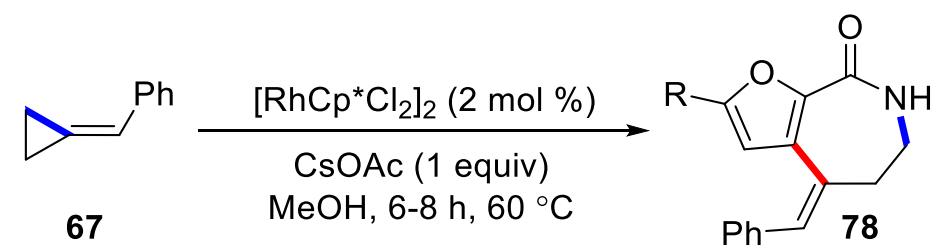

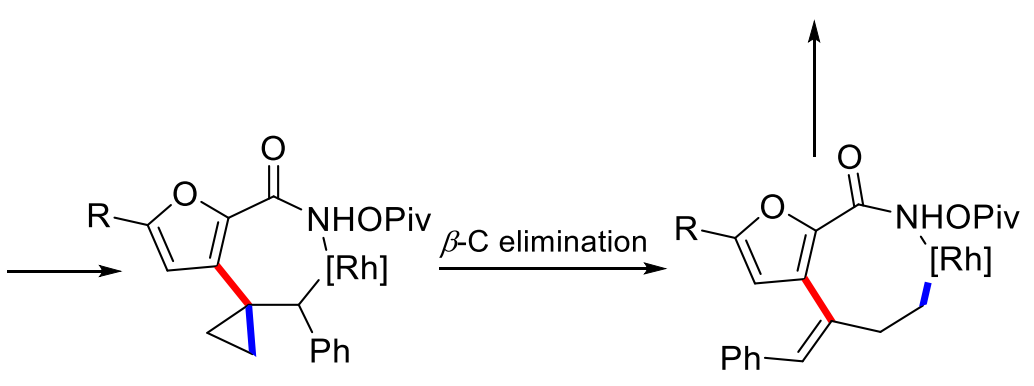

76
77

Scheme 1.27 Intermolecular tandem $\mathrm{C}-\mathrm{H}$ and $\mathrm{C}-\mathrm{C}$ activation.

During the past years, $3 \mathrm{~d}$ metal catalysis was proven to be an ideal alternative for tandem C-H and C-C activations. ${ }^{[24 c, 85]}$ In 2016, Ackermann disclosed the first example of cobalt-catalyzed $\mathrm{C}-\mathrm{H}$ activation and $\mathrm{C}-\mathrm{C}$ cleavage (Scheme 1.28a). ${ }^{[85 d]}$ The reaction featured a high catalytic efficacy at room temperature. In addition, this transformation resulted in an unprecedented diastereoselectivity affording the thermodynamically less stable Z-alkenes $\mathbf{8 1}$ 


\section{Introduction}

as the product. One year later, Ackermann reported the formation of tetracyclic compounds 84 through manganese-catalyzed stereoselective $\mathrm{C}-\mathrm{H} / \mathrm{C}-\mathrm{C}$ activation with methylenecyclopropane 83 (Scheme 1.28b). ${ }^{[24 c]}$ Excellent levels of positional selectivity as well as diastereoselectivity were achieved in this transformation.

a) Cobalt-catalyzed $\mathrm{C}-\mathrm{H} / \mathrm{C}-\mathrm{C}$ activation

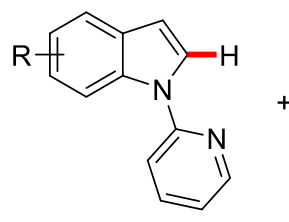

79

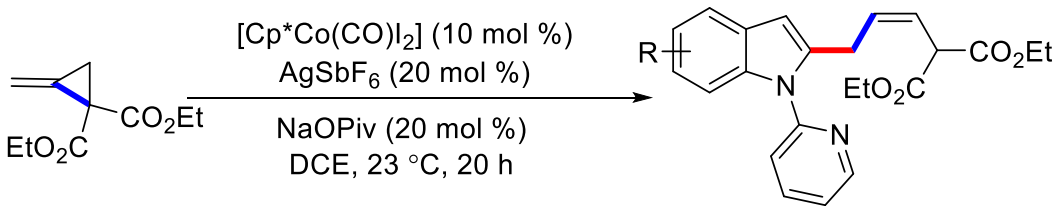

80

81<smiles>CCOC(=O)C(/C=C\Cc1cc2cc(OC)ccc2n1-c1ccccn1)CC</smiles>

81a: $82 \%(E / Z=1: 11)$

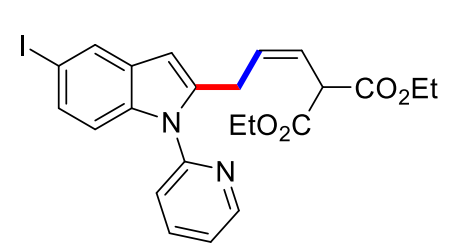

81b: $78 \%(E / Z=1: 14)$

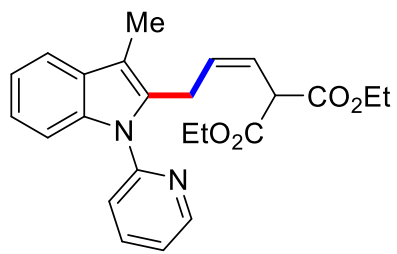

81c: $87 \%(E / Z=1: 9)$

b) Manganese-catalyzed C-H/C-C activation

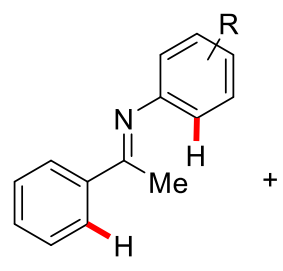

82

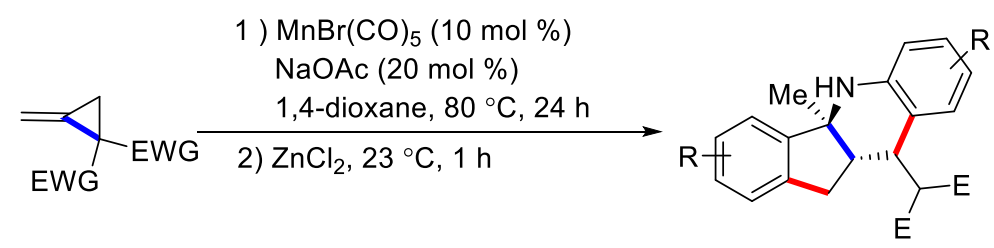

84

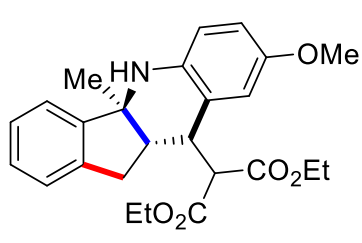

84a: $74 \%(10 \mathrm{mmol})$

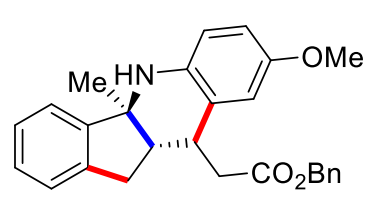

84b: $55 \%$<smiles></smiles>

84c: $74 \%$

Scheme $1.283 \mathrm{~d}$ metal-catalyzed tandem $\mathrm{C}-\mathrm{H}$ and $\mathrm{C}-\mathrm{C}$ activation.

Tandem $\mathrm{C}-\mathrm{H}$ activation/C-C cleavage reactions can also occur under assistance of bidentate directing groups, using cobalt acetate as the catalyst 


\section{Introduction}

(Scheme 1.29). ${ }^{[85 a]}$ Instead of a reductive elimination to form a C-N bond, which is observed in the rhodium-catalyzed annulation of alkylidenecyclopropanes annulations, ${ }^{[84]}$ a second $\mathrm{C}-\mathrm{H}$ activation occurred to form the ring opening product $\mathbf{8 7}$ under cobalt catalysis.<smiles>O=C(Nc1cccc2cccnc12)c1ccccc1</smiles>

29<smiles>CC=[Tl]</smiles><smiles>O=C1c2ccccc2C2(CC2)C(c2ccccc2)C1(Cl)c1ccccc1</smiles>

85<smiles>C(=C1[CH+]C1)c1ccccc1</smiles>

67

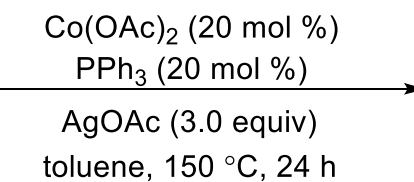

toluene, $150{ }^{\circ} \mathrm{C}, 24 \mathrm{~h}$<smiles>O=C(Nc1cccc2cccnc12)c1ccccc1C1=Cc2ccccc2CC1</smiles>

87

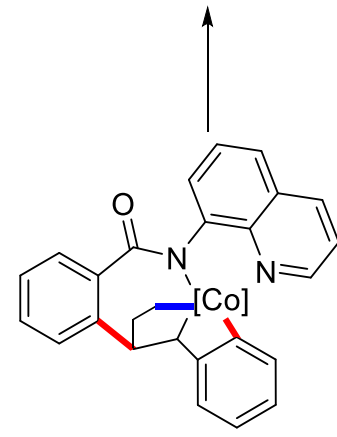

86

Scheme 1.29 Cobalt-catalyzed C-H/C-C/C-H activation. 


\section{Objectives}

\section{Objectives}

Transition metal-catalyzed $\mathrm{C}-\mathrm{H}$ activations have emerged as a powerful platform for efficient and sustainable $\mathrm{C}-\mathrm{C}$ and $\mathrm{C}-$ Het bond formations. While most transformations were accomplished with precious and toxic $4 \mathrm{~d}$ and $5 \mathrm{~d}$ metal catalysts, sustainable catalytic manifolds by $3 \mathrm{~d}$ metal catalysis, ${ }^{[30]}$ and especially iron-catalyzed $\mathrm{C}-\mathrm{H}$ transformations, $\left.{ }^{[31}, 33,86\right]$ have attracted significant attention due to their Earth-abundance, cost-efficiency, and low toxicity. ${ }^{[32]}$

Despite considerable progress, iron-catalyzed C-H annulation reactions ${ }^{[57-61,63]}$ continue to be challenging transformation with major limitations in: 1) types of coupling partners with only alkynes were reported thus far, 2) the requirement of an excess of DCIB as an external oxidant, 3) lack of product diversity, due to a narrow substrate scope in some cases, 4) not fully elucidated reaction mechanism, and 5) absence of efficient protocols for removal of the TAH group.

Therefore, it is highly desirable to establish a novel approach for low-valent ironcatalyzed $\mathrm{C}-\mathrm{H}$ annulations with allenes under redox-neutral conditions (Scheme 2.1).

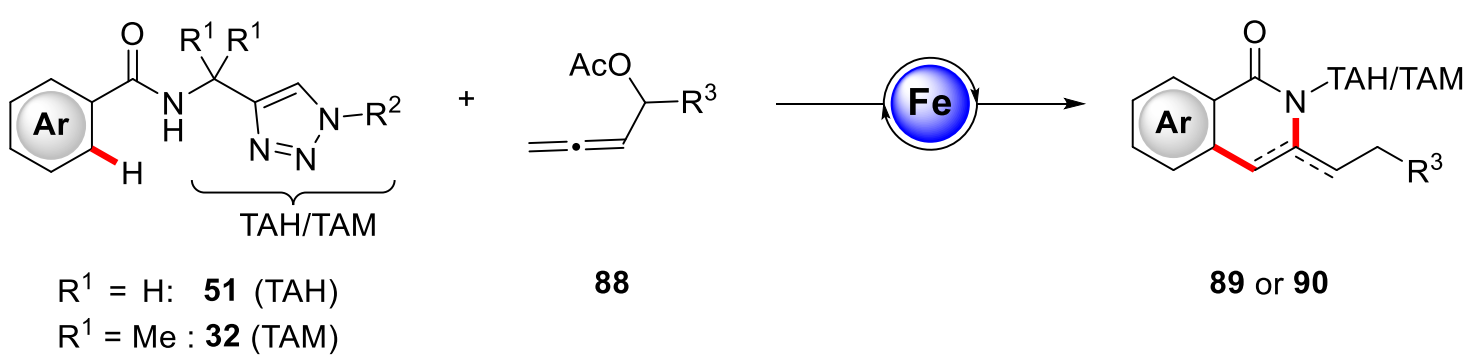

Scheme 2.1 Iron-catalyzed redox-neutral annulation with allenes.

Remaining limitations in iron-catalyzed $\mathrm{C}-\mathrm{H}$ alkyne annulation, such as the lack of detailed mechanistic studies and efficient procedures to remove the TAH group, promoted us to develop iron-catalyzed $\mathrm{C}-\mathrm{H}$ annulations with propargyl acetates with the main purpose to shed light on the mechanism of iron- 


\section{Objectives}

catalyzed redox-neutral annulations with alkynes and the removal of TAH group (Scheme 2.2).

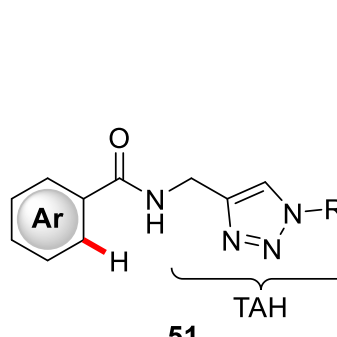

51

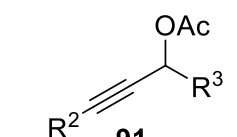

91

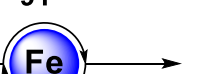

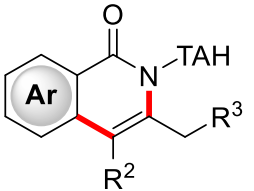

92

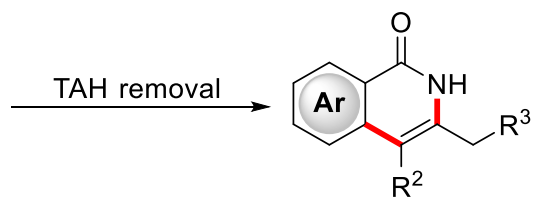

93

Scheme 2.2 Iron-catalyzed redox-neutral annulation with alkynes.

A significant stimulus in $\mathrm{C}-\mathrm{H}$ activation chemistry was recently gained by merging $\mathrm{C}-\mathrm{H}$ activation with challenging $\mathrm{C}-\mathrm{C}$ cleavages. $\left.{ }^{[71,} 73\right]$ While considerable progress has been achieved, this methodology was still limited by 1) the requirement of precious metals, ${ }^{[83-84]}$ 2) activated vinylcyclopropanes, ${ }^{[24 c, 85 b-85 d]}$ and 3) harsh oxidative conditions. ${ }^{[85 a]}$ Thus, a protocol to overcome these limitations would be highly desirable.

To combine $\mathrm{C}-\mathrm{H}$ activation with challenging $\mathrm{C}-\mathrm{C}$ activation under iron catalysis as well as to further diversify the application of BCPs in $\mathrm{C}-\mathrm{H}$ activation, the application of bicyclopropylidene derivatives in iron-catalyzed $\mathrm{C}-\mathrm{H} / \mathrm{C}-\mathrm{C}$ activation should prove highly valuable (Scheme 2.3). 


\section{Objectives}

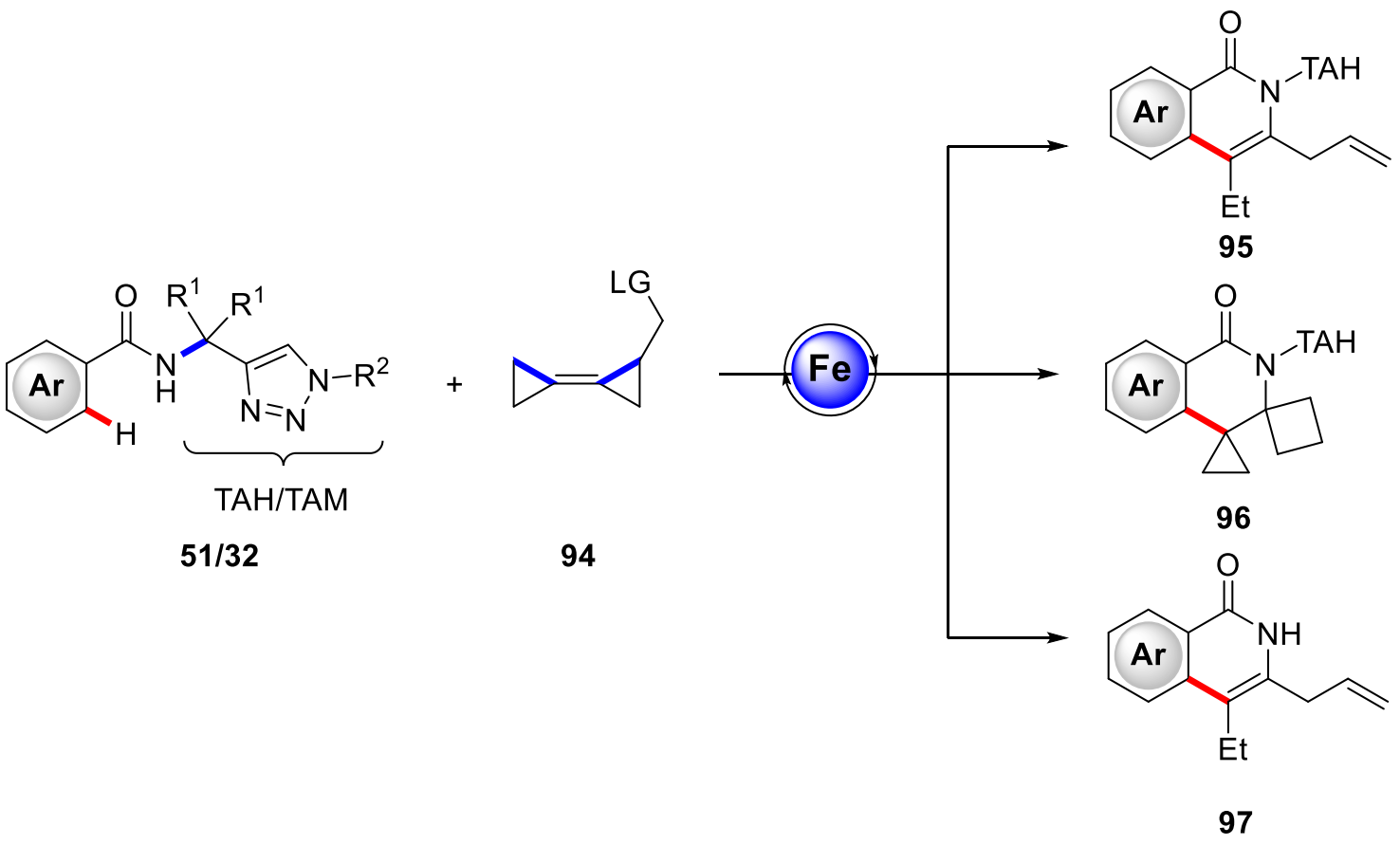

Scheme 2.3 Iron-catalyzed C-H/C-C activation with BCPs. 
3. Results and Discussion

\section{Results and Discussion}

\subsection{Iron-Catalyzed $\mathrm{C}-\mathrm{H} / \mathrm{N}-\mathrm{H}$ Allene Annulation}

Iron-catalyzed C-H oxidative annulations have emerged as a powerful tool for $\mathrm{N}$-heterocycle constructions. While these strategies were limited to alkynes as the coupling partners and highlighted the requirement of an excess of DCIB as the external oxidant, a study of iron-catalyzed $\mathrm{C}-\mathrm{H}$ oxidative annulations with alternative coupling partners under redox-neutral conditions would be highly considerable.

\subsubsection{Optimization Studies}

The optimization studies began by probing various reaction conditions for the envisioned iron-catalyzed $\mathrm{C}-\mathrm{H}$ functionalization of benzamide 51a with allene 88a (Table 3.1). The investigation on the amount of solvent and the addition order of allenes (see general procedure GPA') indicated that a high concentration of Grignard reagent and zinc salts was required for the formation of the active iron catalyst (entries 1-3). In addition, the use of biomass-derived solvent ${ }^{[87]}$ 2-MeTHF delivered product 89 aa in moderate yield (entry 4). $\mathrm{PrMgBr}$ proved to be the additive of choice (entries 5 and 6). The allene annulation smoothly occurred at room temperature and with reduced catalyst loading (entries 7-10). 


\section{Results and Discussion}

Table 3.1 Optimization of iron-catalyzed $\mathrm{C}-\mathrm{H}$ activation with allenes 88a.

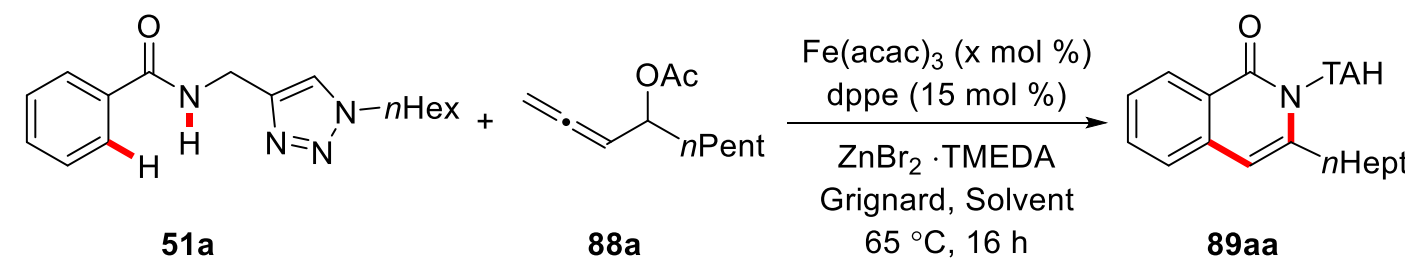

\begin{tabular}{|c|c|c|c|c|}
\hline Entry & $\mathrm{X} \mathrm{mol} \mathrm{\%}$ & Grignard reagent & Solvent (y mL) & Yield/\% \\
\hline 1 & 15 & PrMgBr & THF (1.0) & $44^{[\mathrm{b}]}$ \\
\hline 2 & 15 & IPrMgBr & THF $(0.4)$ & 91 \\
\hline 3 & 15 & PPrMgBr & THF $(0.4)$ & $46^{[c]}$ \\
\hline 4 & 15 & PrMgBr & 2-MeTHF (0.4) & $59^{[b]}$ \\
\hline 5 & 15 & $\mathrm{MeMgBr}$ & THF $(0.4)$ & 71 \\
\hline 6 & 15 & iPrMgCl & THF (0.4) & 64 \\
\hline 7 & 15 & PrMgBr & THF (0.4) & $66^{[\mathrm{d}]}$ \\
\hline 8 & 1 & PrMgBr & THF (0.4) & 38 \\
\hline 9 & 5 & IPrMgBr & THF (0.4) & 35 \\
\hline 10 & 10 & $\mathrm{PrMgBr}$ & THF (0.4) & 82 \\
\hline
\end{tabular}

[a] Reaction conditions: $51 \mathrm{a}\left(0.30 \mathrm{mmol}\right.$ ), 88a (3 equiv), $\mathrm{Fe}(\mathrm{acac})_{3}$ (x mol \%), dppe (15 mol \%), $\mathrm{ZnBr}_{2} \cdot \mathrm{TMEDA}^{2}$ (2 equiv), Grignard reagent (3.0 M, 3 equiv), Solvent (y mL), $65^{\circ} \mathrm{C}, 16 \mathrm{~h}$; yields of isolated products. [b] used $51 \mathrm{a}(0.15 \mathrm{mmol})$ [c] adding $88 \mathrm{a}$ at the same time with catalyst. [d] $25^{\circ} \mathrm{C}$.

To further optimize the reaction, different types of catalyst, ligand and leaving group were tested in the transformation (Table 3.2). The unique power of the iron catalysis regime was reflected by cobalt, manganese and nickel catalysts falling short in providing the desired product 89aa (entries 1-5). Various simple phosphine and nitrogen-based ligand were also tested, but failed to provide the 


\section{Results and Discussion}

desired product 89aa in synthetically useful yields (entries 6-12). The investigation on different leaving groups revealed allenyl acetate $8 \mathbf{8 a}$ to be optimal for an external-oxidant-free $\mathrm{C}-\mathrm{H}$ annulation (entries 13-17).

Table 3.2 Optimization of iron-catalyzed $\mathrm{C}-\mathrm{H}$ activation with allenes $\mathbf{8 8}$.<smiles>[R10]Cn1cc(CNC(=O)c2ccccc2)nn1</smiles>

$51 \mathrm{a}$<smiles>C=CC(C=C)C(O)(Cl)Cl</smiles>

88

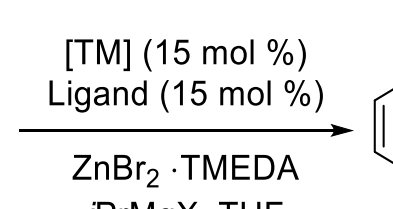
iPrMgX, THF $65^{\circ} \mathrm{C}, 16 \mathrm{~h}$<smiles>O=c1c2ccccc2cc([Hg][Tl])n1[AlH2]</smiles>

89aa

\begin{tabular}{|c|c|c|c|c|}
\hline Entry & [TM] & Ligand & LG & Yield [\%] \\
\hline 1 & --- & dppe & OAc (88a) & --- \\
\hline 2 & $\mathrm{CoCl}_{2}$ & dppe & OAc (88a) & --- \\
\hline 3 & $\mathrm{MnCl}_{2}$ & dppe & OAc (88a) & --- \\
\hline 4 & $\mathrm{Ni}(\mathrm{acac})_{2}$ & dppe & OAc (88a) & --- \\
\hline 5 & $\mathrm{Fe}(\mathrm{acac})_{3}$ & dppe & OAc (88a) & 91 \\
\hline 6 & $\mathrm{Fe}(\mathrm{acac})_{3}$ & dppen & OAc (88a) & 25 \\
\hline 7 & $\mathrm{Fe}(\mathrm{acac})_{3}$ & $\mathrm{dppz}$ & OAc (88a) & trace \\
\hline 8 & $\mathrm{Fe}(\mathrm{acac})_{3}$ & $\mathrm{PPh}_{3}$ & OAc (88a) & --- \\
\hline 9 & $\mathrm{Fe}(\mathrm{acac})_{3}$ & dppp & OAc (88a) & --- \\
\hline 10 & $\mathrm{Fe}(\mathrm{acac})_{3}$ & Xantphos & OAc (88a) & --- \\
\hline 11 & $\mathrm{Fe}(\mathrm{acac})_{3}$ & phen & OAc (88a) & --- \\
\hline 12 & $\mathrm{Fe}(\mathrm{acac})_{3}$ & 2,2'-bipyridine & OAc (88a) & --- \\
\hline 13 & $\mathrm{Fe}(\mathrm{acac})_{3}$ & dppe & $\mathrm{Cl}(\mathbf{8 8 b})$ & 16 \\
\hline
\end{tabular}


3. Results and Discussion

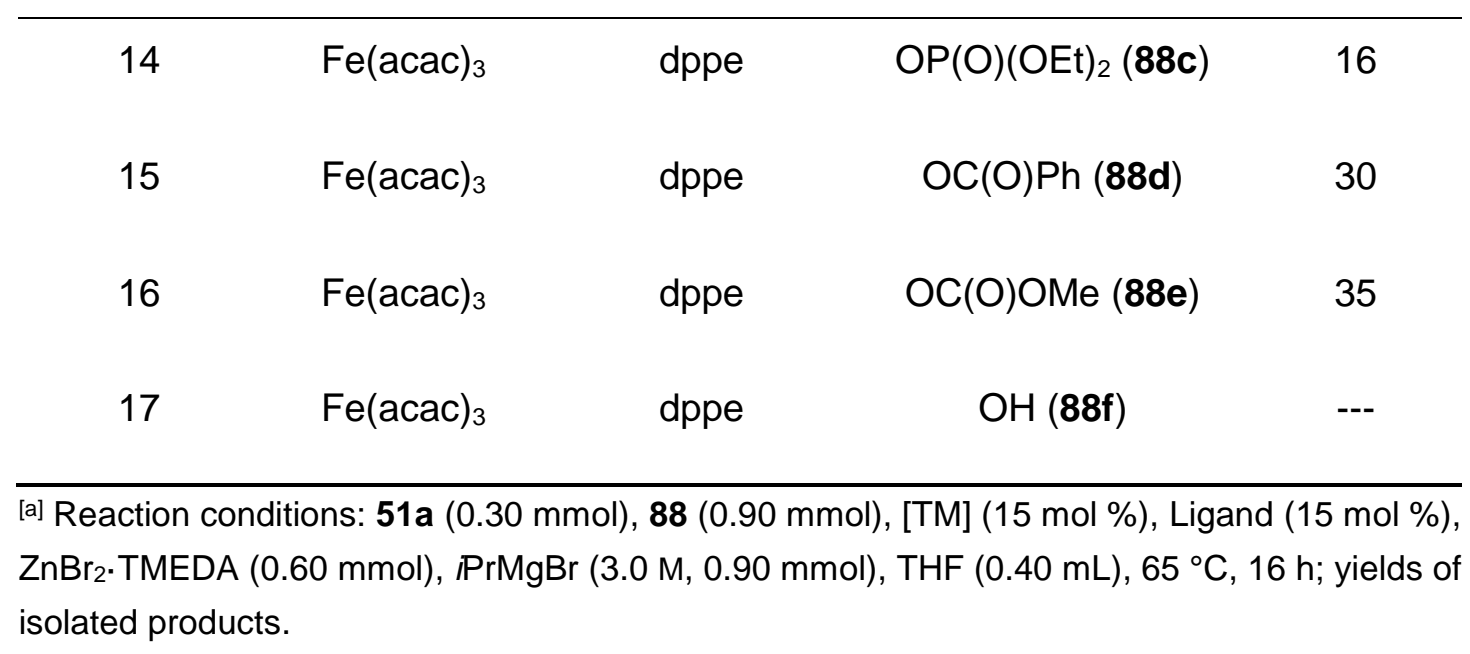

\subsubsection{Impact of Directing Group on C-H Functionalization}

With the optimized condition in hand, we further tested the impact of various bidentate directing group on this transformation (Table 3.3). Thus, a variety of methylene-tethered triazoles TAH delivered the desired isoquinolones 89aa89da in high yields (entries 1-4), tolerating among others a reactive alkyl chloride 51d without any cross-coupling products being observed. In addition, the modular nature of the triazole group further enabled the synthesis of the non-aromatic exo-methylene dihydroisoquinolines 90 through the judicious choice of the TAM group which was proved to be invalid for iron-catalyzed C$\mathrm{H}$ annulation with alkynes ${ }^{[61]}$ (entries 5-7). However, other bulky groups at the triazole directing group did not give the desired product (entries 8-9). 


\section{Results and Discussion}

Table 3.3 Impact of directing group on $\mathrm{C}-\mathrm{H}$ functionalization.

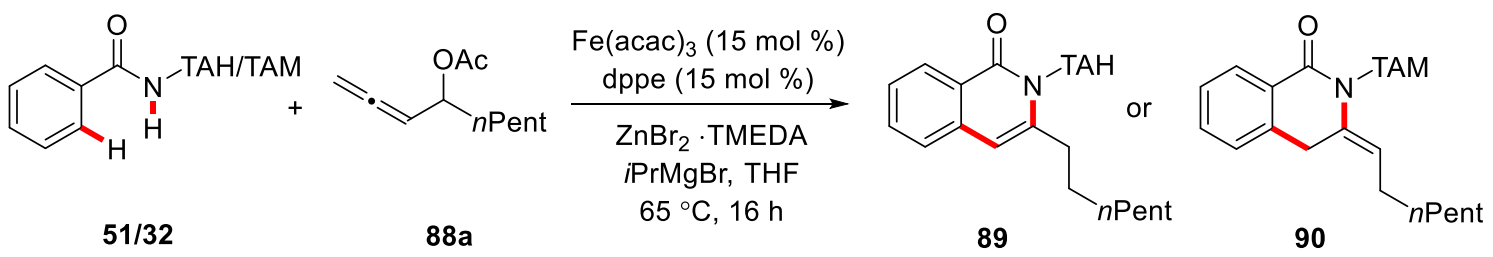

\section{Entry \\ 1<smiles>CCn1cc(CNC(=O)c2ccccc2)nn1</smiles>

$51 a$

2<smiles>COn1cc(CNC(=O)c2ccccc2)nn1</smiles>

$51 b$

3<smiles>O=C(NCc1cn(Cc2ccccc2)nn1)c1ccccc1</smiles>

$51 c$

4<smiles>Cn1cc(CNC(=O)c2ccccc2)nn1</smiles>

51d

5<smiles>CCCCn1cc(C(C)(C)NC(=O)c2ccccc2)nn1</smiles>

$89 / 90$

Yield

[\%]<smiles>O=c1c2ccccc2cc(CCP(O)O)n1Cc1cn(C[Ge])nn1</smiles>

89aa<smiles>CCOn1cc(Cn2c(CCP(c3ccccc3)c3ccccc3)cc3ccccc3c2=O)nn1</smiles>

89ba<smiles>O=c1c2ccccc2cc(CCP(c2ccccc2)c2ccccc2)n1Cc1cn(Cc2ccccc2)nn1</smiles>

$89 \mathrm{ca}$<smiles>Cn1cc(Cn2c(CCP(O)c3ccccc3)cc3ccccc3c2=O)nn1</smiles>

89da<smiles>CCCCn1cc(C(C)(C)N2C(=O)c3ccccc3C/C2=C\CP(=O)(O)c2ccccc2)nn1</smiles> 
6<smiles>CC(C)(NC(=O)c1ccccc1)c1cn(Cc2ccccc2)nn1</smiles>

$32 b$

7<smiles>CC(C)(NC(=O)c1ccccc1)c1cn(PN)nn1</smiles>

$32 \mathrm{c}$<smiles>O=C(NC(c1ccccc1)(c1ccccc1)c1cn(Cc2ccccc2)nn1)c1ccccc1</smiles>

32d

9<smiles>O=C(NC1(c2cn(Cc3ccccc3)nn2)CCCCC1)c1ccccc1</smiles>

8<smiles>CCCCC=C1Cc2ccccc2C(=O)N1C(C)(C)c1cn(Cc2ccccc2)nn1</smiles>

$90 \mathrm{ba}$<smiles>CC(C)(c1cn(P)nn1)N1C(=O)c2ccccc2C/C1=C\CCP</smiles>

$90 \mathrm{ca}$

$32 \mathrm{e}$

[a] Reaction conditions: 51/32 $(0.30 \mathrm{mmol}), \mathbf{8 8 a}(0.90 \mathrm{mmol}), \mathrm{Fe}(\mathrm{acac})_{3}(15 \mathrm{~mol} \%)$, dppe (15 mol \%), ZnBr2. TMEDA (0.60 mmol), $\operatorname{PrMgBr}(3 \mathrm{M}, 0.90 \mathrm{mmol}), \operatorname{THF}(0.40 \mathrm{~mL}), 65^{\circ} \mathrm{C}, 16$ $\mathrm{h}$; yields of isolated products.

No transformation was observed when employing bidentate directing groups which were otherwise widely used in $3 d$ transition metal catalyzed system (Scheme 3.1). These observations suggested that the structure as well as the electronic properties of the directing group are crucial to achieve successful C$\mathrm{H}$ activation catalyzed by the in situ generated low-valent iron species. 


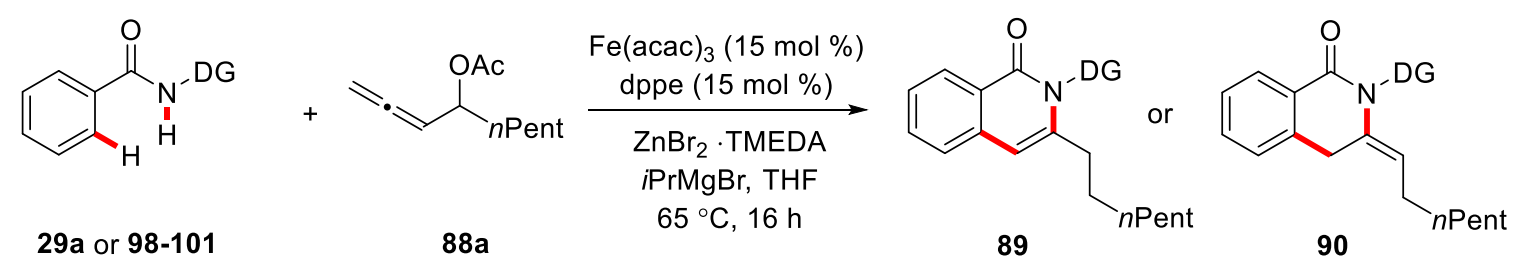<smiles>Cc1ccc(C(=O)Nc2cccc3cccnc23)cc1</smiles>

29a: N.R.<smiles>Cc1ccc(C(=O)NCc2ccccn2)cc1</smiles>

98: N.R<smiles>Cc1ccc(C(=O)Nc2ccccc2NC(=O)C(C)(C)C)cc1</smiles>

99: N.R.<smiles>Cc1c(C(=O)NC(C)c2ccccc2)nnn1Cc1ccccc1</smiles>

100: N.R.<smiles>CC(NC(=O)c1ccccn1)c1ccccc1</smiles>

101: N.R.

Scheme 3.1 Limitations on directing group. ${ }^{[a]}$

\subsubsection{Substrate Scope and Limitations}

Under the optimized iron-catalyzed $\mathrm{C}-\mathrm{H}$ activation conditions, we next explored its versatility with a range of substituted TAH-benzamides 51 (Table 3.4). With regard to para-substituted $\mathrm{TAH}$-benzamides $\mathbf{5 1 e - 5 1 j}$, the corresponding isoquinolone products $89 \mathrm{ea-89ja}$ were obtained in moderate to high yields, (entries 2-7). Likewise, chloro at the para-position 51j were efficiently converted to synthetically useful isoquinolones without any dehalogenation product being observed (entrie 7). Di-substituted benzamides 51k and 51I yielded the corresponding products 89ka and 89la in good regioselectivity (entries 8 and 9). Furthermore, thiophenyl-derived benzamide $51 \mathrm{~m}$ furnishing the desired products $89 \mathrm{ma}$ in moderate yield, while furanyl-derived benzamide 51n proved to be unsuitable for the transformation (entries 10 and 11). Unfortunately, the olefinic $\mathrm{C}\left(\mathrm{sp}^{2}\right)-\mathrm{H}$ and aliphatic $\mathrm{C}\left(\mathrm{sp}^{3}\right)-\mathrm{H}$ bond were incompatible for this transformation (entries 12-14). 
Table 3.4 Substrate scope of TAH benzamide $5 \mathbf{1 .}$

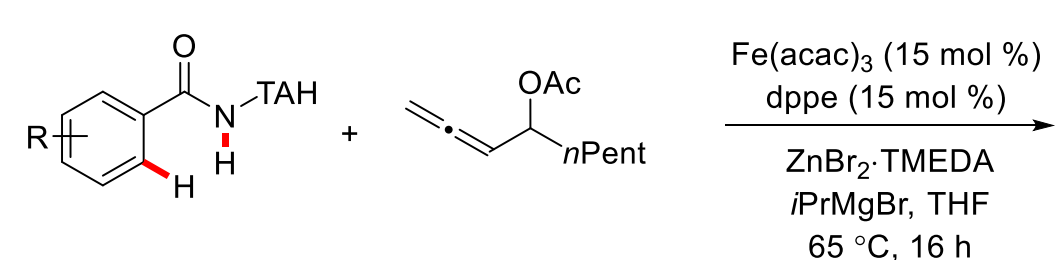

51

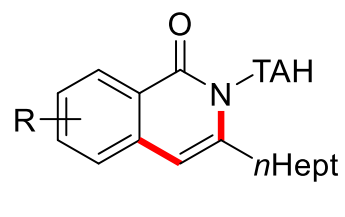

89

(2)]




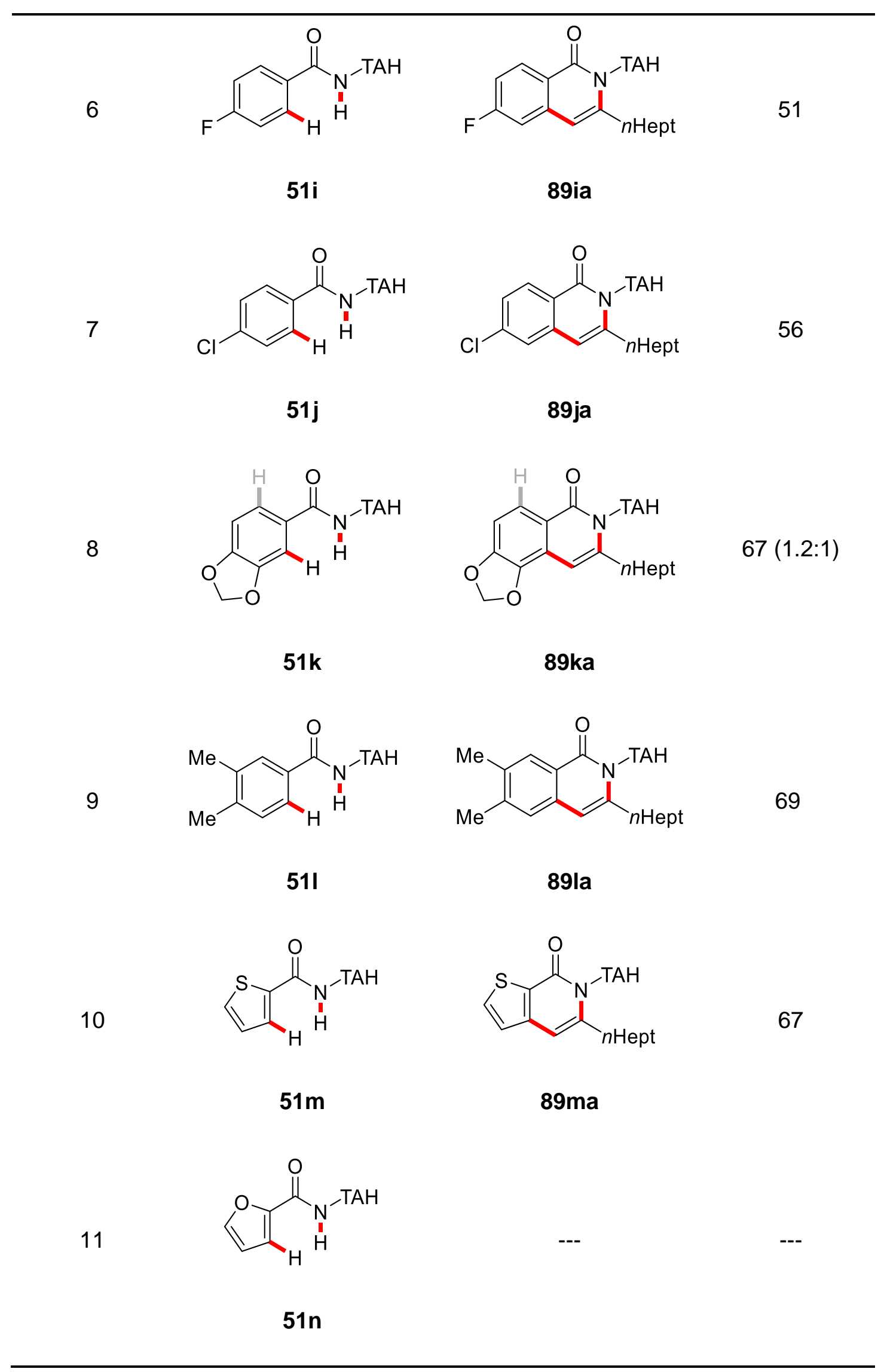


12<smiles>O=C(N[Tl])C1=CCCCC1</smiles>

510

13

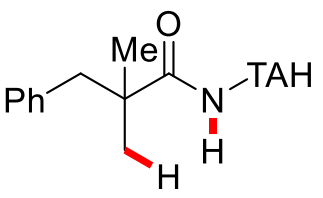

$51 p$

14<smiles>O=C(N[Tl])C1CCCCC1</smiles>

$51 q$

[a] Reaction conditions: 51 (0.30 mmol), 88a $(0.90 \mathrm{mmol}), \mathrm{Fe}(\mathrm{acac})_{3}(15 \mathrm{~mol} \%)$, dppe (15 mol \%), ZnBr2.TMEDA (0.60 mmol), $\operatorname{PrMgBr}(3.0 \mathrm{M}, 0.90 \mathrm{mmol}), \operatorname{THF}(0.40 \mathrm{~mL}), 65^{\circ} \mathrm{C}$, $16 \mathrm{~h}$; yields of isolated products.

The modular nature of the triazole group TAM provided an access to various exo-methylene isoquinolines 90 with ample scope (Table 3.5). Differently decorated aromatic amides delivered the desired products $90 \mathrm{fa}-90 \mathrm{ja}$ with high levels of positional selectivity control, with the reaction occurring at the less sterically congested site (entries $1-6)$. However, other types of $\mathrm{C}\left(\mathrm{sp}^{2}\right)-\mathrm{H}$ bond, such as in furanyl-, naphthyl-, olefinic and $\mathrm{C}\left(\mathrm{sp}^{3}\right)-\mathrm{H}$ bonds fell short in the envisioned iron-catalyzed annulations (entries 7-11). 


\section{Results and Discussion}

Table 3.5 Substrate scope of TAM benzamide.
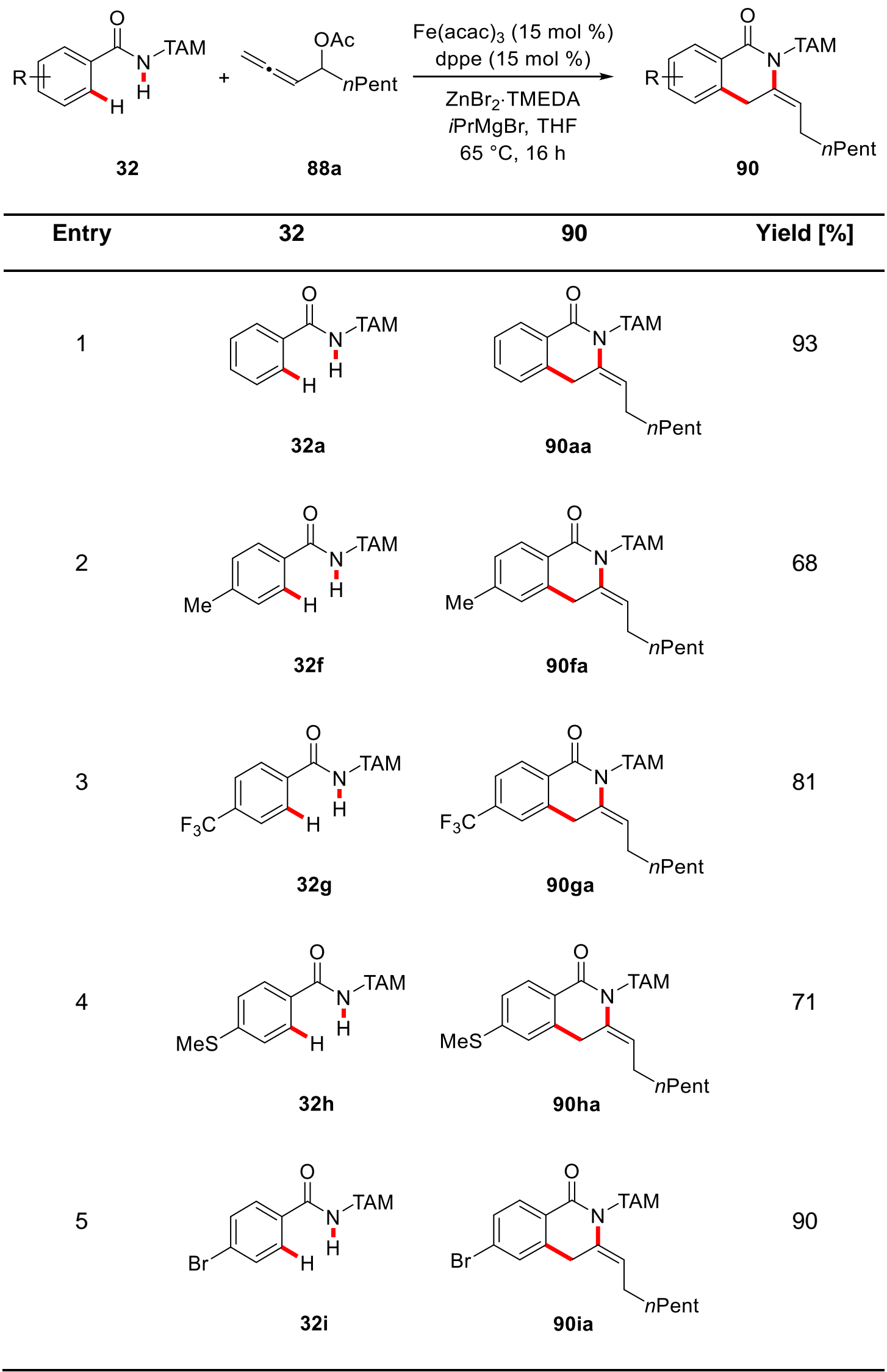


\section{Results and Discussion}

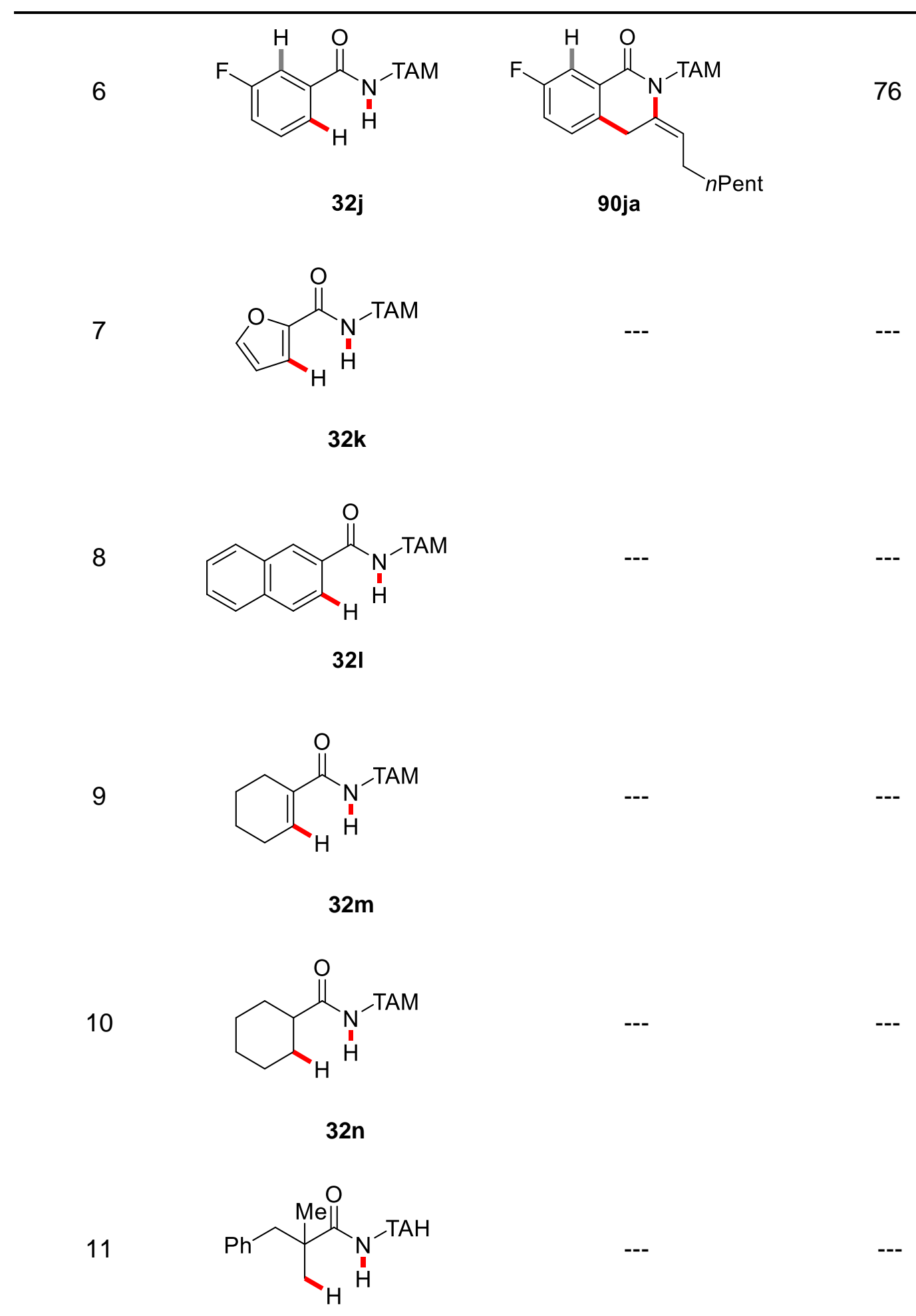

320

[a] Reaction conditions: $32(0.30 \mathrm{mmol}), 88 \mathrm{a}(0.90 \mathrm{mmol}), \mathrm{Fe}(\mathrm{acac})_{3}(15 \mathrm{~mol} \%)$, dppe (15 mol \%), $\mathrm{ZnBr}_{2} \cdot \mathrm{TMEDA}(0.60 \mathrm{mmol}), \operatorname{PrMgBr}(3.0 \mathrm{M}, 0.90 \mathrm{mmol}), \operatorname{THF}(0.40 \mathrm{~mL}), 65^{\circ} \mathrm{C}$, $16 \mathrm{~h}$; yields of isolated products. 


\section{Results and Discussion}

Furthermore, the versatile iron catalyst further enabled the efficient conversion of decorated allenes $\mathbf{8 8}$ and TAM-benzamide $\mathbf{3 2 a}$ to furnish the corresponding exo-methylene isoquinolines 90 with moderate to high yields (Table 3.6). Allenyl acetates bearing alkyl groups with different chain-lengths and functional group were efficiently converted (entries 1-4). Allenes with aromatic substituted at the $\alpha$-position of acetate group or the di-substituted allene failed to give the product (entries 5-7).

Table 3.6 Substrate scope of TAM substrate $32 \mathrm{a}$ with various allenes $\mathbf{8 8}$.<smiles>[Y16][I+]NC(=O)c1ccccc1</smiles>

$32 \mathrm{a}$<smiles>[R]C([R])(C=C)OC(C)=O</smiles>

88

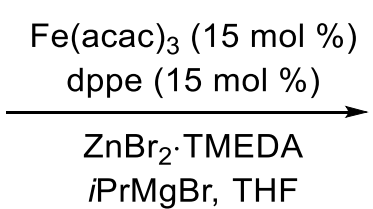

$65{ }^{\circ} \mathrm{C}, 16 \mathrm{~h}$<smiles>[R]C([R])/C=C1\Cc2ccccc2C(=O)N1[Y16]</smiles>

90

Entry Yield [\%]




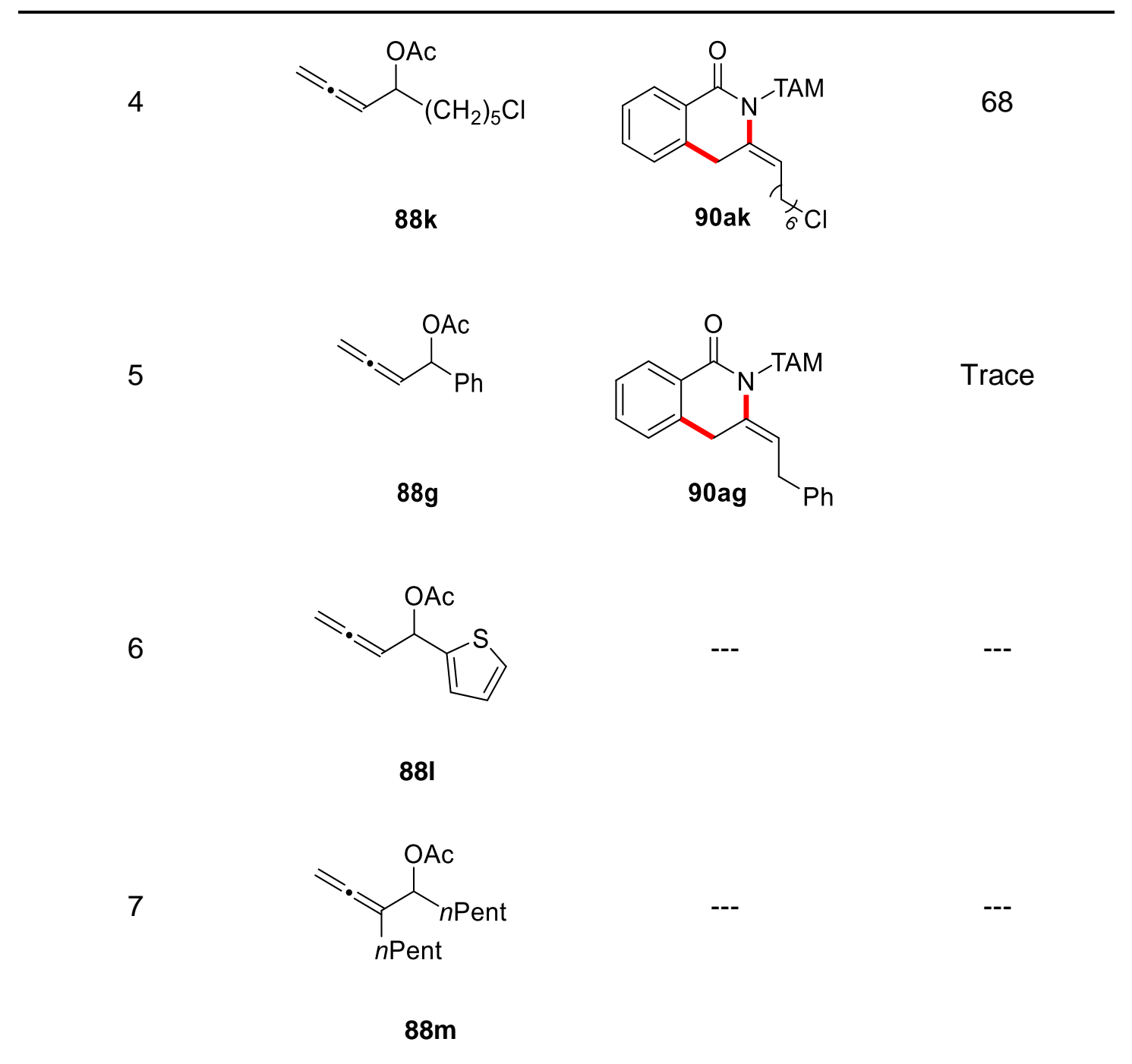

[a] Reaction conditions: 32a $(0.30 \mathrm{mmol}), 88(0.90 \mathrm{mmol}), \mathrm{Fe}(\mathrm{acac})_{3}(15 \mathrm{~mol} \%)$, dppe (15 mol \%), ZnBr $2 \cdot \operatorname{TMEDA}\left(0.60 \mathrm{mmol}\right.$ ), $\operatorname{PrMgBr}(3.0 \mathrm{M}, 0.90 \mathrm{mmol}), \operatorname{THF}(0.40 \mathrm{~mL}), 65^{\circ} \mathrm{C}, 16$ $\mathrm{h}$; yields of isolated products.

\subsubsection{Traceless Removal of TAM Group}

The TAM directing group was tracelessly removed in a user-friendly one-pot fashion further illustrate the synthetic utility of the iron-catalyzed redox-neutral $\mathrm{C}-\mathrm{H}$ annulation with allenes (Scheme 3.2).

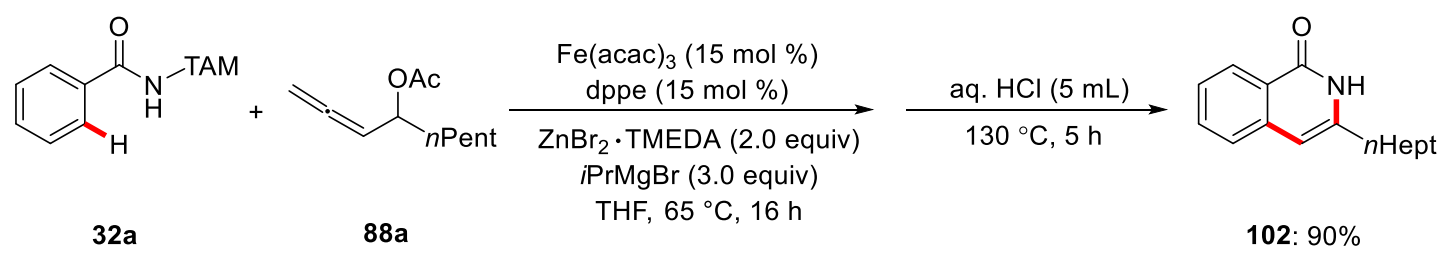

Scheme 3.2 Traceless removal of TAM group. 
Crystals suitable for X-ray diffraction were then grown by slow evaporation, unambiguously confirming the connectivity of product 89la (Scheme 3.3).

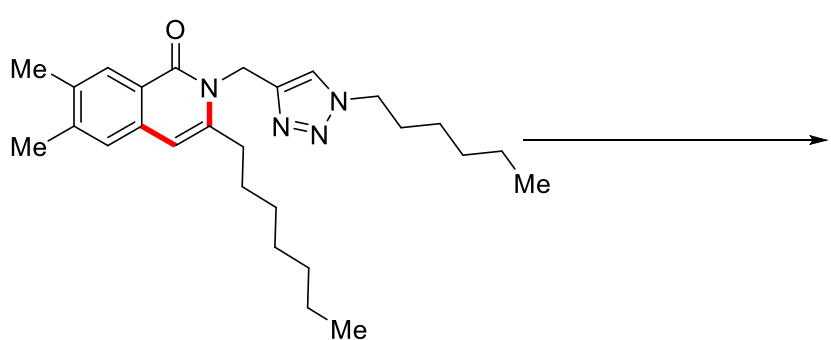

891a

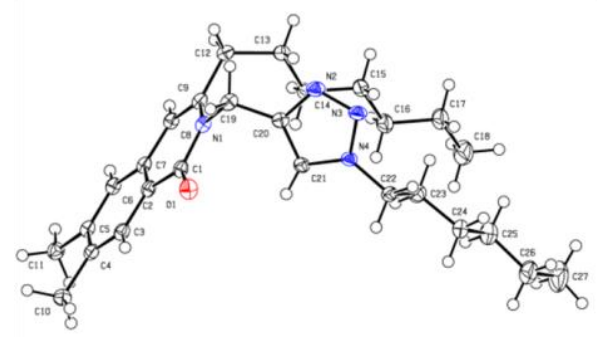

$891 \mathrm{a}$

Scheme 3.3 Molecular structure of 89 la with thermal ellipoids at $50 \%$ probability level. The crystal structure was measured and solved by Dr. Christopher Golz.

\subsubsection{Mechanistic Studies}

Given the unique features of the developed iron-catalyzed $\mathrm{C}-\mathrm{H}$ annulation, we became intrigued by studying its mode of action. Mechanistic approaches including experiment, Mössbauer spectroscopy and DFT computation were carefully conducted to reveal the detail mechanism.

\section{Competition Experiment}

Intermolecular competition experiments revealed an inherent higher reactivity

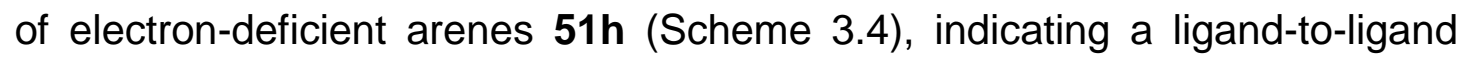
hydrogen transfer $(\mathrm{LLHT})^{[24 d, 46,88]}$ mechanism which prefer a kinetically $\mathrm{C}-\mathrm{H}$ acidic substrates to be operative for the $\mathrm{C}-\mathrm{H}$ activation. Different from $\sigma$-bond metathesis with early transition metals and base-assisted metalation most commonly with carboxylate ligands, the LLHT was reported in the cases with late transition metals and normally with nitrogen ligands. 
3. Results and Discussion
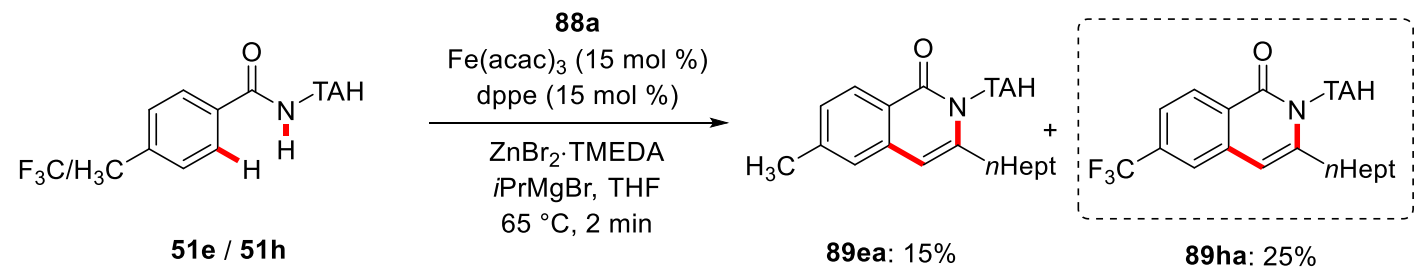

Scheme 3.4 Competition reaction of iron-catalyzed $\mathrm{C}-\mathrm{H} / \mathrm{N}-\mathrm{H}$ annulation.

\section{Reactions with Isotopically-labelled Substrates}

A C-D functionalization with the isotopically labelled substrate [D]5-51a either by independent reactions using in situ React-IR measurement (Scheme 3.5a) or an intermolecular KIE measurement through a one-pot reaction fashion (Scheme 3.5b), showed no significant kinetic isotope effect $\left(k_{H} / k_{D}=1.2\right.$ or 1.5$)$, providing support for a facile $\mathrm{C}-\mathrm{H}$ cleavage which is not the rate-determining step of the overall reaction.

a)<smiles>NNC(=O)c1ccc(O)cc1</smiles>

$51 \mathrm{a}$ or $[D]_{5}-51 \mathrm{a}$

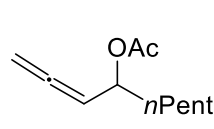

$88 a$

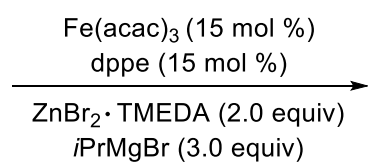

THF, $23^{\circ} \mathrm{C}$
$k_{H} / k_{D}=1.2$

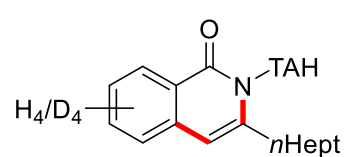

$89 a a$ or $[D]_{4}-89 a a$

b)

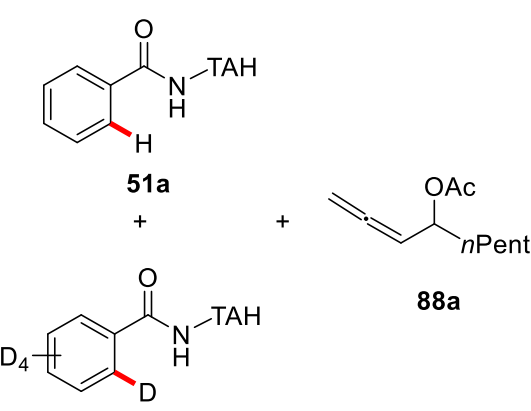

$[D]_{5}-51 a$<smiles>O=c1c2ccccc2cc([Hg][TlH])n1[AlH2]</smiles>

89 aа

$+$<smiles>[2H]c1ccc2c(=O)n([AlH2])c([Hg][Na])cc2c1</smiles>

$[D]_{4}-89 a a$

Scheme 3.5 KIE studies of iron-catalyzed C-H annulation with allenes 88a.

No deuterium scrambling was observed when isotopically labelled substrate [D]5-51a was employed (Scheme 3.6a). Furthermore, deuterium scrambling was not observed when using deuterium-labelled solvent (Scheme 3.6b) or isotopically labelled substrate [D]1-51a (Scheme 3.6c). In contrast, the 


\section{Results and Discussion}

specifically deuterium-labelled allene $[D]_{2}-88 a$ resulted in the site-selective deuterium incorporation in the products [D]2-90aa (Scheme 3.6d), highlighting the key role of the $\mathrm{C}-\mathrm{O} / \mathrm{C}-\mathrm{H}$ cleavage within an external oxidant-free allene annulation process. In addition, the same result was deuterium scrambling was observed in the product, when TAH benzamide 51a was reacted with $[\mathrm{D}]_{2}-\mathbf{8 8 a}$, which was performed by Dr. T. Müller. ${ }^{[89]}$

a)<smiles></smiles>

$\left[D_{5}\right]-51 a$<smiles>O=C(NI)c1ccccc1</smiles>

$51 \mathrm{a}$

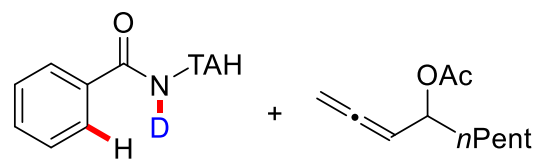

$\left[D_{1}\right]-51 a$

$88 a$

d)<smiles>[2H]C([2H])=CC=CC(OC(C)=O)C(=O)OCc1ccccc1</smiles>

$32 a$

$88 a$

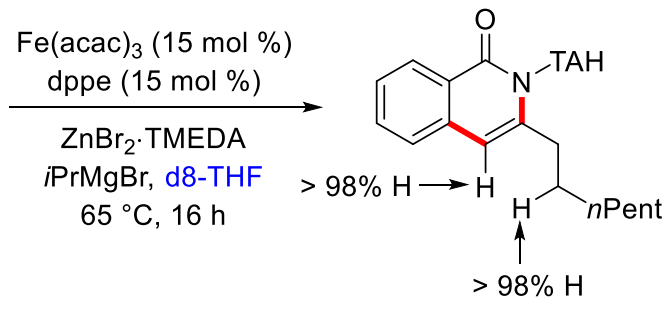

89aa: $64 \%$

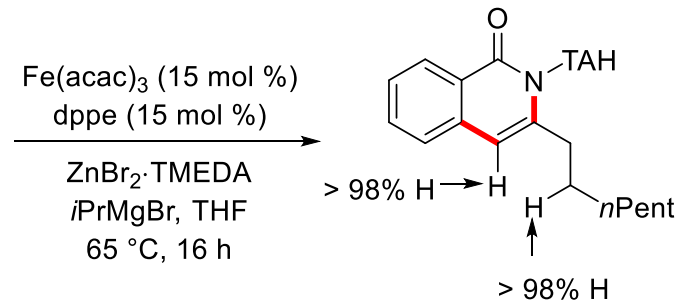

89aa: $64 \%$

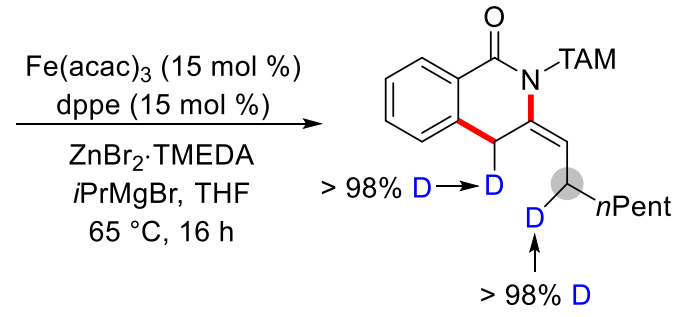

$[D]_{2}-90$ aa: $71 \%$

Scheme 3.6 Experiments with isotopically-labelled substrates. 


\section{Results and Discussion}

To further unveil the role of the acetate leaving group, two control experiment were conducted, one was employing alkyl allene $88 \mathrm{n}$ under the standard condition, which was performed by Dr. T. Müller (Scheme 3.7a), the other one was using the standard allene $\mathbf{8 8 a}$ but adding DCIB as an additional oxidant (Scheme 3.7b). To the end, the reaction under otherwise identical reaction conditions led to the corresponding hydroarylation product 103 , while the reaction in the presence of DCIB gave the standard product 89aa. These observations highlighted an oxidation-induced reductive elimination occurring during the annulation process.

a)

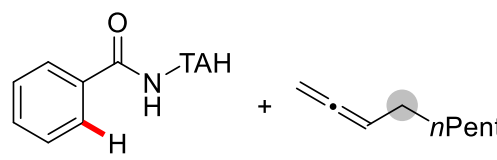

b)<smiles>O=C(N[Tl])c1ccccc1</smiles>

$51 \mathrm{a}$<smiles>[C+]=CC(C=C)OC(C)=O</smiles>

$88 a$

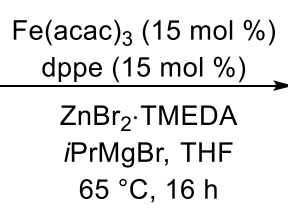

(performed by T. Müller)

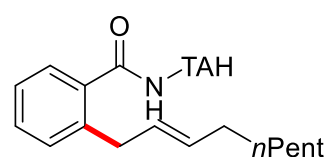

103: $25 \%$

Scheme 3.7 Role of leaving groups in iron-catalyzed C-H annulation.

\section{Mössbauer Spectroscopic Studies}

As to the catalyst's mode of action, detailed step-to-step Mössbauer spectroscopic studies were conducted to unveil the oxidation and spin states of the iron intermediate species (Table 3.7). In order to avoid the influence of ironcatalyzed $\beta$-H-elimination of Grinard reagent, $\mathrm{MeMgBr}$ was used instead of iPrMgBr for the Mössbauer measurement. As the amount of Grignard reacgent and zinc salts was largely excess comparing with iron catalyst in the standard condition, 9 equivalent of $\mathrm{MeMgBr}$ and 6 equivalent of $\mathrm{ZnBr}_{2} \cdot \mathrm{TMEDA}$ were used here to create similar reduce environment for iron catalyst. To this end, the 


\section{Results and Discussion}

presence of high-spin iron(II) intermediate species were supported by these observations. ${ }^{[90]}$ This research was performed in collaboration with the research group of Prof. Dr. F. Meyer. After sample preparation, the data was recorded and interpreted by Dr. S. Demeshko.

Table 3.7 Mössbauer parameters of reaction mixtures.

\begin{tabular}{|c|c|c|c|c|c|}
\hline Entry & Reaction & $\begin{array}{c}\text { Valence of } \\
\text { Iron/ } \\
\text { Spin State }\end{array}$ & $\begin{array}{c}\delta \\
\left(\mathrm{mm} \mathrm{s}^{-1}\right)\end{array}$ & $\begin{array}{c}\Delta E_{Q} \\
\left(\mathrm{~mm} \mathrm{~s}^{-1}\right)\end{array}$ & $\begin{array}{l}\text { rel. int. } \\
\qquad \%)\end{array}$ \\
\hline 1 & ${ }^{57} \mathrm{FeCl}_{2}+\mathrm{THF}$ & $+2^{\mathrm{HS}}$ & 1.26 & 3.05 & 100 \\
\hline 2 & Entry $1+\mathrm{MeMgBr}$ & $+1.4^{[91]}$ & 0.29 & 0.88 & 100 \\
\hline \multirow[t]{3}{*}{3} & Entry $2+$ & $+2^{\mathrm{HS}}$ & 1.01 & 2.69 & 69 \\
\hline & $\mathrm{ZnBr}_{2} \cdot \mathrm{TMEDA}$ & $+2^{\mathrm{HS}}$ & 1.36 & 2.56 & 31 \\
\hline & & $+2^{\mathrm{HS}}$ & 0.92 & 1.42 & 23 \\
\hline \multirow[t]{3}{*}{4} & Entry $3+$ dppe & $+2^{\mathrm{HS}}$ & 0.98 & 2.57 & 40 \\
\hline & & $+2^{\mathrm{HS}}$ & 1.24 & 2.68 & 37 \\
\hline & & n.a. ${ }^{[a]}$ & 0.26 & 1.01 & 43 \\
\hline \multirow[t]{2}{*}{5} & Entry $4+51 a$ & $+2^{\mathrm{HS}}$ & 1.14 & 2.45 & 36 \\
\hline & & $+2^{\mathrm{HS}}$ & 1.00 & 3.17 & 21 \\
\hline \multirow[t]{3}{*}{6} & Entry $5+88 a$ & n.a. ${ }^{[a]}$ & 0.24 & 1.43 & 28 \\
\hline & & $+2^{\mathrm{HS}}$ & 0.68 & 1.94 & 29 \\
\hline & & $+2^{\mathrm{HS}}$ & 1.12 & 2.60 & 43 \\
\hline
\end{tabular}

${ }^{[a]}$ n.a. = not assigned. The data were recorded and interpreted by Dr. S. Demeshko. 
3. Results and Discussion

\subsubsection{Proposed Mechanism}

Based on the mechanistic findings, the iron-catalyzed allene annulation is proposed to be initiated by facile $\mathrm{C}-\mathrm{H}$ metalation via LLHT, along with allene migratory insertion (Scheme 3.8). Thereafter, oxidation-induced reductive elimination takes place to generate the iron allyl complex 107. Based on the selective deuterium transposition, the iron allyl complex 107 was proposed to undergo a unique intramolecular $\mathrm{C}-\mathrm{H}$ activation by 1,4-iron migration ${ }^{[92]}$ which was considered as the key step to generate the stabilized allylic-benzylic iron intermediate 108. Proto-demetallation with the amide motif of the substrate $51 / 32$ delivers the intermediate 109 or the final product $\mathbf{9 0}$. The intermediate 109 finally undergoes isomerization to furnish the corresponding isoquinolone 89. The crucial 1,4 iron migration was further supported by computational studies that were conducted by Dr. J. C. A. Oliveira. ${ }^{[89]}$ 


\section{Results and Discussion}

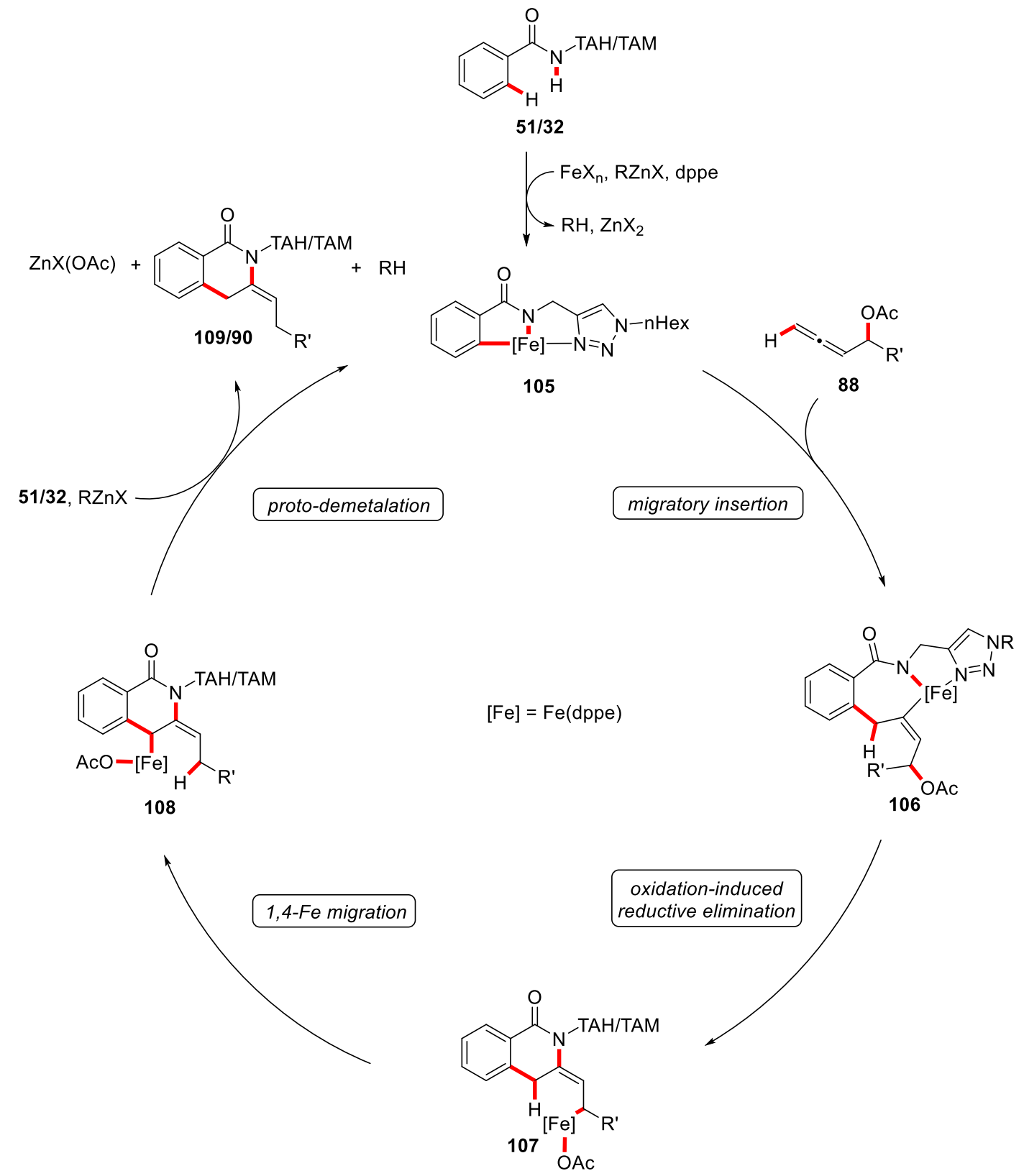

Scheme 3.8 Proposed mechanism for iron-catalyzed C-H annulation with allenes $\mathbf{8 8}$. 


\subsection{Iron-Catalyzed C-H/N-H Propargyl Acetate Annulation}

While a previous report on iron-catalyzed alkyne annulations[61] showed limitations in substrate scope and a procedure to remove the TAH group was not available, it was valuable to investigate the reactivity of propargyl acetates in iron-catalyzed $\mathrm{C}-\mathrm{H}$ annulations.

\subsubsection{Optimization Study and Substrate Scope}

Under the standard reaction condition for the allene annulations (Chapter 3.1.1), a similar reactivity was accomplished with propargyl acetates $\mathbf{9 1 a}$, the reaction was found by Dr. T. Müller. The yield increased to $60 \%$ when using Fe(acac)2 instead of $\mathrm{Fe}(\mathrm{acac}) 3$. This finding suggested that an iron(II) catalyst may be more reactive than iron(III) catalysts (Scheme 3.9).<smiles>O=C(NI)c1ccccc1</smiles>

$51 \mathrm{a}$

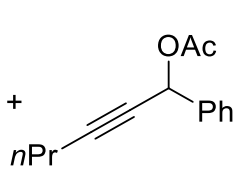

$91 \mathrm{a}$

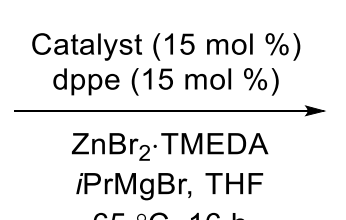

$65^{\circ} \mathrm{C}, 16 \mathrm{~h}$

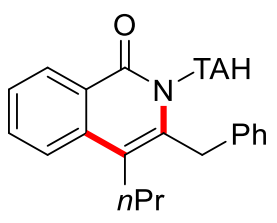

92aa

Catalyst $=\mathrm{Fe}(\mathrm{acac})_{3}, 51 \%$ (found by $\mathrm{Dr}$. T. Müller)

Catalyst $=\mathrm{Fe}(\mathrm{acac})_{2}, 60 \%$

Scheme 3.9 Test reaction of propargyl acetate 91a.

For consistency and reproducibility, the optimization studies and the substrate scope were performed by Dr. T. Müller. ${ }^{[93]}$

These experiments showed that: As in the allene annulation reactions (Chapter 3.1.1), dppe proved to be the ligand of choice and $\mathrm{FeCl}_{2}$ showed higher activity in the catalytic reaction. The propargyl acetate annulation required more solvent and a lower reaction temperature. Furthermore, the propargyl acetate annulations with the $\mathrm{TAH}$-substrates showed similar reactivity as was observed with the allenes. However, the TAM-substrates, which were compatible for allene annulations, fell short in providing the target products here. The 


\section{Results and Discussion}

inherently decreased reactivity of the TAM-substrate can be partially attributed to the increased steric bulk of propargyl acetates as compared to the allenes.

\subsubsection{Traceless Electrochemical Removal of TAH Group}

Efforts first have been made to chemically remove the TAH group. Unfortunately, all attempts failed to deliver the target product 93aa (Table 3.8).

Table 3.8 Failed attempts for removal of TAH group.

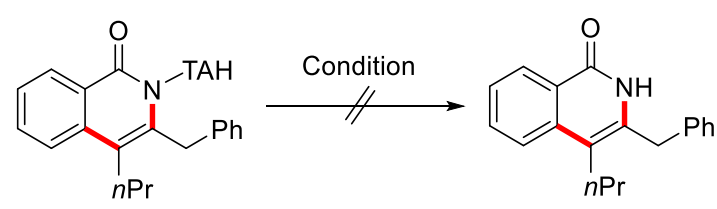

92aa

93aa

\begin{tabular}{|c|c|}
\hline Entry & Conditions \\
\hline & 1) $\operatorname{LDA}$ ( 2 equiv) $/ \mathrm{THF},-78^{\circ} \mathrm{C}, 5 \mathrm{~min}$ \\
\hline \multirow[t]{3}{*}{1} & 2) $\mathrm{O}_{2},-78^{\circ} \mathrm{C}$ \\
\hline & 3) $10 \mathrm{~min}$ \\
\hline & 4) $\mathrm{NH}_{4} \mathrm{Cl} / \mathrm{H}_{2} \mathrm{O},-78-23^{\circ} \mathrm{C}, 1 \mathrm{~h}$ \\
\hline \multirow[t]{2}{*}{2} & 1) $\mathrm{BBr}_{3}$ (5.3 equiv), $\mathrm{DCM}, 0-23^{\circ} \mathrm{C}, 16 \mathrm{~h}$ \\
\hline & 2) $\mathrm{Phl}(\mathrm{TFA})_{2}, \mathrm{MeCN} / \mathrm{THF} / \mathrm{H}_{2} \mathrm{O}, 0^{\circ} \mathrm{C}, 2 \mathrm{~h}$ \\
\hline 3 & $\mathrm{BF}_{3} \mathrm{Et}_{2} \mathrm{O}$ ( 1.5 equiv), dry $\mathrm{MeOH}, 130^{\circ} \mathrm{C}, 16 \mathrm{~h}$ \\
\hline 4 & $\mathrm{NOBF}_{4}$ (2.0 equiv), $\mathrm{MeCN}, 50^{\circ} \mathrm{C}, 16 \mathrm{~h}$ \\
\hline 5 & $\mathrm{H}_{2} \mathrm{O}_{2}(5 \mathrm{~mL}), \mathrm{CF}_{3} \mathrm{COOH}(4 \mathrm{~mL}), 40^{\circ} \mathrm{C}, 18 \mathrm{~h}$ \\
\hline 6 & Conc. aq. $\mathrm{HCl}(1 \mathrm{~mL}), \mathrm{THF}, 130^{\circ} \mathrm{C}, 16 \mathrm{~h}$ \\
\hline 7 & Conc. aq. $\mathrm{HCl}(1 \mathrm{~mL}), \mathrm{THF}, 130^{\circ} \mathrm{C}, 16 \mathrm{~h}$ \\
\hline 8 & $\mathrm{H}_{2} \mathrm{SO}_{4}(1 \mathrm{~mL}), \mathrm{THF}, 130^{\circ} \mathrm{C}, 16 \mathrm{~h}$ \\
\hline
\end{tabular}


The TAH group of product 92aa could be removed in a traceless manner through electro-oxidative cleavage (Table 3.9). The corresponding isoquinolone 93aa was obtained in good yield using two equivalents of zinc salt and three equivalents of $\mathrm{PrMgBr}$ (entry 1 ). The yield decreased with increasing amounts of $\operatorname{PrMgBr}$ (entries 2-4). In addition, when only the Grignard reagent was present, the transformation was achieved in a low yield, while the sole use of zinc or magnesium salts fell short in giving the product (entries 5-8). Furthermore, $n \mathrm{Bu}_{4} \mathrm{NBF}_{4}, \mathrm{H}_{2} \mathrm{O}$ as well as aqueous $\mathrm{NH}_{4} \mathrm{Cl}$ were tested as additives, significant product formation was not detected (entries 9-11). These observations suggested that the combination of $\mathrm{ZnBr2}$.TMEDA and Grignard reagent was crucial for an efficient transformation.

Table 3.9 Optimization of traceless removal of the TAH group.

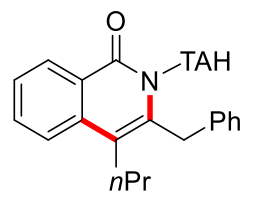

92aa

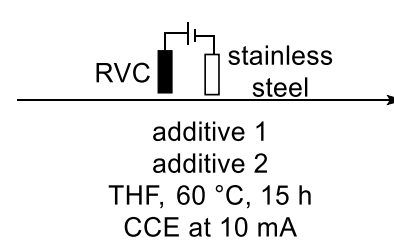

CCE at $10 \mathrm{~mA}$

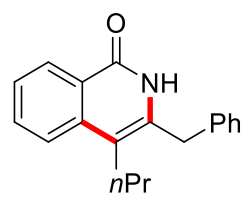

93aa: $73 \%$

\begin{tabular}{|c|c|c|c|}
\hline Entry & Additive 1 (x equiv) & Additive 2 (y equiv) & Yield [\%] \\
\hline 1 & ZnBr-TMEDA (2) & PrMgBr (3) & 73 \\
\hline 2 & ZnBr·TMEDA (2) & PrMgBr (6) & 72 \\
\hline 3 & $\mathrm{ZnBr} \cdot \mathrm{TMEDA}(2)$ & PrMgBr (9) & 63 \\
\hline 4 & ZnBr·TMEDA (3) & IPrMgBr (9) & 40 \\
\hline 5 & iPrMgBr (9) & --- & 38 \\
\hline
\end{tabular}




\begin{tabular}{cccc}
\hline 6 & $\mathrm{MgBr}_{2}(10)$ & --- & n.r. \\
7 & $\mathrm{ZnBr} \cdot \mathrm{TMEDA}^{(10)}$ & --- & n.r. \\
8 & $\mathrm{ZnBr}_{2}(10)$ & --- & n.r. \\
9 & $n \mathrm{Bu}_{4} \mathrm{NBF}_{4}(4)$ & -- & \\
$10^{[\mathrm{bb}]}$ & $\mathrm{H}_{2} \mathrm{O}$ & --- & n.r. \\
$11^{[\mathrm{bb}]}$ & aq. $\mathrm{NH}_{4} \mathrm{Cl}$ & -- & n.r. \\
\hline
\end{tabular}

[a] Reaction conditions: 92aa ( $0.30 \mathrm{mmol})$, additive 1 (x equiv), additive (y equiv), THF (2 mL), $60{ }^{\circ} \mathrm{C}, 16 \mathrm{~h}$; yields of isolated products. ${ }^{[\mathrm{b}]} 2 \mathrm{~mL}$ of additive 1 was used.

\subsubsection{Mechanistic Studies}

Mechanistic experiments were performed by Dr. T. Müller ${ }^{[93]}$ including 1) intermolecular competition experiments, 2) reactions with the isotopicallylabelled substrates, and 3) Hammett-plot analysis of the initial rates of the iron catalyzed $\mathrm{C}-\mathrm{H}$ activation with a range of propargyl acetates.

These experiments showed that a LLHT mechanism could be possible and that the $\mathrm{C}-\mathrm{H}$ activation event is not the rate-determining step. Furthermore, no deuterium was incorporated into the product 92aa by using various isotopicallylabelled substrates, such as [D5]-benzamide, [D]-benzamide, [D6]-iPrMgBr, $\left[D_{20}\right]-d p p e$. A change in the rate-determining step could exist.

Furthermore, when the standard reaction was conducted in the presence of

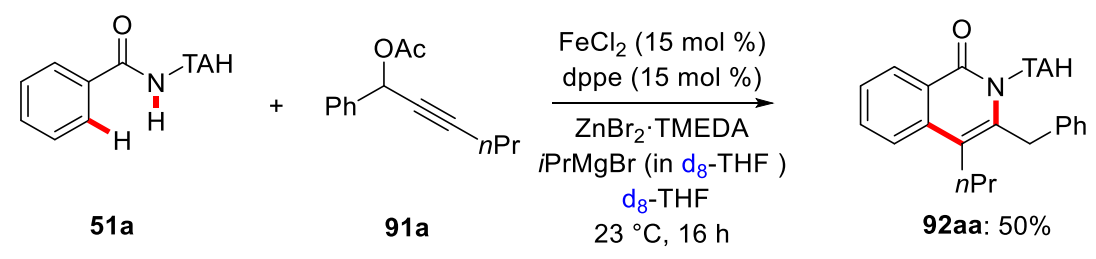

Scheme 3.10 Reaction with isotopically-labelled solvent. 


\section{Results and Discussion}

isotopically-labelled solvent, no deuterium was incorporated into the product (Scheme 3.10).

While no deuterium incorporation in product 92aa was obsedved in the reaction with [D5]-51a (Scheme 3.11a, performed by Dr. T. Müller), the following experiments were conducted to understand where the proton at the orthoposition of the benzamide 51a was ending in. $\mathrm{H}_{2}$ was detected by headspace GC analysis in the standard catalytic reaction (Scheme 3.11b). In addition, the proton of amide in the substrate 51a can be deprotonated by $\mathrm{PhZnCl}$ (Scheme 3.11c). Thus, $\mathrm{H}_{2}$ could be formed through $\beta$-hydride elimination of the Fe-alkyl complex 111 (Scheme 3.13) or by-reaction of iron reacting with Grignard reagent. To further confirm, a DFT calculation was conducted by Dr. J. C. A. Oliveira. These results showed that the formation of $\mathrm{H}_{2}$ through $\beta$-hydride elimination of iron-alkyl complex $\mathbf{1 1 1}$ is less possible during the $\mathrm{C}-\mathrm{H}$ activation event (Scheme 3.13). Based on these findings, we proposed that the proton of benzamide 51a which participate in $\mathrm{C}-\mathrm{H}$ activation would be transfered to the isopropyl group in complex 111 then form propane gas (Scheme 3.13).

a)<smiles>O=C(NN=[IH])c1ccccc1</smiles>

$[D]_{5}-51 a$<smiles>O=C(N[InH2])c1ccccc1</smiles>

$51 \mathrm{a}$<smiles>NNC(=O)c1ccccc1</smiles>

$51 \mathrm{a}$

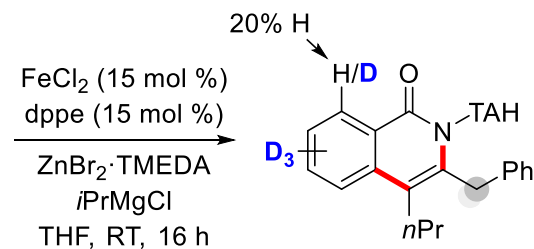

$[D]_{n}-92 a a: 65 \%$

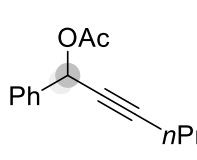

91a

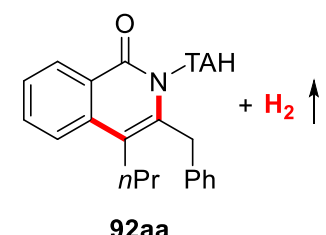

THF, RT, $16 \mathrm{~h}$
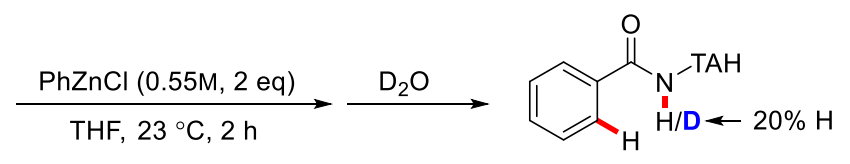

$[D]_{1}-51 a$

Scheme 3.11 Detection of $\mathrm{H}_{2}$ and deprotonation of benzamide 51a. 


\section{Results and Discussion}

In order to capture the intermediate, a reaction with di-phenyl substituted propargyl acetate 91b was performed (Scheme 3.12). Unfortunately, no transformation was observed under the standard conditions.

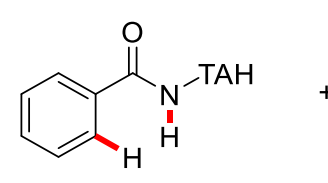

$51 \mathrm{a}$

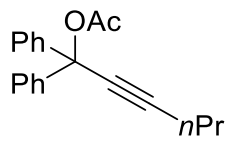

$91 b$

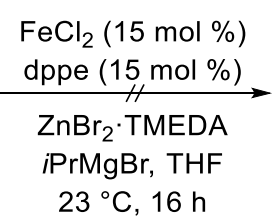

$23{ }^{\circ} \mathrm{C}, 16 \mathrm{~h}$

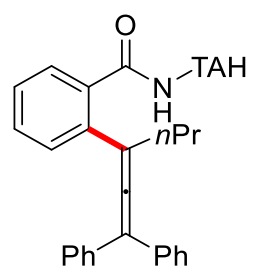

110

Scheme 3.12 Reaction with di-phenyl substituted propargyl acetate $\mathbf{9 1 b}$.

\section{Mössbauer Spectroscopy Studies}

To further gain insights into the catalyst's mode of action, Mössbauer spectroscopic studies were conducted to unveil the oxidation and spin states of the iron intermediate species (Table 3.10). In order to avoid the influence of iron-catalyzed $\beta$-H-elimination of Grinard reagent, $\mathrm{MeMgBr}$ was used instead of $\mathrm{PrMgBr}$ for the Mössbauer measurement. As the amount of Grignard reacgent and zinc salts was largely excess comparing with iron catalyst in the standard condition, 9 equivalent of $\mathrm{MeMgBr}$ and 6 equivalent of $\mathrm{ZnBr}_{2} \cdot \mathrm{TMEDA}$ were used here to creat similar reduce environment for the iron catalyst. Our observations provided strong support for the presence of high-spin iron(II) intermediate species. ${ }^{[90]}$ This research work was performed in collaboration with the research group of Prof. Dr. F. Meyer. After sample preparation, the data were recorded and interpreted by Dr. S. Demeshko. 
3. Results and Discussion

Table 3.10 Mössbauer parameters of reaction mixtures.

\begin{tabular}{|c|c|c|c|c|c|}
\hline Entry & Reaction & $\begin{array}{c}\text { Valence of } \\
\text { Iron/ } \\
\text { Spin State }\end{array}$ & $\begin{array}{c}\delta \\
\left(\mathrm{mm} \mathrm{s}^{-1}\right)\end{array}$ & $\begin{array}{c}\Delta E_{Q} \\
\left(\mathrm{~mm} \mathrm{~s}^{-1}\right)\end{array}$ & $\begin{array}{l}\text { rel. int. } \\
\qquad \%)\end{array}$ \\
\hline 1 & ${ }^{57} \mathrm{FeCl}_{2}+\mathrm{THF}$ & $+2^{\mathrm{HS}}$ & 1.26 & 3.05 & 100 \\
\hline 2 & Entry $1+\mathrm{MeMgBr}$ & $+1.4^{[91]}$ & 0.29 & 0.88 & 100 \\
\hline \multirow[t]{3}{*}{3} & Entry $2+$ & $+2^{\mathrm{HS}}$ & 1.01 & 2.69 & 69 \\
\hline & $\mathrm{ZnBr}_{2} \cdot \mathrm{TMEDA}$ & $+2^{\mathrm{HS}}$ & 1.36 & 2.56 & 31 \\
\hline & & $+2^{\mathrm{HS}}$ & 0.92 & 1.42 & 23 \\
\hline \multirow[t]{3}{*}{4} & Entry $3+$ dppe & $+2^{\mathrm{HS}}$ & 0.98 & 2.57 & 40 \\
\hline & & $+2^{\mathrm{HS}}$ & 1.24 & 2.68 & 37 \\
\hline & & n.a. ${ }^{[a]}$ & 0.26 & 1.01 & 43 \\
\hline \multirow[t]{2}{*}{5} & Entry $4+51 a$ & $+2^{\mathrm{HS}}$ & 1.14 & 2.45 & 36 \\
\hline & & $+2^{\mathrm{HS}}$ & 1.00 & 3.17 & 21 \\
\hline \multirow[t]{2}{*}{6} & Entry $5+91 \mathbf{a}$ & $+2^{\mathrm{HS}}$ & 1.00 & 2.94 & 48 \\
\hline & & $+2^{\mathrm{HS}}$ & 0.95 & 2.29 & 52 \\
\hline
\end{tabular}




\section{Results and Discussion}

\subsubsection{Proposed Mechanism}

Based on our studies, a plausible catalytic cycle was proposed (Scheme 3.13). The catalytic cycle consists of: a) a reversible, facile $\mathrm{C}-\mathrm{H}$ activation via LLHT, b) alkyne migratory insertion, c) exergonic $\beta$-O-elimination, d) allene migratory insertion, and e) proto-demetallation to deliver the desired isoquinolone product 92 and regenerate the active iron species 111.

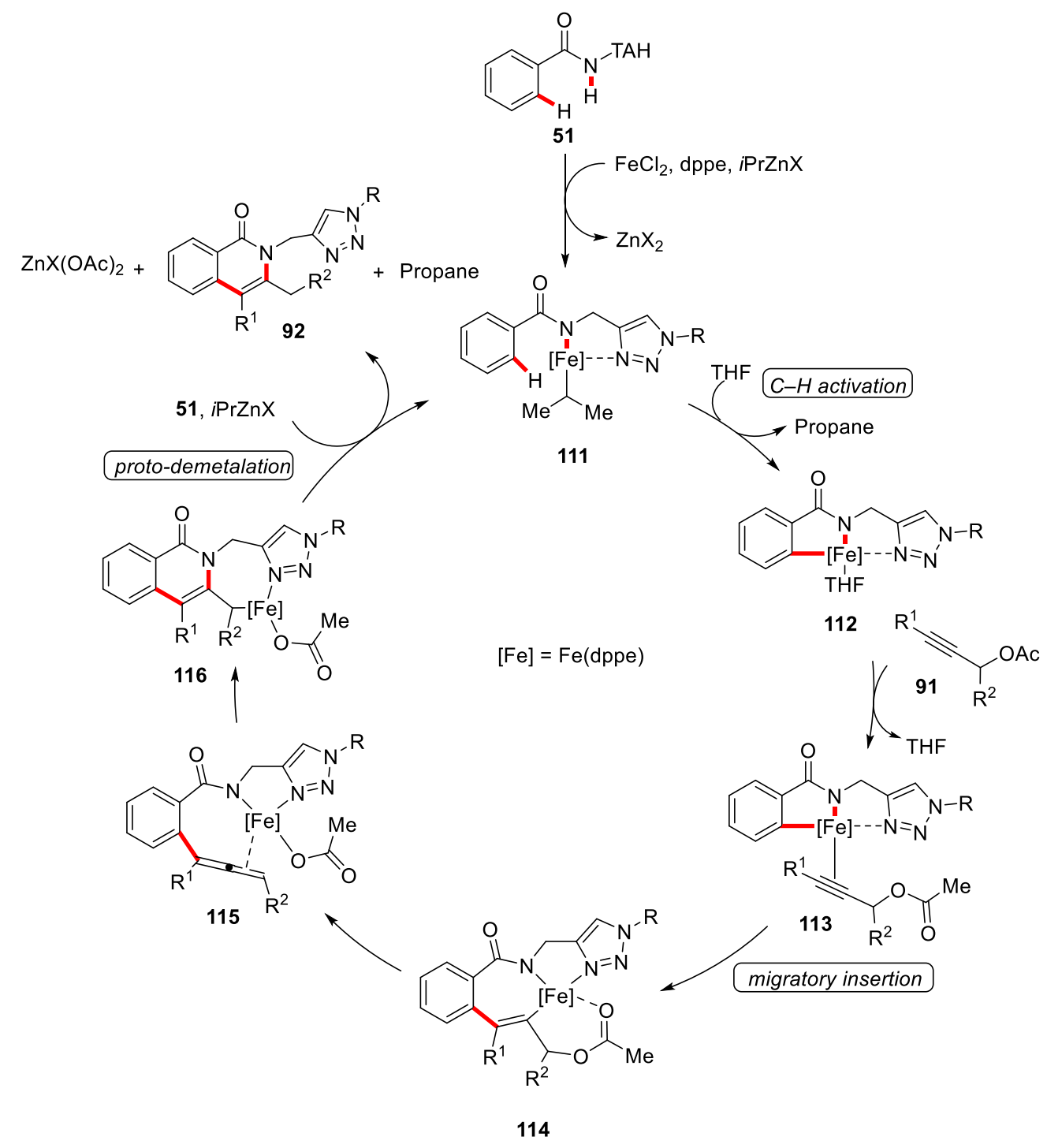

Scheme 3.13 Proposed mechanism for the iron-catalyzed annulation with $\mathbf{9 1 .}$ 


\subsection{Iron-Catalyzed C-H/C-C Activation with Bicyclopropylidenes}

In recent years, the merger of $\mathrm{C}-\mathrm{H}$ activation with challenging $\mathrm{C}-\mathrm{C}$ cleavages has been developed for the construction of novel molecules. Despite considerable achievements, this approach was largely thus far restricted to precious metal catalysts, ${ }^{[83-84]}$ activated vinylcyclopropanes, ${ }^{\text {24c, } 85 b-85 d]}$ as well as harsh oxidative conditions. ${ }^{[85 a]}$

\subsubsection{Optimization Studies}

A series of BCP derivatives were tested under the standard reaction conditions of the iron-catalyzed $\mathrm{C}-\mathrm{H}$ oxidative annulation with allenes. To our delight, when substrate 94a was used as the coupling partner, bispiro-fused product 96aa was obtained in $45 \%$ yield (Scheme 3.14 ).

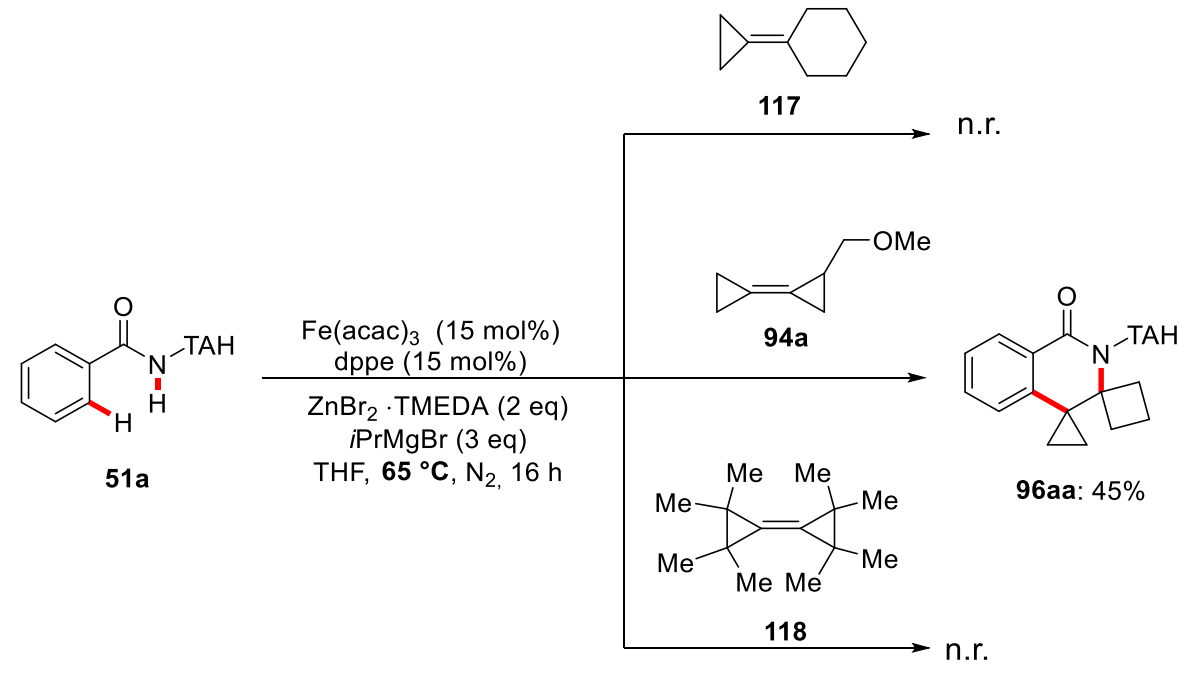

Scheme 3.14 Test reactions with bicyclopropylidenes.

Thereafter, considerable efforts were devoted to improve the yield of the structurally interesting product (Table 3.11). We initiated our optimization by testing different iron catalysts, and $\mathrm{Fe}(\mathrm{acac})_{3}$ delivered the best results among the tested catalysts (entries 1-4). In addition, various Grignard reagents are 


\section{Results and Discussion}

probed, and $\mathrm{PrMgBr}$ proved to be the best (entries 5-10). Other etheric solvents turned out to be less effective than THF (entries 11-15). Increasing the concentration of $\mathrm{PrMgBr}$ did not facilitate the reaction (entries 16 and 17). Adding the BCP substrate 94a dropwise instead of in one portion showed a comparable reactivity (entry 18 ). The yield dropped to $26 \%$ when the reaction was run at $80^{\circ} \mathrm{C}$, while further decreasing the temperature to $23^{\circ} \mathrm{C}$ almost shut down the reaction (entries 19 and 20). As the use of acetate as the leaving group was mandatory to achieve reasonable conversion in the iron-catalyzed annulation of allenyl acetates, we reinvestigated the role of the leaving group. When acetate or carbonate was installed on the BCP, the isoquinolone 95aa could be obtained as main product. In contrast, with alkoxy as the leaving group, product 96aa was obtained (entries 21-26). The yield of product 95aa decreased when $\mathrm{FeCl}_{2}$ was used instead of $\mathrm{Fe}(\mathrm{acac})_{3}$, and a higher concentration of Grignard reagent was employed (entries 27-29). Interestingly, biomass-derived solvent 2-MeTHF also enabled the isoquinolone 95aa transformation, while it proved to be inefficient for the reaction using methoxy as the leaving group (entries 15 and 30). Furthermore, the isoquinolone 95aa synthesis worked efficiently even at room temperature (entry 31 ). 


\section{Results and Discussion}

Table 3.11 Optimizations of iron-catalyzed $\mathrm{C}-\mathrm{H} / \mathrm{C}-\mathrm{C}$ activation.

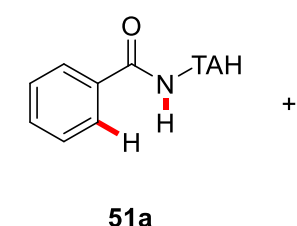

$51 \mathrm{a}$

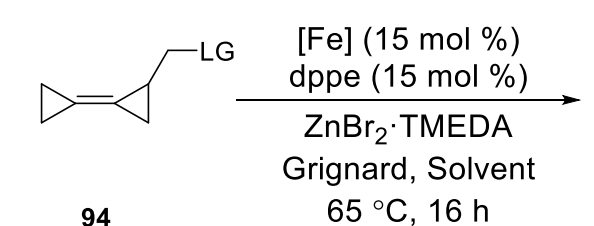

94 $65^{\circ} \mathrm{C}, 16 \mathrm{~h}$

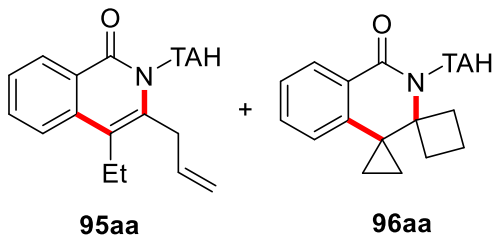

$\begin{array}{llll}L G=O M e & (\mathbf{9 4 a}) & L G=O T H P & (\mathbf{9 4 e}) \\ L G=O E t & (\mathbf{9 4 b}) & L G=O C(O) O M e & (\mathbf{9 4 f}) \\ L G=O B n & (\mathbf{9 4 c}) & L G=\text { OAc } & (\mathbf{9 4 g}) \\ L G=O P h & (\mathbf{9 4 d}) & \end{array}$

\begin{tabular}{|c|c|c|c|c|c|c|}
\hline Entry $^{a}$ & Catalyst & $\begin{array}{c}\text { Grignard reagent } \\
(x \mathrm{M})\end{array}$ & Solvent & LG & $\begin{array}{c}96 a a \\
{[\%]}\end{array}$ & $\begin{array}{l}95 \mathrm{aa} \\
{[\%]}\end{array}$ \\
\hline 1 & $\mathrm{Fe}(\mathrm{acac})_{2}$ & $\operatorname{PrMgBr}(3)$ & THF & OMe & 25 & --- \\
\hline 2 & $\mathrm{FeCl}_{3}$ & $\operatorname{PrMgBr}(3)$ & THF & $\mathrm{OMe}$ & 25 & --- \\
\hline 3 & $\mathrm{Fe}(\mathrm{dbm})_{3}$ & $\operatorname{PrMgBr}(3)$ & THF & $\mathrm{OMe}$ & 21 & --- \\
\hline 4 & $\mathrm{Fe}(\mathrm{acac})_{3}$ & $\operatorname{PrMgBr}(3)$ & THF & $\mathrm{OMe}$ & 45 & --- \\
\hline 5 & $\mathrm{Fe}(\mathrm{acac})_{3}$ & $\operatorname{MeMgBr}(3)$ & THF & OMe & 42 & --- \\
\hline 6 & $\mathrm{Fe}(\mathrm{acac})_{3}$ & tBuMgCl (2) & THF & OMe & 40 & --- \\
\hline 7 & $\mathrm{Fe}(\mathrm{acac})_{3}$ & CyMgCl (2) & THF & $\mathrm{OMe}$ & 24 & --- \\
\hline 8 & $\mathrm{Fe}(\mathrm{acac})_{3}$ & $\mathrm{TMSCH}_{2} \mathrm{MgCl}(2.5)$ & THF & $\mathrm{OMe}$ & --- & --- \\
\hline 9 & $\mathrm{Fe}(\mathrm{acac})_{3}$ & IPrMgCl (1) & THF & $\mathrm{OMe}$ & 23 & --- \\
\hline 10 & $\mathrm{Fe}(\mathrm{acac})_{3}$ & cycloproplyMgBr (1) & THF & $\mathrm{OMe}$ & 14 & --- \\
\hline $11^{\mathrm{b}}$ & $\mathrm{Fe}(\mathrm{acac})_{3}$ & $\operatorname{PrMgBr}(3)$ & $\mathrm{Et}_{2} \mathrm{O}$ & $\mathrm{OMe}$ & 21 & --- \\
\hline 12 & $\mathrm{Fe}(\mathrm{acac})_{3}$ & $\operatorname{PrMgBr}(3)$ & DME & $\mathrm{OMe}$ & --- & --- \\
\hline 13 & $\mathrm{Fe}(\mathrm{acac})_{3}$ & $\operatorname{PrMgBr}(3)$ & dioxane & $\mathrm{OMe}$ & --- & --- \\
\hline 14 & $\mathrm{Fe}(\mathrm{acac})_{3}$ & $\operatorname{PrMgBr}(3)$ & $(n \mathrm{Bu})_{2} \mathrm{O}$ & $\mathrm{OMe}$ & --- & --- \\
\hline
\end{tabular}


3. Results and Discussion

\begin{tabular}{|c|c|c|c|c|c|c|}
\hline 15 & $\mathrm{Fe}(\mathrm{acac})_{3}$ & IPrMgBr (3) & 2-MeTHF & OMe & --- & --- \\
\hline $16^{c}$ & $\mathrm{Fe}(\mathrm{acac})_{3}$ & iPrMgBr (3) & THF & OMe & 26 & --- \\
\hline 17 & $\mathrm{Fe}(\mathrm{acac})_{3}$ & IPrMgBr (4.3) & THF & OMe & --- & --- \\
\hline $18^{d}$ & $\mathrm{Fe}(\mathrm{acac})_{3}$ & PrMgBr (3) & THF & OMe & 40 & --- \\
\hline $19^{e}$ & $\mathrm{Fe}(\mathrm{acac})_{3}$ & PrMgBr (3) & THF & OMe & trace & --- \\
\hline $20^{f}$ & $\mathrm{Fe}(\mathrm{acac})_{3}$ & iPrMgBr (3) & THF & OMe & 26 & --- \\
\hline 21 & $\mathrm{Fe}(\mathrm{acac})_{3}$ & PrMgBr (3) & THF & OEt & 35 & --- \\
\hline 22 & $\mathrm{Fe}(\mathrm{acac})_{3}$ & PrMgBr (3) & THF & OBn & trace & --- \\
\hline 23 & $\mathrm{Fe}(\mathrm{acac})_{3}$ & IPrMgBr (3) & THF & OPh & --- & --- \\
\hline 24 & $\mathrm{Fe}(\mathrm{acac})_{3}$ & IPrMgBr (3) & THF & $94 e$ & 30 & 15 \\
\hline 25 & $\mathrm{Fe}(\mathrm{acac})_{3}$ & PrMgBr (3) & THF & $94 f$ & --- & 70 \\
\hline 26 & $\mathrm{Fe}(\mathrm{acac})_{3}$ & IPrMgBr (3) & THF & OAc & --- & 80 \\
\hline 27 & $\mathrm{FeCl}_{2}$ & IPrMgBr (3) & THF & OAc & --- & 53 \\
\hline 28 & $\mathrm{Fe}(\mathrm{acac})_{3}$ & iPrMgBr (4.28) & THF & OAc & --- & 47 \\
\hline $29^{c}$ & $\mathrm{Fe}(\mathrm{acac})_{3}$ & PrMgBr (3) & THF & OAc & --- & 53 \\
\hline 30 & $\mathrm{Fe}(\mathrm{acac})_{3}$ & iPrMgBr (3) & 2-MeTHF & OAC & --- & 70 \\
\hline $31^{e}$ & $\mathrm{Fe}(\mathrm{acac})_{3}$ & IPrMgBr (3) & 2-MeTHF & OAc & --- & 64 \\
\hline \multicolumn{7}{|c|}{ 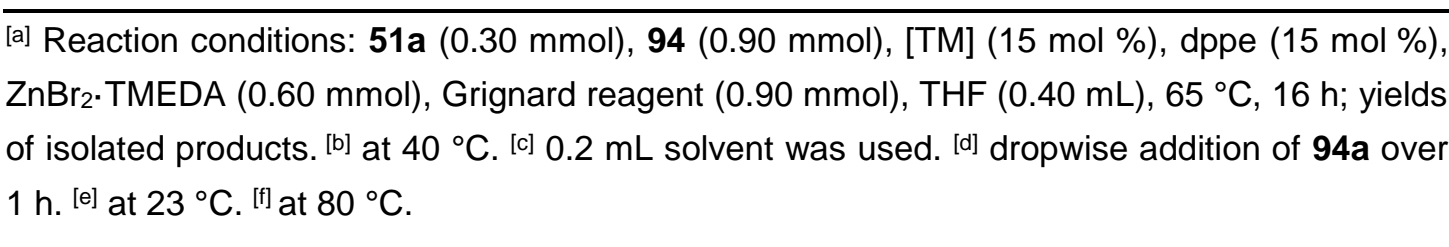 } \\
\hline
\end{tabular}




\section{Results and Discussion}

\subsubsection{Impact of the N-Substituent on the C-H/C-C Activation}

The iron-catalyzed $\mathrm{C}-\mathrm{H} / \mathrm{C}-\mathrm{C}$ activation with different $\mathrm{TAH}$ groups provided various isoquinolones in moderate to good yields (Table 3.12). Among them, methylene-tethered TAH triazoles delivered the desired isoquinolones 95 in good yields (entries 1-4), tolerating among others a reactive alkyl chloride $\mathbf{5 1 d}$ without any cross-coupling products being observed (entry 5).

Table 3.12 Impact of different TAH groups on the $\mathrm{C}-\mathrm{H} / \mathrm{C}-\mathrm{C}$ activation.<smiles>O=C(NI)c1ccccc1</smiles>

51

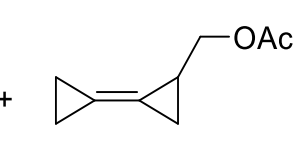

$94 \mathrm{~g}$

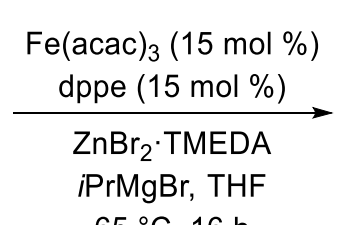

$65^{\circ} \mathrm{C}, 16 \mathrm{~h}$<smiles>C=CCc1c(CC)c2ccccc2c(=O)n1[AlH2]</smiles>

95

Entry [\%]


4<smiles>O=C(NCc1cn(CCF)nn1)c1ccccc1</smiles>

$51 \mathrm{r}$

5

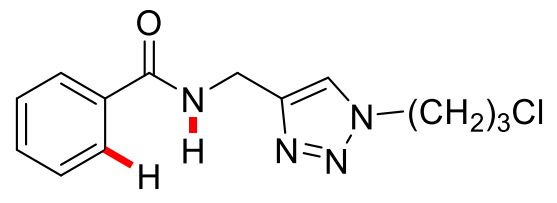

51d<smiles>C=CCc1c(CC)c2ccccc2c(=O)n1Cc1cn(CCF)nn1</smiles>

95rg<smiles>C=CCc1c(CC)c2ccccc2c(=O)n1Cc1cn(CCCl)nn1</smiles>

95dg
60

50

[a] Reaction conditions: $51(0.30 \mathrm{mmol}), 94 \mathrm{~g}(0.90 \mathrm{mmol}), \mathrm{Fe}(\mathrm{acac})_{3}(15 \mathrm{~mol} \%)$, dppe (15 mol \%), ZnBr $2 \cdot \operatorname{TMEDA}(0.60 \mathrm{mmol}), \operatorname{PrMgBr}(3.0 \mathrm{M}, 0.90 \mathrm{mmol}), \operatorname{THF}(0.40 \mathrm{~mL}), 65^{\circ} \mathrm{C}$, $16 \mathrm{~h}$; yields of isolated products.

Notably, when TAM benzamide $32 \mathrm{a}$ was used, the triazole group was directly removed in situ, leading to the products of free isoquinolone $\mathbf{9 7}$ and triazole substituted alkene 119 (Scheme 3.15). Employing tetrahydropyranyl as the leaving group on the BCP (94e), the yield of the free isoquinolone 97 was increased to $52 \%$. While previous studies on iron-catalyzed $\mathrm{C}-\mathrm{H}$ annulation always needed an additional step for TAM group removal, this finding provided an alternative way to synthesize the $\mathrm{NH}$-free isoquinolone. However, no product

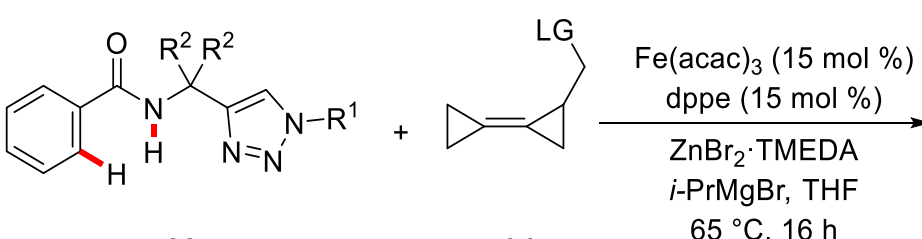

32<smiles>[R]NC(=O)NC(=O)c1ccccc1C(C)(c1ccccc1)c1cn(Cc2ccccc2)nn1</smiles>

32d: N.R.

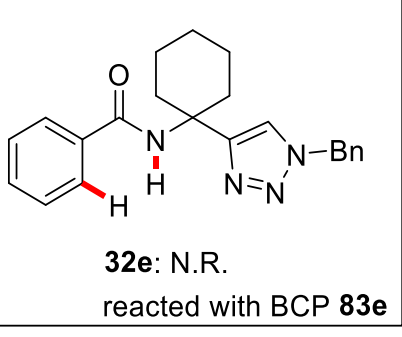

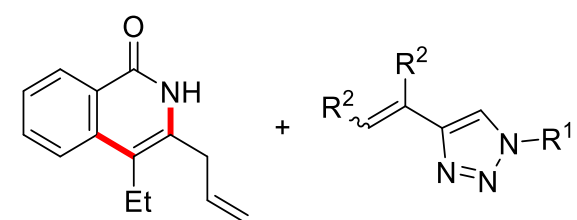

97

119

\begin{tabular}{|c|c|c|c|}
\hline LG & yield & 97 [\%] & yield $119[\%]$ \\
\hline OMe (94a) & & --- & --- \\
\hline OAc $\quad(94 \mathrm{~g})$ & & 30 & 24 \\
\hline OTHP (94e) & & 52 & 52 \\
\hline
\end{tabular}

Scheme 3.15 Impact of different TAM groups on the $\mathrm{C}-\mathrm{H} / \mathrm{C}-\mathrm{C}$ activation. 


\section{Results and Discussion}

formation was observed when other bulky groups were introduced on the TAM group (Scheme 3.15).

\subsubsection{Substrate Scope and Limitations}

Next, the reactivity of various substituted $\mathrm{TAH}$ substrates and BCP acetates was investigated (Table 3.13). This transformation tolerated various functional groups, such as thioether (51s) and chloro (51j) (entries 1-6). For the paramethyl substituted TAH substrate 51 e, under the standard condition only $16 \%$ of the product 95eg were obtained. By prolonging the reaction time and lowering the reaction temperature, the yield was improved to $60 \%$ (entry 2). meta-Substituted TAH substrates, such as methyl, chloro or bromo, were efficiently converted to the desired isoquinolones $95 \mathrm{tg}-\mathbf{9 5} \mathbf{w g}$ with high chemoand regio-selectivities (entries 7-10).

Table 3.13 Substrate scope of TAH benzamide 51 .

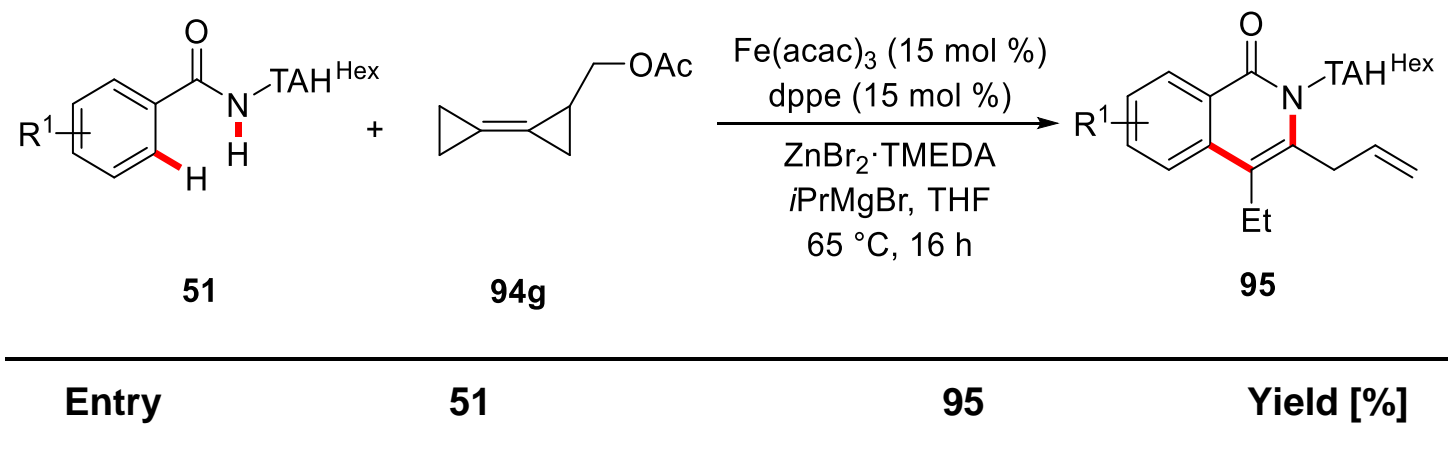

1<smiles>O=C(NN=[In])c1ccccc1</smiles>

$51 \mathrm{a}$

2<smiles>Cc1ccc(C(=O)N[AlH2])cc1</smiles>

$51 \mathrm{e}$<smiles>C=CCc1c(CC)c2ccccc2c(=O)n1[AlH2]</smiles>

95ag<smiles>C=CCc1c(CC)c2cc(C)ccc2c(=O)n1[AlH2]</smiles>

95eg
80 $16(60)^{[b]}$ 
3. Results and Discussion

3<smiles>COc1ccc(C(=O)N[Tl])cc1</smiles>

$51 \mathrm{~g}$

4<smiles></smiles>

51s

5<smiles>O=C(N[AlH2])c1ccc(-c2ccccc2)cc1</smiles>
$51 f$

6<smiles>O=C(N[AlH2])c1ccc(Cl)cc1</smiles>

51j<smiles>Cc1cccc(C(=O)N[Tl])c1</smiles>

$51 t$<smiles>O=C(N[TlH])c1cccc(F)c1</smiles>

$51 \mathrm{u}$<smiles></smiles>

95gg<smiles>C=CCc1c(CC)c2cc(S(C)(=O)=O)ccc2c(=O)n1[AlH2]</smiles>

95sg<smiles>C=CCc1c(CC)c2cc(-c3ccccc3)ccc2c(=O)n1[AlH2]</smiles>

95fg<smiles>C=CCc1c(CC)c2cc(Cl)ccc2c(=O)n1[AlH2]</smiles>

95jg

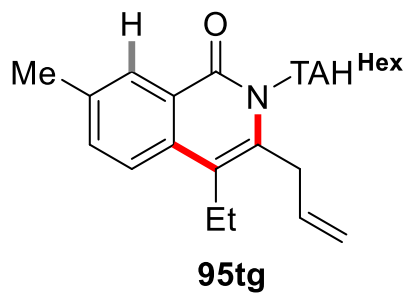




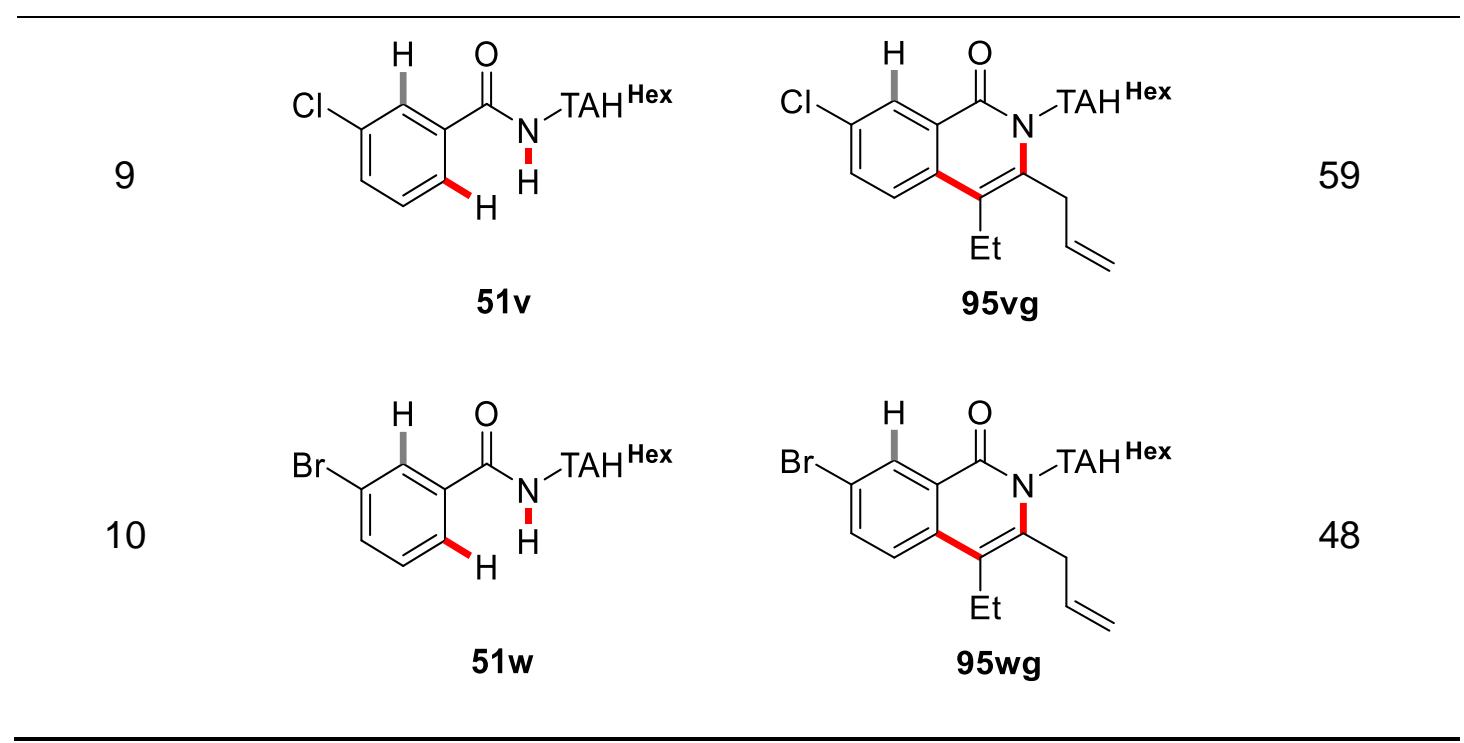

[a] Reaction conditions: 51 (0.30 mmol), 94g (0.90 mmol), Fe(acac)3 $(15 \mathrm{~mol} \%)$, dppe (15 mol \%), ZnBr2.TMEDA (0.60 mmol), $\operatorname{PrMgBr}(3.0 \mathrm{M}, 0.90 \mathrm{mmol}), \operatorname{THF}(0.40 \mathrm{~mL}), 65^{\circ} \mathrm{C}$, $16 \mathrm{~h}$; yields of isolated products.

A rare selective $\mathrm{C}-\mathrm{F} / \mathrm{C}-\mathrm{H}$ activation could be induced when the para- $\mathrm{CF}_{3}$ substituted $\mathrm{TAH}$-substrate $\mathbf{5 1 h}$ was used, providing the $\mathrm{C}-\mathrm{H} / \mathrm{C}-\mathrm{C} / \mathrm{C}-\mathrm{F} / \mathrm{C}-\mathrm{H}$ functionalized product 95hg' (Scheme 3.16a). Additionally, meta- $\mathrm{CF}_{3}$ substituted TAH-substrate 51x afforded the by-product 95xg' with conservation of one cyclopropane ring (Scheme 3.16b). These findings strongly supported a $\beta-O$ elimination or $\beta-C$ elimination mechanism to be responsible for the ring opening of the cyclopropanes. For the para- $\mathrm{CF}_{3}$ substituted TAM-substrate $\mathbf{3 2 g}$, the $\mathrm{C}-\mathrm{F} / \mathrm{C}-\mathrm{H}$ functionalization product $\mathbf{9 7 g g}$ ' was here not observed (Scheme $3.16 \mathrm{c}$ ), which is suggestive of the $\mathrm{C}-\mathrm{N}$ bond cleavage taking place preferentially over the $\mathrm{C}-\mathrm{C}$ cleavage of the second cyclopropane ring during the formation of the free isoquinolone products 97 (Scheme 3.21, pathway C). 


\section{Results and Discussion}

a)

(1)

$51 \mathrm{~h}$

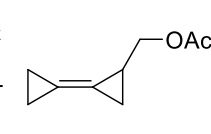

$94 \mathrm{~g}$

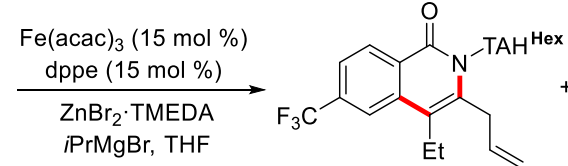

95hg: $7 \%$

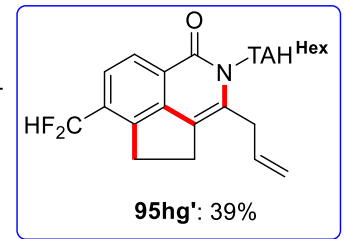

95hg': 39\%

b)<smiles>O=C(N[TlH])c1cccc(C(F)(F)F)c1</smiles>

$51 x$

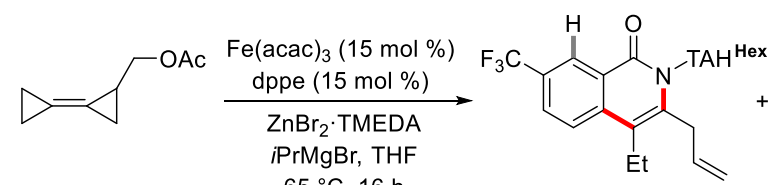

$94 \mathrm{~g}$ 95xg: $37 \%$

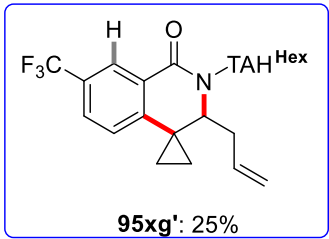

95xg': $25 \%$

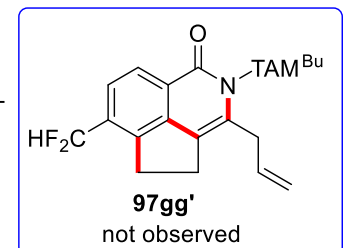

$32 \mathrm{~g}$

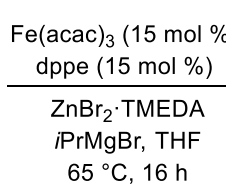

$65^{\circ} \mathrm{C}, 16 \mathrm{~h}$

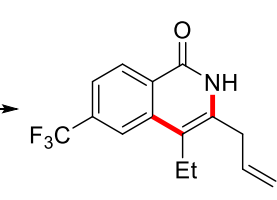

97gg: $35 \%$

Scheme 3.16 Impact of $\mathrm{CF}_{3}$-substitution of benzamide.

Pre-installed long alkyl chain or phenyl group at the $\alpha$-position of the BCP acetate significantly decreased the efficiency of the transformation (Table 3.14, entries 1 and 2). It is also worth to mention that the two cyclopropane rings of the BCP derivative are necessary for this $\mathrm{C}-\mathrm{H}$ annulation reaction. The absence or replacement of one of them shut down the transformation (entries $3-6)$. 


\section{Results and Discussion}

Table 3.14 Substrate scope of BCP 94.<smiles>O=C(N[Tl])c1ccccc1</smiles>

$51 a$<smiles>[R]C(OC(C)=O)C1CC1=C1CC1</smiles>

94

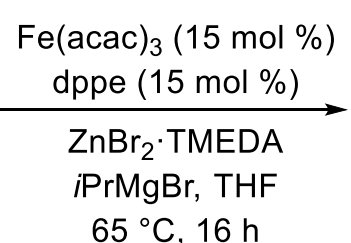

$65^{\circ} \mathrm{C}, 16 \mathrm{~h}$

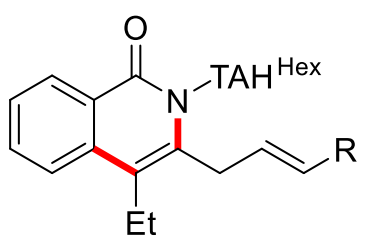

95

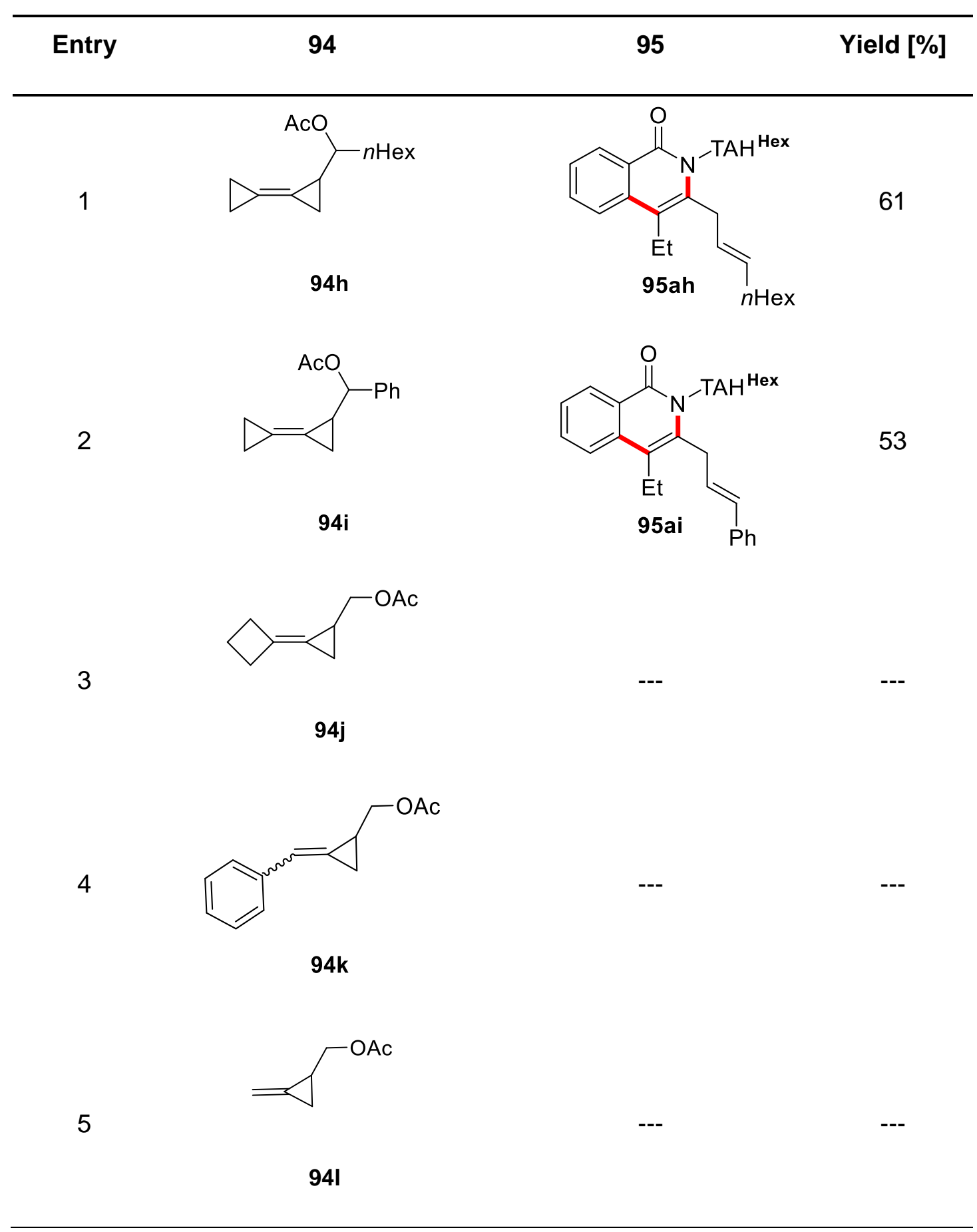


6

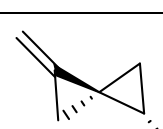

6

$$
\text { AcO }
$$

$94 m$

[a] Reaction conditions: 51a $(0.30 \mathrm{mmol}), 94(0.90 \mathrm{mmol}), \mathrm{Fe}(\mathrm{acac}) 3(15 \mathrm{~mol} \%)$, dppe (15 mol \%), ZnBr $2 \cdot \operatorname{TMEDA}(0.60 \mathrm{mmol}), \operatorname{PrMgBr}(3.0 \mathrm{M}, 0.90 \mathrm{mmol}), \operatorname{THF}(0.40 \mathrm{~mL}), 65^{\circ} \mathrm{C}$, $16 \mathrm{~h}$; yields of isolated products.

Efforts also have been made to extend the scope of the bispiro-fused product 96. Unfortunately, BCPs bearing methoxy as the leaving group only afforded the corresponding products in low yields when reacted with different TAH substrates 51 (Table 3.15, entries 1-9). TAM substrates 32 were tested as well, however, no target product formation was observed (entries 10-12).

Table 3.15 Substrate scope of bispiro-fused isoquinolone 96 formation.

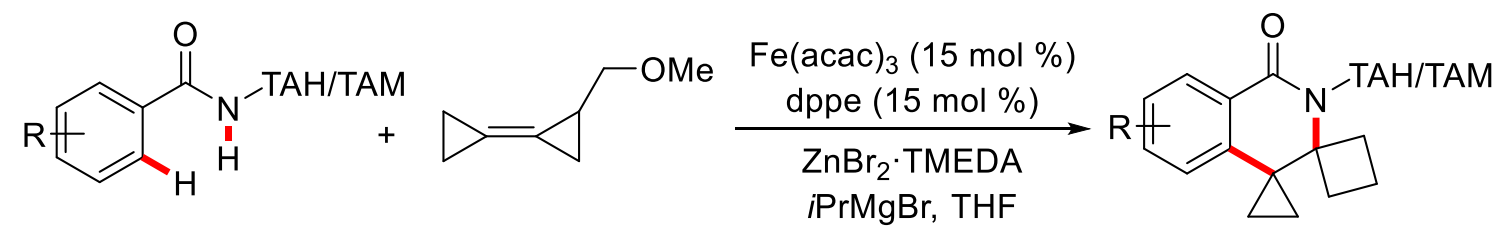
$51 / 32$ $94 a$

$65^{\circ} \mathrm{C}, 16 \mathrm{~h}$

96

Entry Yield [\%]


3<smiles>O=C(NCc1cn(-c2ccccc2)nn1)c1ccccc1</smiles>

$51 y$

4<smiles>O=C(NCc1cn(CCCl)nn1)c1ccccc1</smiles>

51d

5<smiles>Cc1ccc(C(=O)NCc2cn(C=[W])nn2)c(C)c1</smiles>

6<smiles>CS(=O)(=O)c1ccc(C(=O)NCc2cn(C=[W])nn2)cc1</smiles>

7<smiles>O=C(NCc1cn(C[Ga])nn1)c1ccc(C(F)(F)F)cc1</smiles>

$51 \mathrm{~h}$

8<smiles>[R]Cn1cc(CNC(=O)c2cccc(Br)c2)nn1</smiles>

$51 w$<smiles>O=C1c2ccccc2C2(CC2)C2(CCC2)N1Cc1cn(-c2ccccc2)nn1</smiles>

96ya<smiles>Cn1cc(CN2C(=O)c3ccccc3C3(CC3)C23CCC3)nn1</smiles>

96da<smiles>Cc1ccc2c(c1)C1(CC1)C1(CCC1)N(Cc1cn(C[Ge])nn1)C2=O</smiles><smiles>O=C1C(=O)N(Cc2cn(CO[Ga])nn2)C2(CCC2)C2(CC2)c2ccc(Br)cc21</smiles> 
9<smiles>CCn1cc(CNC(=O)c2cccc(F)c2)nn1</smiles>

$51 \mathrm{u}$

10<smiles>CCCCn1cc(C(C)(C)NC(=O)c2ccccc2)nn1</smiles>

$32 a$

11<smiles>CC(NC(=O)c1ccccc1)(c1ccccc1)c1cn(Cc2ccccc2)nn1</smiles>

12<smiles>O=C(NC1(c2cn(Cc3ccccc3)nn2)CCCCC1)c1ccccc1</smiles>

$32 e$<smiles>[2H]c1c(F)ccc2c1C(=O)C(=O)N(Cc1cn(CO[W])nn1)C1(CCC1)C21CC1</smiles>

96ua

a] Reaction conditions: $\mathbf{5 1 / 3 2}(0.30 \mathrm{mmol})$, 88a $(0.90 \mathrm{mmol}), \mathrm{Fe}(\mathrm{acac})_{3}(15 \mathrm{~mol} \%)$, dppe (15 mol \%), ZnBr2.TMEDA (0.60 mmol), $\operatorname{PrMgBr}(3.0 \mathrm{M}, 0.90 \mathrm{mmol}), \operatorname{THF}(0.40 \mathrm{~mL}), 65^{\circ} \mathrm{C}$, $16 \mathrm{~h}$; yields of isolated products.

\subsubsection{Removal of TAH Group}

The TAH group of the bispiro-fused isoquinolone 96aa was removed in an electro-oxidative fashion without breaking the strained rings (Scheme 3.17). 


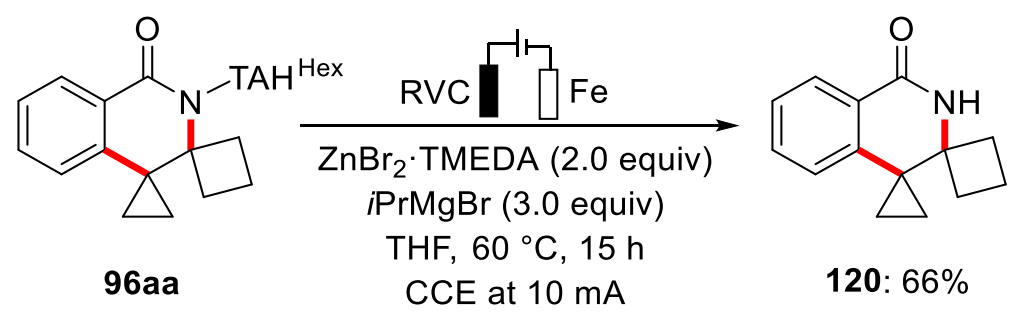

Scheme 3.17 Traceless electrochemical removal of the TAH group.

Crystals suitable for X-ray diffraction were then grown by slow evaporation, unambiguously confirming the connectivity of product $\mathbf{1 2 0}$ (Scheme 3.18).<smiles>O=C1NC2(CCC2)C2(CC2)c2ccccc21</smiles>

120

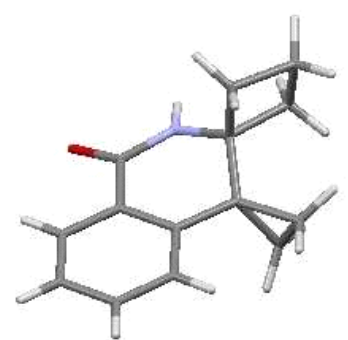

120 (CCDC 2018011)

Scheme 3.18 Molecular structure of $\mathbf{1 2 0}$ with thermal ellipoids at $50 \%$ probability level. The crystal structure was measured and solved by Dr. Christopher Golz.

\subsubsection{Mechanistic Studies}

In order to shed light on the reaction mechanism, experimental and Mössbauer spectroscopic studies were conducted.

\section{Experimental Studies}

A comparable reactivity between electron-deficient benzamide $51 \mathrm{~h}$ and electron-rich benzamide 51e was observed (Scheme 3.19a). A C-D/N-H functionalization with the isotopically labelled substrates $[D]_{5}-51 \mathrm{r}$ or $[D]_{5}-51 \mathrm{a}$, either by independent reactions or an intermolecular KIE measurement in a one-pot fashion, showed a very minor kinetic isotope effect $\left(k_{H} / k_{D}=1.2\right)$, 


\section{Results and Discussion}

providing support for a facile $\mathrm{C}-\mathrm{H}$ cleavage which is not the rate-determining step of the overall reaction (Scheme 3.19b and 3.19c).

a) Competition Experiment<smiles>Cc1ccc(C(=O)N[AlH2])cc1</smiles>

and<smiles>O=C(N[AlH2])c1ccc(C(F)(F)F)cc1</smiles>

$51 \mathrm{~h}(0.15 \mathrm{mmol})$
$\mathrm{Fe}(\mathrm{acac})_{3}(15 \mathrm{~mol} \%)$ dppe $(15 \mathrm{~mol} \%)$ $\mathrm{ZnBr}_{2} \cdot \mathrm{TMEDA}$ iPrMgBr, THF, $65^{\circ} \mathrm{C}$ $\mathrm{THF}, 65^{\circ} \mathrm{C}, 10 \mathrm{~min}$ $94 \mathrm{~g}$<smiles>C=CCc1c(CC)c2cc(C)ccc2c(=O)n1[AlH2]</smiles>

95eg: $34 \%$ $+$<smiles>C=CCC1=C2CCc3ccc(C(F)F)c(c32)C1=O</smiles>

95hg: $15 \%$

95hg': $23 \%$

b) Intermolecular KIE (independent reactions)

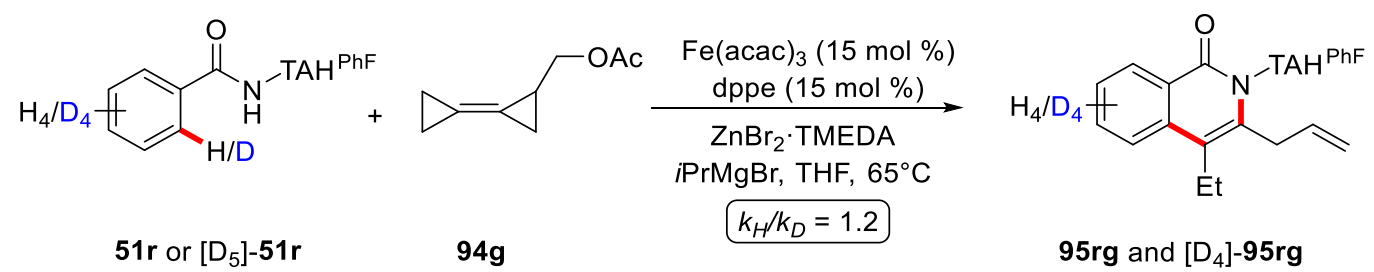

c) Intermolecular KIE (one-pot)

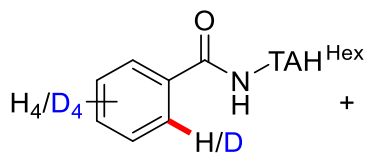

$51 \mathrm{a}$ or $\left[\mathrm{D}_{5}\right]-51 \mathrm{a}$<smiles>CC(=O)OCC1CC1=C1CC1</smiles>

$94 \mathrm{~g}$

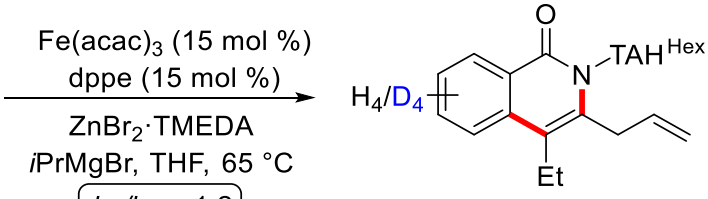

95ag and $\left[D_{4}\right]-95 \mathrm{ag}$

Scheme 3.19 Competition reaction and KIE studies.

The deuterium-labelled substrate [ $\left.D_{5}\right]-51 a$ resulted in site selective deuterium incorporation of the product $\left[D_{n}\right]-95 a g$ or $\left[D_{n}\right]-96 a a$, being indicative of a LLHT mechanism (Scheme 3.20a and 3.20b). Interestingly, deuterium incorporation was position-selective for the corresponding products (Scheme 3.20c and 3.20d), which indicates an iron-catalyzed C-C cleavage occurring during the catalytic reaction. The partial deuterium incorporation of the products [D]-95ag and [D]-96aa (Scheme 3.20c and 3.20d) indicates that intermediates 125 and 


\section{Results and Discussion}

126 could be the resting states for the corresponding pathways A and B (Scheme 3.21). In addition, diastereo-selective deuterium incorporation in the products $\left[D_{n}\right]-96 a a$ and $[D]-96 a a$ was observed, (Scheme 3.20b and 3.20d) which suggests a migratory insertion taking place for the formation of intermediate 126 (Scheme 3.21, pathway B).

(a)

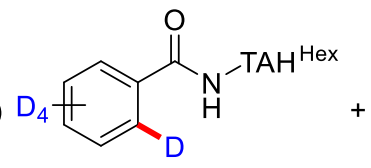
$\left[\mathrm{D}_{5}\right]-51 \mathrm{a}$

(b)<smiles>[2H]c1ccccc1C(=O)NN=C</smiles>
$\left[\mathrm{D}_{5}\right]-51 \mathrm{a}$<smiles>OCC1CC1C1CC1</smiles>

$94 \mathrm{~g}$

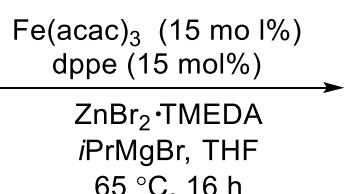

$65^{\circ} \mathrm{C}, 16 \mathrm{~h}$

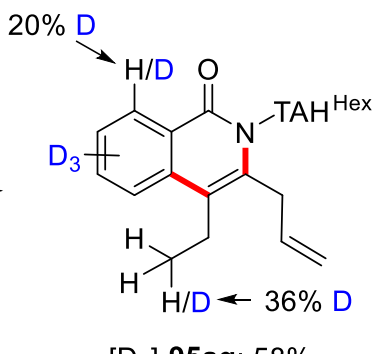

$\left[D_{n}\right]-95$ ag: $58 \%$

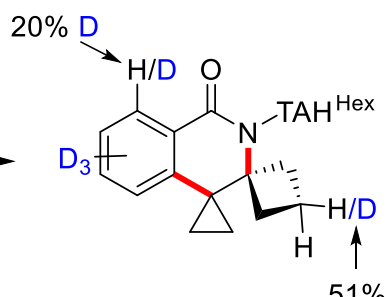
$\left[D_{n}\right]-96 a a: 17 \% 51 \%$ D

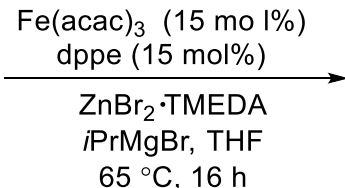

$94 a$

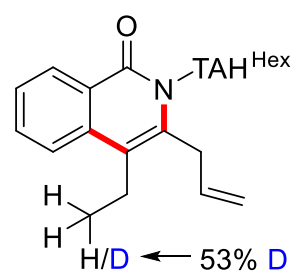

[D]-95ag: $17 \%$

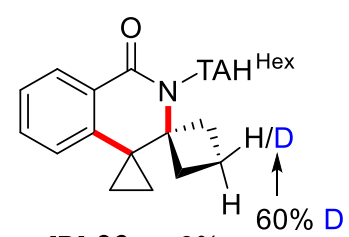

[D]-96aa: $9 \%$

Scheme 3.20 Isotopically-labelled experiments. 


\section{Results and Discussion}

\section{Mössbauer spectroscopy studies}

For further understanding the iron's oxidation and spin states in the reaction, detailed Mössbauer spectroscopic studies were conducted. In order to avoid the influence of iron-catalyzed $\beta$-H-elimination of Grinard reagent, $\mathrm{MeMgBr}$ was used instead of $\mathrm{PrMgBr}$ for the Mössbauer measurement. Overall, the presence of high-spin iron(II) intermediates were support by our observations. ${ }^{[90]}$ These studies were performed in collaboration with the research group of Prof. Dr. F. Meyer. After sample preparation, the data were recorded and interpreted by Dr. S. Demeshko.

Table 3.16 Mössbauer parameters of reaction mixtures.

\begin{tabular}{|c|c|c|c|c|c|}
\hline Entry & Reaction & $\begin{array}{l}\text { Valence of Iron / } \\
\text { Spin State }\end{array}$ & $\begin{array}{c}\delta \\
\left(\mathrm{mm} \cdot \mathrm{s}^{-1}\right)\end{array}$ & $\begin{array}{c}\Delta E Q \\
\left(\mathrm{~mm} \cdot \mathrm{s}^{-1}\right)\end{array}$ & $\begin{array}{l}\text { rel. int. } \\
\text { (\%) }\end{array}$ \\
\hline 1 & ${ }^{57} \mathrm{FeCl}_{2}+\mathrm{THF}$ & $+2^{\mathrm{HS}}$ & 1.26 & 3.05 & 100 \\
\hline 2 & Entry $1+\mathrm{MeMgBr}$ & $+1.4^{[91]}$ & 0.29 & 0.88 & 100 \\
\hline \multirow{2}{*}{3} & Entry $2+$ & $+2^{\mathrm{HS}}$ & 1.01 & 2.69 & 69 \\
\hline & $\mathrm{ZnBr}_{2} \cdot \mathrm{TMEDA}$ & $+2^{\mathrm{HS}}$ & 1.36 & 2.56 & 31 \\
\hline \multirow{3}{*}{4} & \multirow{3}{*}{ Entry $3+$ dppe } & $+2^{\mathrm{HS}}$ & 0.92 & 1.42 & 23 \\
\hline & & $+2^{\mathrm{HS}}$ & 0.98 & 2.57 & 40 \\
\hline & & $+2^{\mathrm{HS}}$ & 1.24 & 2.68 & 37 \\
\hline \multirow{3}{*}{5} & \multirow{3}{*}{ Entry $4+51 a$} & $+2^{\mathrm{HS}}$ & 0.89 & 2.05 & 30 \\
\hline & & $+2^{\mathrm{HS}}$ & 0.93 & 2.63 & 49 \\
\hline & & $+2^{\mathrm{HS}}$ & 1.02 & 3.07 & 21 \\
\hline \multirow{3}{*}{6} & \multirow{3}{*}{ Entry $5+94 g$} & $+2^{\mathrm{HS}}$ & 0.95 & 2.22 & 33 \\
\hline & & $+2^{\mathrm{HS}}$ & 1.02 & 2.79 & 55 \\
\hline & & $+2^{\mathrm{HS}}$ & 1.05 & 3.13 & 12 \\
\hline \multirow{3}{*}{7} & \multirow{3}{*}{$\begin{array}{l}\text { Entry } 4+32 a+ \\
94 \mathrm{~g}\end{array}$} & $+2^{\mathrm{HS}}$ & 0.92 & 2.09 & 44 \\
\hline & & $+2^{\mathrm{HS}}$ & 0.95 & 2.66 & 36 \\
\hline & & $+2^{\mathrm{HS}}$ & 1.03 & 3.00 & 20 \\
\hline
\end{tabular}




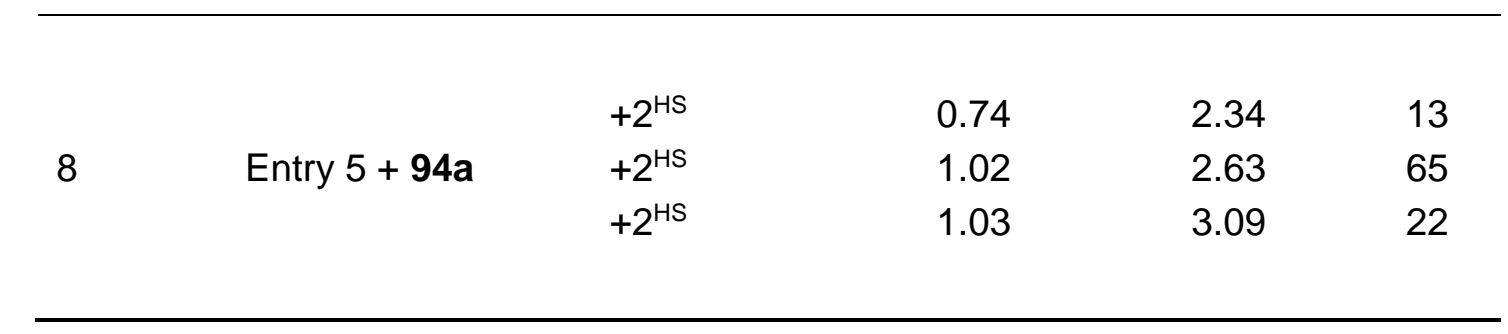

The data were recorded and interpreted by Dr. S. Demeshko.

\subsubsection{Proposed Mechanism}

Based on experimental studies and previous findings, ${ }^{[94]}$ we propose a novel iron-catalyzed $\mathrm{C}-\mathrm{H} / \mathrm{C}-\mathrm{C}$ activation sequence, involving three pathways can lead to three different product formations (Scheme 3.21).

The catalytic cycle is initiated by a reversible $\mathrm{C}-\mathrm{H}$ activation via LLHT to generate the cyclometalated iron species 121, which can undergo coordination and migratory insertion to deliver complex 123. After oxidation-induced reductive elimination ${ }^{[46,94]}$ and $\beta$-elimination of intermediate 123 , intermediate 124 is formed. From intermediate 124, depending on the combination of leaving group and $\mathrm{N}$-substituent, three pathways can lead to three different products. In pathway $\mathbf{A}$, intermediate 124 undergoes $\beta$-C-elimination to give intermediate 125 , subsequent with proto-demetallation to yield product 95ag and regenerate the active iron species 121. In pathway $\mathbf{B}$, migratory insertion of the alkene takes place to form the intermediate 126. After proto-demetallation, product 96aa is provided. Finally, in pathway $\mathbf{C}$, a $\beta$-C-elimination occurs at the $\mathrm{N}-\mathrm{C}$ bond which connects the directing group and benzamide moiety, thus forming the intermediates 127 and 128. Intermediate 128 undergoes $\beta$ - $\mathrm{H}$-elimination to release the alkene $119 \mathrm{a}$ and generate iron hydride species which reduces the intermediate 127 to generate intermediate 129. After $\beta$-C-elimination and protodemetallation, intermediate 129 yields the final product 97 ag and releases the active iron species 121. 


\section{Results and Discussion}

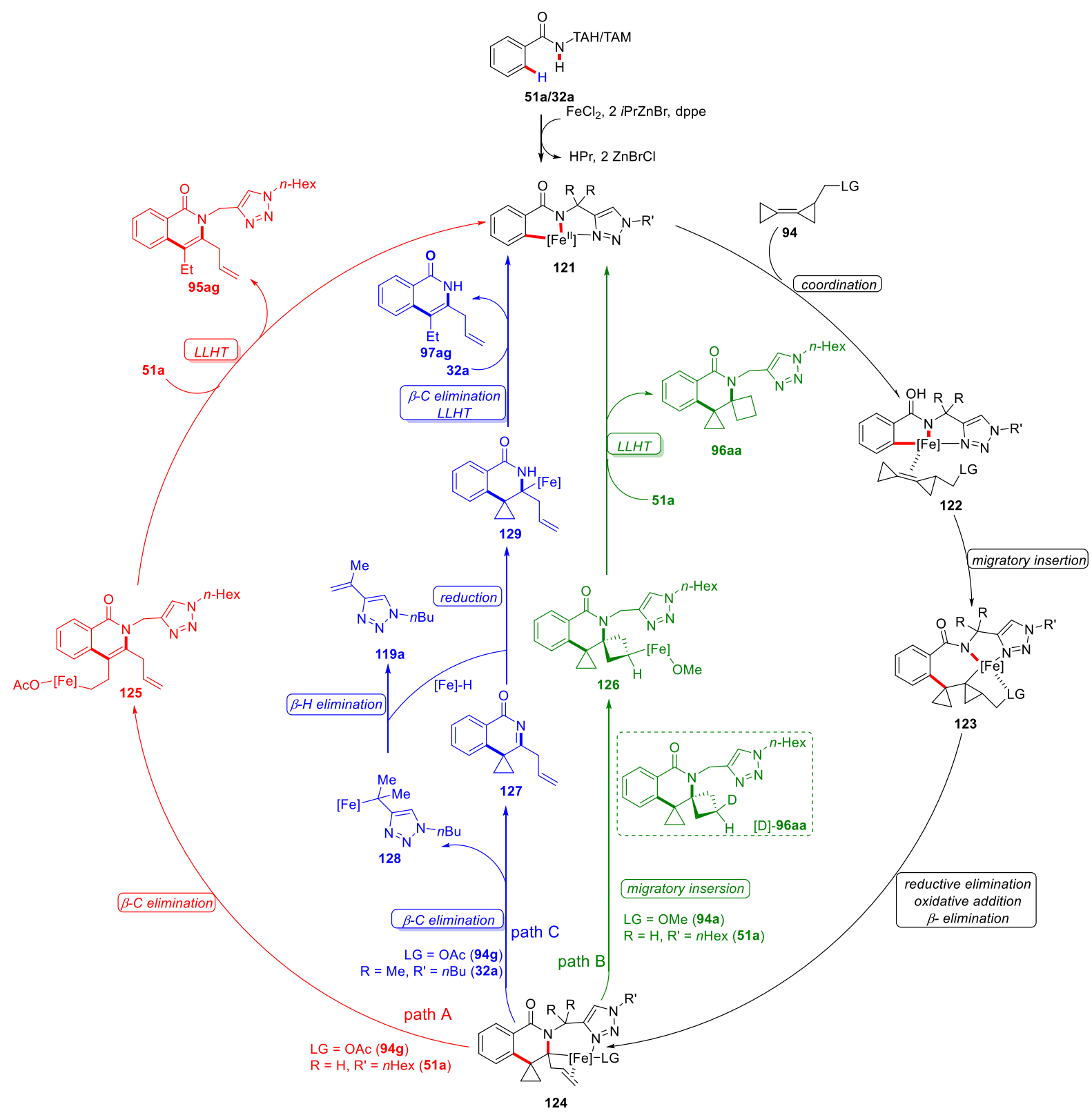

Scheme 3.21 Proposed catalytic cycle for iron-catalyzed $\mathrm{C}-\mathrm{H} / \mathrm{C}-\mathrm{C}$ activations. 


\section{Summary and Outlook}

\section{Summary and Outlook}

The last decades have witnessed considerable progress in iron-catalyzed $\mathrm{C}-\mathrm{H}$ functionalizations for a sustainable and economically-efficient access to $\mathrm{C}-\mathrm{C}$ and $\mathrm{C}-\mathrm{Het}$ bonds. Despite considerable progress, several limitations in ironcatalyzed $\mathrm{C}-\mathrm{H}$ annulation reactions need to be overcame. First, the types of viable coupling partners for this methodology are severly restricted, only alkynes were reported thus far. Next, an excess of DCIB as an external oxidant was requied for an efficient annulation. In addition, a narrow substrate scope was presented in several cases. Then, the reaction mechanism was not fully elucidated. Last, efficient protocols for the removal of the TAH group are missing.

In the first project, iron-catalyzed $\mathrm{C}-\mathrm{H}$ annulations with allenes 88 were disclosed (Scheme 4.1). ${ }^{[89]}$ The notable achievements feature 1) a novel ironcatalyzed annulation reaction with allenes, 2) $\mathrm{C}-\mathrm{H}$ activation at room temperature, 3) external-oxidant-free conditions, 4) not only TAH benzamides 51, TAM benzamides 32 can be compatible for this novel transformation, and

5) detailed mechanistic insight into this 1,4-iron migration pathway for facile C$\mathrm{H}$ activations. 


\section{Summary and Outlook}<smiles>CCCCCCn1cc(CNC(=O)c2ccccc2)nn1</smiles>

51

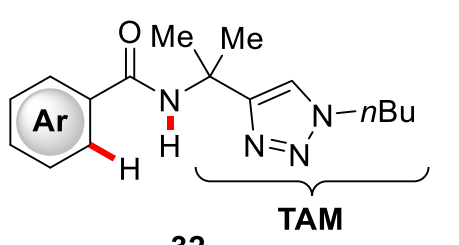

32

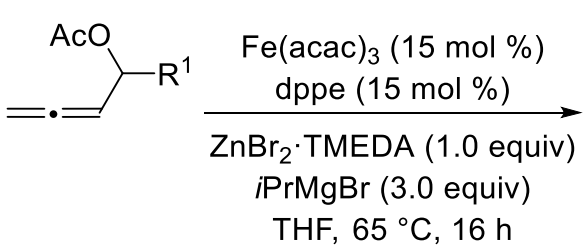

88

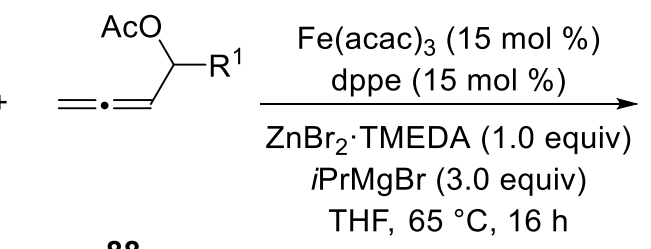

88<smiles>[R]CCc1cc2ccccc2c(=O)n1[AlH2]</smiles>

89<smiles>[R]CC=C1Cc2ccccc2C(=O)N1[Y10]</smiles>

90

Scheme 4.1 Iron-catalyzed $\mathrm{C}-\mathrm{H} / \mathrm{N}-\mathrm{H}$ redox-neutral annulations with allenes $\mathbf{8 8}$.

Within the second project, the synthesis of 3,4-disubstituted isoquinolones 92 through iron-catalyzed $\mathrm{C}-\mathrm{H}$ annulations with propargyl acetates 91 was realized (Scheme 4.2). ${ }^{[93]}$ Notably, the TAH group, whose removal proved to be difficult, can be tracelessly removed in an electrochemical fashion.

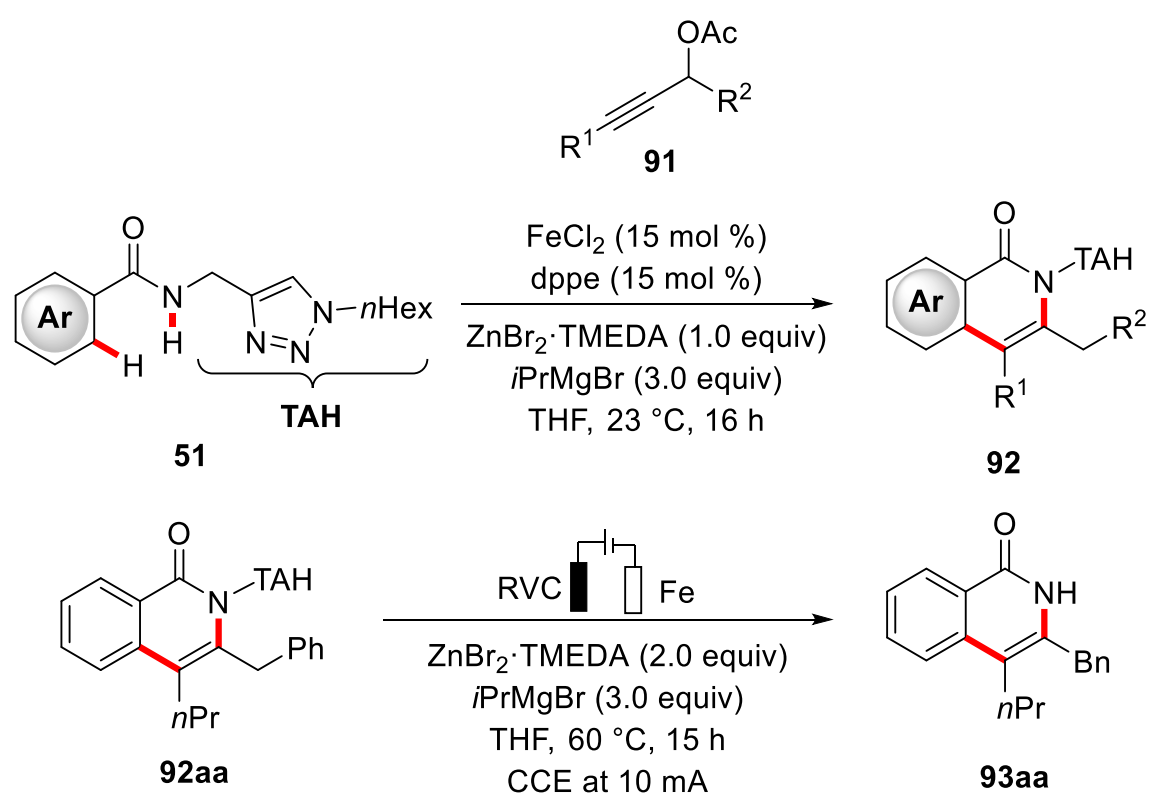

Scheme 4.2 Iron-catalyzed $\mathrm{C}-\mathrm{H} / \mathrm{N}-\mathrm{H}$ redox-neutral annulations with alkynes 91 .

In the third project, the merger of $\mathrm{C}-\mathrm{H}$ activation and $\mathrm{C}-\mathrm{C}$ cleavage by iron catalysis was achieved by the application of BCPs 94 (Scheme 4.3). Salient features of this novel transformation include 1) first iron-catalyzed $\mathrm{C}-\mathrm{H} / \mathrm{C}-\mathrm{C}$ 


\section{Summary and Outlook}

functionalizations, 2) the use of BCP derivatives 94 as coupling partners, 3) oxidant-free catalysis avoiding harsh conditions, 4) selective $C-C$ cleavage enable divers product formation, and 5) a mono-selective $\mathrm{C}-\mathrm{F} / \mathrm{C}-\mathrm{H}$ activation sequence of trifluoromethylarenes.

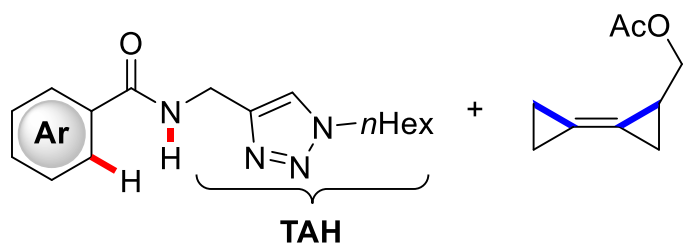

51

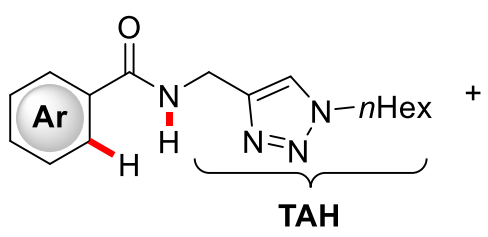

51

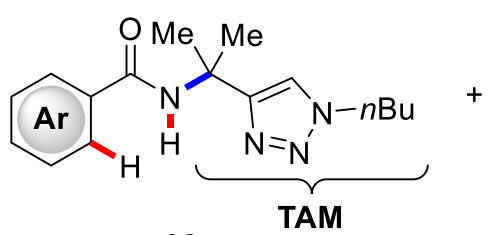

32

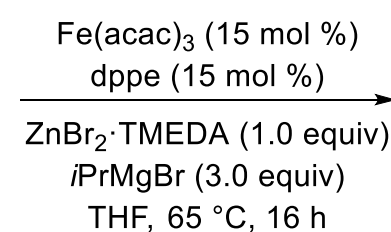

$94 \mathrm{~g}$<smiles>COCC1CC1C1CC1</smiles>

$94 a$<smiles>CC(=O)OCC1CC1=C1CC1</smiles>

$94 \mathrm{~g}$<smiles>C=CCc1c(CC)c2ccccc2c(=O)n1[TlH]</smiles>

95

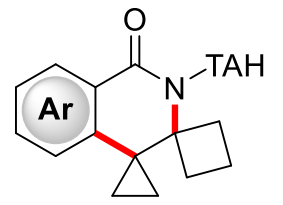

96<smiles>C=CCc1[nH]c(=O)c2ccccc2c1CC</smiles>

97

Scheme 4.3 Iron-catalyzed C-H/C-C activation with BCPs 94. 


\section{Experimental Part}

\section{Experimental Part}

\subsection{General Remarks}

All reactions involving moisture- or air-sensitive reagents or products were performed under an inert atmosphere of nitrogen using pre-dried glassware and standard Schlenk techniques. If not otherwise noted yields refer to isolated compounds, estimated to be $>95 \%$ pure as determined by ${ }^{1} \mathrm{H}$ NMR and GC analysis.

\section{Vacuum}

A Vacuubrand RZ 6 vacuum pump was used throughout the course of this thesis. The pressure was measured to be 0.7 mbar (uncorrected value).

\section{Melting Points}

Melting points were measured on a Stuart® Melting Point Apparatus SMP3 from Barloworld Scientific. Values are uncorrected.

\section{Chromatography}

Analytical thin layer chromatography (TLC) was performed on silica gel 60 F254 aluminum sheets from MERCK. Plates were either visualized under irradiation at $254 \mathrm{~nm}$ or $365 \mathrm{~nm}$ or developed by treatment with a potassium permanganate solution followed by careful warming. Chromatographic purification was accomplished by flash column chromatography on MERCK Geduran® silica gel, grade 60 (40-63 $\mu \mathrm{m}, 70-230$ mesh ASTM).

\section{Gas Chromatography}

Monitoring of reaction process via gas chromatography or coupled gas chromatography-mass spectrometry was performed using a 7890 GC-system with/without mass detector 5975C (Triple-Axis-Detector) or a 7890B GCsystem coupled with a 5977A mass detector, both from Agilent Technologies®. 


\section{Experimental Part}

\section{Infrared Spectroscopy}

Infrared (IR) spectra were recorded using a Bruker ${ }^{\circledR}$ Alpha-P ATR spectrometer. Liquid samples were measured as film and solid samples neat. Spectra were recorded in the range from 4000 to $400 \mathrm{~cm}^{-1}$. Analysis of the spectral data were carried out using Opus 6. Absorption is given in wave numbers $\left(\mathrm{cm}^{-1}\right)$.

\section{Nuclear Magnetic Resonance Spectroscopy}

Nuclear magnetic resonance (NMR) spectra were recorded on Mercury Plus 300 , VNMRS 300, Inova 500 and 600 from Varian®, or Avance 300, Avance III 300 and 400, Avance III HD 400 and 500 from Bruker®. Chemical shifts are reported in $\delta$-values in ppm relative to the residual proton peak or carbon peak of the deuterated solvent.

\begin{tabular}{lcc}
\hline Solvent & ${ }^{1} \mathrm{H}$ NMR & ${ }^{13} \mathrm{C}$ NMR \\
\hline $\mathrm{CDCl}_{3}$ & 7.26 & 77.16 \\
$\mathrm{C}_{6} \mathrm{D}_{6}$ & 7.16 & 128.06 \\
\hline
\end{tabular}

The following abbreviations are used to describe the observed multiplicities: $s$ (singlet), d (doublet), t (triplet), q (quartet), p (pentet), h (hexet), hept (heptet), $\mathrm{m}$ (multiplet) or analogous representations. The coupling constants $J$ are reported in Hertz $(\mathrm{Hz})$. Analysis of the recorded spectra was carried out using MestReNova 10 software.

\section{Mass Spectrometry}

Electron ionization (EI) and El high resolution mass spectra (HRMS) were measured on a time-of-flight mass spectrometer AccuTOF from JOEL. Electrospray ionization (ESI) mass spectra were recorded on an lo-Trap mass spectrometer LCQ from Finnigan, a quadropole time-of-flight maXis from Bruker Daltonic or on a time-of-flight mass spectrometer microTOF from Bruker 


\section{Experimental Part}

Daltonic. ESI-HRMS spectra were recorded on a Bruker Apex IV or Bruker Daltonic 7T, fourier transform ion cyclotron resonance (FTICR) mass spectrometer. The ratios of mass to charge $(\mathrm{m} / \mathrm{z})$ are indicated, intensities relative to the base peak $(I=100)$ are given in parentheses.

\section{Electrocatalysis}

Electrocatalysis was conducted using an AXIOMET AX-3003P potentiostat in constant current mode.

\section{Mössbauer Spectroscopy}

Mößbauer spectra were recorded with a ${ }^{57} \mathrm{Co}$ source in a Rh matrix using an alternating constant acceleration Wissel Mössbauer spectrometer operated in the transmission mode and equipped with a Janis closed-cycle helium cryostat. Isomer shifts are given relative to iron metal at ambient temperature. Simulation of the experimental data was performed with the Mfit program $^{[95]}$ using Lorentzian line doublets.

\section{Solvents}

Solvents for column chromatography were purified via distillation under reduced pressure prior to their use. All solvents for reactions involving moisturesensitive reagents were dried, distilled and stored under inert atmosphere ( $\mathrm{Ar}$ or $\mathrm{N}_{2}$ ) according to following standard procedures:

Purified by solvent purification system (SPS-800, M. Braun): $\mathrm{CH}_{2} \mathrm{Cl}_{2}$, toluene, tetrahydrofurane, dimethylformamide, diethylether.

Dried and distilled over sodium/benzophenone: 1,4-dioxane, DME, 2-MeTHF. Dried and distilled over $\mathrm{CaH}_{2}:$ 1,2-dichloroethane

\section{Chemicals}

Chemicals obtained from commercial sources with a purity $>95 \%$ were used as received without further purification. Stainless steel electrodes (Type 304, $10 \mathrm{~mm} \times 15 \mathrm{~mm} \times 0.25 \mathrm{~mm}$; obtained from abcr, Germany) and RVC electrodes $(5 \mathrm{~mm} \times 10 \mathrm{~mm} \times 6 \mathrm{~mm}$, SIGRACELL® GFA 6 EA, obtained from SGL Carbon, Wiesbaden, Germany) were connected using stainless steel 


\section{Experimental Part}

adapters. The following compounds were known from the literature and were synthesized according to the previously known methods:

TAH- and TAM- benzamides 51 and $\mathbf{3 2},{ }^{[45,53,61]}$ allenyl acetates 88, ${ }^{[96]}$ ${ }^{57} \mathrm{FeCl}_{2},{ }^{\left[{ }^{17]}\right.}$ propargyl acetates $91,{ }^{[98]}$ cyclopropylidenecyclohexane 117, ${ }^{[99]}$ permethylated bicyclopropylidene $\mathbf{1 1 8},{ }^{[100]}$ BCP derivatives $\mathbf{9 4 a - 9 4 9},{ }^{[101]}$ (Methylenecyclopropyl)methylacetate $94 k-941,{ }^{[102]}$ methylenespiropentylacet-ate $9 \mathbf{4 m} \cdot{ }^{[103]}$ 


\section{Experimental Part}

\subsection{General Procedures}

General Procedure A (GPA): Iron-Catalyzed C-H/N-H Allene Annulation To a stirred solution of $\mathbf{5 1 / 3 2}(0.30 \mathrm{mmol}), \mathrm{ZnBr} \cdot \mathrm{TMEDA}$ (206 $\mathrm{mg}, 0.60 \mathrm{mmol}$ ) and dppe (17.9 mg, $15 \mathrm{~mol} \%)$ in THF (0.20 mL), $\operatorname{PrMgBr}(3.0 \mathrm{M}$ in 2-MeTHF, $300 \mu \mathrm{L}, 0.90 \mathrm{mmol}$ ) was added in one portion and the reaction mixture was stirred for $5 \mathrm{~min}$ at ambient temperature. $\mathrm{Fe}(\mathrm{acac}) 3(15.9 \mathrm{mg}, 15 \mathrm{~mol} \%)$ was added in a single portion. After stirring the solution for additional $5 \mathrm{~min}$, allene $88(0.90 \mathrm{mmol}, 3.0$ equiv) was added as a solution in THF $(0.20 \mathrm{~mL})$ in one portion. The mixture was placed in a pre-heated oil bath at $65^{\circ} \mathrm{C}$. After stirring for $16 \mathrm{~h}$, sat. aqueous $\mathrm{NH}_{4} \mathrm{Cl}(2.0 \mathrm{~mL})$ was added to the reaction mixture, which was then extracted with $\mathrm{CH}_{2} \mathrm{Cl}_{2}(3 \times 15 \mathrm{~mL})$. The combined organic extracts were dried over $\mathrm{Na}_{2} \mathrm{SO}_{4}$, filtered and concentrated. The crude product was purified by column chromatography on silica gel to afford the desired product $89 / 90$.

\section{General Procedure A' (GPA'): Iron-Catalyzed C-H/N-H Allene Annulation}

To a stirred solution of $\mathbf{5 1 / 3 2}(0.30 \mathrm{mmol}), \mathrm{ZnBr} \cdot \operatorname{TMEDA}$ (206 mg, $0.60 \mathrm{mmol}$ ) and dppe (17.9 mg, $15 \mathrm{~mol} \%)$ in THF (0.20 mL), iPrMgBr (3.0 M in 2-MeTHF, $300 \mu \mathrm{L}, 0.90 \mathrm{mmol}$ ) was added in one portion and the reaction mixture was stirred for $5 \mathrm{~min}$ at ambient temperature. Fe(acac)3 (15.9 mg, $15 \mathrm{~mol} \%)$, THF $(0.20 \mathrm{~mL})$, allene $88(0.90 \mathrm{mmol}, 3.0$ equiv) was added to the mixture at the same time. The resulting mixture was placed in a pre-heated oil bath at $65^{\circ} \mathrm{C}$. After stirring for $16 \mathrm{~h}$, sat. aqueous $\mathrm{NH}_{4} \mathrm{Cl}(2.0 \mathrm{~mL})$ was added to the reaction mixture, which was then extracted with $\mathrm{CH}_{2} \mathrm{Cl}_{2}(3 \times 15 \mathrm{~mL})$. The combined organic extracts were dried over $\mathrm{Na}_{2} \mathrm{SO}_{4}$, filtered and concentrated. The crude product was purified by column chromatography on silica gel to afford the desired product 89/90. 


\section{Experimental Part}

\section{General Procedure B (GPB): Iron-Catalyzed C-H/N-H Alkyne Annulation}

To a stirred solution of $51(0.30 \mathrm{mmol}), \mathrm{ZnBr} \cdot \mathrm{TMEDA}(205 \mathrm{mg}, 0.60 \mathrm{mmol})$ and dppe (17.9 mg, $15 \mathrm{~mol} \%)$ in THF (0.40 mL), iPrMgBr (3.0 M in 2-MeTHF, 300 $\mu \mathrm{L}, 0.90 \mathrm{mmol}$ ) was added in one portion and the reaction mixture was stirred for $5 \mathrm{~min}$ at ambient temperature. Then, $\mathrm{Fe}(\mathrm{acac}) 2(5.7 \mathrm{mg}, 15 \mathrm{~mol} \%)$ was added in a single portion. After stirring the solution for additional $5 \mathrm{~min}$, alkyne 91 (0.90 mmol, 3.0 equiv) was added as a solution in THF $(0.40 \mathrm{~mL})$. Then, the mixture was stirred at ambient temperature. After stirring for $16 \mathrm{~h}$, sat. aqueous $\mathrm{NH}_{4} \mathrm{Cl}(3.0 \mathrm{~mL})$ was added to the reaction mixture, which was extracted with $\mathrm{CH}_{2} \mathrm{Cl}_{2}(3 \times 15 \mathrm{~mL})$. The combined organic extracts were dried over $\mathrm{Na}_{2} \mathrm{SO}_{4}$, filtered and concentrated under reduced pressure. The crude product was purified by column chromatography on silica gel to afford the desired product 92.

\section{General Procedure C (GPC): Iron-Catalyzed C-H/C-C Activation}

To a stirred solution of $\mathbf{5 1 / 3 2}(0.30 \mathrm{mmol}), \mathrm{ZnBr} \cdot \mathrm{TMEDA}(206 \mathrm{mg}, 0.60 \mathrm{mmol})$ and dppe (17.9 mg, $15 \mathrm{~mol} \%)$ in THF (0.20 mL), iPrMgBr (3.0 M in 2-MeTHF, $300 \mu \mathrm{L}, 0.90 \mathrm{mmol}$ ) was added in one portion and the reaction mixture was stirred for $5 \mathrm{~min}$ at ambient temperature. Fe(acac)3 (15.9 mg, $15 \mathrm{~mol} \%$ ) was added in a single portion. After stirring the solution for additional $5 \mathrm{~min}$, BCP 94 ( $0.90 \mathrm{mmol}, 3.0$ equiv) was added as a solution in THF $(0.20 \mathrm{~mL})$ in one portion. The mixture was placed in a pre-heated oil bath at $65^{\circ} \mathrm{C}$. After stirring for $16 \mathrm{~h}$, sat. aqueous $\mathrm{NH}_{4} \mathrm{Cl}(2.0 \mathrm{~mL})$ was added to the reaction mixture, which was then extracted with $\mathrm{CH}_{2} \mathrm{Cl}_{2}(3 \times 15 \mathrm{~mL})$. The combined organic extracts were dried over $\mathrm{Na}_{2} \mathrm{SO}_{4}$, filtered and concentrated. The crude product was purified by column chromatography on silica gel to afford the desired product 95/96/97. 


\section{Experimental Part}

\section{General Procedure D (GPD): Electrochemical Removal of TAH Group}

The electrochemical removal of the TAH group was carried out in an undivided cell with RVC anode $(10 \mathrm{~mm} \times 5 \mathrm{~mm} \times 6 \mathrm{~mm})$ and a steel cathode $(20 \mathrm{~mm} \times 10 \mathrm{~mm} \times 0.25 \mathrm{~mm})$. To a stirred solution of isoquinolone 92/96 (0.3 mmol) and $\mathrm{ZnBr}_{2} \cdot \mathrm{TMEDA}$ (150 mg, $0.44 \mathrm{mmol}$ ) in THF (2.0 mL), $\mathrm{PrMgBr}$ (3.0 $\mathrm{M}$ in 2-MeTHF, $220 \mu \mathrm{L}, 0.66 \mathrm{mmol}$ ) was added in one portion. The electrocatalysis was performed at $60{ }^{\circ} \mathrm{C}$ with a constant current of $10.0 \mathrm{~mA}$ maintained for $15 \mathrm{~h}$. Then, the mixture was allowed to cool to ambient temperature, and saturated aq. $\mathrm{NH}_{4} \mathrm{Cl}(3.0 \mathrm{~mL})$ was added. The $\mathrm{RVC}$ anode was washed with $\mathrm{CH}_{2} \mathrm{Cl}_{2}(3 \times 10 \mathrm{~mL})$ in an ultrasonic bath. The combined aqueous phases were extracted with $\mathrm{CH}_{2} \mathrm{Cl}_{2}(3 \times 15 \mathrm{~mL})$, dried over $\mathrm{Na}_{2} \mathrm{SO}_{4}$,

filtered and concentrated under reduced pressure. Purification by column chromatography $($ nhexane/EtOAc $=3 / 2$ ) yielded 93/120. 
5. Experimental Part

\subsection{Iron-Catalyzed C-H/N-H Annulation with Allenes}

\subsubsection{Analytical Data - Products with Different N-Substituted Triazolyl Moieties}

3-n-Heptyl-2-[(1-n-hexyl-1 H-1,2,3-triazol-4-yl)methyl]isoquinolin-1(2H)one(89aa)<smiles>CCn1cc(Cn2c(-c3ccccc3)cc3ccccc3c2=O)nn1</smiles>

The general procedure GPA was followed using $51 \mathrm{a}(85.9 \mathrm{mg}, 0.30 \mathrm{mmol})$ and allene $88 \mathrm{a}(164 \mathrm{mg}, 0.90 \mathrm{mmol})$. Purification by column chromatography ( $n$ hexane/EtOAc $=4 / 1)$ yielded 89aa $(112 \mathrm{mg}, 91 \%)$ as white solid .

M.p. $=76-78{ }^{\circ} \mathrm{C} .{ }^{1} \mathrm{H}$ NMR $\left(600 \mathrm{MHz}, \mathrm{CDCl}_{3}\right): \delta=8.35(\mathrm{~d}, J=8.0 \mathrm{~Hz}, 1 \mathrm{H}), 7.70$ (s, 1H), 7.60-7.56 (m, 1H), 7.43-7.38 (m, 2H), $6.34(\mathrm{~s}, 1 \mathrm{H}), 5.38(\mathrm{~s}, 2 \mathrm{H}), 4.24$ (t, $J=7.3 \mathrm{~Hz}, 2 \mathrm{H}), 2.98(\mathrm{t}, J=7.7 \mathrm{~Hz}, 2 \mathrm{H}), 1.86-1.80(\mathrm{~m}, 2 \mathrm{H}), 1.71$ (dt, $J=15.4,7.7 \mathrm{~Hz}, 2 \mathrm{H}), 1.48(\mathrm{dt}, J=15.4,7.3 \mathrm{~Hz}, 2 \mathrm{H}), 1.40-1.34(\mathrm{~m}, 2 \mathrm{H}), 1.32-$ $1.23(\mathrm{~m}, 10 \mathrm{H}), 0.89(\mathrm{t}, J=6.9 \mathrm{~Hz}, 3 \mathrm{H}), 0.83(\mathrm{t}, J=7.0 \mathrm{~Hz}, 3 \mathrm{H}) .{ }^{13} \mathrm{C}$ NMR $\left(126 \mathrm{MHz}, \mathrm{CDCl}_{3}\right): \delta=163.3\left(\mathrm{C}_{\mathrm{q}}\right), 144.1\left(\mathrm{C}_{\mathrm{q}}\right), 143.6\left(\mathrm{C}_{\mathrm{q}}\right), 136.9\left(\mathrm{C}_{\mathrm{q}}\right), 132.3$ $(\mathrm{CH}), 127.7(\mathrm{CH}), 125.9(\mathrm{CH}), 125.4(\mathrm{CH}), 124.3\left(\mathrm{C}_{\mathrm{q}}\right), 123.8(\mathrm{CH}), 105.2(\mathrm{CH})$, $50.5\left(\mathrm{CH}_{2}\right), 39.2\left(\mathrm{CH}_{2}\right), 33.2\left(\mathrm{CH}_{2}\right), 31.9\left(\mathrm{CH}_{2}\right), 31.3\left(\mathrm{CH}_{2}\right), 30.3\left(\mathrm{CH}_{2}\right), 29.4$ $\left(\mathrm{CH}_{2}\right), 29.3\left(\mathrm{CH}_{2}\right), 28.9\left(\mathrm{CH}_{2}\right), 26.3\left(\mathrm{CH}_{2}\right), 22.8\left(\mathrm{CH}_{2}\right), 22.6\left(\mathrm{CH}_{2}\right), 14.3\left(\mathrm{CH}_{3}\right)$, $14.1\left(\mathrm{CH}_{3}\right)$. IR (ATR): 2926, 2853, 1643, 1618, 1593, 1413, 1052, 801, 756, $690 \mathrm{~cm}^{-1}$. MS (EI) m/z (relative intensity): 408 (70) [M] ${ }^{+}, 337$ (53), 324 (47), 295 (63), 242 (48), 172 (39), 159 (91), 43 (100). HR-MS (EI) m/z calcd for $\mathrm{C}_{25} \mathrm{H}_{36} \mathrm{~N} 4 \mathrm{O}[\mathrm{M}]^{+}$408.2889, found 408.2879. 


\section{3-n-Heptyl-2-[(1-n-octyl-1 H-1,2,3-triazol-4-yl)methyl]isoquinolin-1(2H)-} one (89ba)

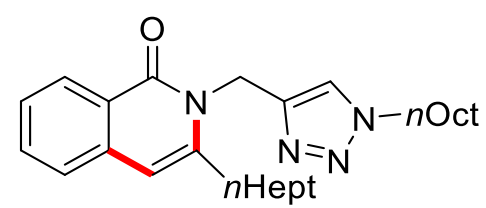

The general procedure GPA was followed using 51b (94.3 $\mathrm{mg}, 0.30 \mathrm{mmol})$ and allene $88 \mathrm{a}(164 \mathrm{mg}, 0.90 \mathrm{mmol})$. Purification by column chromatography ( $n$ hexane/EtOAc $=3 / 1)$ yielded $89 \mathrm{ba}(107 \mathrm{mg}, 82 \%)$ as white solid.

M.p. $=56-57^{\circ} \mathrm{C} .{ }^{1} \mathrm{H}$ NMR $\left(600 \mathrm{MHz}, \mathrm{CDCl}_{3}\right): \delta=8.33(\mathrm{dd}, J=8.1,1.2 \mathrm{~Hz}, 1 \mathrm{H})$, 7.70 (s, 1H), 7.56 (ddd, J=8.1, 7.0, 1.3 Hz, 1H), 7.42-7.35 (m, 2H), 6.33 (s, $1 \mathrm{H}), 5.36(\mathrm{~s}, 2 \mathrm{H}), 4.23(\mathrm{t}, J=7.8 \mathrm{~Hz}, 2 \mathrm{H}), 2.96(\mathrm{t}, J=7.8 \mathrm{~Hz}, 2 \mathrm{H}), 1.90-1.78(\mathrm{~m}$, $2 \mathrm{H}), 1.73-1.67(\mathrm{~m}, 2 \mathrm{H}), 1.54-1.42(\mathrm{~m}, 2 \mathrm{H}), 1.38-1.31(\mathrm{~m}, 2 \mathrm{H}), 1.30-1.26(\mathrm{~m}$, 4H), $1.25-1.18(\mathrm{~m}, 10 \mathrm{H}), 0.87(\mathrm{t}, J=7.0 \mathrm{~Hz}, 3 \mathrm{H}), 0.83(\mathrm{t}, J=7.1 \mathrm{~Hz}, 3 \mathrm{H})$. ${ }^{13} \mathrm{C} \mathrm{NMR}\left(126 \mathrm{MHz}_{\mathrm{CDCl}}\right): \delta=163.2\left(\mathrm{C}_{\mathrm{q}}\right), 144.0\left(\mathrm{C}_{\mathrm{q}}\right), 143.6\left(\mathrm{C}_{\mathrm{q}}\right), 136.9\left(\mathrm{C}_{\mathrm{q}}\right)$, $132.3(\mathrm{CH}), 127.6(\mathrm{CH}), 125.9(\mathrm{CH}), 125.4(\mathrm{CH}), 124.2\left(\mathrm{C}_{\mathrm{q}}\right), 123.7(\mathrm{CH}), 105.1$ $(\mathrm{CH}), 50.5\left(\mathrm{CH}_{2}\right), 39.2\left(\mathrm{CH}_{2}\right), 33.1\left(\mathrm{CH}_{2}\right), 31.9\left(\mathrm{CH}_{2}\right), 31.8\left(\mathrm{CH}_{2}\right), 30.3\left(\mathrm{CH}_{2}\right)$, $29.4\left(\mathrm{CH}_{2}\right), 29.3\left(\mathrm{CH}_{2}\right), 29.1\left(\mathrm{CH}_{2}\right), 29.0\left(\mathrm{CH}_{2}\right), 28.9\left(\mathrm{CH}_{2}\right), 26.6\left(\mathrm{CH}_{2}\right), 22.8$ $\left(\mathrm{CH}_{2}\right), 22.7\left(\mathrm{CH}_{2}\right), 14.2\left(\mathrm{CH}_{3}\right), 14.2\left(\mathrm{CH}_{3}\right) . \mathbf{I R}(\mathrm{ATR}):$ 2954, 2918, 2852, 1648, 1592, 1461, 1337, 1169, 1048, $723 \mathrm{~cm}^{-1}$. MS (El) $\mathrm{m} / \mathrm{z}$ (relative intensity): 436 (75) [M]+, 365 (47), 352 (40), 242 (43), 159 (100). HR-MS (EI) m/z calcd for $\mathrm{C}_{27} \mathrm{H}_{40} \mathrm{~N}_{4} \mathrm{O}[\mathrm{M}]^{+}$436.3202, found 436.3208. 


\section{2-[(1-Benzyl-1H-1,2,3-triazol-4-yl)methyl]-3-n-heptylisoquinolin-1(2H)- one (89ca)}

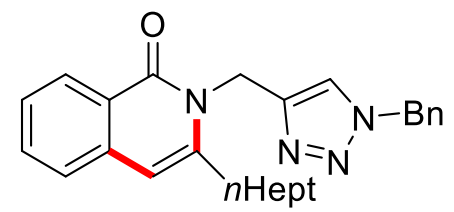

The general procedure GPA was followed using $51 \mathrm{c}(87.7 \mathrm{mg}, 0.30 \mathrm{mmol})$ and allene $88 \mathrm{a}$ (164 $\mathrm{mg}, 0.90 \mathrm{mmol}$ ). Purification by column chromatography (nhexane/EtOAc $=3 / 1)$ yielded $89 \mathrm{ca}(99.5 \mathrm{mg}, 80 \%)$ as white solid.

M.p. $=96-97{ }^{\circ} \mathrm{C} .{ }^{1} \mathrm{H}$ NMR $\left(300 \mathrm{MHz}, \mathrm{CDCl}_{3}\right): \delta=8.32(\mathrm{dd}, J=8.1,1.3 \mathrm{~Hz}, 1 \mathrm{H})$, 7.68 (s, 1H), 7.58 (ddd, $J=8.1,7.1,1.3 \mathrm{~Hz}, 1 \mathrm{H}), 7.46-7.39(\mathrm{~m}, 2 \mathrm{H}), 7.39-7.32$ (m, 3H), 7.30-7.25 (m, 2H), $6.34(\mathrm{~s}, 1 \mathrm{H}), 5.43(\mathrm{~s}, 2 \mathrm{H}), 5.36(\mathrm{~s}, 2 \mathrm{H}), 2.98(\mathrm{t}$, $J=7.8 \mathrm{~Hz}, 2 \mathrm{H}), 1.78-1.65(\mathrm{~m}, 2 \mathrm{H}), 1.58-1.40(\mathrm{~m}, 2 \mathrm{H}), 1.40-1.27(\mathrm{~m}, 6 \mathrm{H}), 0.91$ $(\mathrm{t}, J=6.9 \mathrm{~Hz}, 3 \mathrm{H}) .{ }^{13} \mathrm{C}$ NMR $\left(75 \mathrm{MHz}, \mathrm{CDCl}_{3}\right): \delta=163.4\left(\mathrm{C}_{\mathrm{q}}\right), 144.6\left(\mathrm{C}_{\mathrm{q}}\right), 143.6$ $\left(\mathrm{C}_{\mathrm{q}}\right), 137.0\left(\mathrm{C}_{\mathrm{q}}\right), 134.6\left(\mathrm{C}_{\mathrm{q}}\right), 132.4(\mathrm{CH}), 129.2(\mathrm{CH}), 128.8(\mathrm{CH}), 128.2(\mathrm{CH})$, $127.7(\mathrm{CH}), 126.0(\mathrm{CH}), 125.5(\mathrm{CH}), 124.2\left(\mathrm{C}_{\mathrm{q}}\right), 124.0(\mathrm{CH}), 105.2(\mathrm{CH}), 54.3$ $\left(\mathrm{CH}_{2}\right), 39.1\left(\mathrm{CH}_{2}\right), 33.1\left(\mathrm{CH}_{2}\right), 31.9\left(\mathrm{CH}_{2}\right), 29.4\left(\mathrm{CH}_{2}\right), 29.3\left(\mathrm{CH}_{2}\right), 28.8\left(\mathrm{CH}_{2}\right)$, $22.8\left(\mathrm{CH}_{2}\right), 14.2\left(\mathrm{CH}_{3}\right)$. IR (ATR): 2956, 2919, 2853, 1646, 1622, 1455, 1050, 728, 710, $693 \mathrm{~cm}^{-1}$. MS (EI) $\mathrm{m} / z$ (relative intensity): 414 (26) [M]+, 295 (26), 242 (15), 159 (30), 91(100). HR-MS (El) $m / z$ calcd for $\mathrm{C}_{26} \mathrm{H}_{30} \mathrm{~N}_{4} \mathrm{O}$ [M] 414.2420 , found 414.2434 . 
2-[\{1-(2-Chloropropyl)-1 H-1,2,3-triazol-4-yl\}methyl]-3-heptylisoquinolin$1(2 H)$-one (89da)

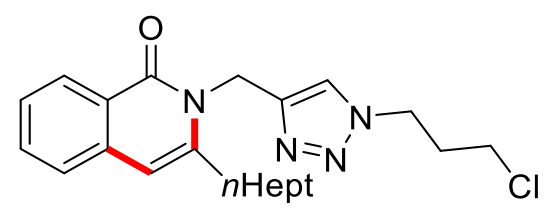

The general procedure GPA was followed using $51 \mathrm{~d}(83.6 \mathrm{mg}, 0.30 \mathrm{mmol})$ and allene $88 \mathrm{a}$ (164 $\mathrm{mg}, 0.90 \mathrm{mmol}$ ). Purification by column chromatography (nhexane/EtOAc $=3 / 1)$ yielded $89 \mathrm{da}(82.8 \mathrm{mg}, 69 \%)$ as white solid.

M.p. $=110-111^{\circ} \mathrm{C} .{ }^{1} \mathrm{H}$ NMR $\left(300 \mathrm{MHz}, \mathrm{CDCl}_{3}\right): \delta=8.32(\mathrm{~d}, J=8.0 \mathrm{~Hz}, 1 \mathrm{H})$, $7.75(\mathrm{~s}, 1 \mathrm{H}), 7.60-7.52(\mathrm{~m}, 1 \mathrm{H}), 7.44-7.35(\mathrm{~m}, 2 \mathrm{H}), 6.33(\mathrm{~s}, 1 \mathrm{H}), 5.36(\mathrm{~s}, 2 \mathrm{H})$, $4.43(\mathrm{t}, J=6.7 \mathrm{~Hz}, 2 \mathrm{H}), 3.47(\mathrm{t}, J=6.1 \mathrm{~Hz}, 2 \mathrm{H}), 2.96(\mathrm{t}, J=7.8 \mathrm{~Hz}, 2 \mathrm{H}), 2.38-$ $2.18(\mathrm{~m}, 2 \mathrm{H}), 1.78-1.64(\mathrm{~m}, 2 \mathrm{H}), 1.51-1.43(\mathrm{~m}, 2 \mathrm{H}), 1.39-1.32(\mathrm{~m}, 2 \mathrm{H}), 1.31-$ $1.26(\mathrm{~m}, 4 \mathrm{H}), 0.87(\mathrm{t}, J=6.8 \mathrm{~Hz}, 3 \mathrm{H}) .{ }^{13} \mathrm{C}$ NMR $\left(75 \mathrm{MHz}, \mathrm{CDCl}_{3}\right): \delta=163.4$ $\left(\mathrm{C}_{\mathrm{q}}\right), 144.3\left(\mathrm{C}_{\mathrm{q}}\right), 143.6\left(\mathrm{C}_{\mathrm{q}}\right), 137.0\left(\mathrm{C}_{\mathrm{q}}\right), 132.5(\mathrm{CH}), 127.8(\mathrm{CH}), 126.1(\mathrm{CH})$, $125.5(\mathrm{CH}), 124.6(\mathrm{CH}), 124.3\left(\mathrm{C}_{\mathrm{q}}\right), 105.3(\mathrm{CH}), 47.3\left(\mathrm{CH}_{2}\right), 41.3\left(\mathrm{CH}_{2}\right), 39.1$ $\left(\mathrm{CH}_{2}\right), 33.2\left(\mathrm{CH}_{2}\right), 32.7\left(\mathrm{CH}_{2}\right), 31.9\left(\mathrm{CH}_{2}\right), 29.4\left(\mathrm{CH}_{2}\right), 29.3\left(\mathrm{CH}_{2}\right), 28.8\left(\mathrm{CH}_{2}\right)$, $22.8\left(\mathrm{CH}_{2}\right), 14.2\left(\mathrm{CH}_{3}\right)$. IR (ATR): 2954, 2926, 2856, 1715, 1648, 1464, 1285, 1087, 799, $764 \mathrm{~cm}^{-1}$. MS (EI) $\mathrm{m} / \mathrm{z}$ (relative intensity): $400(57)\left[{ }^{35} \mathrm{Cl}, \mathrm{M}\right]^{+}, 316$ (37), 295 (86), 242 (66), 172 (46), 159 (100). HR-MS (ESI) m/z calcd for $\mathrm{C}_{22} \mathrm{H}_{30}{ }^{35} \mathrm{CIN} 4 \mathrm{O}[\mathrm{M}+\mathrm{H}]^{+}$401.2103, found 401.2099. 
(E)-2-[2-(1-n-Butyl-1 H-1,2,3-triazol-4-yl)propan-2-yl]-3-heptylidene-3,4-dihydro-isoquinolin-1(2H)-one (90aa)

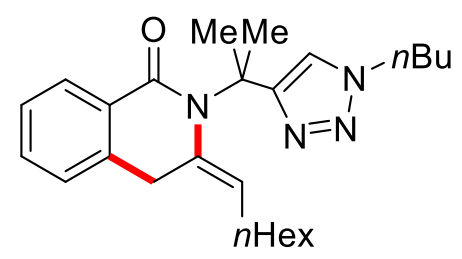

The general procedure GPA was followed using $32 \mathrm{a}(85.9 \mathrm{mg}, 0.30 \mathrm{mmol})$ and allene $88 \mathrm{a}(164 \mathrm{mg}, 0.90 \mathrm{mmol})$. Purification by column chromatography ( $n$ hexane/EtOAc $=3 / 1)$ yielded 90aa $(114 \mathrm{mg}, 93 \%)$ as a colorless oil.

${ }^{1} \mathrm{H}$ NMR $\left(600 \mathrm{MHz}, \mathrm{C}_{6} \mathrm{D}_{6}\right): \delta=8.35$ (dd, $\left.J=7.6,1.5 \mathrm{~Hz}, 1 \mathrm{H}\right), 7.49(\mathrm{~s}, 1 \mathrm{H}), 7.05$ (ddd, $J=7.5,7.5,1.5 \mathrm{~Hz}, 1 \mathrm{H}$ ), 7.00 (ddd, $J=7.5,7.5,1.3 \mathrm{~Hz}, 1 \mathrm{H}$ ), 6.84 (d, $J=7.2,1 \mathrm{H}$ ), $5.54(\mathrm{t}, J=7.8,1 \mathrm{H}), 3.69(\mathrm{t}, J=7.3 \mathrm{~Hz}, 2 \mathrm{H}), 3.42(\mathrm{~s}, 2 \mathrm{H}), 2.13$ (s, $6 \mathrm{H}), 1.88(\mathrm{dt}, J=7.3 \mathrm{~Hz}, 2 \mathrm{H}), 1.40-1.33(\mathrm{~m}, 2 \mathrm{H}), 1.22-1.07(\mathrm{~m}, 8 \mathrm{H}), 1.00-0.91$ $(\mathrm{m}, 2 \mathrm{H}), 0.83(\mathrm{t}, J=7.2 \mathrm{~Hz}, 3 \mathrm{H}), 0.63(\mathrm{t}, J=7.4 \mathrm{~Hz}, 3 \mathrm{H}) .{ }^{13} \mathrm{C}$ NMR $(126 \mathrm{MHz}$, $\left.\mathrm{C}_{6} \mathrm{D}_{6}\right): \delta=164.7\left(\mathrm{C}_{\mathrm{q}}\right), 153.7\left(\mathrm{C}_{\mathrm{q}}\right), 139.0\left(\mathrm{C}_{\mathrm{q}}\right), 135.6\left(\mathrm{C}_{\mathrm{q}}\right), 131.6(\mathrm{CH}), 131.5\left(\mathrm{C}_{\mathrm{q}}\right)$, $129.1(\mathrm{CH}), 126.8(\mathrm{CH}), 126.4(\mathrm{CH}), 123.1(\mathrm{CH}), 121.9(\mathrm{CH}), 58.0\left(\mathrm{C}_{\mathrm{q}}\right), 49.7$ $\left(\mathrm{CH}_{2}\right), 32.9\left(\mathrm{CH}_{2}\right), 32.5\left(\mathrm{CH}_{2}\right), 32.1\left(\mathrm{CH}_{2}\right), 30.2\left(\mathrm{CH}_{2}\right), 30.0\left(\mathrm{CH}_{3}\right), 29.5\left(\mathrm{CH}_{2}\right)$, $27.6\left(\mathrm{CH}_{2}\right), 23.1\left(\mathrm{CH}_{2}\right), 20.1\left(\mathrm{CH}_{2}\right), 14.5\left(\mathrm{CH}_{3}\right), 13.7\left(\mathrm{CH}_{3}\right)$. IR $(\mathrm{ATR}):$ 2956, 2927, 2856, 1649, 1457, 1375, 1323, 1169, 1046, $737 \mathrm{~cm}^{-1}$. MS (EI) m/z (relative intensity): 408 (6) [M] ${ }^{+}, 323$ (12), 243 (16), 172 (35), 166 (100), 172 (51), 57 (55). HR-MS (EI) $m / z$ calcd forC ${ }_{25} \mathrm{H}_{36} \mathrm{~N}_{4} \mathrm{O}[\mathrm{M}]^{+} 408.2889$, found 408.2893. 
E)-2-[2-(1-Benzyl-1 H-1,2,3-triazol-4-yl)propan-2-yl]-3-hept-1-ylidene-3,4dihydro-isoquinolin-1(2H)-one (90ba)<smiles>CC(C)(c1cn(Cc2ccccc2)nn1)N1C(=O)c2ccccc2C/C1=C/O</smiles>

The general procedure GPA was followed using $\mathbf{3 2 b}$ (96.1 $\mathrm{mg}, 0.30 \mathrm{mmol})$ and allene 88a (164 mg, $0.90 \mathrm{mmol}$ ). Purification by column chromatography (nhexane/EtOAc $=3 / 1)$ yielded $90 \mathrm{ba}(100 \mathrm{mg}, 76 \%)$ as colorless oil.

${ }^{1} \mathrm{H}$ NMR $\left(600 \mathrm{MHz}, \mathrm{C}_{6} \mathrm{D}_{6}\right): \delta=8.34(\mathrm{dd}, J=7.7,1.5 \mathrm{~Hz}, 1 \mathrm{H}), 7.45(\mathrm{~s}, 1 \mathrm{H}), 7.03$ (ddd, $J=7.4,7.4,1.5 \mathrm{~Hz}, 1 \mathrm{H}), 7.01-6.96(\mathrm{~m}, 4 \mathrm{H}), 6.90(\mathrm{dd}, J=7.9,1.6 \mathrm{~Hz}$, 2H), $6.82(\mathrm{~d}, J=7.7 \mathrm{~Hz}, 1 \mathrm{H}), 5.51(\mathrm{t}, J=7.7 \mathrm{~Hz}, 1 \mathrm{H}), 4.86(\mathrm{~s}, 2 \mathrm{H}), 3.40(\mathrm{~s}, 2 \mathrm{H})$, 2.04 (s, 6H), 1.85 (dt, $J=7.2 \mathrm{~Hz}, 2 \mathrm{H}), 1.20-1.08(\mathrm{~m}, 8 \mathrm{H}), 0.84(\mathrm{t}, J=7.2 \mathrm{~Hz}$, 3H). ${ }^{13} \mathrm{C}$ NMR $\left(126 \mathrm{MHz}, \mathrm{C}_{6} \mathrm{D}_{6}\right): \delta=164.7\left(\mathrm{C}_{\mathrm{q}}\right), 154.4\left(\mathrm{C}_{\mathrm{q}}\right), 139.0\left(\mathrm{C}_{\mathrm{q}}\right), 136.1$ $\left(\mathrm{C}_{\mathrm{q}}\right), 135.5\left(\mathrm{C}_{\mathrm{q}}\right), 131.5(\mathrm{CH}), 131.5\left(\mathrm{C}_{\mathrm{q}}\right), 129.1(\mathrm{CH}), 129.0(\mathrm{CH}), 128.4(\mathrm{CH})$, $128.0(\mathrm{CH}), 126.9(\mathrm{CH}), 126.3(\mathrm{CH}), 123.1(\mathrm{CH}), 121.9(\mathrm{CH}), 58.0\left(\mathrm{C}_{\mathrm{q}}\right), 53.6$ $\left(\mathrm{CH}_{2}\right), 32.8\left(\mathrm{CH}_{2}\right), 32.1\left(\mathrm{CH}_{2}\right), 30.1\left(\mathrm{CH}_{2}\right), 29.8\left(\mathrm{CH}_{3}\right), 29.5\left(\mathrm{CH}_{2}\right), 27.5\left(\mathrm{CH}_{2}\right)$, $23.1\left(\mathrm{CH}_{2}\right), 14.5\left(\mathrm{CH}_{3}\right)$. IR (ATR): 2926, 2854, 1647, 1456, 1374, 1323, 1169 , 1046, 733, $499 \mathrm{~cm}^{-1}$. MS (ESI) m/z (relative intensity): 907 (100) [2M+Na] ${ }^{+}, 465$ (47) $[\mathrm{M}+\mathrm{Na}]^{+}, 443(48)[\mathrm{M}+\mathrm{H}]^{+}, 200$ (50). HR-MS (ESI) $\mathrm{m} / z$ calcd for $\mathrm{C}_{28} \mathrm{H}_{35} \mathrm{~N}_{4} \mathrm{O}$ $[\mathrm{M}+\mathrm{H}]^{+}$443.2805, found 443.2803 . 
(E)-3-Hept-1-ylidene-2-[2-\{1-(4-methoxyphenyl)-1H-1,2,3-triazol-4-yl\}propan-2-yl]-3,4-dihydroisoquinolin-1(2H)-one (90ca)

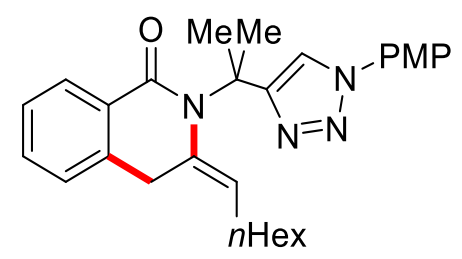

The general procedure GPA was followed using 32c (101 $\mathrm{mg}, 0.30 \mathrm{mmol})$ and allene 88a (164 mg, $0.90 \mathrm{mmol}$ ). Purification by column chromatography (nhexane/EtOAc $=3 / 1)$ yielded $90 \mathrm{ca}(100 \mathrm{mg}, 73 \%)$ as colorless oil.

${ }^{1} \mathrm{H}$ NMR $\left(300 \mathrm{MHz}, \mathrm{C}_{6} \mathrm{D}_{6}\right): \delta=8.39(\mathrm{dd}, J=7.6,1.7 \mathrm{~Hz}, 1 \mathrm{H}), 7.97(\mathrm{~s}, 1 \mathrm{H}), 7.33$ (d, $J=9.0 \mathrm{~Hz}, 2 \mathrm{H}), 7.10-6.94(\mathrm{~m}, 2 \mathrm{H}), 6.90-6.78(\mathrm{~m}, 1 \mathrm{H}), 6.64-6.49(\mathrm{~m}, 2 \mathrm{H})$, 5.55 (t, $J=8.1 \mathrm{~Hz}, 1 \mathrm{H}$ ), $3.44(\mathrm{~s}, 2 \mathrm{H}), 3.20$ (s, 3H), 2.18 (s, 6H), 1.86 (t, $J=$ $7.2 \mathrm{~Hz}, 2 \mathrm{H}), 1.23-1.05(\mathrm{~m}, 8 \mathrm{H}), 0.83(\mathrm{t}, J=6.9 \mathrm{~Hz}, 3 \mathrm{H}) .{ }^{13} \mathrm{C}$ NMR $(75 \mathrm{MHz}$, $\left.\mathrm{C}_{6} \mathrm{D}_{6}\right): \delta=164.9\left(\mathrm{C}_{\mathrm{q}}\right), 159.6\left(\mathrm{C}_{\mathrm{q}}\right), 154.5\left(\mathrm{C}_{\mathrm{q}}\right), 139.0\left(\mathrm{C}_{\mathrm{q}}\right), 135.5\left(\mathrm{C}_{\mathrm{q}}\right), 131.6(\mathrm{CH})$, $131.4\left(\mathrm{C}_{\mathrm{q}}\right), 131.3\left(\mathrm{C}_{\mathrm{q}}\right), 129.2(\mathrm{CH}), 126.9(\mathrm{CH}), 126.4(\mathrm{CH}), 123.2(\mathrm{CH}), 122.1$ $(\mathrm{CH}), 120.3(\mathrm{CH}), 114.7(\mathrm{CH}), 57.9\left(\mathrm{C}_{\mathrm{q}}\right), 55.0\left(\mathrm{CH}_{3}\right), 32.7\left(\mathrm{CH}_{2}\right), 32.0\left(\mathrm{CH}_{2}\right)$, $30.0\left(\mathrm{CH}_{2}\right), 29.7\left(\mathrm{CH}_{3}\right), 29.4\left(\mathrm{CH}_{2}\right), 27.5\left(\mathrm{CH}_{2}\right), 23.0\left(\mathrm{CH}_{2}\right), 14.3\left(\mathrm{CH}_{3}\right)$. IR (ATR): 2928, 2855, 2167, 1648, 1516, 1252, 1172, 1038, 735, $499 \mathrm{~cm}^{-1}$. MS (El) $m / z$ (relative intensity): 458 (5) [M] ${ }^{+}, 415$ (13), 373 (12), 216 (41), 188 (100), 172 (51). HR-MS (EI) $\mathrm{m} / z$ calcd for $\mathrm{C}_{28} \mathrm{H}_{34} \mathrm{~N}_{4} \mathrm{O}_{2}[\mathrm{M}]^{+}$458.2682, found 458.2670 . 


\subsubsection{Analytical Data - Products 89}

\section{3-n-Heptyl-2-[(1-n-hexyl-1H-1,2,3-triazol-4-yl)methyl]-6-methylisoquino-} lin-1(2H)-one (89ea)

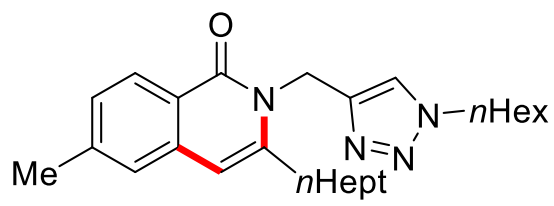

The general procedure GPA was followed using $51 \mathrm{e}(90.1 \mathrm{mg}, 0.30 \mathrm{mmol})$ and allene $88 \mathrm{a}$ (164 $\mathrm{mg}, 0.90 \mathrm{mmol})$. Purification by column chromatography ( $n$ hexane/EtOAc $=3 / 1)$ yielded 89 ea $(101 \mathrm{mg}, 80 \%)$ as white solid.

M. p. $=71-72{ }^{\circ} \mathrm{C} .{ }^{1} \mathbf{H}$ NMR $\left(600 \mathrm{MHz}, \mathrm{CDCl}_{3}\right): \delta=8.21(\mathrm{~d}, J=8.1 \mathrm{~Hz}, 1 \mathrm{H}), 7.68$ (s, 1H), $7.20(\mathrm{dd}, J=8.1,1.7 \mathrm{~Hz} 1 \mathrm{H}), 7.18(\mathrm{~s}, 1 \mathrm{H}), 6.26(\mathrm{~s}, 1 \mathrm{H}), 5.35(\mathrm{~s}, 2 \mathrm{H})$, 4.40-4.08 (m, 2H), 3.03-2.82 (m, 2H), $2.41(\mathrm{~s}, 3 \mathrm{H}), 1.90-1.75(\mathrm{~m}, 2 \mathrm{H}), 1.71-$ $1.65(\mathrm{~m}, 2 \mathrm{H}), 1.48-1.42(\mathrm{~m}, 2 \mathrm{H}), 1.38-1.32(\mathrm{~m}, 2 \mathrm{H}), 1.31-1.26(\mathrm{~m}, 4 \mathrm{H}), 1.26-$ $1.22(\mathrm{~m}, 6 \mathrm{H}), 0.87(\mathrm{t}, J=7.0 \mathrm{~Hz}, 3 \mathrm{H}), 0.82(\mathrm{t}, J=6.9 \mathrm{~Hz}, 3 \mathrm{H}) .{ }^{13} \mathrm{C}$ NMR $\left(126 \mathrm{MHz}, \mathrm{CDCl}_{3}\right): \delta=163.2\left(\mathrm{C}_{\mathrm{q}}\right), 144.2\left(\mathrm{C}_{\mathrm{q}}\right), 143.5\left(\mathrm{C}_{\mathrm{q}}\right), 142.8\left(\mathrm{C}_{\mathrm{q}}\right), 137.0$ $\left(\mathrm{C}_{\mathrm{q}}\right), 127.6(\mathrm{CH}), 127.6(\mathrm{CH}), 125.0(\mathrm{CH}), 123.7(\mathrm{CH}), 122.0\left(\mathrm{C}_{\mathrm{q}}\right), 105.0(\mathrm{CH})$, $50.4\left(\mathrm{CH}_{2}\right), 39.1\left(\mathrm{CH}_{2}\right), 33.1\left(\mathrm{CH}_{2}\right), 31.9\left(\mathrm{CH}_{2}\right), 31.2\left(\mathrm{CH}_{2}\right), 30.2\left(\mathrm{CH}_{2}\right), 29.4$ $\left(\mathrm{CH}_{2}\right), 29.3\left(\mathrm{CH}_{2}\right), 28.9\left(\mathrm{CH}_{2}\right), 26.3\left(\mathrm{CH}_{2}\right), 22.8\left(\mathrm{CH}_{2}\right), 22.5\left(\mathrm{CH}_{2}\right), 21.9\left(\mathrm{CH}_{3}\right)$, $14.2\left(\mathrm{CH}_{3}\right), 14.0\left(\mathrm{CH}_{3}\right)$. IR (ATR): 2927, 2856, 1649, 1625, 1601, 1264, 1046, 788, 735, $702 \mathrm{~cm}^{-1}$. MS (ESI) $\mathrm{m} / \mathrm{z}$ (relative intensity): $445(100)[\mathrm{M}+\mathrm{Na}]^{+}, 423$ (45) $[\mathrm{M}+\mathrm{H}]^{+}, 399(5), 377$ (15). HR-MS (ESI) $\mathrm{m} / \mathrm{z}$ calcd for $\mathrm{C}_{26} \mathrm{H}_{39} \mathrm{~N}_{4} \mathrm{O}[\mathrm{M}+\mathrm{H}]^{+}$ 423.3118, found 423.3118 . 
3-n-Heptyl-2-[(1-n-hexyl-1 H-1,2,3-triazol-4-yl)methyl]-6-phenylisoquinolin-1(2H)-one (89fa)<smiles>O=C(OCn1cc(Cn2c(-c3ccccc3)cc3cc(-c4ccccc4)ccc3c2=O)nn1)c1ccccc1</smiles>

The general procedure GPA was followed using $51 \mathrm{f}(109 \mathrm{mg}, 0.30 \mathrm{mmol})$ and allene $88 \mathrm{a}(164 \mathrm{mg}, 0.90 \mathrm{mmol})$. Purification by column chromatography ( $n$ hexane/EtOAc $=3 / 1)$ yielded $89 \mathrm{fa}(102 \mathrm{mg}, 70 \%)$ as white solid.

M.p. $=95-96{ }^{\circ} \mathrm{C} .{ }^{1} \mathbf{H}$ NMR $\left(300 \mathrm{MHz}, \mathrm{CDCl}_{3}\right): \delta=8.41(\mathrm{~d}, J=8.2 \mathrm{~Hz}, 1 \mathrm{H}), 7.72$ (s, 1H), 7.69-7.60 (m, 4H), 7.52-7.37 (m, 3H), $6.41(\mathrm{~s}, 1 \mathrm{H}), 5.40(\mathrm{~s}, 2 \mathrm{H}), 4.26$ (t, $J=7.5 \mathrm{~Hz}, 2 \mathrm{H}), 3.00(\mathrm{t}, J=7.8 \mathrm{~Hz}, 2 \mathrm{H}), 1.90-1.83(\mathrm{~m}, 2 \mathrm{H}), 1.77-1.70(\mathrm{~m}$, $2 \mathrm{H}), 1.55-1.46(\mathrm{~m}, 2 \mathrm{H}), 1.41-1.35(\mathrm{~m}, 2 \mathrm{H}), 1.34-1.24(\mathrm{~m}, 10 \mathrm{H}), 0.90(\mathrm{t}$, $J=7.2 \mathrm{~Hz}, 3 \mathrm{H}), 0.85(\mathrm{t}, J=6.9 \mathrm{~Hz}, 3 \mathrm{H}) .{ }^{13} \mathrm{C} \mathrm{NMR}\left(75 \mathrm{MHz}, \mathrm{CDCl}_{3}\right): \delta=163.3$ $\left(\mathrm{C}_{\mathrm{q}}\right), 145.2\left(\mathrm{C}_{\mathrm{q}}\right), 144.2\left(\mathrm{C}_{\mathrm{q}}\right), 144.1\left(\mathrm{C}_{\mathrm{q}}\right), 140.4\left(\mathrm{C}_{\mathrm{q}}\right), 137.4\left(\mathrm{C}_{\mathrm{q}}\right), 129.0(\mathrm{CH})$, $128.4(\mathrm{CH}), 128.2(\mathrm{CH}), 127.5(\mathrm{CH}), 125.3(\mathrm{CH}), 123.9(\mathrm{CH}), 123.7(\mathrm{CH}), 123.2$ $\left(\mathrm{C}_{\mathrm{q}}\right), 105.4(\mathrm{CH}), 50.5\left(\mathrm{CH}_{2}\right), 39.1\left(\mathrm{CH}_{2}\right), 33.2\left(\mathrm{CH}_{2}\right), 31.9\left(\mathrm{CH}_{2}\right), 31.2\left(\mathrm{CH}_{2}\right)$, $30.3\left(\mathrm{CH}_{2}\right), 29.4\left(\mathrm{CH}_{2}\right), 29.3\left(\mathrm{CH}_{2}\right), 28.8\left(\mathrm{CH}_{2}\right), 26.3\left(\mathrm{CH}_{2}\right), 22.8\left(\mathrm{CH}_{2}\right), 22.5$ $\left(\mathrm{CH}_{2}\right), 14.2\left(\mathrm{CH}_{3}\right), 14.0\left(\mathrm{CH}_{3}\right)$. IR (ATR): 2925, 2855, 1647, 1622, 1598, 1422 , 1044, 757, $697 \mathrm{~cm}^{-1}$. MS (EI) $\mathrm{m} / z$ (relative intensity): 484 (86) [M], 413 (36), 371 (57), 318 (50), 235 (61), 225 (44), 43 (100). HR-MS (ESI) m/z calcd $\mathrm{C}_{31} \mathrm{H}_{41} \mathrm{~N}_{4} \mathrm{O}[\mathrm{M}+\mathrm{H}]^{+}$485.3275, found 485.3267. 
3-n-Heptyl-2-[(1-n-hexyl-1H-1,2,3-triazol-4-yl)methyl]-6-methoxyisoquinolin-1(2H)-one (89ga)<smiles>COc1ccc2c(=O)n(Cc3cn(C=[W])nn3)c(O)cc2c1</smiles>

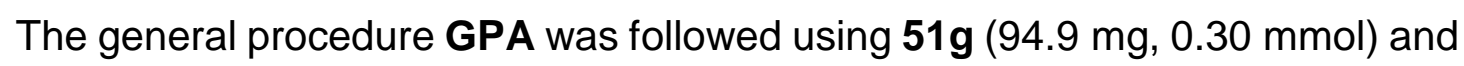
allene $88 \mathrm{a}(164 \mathrm{mg}, 0.90 \mathrm{mmol})$. Purification by column chromatography ( $n$ hexane/EtOAc $=3 / 1)$ yielded $89 \mathrm{ga}(108 \mathrm{mg}, 82 \%)$ as white solid.

M.p. $=62-63^{\circ} \mathrm{C} .{ }^{1} \mathbf{H}$ NMR $\left(600 \mathrm{MHz}, \mathrm{CDCl}_{3}\right): \delta=8.24(\mathrm{~d}, J=8.9 \mathrm{~Hz}, 1 \mathrm{H}), 7.69$ (s, 1H), $6.97(\mathrm{dd}, J=8.9,2.5 \mathrm{~Hz}, 1 \mathrm{H}), 6.76(\mathrm{~d}, J=2.5 \mathrm{~Hz}, 1 \mathrm{H}), 6.26(\mathrm{~s}, 1 \mathrm{H})$, 5.34 (s, 2H), 4.23 (t, J=7.5 Hz, 2H), 3.87 (s, 3H), 2.94 (t, J= 7.8 Hz, 2H), 1.86$1.79(\mathrm{~m}, 2 \mathrm{H}), 1.73-1.65(\mathrm{~m}, 2 \mathrm{H}), 1.50-1.43(\mathrm{~m}, 2 \mathrm{H}), 1.39-1.33(\mathrm{~m}, 2 \mathrm{H}), 1.32-$ $1.27(\mathrm{~m}, 4 \mathrm{H}), 1.27-1.22(\mathrm{~m}, 6 \mathrm{H}), 0.88(\mathrm{t}, J=6.9 \mathrm{~Hz}, 3 \mathrm{H}), 0.82(\mathrm{t}, J=7.2 \mathrm{~Hz}$, 3H). ${ }^{13} \mathrm{C}$ NMR $\left(126 \mathrm{MHz} \mathrm{CDCl}_{3}\right): \delta=162.9\left(\mathrm{C}_{\mathrm{q}}\right), 162.8\left(\mathrm{C}_{\mathrm{q}}\right), 144.3\left(\mathrm{C}_{\mathrm{q}}\right), 144.2$ $\left(\mathrm{C}_{\mathrm{q}}\right), 139.0\left(\mathrm{C}_{\mathrm{q}}\right), 129.7(\mathrm{CH}), 123.7(\mathrm{CH}), 118.2\left(\mathrm{C}_{\mathrm{q}}\right), 115.8(\mathrm{CH}), 106.0(\mathrm{CH})$, $105.0(\mathrm{CH}), 55.6\left(\mathrm{CH}_{3}\right), 50.5\left(\mathrm{CH}_{2}\right), 39.0\left(\mathrm{CH}_{2}\right), 33.2\left(\mathrm{CH}_{2}\right), 31.9\left(\mathrm{CH}_{2}\right), 31.3$ $\left(\mathrm{CH}_{2}\right), 30.3\left(\mathrm{CH}_{2}\right), 29.4\left(\mathrm{CH}_{2}\right), 29.3\left(\mathrm{CH}_{2}\right), 28.9\left(\mathrm{CH}_{2}\right), 26.3\left(\mathrm{CH}_{2}\right), 22.8\left(\mathrm{CH}_{2}\right)$, $22.5\left(\mathrm{CH}_{2}\right), 14.3\left(\mathrm{CH}_{3}\right), 14.1\left(\mathrm{CH}_{3}\right)$. IR (ATR): 2953, 2925, 2855, 1648, 1619, 1596, 1250, 1168, 1028, $788 \mathrm{~cm}^{-1}$. MS (EI) $\mathrm{m} / \mathrm{z}$ (relative intensity): 438 (96) [M] ${ }^{+}, 367$ (61), 325 (100), 272 (72), 202 (49), 189 (75). HR-MS (EI) m/z calcd for $\mathrm{C}_{26} \mathrm{H}_{38} \mathrm{~N}_{4} \mathrm{O}_{2}[\mathrm{M}]^{+} 438.2995$, found 438.2996. 
3-n-Heptyl-2-[(1-n-hexyl-1H-1,2,3-triazol-4-yl)methyl]-6-(trifluoromethyl)isoquinolin-1(2H)-one (89ha)<smiles>[R4]Cn1cc(Cn2c(O)cc3cc(C(F)(F)F)ccc3c2=O)nn1</smiles>

The general procedure GPA was followed using $51 \mathrm{~h}(106 \mathrm{mg}, 0.30 \mathrm{mmol})$ and allene $88 \mathrm{a}(164 \mathrm{mg}, 0.90 \mathrm{mmol})$. Purification by column chromatography ( $n$ hexane/EtOAc $=3 / 1)$ yielded $89 \mathrm{ha}(92.9 \mathrm{mg}, 65 \%)$ as white solid .

M.p. $=114-116{ }^{\circ} \mathrm{C} .{ }^{1} \mathrm{H}$ NMR $\left(300 \mathrm{MHz}, \mathrm{CDCl}_{3}\right): \delta=8.44(\mathrm{dd}, J=8.4,1.0 \mathrm{~Hz}$, 1H), 7.74-7.68 (m, 2H), 7.58 (dd, J=8.4, $1.7 \mathrm{~Hz}, 1 \mathrm{H}), 6.41(\mathrm{~s}, 1 \mathrm{H}), 5.38$ (s, 2H), 4.26 (t, J=7.5 Hz, 2H), 3.03 (t, J=7.8 Hz, 2H), 1.91-1.79 (m, 2H), 1.76$1.69(\mathrm{~m}, 2 \mathrm{H}), 1.52-1.44(\mathrm{~m}, 2 \mathrm{H}), 1.42-1.35(\mathrm{~m}, 2 \mathrm{H}), 1.34-1.29(\mathrm{~m}, 4 \mathrm{H}), 1.28-$ $1.22(\mathrm{~m}, 6 \mathrm{H}), 0.88(\mathrm{t}, J=7.0 \mathrm{~Hz}, 3 \mathrm{H}), 0.84(\mathrm{t}, J=7.0 \mathrm{~Hz}, 3 \mathrm{H}) .{ }^{13} \mathrm{C}$ NMR $\left(75 \mathrm{MHz}, \mathrm{CDCl}_{3}\right): \delta=162.6\left(\mathrm{C}_{\mathrm{q}}\right), 145.5\left(\mathrm{C}_{\mathrm{q}}\right), 143.6\left(\mathrm{C}_{\mathrm{q}}\right), 136.9\left(\mathrm{C}_{\mathrm{q}}\right), 134.0(\mathrm{q}$, $\left.{ }^{2} J_{C-F}=32.4 \mathrm{~Hz}, \mathrm{C}_{\mathrm{q}}\right), 128.9(\mathrm{CH}), 126.2\left(\mathrm{C}_{\mathrm{q}}\right), 123.9(\mathrm{CH}), 123.9\left(\mathrm{q},{ }^{1} \mathrm{~J}_{\mathrm{C}-\mathrm{F}}=272.7\right.$ $\mathrm{Hz}, \mathrm{C}_{\mathrm{q}}$ ), 122.8 (q, $\left.{ }^{3} \mathrm{~J}_{\mathrm{C}-\mathrm{F}}=4.2 \mathrm{~Hz}, \mathrm{CH}\right), 121.8$ (q, $\left.{ }^{3} \mathrm{~J}_{\mathrm{C}-\mathrm{F}}=3.5 \mathrm{~Hz}, \mathrm{CH}\right), 104.8(\mathrm{CH})$, $50.5\left(\mathrm{CH}_{2}\right), 39.3\left(\mathrm{CH}_{2}\right), 33.2\left(\mathrm{CH}_{2}\right), 31.9\left(\mathrm{CH}_{2}\right), 31.2\left(\mathrm{CH}_{2}\right), 30.2\left(\mathrm{CH}_{2}\right), 29.3$ $\left(\mathrm{CH}_{2}\right), 29.3\left(\mathrm{CH}_{2}\right), 28.7\left(\mathrm{CH}_{2}\right), 26.2\left(\mathrm{CH}_{2}\right), 22.8\left(\mathrm{CH}_{2}\right), 22.5\left(\mathrm{CH}_{2}\right), 14.2\left(\mathrm{CH}_{3}\right)$, $14.0\left(\mathrm{CH}_{3}\right) .{ }^{19} \mathrm{~F}$ NMR (282 MHz, $\left.\mathrm{CDCl}_{3}\right): \delta=-63.08$ (s). IR (ATR): 2925, 2855, 1653, 1607, 1322, 1157, 1121, 1065, 796, $693 \mathrm{~cm}^{-1}$. MS (EI) $\mathrm{m} / z$ (relative intensity): 476 (73) [M] $]^{+}, 405$ (44), 392 (44), 227 (54), 167 (35), 138 (42), 43 (100). HR-MS (El) $\mathrm{m} / z$ calcd for $\mathrm{C}_{26} \mathrm{H}_{35} \mathrm{~F}_{3} \mathrm{~N}_{4} \mathrm{O}[\mathrm{M}]^{+} 476.2763$, found 476.2759. 
6-Fluoro-3-n-heptyl-2-[(1-n-hexyl-1H-1,2,3-triazol-4-yl)methyl]isoquinolin$1(2 H)$-one (89ia)

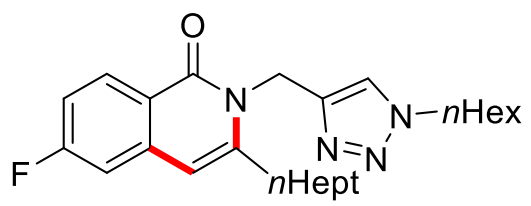

The general procedure GPA was followed using $51 \mathrm{i}(91.3 \mathrm{mg}, 0.30 \mathrm{mmol})$ and allene $88 \mathrm{a}(164 \mathrm{mg}, 0.90 \mathrm{mmol})$. Purification by column chromatography ( $n$ hexane/EtOAc $=3 / 1)$ yielded $89 i a(65.3 \mathrm{mg}, 51 \%)$ as white solid.

M.p. $=57-58^{\circ} \mathrm{C} .{ }^{1} \mathrm{H}$ NMR $\left(300 \mathrm{MHz}, \mathrm{CDCl}_{3}\right): \delta=8.34(\mathrm{dd}, \mathrm{J}=8.9 \mathrm{~Hz}, 5.7 \mathrm{~Hz}$, $1 \mathrm{H}), 7.70(\mathrm{~s}, 1 \mathrm{H}), 7.15-6.95(\mathrm{~m}, 2 \mathrm{H}), 6.28(\mathrm{~s}, 1 \mathrm{H}), 5.35(\mathrm{~s}, 2 \mathrm{H}), 4.25$ (t, $J=7.4 \mathrm{~Hz}, 2 \mathrm{H}), 2.97$ (t, $J=7.7 \mathrm{~Hz}, 2 \mathrm{H}), 1.95-1.77(\mathrm{~m}, 2 \mathrm{H}), 1.77-1.61(\mathrm{~m}, 2 \mathrm{H})$, 1.53-1.42 (m, 2H), 1.40-1.34 (m, 2H), 1.32-1.23 (m, 10H), $0.83(\mathrm{t}, J=7.5 \mathrm{~Hz}$, $3 \mathrm{H}), 0.83(\mathrm{t}, J=7.2 \mathrm{~Hz}, 3 \mathrm{H}) .{ }^{13} \mathrm{C}$ NMR $\left(126 \mathrm{MHz}, \mathrm{CDCl}_{3}\right): \delta=165.2(\mathrm{~d}$, $\left.{ }^{1} J_{C-F}=251.8 \mathrm{~Hz}, \mathrm{C}_{\mathrm{q}}\right), 162.6\left(\mathrm{C}_{\mathrm{q}}\right), 145.2\left(\mathrm{C}_{\mathrm{q}}\right), 143.8\left(\mathrm{C}_{\mathrm{q}}\right), 139.1\left(\mathrm{~d},{ }^{3} \mathrm{~J}_{\mathrm{C}-\mathrm{F}}=\right.$ $\left.10.5 \mathrm{~Hz}, \mathrm{C}_{\mathrm{q}}\right), 130.9\left(\mathrm{~d},{ }^{3} \mathrm{~J}_{\mathrm{C}-\mathrm{F}}=10.1 \mathrm{~Hz}, \mathrm{CH}\right), 123.7(\mathrm{CH}), 120.9\left(\mathrm{~d},{ }^{4} \mathrm{~J}_{\mathrm{C}-\mathrm{F}}=1.6\right.$ $\left.\mathrm{Hz}, \mathrm{C}_{\mathrm{q}}\right), 114.6\left(\mathrm{~d},{ }^{2} \mathrm{~J}_{\mathrm{C}-\mathrm{F}}=23.6 \mathrm{~Hz}, \mathrm{CH}\right), 110.0\left(\mathrm{~d},{ }^{2} \mathrm{~J}_{\mathrm{C}-\mathrm{F}}=21.6 \mathrm{~Hz}, \mathrm{CH}\right), 104.5$ $(\mathrm{CH}), 50.5\left(\mathrm{CH}_{2}\right), 39.1\left(\mathrm{CH}_{2}\right), 33.2\left(\mathrm{CH}_{2}\right), 31.9\left(\mathrm{CH}_{2}\right), 31.2\left(\mathrm{CH}_{2}\right), 30.3\left(\mathrm{CH}_{2}\right)$, $29.4\left(\mathrm{CH}_{2}\right), 29.3\left(\mathrm{CH}_{2}\right), 28.8\left(\mathrm{CH}_{2}\right), 26.3\left(\mathrm{CH}_{2}\right), 22.8\left(\mathrm{CH}_{2}\right), 22.5\left(\mathrm{CH}_{2}\right), 14.3$ $\left(\mathrm{CH}_{3}\right), 14.0\left(\mathrm{CH}_{3}\right) .{ }^{19} \mathrm{~F}$ NMR $\left(282 \mathrm{MHz}, \mathrm{CDCl}_{3}\right): \delta=-106.75$ (ddd, $J=8.9,8.9$, $5.9 \mathrm{~Hz}$ ). IR (ATR): 2927, 2857, 1645, 1623, 1604, 1446, 1249, 1154, 793, $474 \mathrm{~cm}^{-1}$. MS (ESI) $\mathrm{m} / \mathrm{z}$ (relative intensity): 875 (100) [2M+Na] $]^{+}, 449$ (20) $[\mathrm{M}+\mathrm{Na}]^{+}, 427(64)[\mathrm{M}+\mathrm{H}]^{+}$. HR-MS (ESI) $\mathrm{m} / z$ calcd for $\mathrm{C}_{25} \mathrm{H}_{36} \mathrm{FN}_{4} \mathrm{O}[\mathrm{M}+\mathrm{H}]^{+}$ 427.2868, found 427.2869 . 
6-Chloro-3-n-heptyl-2-[(1-n-hexyl-1 H-1,2,3-triazol-4-yl)methyl]isoquinolin$1(2 H)$-one (89ja)<smiles>O=c1c2ccc(Cl)cc2cc(O)n1Cc1cn(CO[Na])nn1</smiles>

The general procedure GPA was followed using 51j (96.2 mg, $0.30 \mathrm{mmol})$ and allene $88 \mathrm{a}(164 \mathrm{mg}, 0.90 \mathrm{mmol})$. Purification by column chromatography ( $n$ hexane/EtOAc $=3 / 1)$ yielded $89 \mathrm{ja}(74.4 \mathrm{mg}, 56 \%)$ as white solid.

M.p. $=58-59^{\circ} \mathrm{C} .{ }^{1} \mathbf{H}$ NMR $\left(500 \mathrm{MHz}, \mathrm{CDCl}_{3}\right): \delta=8.24(\mathrm{~d}, J=8.6 \mathrm{~Hz}, 1 \mathrm{H}), 7.69$ (s, 1H), 7.38 (d, J=2.0 Hz, 1H), 7.31 (dd, J=8.6, $2.0 \mathrm{~Hz}, 1 \mathrm{H}), 6.25(\mathrm{~s}, 1 \mathrm{H})$, $5.34(\mathrm{~s}, 2 \mathrm{H}), 4.24$ (t, J=7.4 Hz, 2H), 2.97 (t, J=7.8 Hz, 2H), 1.87-1.79 (m, $2 \mathrm{H}), 1.74-1.64(\mathrm{~m}, 2 \mathrm{H}), 1.50-1.42(\mathrm{~m}, 2 \mathrm{H}), 1.39-1.33(\mathrm{~m}, 2 \mathrm{H}), 1.31-1.27(\mathrm{~m}$, 4H), 1.27-1.22 (m, 6H), $0.87(\mathrm{t}, J=7.0 \mathrm{~Hz}, 3 \mathrm{H}), 0.83(\mathrm{t}, J=7.0 \mathrm{~Hz}, 3 \mathrm{H})$. ${ }^{13} \mathrm{C}$ NMR $\left(126 \mathrm{MHz}, \mathrm{CDCl}_{3}\right): \delta=162.8\left(\mathrm{C}_{\mathrm{q}}\right), 145.3\left(\mathrm{C}_{\mathrm{q}}\right), 143.8\left(\mathrm{C}_{\mathrm{q}}\right), 138.8\left(\mathrm{C}_{\mathrm{q}}\right)$, $138.2\left(\mathrm{C}_{\mathrm{q}}\right), 129.6(\mathrm{CH}), 126.5(\mathrm{CH}), 124.6(\mathrm{CH}), 123.8(\mathrm{CH}), 122.5\left(\mathrm{C}_{\mathrm{q}}\right), 104.2$ $(\mathrm{CH}), 50.5\left(\mathrm{CH}_{2}\right), 39.1\left(\mathrm{CH}_{2}\right), 33.1\left(\mathrm{CH}_{2}\right), 31.8\left(\mathrm{CH}_{2}\right), 31.2\left(\mathrm{CH}_{2}\right), 30.2\left(\mathrm{CH}_{2}\right)$, $29.3\left(\mathrm{CH}_{2}\right), 29.2\left(\mathrm{CH}_{2}\right), 28.7\left(\mathrm{CH}_{2}\right), 26.2\left(\mathrm{CH}_{2}\right), 22.7\left(\mathrm{CH}_{2}\right), 22.5\left(\mathrm{CH}_{2}\right), 14.2$ $\left(\mathrm{CH}_{3}\right), 13.0\left(\mathrm{CH}_{3}\right)$. IR (ATR): 2954, 2927, 1717, 1650, 1593, 1464, 1286, 1049, $786 \mathrm{~cm}^{-1}$. MS (EI) $\mathrm{m} / z$ (relative intensity): 442 (72) [ $\left.{ }^{35} \mathrm{Cl}, \mathrm{M}\right]^{+}, 371$ (49), 358 (45), 329 (41), 193 (57), 138 (60), 43 (100). HR-MS (EI) $\mathrm{m} / z$ calcd for $\mathrm{C}_{25} \mathrm{H}_{35}{ }^{35} \mathrm{CIN}_{4} \mathrm{O}$ [M]+442.2499, found 442.2499. 
8-n-Heptyl-7-[(1-n-hexyl-1H-1,2,3-triazol-4-yl)methyl]-[1,3]dioxolo[4,5-f]isoquinolin-6(7H)-one (89ka) and 7-n-Heptyl-6-[(1-n-hexyl-1H-1,2,3-triazol-4yl)methyl]-[1,3]dioxolo[4,5-g]isoquinolin-5(6h)-one (89ka')

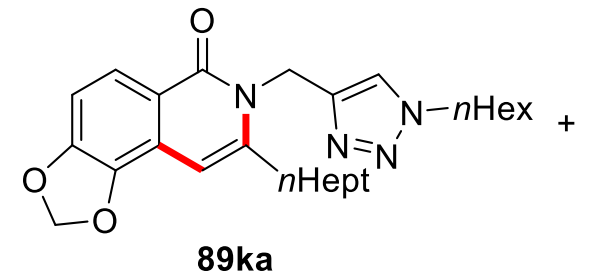

$89 \mathrm{ka}$

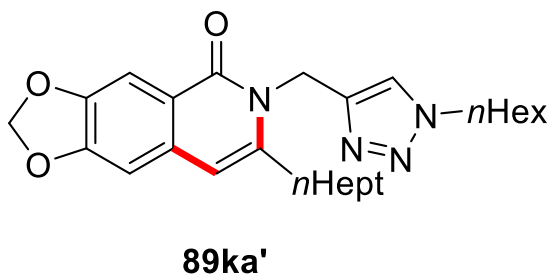

$89 \mathrm{ka}^{\prime}$

The general procedure GPA was followed using $51 \mathrm{k}(99.1 \mathrm{mg}, 0.30 \mathrm{mmol})$ and allene $88 \mathrm{a}$ ( $164 \mathrm{mg}, 0.90 \mathrm{mmol}$ ). Purification by column chromatography ( $n$ hexane/EtOAc = 3/1) yielded 89ka (49.6 mg, 36\%) and 89ka' (41.3 mg, 31\%) as white solids.

8-n-Heptyl-7-[(1-n-hexyl-1H-1,2,3-triazol-4-yl)methyl]-[1,3]dioxolo[4,5-f]isoquinolin-6(7H)-one (89ka):

M.p. $=62-63^{\circ} \mathrm{C} .{ }^{1} \mathrm{H}$ NMR $\left(600 \mathrm{MHz}, \mathrm{CDCl}_{3}\right): \delta=7.96(\mathrm{~d}, J=8.5 \mathrm{~Hz}, 1 \mathrm{H}), 7.68$ $(\mathrm{s}, 1 \mathrm{H}), 6.95(\mathrm{~d}, J=8.5 \mathrm{~Hz}, 1 \mathrm{H}), 6.31(\mathrm{~s}, 1 \mathrm{H}), 6.11(\mathrm{~s}, 2 \mathrm{H}), 5.33(\mathrm{~s}, 2 \mathrm{H}), 4.24(\mathrm{t}$, $J=7.3 \mathrm{~Hz}, 2 \mathrm{H}), 2.95(\mathrm{t}, J=7.8 \mathrm{~Hz}, 2 \mathrm{H}), 1.87-1.82(\mathrm{~m}, 2 \mathrm{H}), 1.73-1.67(\mathrm{~m}, 2 \mathrm{H})$, $1.51-1.44(\mathrm{~m}, 2 \mathrm{H}), 1.39-1.34(\mathrm{~m}, 2 \mathrm{H}), 1.31-1.25(\mathrm{~m}, 10 \mathrm{H}), 0.88(\mathrm{t}, J=6.9 \mathrm{~Hz}$, $3 \mathrm{H}), 0.84$ (t, $J=7.2 \mathrm{~Hz}, 3 \mathrm{H}) .{ }^{13} \mathrm{C}$ NMR (126 MHz, $\left.\mathrm{CDCl}_{3}\right): \delta=162.7\left(\mathrm{C}_{\mathrm{q}}\right), 149.5$ $\left(\mathrm{C}_{\mathrm{q}}\right), 144.4\left(\mathrm{C}_{\mathrm{q}}\right), 144.2\left(\mathrm{C}_{\mathrm{q}}\right), 140.6\left(\mathrm{C}_{\mathrm{q}}\right), 123.7(\mathrm{CH}), 123.1(\mathrm{CH}), 121.4\left(\mathrm{C}_{\mathrm{q}}\right)$, $119.6\left(\mathrm{C}_{q}\right), 108.2(\mathrm{CH}), 102.2\left(\mathrm{CH}_{2}\right), 97.6(\mathrm{CH}), 50.5\left(\mathrm{CH}_{2}\right), 39.1\left(\mathrm{CH}_{2}\right), 33.4$ $\left(\mathrm{CH}_{2}\right), 31.9\left(\mathrm{CH}_{2}\right), 31.3\left(\mathrm{CH}_{2}\right), 30.3\left(\mathrm{CH}_{2}\right), 29.4\left(\mathrm{CH}_{2}\right), 29.3\left(\mathrm{CH}_{2}\right), 28.8\left(\mathrm{CH}_{2}\right)$, $26.3\left(\mathrm{CH}_{2}\right), 22.8\left(\mathrm{CH}_{2}\right), 22.6\left(\mathrm{CH}_{2}\right), 14.3\left(\mathrm{CH}_{3}\right), 14.1\left(\mathrm{CH}_{3}\right)$. IR (ATR): 2954, $2921,1602,1589,1477,1425,1243,1036,936,749 \mathrm{~cm}^{-1}$. MS (EI) $\mathrm{m} / z$ (relative intensity): 452 (100) [M] ${ }^{+}, 381$ (45), 368 (40), 339 (57), 286 (71), 203 (98). HR-MS (EI) $m / z$ calcd for $\mathrm{C}_{26} \mathrm{H}_{36} \mathrm{~N}_{4} \mathrm{O}_{3}[\mathrm{M}]^{+} 452.2787$, found 452.2779 . 
7-n-Heptyl-6-[(1-n-hexyl-1 H-1,2,3-triazol-4-yl)methyl]-[1,3]dioxolo[4,5-g]isoquinolin-5(6H)-one (89ka'):

M.p. $=90-91^{\circ} \mathrm{C} .{ }^{1} \mathrm{H}$ NMR $\left(300 \mathrm{MHz}, \mathrm{CDCl}_{3}\right): \delta=7.69(\mathrm{~s}, 1 \mathrm{H}), 7.68(\mathrm{~s}, 1 \mathrm{H})$, $6.77(\mathrm{~s}, 1 \mathrm{H}), 6.23(\mathrm{~s}, 1 \mathrm{H}), 6.04(\mathrm{~s}, 2 \mathrm{H}), 5.36(\mathrm{~s}, 2 \mathrm{H}), 4.25(\mathrm{t}, J=7.4 \mathrm{~Hz}, 2 \mathrm{H})$, $2.94(\mathrm{t}, J=7.8 \mathrm{~Hz}, 2 \mathrm{H}), 1.91-1.80(\mathrm{~m}, 2 \mathrm{H}), 1.71-1.66(\mathrm{~m}, 2 \mathrm{H}), 1.50-1.43(\mathrm{~m}$, 2H), 1.40-1.34 (m, 2H), 1.31-1.23 (m,10H), 0.89 (t, J=7.0 Hz, 3H), 0.84 (t, $J=7.2 \mathrm{~Hz}, 3 \mathrm{H}) .{ }^{13} \mathrm{C}$ NMR $\left(126 \mathrm{MHz}, \mathrm{CDCl}_{3}\right): \delta=162.4\left(\mathrm{C}_{\mathrm{q}}\right), 152.0\left(\mathrm{C}_{\mathrm{q}}\right), 147.2$ $\left(\mathrm{C}_{\mathrm{q}}\right), 144.1\left(\mathrm{C}_{\mathrm{q}}\right), 142.4\left(\mathrm{C}_{\mathrm{q}}\right), 134.4\left(\mathrm{C}_{\mathrm{q}}\right), 123.8(\mathrm{CH}), 119.6\left(\mathrm{C}_{\mathrm{q}}\right), 105.5(\mathrm{CH})$, $105.1(\mathrm{CH}), 103.2(\mathrm{CH}), 101.6\left(\mathrm{CH}_{2}\right), 50.5\left(\mathrm{CH}_{2}\right), 39.3\left(\mathrm{CH}_{2}\right), 33.1\left(\mathrm{CH}_{2}\right), 32.0$ $\left(\mathrm{CH}_{2}\right), 31.3\left(\mathrm{CH}_{2}\right), 30.3\left(\mathrm{CH}_{2}\right), 29.5\left(\mathrm{CH}_{2}\right), 29.4\left(\mathrm{CH}_{2}\right), 29.0\left(\mathrm{CH}_{2}\right), 26.4\left(\mathrm{CH}_{2}\right)$, $22.8\left(\mathrm{CH}_{2}\right), 22.6\left(\mathrm{CH}_{2}\right), 14.3\left(\mathrm{CH}_{3}\right), 14.1\left(\mathrm{CH}_{3}\right)$. IR (ATR): 2954, 2924, 2857, 1649, 1597, 1478, 1427, 1247, 1037, $934 \mathrm{~cm}^{-1}$. MS (EI) $\mathrm{m} / z$ (relative intensity): 452 (100) [M]+, 339 (63), 286 (51), 203 (71). HR-MS (ESI) m/z calcd for $\mathrm{C}_{26} \mathrm{H}_{37} \mathrm{~N}_{4} \mathrm{O}_{3}[\mathrm{M}+\mathrm{H}]^{+} 453.2860$, found 453.2858 .

3-n-Heptyl-2-[(1-n-hexyl-1H-1,2,3-triazol-4-yl)methyl]-6,7-dimethylisoquin olin-1(2H)-one (89la)

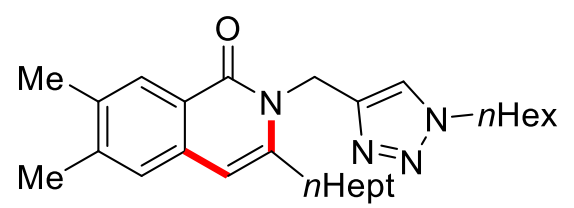

The general procedure GPA was followed using 891 (94.3 $\mathrm{mg}, 0.30 \mathrm{mmol})$ and allene $88 \mathrm{a}$ (164 $\mathrm{mg}, 0.90 \mathrm{mmol})$. Purification by column chromatography ( $n$ hexane/EtOAc $=4 / 1)$ yielded 891 a $(90.4 \mathrm{mg}, 69 \%)$ as white solid .

M.p. $=105-106{ }^{\circ} \mathrm{C} .{ }^{1} \mathrm{H}$ NMR $\left(600 \mathrm{MHz} \mathrm{CDCl}_{3}\right): \delta=8.08(\mathrm{~s}, 1 \mathrm{H}), 7.68(\mathrm{~s}, 1 \mathrm{H})$, $7.17(\mathrm{~s}, 1 \mathrm{H}), 6.24(\mathrm{~s}, 1 \mathrm{H}), 5.35(\mathrm{~s}, 2 \mathrm{H}), 4.22(\mathrm{t}, J=7.8 \mathrm{~Hz}, 2 \mathrm{H}), 2.92$ (t, $J=7.8 \mathrm{~Hz}, 2 \mathrm{H}), 2.35(\mathrm{~s}, 3 \mathrm{H}), 2.33(\mathrm{~s}, 3 \mathrm{H}), 1.87-1.77(\mathrm{~m}, 2 \mathrm{H}), 1.71-1.64(\mathrm{~m}$, $2 \mathrm{H}), 1.48-1.42(\mathrm{~m}, 2 \mathrm{H}), 1.38-1.31(\mathrm{~m}, 2 \mathrm{H}), 1.29-1.27(\mathrm{~m}, 4 \mathrm{H}), 1.26-1.22(\mathrm{~m}$, $6 \mathrm{H}), 0.87(\mathrm{t}, J=7.0 \mathrm{~Hz}, 3 \mathrm{H}), 0.82(\mathrm{t}, J=7.2 \mathrm{~Hz}, 3 \mathrm{H}) .{ }^{13} \mathrm{C}$ NMR (126 MHz, $\left.\mathrm{CDCl}_{3}\right): \delta=163.1\left(\mathrm{C}_{\mathrm{q}}\right), 144.3\left(\mathrm{C}_{\mathrm{q}}\right), 142.6\left(\mathrm{C}_{\mathrm{q}}\right), 142.2\left(\mathrm{C}_{\mathrm{q}}\right), 135.3\left(\mathrm{C}_{\mathrm{q}}\right), 135.2$ 104 


\section{Experimental Part}

$\left(\mathrm{C}_{\mathrm{q}}\right), 127.6(\mathrm{CH}), 125.7(\mathrm{CH}), 123.7(\mathrm{CH}), 122.4\left(\mathrm{C}_{\mathrm{q}}\right), 104.8(\mathrm{CH}), 50.4\left(\mathrm{CH}_{2}\right)$, $39.1\left(\mathrm{CH}_{2}\right), 33.1\left(\mathrm{CH}_{2}\right), 31.9\left(\mathrm{CH}_{2}\right), 31.2\left(\mathrm{CH}_{2}\right), 30.3\left(\mathrm{CH}_{2}\right), 29.4\left(\mathrm{CH}_{2}\right), 29.3$ $\left(\mathrm{CH}_{2}\right), 28.9\left(\mathrm{CH}_{2}\right), 26.3\left(\mathrm{CH}_{2}\right), 22.8\left(\mathrm{CH}_{2}\right), 22.5\left(\mathrm{CH}_{2}\right), 20.4\left(\mathrm{CH}_{3}\right), 19.9\left(\mathrm{CH}_{3}\right)$, $14.2\left(\mathrm{CH}_{3}\right), 14.0\left(\mathrm{CH}_{3}\right)$. IR (ATR): 2954, 2921, 2857, 1647, 1594, 1455, 1378, 1052, 897, $797 \mathrm{~cm}^{-1}$. MS (ESI) $\mathrm{m} / \mathrm{z}$ (relative intensity): 896 (56) [2M+Na] ${ }^{+}, 437$ (100) $[\mathrm{M}+\mathrm{H}]^{+}$. HR-MS (ESI) $\mathrm{m} / z$ calcd for $\mathrm{C}_{27} \mathrm{H}_{41} \mathrm{~N}_{4} \mathrm{O}[\mathrm{M}+\mathrm{H}]^{+} 437.3275$, found 437.3271.

\section{5-n-Heptyl-6-[(1-n-hexyl-1H-1,2,3-triazol-4-yl)methyl]thieno[2,3-c]pyridin-} $7(6 H)$-one (89ma)

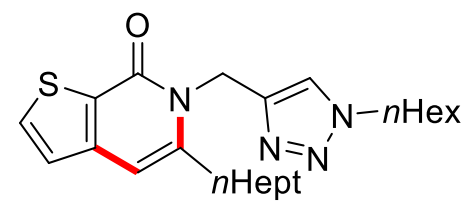

The general procedure GPA was followed using $51 \mathrm{~m}(87.7 \mathrm{mg}, 0.30 \mathrm{mmol})$ and allene $88 \mathrm{a}$ ( $164 \mathrm{mg}, 0.90 \mathrm{mmol})$. Purification by column chromatography ( $n$ hexane/EtOAc $=4 / 1)$ yielded $89 \mathrm{ma}(83.3 \mathrm{mg}, 67 \%)$ as white solid.

M.p. $=94-95^{\circ} \mathrm{C} .{ }^{1} \mathrm{H}$ NMR $\left(600 \mathrm{MHz}, \mathrm{CDCl}_{3}\right): \delta=7.75(\mathrm{~s}, 1 \mathrm{H}), 7.62(\mathrm{~d}, J=5.1$ $\mathrm{Hz}, 1 \mathrm{H}), 7.10(\mathrm{~d}, J=5.1 \mathrm{~Hz}, 1 \mathrm{H}), 6.50(\mathrm{~s}, 1 \mathrm{H}), 5.39(\mathrm{~s}, 2 \mathrm{H}), 4.24(\mathrm{t}, J=7.8 \mathrm{~Hz}$, 2H), $3.00(\mathrm{t}, J=3.0 \mathrm{~Hz}, 2 \mathrm{H}), 1.86-1.80(\mathrm{~m}, 2 \mathrm{H}), 1.72-1.65(\mathrm{~m}, 2 \mathrm{H}), 1.50-1.43$ $(\mathrm{m}, 2 \mathrm{H}), 1.39-1.33(\mathrm{~m}, 2 \mathrm{H}), 1.30-1.22(\mathrm{~m}, 10 \mathrm{H}), 0.88(\mathrm{t}, J=7.0 \mathrm{~Hz}, 3 \mathrm{H}), 0.85-$ 0.81 (t, $J=7.2 \mathrm{~Hz}, 3 \mathrm{H}) .{ }^{13} \mathrm{C}$ NMR $\left(126 \mathrm{MHz}, \mathrm{CDCl}_{3}\right): \delta=159.4\left(\mathrm{C}_{\mathrm{q}}\right), 145.3\left(\mathrm{C}_{\mathrm{q}}\right)$, $145.1\left(\mathrm{C}_{\mathrm{q}}\right), 143.8\left(\mathrm{C}_{\mathrm{q}}\right), 133.3(\mathrm{CH}), 127.5\left(\mathrm{C}_{\mathrm{q}}\right), 124.0(\mathrm{CH}), 124.0(\mathrm{CH}), 102.5$ $(\mathrm{CH}), 50.5\left(\mathrm{CH}_{2}\right), 39.1\left(\mathrm{CH}_{2}\right), 33.3\left(\mathrm{CH}_{2}\right), 31.9\left(\mathrm{CH}_{2}\right), 31.3\left(\mathrm{CH}_{2}\right), 30.3\left(\mathrm{CH}_{2}\right)$, $29.4\left(\mathrm{CH}_{2}\right), 29.3\left(\mathrm{CH}_{2}\right), 28.1\left(\mathrm{CH}_{2}\right), 26.3\left(\mathrm{CH}_{2}\right), 22.8\left(\mathrm{CH}_{2}\right), 22.5\left(\mathrm{CH}_{2}\right), 14.3$ $\left(\mathrm{CH}_{3}\right), 14.1\left(\mathrm{CH}_{3}\right)$. IR (ATR): 3061, 2923, 2853, 1635, 1576, 1444, 1053, 805, 792, $657 \mathrm{~cm}^{-1}$. MS (ESI) $\mathrm{m} / \mathrm{z}$ (relative intensity): 851 (100) [2M+Na] ${ }^{+}, 437$ (38) $[\mathrm{M}+\mathrm{Na}]^{+}, 415(20)[\mathrm{M}+\mathrm{H}]^{+}$. HR-MS (ESI) $\mathrm{m} / z$ calcd for $\mathrm{C}_{23} \mathrm{H}_{35} \mathrm{~N}_{4} \mathrm{OS}[\mathrm{M}+\mathrm{H}]^{+}$ 415.2526, found 415.2525 . 


\subsubsection{Analytical Data - Products 90}

(E)-2-[2-(1-n-Butyl-1H-1,2,3-triazol-4-yl)propan-2-yl]-3-heptylidene-6-methyl-3,4-dihydroisoquinolin-1(2H)-one (90fa)<smiles>CCCCn1cc(C(C)(C)N2C(=O)c3ccc(C)cc3C/C2=C\O)nn1</smiles>

The general procedure GPA was followed using $32 \mathrm{f}(90.1 \mathrm{mg}, 0.30 \mathrm{mmol})$ and allene 88a (164 mg, $0.90 \mathrm{mmol})$. Purification by column chromatography ( $n$ hexane/EtOAc $=3 / 1)$ yielded $90 \mathrm{fa}(86.2 \mathrm{mg}, 68 \%)$ as a colorless oil.

${ }^{1} \mathrm{H}$ NMR $\left(600 \mathrm{MHz}, \mathrm{C}_{6} \mathrm{D}_{6}\right): \delta=8.32(\mathrm{~d}, J=7.9 \mathrm{~Hz}, 1 \mathrm{H}), 7.50(\mathrm{~s}, 1 \mathrm{H}), 6.81$ (dd, $J=7.9,1.7,1 \mathrm{H}), 6.63(\mathrm{~s}, 1 \mathrm{H}), 5.58(\mathrm{t}, J=7.7 \mathrm{~Hz}, 1 \mathrm{H}), 3.65(\mathrm{t}, J=7.3 \mathrm{~Hz}, 2 \mathrm{H})$, 3.43 (s, 2H), 2.17 (s, 6H), 2.00 (s, 3H), 1.93 (dt, $J=7.4 \mathrm{~Hz}, 2 \mathrm{H}$ ), 1.39-1.30 (m, 2H), 1.21-1.10 (m, 8H), 0.98-0.91 (m, 2H), $0.84(\mathrm{t}, J=7.1 \mathrm{~Hz}, 3 \mathrm{H}), 0.62(\mathrm{t}$, $J=7.4 \mathrm{~Hz}, 3 \mathrm{H}) .{ }^{13} \mathrm{C}$ NMR $\left(126 \mathrm{MHz}, \mathrm{C}_{6} \mathrm{D}_{6}\right): \delta=164.9\left(\mathrm{C}_{\mathrm{q}}\right), 153.7\left(\mathrm{C}_{\mathrm{q}}\right), 141.8$ $\left(\mathrm{C}_{\mathrm{q}}\right), 139.0\left(\mathrm{C}_{\mathrm{q}}\right), 135.8\left(\mathrm{C}_{\mathrm{q}}\right), 129.2(\mathrm{CH}), 129.0\left(\mathrm{C}_{\mathrm{q}}\right), 127.7(\mathrm{CH}), 127.0(\mathrm{CH})$, $122.8(\mathrm{CH}), 122.0(\mathrm{CH}), 57.9\left(\mathrm{C}_{\mathrm{q}}\right), 49.6\left(\mathrm{CH}_{2}\right), 32.9\left(\mathrm{CH}_{2}\right), 32.5\left(\mathrm{CH}_{2}\right), 32.1$ $\left(\mathrm{CH}_{2}\right), 30.2\left(\mathrm{CH}_{2}\right), 30.1\left(\mathrm{CH}_{3}\right), 29.5\left(\mathrm{CH}_{2}\right), 27.6\left(\mathrm{CH}_{2}\right), 23.2\left(\mathrm{CH}_{2}\right), 21.5\left(\mathrm{CH}_{3}\right)$, $20.1\left(\mathrm{CH}_{2}\right), 14.5\left(\mathrm{CH}_{3}\right), 13.6\left(\mathrm{CH}_{3}\right)$. IR (ATR): 2957, 2930, 2871, 1648, 1457, 1378, 1163, 1046, 835, $498 \mathrm{~cm}^{-1}$. MS (ESI) $\mathrm{m} / z$ (relative intensity): 868 (100) $[2 \mathrm{M}+\mathrm{Na}]^{+}, 445(94)[\mathrm{M}+\mathrm{Na}]^{+}, 423(93)[\mathrm{M}+\mathrm{H}]^{+}, 407(100)[\mathrm{M}+\mathrm{H}]^{+}$. HR-MS (ESI) $\mathrm{m} / \mathrm{z}$ calcd for $\mathrm{C}_{26} \mathrm{H}_{39} \mathrm{~N}_{4} \mathrm{O}[\mathrm{M}+\mathrm{H}]^{+} 423.3118$, found 423.3114 . 
(E)-2-[2-(1-n-Butyl-1 H-1,2,3-triazol-4-yl)propan-2-yl]-3-heptylidene-6-(trifluoro-methyl)-3,4-dihydroisoquinolin-1(2H)-one (90ga)

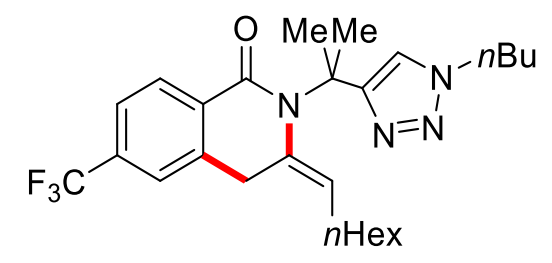

The general procedure GPA was followed using $\mathbf{3 2 g}$ (106 $\mathrm{mg}, 0.30 \mathrm{mmol})$ and allene $88 \mathrm{a}$ ( $164 \mathrm{mg}, 0.90 \mathrm{mmol}$ ). Purification by column chromatography ( $n$ hexane/EtOAc $=3 / 1)$ yielded $90 \mathrm{ga}(116 \mathrm{mg}, 81 \%)$ as a colorless oil.

${ }^{1} \mathrm{H}$ NMR $\left(600 \mathrm{MHz}, \mathrm{C}_{6} \mathrm{D}_{6}\right): \delta=8.19(\mathrm{~d}, J=8.1 \mathrm{~Hz}, 1 \mathrm{H}), 7.35(\mathrm{~s}, 1 \mathrm{H}), 7.15-7.11$ (m, 1H), 7.09 (d, $J=1.7 \mathrm{~Hz}, 1 \mathrm{H}$ ), 5.57 (t, $J=7.8 \mathrm{~Hz}, 1 \mathrm{H}$ ), 3.66 (t, $J=7.3 \mathrm{~Hz}$, 2H), $3.27(\mathrm{~s}, 2 \mathrm{H}), 2.08(\mathrm{~s}, 6 \mathrm{H}), 1.83(\mathrm{dt}, J=7.4 \mathrm{~Hz}, 2 \mathrm{H}), 1.37-1.32(\mathrm{~m}, 2 \mathrm{H})$, 1.19-1.05 (m, 8H), 0.98-0.92 (m, 2H), $0.84(\mathrm{t}, J=7.2 \mathrm{~Hz}, 3 \mathrm{H}), 0.63(\mathrm{t}$, $J=7.4 \mathrm{~Hz}, 3 \mathrm{H}) .{ }^{13} \mathrm{C}$ NMR $\left(126 \mathrm{MHz}, \mathrm{C}_{6} \mathrm{D}_{6}\right): \delta=163.4\left(\mathrm{C}_{\mathrm{q}}\right), 153.3\left(\mathrm{C}_{\mathrm{q}}\right), 139.8$ $\left(\mathrm{C}_{\mathrm{q}}\right), 134.5\left(\mathrm{C}_{\mathrm{q}}\right), 134.4\left(\mathrm{C}_{\mathrm{q}}\right) 133.0\left(\mathrm{q},{ }^{2} \mathrm{~J}_{\mathrm{C}-\mathrm{F}}=32.0 \mathrm{~Hz}, \mathrm{C}_{\mathrm{q}}\right), 129.6(\mathrm{CH}), 128.3$ $(\mathrm{CH}), 124.6\left(\mathrm{q},{ }^{1} \mathrm{~J}_{\mathrm{C}-\mathrm{F}}=272.3 \mathrm{~Hz}, \mathrm{C}_{\mathrm{q}}\right), 123.7\left(\mathrm{q},{ }^{3} \mathrm{~J}_{\mathrm{C}-\mathrm{F}}=3.6 \mathrm{~Hz}, \mathrm{CH}\right), 123.4(\mathrm{q}$, $\left.{ }^{3} \mathrm{JC}_{\mathrm{F}}=3.7 \mathrm{~Hz}, \mathrm{CH}\right), 121.6(\mathrm{CH}), 58.2\left(\mathrm{C}_{\mathrm{q}}\right), 49.7\left(\mathrm{CH}_{2}\right), 32.5\left(\mathrm{CH}_{2}\right), 32.5\left(\mathrm{CH}_{2}\right)$, $32.1\left(\mathrm{CH}_{2}\right), 30.0\left(\mathrm{CH}_{2}\right), 29.8\left(\mathrm{CH}_{3}\right), 29.4\left(\mathrm{CH}_{2}\right), 27.6\left(\mathrm{CH}_{2}\right), 23.1\left(\mathrm{CH}_{2}\right), 20.0$ $\left(\mathrm{CH}_{2}\right), 14.4\left(\mathrm{CH}_{3}\right), 13.6\left(\mathrm{CH}_{3}\right) .{ }^{19} \mathrm{~F}$ NMR $\left(282 \mathrm{MHz}, \mathrm{C}_{6} \mathrm{D}_{6}\right): \delta=-62.50$ (s). IR (ATR): 2930, 2858, 1652, 1458, 1431, 1324, 1166, 1126, 730, $418 \mathrm{~cm}^{-1}$. MS (ESI) $m / z$ (relative intensity): 975 (75) [2M+Na] ${ }^{+}, 953(13)[2 \mathrm{M}+\mathrm{H}]^{+}, 499$ (42) $[\mathrm{M}+\mathrm{Na}]^{+}, 477(100)[\mathrm{M}+\mathrm{H}]^{+}$. HR-MS (ESI) $\mathrm{m} / z$ calcd for $\mathrm{C}_{26} \mathrm{H}_{36} \mathrm{~F}_{3} \mathrm{~N}_{4} \mathrm{O}[\mathrm{M}+\mathrm{H}]^{+}$ 477.2836, found 477.2831 . 
(E)-2-[2-(1-n-Butyl-1 H-1,2,3-triazol-4-yl)propan-2-yl]-3-heptylidene-6-(methylthio)-3,4-dihydroisoquinolin-1(2H)-one (90ha)<smiles>CCCCn1cc(C(C)(C)N2C(=O)c3ccc(OC)cc3C/C2=C\O)nn1</smiles>

The general procedure GPA was followed using $32 \mathrm{~h}(99.7 \mathrm{mg}, 0.30 \mathrm{mmol})$ and allene $88 \mathrm{a}$ ( $164 \mathrm{mg}, 0.90 \mathrm{mmol}$ ). Purification by column chromatography (nhexane/EtOAc $=3 / 1)$ yielded $90 \mathrm{ha}(96.8 \mathrm{mg}, 71 \%$ ) as a colorless oil.

${ }^{1} \mathrm{H}$ NMR $\left(300 \mathrm{MHz}, \mathrm{C}_{6} \mathrm{D}_{6}\right): \delta=8.27(\mathrm{~d}, J=8.1,1 \mathrm{H}), 7.46(\mathrm{~s}, 1 \mathrm{H}), 6.83(\mathrm{dd}$, $J=8.2,2.0 \mathrm{~Hz}, 1 \mathrm{H}), 6.80(\mathrm{~s}, 1 \mathrm{H}), 5.58(\mathrm{t}, J=7.7 \mathrm{~Hz}, 1 \mathrm{H}), 3.65(\mathrm{t}, J=7.3 \mathrm{~Hz}$, $2 \mathrm{H}), 3.37(\mathrm{~s}, 2 \mathrm{H}), 2.16(\mathrm{~s}, 6 \mathrm{H}), 1.95-1.88(\mathrm{~m}, 2 \mathrm{H}), 1.87(\mathrm{~s}, 3 \mathrm{H}), 1.45-1.29(\mathrm{~m}$, $2 \mathrm{H}), 1.23-1.07(\mathrm{~m}, 8 \mathrm{H}), 1.02-0.90(\mathrm{~m}, 2 \mathrm{H}), 0.85(\mathrm{t}, J=6.9 \mathrm{~Hz}, 3 \mathrm{H}), 0.63(\mathrm{t}$, $J=7.3 \mathrm{~Hz}, 3 \mathrm{H}) .{ }^{13} \mathrm{C}$ NMR $\left(126 \mathrm{MHz}, \mathrm{C}_{6} \mathrm{D}_{6}\right): \delta=164.7\left(\mathrm{C}_{\mathrm{q}}\right), 153.7\left(\mathrm{C}_{\mathrm{q}}\right), 143.9$ $\left(\mathrm{C}_{\mathrm{q}}\right), 139.4\left(\mathrm{C}_{\mathrm{q}}\right), 135.4\left(\mathrm{C}_{\mathrm{q}}\right), 129.6(\mathrm{CH}), 128.4\left(\mathrm{C}_{\mathrm{q}}\right) 123.8(\mathrm{CH}), 123.4(\mathrm{CH})$, $123.2(\mathrm{CH}), 121.9(\mathrm{CH}), 57.9\left(\mathrm{C}_{\mathrm{q}}\right), 49.7\left(\mathrm{CH}_{2}\right), 32.9\left(\mathrm{CH}_{2}\right), 32.4\left(\mathrm{CH}_{2}\right), 32.1$ $\left(\mathrm{CH}_{2}\right)$, $30.2\left(\mathrm{CH}_{2}\right), 30.0\left(\mathrm{CH}_{3}\right), 29.5\left(\mathrm{CH}_{2}\right), 27.6\left(\mathrm{CH}_{2}\right), 23.2\left(\mathrm{CH}_{2}\right), 20.1\left(\mathrm{CH}_{2}\right)$, $14.7\left(\mathrm{CH}_{3}\right), 14.5\left(\mathrm{CH}_{3}\right), 13.6\left(\mathrm{CH}_{3}\right)$. IR (ATR): 2956, 2927, 2856, 1645, 1593, 1323, 1164, 1046, 831, $677 \mathrm{~cm}^{-1}$. MS (ESI) $\mathrm{m} / \mathrm{z}$ (relative intensity): 932 (100) $[2 \mathrm{M}+\mathrm{Na}]^{+}, 910(18)[2 \mathrm{M}+\mathrm{H}]^{+}, 477(39)[\mathrm{M}+\mathrm{Na}]^{+}, 455(46)[\mathrm{M}+\mathrm{H}]^{+}$. HR-MS (ESI) $\mathrm{m} / \mathrm{z}$ calcd for $\mathrm{C}_{26} \mathrm{H}_{39} \mathrm{~N}_{4} \mathrm{OS}[\mathrm{M}+\mathrm{H}]^{+} 455.2839$, found 455.2837 . 
(E)-6-Bromo-2-[2-(1-n-butyl-1H-1,2,3-triazol-4-yl)propan-2-yl]-3-heptylidene-3,4-dihydro-isoquinolin-1(2H)-one (90ia)<smiles>CCCCn1cc(C(C)(C)N2C(=O)c3ccc(Br)cc3C/C2=C\O)nn1</smiles>

The general procedure GPA was followed using $32 \mathbf{i}(110 \mathrm{mg}, 0.30 \mathrm{mmol})$ and allene $88 \mathrm{a}$ (164 $\mathrm{mg}, 0.90 \mathrm{mmol})$. Purification by column chromatography ( $n$ hexane/EtOAc $=3 / 1)$ yielded 90ia $(131 \mathrm{mg}, 90 \%)$ as a colorless oil.

${ }^{1} \mathrm{H}$ NMR $\left(300 \mathrm{MHz}, \mathrm{C}_{6} \mathrm{D}_{6}\right): \delta=8.03(\mathrm{~d}, J=8.3 \mathrm{~Hz}, 1 \mathrm{H}), 7.38(\mathrm{~s}, 1 \mathrm{H}), 7.06$ (dd, $J=8.3,2.0 \mathrm{~Hz}, 1 \mathrm{H}), 6.96(\mathrm{~s}, 1 \mathrm{H}), 5.56(\mathrm{t}, J=7.8 \mathrm{~Hz}, 1 \mathrm{H}), 3.64(\mathrm{t}, J=7.3 \mathrm{~Hz}$, 2H), $3.23(\mathrm{~s}, 2 \mathrm{H}), 2.09(\mathrm{~s}, 6 \mathrm{H}), 1.90-1.76(\mathrm{~m}, 2 \mathrm{H}), 1.42-1.26(\mathrm{~m}, 2 \mathrm{H}), 1.24-$ $1.08(\mathrm{~m}, 8 \mathrm{H}), 1.01-0.83(\mathrm{~m}, 5 \mathrm{H}), 0.62(\mathrm{t}, J=7.3 \mathrm{~Hz}, 3 \mathrm{H}) .{ }^{13} \mathrm{C}$ NMR $(126 \mathrm{MHz}$, $\left.\mathrm{C}_{6} \mathrm{D}_{6}\right): \delta=163.9\left(\mathrm{C}_{\mathrm{q}}\right), 153.4\left(\mathrm{C}_{\mathrm{q}}\right), 140.9\left(\mathrm{C}_{\mathrm{q}}\right), 134.8\left(\mathrm{C}_{\mathrm{q}}\right), 130.7(\mathrm{CH}), 130.3\left(\mathrm{C}_{\mathrm{q}}\right)$, $130.2(\mathrm{CH}), 129.4(\mathrm{CH}), 126.2\left(\mathrm{C}_{\mathrm{q}}\right), 123.8(\mathrm{CH}), 121.7(\mathrm{CH}), 58.1\left(\mathrm{C}_{\mathrm{q}}\right), 49.7$ $\left(\mathrm{CH}_{2}\right), 32.5\left(\mathrm{CH}_{2}\right), 32.5\left(\mathrm{CH}_{2}\right), 32.1\left(\mathrm{CH}_{2}\right), 30.1\left(\mathrm{CH}_{2}\right), 29.8\left(\mathrm{CH}_{3}\right), 29.5\left(\mathrm{CH}_{2}\right)$, $27.6\left(\mathrm{CH}_{2}\right), 23.2\left(\mathrm{CH}_{2}\right), 20.0\left(\mathrm{CH}_{2}\right), 14.5\left(\mathrm{CH}_{3}\right), 13.6\left(\mathrm{CH}_{3}\right)$. IR (ATR): 2956, 2927, 2855, 1649, 1590, 1321, 1167, 1045, 766, $498 \mathrm{~cm}^{-1}$. MS (ESI) m/z (relative intensity): 509 (16) [ $\left.{ }^{79} \mathrm{Br}, 2 \mathrm{M}+\mathrm{Na}\right]^{+}, 487(34)\left[{ }^{79} \mathrm{Br}, \mathrm{M}+\mathrm{H}\right]^{+}, 166$ (100). HR-MS (ESI) $m / z$ calcd for $\mathrm{C}_{25} \mathrm{H}_{36}{ }^{79} \mathrm{BrN}_{4} \mathrm{O}[\mathrm{M}+\mathrm{H}]^{+}$487.2067, found 487.2071. 
(E)-2-[2-(1-n-Butyl-1 H-1,2,3-triazol-4-yl)propan-2-yl]-7-fluoro-3-heptylidene-3,4-dihydro-isoquinolin-1(2H)-one (90ja)<smiles>CCCCn1cc(C(C)(C)N2C(=O)c3cc(F)ccc3C/C2=C\O)nn1</smiles>

The general procedure GPA was followed using 32j (91.3 $\mathrm{mg}, 0.30 \mathrm{mmol})$ and allene $88 \mathrm{a}(164 \mathrm{mg}, 0.90 \mathrm{mmol})$. Purification by column chromatography ( $n$ hexane/EtOAc $=3 / 1)$ yielded $\mathbf{9 0 j a}(97.3 \mathrm{mg}, 76 \%)$ as a colorless oil.

${ }^{1}$ H NMR $\left(600 \mathrm{MHz}, \mathrm{C}_{6} \mathrm{D}_{6}\right): \delta=8.06(\mathrm{dd}, J=9.3,2.8 \mathrm{~Hz}, 1 \mathrm{H}), 7.43(\mathrm{~s}, 1 \mathrm{H}), 6.72$ (ddd, $J=8.3,8.3,2.8 \mathrm{~Hz}, 1 \mathrm{H}), 6.60(\mathrm{dd}, J=8.3,5.1 \mathrm{~Hz}, 1 \mathrm{H}), 5.55$ (t, J=7.8 Hz, 1H), 3.69 (t, J=7.3 Hz, 2H), 3.32 (s, 2H), 2.09 (s, 6H), 1.87 (dt, J=7.3 Hz, 2H), 1.41-1.33 (m, 2H), 1.21-1.06 (m, 8H), 1.00-0.90 (m, 2H), $0.84(\mathrm{t}, J=7.2 \mathrm{~Hz}$, $3 \mathrm{H}), 0.64(\mathrm{t}, J=7.4 \mathrm{~Hz}, 3 \mathrm{H}) .{ }^{13} \mathrm{C}$ NMR $\left(126 \mathrm{MHz}, \mathrm{C}_{6} \mathrm{D}_{6}\right): \delta=163.5\left(\mathrm{~d},{ }^{4} \mathrm{~J} \mathrm{C}-\right.$ $\left.\mathrm{F}=2.5 \mathrm{~Hz}, \mathrm{C}_{\mathrm{q}}\right), 162.1\left(\mathrm{~d},{ }^{1} \mathrm{~J}_{\mathrm{C}-\mathrm{F}}=244.0 \mathrm{~Hz}, \mathrm{C}_{\mathrm{q}}\right), 153.4\left(\mathrm{C}_{\mathrm{q}}\right), 135.2\left(\mathrm{C}_{\mathrm{q}}\right), 134.7$ $\left(\mathrm{d},{ }^{4} \mathrm{~J}_{\mathrm{C}-\mathrm{F}}=3.0 \mathrm{~Hz}, \mathrm{C}_{\mathrm{q}}\right), 133.4\left(\mathrm{~d},{ }^{3} \mathrm{~J}_{\mathrm{C}-\mathrm{F}}=7.1 \mathrm{~Hz}, \mathrm{C}_{\mathrm{q}}\right), 128.4(\mathrm{CH}), 123.6(\mathrm{CH})$, $121.8(\mathrm{CH}), 118.5\left(\mathrm{~d},{ }^{2} \mathrm{~J} \mathrm{C}-\mathrm{F}=22.0 \mathrm{~Hz}, \mathrm{CH}\right), 115.4\left(\mathrm{~d},{ }^{2} \mathrm{~J}-\mathrm{F}=23.0 \mathrm{~Hz}, \mathrm{CH}\right), 58.2$ $\left(\mathrm{C}_{\mathrm{q}}\right), 49.7\left(\mathrm{CH}_{2}\right), 32.5\left(\mathrm{CH}_{2}\right), 32.1\left(\mathrm{CH}_{2}\right), 32.0\left(\mathrm{CH}_{2}\right), 30.1\left(\mathrm{CH}_{2}\right), 29.8\left(\mathrm{CH}_{3}\right)$, $29.5\left(\mathrm{CH}_{2}\right), 27.6\left(\mathrm{CH}_{2}\right), 23.1\left(\mathrm{CH}_{2}\right), 20.0\left(\mathrm{CH}_{2}\right), 14.4\left(\mathrm{CH}_{3}\right), 13.6\left(\mathrm{CH}_{3}\right) .{ }^{19} \mathrm{~F}$ NMR $\left(282 \mathrm{MHz}, \mathrm{C}_{6} \mathrm{D}_{6}\right): \delta=-115.37$ (td, $\left.J=8.6,5.0 \mathrm{~Hz}\right)$. IR (ATR): 2955, 2928, 2858, 1713, 1684, 1606, 1484, 1347, 1280, 1151, $783 \mathrm{~cm}^{-1}$. MS (ESI) m/z (relative intensity): $875(56)[2 \mathrm{M}+\mathrm{Na}]^{+}, 853(11)[2 \mathrm{M}+\mathrm{H}]^{+}, 427(100)[\mathrm{M}+\mathrm{H}]^{+}, 166(96)$. 


\subsubsection{Analytical Data - Products of TAM Benzamide Annulation with Different Allene Acetates}

(E)-2-[2-(1-n-Butyl-1H-1,2,3-triazol-4-yl)propan-2-yl]-3-hexylidene-3,4-dihydro-isoquinolin-1(2H)-one (90ah)

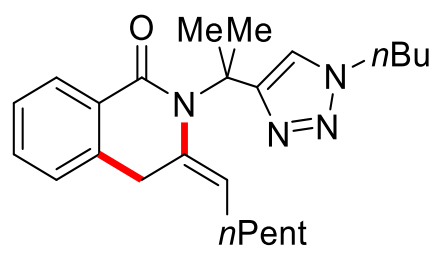

The general procedure GPA was followed using $32 \mathrm{a}(85.9 \mathrm{mg}, 0.30 \mathrm{mmol})$ and allene $88 \mathrm{~h}(151 \mathrm{mg}, 0.90 \mathrm{mmol})$. Purification by column chromatography ( $n$ hexane/EtOAc $=3 / 1)$ yielded $90 \mathrm{ah}(90.0 \mathrm{mg}, 76 \%)$ as a colorless oil.

${ }^{1} \mathrm{H}$ NMR $\left(600 \mathrm{MHz}, \mathrm{C}_{6} \mathrm{D}_{6}\right): \delta=8.40(\mathrm{dd}, J=7.6,1.5 \mathrm{~Hz}, 1 \mathrm{H}), 7.47(\mathrm{~s}, 1 \mathrm{H}), 7.03$ (ddd, $J=7.4,7.4,1.6 \mathrm{~Hz}, 1 \mathrm{H}$ ), 6.99 (ddd, $J=7.4,7.4,1.4 \mathrm{~Hz}, 1 \mathrm{H}$ ), 6.82 (dd, $J=7.4,1.0 \mathrm{~Hz}, 1 \mathrm{H}$ ), 5.57 (t, $J=7.7 \mathrm{~Hz}, 1 \mathrm{H}$ ), 3.65 (t, $J=7.3 \mathrm{~Hz}, 2 \mathrm{H}$ ), 3.40 (s, 2H), $2.15(\mathrm{~s}, 6 \mathrm{H}), 1.86(\mathrm{dt}, J=7.5 \mathrm{~Hz}, 2 \mathrm{H}), 1.38-1.29(\mathrm{~m}, 2 \mathrm{H}), 1.18-1.05(\mathrm{~m}$, $6 \mathrm{H}), 0.98-0.91(\mathrm{~m}, 2 \mathrm{H}), 0.79(\mathrm{t}, J=7.2 \mathrm{~Hz}, 3 \mathrm{H}), 0.62(\mathrm{t}, J=7.4 \mathrm{~Hz}, 3 \mathrm{H})$. ${ }^{13} \mathrm{C}$ NMR (126 MHz, $\left.\mathrm{C}_{6} \mathrm{D}_{6}\right): \delta=164.7\left(\mathrm{C}_{\mathrm{q}}\right), 153.6\left(\mathrm{C}_{\mathrm{q}}\right), 139.0\left(\mathrm{C}_{\mathrm{q}}\right), 135.5\left(\mathrm{C}_{\mathrm{q}}\right)$, $131.5(\mathrm{CH}), 131.5\left(\mathrm{C}_{\mathrm{q}}\right), 129.1(\mathrm{CH}), 126.9(\mathrm{CH}), 126.3(\mathrm{CH}), 123.1(\mathrm{CH}), 121.9$ $(\mathrm{CH}), 58.0\left(\mathrm{C}_{\mathrm{q}}\right), 49.6\left(\mathrm{CH}_{2}\right), 32.9\left(\mathrm{CH}_{2}\right), 32.4\left(\mathrm{CH}_{2}\right), 32.0\left(\mathrm{CH}_{2}\right), 30.0\left(\mathrm{CH}_{2}\right)$, $29.9\left(\mathrm{CH}_{3}\right), 27.5\left(\mathrm{CH}_{2}\right), 23.0\left(\mathrm{CH}_{2}\right), 20.0\left(\mathrm{CH}_{2}\right), 14.4\left(\mathrm{CH}_{3}\right), 13.6\left(\mathrm{CH}_{3}\right)$. IR (ATR): 2927, 2861, 1647, 1457, 1372, 1319, 1168, 1045, $736 \mathrm{~cm}^{-1}$. MS (ESI) $m / z$ (relative intensity): $811(4)[2 \mathrm{M}+\mathrm{Na}]^{+}, 395(22)[\mathrm{M}+\mathrm{H}]^{+}, 166$ (100). HR-MS (ESI) $m / z$ calcd for $\mathrm{C}_{24} \mathrm{H}_{35} \mathrm{~N}_{4} \mathrm{O}[\mathrm{M}+\mathrm{H}]^{+} 395.2805$, found 395.2800. 
(E)-2-[2-(1-n-Butyl-1H-1,2,3-triazol-4-yl)propan-2-yl]-3-(3-phenylpropylidene)-3,4-dihydroisoquinolin-1(2H)-one (90ai)

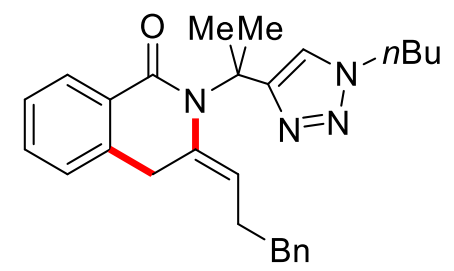

The general procedure GPA was followed using $\mathbf{3 2 a}(85.9 \mathrm{mg}, 0.30 \mathrm{mmol})$ and allene $88 \mathrm{i}$ ( $182 \mathrm{mg}, 0.90 \mathrm{mmol}$ ). Purification by column chromatography ( $n$ hexane/EtOAc $=3 / 1)$ yielded 90 ai $(112 \mathrm{mg}, 87 \%$ ) as a colorless oil.

${ }^{1} \mathrm{H}$ NMR $\left(300 \mathrm{MHz}, \mathrm{C}_{6} \mathrm{D}_{6}\right): \delta=8.49-8.27(\mathrm{~m}, 1 \mathrm{H}), 7.44(\mathrm{~s}, 1 \mathrm{H}), 7.13-7.05(\mathrm{~m}$, $2 \mathrm{H})$, 7.03-6.98 (m, 3H), 6.97-6.93 (m, 2H), 6.77-6.72 (m, 1H), $5.56(\mathrm{t}$, $J=7.6 \mathrm{~Hz}, 1 \mathrm{H}$ ), 3.66 (t, $J=7.3 \mathrm{~Hz}, 2 \mathrm{H}$ ), 3.31 (s, 2H), 2.37 (t, $J=7.7 \mathrm{~Hz}, 2 \mathrm{H}$ ), 2.18-2.12 (m, 2H), $2.10(\mathrm{~s}, 6 \mathrm{H}), 1.46-1.24(\mathrm{~m}, 2 \mathrm{H}), 1.02-0.86(\mathrm{~m}, 2 \mathrm{H}), 0.62(\mathrm{t}$, $J=7.3 \mathrm{~Hz}, 3 \mathrm{H}) .{ }^{13} \mathrm{C}$ NMR $\left(75 \mathrm{MHz}, \mathrm{C}_{6} \mathrm{D}_{6}\right): \delta=164.7\left(\mathrm{C}_{\mathrm{q}}\right), 153.7\left(\mathrm{C}_{\mathrm{q}}\right), 141.7$ $\left(\mathrm{C}_{\mathrm{q}}\right), 138.8\left(\mathrm{C}_{\mathrm{q}}\right), 136.0\left(\mathrm{C}_{\mathrm{q}}\right), 131.6(\mathrm{CH}), 131.3\left(\mathrm{C}_{\mathrm{q}}\right), 129.0(\mathrm{CH}), 128.7(\mathrm{CH})$, $128.6(\mathrm{CH}), 126.8(\mathrm{CH}), 126.4(\mathrm{CH}), 126.3(\mathrm{CH}), 122.0(\mathrm{CH}), 121.8(\mathrm{CH}), 57.9$ $\left(\mathrm{C}_{\mathrm{q}}\right), 49.5\left(\mathrm{CH}_{2}\right), 36.1\left(\mathrm{CH}_{2}\right), 32.6\left(\mathrm{CH}_{2}\right), 32.3\left(\mathrm{CH}_{2}\right), 29.8\left(\mathrm{CH}_{3}\right), 29.3\left(\mathrm{CH}_{2}\right)$, $19.9\left(\mathrm{CH}_{2}\right), 13.5\left(\mathrm{CH}_{3}\right)$. IR (ATR): 2931, 2866, 1648, 1456, 1373, 1321, 1167, 738, $699 \mathrm{~cm}^{-1}$. MS (ESI) $\mathrm{m} / z$ (relative intensity): 451 (78) $[\mathrm{M}+\mathrm{Na}]^{+}, 429$ (100)[M+H]+. HR-MS (ESI) $m / z$ calcd for $\mathrm{C}_{27} \mathrm{H}_{33} \mathrm{~N}_{4} \mathrm{O}[\mathrm{M}+\mathrm{H}]^{+} 429.2649$, found 429.2650 . 
(E)-3-[4-(Benzyloxy)butylidene]-2-[2-(1-n-butyl-1H-1,2,3-triazol-4-yl)propan-2-yl]-3,4-dihydroisoquinolin-1(2H)-one (90aj)

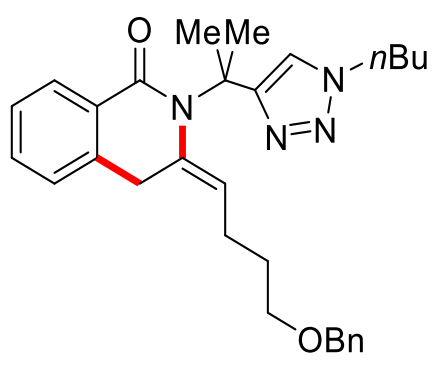

The general procedure GPA was followed using $32 \mathrm{a}(85.9 \mathrm{mg}, 0.30 \mathrm{mmol})$ and allene $88 \mathbf{j}$ ( $222 \mathrm{mg}, 0.90 \mathrm{mmol}$ ). Purification by column chromatography (nhexane/EtOAc $=3 / 1)$ yielded 90 aj $(111 \mathrm{mg}, 78 \%)$ as a colorless oil.

${ }^{1} \mathrm{H}$ NMR $\left(300 \mathrm{MHz}, \mathrm{C}_{6} \mathrm{D}_{6}\right): \delta=8.41-8.36(\mathrm{~m}, 1 \mathrm{H}), 7.44(\mathrm{~s}, 1 \mathrm{H}), 7.30-7.25(\mathrm{~m}$, 2H), 7.23-7.18 (m, 2H), 7.14-7.07 (m, 1H), 7.03-6.97 (m, 2H), 6.80-6.74 (m, $1 \mathrm{H}), 5.53(\mathrm{t}, J=7.9 \mathrm{~Hz}, 1 \mathrm{H}), 4.22(\mathrm{~s}, 2 \mathrm{H}), 3.66(\mathrm{t}, J=7.3 \mathrm{~Hz}, 2 \mathrm{H}), 3.41(\mathrm{~s}, 2 \mathrm{H})$, $3.13(\mathrm{t}, J=6.0 \mathrm{~Hz}, 2 \mathrm{H}), 2.12(\mathrm{~s}, 6 \mathrm{H}), 2.04(\mathrm{dt}, J=7.4 \mathrm{~Hz}, 2 \mathrm{H}), 1.48-1.29(\mathrm{~m}$, $4 \mathrm{H}), 1.04-0.85(\mathrm{~m}, 2 \mathrm{H}), 0.62(\mathrm{t}, J=7.3 \mathrm{~Hz}, 3 \mathrm{H}) .{ }^{13} \mathrm{C} \mathrm{NMR}\left(75 \mathrm{MHz}, \mathrm{C}_{6} \mathrm{D}_{6}\right)$ : $\delta=164.8\left(\mathrm{C}_{\mathrm{q}}\right), 153.6\left(\mathrm{C}_{\mathrm{q}}\right), 139.5\left(\mathrm{C}_{\mathrm{q}}\right), 139.0\left(\mathrm{C}_{\mathrm{q}}\right), 136.1\left(\mathrm{C}_{\mathrm{q}}\right), 131.5(\mathrm{CH}), 131.4$ $\left(\mathrm{C}_{\mathrm{q}}\right), 129.0(\mathrm{CH}), 128.6(\mathrm{CH}), 127.7(\mathrm{CH}), 127.6(\mathrm{CH}), 126.8(\mathrm{CH}), 126.5(\mathrm{CH})$, $122.3(\mathrm{CH}), 121.9(\mathrm{CH}), 73.0\left(\mathrm{CH}_{2}\right), 69.3\left(\mathrm{CH}_{2}\right), 57.9\left(\mathrm{C}_{\mathrm{q}}\right), 49.5\left(\mathrm{CH}_{2}\right), 32.5$ ( $\left.\mathrm{CH}_{2}\right), 32.3\left(\mathrm{CH}_{2}\right), 30.0\left(\mathrm{CH}_{2}\right), 29.8\left(\mathrm{CH}_{3}\right), 23.9\left(\mathrm{CH}_{2}\right), 19.9\left(\mathrm{CH}_{2}\right), 13.5\left(\mathrm{CH}_{3}\right)$. IR (ATR): 2930, 2863, 1648, 1456, 1371, 1320, 1102, 738, 697, $459 \mathrm{~cm}^{-1}$. MS (ESI) $m / z$ (relative intensity): $495(6)[\mathrm{M}+\mathrm{Na}]^{+}, 473(31)[\mathrm{M}+\mathrm{H}]^{+}, 308(10)$, 166 (100), 117 (19). HR-MS (ESI) $\mathrm{m} / z$ calcd for $\mathrm{C}_{29} \mathrm{H}_{37} \mathrm{~N}_{4} \mathrm{O}_{2}[\mathrm{M}+\mathrm{H}]^{+} 473.2911$, found 473.2911 . 
(E)-2-[2-(1-n-Butyl-1H-1,2,3-triazol-4-yl)propan-2-yl]-3-(7-chloroheptylidene)-3,4-dihydroisoquinolin-1(2H)-one (90ak)

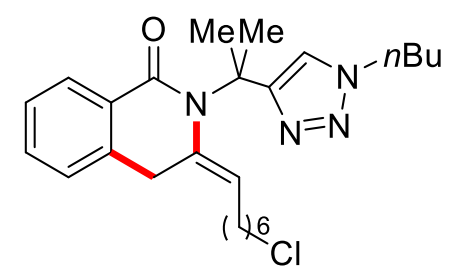

The general procedure GPA was followed using $32 \mathrm{a}(85.9 \mathrm{mg}, 0.30 \mathrm{mmol})$ and allene 88k (195 mg, $0.90 \mathrm{mmol}$ ). Purification by column chromatography (nhexane/EtOAc $=3 / 1$ ) yielded 90ak $(90.4 \mathrm{mg}, 68 \%$ ) as a colorless oil.

${ }^{1} \mathrm{H}$ NMR $\left(300 \mathrm{MHz}, \mathrm{C}_{6} \mathrm{D}_{6}\right): \delta=8.41-8.32(\mathrm{~m}, 1 \mathrm{H}), 7.49(\mathrm{~s}, 1 \mathrm{H}), 7.09-6.95(\mathrm{~m}$, 2H), 6.88-6.76 (m, 1H), 5.56 (t, $J=7.8 \mathrm{~Hz}, 1 \mathrm{H}$ ), 3.67 (t, $J=7.3 \mathrm{~Hz}, 2 \mathrm{H}), 3.40$ (s, 2H), $3.08(\mathrm{t}, J=6.7 \mathrm{~Hz}, 2 \mathrm{H}), 2.13(\mathrm{~s}, 6 \mathrm{H}), 1.83(\mathrm{dt}, J=7.4 \mathrm{~Hz}, 2 \mathrm{H}), 1.42-$ $1.27(\mathrm{~m}, 4 \mathrm{H}), 1.09-0.86(\mathrm{~m}, 8 \mathrm{H}), 0.63(\mathrm{t}, J=7.3 \mathrm{~Hz}, 3 \mathrm{H}) .{ }^{13} \mathrm{C}$ NMR $(126 \mathrm{MHz}$, $\left.\mathrm{C}_{6} \mathrm{D}_{6}\right): \delta=164.7\left(\mathrm{C}_{\mathrm{q}}\right), 153.5\left(\mathrm{C}_{\mathrm{q}}\right), 139.0\left(\mathrm{C}_{\mathrm{q}}\right), 135.6\left(\mathrm{C}_{\mathrm{q}}\right), 131.6(\mathrm{CH}), 131.4\left(\mathrm{C}_{\mathrm{q}}\right)$, $129.1(\mathrm{CH}), 126.9(\mathrm{CH}), 126.3(\mathrm{CH}), 122.9(\mathrm{CH}), 122.0(\mathrm{CH}), 57.9\left(\mathrm{C}_{q}\right), 49.7$ $\left(\mathrm{CH}_{2}\right), 45.1\left(\mathrm{CH}_{2}\right), 32.9\left(\mathrm{CH}_{2}\right), 32.9\left(\mathrm{CH}_{2}\right), 32.5\left(\mathrm{CH}_{2}\right), 29.9\left(\mathrm{CH}_{3}\right), 29.8\left(\mathrm{CH}_{2}\right)$, $28.8\left(\mathrm{CH}_{2}\right), 27.3\left(\mathrm{CH}_{2}\right), 27.0\left(\mathrm{CH}_{2}\right), 20.0\left(\mathrm{CH}_{2}\right), 13.7\left(\mathrm{CH}_{3}\right)$. IR (ATR): 2931, 2857, 1601, 1457, 1374, 1323, 1306, 1046, $737 \mathrm{~cm}^{-1}$. MS (EI) $\mathrm{m} / \mathrm{z}$ (relative intensity): 442 (6) [ $\left.{ }^{35} \mathrm{Cl}, \mathrm{M}\right]^{+}, 323$ (15), 242 (13), 172 (39), 166 (100), 84 (38). HR-MS (ESI) $m / z$ calcd for $\mathrm{C}_{25} \mathrm{H}_{35} \mathrm{~N}_{4} \mathrm{O}^{35} \mathrm{Cl}[\mathrm{M}+\mathrm{Na}]^{+} 465.2392$, found 465.2380 . 


\section{Experimental Part}

\subsubsection{Traceless Removal of TAM Group}

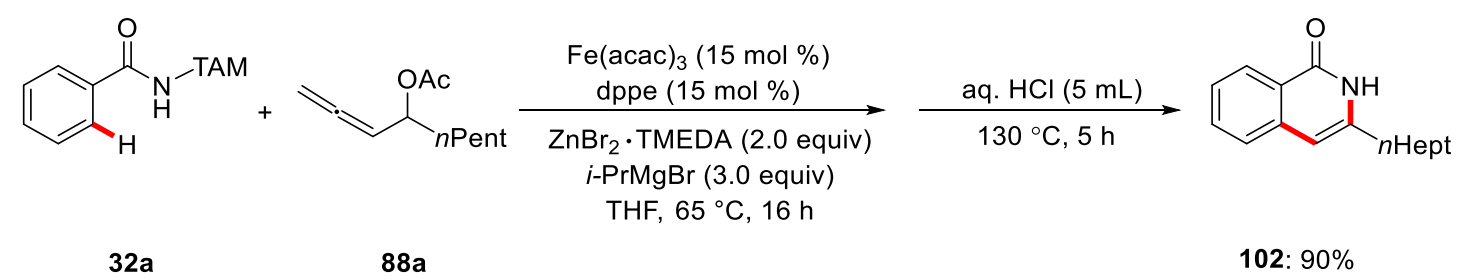

To a stirred solution of benzamide $32 \mathrm{a}(85.9 \mathrm{mg}, 0.30 \mathrm{mmol}), \mathrm{ZnBr} 2 \cdot \mathrm{TMEDA}$ (206 mg, $0.60 \mathrm{mmol})$, dppe (17.9 mg, $15 \mathrm{~mol} \%$ ) in THF (0.20 mL), $\mathrm{PrMgBr}$ (3.0 $\mathrm{M}$ in 2-MeTHF, $300 \mu \mathrm{L}, 0.90 \mathrm{mmol}$ ) was added in one portion and the reaction mixture was stirred for $5 \mathrm{~min}$ at ambient temperature. Then, $\mathrm{Fe}(\mathrm{acac})_{3}$ (15.9 mg, $15 \mathrm{~mol} \%$ ) was added in a single portion. After stirring the solution for an additional $5 \mathrm{~min}$, allene $88 \mathrm{a}$ ( $164 \mathrm{mg}, 0.90 \mathrm{mmol}$ ) was added as a solutionin THF $(0.20 \mathrm{~mL})$ in one portion. After completion, the mixture was placed in a pre-heated oil bath at $65^{\circ} \mathrm{C}$, and stirred for $16 \mathrm{~h}$. The reaction mixture was then transfered into a sealed tube using THF $(2.0 \mathrm{~mL})$. Conc. $\mathrm{HCl}(5.0 \mathrm{~mL})$ was added, and the reaction mixture was placed in a pre-heated oil bath at $130^{\circ} \mathrm{C}$ and stirred for $5 \mathrm{~h}$. The mixture was allowed to cool to ambient temperature. The reaction mixture was extracted with $\mathrm{CH}_{2} \mathrm{Cl}_{2}(3 \times 15 \mathrm{~mL})$, and the combined organic layers were washed with sat. aqueous $\mathrm{NaHCO}_{3}(15 \mathrm{~mL})$, dried over $\mathrm{Na}_{2} \mathrm{SO}_{4}$, filtered and concentrated. Purification by column chromatography ( $n$ hexane/EtOAc $=5 / 1)$ yielded $102(65.7 \mathrm{mg}, 90 \%)$ as a white solid.

M.p. $=86-87^{\circ} \mathrm{C} .{ }^{1} \mathrm{H}$ NMR $\left(600 \mathrm{MHz}, \mathrm{CDCl}_{3}\right): \delta=10.82(\mathrm{~s}, 1 \mathrm{H}), 8.39-8.36(\mathrm{~m}$, 1H), 7.62 (ddd, $J=8.1,7.1,1.4 \mathrm{~Hz}, 1 \mathrm{H}$ ), 7.47 (d, $J=7.9 \mathrm{~Hz}, 1 \mathrm{H}$ ), 7.42 (ddd, $J=8.1,7.1,1.1 \mathrm{~Hz}, 1 \mathrm{H}), 6.31(\mathrm{~s}, 1 \mathrm{H}), 2.63(\mathrm{t}, J=7.0 \mathrm{~Hz}, 2 \mathrm{H}), 1.75(\mathrm{dt}, J=15.3$, $7.6 \mathrm{~Hz}, 2 \mathrm{H}), 1.43-1.38(\mathrm{~m}, 2 \mathrm{H}), 1.37-1.32(\mathrm{~m}, 2 \mathrm{H}), 1.30-1.25(\mathrm{~m}, 4 \mathrm{H}), 0.87(\mathrm{t}$, $J=7.0 \mathrm{~Hz}, 3 \mathrm{H}) .{ }^{13} \mathrm{C}$ NMR $\left(126 \mathrm{MHz}, \mathrm{CDCl}_{3}\right): \delta=164.5\left(\mathrm{C}_{\mathrm{q}}\right), 142.0\left(\mathrm{C}_{\mathrm{q}}\right), 138.8$ $\left(\mathrm{C}_{\mathrm{q}}\right), 132.6(\mathrm{CH}), 127.4(\mathrm{CH}), 125.8(\mathrm{CH}), 125.7(\mathrm{CH}), 124.5\left(\mathrm{C}_{\mathrm{q}}\right), 103.9(\mathrm{CH})$, 33.7 $\left(\mathrm{CH}_{2}\right), 31.9\left(\mathrm{CH}_{2}\right), 29.3\left(\mathrm{CH}_{2}\right), 29.2\left(\mathrm{CH}_{2}\right), 28.6\left(\mathrm{CH}_{2}\right), 22.9\left(\mathrm{CH}_{2}\right), 14.3$ $\left(\mathrm{CH}_{3}\right)$. IR (ATR): 2926, 2855, 1642, 1607, 1555, 1465, 1346, 1044, 755, 
$582 \mathrm{~cm}^{-1}$. MS (EI) m/z (relative intensity): 243 (42) [M]+, 172 (29), 159 (100), 158 (18), 41 (33). HR-MS (EI) $\mathrm{m} / z$ calcd for $\mathrm{C}_{16} \mathrm{H}_{21} \mathrm{NO}[\mathrm{M}]^{+} 243.1623$, found 243.1623.

\subsubsection{Mechanistic Studies}

\section{Intermolecular Competition Experiment}<smiles>Cc1ccc(C(=O)N[Tl])cc1</smiles>

51e $(0.15 \mathrm{mmol})$<smiles>O=C(N[Tl])c1ccc(C(F)(F)F)cc1</smiles>

$51 \mathrm{~h}(0.15 \mathrm{mmol})$

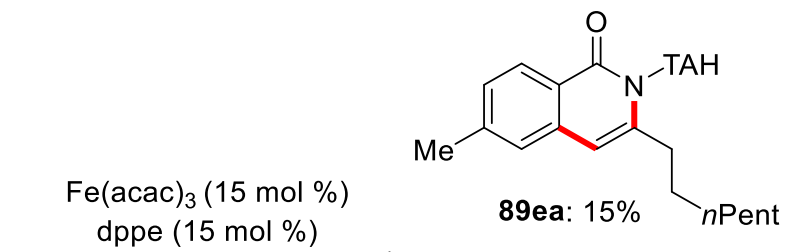

$\mathrm{ZnBr}_{2} \cdot \mathrm{TMEDA}$ (2.0 equiv) iPrMgBr (3.0 equiv) $\mathrm{THF}, 65^{\circ} \mathrm{C}, 2 \mathrm{~min}$

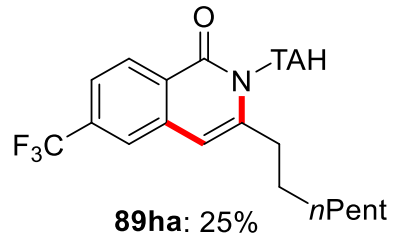

To a stirred solution of $51 \mathrm{e}(45.1 \mathrm{mg}, 0.15 \mathrm{mmol}), 51 \mathrm{~h}(53.3 \mathrm{mg}, 0.15 \mathrm{mmol})$, $\mathrm{ZnBr}_{2} \cdot$ TMEDA (206 mg, $0.60 \mathrm{mmol}$ ), dppe (17.9 mg, $15 \mathrm{~mol} \%$ ) in THF (0.20 mL), $\operatorname{PrMgBr}(3.0 \mathrm{M}$ in 2-MeTHF, $300 \mu \mathrm{L}, 0.90 \mathrm{mmol}$ ) was added in one portion and the reaction mixture was stirred for $5 \mathrm{~min}$ at ambient temperature. Then, $\mathrm{Fe}(\mathrm{acac})_{3}(15.9 \mathrm{mg}, 15 \mathrm{~mol} \%)$ was added in a single portion. After stirring the solution for additional $5 \mathrm{~min}$, a solution of allene $88 \mathrm{a}$ (164 mg, $0.90 \mathrm{mmol})$ in THF $(0.20 \mathrm{~mL})$ was added in one portion. The mixture was placed in a pre-heated oil bath at $65{ }^{\circ} \mathrm{C}$. After stirring for 2 min, sat. aqueous $\mathrm{NH}_{4} \mathrm{Cl}$ $(2.0 \mathrm{~mL})$ was added to the reaction mixture, which was extracted with $\mathrm{CH}_{2} \mathrm{Cl}_{2}$ $(3 \times 15 \mathrm{~mL})$. The combined organic extracts were dried over $\mathrm{Na}_{2} \mathrm{SO}_{4}$, filtered and concentrated. Purification by column chromatography ( $n$ hexane/EtOAc $=3 / 1)$ yielded 89 ea $(19.0 \mathrm{mg}, 15 \%)$ and $89 \mathrm{ha}(35.7 \mathrm{mg}, 25 \%)$. 


\section{Kinetic Isotope Effect (KIE) Measurement}

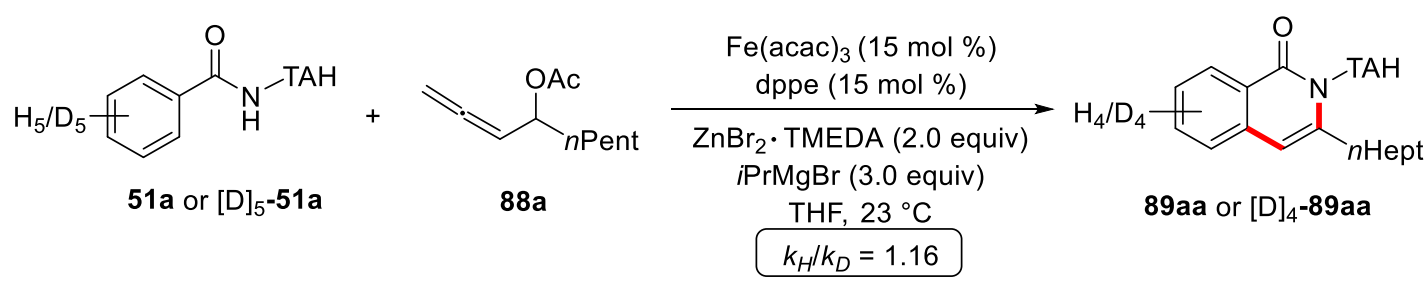

To a stirred solution of $51 \mathrm{a}(172 \mathrm{mg}, 0.60 \mathrm{mmol})$ or $[\mathrm{D}] 5-51 \mathrm{a}(175 \mathrm{mg}$, $0.60 \mathrm{mmol}$ ), $\mathrm{ZnBr} \cdot$ TMEDA (412 mg, $1.20 \mathrm{mmol}$ ) and dppe (35.8 mg, $15 \mathrm{~mol} \%$ ) in THF (1.2 mL), $\operatorname{PrMgBr}(3.0 \mathrm{M}$ in THF, $600 \mu \mathrm{L}, 1.80 \mathrm{mmol}$ ) was added in one portion and the reaction mixture was stirred for $5 \mathrm{~min}$ at ambient temperature. $\mathrm{Fe}(\mathrm{acac})_{3}(31.8 \mathrm{mg}, 15 \mathrm{~mol} \%)$ was added in a single portion. After stirring the solution for additional $5 \mathrm{~min}$, allene $88 \mathrm{a}$ (328 $\mathrm{mg}, 1.80 \mathrm{mmol}$ ) was added as a solution in THF (1.2 mL) in one portion. An in stitu IR spectrum was acquired every $30 \mathrm{~s}$ for $2 \mathrm{~h}$.

The KIE was determined by measuring initial rates from the increase of the peak at $1643 \mathrm{~cm}^{-1}$, which corresponds to a $\mathrm{C}=\mathrm{O}$ vibration of product 89aa. The absolute peak area was measured from 1659 to $1635 \mathrm{~cm}^{-1}$ with a one-point baseline at $1659 \mathrm{~cm}^{-1}$. A linear fit was employed to derive the initial rates. 


\section{Experimental Part}
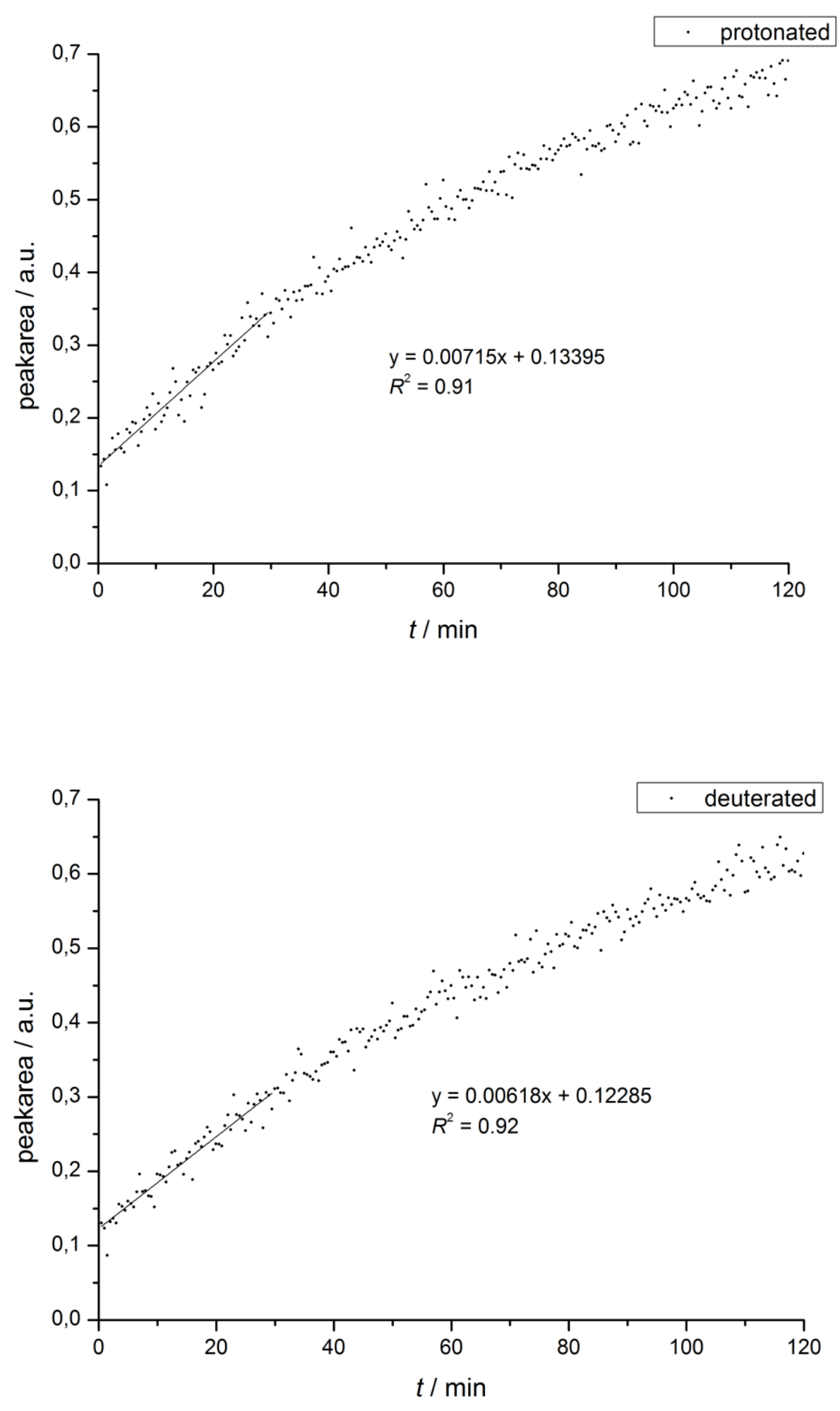

Figure 5.1. Plot of peak area at $1643 \mathrm{~cm}^{-1}$ vs reaction time for 89aa (top) and [D] $]^{-}$ 89aa (bottom). 


\section{Intermolecular KIE Measurement}
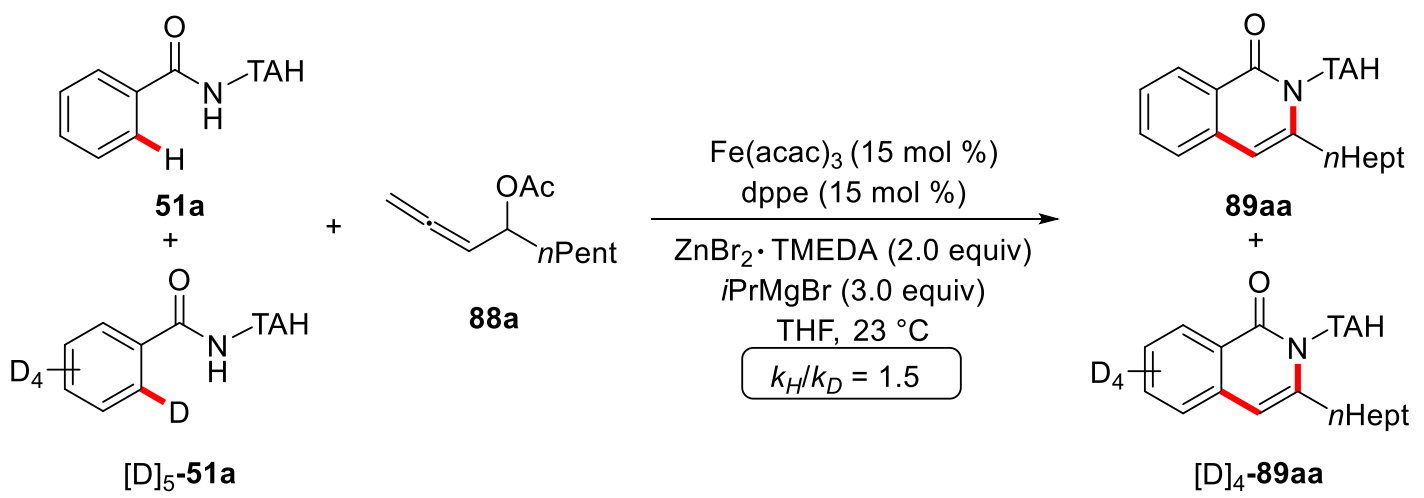

To a stirred solution of $51 \mathrm{a}(43.0 \mathrm{mg}, 0.15 \mathrm{mmol})$, [D]5-51a $(43.7 \mathrm{mg}$, $0.15 \mathrm{mmol}$ ), $\mathrm{ZnBr}_{2} \cdot$ TMEDA (206 mg, $0.60 \mathrm{mmol}$ ) and dppe (17.9 mg, $15 \mathrm{~mol}$ \%) in THF (0.6 mL), $\operatorname{PrMgBr}(3.0 \mathrm{M}$ in THF, $300 \mu \mathrm{L}, 0.9 \mathrm{mmol})$ was added in one portion and the reaction mixture was stirred for $5 \mathrm{~min}$ at ambient temperature. $\mathrm{Fe}(\mathrm{acac})_{3}(15.9 \mathrm{mg}, 15 \mathrm{~mol} \%)$ was added in a single portion. After stirring the solution for additional $5 \mathrm{~min}$, allene $88 \mathrm{a}$ (164 mg, $0.90 \mathrm{mmol})$ was added as a solution in THF $(0.6 \mathrm{~mL})$ in one portion. After stirring for $45 \mathrm{~min}$, sat. aqueous $\mathrm{NH}_{4} \mathrm{Cl}(2.0 \mathrm{~mL})$ was added to the reaction mixture, which was then extracted with $\mathrm{CH}_{2} \mathrm{Cl}_{2}(3 \times 15 \mathrm{~mL})$. The combined organic extracts were dried over $\mathrm{Na}_{2} \mathrm{SO}_{4}$, filtered and concentrated. The crude product was purified by column chromatography ( $n$ hexane/EtOAc $=3 / 1$ ). The mixture was analyzed by ${ }^{1} \mathrm{H}-\mathrm{NMR}$ spectroscopy to determine the ratio of $89 \mathrm{aa} /[\mathrm{D}] 4-89 \mathrm{aa}$. 


\section{Experimental Part}
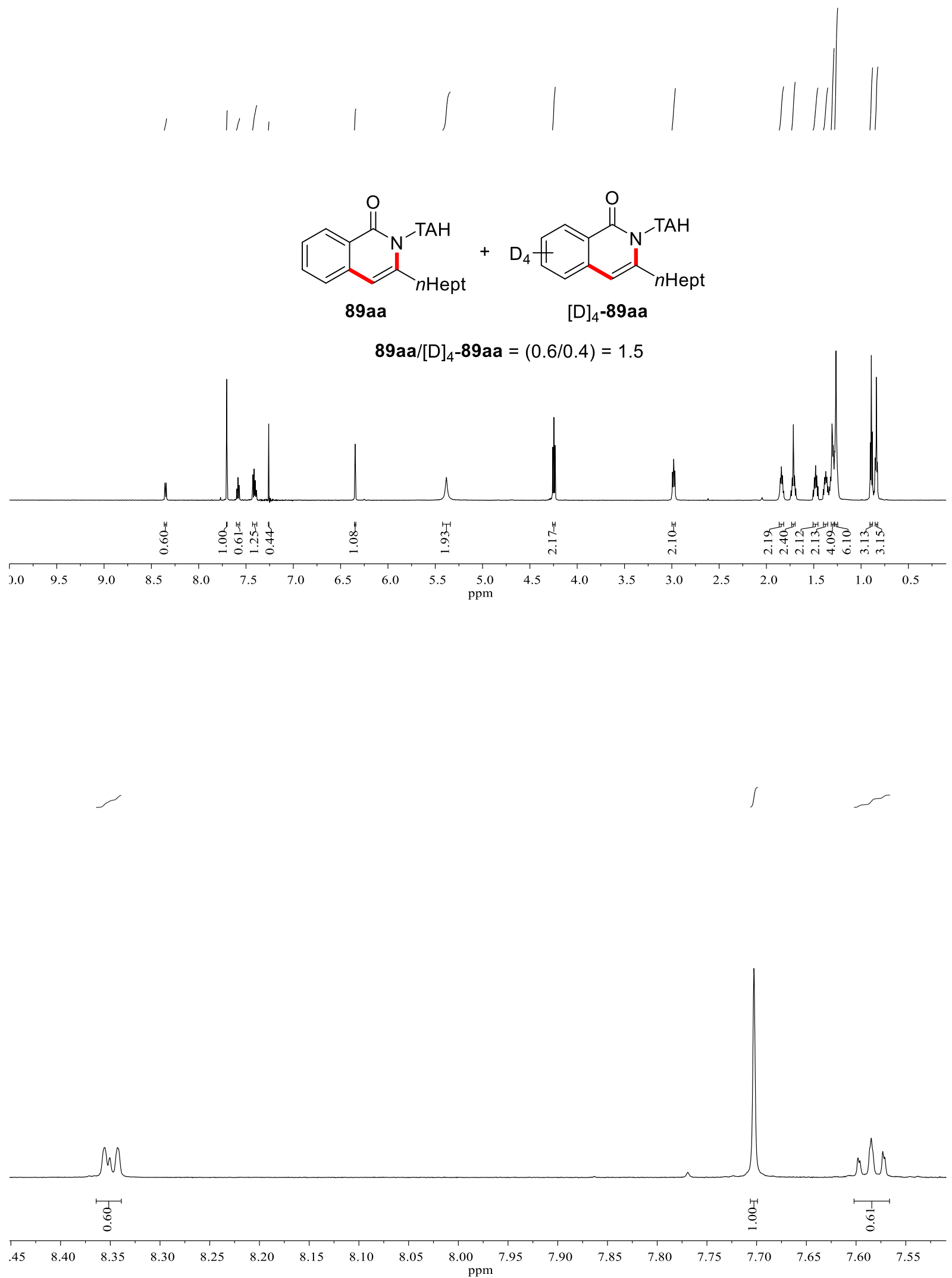


\section{Experimental Part}

\section{Experiments with Isotopically-labelled Substrates}

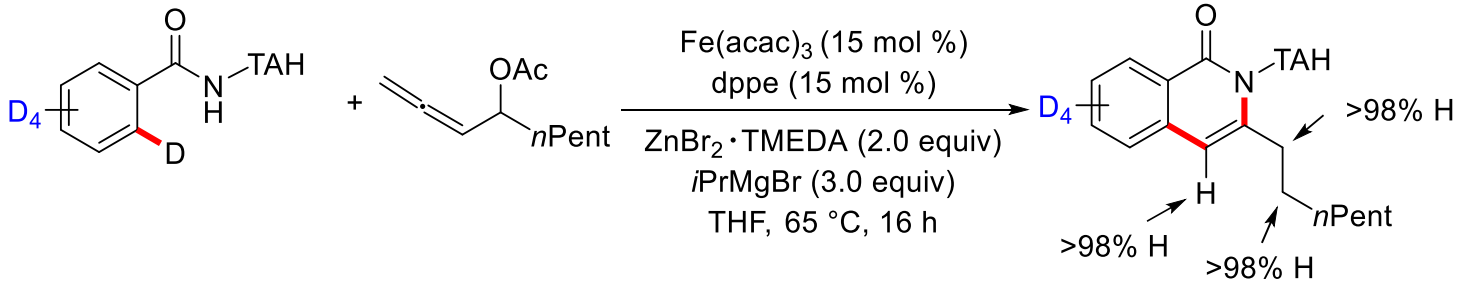

$[\mathrm{D}]_{5}-51 \mathrm{a}$

$88 a$

$[D]_{4}-89$ aa: $64 \%$

To a stirred solution of [D]5-51a (87.4 mg, $0.30 \mathrm{mmol}), \mathrm{ZnBr} \cdot$ TMEDA (206 mg, $0.60 \mathrm{mmol})$, dppe (17.9 mg, $15 \mathrm{~mol} \%)$ in THF (0.20 mL), $\operatorname{PrMgBr}(3.0 \mathrm{M}$ in 2MeTHF, $300 \mu \mathrm{L}, 0.90 \mathrm{mmol}$ ) was added in one portion and the reaction mixture was stirred for $5 \mathrm{~min}$ at ambient temperature. Then, Fe(acac) $)_{3}$ (15.9 mg, $15 \mathrm{~mol} \%$ ) was added in a single portion. After stirring the solution for additional $5 \mathrm{~min}$, a solution of allene $88 \mathrm{a}(164 \mathrm{mg}, 0.90 \mathrm{mmol})$ in THF $(0.20 \mathrm{~mL})$ was added in one portion. The mixture was placed in a pre-heated oil bath at $65^{\circ} \mathrm{C}$. After stirring for $16 \mathrm{~h}$, sat. aqueous $\mathrm{NH}_{4} \mathrm{Cl}(2.0 \mathrm{~mL})$ was added to the reaction mixture, which was extracted with $\mathrm{CH}_{2} \mathrm{Cl}_{2}(3 \times 15 \mathrm{~mL})$. The combined organic extracts were dried over $\mathrm{Na}_{2} \mathrm{SO}_{4}$, filtered and concentrated. Purification by column chromatography ( $n$ hexane/EtOAc $=3 / 1$ ) yielded [D]4-89aa $(79.2 \mathrm{mg}$, $64 \%$ ) as white solid. HR-MS (ESI) $m / z$ calcd for $\mathrm{C}_{25} \mathrm{H}_{33} \mathrm{~N}_{4} \mathrm{OD}_{4}[\mathrm{M}+\mathrm{H}]^{+} 413.3213$, found 413.3201. 


\section{Experimental Part}
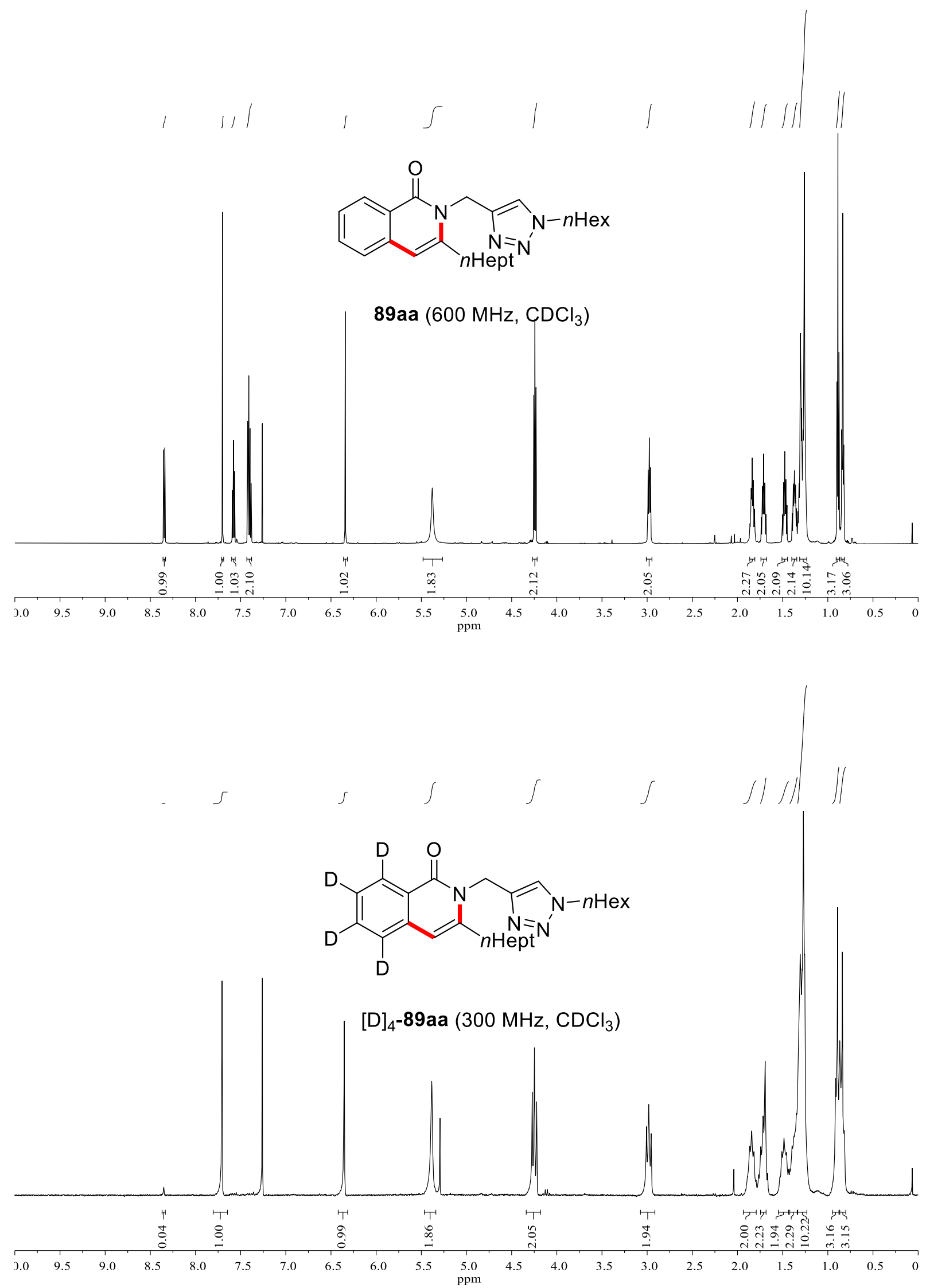
<smiles>C=C=CC(OC(C)=O)C(=O)OCC</smiles>

$51 \mathrm{a}$

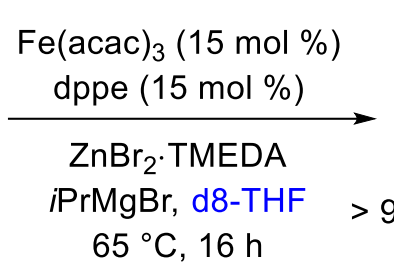

$65^{\circ} \mathrm{C}, 16 \mathrm{~h}$

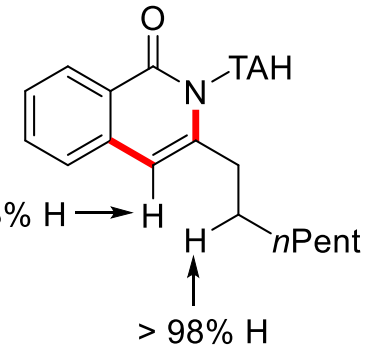

89aa: $64 \%$

To a stirred solution of $\mathbf{5 1 a}(85.9 \mathrm{mg}, 0.30 \mathrm{mmol}), \mathrm{ZnBr} \cdot$ TMEDA (206 mg, 0.60 $\mathrm{mmol}$ ), dppe (17.9 mg, $15 \mathrm{~mol} \%)$ in d8-THF $(0.20 \mathrm{~mL}$ ), $\operatorname{PrMgBr}(3.0 \mathrm{M}$ in 2MeTHF, $300 \mu \mathrm{L}, 0.90 \mathrm{mmol}$ ) was added in a single portion and the reaction mixture was stirred for $5 \mathrm{~min}$ at ambient temperature. Then, $\mathrm{Fe}(\mathrm{acac})_{3}$ (15.9 mg, $15 \mathrm{~mol} \%$ ) was added in a single portion. After stirring the solution for additional $5 \mathrm{~min}$, a solution of allene $88 \mathrm{a}(166 \mathrm{mg}, 0.90 \mathrm{mmol}$ ) in d8-THF $(0.20 \mathrm{~mL})$ was added in one portion. The mixture was placed in a pre-heated oil bath at $65^{\circ} \mathrm{C}$. After stirring for $16 \mathrm{~h}$, sat. aqueous $\mathrm{NH}_{4} \mathrm{Cl}(2.0 \mathrm{~mL})$ was added to the reaction mixture, which was extracted with $\mathrm{CH}_{2} \mathrm{Cl}_{2}(3 \times 15 \mathrm{~mL})$. The combined organic extracts were dried over $\mathrm{Na}_{2} \mathrm{SO}_{4}$, filtered and concentrated. The crude product was purified by column chromatography (nhexane/EtOAc $=3 / 1$ ) yielded 89aa $(76.4 \mathrm{mg}, 64 \%$ ).<smiles>[2H]N([Tl])C(=O)c1ccccc1</smiles><smiles>C=C=CC(C=C)PC(C)=O</smiles>

$[D]-51 a$

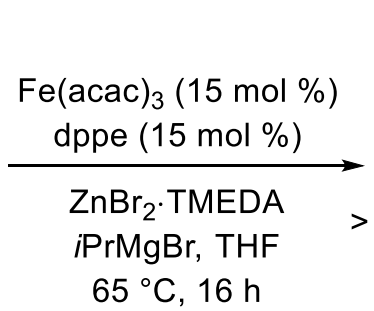

$65^{\circ} \mathrm{C}, 16 \mathrm{~h}$

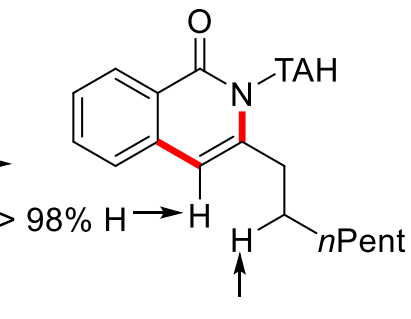

$>98 \% \mathrm{H}$

[D]-89aa: 64\%

To a stirred solution of [D]-51a $(86.1 \mathrm{mg}, 0.30 \mathrm{mmol}$ ), $\mathrm{ZnBr} 2 \cdot$ TMEDA (206 mg, $0.60 \mathrm{mmol})$, dppe (17.9 mg, $15 \mathrm{~mol} \%)$ in THF $(0.20 \mathrm{~mL}), \operatorname{PrMgBr}(3.0 \mathrm{M}$ in 2MeTHF, $300 \mu \mathrm{L}, 0.90 \mathrm{mmol}$ ) was added in a single portion and the reaction mixture was stirred for $5 \mathrm{~min}$ at ambient temperature. Then, $\mathrm{Fe}(\mathrm{acac})_{3}$ 


\section{Experimental Part}

(15.9 mg, $15 \mathrm{~mol} \%$ ) was added in a single portion. After stirring the solution for additional $5 \mathrm{~min}$, a solution of allene $88 \mathrm{a}$ (166 mg, $0.90 \mathrm{mmol})$ in THF $(0.20 \mathrm{~mL}$ ) was added in one portion. The mixture was placed in a pre-heated oil bath at $65{ }^{\circ} \mathrm{C}$. After stirring for $16 \mathrm{~h}$, sat. aqueous $\mathrm{NH}_{4} \mathrm{Cl}(2.0 \mathrm{~mL})$ was added to the reaction mixture, which was extracted with $\mathrm{CH}_{2} \mathrm{Cl}_{2}(3 \times 15 \mathrm{~mL})$. The combined organic extracts were dried over $\mathrm{Na}_{2} \mathrm{SO}_{4}$, filtered and concentrated. The crude product was purified by column chromatography ( $n$ hexane/EtOAc $=3 / 1$ ) yielded [D]-89aa (76.4 mg, 64\%).<smiles>N#[14C]NC(=O)c1ccccc1</smiles>

$32 a$<smiles>[2H]C([2H])=CC([18OH])[Po]</smiles>

$[\mathrm{D}]_{2}-88 \mathrm{a}$

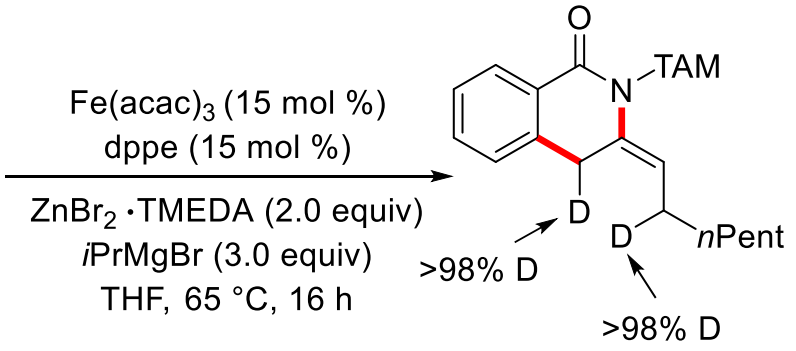

$[D]_{2}-90$ aa: $71 \%$

To a stirred solution of $\mathbf{3 2 a}$ ( $85.9 \mathrm{mg}, 0.30 \mathrm{mmol}), \mathrm{ZnBr} 2 \cdot \mathrm{TMEDA}$ (206 mg, 0.60 mmol), dppe (17.9 mg, $15 \mathrm{~mol} \%)$ in $\operatorname{THF}(0.20 \mathrm{~mL}), \operatorname{PrMgBr}(3.0 \mathrm{M}$ in 2MeTHF, $300 \mu \mathrm{L}, 0.90 \mathrm{mmol}$ ) was added in a single portion and the reaction mixture was stirred for $5 \mathrm{~min}$ at ambient temperature. Then, $\mathrm{Fe}(\mathrm{acac})_{3}$ (15.9 $\mathrm{mg}, 15 \mathrm{~mol} \%$ ) was added in a single portion. After stirring the solution for additional $5 \mathrm{~min}$, a solution of allene [D]2-88a (166 mg, $0.90 \mathrm{mmol})$ in THF $(0.20 \mathrm{~mL})$ was added in one portion. The mixture was placed in a pre-heated oil bath at $65^{\circ} \mathrm{C}$. After stirring for $16 \mathrm{~h}$, sat. aqueous $\mathrm{NH}_{4} \mathrm{Cl}(2.0 \mathrm{~mL})$ was added to the reaction mixture, which was extracted with $\mathrm{CH}_{2} \mathrm{Cl}_{2}(3 \times 15 \mathrm{~mL})$. The combined organic extracts were dried over $\mathrm{Na}_{2} \mathrm{SO}_{4}$, filtered and concentrated. The crude product was purified by column chromatography (nhexane/EtOAc $=3 / 1$ ) yielded $[\mathrm{D}]_{2}-90$ aa $(87.5 \mathrm{mg}, 71 \%)$. HR-MS $(\mathrm{ESI}) \mathrm{m} / \mathrm{z}$ calcd for $\mathrm{C}_{25} \mathrm{H}_{35} \mathrm{~N}_{4} \mathrm{OD}_{2}[\mathrm{M}+\mathrm{H}]^{+} 411.3087$, found 411.3094 . 
5. Experimental Part
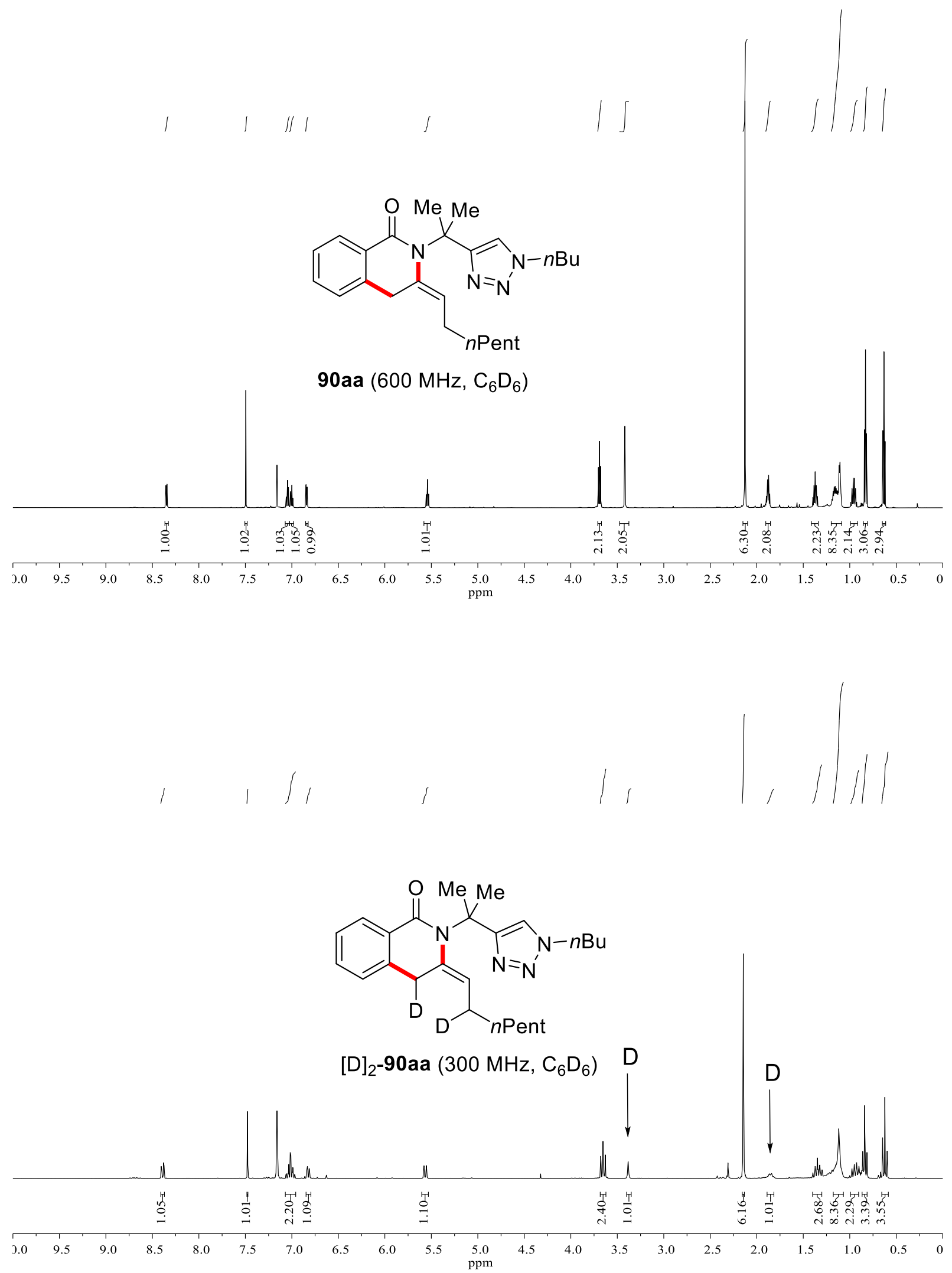


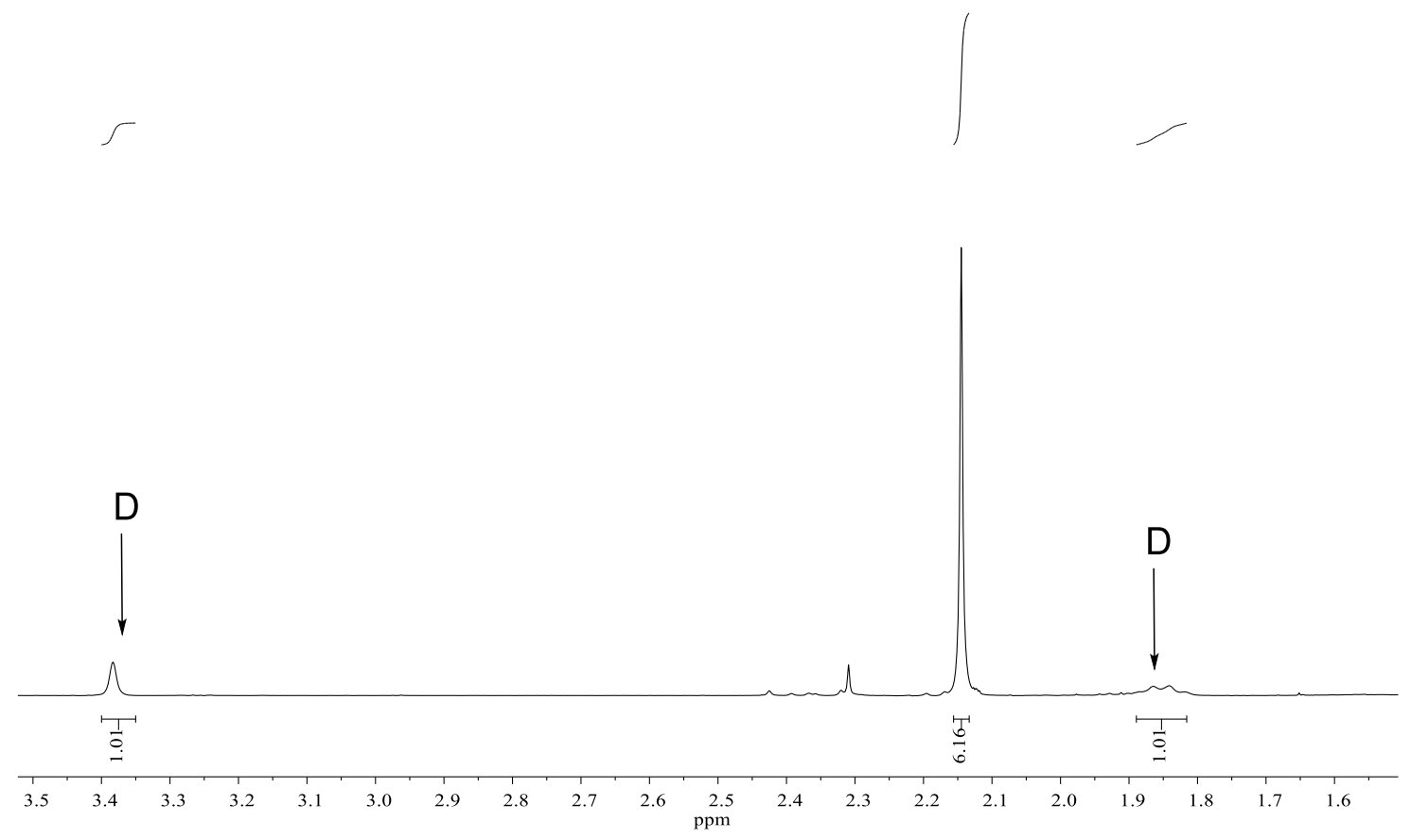

\section{Experiments with DCIB as Additive}<smiles>O=C(N[TlH])c1ccccc1</smiles>

$51 a$<smiles>C=CC(C=P)OC(C)=O</smiles>

$88 a$

$$
\begin{gathered}
\mathrm{Fe}(\mathrm{acac})_{3}(15 \mathrm{~mol} \%) \\
\mathrm{dppe}(15 \mathrm{~mol} \%)
\end{gathered}
$$$$
\text { iPrMgBr, DCIB }
$$$$
\text { THF }
$$

$65^{\circ} \mathrm{C}, 16 \mathrm{~h}$<smiles>CCCCCCOc1cc2ccccc2c(=O)n1[AlH2]</smiles>

89aa: $85 \%$

To a stirred solution of $51 \mathrm{a}(86.1 \mathrm{mg}, 0.30 \mathrm{mmol}), \mathrm{ZnBr}_{2} \cdot \mathrm{TMEDA}$ (206 mg, $0.60 \mathrm{mmol})$, dppe (17.9 mg, $15 \mathrm{~mol} \%)$ in THF (0.20 mL), $\operatorname{PrMgBr}(3.0 \mathrm{M}$ in 2MeTHF, $300 \mu \mathrm{L}, 0.90 \mathrm{mmol}$ ) was added in a single portion and the reaction mixture was stirred for $5 \mathrm{~min}$ at ambient temperature. Then, $\mathrm{Fe}(\mathrm{acac})_{3}$ (15.9 mg, $15 \mathrm{~mol} \%$ ) was added in a single portion. After stirring the solution for additional $5 \mathrm{~min}$, a solution of allene $88 \mathrm{a}(166 \mathrm{mg}, 0.90 \mathrm{mmol})$ and DCIB (76.2 $\mathrm{mg}, 0.60 \mathrm{mmol})$ in THF $(0.20 \mathrm{~mL})$ was added in one portion. The mixture was placed in a pre-heated oil bath at $65^{\circ} \mathrm{C}$. After stirring for $16 \mathrm{~h}$, sat. aqueous $\mathrm{NH}_{4} \mathrm{Cl}(2.0 \mathrm{~mL})$ was added to the reaction mixture, which was extracted with $\mathrm{CH}_{2} \mathrm{Cl}_{2}(3 \times 15 \mathrm{~mL})$. The combined organic extracts were dried over $\mathrm{Na}_{2} \mathrm{SO}_{4}$, 
filtered and concentrated. The crude product was purified by column chromatography ( $n$ hexane/EtOAc $=3 / 1$ ) yielded 89aa $(101 \mathrm{mg}, 85 \%)$.

\subsection{Iron-Catalyzed $\mathrm{C}-\mathrm{H} / \mathrm{N}-\mathrm{H}$ Annulation with Propargyl Acetates}

\subsubsection{Analytical Data - Products 92}

3-Benzyl-2-[(1-n-hexyl-1H-1,2,3-triazol-4-yl)methyl]-4-npropylisoquinolin$1(2 H)$-one (92aa)<smiles>CCn1cc(Cn2c(=O)c3ccccc3c(=O)n2Cc2ccccc2C(C)C)nn1</smiles>

The general procedure GPB was followed using $51 \mathrm{a}(85.9 \mathrm{mg}, 0.30 \mathrm{mmol})$ and alkyne $88 \mathrm{a}$ ( $130 \mathrm{mg}, 0.60 \mathrm{mmol})$. Purification by column chromatography (nhexane/EtOAc $=3 / 2$ ) yielded 92aa $(79.5 \mathrm{mg}, 60 \%$ ) as a white solid.

M.p. $=97-98^{\circ} \mathrm{C} .{ }^{1} \mathrm{H}$ NMR $\left(600 \mathrm{MHz}, \mathrm{CDCl}_{3}\right): \delta=8.49(\mathrm{~d}, J=8.0 \mathrm{~Hz}, 1 \mathrm{H})$, 7.74-7.68 (m, 3H), $7.48(\mathrm{t}, J=7.3 \mathrm{~Hz}, 1 \mathrm{H}), 7.33$ (t, $J=7.7 \mathrm{~Hz}, 2 \mathrm{H}), 7.28-7.24$ (m, 3H), 5.19 (br s, 2H), 4.61 (s, 2H), $4.26(\mathrm{t}, J=7.3 \mathrm{~Hz}, 2 \mathrm{H}), 2.77-2.71(\mathrm{~m}$, $2 \mathrm{H}), 1.89-1.82(\mathrm{~m}, 2 \mathrm{H}), 1.61-1.53(\mathrm{~m}, 2 \mathrm{H}), 1.32-1.23(\mathrm{~m}, 6 \mathrm{H}), 0.99(\mathrm{t}$, $J=7.3 \mathrm{~Hz}, 3 \mathrm{H}), 0.84(\mathrm{t}, J=6.7 \mathrm{~Hz}, 3 \mathrm{H}) .{ }^{13} \mathrm{C} \mathrm{NMR}\left(126 \mathrm{MHz}, \mathrm{CDCl}_{3}\right): \delta=162.7$ $\left(\mathrm{C}_{\mathrm{q}}\right), 144.2\left(\mathrm{C}_{\mathrm{q}}\right), 137.4\left(\mathrm{C}_{\mathrm{q}}\right), 137.1\left(\mathrm{C}_{\mathrm{q}}\right), 136.7\left(\mathrm{C}_{\mathrm{q}}\right), 132.4(\mathrm{CH}), 129.1(\mathrm{CH})$, $128.3(\mathrm{CH}), 128.0(\mathrm{CH}), 126.9(\mathrm{CH}), 126.2(\mathrm{CH}), 125.3\left(\mathrm{C}_{\mathrm{q}}\right), 124.0(\mathrm{CH}), 123.1$ $(\mathrm{CH}), 116.4\left(\mathrm{C}_{q}\right), 50.5\left(\mathrm{CH}_{2}\right), 40.0\left(\mathrm{CH}_{2}\right), 35.0\left(\mathrm{CH}_{2}\right), 31.3\left(\mathrm{CH}_{2}\right), 30.4\left(\mathrm{CH}_{2}\right)$, $30.3\left(\mathrm{CH}_{2}\right), 26.3\left(\mathrm{CH}_{2}\right), 23.6\left(\mathrm{CH}_{2}\right), 22.6\left(\mathrm{CH}_{2}\right), 14.6\left(\mathrm{CH}_{3}\right), 14.1\left(\mathrm{CH}_{3}\right)$. IR (ATR): 3122, 2952, 2931, 1650, 1610, 1313, 1063, 776, 732, $715 \mathrm{~cm}^{-1}$. MS (EI) $m / z$ (relative intensity): 442 (72) [M] ${ }^{+}, 329$ (32), 276 (86), 248 (100), 
242 (47), 112 (64). HR-MS (EI) $m / z$ calcd for $\mathrm{C}_{28} \mathrm{H}_{34} \mathrm{~N}_{4} \mathrm{O}[\mathrm{M}]^{+} 442.2733$, found 442.2722 .

\subsubsection{Traceless Removal of TAH Group}<smiles>CC(C)c1c(Cc2ccccc2)n([Al])c(=O)c2ccccc12</smiles>

92aa

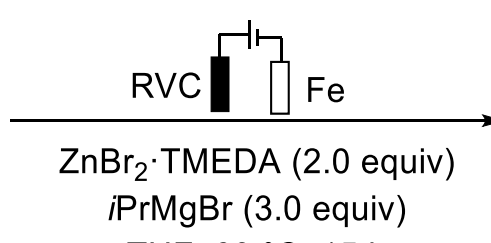

THF, $60{ }^{\circ} \mathrm{C}, 15 \mathrm{~h}$ CCE at $10 \mathrm{~mA}$<smiles>CC(C)c1c(Cc2ccccc2)[nH]c(=O)c2ccccc12</smiles>

93aa: $73 \%$

Figure 5.2 Traceless removal of TAH group.

The general procedure GPD was followed using 92aa (97.0 mg, $0.22 \mathrm{mmol})$. Purification by column chromatography ( $n$ hexane/EtOAc $=3 / 2$ ) yielded 93aa $(54.0 \mathrm{mg}, 73 \%)$ as a white solid.

M.p. $=194-196{ }^{\circ} \mathrm{C} .{ }^{1} \mathbf{H}$ NMR $\left(300 \mathrm{MHz}, \mathrm{CDCl}_{3}\right): \delta=9.92(\mathrm{~s}, 1 \mathrm{H}), 8.44(\mathrm{~d}$, $J=7.9 \mathrm{~Hz}, 1 \mathrm{H}$ ), 7.72 (dd, $J=4.3,2.0 \mathrm{~Hz}, 2 \mathrm{H}$ ), 7.48 (ddd, $J=8.1,5.4,2.8 \mathrm{~Hz}$, $1 \mathrm{H}), 7.38-7.18(\mathrm{~m}, 5 \mathrm{H}), 4.08(\mathrm{~s}, 2 \mathrm{H}), 2.81(\mathrm{t}, J=8.1,2 \mathrm{H}), 1.65-1.54(\mathrm{~m}, 2 \mathrm{H})$, $1.06(\mathrm{t}, J=7.3 \mathrm{~Hz}, 3 \mathrm{H}) .{ }^{13} \mathrm{C}$ NMR (126 MHz, $\left.\mathrm{CDCl}_{3}\right): \delta=163.2\left(\mathrm{C}_{\mathrm{q}}\right), 138.3\left(\mathrm{C}_{\mathrm{q}}\right)$, $137.1\left(\mathrm{C}_{\mathrm{q}}\right), 135.5\left(\mathrm{C}_{\mathrm{q}}\right), 132.6(\mathrm{CH}), 129.1(\mathrm{CH}), 128.9(\mathrm{CH}), 128.0(\mathrm{CH}), 127.3$ $(\mathrm{CH}), 125.9(\mathrm{CH}), 125.6\left(\mathrm{C}_{\mathrm{q}}\right), 123.3(\mathrm{CH}), 114.2\left(\mathrm{C}_{\mathrm{q}}\right), 36.8\left(\mathrm{CH}_{2}\right), 29.0\left(\mathrm{CH}_{2}\right)$, $23.5\left(\mathrm{CH}_{2}\right), 14.4\left(\mathrm{CH}_{3}\right)$. IR (ATR): 3022, 2954, 2871, 2031, 1653, 1630, 1606, 758, 709, $511 \mathrm{~cm}^{-1}$. MS (ESI) m/z (relative intensity): 168 (100), 278 (67) $[\mathrm{M}+\mathrm{H}]^{+}, 577(25)[2 \mathrm{M}+\mathrm{Na}]^{+}$. HR-MS (ESI) m/z calcd for $\mathrm{C}_{19} \mathrm{H}_{19} \mathrm{NO}[\mathrm{M}+\mathrm{H}]^{+}$ 278.1539 , found 278.1538 . 


\subsubsection{Mechanistic Studys}

\section{Reaction Using Deuterium-Labelled Solvent}

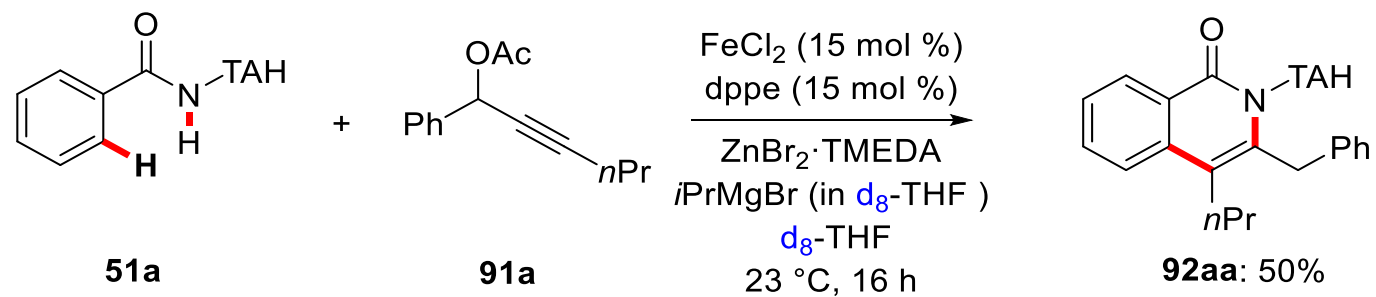

To a stirred solution of 51a (85.9 mg, $0.3 \mathrm{mmol}$ ), $\mathrm{ZnBr}_{2} \cdot \mathrm{TMEDA}$ (205 mg, $0.60 \mathrm{mmol})$ and dppe (17.9 mg, $15 \mathrm{~mol} \%)$ in d8-THF (0.4 mL), $\operatorname{PrMgBr}(0.5 \mathrm{M}$ in $\mathrm{d}_{8}$-THF, $1.8 \mathrm{~mL}, 0.90 \mathrm{mmol}$ ) was added in one portion and the reaction mixture was stirred for $5 \mathrm{~min}$ at ambient temperature. Then, $\mathrm{FeCl}_{2}(5.7 \mathrm{mg}$, $15 \mathrm{~mol} \%)$ was added in a single portion. After stirring for additional $5 \mathrm{~min}$, a solution of alkyne $91 \mathrm{a}(130 \mathrm{mg}, 0.60 \mathrm{mmol})$ in $\mathrm{d}_{8}-\mathrm{THF}(0.40 \mathrm{~mL})$ was added in one portion. The reaction mixture was stirred at ambient temperature. After $16 \mathrm{~h}$, sat. aqueous $\mathrm{NH}_{4} \mathrm{Cl}(3.0 \mathrm{~mL})$ was added and the reaction mixture was extracted with $\mathrm{CH}_{2} \mathrm{Cl}_{2}(3 \times 15 \mathrm{~mL})$. The combined organic extracts were dried over $\mathrm{Na}_{2} \mathrm{SO}_{4}$, filtered and concentrated. Purification by column chromatography ( $n$ hexane/EtOAc $=3 / 2$ ) yielded the annulated isoquinolone 92aa $(86.8 \mathrm{mg}$, $50 \%)$ as a white solid.

\section{GC-Headspace Detection of $\mathrm{H}_{2}$ for Standard Reaction}

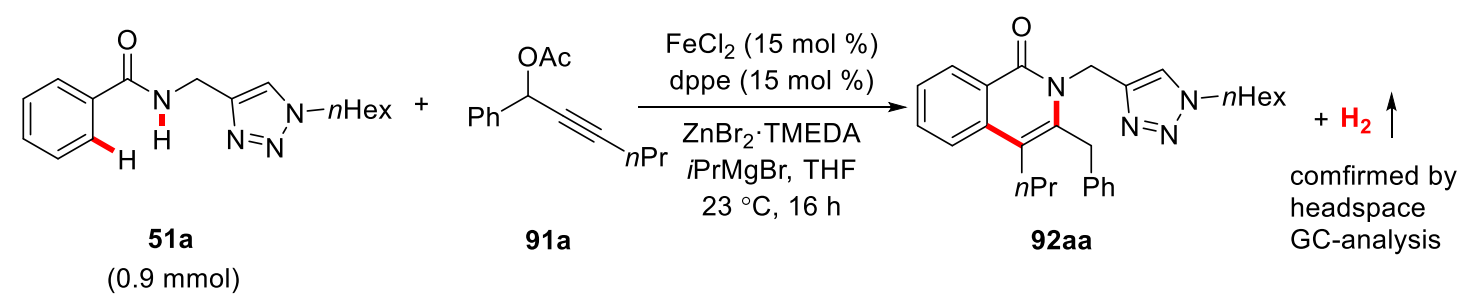

To a stirred solution of $51 \mathrm{a}(0.9 \mathrm{mmol}), \mathrm{ZnBr}_{2} \cdot \operatorname{TMEDA}$ (2.0 equiv) and dppe (15 mol \%) in THF (1.2 mL), $\operatorname{PrMgBr}$ (3.0 M in 2-MeTHF, 3.0 equiv) was added in one portion and the reaction mixture was stirred for $5 \mathrm{~min}$ at ambient temperature. Then, $\mathrm{FeCl}_{2}(15 \mathrm{~mol} \%)$ was added in a single portion. After 


\section{Experimental Part}

stirring the solution for additional $5 \mathrm{~min}$, alkyne $91 \mathrm{a}(2.70 \mathrm{mmol}, 3.0$ equiv) was added as a solution in THF (1.2 mL). Then, the mixture was stirred at ambient temperature. After stirring for $16 \mathrm{~h}$, the gas of headspace was injected to GCMs.

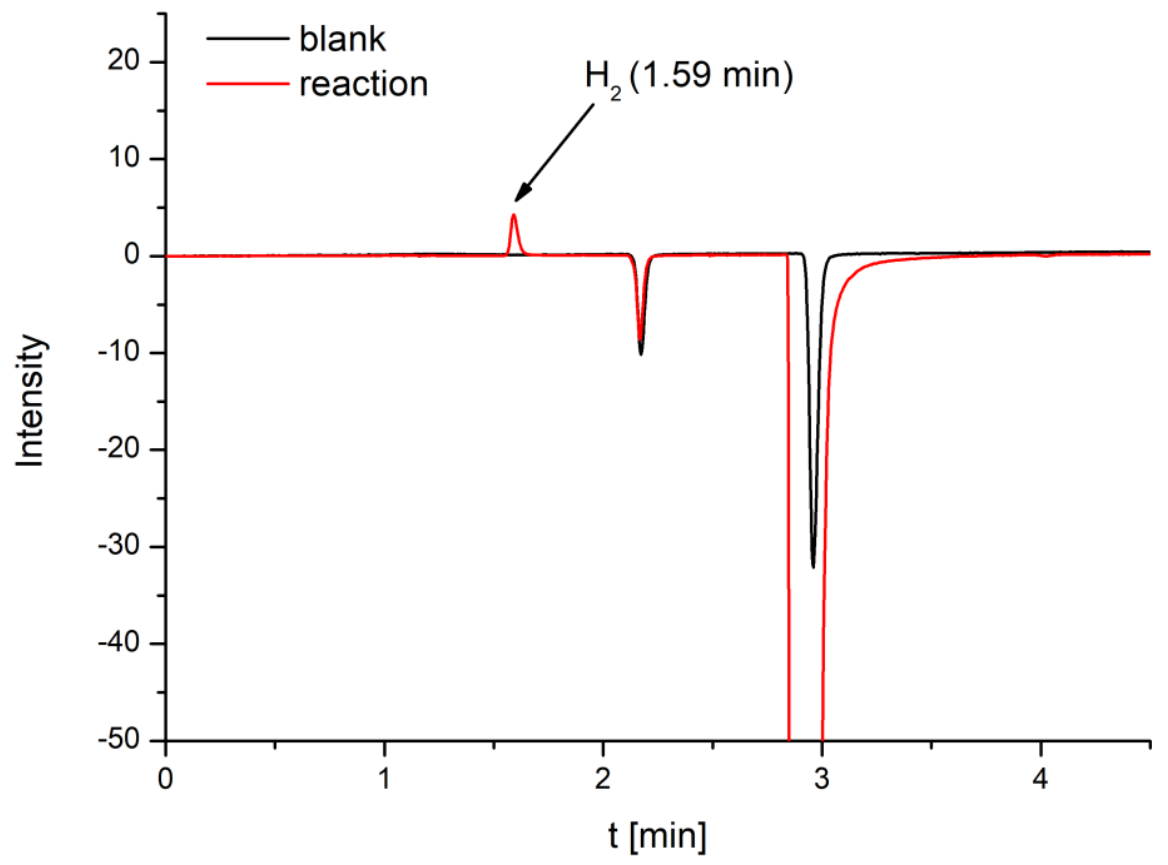

\section{Deprotonation of Substrate 51a by $\mathrm{PhZnCl}$}

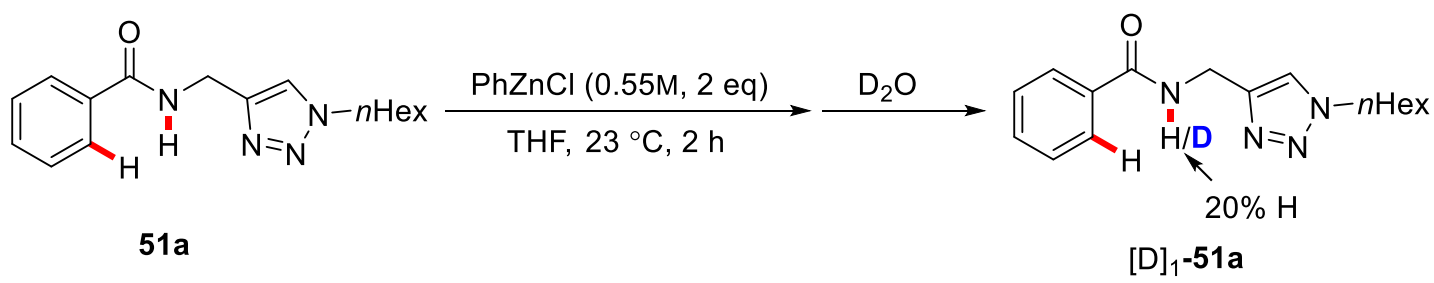

To a Schlenk tube charged with 51a $(85.9 \mathrm{mg}, 0.30 \mathrm{mmol}), \mathrm{PhZnCl}(0.55 \mathrm{M}$ in THF, $1.1 \mathrm{~mL}, 2.0$ equiv) was added in one portion and the reaction mixture was stirred at ambient temperature. After $2 \mathrm{~h}, \mathrm{D}_{2} \mathrm{O}(2.0 \mathrm{~mL})$ was added and the mixture was extracted with $\mathrm{CH}_{2} \mathrm{Cl}_{2}(3 \times 15 \mathrm{~mL})$. The combined organic extracts were dried over $\mathrm{Na}_{2} \mathrm{SO}_{4}$, filtered and concentrated under reduced pressure. Deuterium contents were determined by ${ }^{1} \mathrm{H}$ NMR spectroscopic analysis. 


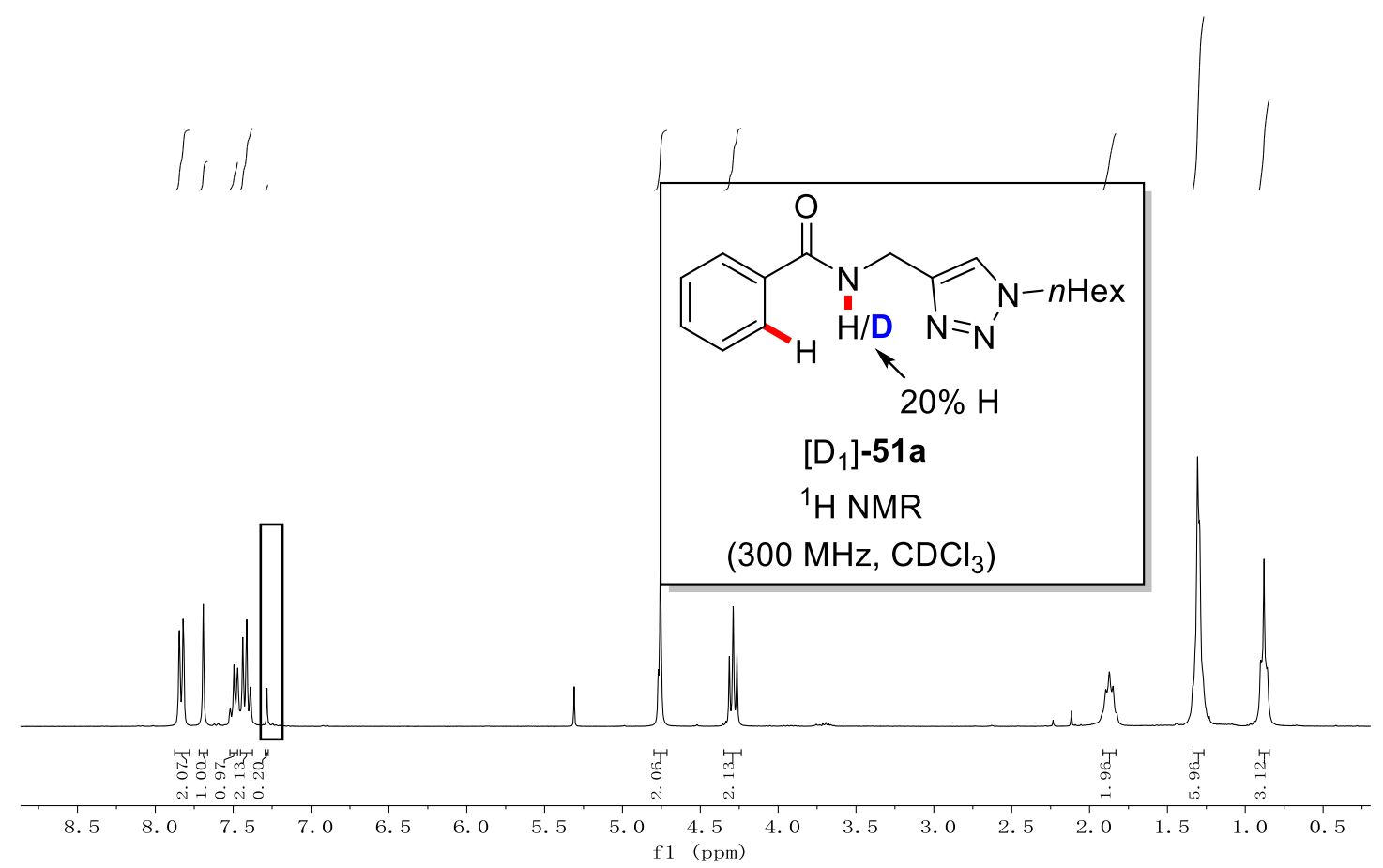

Reaction Using Propargyl Acetate 91b<smiles>NNC(=O)c1ccccc1</smiles>

$51 \mathrm{a}$<smiles>CC(=O)OC(C#CC(C)C)(c1ccccc1)c1ccccc1</smiles>

91b

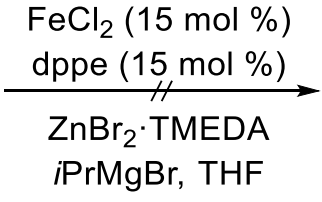

$23^{\circ} \mathrm{C}, 16 \mathrm{~h}$<smiles>O=C(N[TlH])c1ccccc1C(=C=C(c1ccccc1)c1ccccc1)c1ccccc1</smiles>

110

To a stirred solution of $51 \mathrm{a}(85.9 \mathrm{mg}, 0.30 \mathrm{mmol}), \mathrm{ZnBr}_{2} \cdot \mathrm{TMEDA}$ (205 mg, $0.60 \mathrm{mmol})$ and dppe (17.9 mg, $15 \mathrm{~mol} \%)$ in THF (0.40 mL), $\operatorname{PrMgBr}(3.0 \mathrm{M}$ in THF, $300 \mu \mathrm{L}, 0.90 \mathrm{mmol}$ ) was added in oneportion and the reaction mixture was stirred for $5 \mathrm{~min}$ at ambient temperature. Then, $\mathrm{FeCl}_{2}(5.7 \mathrm{mg}, 15 \mathrm{~mol} \%)$ was added in a single portion. After stirring the solution for additional $5 \mathrm{~min}$, alkyne $91 \mathrm{~b}$ (175 mg, $0.60 \mathrm{mmol})$ was added as a solution in THF $(0.40 \mathrm{~mL})$. Then, the mixture was stirred at ambient temperature. After stirring for $16 \mathrm{~h}$, sat. aqueous $\mathrm{NH}_{4} \mathrm{Cl}(3.0 \mathrm{~mL})$ was added and the reaction mixture was extracted with $\mathrm{CH}_{2} \mathrm{Cl}_{2}(3 \times 15 \mathrm{~mL})$. The combined organic extracts were dried over 
$\mathrm{Na}_{2} \mathrm{SO}_{4}$, filtered and concentrated. Product $\mathbf{1 1 0}$ was not observed by ${ }^{1} \mathrm{H}$ NMR spectroscopic analysis.

\subsection{Iron-Catalyzed C-H/C-C Activations}

\subsubsection{Analytical Data - Products with Different N-Substituted Triazolyl Moieties}

3-Allyl-2-[(1-n-hexyl-1 H-1,2,3-triazol-4-yl)methyl]-4- $n$-propylisoquinolin1(2H)-one (95ag):<smiles>C=CCc1c(CC)c2ccccc2c(=O)n1Cc1cn(C[Ga])nn1</smiles>

The general procedure GPC was followed using $51 \mathrm{a}(85.9 \mathrm{mg}, 0.30 \mathrm{mmol})$ and BCP $94 \mathrm{~g}(137 \mathrm{mg}, 0.90 \mathrm{mmol})$. Purification by column chromatography ( $n$ hexane/EtOAc $=3 / 2)$ yielded $95 \mathrm{ag}(90.8 \mathrm{mg}, 80 \%)$ as colourless oil.

${ }^{1} \mathrm{H}$ NMR $\left(300 \mathrm{MHz}, \mathrm{CDCl}_{3}\right): \delta=8.44(\mathrm{~d}, J=7.8 \mathrm{~Hz}, 1 \mathrm{H}), 7.74(\mathrm{~s}, 1 \mathrm{H}), 7.70$ $7.56(\mathrm{~m}, 2 \mathrm{H}), 7.49-7.37(\mathrm{~m}, 1 \mathrm{H}), 6.18-6.05(\mathrm{~m}, 1 \mathrm{H}), 5.32(\mathrm{~s}, 2 \mathrm{H}), 5.20(\mathrm{dd}$, $J=10.3,1.5 \mathrm{~Hz}, 1 \mathrm{H}), 5.02(\mathrm{dd}, J=17.3,1.5 \mathrm{~Hz}, 1 \mathrm{H}), 4.24(\mathrm{t}, J=7.5 \mathrm{~Hz}, 2 \mathrm{H})$, $3.89(\mathrm{~s}, 2 \mathrm{H}), 2.71(\mathrm{q}, J=7.5 \mathrm{~Hz}, 2 \mathrm{H}), 1.87-1.78(\mathrm{~m}, 2 \mathrm{H}), 1.30-1.21(\mathrm{~m}, 6 \mathrm{H})$, $1.15(\mathrm{t}, J=7.5 \mathrm{~Hz}, 3 \mathrm{H}), 0.81(\mathrm{t}, J=6.9 \mathrm{~Hz}, 3 \mathrm{H}) .{ }^{13} \mathrm{C}$ NMR $\left(126 \mathrm{MHz}, \mathrm{CDCl}_{3}\right)$ : $\delta=162.6\left(\mathrm{C}_{\mathrm{q}}\right), 144.4\left(\mathrm{C}_{\mathrm{q}}\right), 136.4\left(\mathrm{C}_{\mathrm{q}}\right), 136.4\left(\mathrm{C}_{\mathrm{q}}\right), 134.2(\mathrm{CH}), 132.3(\mathrm{CH}), 128.2$ $(\mathrm{CH}), 126.0(\mathrm{CH}), 125.1\left(\mathrm{C}_{\mathrm{q}}\right), 124.0(\mathrm{CH}), 122.8(\mathrm{CH}), 117.1\left(\mathrm{CH}_{2}\right), 117.1\left(\mathrm{C}_{\mathrm{q}}\right)$, $50.5\left(\mathrm{CH}_{2}\right), 40.0\left(\mathrm{CH}_{2}\right), 33.1\left(\mathrm{CH}_{2}\right), 31.3\left(\mathrm{CH}_{2}\right), 30.3\left(\mathrm{CH}_{2}\right), 26.3\left(\mathrm{CH}_{2}\right), 22.5$ $\left(\mathrm{CH}_{2}\right), 21.1\left(\mathrm{CH}_{2}\right), 14.7\left(\mathrm{CH}_{3}\right), 14.1\left(\mathrm{CH}_{3}\right)$. IR (ATR): 2925, 2855, 1642, 1592 , 1337, 1183, 1047, 968, 773, $678 \mathrm{~cm}^{-1}$. MS (ESI) m/z (relative intensity): 379 (100) $[\mathrm{M}+\mathrm{H}]^{+}, 401(21)[\mathrm{M}+\mathrm{Na}]^{+}, 757(36)[2 \mathrm{M}+\mathrm{H}]^{+}, 779(50)[2 \mathrm{M}+\mathrm{Na}]^{+}$. HR-MS (ESI) $m / z$ calcd for $\mathrm{C}_{23} \mathrm{H}_{31} \mathrm{~N}_{4} \mathrm{O}[\mathrm{M}+\mathrm{H}]^{+} 379.2492$, found 379.2492. 
3-Allyl-2-[(1-octyl-1H-1,2,3-triazol-4-yl)methyl]-4-ethylisoquinolin-1(2H)one $(95 \mathrm{bg})$ :

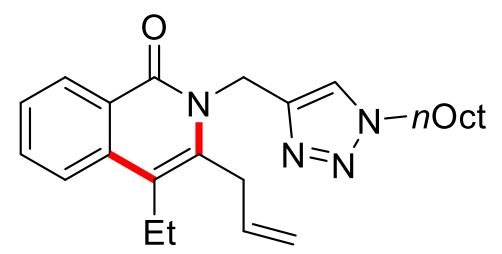

The general procedure GPC was followed using $51 \mathrm{~b}(98.6 \mathrm{mg}, 0.30 \mathrm{mmol})$ and BCP $94 \mathrm{~g}(137 \mathrm{mg}, 0.90 \mathrm{mmol})$. Purification by column chromatography ( $n$ hexane/EtOAc $=3 / 2$ ) yielded $95 \mathrm{bg}(82.9 \mathrm{mg}, 68 \%)$ as colourless oil.

${ }^{1} \mathrm{H}$ NMR $\left(400 \mathrm{MHz}, \mathrm{CDCl}_{3}\right): \delta=8.44(\mathrm{~d}, J=7.8 \mathrm{~Hz}, 1 \mathrm{H}), 7.74(\mathrm{~s}, 1 \mathrm{H}), 7.68-7.60$ (m, 2H), $7.43(\mathrm{~d}, J=8.1 \mathrm{~Hz}, 1 \mathrm{H}), 6.11$ (ddt, $J=17.3,10.3,4.7 \mathrm{~Hz}, 1 \mathrm{H}), 5.32$ (s, 2H), 5.20 (dd, $J=10.3,1.5 \mathrm{~Hz}, 1 \mathrm{H}), 5.02$ (dd, $J=17.3,1.5 \mathrm{~Hz}, 1 \mathrm{H}), 4.22$ (t, $J=7.4 \mathrm{~Hz}, 2 \mathrm{H}), 3.90$ (s, 2H), 2.71 (q, $J=7.5 \mathrm{~Hz}, 2 \mathrm{H}), 1.82(\mathrm{t}, J=7.4 \mathrm{~Hz}, 2 \mathrm{H}$ ), 1.28-1.18 (m, 10H), $1.15(\mathrm{t}, J=7.5 \mathrm{~Hz}, 3 \mathrm{H}), 0.81(\mathrm{~d}, J=7.1 \mathrm{~Hz}, 3 \mathrm{H}) .{ }^{13} \mathrm{C}$ NMR $\left(101 \mathrm{MHz}, \mathrm{CDCl}_{3}\right): \delta=162.8\left(\mathrm{C}_{\mathrm{q}}\right), 144.5\left(\mathrm{C}_{\mathrm{q}}\right), 136.6\left(\mathrm{C}_{\mathrm{q}}\right), 136.5\left(\mathrm{C}_{\mathrm{q}}\right), 134.3$ $(\mathrm{CH}), 132.5(\mathrm{CH}), 128.3(\mathrm{CH}), 126.1(\mathrm{CH}), 125.2\left(\mathrm{C}_{\mathrm{q}}\right), 124.2(\mathrm{CH}), 122.9(\mathrm{CH})$, $117.2\left(\mathrm{CH}_{2}\right), 117.2\left(\mathrm{C}_{\mathrm{q}}\right), 50.5\left(\mathrm{CH}_{2}\right), 39.9\left(\mathrm{CH}_{2}\right), 33.0\left(\mathrm{CH}_{2}\right), 31.8\left(\mathrm{CH}_{2}\right), 30.3$ $\left(\mathrm{CH}_{2}\right), 29.1\left(\mathrm{CH}_{2}\right), 29.0\left(\mathrm{CH}_{2}\right), 26.6\left(\mathrm{CH}_{2}\right), 22.7\left(\mathrm{CH}_{2}\right), 21.0\left(\mathrm{CH}_{2}\right), 14.6\left(\mathrm{CH}_{3}\right)$, $14.2\left(\mathrm{CH}_{3}\right)$. IR (ATR): 2926, 2855, 1643, 1592, 1428, 1336, 1047, 916, 773, $700 \mathrm{~cm}^{-1}$. MS (ESI) m/z (relative intensity): $407(100)[\mathrm{M}+\mathrm{H}]^{+}, 429(21)[\mathrm{M}+\mathrm{Na}]^{+}$, $769(50)[2 \mathrm{M}+\mathrm{H}]^{+}, 835(54)[2 \mathrm{M}+\mathrm{Na}]^{+}$. HR-MS (ESI) $m / z$ calcd for $\mathrm{C}_{25} \mathrm{H}_{35} \mathrm{~N}_{4} \mathrm{O}$ $[\mathrm{M}+\mathrm{H}]^{+}$407.2805, found 407.2805. 
3-Allyl-2-[(1-benzyl-1 H-1,2,3-triazol-4-yl)methyl]-4-ethylisoquinolin-1(2H)one $(95 \mathrm{cg})$ :

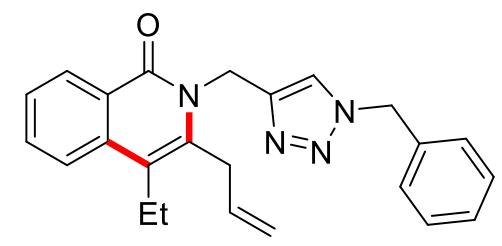

The general procedure GPC was followed using $51 \mathrm{c}(87.7 \mathrm{mg}, 0.30 \mathrm{mmol})$ and BCP $94 \mathrm{~g}$ (137 mg, $0.90 \mathrm{mmol})$. Purification by column chromatography ( $n$ hexane/EtOAc $=3 / 2)$ yielded $95 \mathrm{cg}(70.4 \mathrm{mg}, 61 \%)$ as colourless oil.

${ }^{1} \mathrm{H}$ NMR $\left(400 \mathrm{MHz}, \mathrm{CDCl}_{3}\right): \delta=8.41(\mathrm{dd}, J=8.0,0.7 \mathrm{~Hz}, 1 \mathrm{H}), 7.72(\mathrm{~s}, 1 \mathrm{H})$, 7.68-7.61 (m, 2H), 7.41 (ddd, $J=8.1,6.4,1.8 \mathrm{~Hz}, 1 \mathrm{H}), 7.32-7.27(\mathrm{~m}, 3 \mathrm{H})$, 7.24-7.21 (m, 2H), 6.16-6.06 (m, 1H), $5.41(\mathrm{~s}, 2 \mathrm{H}), 5.30$ (s, 2H), 5.19 (dd, $J=10.3,1.3 \mathrm{~Hz}, 1 \mathrm{H}), 5.01$ (dd, $J=17.3,1.3 \mathrm{~Hz}, 1 \mathrm{H}), 3.89$ (s, 2H), 2.70 (q, $J=7.5 \mathrm{~Hz}, 2 \mathrm{H}), 1.15(\mathrm{t}, J=7.5 \mathrm{~Hz}, 3 \mathrm{H}) .{ }^{13} \mathrm{C} \mathrm{NMR}\left(101 \mathrm{MHz}, \mathrm{CDCl}_{3}\right): \delta=162.7$ $\left(\mathrm{C}_{\mathrm{q}}\right), 144.9\left(\mathrm{C}_{\mathrm{q}}\right), 136.5\left(\mathrm{C}_{\mathrm{q}}\right), 136.3\left(\mathrm{C}_{\mathrm{q}}\right), 134.6\left(\mathrm{C}_{\mathrm{q}}\right), 134.2(\mathrm{CH}), 132.4(\mathrm{CH})$, $129.1(\mathrm{CH}), 128.8(\mathrm{CH}), 128.3(\mathrm{CH}), 128.2(\mathrm{CH}), 126.0(\mathrm{CH}), 125.1\left(\mathrm{C}_{\mathrm{q}}\right), 124.2$ $(\mathrm{CH}), 122.9(\mathrm{CH}), 117.1\left(\mathrm{CH}_{2}\right), 117.1\left(\mathrm{C}_{\mathrm{q}}\right), 54.2\left(\mathrm{CH}_{2}\right), 39.8\left(\mathrm{CH}_{2}\right), 33.0\left(\mathrm{CH}_{2}\right)$, $20.9\left(\mathrm{CH}_{2}\right), 14.6\left(\mathrm{CH}_{3}\right)$. IR (ATR): 2958, 2928, 1642, 1602, 1472, 1433, 1302 , 1033, 812, $778 \mathrm{~cm}^{-1}$. MS (ESI) $\mathrm{m} / \mathrm{z}$ (relative intensity): $385(100)[\mathrm{M}+\mathrm{H}]^{+}, 407$ (23) $[\mathrm{M}+\mathrm{Na}]^{+}, 769(35)[2 \mathrm{M}+\mathrm{H}]^{+}, 791(48)[2 \mathrm{M}+\mathrm{Na}]^{+}$. HR-MS (ESI) $\mathrm{m} / z$ calcd for $\mathrm{C}_{24} \mathrm{H}_{25} \mathrm{~N}_{4} \mathrm{O}[\mathrm{M}+\mathrm{H}]^{+}$385.2023, found 385.2022. 
3-Allyl-4-ethyl-2-\{[1-(4-fluorophenyl)-1 H-1,2,3-triazol-4-yl]methyl\}isoquinolin-1(2H)-one (95rg):<smiles>C=CCc1c(CC)c2ccccc2c(=O)n1Cc1cn(-c2ccc(F)cc2)nn1</smiles>

The general procedure GPC was followed using $51 \mathrm{r}(88.9 \mathrm{mg}, 0.30 \mathrm{mmol})$ and BCP $94 \mathrm{~g}$ (137 $\mathrm{mg}, 0.90 \mathrm{mmol})$. Purification by column chromatography ( $n$ hexane/EtOAc $=3 / 2$ ) yielded $95 \mathrm{rg}(69.9 \mathrm{mg}, 60 \%$ ) as a white solid.

M.p. $=138-139{ }^{\circ} \mathrm{C} .{ }^{1} \mathrm{H}$ NMR $\left(400 \mathrm{MHz}, \mathrm{CDCl}_{3}\right): \delta=8.46(\mathrm{ddd}, J=8.1,1.4$, $0.7 \mathrm{~Hz}, 1 \mathrm{H}$ ), $8.21(\mathrm{~s}, 1 \mathrm{H}), 7.73-7.65(\mathrm{~m}, 4 \mathrm{H}), 7.46$ (ddd, $J=8.1,6.4,1.8 \mathrm{~Hz}$, 1H), 7.19-7.12 (m, 2H), 6.17 (ddt, $J=17.3,10.3,4.7 \mathrm{~Hz}, 1 \mathrm{H}), 5.42(\mathrm{~s}, 2 \mathrm{H}), 5.26$ (dd, $J=10.3,1.3 \mathrm{~Hz}, 1 \mathrm{H}$ ), 5.08 (dd, $J=17.3,1.3 \mathrm{~Hz}, 1 \mathrm{H}$ ), 3.95 (s, 2H), 2.74 (q, $J=7.5 \mathrm{~Hz}, 2 \mathrm{H}), 1.18(\mathrm{t}, J=7.5 \mathrm{~Hz}, 3 \mathrm{H}) .{ }^{13} \mathrm{C}$ NMR $\left(101 \mathrm{MHz}, \mathrm{CDCl}_{3}\right): \delta=162.9$ $\left(\mathrm{C}_{\mathrm{q}}\right), 162.5\left(\mathrm{~d},{ }^{1} J_{C-F}=249.1 \mathrm{~Hz}, \mathrm{C}_{\mathrm{q}}\right), 145.4\left(\mathrm{C}_{\mathrm{q}}\right), 136.6\left(\mathrm{C}_{\mathrm{q}}\right), 136.3\left(\mathrm{C}_{\mathrm{q}}\right), 134.2$ $(\mathrm{CH}), 133.4\left(\mathrm{~d},{ }^{4} J_{C-F}=3.3 \mathrm{~Hz}, \mathrm{C}_{\mathrm{q}}\right), 132.6(\mathrm{CH}), 128.3(\mathrm{CH}), 126.2(\mathrm{CH}), 125.2$ $\left(\mathrm{C}_{\mathrm{q}}\right), 123.0(\mathrm{CH}), 122.8(\mathrm{CH}), 122.6\left(\mathrm{~d},{ }^{3} \mathrm{~J}_{\mathrm{C}-\mathrm{F}}=8.6 \mathrm{~Hz}, \mathrm{CH}\right), 117.4\left(\mathrm{C}_{\mathrm{q}}\right), 117.4$ $\left(\mathrm{CH}_{2}\right), 116.8\left(\mathrm{~d},{ }^{2} J_{C-\mathrm{F}}=23.3 \mathrm{~Hz}, \mathrm{CH}\right), 39.9\left(\mathrm{CH}_{2}\right), 33.1\left(\mathrm{CH}_{2}\right), 21.0\left(\mathrm{CH}_{2}\right), 14.6$ $\left(\mathrm{CH}_{3}\right) .{ }^{19} \mathrm{~F}$ NMR $\left(377 \mathrm{MHz}, \mathrm{CDCl}_{3}\right): \delta=-112.25(\mathrm{tt}, J=8.4,4.6 \mathrm{~Hz})$. IR (ATR): 3081, 2969, 2930, 1639, 1598, 1431, 1313, 1232, 1042, $837 \mathrm{~cm}^{-1}$. MS (ESI) $m / z$ (relative intensity): $389(100)[\mathrm{M}+\mathrm{H}]^{+}, 777(24)[2 \mathrm{M}+\mathrm{H}]^{+}, 799(35)[2 \mathrm{M}+\mathrm{Na}]^{+}$. HR-MS (ESI) $m / z$ calcd for $\mathrm{C}_{23} \mathrm{H}_{22} \mathrm{~N}_{4} \mathrm{OF}[\mathrm{M}+\mathrm{H}]^{+} 389.1772$, found 389.1774. 
3-Allyl-2-\{[1-(3-chloropropyl)-1 H-1,2,3-triazol-4-yl]methyl\}-4-ethylisoquinolin-1(2H)-one $(95 \mathrm{dg})$ :

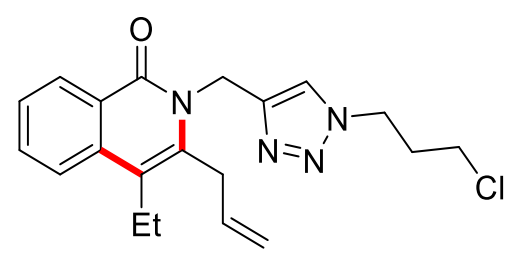

The general procedure GPC was followed using $51 \mathrm{~d}(86.3 \mathrm{mg}, 0.30 \mathrm{mmol})$ and BCP $94 \mathrm{~g}$ (137 mg, $0.90 \mathrm{mmol})$. Purification by column chromatography ( $n$ hexane/EtOAc $=3 / 2$ ) yielded $95 \mathrm{dg}(55.7 \mathrm{mg}, 50 \%)$ as colourless oil.

${ }^{1} \mathrm{H}$ NMR $\left(400 \mathrm{MHz}_{\mathrm{CDCl}}\right): \delta=8.45(\mathrm{~d}, J=8.1 \mathrm{~Hz}, 1 \mathrm{H}), 7.81(\mathrm{~s}, 1 \mathrm{H}), 7.71-7.63$ $(\mathrm{m}, 2 \mathrm{H}), 7.45(\mathrm{~d}, J=8.1 \mathrm{~Hz}, 1 \mathrm{H}), 6.13$ (ddt, $J=17.3,10.3,4.7 \mathrm{~Hz}, 1 \mathrm{H}), 5.33$ (s, 2H), $5.23(\mathrm{dd}, J=10.3,1.9 \mathrm{~Hz}, 1 \mathrm{H}), 5.04(\mathrm{dd}, J=17.3,1.9 \mathrm{~Hz}, 1 \mathrm{H}), 4.45$ (t, $J=6.7 \mathrm{~Hz}, 2 \mathrm{H}$ ), $3.90(\mathrm{~s}, 2 \mathrm{H}), 3.50$ (t, $J=6.1 \mathrm{~Hz}, 2 \mathrm{H}), 2.73(\mathrm{q}, J=7.5 \mathrm{~Hz}, 2 \mathrm{H}$ ), $2.33(\mathrm{q}, J=6.7 \mathrm{~Hz}, 2 \mathrm{H}), 1.17(\mathrm{t}, J=7.5 \mathrm{~Hz}, 3 \mathrm{H}) .{ }^{13} \mathrm{C}$ NMR $\left(101 \mathrm{MHz}, \mathrm{CDCl}_{3}\right)$ : $\delta=162.7\left(\mathrm{C}_{\mathrm{q}}\right), 144.6\left(\mathrm{C}_{\mathrm{q}}\right), 136.5\left(\mathrm{C}_{\mathrm{q}}\right), 136.3\left(\mathrm{C}_{\mathrm{q}}\right), 134.2(\mathrm{CH}), 132.5(\mathrm{CH}), 128.3$ $(\mathrm{CH}), 126.1(\mathrm{CH}), 125.1\left(\mathrm{C}_{\mathrm{q}}\right), 124.8(\mathrm{CH}), 122.9(\mathrm{CH}), 117.2\left(\mathrm{C}_{\mathrm{q}}\right), 117.2\left(\mathrm{CH}_{2}\right)$, $47.2\left(\mathrm{CH}_{2}\right), 41.3\left(\mathrm{CH}_{2}\right), 39.8\left(\mathrm{CH}_{2}\right), 33.0\left(\mathrm{CH}_{2}\right), 32.6\left(\mathrm{CH}_{2}\right), 21.0\left(\mathrm{CH}_{2}\right), 14.6$ $\left(\mathrm{CH}_{3}\right)$. IR (ATR): 2965, 1710, 1611, 1590, 1428, 1338, 1221, 1047, 774, 700 $\mathrm{cm}^{-1}$. MS (ESI) $\mathrm{m} / \mathrm{z}$ (relative intensity): $371(100)\left[{ }^{35} \mathrm{Cl}, \mathrm{M}+\mathrm{H}\right]^{+}, 763(67)\left[{ }^{35} \mathrm{Cl}\right.$, $2 \mathrm{M}+\mathrm{Na}]^{+}$. HR-MS (ESI) $\mathrm{m} / \mathrm{z}$ calcd for $\mathrm{C}_{20} \mathrm{H}_{24} \mathrm{~N}_{4} \mathrm{O}^{35} \mathrm{Cl}[\mathrm{M}+\mathrm{H}]^{+} 371.1633$, found 371.1629 . 
3-Allyl-4-ethylisoquinolin-1(2H)-one (97ae) and 1-Butyl-4-(prop-1-en-2-yl)1H-1,2,3-triazole (119):

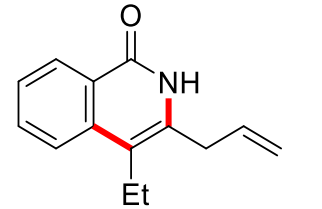

97ae

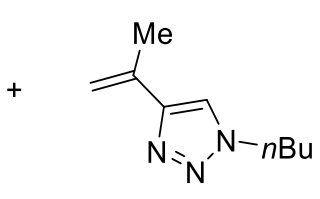

119

The general procedure GPC was followed using $32 \mathrm{a}(85.9 \mathrm{mg}, 0.30 \mathrm{mmol})$ and BCP 94e (177 mg, $0.90 \mathrm{mmol})$. Purification by column chromatography ( $n$ hexane/EtOAc/DCM = 3/1/1) yielded 97 ae $(33.2 \mathrm{mg}, 52 \%$ ) as a white solid and 119 (25.7 mg, 52\%) as colourless oil.

\section{3-Allyl-4-ethylisoquinolin-1(2H)-one (97ae):}

M.p. $=109-110^{\circ} \mathrm{C} .{ }^{1} \mathrm{H}$ NMR $\left(400 \mathrm{MHz}, \mathrm{CDCl}_{3}\right): \delta=9.55(\mathrm{~s}, 1 \mathrm{H}), 8.43$ (dd, $J=8.0,1.0 \mathrm{~Hz}, 1 \mathrm{H}), 7.72-7.67(\mathrm{~m}, 2 \mathrm{H}), 7.45$ (ddd, $J=8.1,5.6,2.6 \mathrm{~Hz}, 1 \mathrm{H})$, 5.91 (ddt, $J=16.7,10.0,6.5 \mathrm{~Hz}, 1 \mathrm{H}), 5.34-5.12(\mathrm{~m}, 2 \mathrm{H}), 3.42$ (d, $J=6.5 \mathrm{~Hz}$, 2H), $2.76(\mathrm{q}, J=7.5 \mathrm{~Hz}, 2 \mathrm{H}), 1.19$ (t, $J=7.5 \mathrm{~Hz}, 3 \mathrm{H}) .{ }^{13} \mathrm{C}$ NMR (101 MHz, $\left.\mathrm{CDCl}_{3}\right): \delta=163.1\left(\mathrm{C}_{\mathrm{q}}\right), 138.1\left(\mathrm{C}_{\mathrm{q}}\right), 133.9\left(\mathrm{C}_{\mathrm{q}}\right), 133.4(\mathrm{CH}), 132.8(\mathrm{CH}), 128.1$ $(\mathrm{CH}), 126.0(\mathrm{CH}), 125.4\left(\mathrm{C}_{\mathrm{q}}\right), 123.1(\mathrm{CH}), 119.2\left(\mathrm{CH}_{2}\right), 115.5\left(\mathrm{C}_{\mathrm{q}}\right), 35.3\left(\mathrm{CH}_{2}\right)$, $19.8\left(\mathrm{CH}_{2}\right), 14.8\left(\mathrm{CH}_{3}\right)$. IR (ATR): 2965, 2932, 1726, 1654, 1607, 1552, 1469 , 1355, 914, $773 \mathrm{~cm}^{-1}$. MS (ESI) $\mathrm{m} / z$ (relative intensity): $214(100)[\mathrm{M}+\mathrm{H}]^{+}, 256$ (64), 321 (77), 449 (54) [2M+Na] ${ }^{+}$. HR-MS (ESI) $m / z$ calcd for $\mathrm{C}_{14} \mathrm{H}_{16} \mathrm{NO}[\mathrm{M}+\mathrm{H}]^{+}$ 214.1226, found 214.1227.

\section{1-Butyl-4-(prop-1-en-2-yl)-1 H-1,2,3-triazole (119):}

${ }^{1} \mathrm{H}$ NMR $\left(400 \mathrm{MHz}, \mathrm{CDCl}_{3}\right): \delta=7.47(\mathrm{~s}, 1 \mathrm{H}), 5.69(\mathrm{~s}, 1 \mathrm{H}), 5.09(\mathrm{~s}, 1 \mathrm{H}), 4.34(\mathrm{t}$, $J=7.2 \mathrm{~Hz}, 2 \mathrm{H}), 2.14(\mathrm{~d}, J=1.2 \mathrm{~Hz}, 3 \mathrm{H}), 1.89(\mathrm{p}, J=7.4 \mathrm{~Hz}, 2 \mathrm{H}), 1.37$ (h, $J=7.4 \mathrm{~Hz}, 2 \mathrm{H}), 0.96(\mathrm{t}, J=7.4 \mathrm{~Hz}, 3 \mathrm{H}) \cdot{ }^{13} \mathrm{C}$ NMR $\left(101 \mathrm{MHz}, \mathrm{CDCl}_{3}\right): \delta=148.9$ $\left(\mathrm{C}_{\mathrm{q}}\right), 133.9\left(\mathrm{C}_{\mathrm{q}}\right), 119.5(\mathrm{CH}), 112.4\left(\mathrm{CH}_{2}\right), 50.1\left(\mathrm{CH}_{2}\right), 32.5\left(\mathrm{CH}_{2}\right), 20.8\left(\mathrm{CH}_{3}\right)$, $19.9\left(\mathrm{CH}_{2}\right), 13.6\left(\mathrm{CH}_{3}\right)$. IR (ATR): 3124, 2959, 2933, 2873, 1640, 1456, 1228 , 


\section{Experimental Part}

1127, 1046, 892, $\mathrm{cm}^{-1}$. MS (ESI) $\mathrm{m} / \mathrm{z}$ (relative intensity): $166(100)[\mathrm{M}+\mathrm{H}]^{+}, 188$ (54) $[\mathrm{M}+\mathrm{Na}]^{+}$. HR-MS (ESI) $\mathrm{m} / z$ calcd for $\mathrm{C}_{9} \mathrm{H}_{16} \mathrm{~N}_{3}[\mathrm{M}+\mathrm{H}]^{+} 166.1339$, found 166.1341 .

\subsubsection{Analytical Data - Isoquinolone 95}

3-Allyl-4-ethyl-2-[(1-hexyl-1 H-1,2,3-triazol-4-yl)methyl]-6-methyisoquinolin-1(2H)-one (95eg):<smiles>C=CCc1c(CC)c2cc(C)ccc2c(=O)n1Cc1cn(CCCCC)nn1</smiles>

The general procedure GPC was followed using $51 e(90.1 \mathrm{mg}, 0.30 \mathrm{mmol})$ and BCP $94 \mathrm{~g}$ (137 $\mathrm{mg}, 0.90 \mathrm{mmol})$. Purification by column chromatography ( $n$ hexane/EtOAc $=3 / 2)$ yielded 95 eg $(70.7 \mathrm{mg}, 60 \%)$ as colourless oil.

${ }^{1} \mathrm{H}$ NMR $\left(300 \mathrm{MHz}, \mathrm{CDCl}_{3}\right): \delta=8.36(\mathrm{~d}, J=8.2 \mathrm{~Hz}, 1 \mathrm{H}), 7.77(\mathrm{~s}, 1 \mathrm{H}), 7.47(\mathrm{~s}$, $1 \mathrm{H}), 7.37-7.26(\mathrm{~m}, 1 \mathrm{H}), 6.15$ (ddt, $J=17.3,10.3,4.6 \mathrm{~Hz}, 1 \mathrm{H}), 5.34(\mathrm{~s}, 2 \mathrm{H}), 5.23$ (dd, $J=10.3,1.6 \mathrm{~Hz}, 1 \mathrm{H}), 5.05(\mathrm{dd}, J=17.3,1.6 \mathrm{~Hz}, 1 \mathrm{H}), 4.27$ (t, $J=7.4 \mathrm{~Hz}$, 2H), 3.91 (d, $J=4.6 \mathrm{~Hz}, 2 \mathrm{H}$ ), 2.73 (q, $J=7.5 \mathrm{~Hz}, 2 \mathrm{H}$ ), 2.51 (s, 3H), 2.03-1.72 (m, 2H), 1.33-1.22 (m, 6H), $1.18(\mathrm{t}, J=7.5 \mathrm{~Hz}, 3 \mathrm{H}), 0.85(\mathrm{t}, J=7.0 \mathrm{~Hz}, 3 \mathrm{H})$. ${ }^{13} \mathrm{C}$ NMR $\left(75 \mathrm{MHz}, \mathrm{CDCl}_{3}\right): \delta=162.7\left(\mathrm{C}_{\mathrm{q}}\right), 144.6\left(\mathrm{C}_{\mathrm{q}}\right), 142.8\left(\mathrm{C}_{\mathrm{q}}\right), 136.6\left(\mathrm{C}_{\mathrm{q}}\right)$, $136.4\left(\mathrm{C}_{\mathrm{q}}\right), 134.3(\mathrm{CH}), 128.3(\mathrm{CH}), 127.7(\mathrm{CH}), 124.1(\mathrm{CH}), 123.0\left(\mathrm{C}_{\mathrm{q}}\right), 122.7$ $(\mathrm{CH}), 117.1\left(\mathrm{CH}_{2}\right), 116.9\left(\mathrm{C}_{\mathrm{q}}\right), 50.4\left(\mathrm{CH}_{2}\right), 39.8\left(\mathrm{CH}_{2}\right), 33.0\left(\mathrm{CH}_{2}\right), 31.2\left(\mathrm{CH}_{2}\right)$, $30.2\left(\mathrm{CH}_{2}\right), 26.2\left(\mathrm{CH}_{2}\right), 22.5\left(\mathrm{CH}_{2}\right), 22.3\left(\mathrm{CH}_{3}\right), 20.9\left(\mathrm{CH}_{2}\right), 14.6\left(\mathrm{CH}_{3}\right), 14.0$ (CH3). IR (ATR): 2958, 2928, 1642, 1602, 1472, 1433, 1302, 1033, 812, 778 $\mathrm{cm}^{-1}$. MS (ESI) $\mathrm{m} / z$ (relative intensity): $393(71)[\mathrm{M}+\mathrm{H}]^{+}, 415(100)[\mathrm{M}+\mathrm{Na}]^{+}$, 807 (48) [2M+Na] $]^{+}$. HR-MS (ESI) $\mathrm{m} / z$ calcd for $\mathrm{C}_{24} \mathrm{H}_{33} \mathrm{~N}_{4} \mathrm{O}[\mathrm{M}+\mathrm{H}]^{+} 393.2649$, found 393.2650. 
3-Allyl-4-ethyl-2-[(1-hexyl-1 H-1,2,3-triazol-4-yl)methyl]-6-methoxyisoquinolin-1(2H)-one (95gg):<smiles>C=CCc1c(CC)c2cc(OC)ccc2c(=O)n1Cc1cn(C[Na])nn1</smiles>

The general procedure GPC was followed using $51 \mathrm{~g}(94.9 \mathrm{mg}, 0.30 \mathrm{mmol})$ and BCP $94 \mathrm{~g}$ (137 $\mathrm{mg}, 0.90 \mathrm{mmol})$. Purification by column chromatography ( $n$ hexane/EtOAc $=3 / 2$ ) yielded $95 \mathrm{gg}(95.6 \mathrm{mg}, 78 \%$ ) as colourless oil.

${ }^{1} \mathrm{H}$ NMR $\left(400 \mathrm{MHz}, \mathrm{CDCl}_{3}\right): \delta=8.39-8.35(\mathrm{~m}, 1 \mathrm{H}), 7.74(\mathrm{~s}, 1 \mathrm{H}), 7.04-7.00(\mathrm{~m}$, 2H), 6.11 (ddt, $J=17.3,10.4,4.6 \mathrm{~Hz}, 1 \mathrm{H}$ ), $5.30(\mathrm{~s}, 2 \mathrm{H}), 5.21$ (d, $J=10.4 \mathrm{~Hz}$, 1H), 5.02 (d, $J=17.3 \mathrm{~Hz}, 1 \mathrm{H}$ ), 4.24 (t, $J=7.3 \mathrm{~Hz}, 2 \mathrm{H}$ ), 3.90 (s, 3H), 3.88 (s, 2H), 2.67 (q, $J=7.5 \mathrm{~Hz}, 2 \mathrm{H}), 1.84(\mathrm{q}, J=7.2 \mathrm{~Hz}, 2 \mathrm{H}), 1.28-1.22(\mathrm{~m}, 6 \mathrm{H}), 1.16$ (t, $J=7.5 \mathrm{~Hz}, 3 \mathrm{H}), 0.81$ (t, $J=6.7 \mathrm{~Hz}, 3 \mathrm{H}) .{ }^{13} \mathrm{C} \mathrm{NMR}\left(101 \mathrm{MHz}, \mathrm{CDCl}_{3}\right)$ : $\delta=163.0\left(\mathrm{C}_{\mathrm{q}}\right), 162.4\left(\mathrm{C}_{\mathrm{q}}\right), 144.6\left(\mathrm{C}_{\mathrm{q}}\right), 138.5\left(\mathrm{C}_{\mathrm{q}}\right), 137.2\left(\mathrm{C}_{\mathrm{q}}\right), 134.2(\mathrm{CH}), 130.4$ $(\mathrm{CH}), 124.1(\mathrm{CH}), 119.2\left(\mathrm{C}_{\mathrm{q}}\right), 117.1\left(\mathrm{CH}_{2}\right), 116.7\left(\mathrm{C}_{\mathrm{q}}\right), 114.8(\mathrm{CH}), 104.8(\mathrm{CH})$, $55.5\left(\mathrm{CH}_{3}\right), 50.5\left(\mathrm{CH}_{2}\right), 39.7\left(\mathrm{CH}_{2}\right), 33.1\left(\mathrm{CH}_{2}\right), 31.2\left(\mathrm{CH}_{2}\right), 30.2\left(\mathrm{CH}_{2}\right), 26.2$ $\left(\mathrm{CH}_{2}\right), 22.5\left(\mathrm{CH}_{2}\right), 21.1\left(\mathrm{CH}_{2}\right), 14.4\left(\mathrm{CH}_{3}\right), 14.0\left(\mathrm{CH}_{3}\right)$. IR (ATR): 2956, 2929, 1642, 1612, 1491, 1464, 1235, 1215, 1035, $790 \mathrm{~cm}^{-1}$. MS (ESI) $\mathrm{m} / z$ (relative intensity): 409 (67) $[\mathrm{M}+\mathrm{H}]^{+}, 431(100)[\mathrm{M}+\mathrm{Na}]^{+}, 839(48)[2 \mathrm{M}+\mathrm{Na}]^{+}$. HR-MS (ESI) $\mathrm{m} / \mathrm{z}$ calcd for $\mathrm{C}_{24} \mathrm{H}_{33} \mathrm{~N}_{4} \mathrm{O}_{2}[\mathrm{M}+\mathrm{H}]^{+} 409.2598$, found 409.2602 .

\section{3-Allyl-4-ethyl-2-[(1-hexyl-1 H-1,2,3-triazol-4-yl)methyl]-6-(methylthio)iso- quinolin-1(2H)-one (95sg):}<smiles>C=CCc1c(CC)c2cc(S(C)(=O)=O)ccc2c(=O)n1Cc1cn(CC)nn1</smiles>

The general procedure GPC was followed using $51 \mathrm{~s}(99.8 \mathrm{mg}, 0.30 \mathrm{mmol})$ and BCP $94 \mathrm{~g}(137 \mathrm{mg}, 0.90 \mathrm{mmol})$. Purification by column chromatography ( $n$ hexane/EtOAc $=3 / 2$ ) yielded $95 \mathrm{sg}(89.2 \mathrm{mg}, 70 \%)$ as colourless oil. 


\section{Experimental Part}

${ }^{1} \mathrm{H}$ NMR $\left(400 \mathrm{MHz}, \mathrm{CDCl}_{3}\right): \delta=8.33(\mathrm{~d}, J=8.5 \mathrm{~Hz}, 1 \mathrm{H}), 7.74(\mathrm{~s}, 1 \mathrm{H}), 7.42(\mathrm{~d}$, $J=1.8 \mathrm{~Hz}, 1 \mathrm{H}$ ), $7.29(\mathrm{dd}, J=8.5,1.8 \mathrm{~Hz}, 1 \mathrm{H}), 6.12(\mathrm{ddt}, J=17.3,10.3,4.6 \mathrm{~Hz}$, 1H), $5.30(\mathrm{~s}, 2 \mathrm{H}), 5.22$ (dd, $J=10.3,1.4 \mathrm{~Hz}, 1 \mathrm{H}), 5.03(\mathrm{dd}, J=17.3,1.4 \mathrm{~Hz}$, 1H), 4.25 (t, $J=7.4 \mathrm{~Hz}, 2 \mathrm{H}$ ), 3.89 (s, 2H), 2.69 (q, $J=7.5 \mathrm{~Hz}, 2 \mathrm{H}$ ), $2.55(\mathrm{~s}, 3 \mathrm{H})$, $1.89-1.78(\mathrm{~m}, 2 \mathrm{H}), 1.30-1.24(\mathrm{~m}, 6 \mathrm{H}), 1.16(\mathrm{t}, J=7.5 \mathrm{~Hz}, 3 \mathrm{H}), 0.83(J=6.9 \mathrm{~Hz}$, 3H). ${ }^{13} \mathrm{C}$ NMR $\left(101 \mathrm{MHz}, \mathrm{CDCl}_{3}\right): \delta=162.5\left(\mathrm{C}_{\mathrm{q}}\right), 144.7\left(\mathrm{C}_{\mathrm{q}}\right), 144.4\left(\mathrm{C}_{\mathrm{q}}\right), 137.4$ $\left(\mathrm{C}_{\mathrm{q}}\right), 136.8\left(\mathrm{C}_{\mathrm{q}}\right), 134.1(\mathrm{CH}), 128.6(\mathrm{CH}), 124.1(\mathrm{CH}), 123.8(\mathrm{CH}), 122.1\left(\mathrm{C}_{\mathrm{q}}\right)$, $118.5(\mathrm{CH}), 117.2\left(\mathrm{CH}_{2}\right), 116.4\left(\mathrm{C}_{\mathrm{q}}\right), 50.4\left(\mathrm{CH}_{2}\right), 39.8\left(\mathrm{CH}_{2}\right), 33.0\left(\mathrm{CH}_{2}\right), 31.2$ ( $\left.\mathrm{CH}_{2}\right)$, $30.2\left(\mathrm{CH}_{2}\right), 26.2\left(\mathrm{CH}_{2}\right), 22.4\left(\mathrm{CH}_{2}\right), 20.9\left(\mathrm{CH}_{2}\right), 15.2\left(\mathrm{CH}_{3}\right), 14.5\left(\mathrm{CH}_{3}\right)$, $14.0\left(\mathrm{CH}_{3}\right)$. IR (ATR): 2957, 2927, 2870, 1638, 1583, 1428, 1324, 1182, 1047 , $790 \mathrm{~cm}^{-1}$. MS (ESI) $\mathrm{m} / \mathrm{z}$ (relative intensity): $425(100)[\mathrm{M}+\mathrm{H}]^{+}, 447(50)[\mathrm{M}+\mathrm{Na}]^{+}$. HR-MS (ESI) $m / z$ calcd for $\mathrm{C}_{24} \mathrm{H}_{33} \mathrm{~N}_{4} \mathrm{OS}[\mathrm{M}+\mathrm{H}]^{+} 425.2370$, found 425.2379 .

\section{3-Allyl-4-ethyl-2-[(1-hexyl-1 H-1,2,3-triazol-4-yl)methyl]-6-phenylisoquino-} lin-1(2H)-one (95fg):<smiles>C=CCc1c(CC)c2cc(-c3ccccc3)ccc2c(=O)n1Cc1cn(C)nn1</smiles>

The general procedure GPC was followed using $51 \mathrm{f}(109 \mathrm{mg}, 0.30 \mathrm{mmol})$ and BCP $94 \mathrm{~g}$ (137 mg, $0.90 \mathrm{mmol})$. Purification by column chromatography ( $n$ hexane/EtOAc $=3 / 2)$ yielded $95 \mathrm{fg}(83.2 \mathrm{mg}, 61 \%)$ as colourless oil.

${ }^{1} \mathrm{H}$ NMR $\left(400 \mathrm{MHz}, \mathrm{CDCl}_{3}\right): \delta=8.53(\mathrm{~d}, J=8.3 \mathrm{~Hz}, 1 \mathrm{H}), 7.86(\mathrm{~s}, 1 \mathrm{H}), 7.78(\mathrm{~s}$, 1H), 7.72-7.64 (m, 3H), 7.52-7.46 (m, 2H), 7.41 (dd, J= 7.3, 7.3 Hz, 1H), 6.15 (ddd, $J=17.8,10.1,4.9 \mathrm{~Hz}, 1 \mathrm{H}), 5.37(\mathrm{~s}, 2 \mathrm{H}), 5.25(\mathrm{~d}, J=10.4 \mathrm{~Hz}, 1 \mathrm{H}), 5.07$ (d, $J=17.3 \mathrm{~Hz}, 1 \mathrm{H}$ ), 4.27 (t, $J=7.4 \mathrm{~Hz}, 2 \mathrm{H}$ ), $3.94(\mathrm{~s}, 2 \mathrm{H}), 2.80$ (q, $J=7.5 \mathrm{~Hz}$, 2H), $1.85(\mathrm{q}, J=7.2 \mathrm{~Hz}, 2 \mathrm{H}), 1.42-1.25(\mathrm{~m}, 6 \mathrm{H}), 1.22(\mathrm{t}, J=7.5 \mathrm{~Hz}, 3 \mathrm{H}), 0.85$ $(\mathrm{t}, J=6.7 \mathrm{~Hz}, 3 \mathrm{H}) .{ }^{13} \mathrm{C}$ NMR $\left(101 \mathrm{MHz}, \mathrm{CDCl}_{3}\right): \delta=162.7\left(\mathrm{C}_{\mathrm{q}}\right), 145.3\left(\mathrm{C}_{\mathrm{q}}\right)$, $144.5\left(\mathrm{C}_{\mathrm{q}}\right), 140.9\left(\mathrm{C}_{\mathrm{q}}\right), 136.9\left(\mathrm{C}_{\mathrm{q}}\right), 136.9\left(\mathrm{C}_{\mathrm{q}}\right), 134.2(\mathrm{CH}), 129.1(\mathrm{CH}), 129.0$ $(\mathrm{CH}), 128.2(\mathrm{CH}), 127.7(\mathrm{CH}), 125.5(\mathrm{CH}), 124.1(\mathrm{CH}), 124.1\left(\mathrm{C}_{\mathrm{q}}\right), 121.3(\mathrm{CH})$, $117.2\left(\mathrm{CH}_{2}\right), 117.2\left(\mathrm{C}_{\mathrm{q}}\right), 50.5\left(\mathrm{CH}_{2}\right), 39.9\left(\mathrm{CH}_{2}\right), 33.1\left(\mathrm{CH}_{2}\right), 31.2\left(\mathrm{CH}_{2}\right), 30.2$ 


\section{Experimental Part}

( $\left(\mathrm{CH}_{2}\right), 26.3\left(\mathrm{CH}_{2}\right), 22.5\left(\mathrm{CH}_{2}\right), 21.0\left(\mathrm{CH}_{2}\right), 14.7\left(\mathrm{CH}_{3}\right), 14.0\left(\mathrm{CH}_{3}\right)$. IR (ATR): 2929, 2870, 1642, 1615, 1591, 1451, 1429, 1328, 1047, $790 \mathrm{~cm}^{-1}$. MS (ESI) $\mathrm{m} / \mathrm{z}$ (relative intensity): $455(100)[\mathrm{M}+\mathrm{H}]^{+}, 477(29)[\mathrm{M}+\mathrm{Na}]^{+}, 909(33)[2 \mathrm{M}+\mathrm{H}]^{+}$, $931(60)[2 \mathrm{M}+\mathrm{Na}]^{+}$. HR-MS (ESI) $\mathrm{m} / z$ calcd for $\mathrm{C}_{29} \mathrm{H}_{35} \mathrm{~N}_{4} \mathrm{O}[\mathrm{M}+\mathrm{H}]^{+} 455.2805$, found 455,2798 .

3-Allyl-6-chloro-4-ethyl-2-[(1-hexyl-1 H-1,2,3-triazol-4-yl)methyl]isoquinolin-1(2H)-one (95jg):<smiles>C=CCc1c(CC)c2cc(Cl)ccc2c(=O)n1Cc1cn(CC)nn1</smiles>

The general procedure GPC was followed using $51 \mathrm{j}(96.2 \mathrm{mg}, 0.30 \mathrm{mmol})$ and BCP $94 \mathrm{~g}(137 \mathrm{mg}, 0.90 \mathrm{mmol})$. Purification by column chromatography (nhexane/EtOAc $=3 / 2$ ) yielded $95 j \mathrm{jg}(64.4 \mathrm{mg}, 52 \%$ ) as colourless oil.

${ }^{1} \mathrm{H}$ NMR $\left(400 \mathrm{MHz}, \mathrm{CDCl}_{3}\right): \delta=8.38(\mathrm{~d}, J=8.6 \mathrm{~Hz}, 1 \mathrm{H}), 7.75(\mathrm{~s}, 1 \mathrm{H}), 7.64(\mathrm{~s}$, $1 \mathrm{H}), 7.39(\mathrm{~d}, J=8.6 \mathrm{~Hz}, 1 \mathrm{H}), 6.12(\mathrm{ddt}, J=17.4,10.3,4.9 \mathrm{~Hz}, 1 \mathrm{H}), 5.31(\mathrm{~s}, 2 \mathrm{H}$ ), $5.24(\mathrm{~d}, J=10.3 \mathrm{~Hz}, 1 \mathrm{H}), 5.03(\mathrm{~d}, J=17.4 \mathrm{~Hz}, 1 \mathrm{H}), 4.26$ (t, $J=7.3 \mathrm{~Hz}, 2 \mathrm{H}$ ), $3.92(\mathrm{~s}, 2 \mathrm{H}), 2.68$ (q, $J=7.4 \mathrm{~Hz}, 2 \mathrm{H}), 1.85(\mathrm{t}, J=7.2 \mathrm{~Hz}, 2 \mathrm{H}), 1.29-1.22(\mathrm{~m}$, $6 \mathrm{H}), 1.17$ (t, $J=7.4 \mathrm{~Hz}, 3 \mathrm{H}), 0.84$ (t, $J=6.4 \mathrm{~Hz}, 3 \mathrm{H}) .{ }^{13} \mathrm{C}$ NMR $(101 \mathrm{MHz}$, $\left.\mathrm{CDCl}_{3}\right): \delta=162.2\left(\mathrm{C}_{\mathrm{q}}\right), 144.2\left(\mathrm{C}_{\mathrm{q}}\right), 139.2\left(\mathrm{C}_{\mathrm{q}}\right), 138.1\left(\mathrm{C}_{\mathrm{q}}\right), 137.9\left(\mathrm{C}_{\mathrm{q}}\right), 133.9$ $(\mathrm{CH}), 130.2(\mathrm{CH}), 126.6(\mathrm{CH}), 124.2(\mathrm{CH}), 123.5\left(\mathrm{C}_{\mathrm{q}}\right), 122.5(\mathrm{CH}), 117.4\left(\mathrm{CH}_{2}\right)$, $116.3\left(\mathrm{C}_{\mathrm{q}}\right), 50.5\left(\mathrm{CH}_{2}\right), 40.0\left(\mathrm{CH}_{2}\right), 33.1\left(\mathrm{CH}_{2}\right), 31.2\left(\mathrm{CH}_{2}\right), 30.2\left(\mathrm{CH}_{2}\right), 26.3$ ( $\left.\mathrm{CH}_{2}\right), 22.5\left(\mathrm{CH}_{2}\right), 21.0\left(\mathrm{CH}_{2}\right), 14.5\left(\mathrm{CH}_{3}\right), 14.0\left(\mathrm{CH}_{3}\right)$. IR (ATR): 2957, 2929, $1644,1474,1429,1378,1326,1173,1047,790 \mathrm{~cm}^{-1}$. MS (ESI) $\mathrm{m} / z$ (relative intensity): $413(100)\left[{ }^{35} \mathrm{Cl}, \mathrm{M}+\mathrm{H}\right]^{+}, 435(35)\left[{ }^{35} \mathrm{Cl}, \mathrm{M}+\mathrm{Na}\right]^{+}, 847$ (53) $\left[{ }^{35} \mathrm{Cl}\right.$, $2 \mathrm{M}+\mathrm{Na}]^{+}$. HR-MS (ESI) $\mathrm{m} / \mathrm{z}$ calcd for $\mathrm{C}_{23} \mathrm{H}_{30} \mathrm{~N}_{4} \mathrm{O}^{35} \mathrm{Cl}[\mathrm{M}+\mathrm{H}]^{+} 413.2103$, found 413.2101 . 
3-Allyl-4-ethyl-2-[(1-hexyl-1 H-1,2,3-triazol-4-yl)methyl]-7-methylisoquinolin-1(2H)-one $(95 \mathrm{tg})$ :<smiles>C=CCc1c(CC)c2ccc(C)cc2c(=O)n1Cc1cn(COC(=O)O)nn1</smiles>

The general procedure GPC was followed using $51 \mathrm{t}(90.1 \mathrm{mg}, 0.30 \mathrm{mmol})$ and BCP $94 \mathrm{~g}(137 \mathrm{mg}, 0.90 \mathrm{mmol})$. Purification by column chromatography ( $n$ hexane/EtOAc $=3 / 2)$ yielded $95 \mathrm{tg}(75.0 \mathrm{mg}, 64 \%)$ as colourless oil.

${ }^{1} \mathrm{H}$ NMR $\left(400 \mathrm{MHz}, \mathrm{CDCl}_{3}\right): \delta=8.25(\mathrm{~d}, J=2.5 \mathrm{~Hz}, 1 \mathrm{H}), 7.75(\mathrm{~s}, 1 \mathrm{H}), 7.58(\mathrm{~d}$, $J=8.4 \mathrm{~Hz}, 1 \mathrm{H}), 7.47(\mathrm{~d}, J=8.4 \mathrm{~Hz}, 1 \mathrm{H}), 6.12$ (ddt, $J=17.3,10.3,4.6 \mathrm{~Hz}, 1 \mathrm{H})$, $5.33(\mathrm{~s}, 2 \mathrm{H}), 5.20$ (dd, $J=10.3,1.7 \mathrm{~Hz}, 1 \mathrm{H}), 5.02$ (dd, $J=17.3,1.7 \mathrm{~Hz}, 1 \mathrm{H}$ ), $4.23(\mathrm{t}, J=7.4 \mathrm{~Hz}, 2 \mathrm{H}$ ), $3.87(\mathrm{~s}, 2 \mathrm{H}), 2.70$ (q, J=7.5 Hz, 2H), $2.46(\mathrm{~s}, 3 \mathrm{H}), 1.83$ (p, J = 7.3 Hz, 2H), 1.31-1.20 (m, 6H), $1.14(\mathrm{t}, J=7.5 \mathrm{~Hz}, 3 \mathrm{H}), 0.83$ (t, $J=6.8 \mathrm{~Hz}, 3 \mathrm{H}) .{ }^{13} \mathrm{C}$ NMR $\left(101 \mathrm{MHz} \mathrm{CDCl}_{3}\right): \delta=162.7\left(\mathrm{C}_{\mathrm{q}}\right), 144.5\left(\mathrm{C}_{\mathrm{q}}\right), 136.0$ $\left(\mathrm{C}_{\mathrm{q}}\right), 135.3\left(\mathrm{C}_{\mathrm{q}}\right), 134.4(\mathrm{CH}), 134.2\left(\mathrm{C}_{\mathrm{q}}\right), 133.9(\mathrm{CH}), 127.8(\mathrm{CH}), 125.1\left(\mathrm{C}_{\mathrm{q}}\right)$, $124.1(\mathrm{CH}), 122.9(\mathrm{CH}), 117.1\left(\mathrm{CH}_{2}\right), 117.0\left(\mathrm{C}_{\mathrm{q}}\right), 50.4\left(\mathrm{CH}_{2}\right), 39.9\left(\mathrm{CH}_{2}\right), 32.8$ $\left(\mathrm{CH}_{2}\right), 31.1\left(\mathrm{CH}_{2}\right), 30.2\left(\mathrm{CH}_{2}\right), 26.2\left(\mathrm{CH}_{2}\right), 22.4\left(\mathrm{CH}_{2}\right), 21.3\left(\mathrm{CH}_{3}\right), 21.0\left(\mathrm{CH}_{2}\right)$, $14.6\left(\mathrm{CH}_{3}\right), 14.0\left(\mathrm{CH}_{3}\right)$. IR (ATR): 2960, 2929, 1644, 1596, 1504, 1458, 1429, 1340, 1300, $823 \mathrm{~cm}^{-1}$. MS (ESI) $\mathrm{m} / z$ (relative intensity): $393(64)[\mathrm{M}+\mathrm{H}]^{+}, 415$ (100) $[\mathrm{M}+\mathrm{Na}]^{+}$. HR-MS (ESI) $\mathrm{m} / z$ calcd for $\mathrm{C}_{24} \mathrm{H}_{33} \mathrm{~N}_{4} \mathrm{O}[\mathrm{M}+\mathrm{H}]^{+} 393.2649$, found 393.2652 . 
3-Allyl-4-ethyl-7-fluoro-2-[(1-hexyl-1H-1,2,3-triazol-4-yl)methyl]isoquinolin-1(2H)-one (95ug):<smiles>C=CCc1c(CC)c2ccc(F)cc2c(=O)n1Cc1cn(C[Te])nn1</smiles>

The general procedure GPC was followed using $51 \mathrm{u}(91.3 \mathrm{mg}, 0.30 \mathrm{mmol})$ and BCP $94 \mathrm{~g}(137 \mathrm{mg}, 0.90 \mathrm{mmol})$. Purification by column chromatography (nhexane/EtOAc $=3 / 2)$ yielded 95ug $(94.0 \mathrm{mg}, 79 \%)$ as light yellow oil.

${ }^{1} \mathrm{H}$ NMR $\left(600 \mathrm{MHz}, \mathrm{CDCl}_{3}\right): \delta=8.09(\mathrm{dd}, J=9.3,2.9 \mathrm{~Hz}, 1 \mathrm{H}), 7.76(\mathrm{~s}, 1 \mathrm{H}), 7.69$ (dd, $J=9.0,5.0 \mathrm{~Hz}, 1 \mathrm{H}$ ), 7.40 (ddd, $J=9.0,8.0,2.9 \mathrm{~Hz}, 1 \mathrm{H}$ ), 6.14 (ddt, $J=17.3$, 10.3, $4.7 \mathrm{~Hz}, 1 \mathrm{H}$ ), 5.33 (s, 2H), 5.24 (dd, $J=10.3,1.8 \mathrm{~Hz}, 1 \mathrm{H}$ ), 5.04 (dd, $J=17.3,1.8 \mathrm{~Hz}, 1 \mathrm{H}), 4.26(\mathrm{t}, J=7.4 \mathrm{~Hz}, 2 \mathrm{H}), 3.92(\mathrm{~s}, 2 \mathrm{H}), 2.72(\mathrm{q}, J=7.6 \mathrm{~Hz}$, 2H), 1.86 (p, $J=7.2 \mathrm{~Hz}, 2 \mathrm{H}), 1.30-1.24(\mathrm{~m}, 6 \mathrm{H}), 1.17(\mathrm{t}, J=7.6 \mathrm{~Hz}, 3 \mathrm{H}), 0.84$ (t, $J=7.0 \mathrm{~Hz}, 3 \mathrm{H}) .{ }^{13} \mathrm{C}$ NMR $\left(151 \mathrm{MHz}, \mathrm{CDCl}_{3}\right): \delta=162.0\left(\mathrm{~d},{ }^{4} J_{C-F}=3.5 \mathrm{~Hz}\right.$, $\left.\mathrm{C}_{\mathrm{q}}\right), 161.1\left(\mathrm{~d},{ }^{1} J_{C-F}=246.9 \mathrm{~Hz}, \mathrm{C}_{\mathrm{q}}\right), 144.2\left(\mathrm{C}_{\mathrm{q}}\right), 135.7\left(\mathrm{~d},{ }^{4} J_{C-F}=2.5 \mathrm{~Hz}, \mathrm{C}_{\mathrm{q}}\right.$ ), $134.2(\mathrm{CH}), 133.2\left(\mathrm{~d},{ }^{4} J_{C-F}=2.1 \mathrm{~Hz}, \mathrm{C}_{\mathrm{q}}\right), 126.8\left(\mathrm{~d},{ }^{3} \mathrm{~J}_{\mathrm{C}-\mathrm{F}}=7.7 \mathrm{~Hz}, \mathrm{C}_{\mathrm{q}}\right), 125.5$ (d, $\left.{ }^{3} J_{C-F}=7.7 \mathrm{~Hz}, \mathrm{CH}\right), 124.2(\mathrm{CH}), 121.2\left(\mathrm{~d},{ }^{2} \mathrm{~J}_{\mathrm{C}-\mathrm{F}}=23.3 \mathrm{~Hz}, \mathrm{CH}\right), 117.3\left(\mathrm{CH}_{2}\right)$, $116.8\left(\mathrm{C}_{\mathrm{q}}\right), 113.2\left(\mathrm{~d},{ }^{2} \mathrm{~J}_{\mathrm{C}-\mathrm{F}}=22.4 \mathrm{~Hz}, \mathrm{CH}\right), 50.5\left(\mathrm{CH}_{2}\right), 40.1\left(\mathrm{CH}_{2}\right), 32.9\left(\mathrm{CH}_{2}\right)$, $31.2\left(\mathrm{CH}_{2}\right), 30.3\left(\mathrm{CH}_{2}\right), 26.3\left(\mathrm{CH}_{2}\right), 22.5\left(\mathrm{CH}_{2}\right), 21.2\left(\mathrm{CH}_{2}\right), 14.6\left(\mathrm{CH}_{3}\right), 14.0$ $\left(\mathrm{CH}_{3}\right) .{ }^{19} \mathrm{~F}$ NMR $\left(377 \mathrm{MHz}, \mathrm{CDCl}_{3}\right): \delta=-114.75(\mathrm{td}, J=8.6,5.0 \mathrm{~Hz})$. IR (ATR): 2957, 2929, 1644, 1597, 1499, 1431, 1351, 1048, 827, $724 \mathrm{~cm}^{-1}$. MS (ESI) m/z (relative intensity): $397(53)[\mathrm{M}+\mathrm{H}]^{+}, 419(100)[\mathrm{M}+\mathrm{Na}]^{+}, 815(47)[2 \mathrm{M}+\mathrm{Na}]^{+}$. HR-MS (ESI) $m / z$ calcd for $\mathrm{C}_{23} \mathrm{H}_{30} \mathrm{FN}{ }_{4} \mathrm{O}[\mathrm{M}+\mathrm{H}]^{+} 397.2398$, found 397.2400. 
3-Allyl-7-chloro-4-ethyl-2-[(1-hexyl-1 H-1,2,3-triazol-4-yl)methyl]isoquinolin-1(2H)-one (95vg):<smiles>C=CCc1c(CC)c2ccc(Cl)cc2c(=O)n1Cc1cn(CC)nn1</smiles>

The general procedure GPC was followed using $51 \mathrm{v}(96.2 \mathrm{mg}, 0.30 \mathrm{mmol})$ and BCP $94 \mathrm{~g}$ (137 $\mathrm{mg}, 0.90 \mathrm{mmol})$. Purification by column chromatography $($ nhexane/EtOAc $=3 / 2)$ yielded $95 \mathrm{vg}(73.1 \mathrm{mg}, 59 \%)$ as light yellow oil.

${ }^{1} \mathrm{H}$ NMR $\left(300 \mathrm{MHz}, \mathrm{CDCl}_{3}\right): \delta=8.44(\mathrm{dd}, J=2.1,0.7 \mathrm{~Hz}, 1 \mathrm{H}), 7.78(\mathrm{~s}, 1 \mathrm{H})$, 7.70-7.52 (m, 2H), 6.15 (ddt, $J=17.3,10.2,4.6 \mathrm{~Hz}, 1 \mathrm{H}$ ), 5.34 (s, 2H), 5.26 (dd, $J=10.2,1.7 \mathrm{~Hz}, 1 \mathrm{H}), 5.05(\mathrm{dd}, J=17.3,1.7 \mathrm{~Hz}, 1 \mathrm{H}), 4.28(\mathrm{t}, J=7.4 \mathrm{~Hz}, 2 \mathrm{H})$, $3.94(\mathrm{~s}, 2 \mathrm{H}), 2.72(\mathrm{q}, J=7.5 \mathrm{~Hz}, 2 \mathrm{H}), 1.87(\mathrm{p}, J=7.3 \mathrm{~Hz}, 2 \mathrm{H}), 1.37-1.24(\mathrm{~m}$, $6 \mathrm{H}), 1.17$ (t, $J=7.5 \mathrm{~Hz}, 3 \mathrm{H}), 0.86(\mathrm{t}, J=6.7 \mathrm{~Hz}, 3 \mathrm{H}) .{ }^{13} \mathrm{C}$ NMR $(126 \mathrm{MHz}$, $\left.\mathrm{CDCl}_{3}\right): \delta=161.7\left(\mathrm{C}_{\mathrm{q}}\right), 144.1\left(\mathrm{C}_{\mathrm{q}}\right), 136.9\left(\mathrm{C}_{\mathrm{q}}\right), 134.9\left(\mathrm{C}_{\mathrm{q}}\right), 134.0(\mathrm{CH}), 132.8$ $(\mathrm{CH}), 132.1\left(\mathrm{C}_{\mathrm{q}}\right), 127.7(\mathrm{CH}), 126.3\left(\mathrm{C}_{\mathrm{q}}\right), 124.7(\mathrm{CH}), 124.2(\mathrm{CH}), 117.3\left(\mathrm{CH}_{2}\right)$, $116.7\left(\mathrm{C}_{\mathrm{q}}\right), 50.5\left(\mathrm{CH}_{2}\right), 40.1\left(\mathrm{CH}_{2}\right), 33.0\left(\mathrm{CH}_{2}\right), 31.2\left(\mathrm{CH}_{2}\right), 30.2\left(\mathrm{CH}_{2}\right), 26.2$ $\left(\mathrm{CH}_{2}\right), 22.5\left(\mathrm{CH}_{2}\right), 21.0\left(\mathrm{CH}_{2}\right), 14.6\left(\mathrm{CH}_{3}\right), 14.0\left(\mathrm{CH}_{3}\right)$. IR (ATR): 2956, 2928, 1642, 1591, 1461, 1337, 1293, 1047, 910, $824 \mathrm{~cm}^{-1}$. MS (ESI) $\mathrm{m} / z$ (relative intensity): $413(57)\left[{ }^{35} \mathrm{Cl}, \mathrm{M}+\mathrm{H}\right]^{+}, 435$ (100) $\left[{ }^{35} \mathrm{Cl}, \mathrm{M}+\mathrm{Na}\right]^{+}$. HR-MS (ESI) $\mathrm{m} / \mathrm{z}$ calcd for $\mathrm{C}_{23} \mathrm{H}_{30}{ }^{35} \mathrm{CIN}_{4} \mathrm{O}[\mathrm{M}+\mathrm{H}]^{+} 413.2103$, found 413.2104.

3-Allyl-7-bromo-4-ethyl-2-[(1-hexyl-1 H-1,2,3-triazol-4-yl)methyl]isoquinolin-1(2H)-one : (95wg):<smiles>C=CCc1c(CC)c2ccc(Br)cc2c(=O)n1Cc1cn(CC)nn1</smiles>

The general procedure GPC was followed using $51 \mathrm{w}(110 \mathrm{mg}, 0.30 \mathrm{mmol})$ and BCP $94 \mathrm{~g}(137 \mathrm{mg}, 0.90 \mathrm{mmol})$. Purification by column chromatography (nhexane/EtOAc $=3 / 2)$ yielded $95 \mathrm{wg}(65.8 \mathrm{mg}, 48 \%)$ as colourless oil. 
${ }^{1} \mathrm{H}$ NMR $\left(600 \mathrm{MHz}, \mathrm{CDCl}_{3}\right): \delta=8.59(\mathrm{~d}, J=2.2 \mathrm{~Hz}, 1 \mathrm{H}), 7.76(\mathrm{~s}, 1 \mathrm{H}), 7.73(\mathrm{dd}$, $J=8.7,2.2 \mathrm{~Hz}, 1 \mathrm{H}), 7.55(\mathrm{~d}, J=8.7 \mathrm{~Hz}, 1 \mathrm{H}), 6.13(\mathrm{ddt}, J=17.3,10.4,4.7 \mathrm{~Hz}$, $1 \mathrm{H}$ ), 5.32 (s, 2H), 5.24 (dd, $J=10.4,1.2 \mathrm{~Hz}, 1 \mathrm{H}$ ), 5.03 (dd, $J=17.3,1.2 \mathrm{~Hz}$, $1 \mathrm{H}$ ), 4.26 (t, $J=7.4 \mathrm{~Hz}, 2 \mathrm{H}$ ), $3.92(\mathrm{~s}, 2 \mathrm{H}$ ), 2.70 (q, $J=7.5 \mathrm{~Hz}, 2 \mathrm{H}$ ), 1.85 (qd, $J=7.9,7.2,4.0 \mathrm{~Hz}, 2 \mathrm{H}), 1.30-1.25(\mathrm{~m}, 6 \mathrm{H}), 1.15(\mathrm{t}, J=7.5 \mathrm{~Hz}, 3 \mathrm{H}), 0.85$ (t, $J=7.0 \mathrm{~Hz}, 3 \mathrm{H}) .{ }^{13} \mathrm{C}$ NMR $\left(75 \mathrm{MHz}, \mathrm{CDCl}_{3}\right): \delta=161.6\left(\mathrm{C}_{\mathrm{q}}\right), 144.1\left(\mathrm{C}_{\mathrm{q}}\right), 137.1$ $\left(\mathrm{C}_{\mathrm{q}}\right), 135.6(\mathrm{CH}), 135.3\left(\mathrm{C}_{\mathrm{q}}\right), 134.0(\mathrm{CH}), 130.9(\mathrm{CH}), 126.6\left(\mathrm{C}_{\mathrm{q}}\right), 124.9(\mathrm{CH})$, $124.2(\mathrm{CH}), 120.0\left(\mathrm{C}_{\mathrm{q}}\right), 117.3\left(\mathrm{CH}_{2}\right), 116.8\left(\mathrm{C}_{\mathrm{q}}\right), 50.5\left(\mathrm{CH}_{2}\right), 40.1\left(\mathrm{CH}_{2}\right), 33.0$ $\left(\mathrm{CH}_{2}\right), 31.2\left(\mathrm{CH}_{2}\right), 30.3\left(\mathrm{CH}_{2}\right), 26.3\left(\mathrm{CH}_{2}\right), 22.5\left(\mathrm{CH}_{2}\right), 21.0\left(\mathrm{CH}_{2}\right), 14.6\left(\mathrm{CH}_{3}\right)$, $14.0\left(\mathrm{CH}_{3}\right)$. IR (ATR): 2956, 2928, 1644, 1588, 1478, 1336, 1293, 1048, 930, $824 \mathrm{~cm}^{-1}$. MS (ESI) $\mathrm{m} / z$ (relative intensity): 457 (67) [ $\left.{ }^{79} \mathrm{Br}, \mathrm{M}+\mathrm{H}\right]^{+}, 481$ (100), 937 (50). HR-MS (ESI) $\mathrm{m} / z$ calcd for $\mathrm{C}_{23} \mathrm{H}_{30}{ }^{79} \mathrm{BrN}_{4} \mathrm{O}[\mathrm{M}+\mathrm{H}]^{+} 457.1598$, found 457.1598 .

\subsubsection{Analytical Data - Impact of $\mathrm{CF}_{3}$-Substitution of Benzamide}

3-Allyl-4-ethyl-2-[(1-hexyl-1 H-1,2,3-triazol-4-yl)methyl]-6-(trifluoromethyl)isoquinolin-1(2H)-one (95hg) and 3-Allyl-6-(difluoromethyl)-2-[(1-hexyl1H-1,2,3-triazol-4-yl)methyl]-4,5-dihydrocyclopenta[de]isoquinolin-1(2H)one (95hg'):
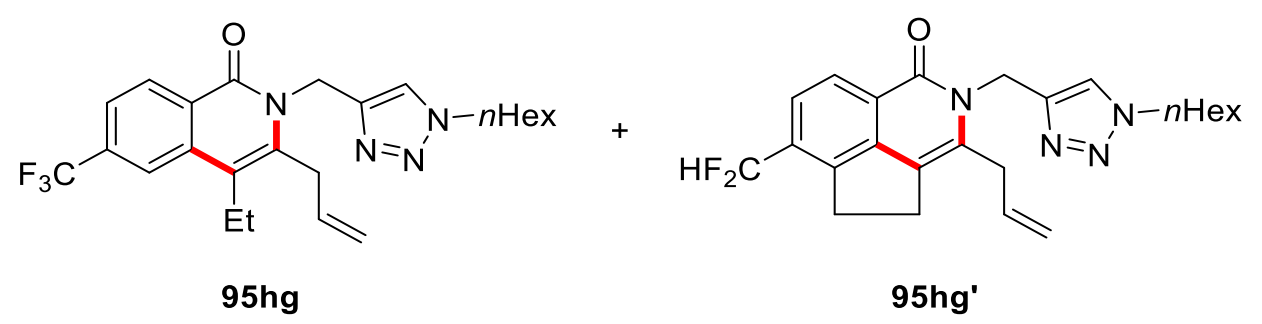

The general procedure GPC was followed using $51 \mathrm{~h}(106 \mathrm{mg}, 0.30 \mathrm{mmol})$ and BCP $94 \mathrm{~g}$ (137 $\mathrm{mg}, 0.90 \mathrm{mmol})$. Purification by column chromatography ( $n$ hexane/EtOAc $=3 / 2$ to $1 / 1$ ) yielded $95 \mathrm{hg}(9.4 \mathrm{mg}, 7 \%$ ) as a white solid. and 95h' (49.8 mg, 39\%) as yellow oil. 


\section{Experimental Part}

\section{3-Allyl-4-ethyl-2-[(1-hexyl-1 H-1,2,3-triazol-4-yl)methyl]-6-(trifluoromethyl)- isoquinolin-1(2H)-one (95hg):}

M.p. $=96-97^{\circ} \mathrm{C} .{ }^{1} \mathrm{H}$ NMR $\left(400 \mathrm{MHz}, \mathrm{CDCl}_{3}\right): \delta=8.55(\mathrm{dd}, J=8.3,1.0 \mathrm{~Hz}, 1 \mathrm{H})$, $7.92(\mathrm{~s}, 1 \mathrm{H}), 7.74(\mathrm{~s}, 1 \mathrm{H}), 7.63$ (dd, $J=8.3,1.6 \mathrm{~Hz}, 1 \mathrm{H}), 6.13$ (ddt, $J=17.3$, 10.3, $4.7 \mathrm{~Hz}, 1 \mathrm{H}$ ), 5.33 (s, 2H), 5.24 (dd, $J=10.3,1.4 \mathrm{~Hz}, 1 \mathrm{H}$ ), 5.02 (dd, $J=17.3,1.4 \mathrm{~Hz}, 1 \mathrm{H}), 4.25(\mathrm{t}, J=7.4 \mathrm{~Hz}, 2 \mathrm{H}), 3.95(\mathrm{~s}, 2 \mathrm{H}), 2.74(\mathrm{q}, J=7.5 \mathrm{~Hz}$, 2H), 1.83 (q, $J=7.3 \mathrm{~Hz}, 2 \mathrm{H}), 1.27-1.22(\mathrm{~m}, 6 \mathrm{H}), 1.17(\mathrm{t}, J=7.5 \mathrm{~Hz}, 3 \mathrm{H}), 0.83$ (t, $J=6.9 \mathrm{~Hz}, 3 \mathrm{H}) .{ }^{13} \mathrm{C}$ NMR $\left(101 \mathrm{MHz}, \mathrm{CDCl}_{3}\right): \delta=162.0\left(\mathrm{C}_{\mathrm{q}}\right), 144.0\left(\mathrm{C}_{\mathrm{q}}\right)$, $138.3\left(\mathrm{C}_{\mathrm{q}}\right), 136.6\left(\mathrm{C}_{\mathrm{q}}\right), 134.1\left(\mathrm{~d},{ }^{2} J_{\mathrm{C}-\mathrm{F}}=32.3 \mathrm{~Hz}, \mathrm{C}_{\mathrm{q}}\right), 133.9(\mathrm{CH}), 129.5(\mathrm{CH})$, $127.3\left(\mathrm{C}_{\mathrm{q}}\right), 124.2(\mathrm{CH}), 124.1\left(\mathrm{~d},{ }^{1} J_{\mathrm{C}-\mathrm{F}}=273.0 \mathrm{~Hz}, \mathrm{C}_{\mathrm{q}}\right), 122.1\left(\mathrm{~d},{ }^{3} J_{C-\mathrm{F}}=3.4 \mathrm{~Hz}\right.$, $\mathrm{CH}), 120.3\left(\mathrm{~d},{ }^{3} J_{\mathrm{C}-\mathrm{F}}=4.2 \mathrm{~Hz}, \mathrm{CH}\right), 117.5\left(\mathrm{CH}_{2}\right), 117.0\left(\mathrm{C}_{\mathrm{q}}\right), 50.5\left(\mathrm{CH}_{2}\right), 40.1$ $\left(\mathrm{CH}_{2}\right), 33.1\left(\mathrm{CH}_{2}\right), 31.2\left(\mathrm{CH}_{2}\right), 30.3\left(\mathrm{CH}_{2}\right), 26.3\left(\mathrm{CH}_{2}\right), 22.5\left(\mathrm{CH}_{2}\right), 21.0\left(\mathrm{CH}_{2}\right)$, $14.6\left(\mathrm{CH}_{3}\right), 14.0\left(\mathrm{CH}_{3}\right) .{ }^{19} \mathrm{~F}$ NMR $\left(376 \mathrm{MHz}, \mathrm{CDCl}_{3}\right): \delta=-62.89$ (s). IR (ATR): 2959, 2931, 2860, 1650, 1597, 1433, 1313, 1130, 1074, $797 \mathrm{~cm}^{-1}$. MS (ESI) $\mathrm{m} / \mathrm{z}$ (relative intensity): $447(86)[\mathrm{M}+\mathrm{H}]^{+}, 469(100)[\mathrm{M}+\mathrm{Na}]^{+}$. HR-MS (ESI) $\mathrm{m} / \mathrm{z}$ calcd for $\mathrm{C}_{24} \mathrm{H}_{30} \mathrm{~F}_{3} \mathrm{~N}_{4} \mathrm{O}[\mathrm{M}+\mathrm{H}]^{+} 447.2366$, found 447.2367 .

\section{3-Allyl-6-(difluoromethyl)-2-[(1-hexyl-1 H-1,2,3-triazol-4-yl)methyl]-4,5-dih- ydrocyclopenta[de]isoquinolin-1(2H)-one (95hg'):}

${ }^{1} \mathrm{H}$ NMR $\left(400 \mathrm{MHz}, \mathrm{CDCl}_{3}\right): \delta=8.05(\mathrm{~d}, J=8.2 \mathrm{~Hz}, 1 \mathrm{H}), 7.72(\mathrm{~s}, 1 \mathrm{H}), 7.45(\mathrm{~d}$, $J=8.2 \mathrm{~Hz}, 1 \mathrm{H}), 6.75(\mathrm{t}, J=55.6 \mathrm{~Hz}, 1 \mathrm{H}), 6.05(\mathrm{ddt}, J=17.3,10.3,5.1 \mathrm{~Hz}, 1 \mathrm{H})$, $5.34(\mathrm{~s}, 2 \mathrm{H}), 5.20(\mathrm{dq}, J=10.3,1.6 \mathrm{~Hz}, 1 \mathrm{H}), 5.08(\mathrm{dq}, J=17.3,1.6 \mathrm{~Hz}, 1 \mathrm{H})$, 4.25 (t, $J=7.3 \mathrm{~Hz}, 2 \mathrm{H}), 3.80(\mathrm{~s}, 2 \mathrm{H}), 3.40-3.34(\mathrm{~m}, 2 \mathrm{H}), 3.15-3.05(\mathrm{~m}, 2 \mathrm{H})$, $1.84(\mathrm{p}, J=7.4 \mathrm{~Hz}, 2 \mathrm{H}), 1.29-1.24(\mathrm{~m}, 6 \mathrm{H}), 0.83(\mathrm{t}, J=6.9 \mathrm{~Hz}, 3 \mathrm{H}) .{ }^{13} \mathrm{C}$ NMR $\left(101 \mathrm{MHz}, \mathrm{CDCl}_{3}\right): \delta=162.3\left(\mathrm{C}_{\mathrm{q}}\right), 144.3\left(\mathrm{C}_{\mathrm{q}}\right), 144.0\left(\mathrm{C}_{\mathrm{q}}\right), 142.0\left(\mathrm{t},{ }^{3} J_{\mathrm{C}-\mathrm{F}}=\right.$ $\left.4.5 \mathrm{~Hz}, \mathrm{C}_{\mathrm{q}}\right), 134.7\left(\mathrm{C}_{\mathrm{q}}\right), 133.3(\mathrm{CH}), 132.3\left(\mathrm{t},{ }^{2} J_{\mathrm{C}-\mathrm{F}}=22.5 \mathrm{~Hz}, \mathrm{C}_{\mathrm{q}}\right), 124.4(\mathrm{CH})$, $124.2\left(\mathrm{t},{ }^{3} J_{\mathrm{C}-\mathrm{F}}=6.5 \mathrm{~Hz}, \mathrm{CH}\right), 123.9(\mathrm{CH}), 123.2\left(\mathrm{C}_{\mathrm{q}}\right), 121.8\left(\mathrm{C}_{\mathrm{q}}\right), 117.2\left(\mathrm{CH}_{2}\right)$, $114.2\left(\mathrm{t},{ }^{1} J_{C-F}=239.0 \mathrm{~Hz}, \mathrm{CH}\right), 50.5\left(\mathrm{CH}_{2}\right), 39.5\left(\mathrm{CH}_{2}\right), 34.5\left(\mathrm{CH}_{2}\right), 31.2\left(\mathrm{CH}_{2}\right)$, 


\section{Experimental Part}

$30.2\left(\mathrm{CH}_{2}\right), 29.7\left(\mathrm{CH}_{2}\right), 27.5\left(\mathrm{CH}_{2}\right), 26.2\left(\mathrm{CH}_{2}\right), 22.5\left(\mathrm{CH}_{2}\right), 14.0\left(\mathrm{CH}_{3}\right) .{ }^{19} \mathrm{~F} \mathrm{NMR}$ (377 MHz, $\mathrm{CDCl}_{3}$ ): $\delta=-112.87$ (d, $J=55.5 \mathrm{~Hz}$ ). IR (ATR): 2955, 2928, 2857, $1664,1619,1428,1371,1103,1027,784 \mathrm{~cm}^{-1}$. MS (ESI) $\mathrm{m} / z$ (relative intensity): $427(100)[\mathrm{M}+\mathrm{H}]^{+}, 449$ (67) $[\mathrm{M}+\mathrm{Na}]^{+}$. HR-MS (ESI) $\mathrm{m} / z$ calcd for $\mathrm{C}_{24} \mathrm{H}_{28} \mathrm{~F}_{2} \mathrm{~N}_{4} \mathrm{ONa}[\mathrm{M}+\mathrm{Na}]^{+} 449.2123$, found 449.2117 .

3-Allyl-4-ethyl-2-[(1-hexyl-1 H-1,2,3-triazol-4-yl)methyl]-7-(trifluoromethyl)isoquinolin-1(2H)-one (95xg) and 3'-Allyl-2'-[(1-hexyl-1H-1,2,3-triazol-4yl)methyl]-7'-(trifluoromethyl)-2',3'-dihydro-1' H-spiro(cyclopropane-1,4'isoquinolin)-1'-one (95xg'):<smiles>C=CCc1c(CC)c2ccc(C(F)(F)F)cc2c(=O)n1Cc1cn(CCCCC)nn1</smiles>

$95 \times g$<smiles>C=CCC1N(Cc2cn(CC)nn2)C(=O)c2cc(C(F)(F)F)ccc2C12CC2</smiles>

$95 \times g^{\prime}$

The general procedure GPC was followed using $51 \times(106 \mathrm{mg}, 0.30 \mathrm{mmol})$ and BCP $94 \mathrm{~g}(137 \mathrm{mg}, 0.90 \mathrm{mmol})$. Purification by column chromatography (nhexane/EtOAc $=3 / 2)$ yielded $95 x g(49.6 \mathrm{mg}, 37 \%)$ as colourless oil and $95 \times x^{\prime}$ (33.5 mg, $\left.25 \%\right)$ as yellow oil.

3-Allyl-4-ethyl-2-[(1-hexyl-1 H-1,2,3-triazol-4-yl)methyl]-7-(trifluoromethyl)isoquinolin-1(2H)-one (95xg):

1H NMR (400 MHz, $\left.\mathrm{CDCl}_{3}\right): \delta=8.75(\mathrm{~s}, 1 \mathrm{H}), 7.89-7.75(\mathrm{~m}, 3 \mathrm{H}), 6.15$ (ddt, $J=17.3,10.2,2.9 \mathrm{~Hz}, 1 \mathrm{H}$ ), $5.35(\mathrm{~s}, 2 \mathrm{H}), 5.26(\mathrm{dd}, J=10.2,1.5 \mathrm{~Hz}, 1 \mathrm{H}), 5.05$ (dd, $J=17.3,1.5 \mathrm{~Hz}, 1 \mathrm{H}$ ), 4.27 (t, $J=6.9 \mathrm{~Hz}, 2 \mathrm{H}), 3.98(\mathrm{~s}, 2 \mathrm{H}), 2.81-2.70(\mathrm{~m}$, 2H), 1.93-1.81 (m, 2H), 1.31-1.25 (m, 6H), $1.18(\mathrm{t}, J=7.6 \mathrm{~Hz}, 3 \mathrm{H}), 0.85(\mathrm{t}$, $J=6.7 \mathrm{~Hz}, 3 \mathrm{H}) .{ }^{13} \mathrm{C}$ NMR $\left(75 \mathrm{MHz}, \mathrm{CDCl}_{3}\right): \delta=162.2\left(\mathrm{C}_{\mathrm{q}}\right), 143.9\left(\mathrm{C}_{\mathrm{q}}\right), 139.2$ $\left(\mathrm{C}_{\mathrm{q}}\right), 139.0\left(\mathrm{C}_{\mathrm{q}}\right), 133.8(\mathrm{CH}), 128.3\left(\mathrm{q},{ }^{3} J_{\mathrm{C}-\mathrm{F}}=3.4 \mathrm{~Hz}, \mathrm{CH}\right), 127.9\left(\mathrm{q},{ }^{2} J_{\mathrm{C}-\mathrm{F}}=33.5\right.$ 


\section{Experimental Part}

$\left.\mathrm{Hz}, \mathrm{C}_{\mathrm{q}}\right), 126.6\left(\mathrm{q},{ }^{1} J_{C-\mathrm{F}}=249.3 \mathrm{~Hz}, \mathrm{C}_{\mathrm{q}}\right), 126.0\left(\mathrm{q},{ }^{3} J_{C-\mathrm{F}}=4.1 \mathrm{~Hz}, \mathrm{CH}\right), 124.9$ $\left(\mathrm{C}_{\mathrm{q}}\right), 124.3(\mathrm{CH}), 123.9(\mathrm{CH}), 117.5\left(\mathrm{CH}_{2}\right), 116.7\left(\mathrm{C}_{\mathrm{q}}\right), 50.5\left(\mathrm{CH}_{2}\right), 40.1\left(\mathrm{CH}_{2}\right)$, 33.2 $\left(\mathrm{CH}_{2}\right), 31.2\left(\mathrm{CH}_{2}\right), 30.3\left(\mathrm{CH}_{2}\right), 26.3\left(\mathrm{CH}_{2}\right), 22.5\left(\mathrm{CH}_{2}\right), 21.1\left(\mathrm{CH}_{2}\right), 14.5$ $\left(\mathrm{CH}_{3}\right), 14.0\left(\mathrm{CH}_{3}\right) .{ }^{19} \mathrm{~F} \mathrm{NMR}\left(282 \mathrm{MHz}, \mathrm{CDCl}_{3}\right): \delta=-62.35$ (s). IR (ATR): 2958, 2930, 1652, 1598, 1554, 1323, 1292, 1163, 1126, $840 \mathrm{~cm}^{-1}$. MS (ESI) $\mathrm{m} / \mathrm{z}$ (relative intensity): $447(57)[\mathrm{M}+\mathrm{H}]^{+}, 469(100)[\mathrm{M}+\mathrm{Na}]^{+}$. HR-MS (ESI) $\mathrm{m} / \mathrm{z}$ calcd for $\mathrm{C}_{24} \mathrm{H}_{30} \mathrm{~F}_{3} \mathrm{~N}_{4} \mathrm{O}[\mathrm{M}+\mathrm{H}]^{+} 447.2366$, found 447.2368 .

3'-Allyl-2'-[(1-hexyl-1H-1,2,3-triazol-4-yl)methyl]-7'-(trifluoromethyl)-2',3'dihydro-1' $H$-spiro(cyclopropane-1,4'-isoquinolin)-1'-one (95xg'):

${ }^{1} \mathrm{H}$ NMR $\left(600 \mathrm{MHz}, \mathrm{CDCl}_{3}\right): \delta=8.31(\mathrm{~d}, J=2.1 \mathrm{~Hz}, 1 \mathrm{H}), 7.65-7.60(\mathrm{~m}, 2 \mathrm{H}), 6.93$ $(\mathrm{d}, J=8.1 \mathrm{~Hz}, 1 \mathrm{H}$ ), 5.71 (ddt, $J=16.8,10.2,7.4 \mathrm{~Hz}, 1 \mathrm{H}$ ), $5.36(\mathrm{~d}, J=14.9 \mathrm{~Hz}$, $1 \mathrm{H}), 4.98-4.94(\mathrm{~m}, 2 \mathrm{H}), 4.29(\mathrm{td}, J=7.2,2.7 \mathrm{~Hz}, 2 \mathrm{H}), 4.19(\mathrm{~d}, J=14.9 \mathrm{~Hz}, 1 \mathrm{H})$, 3.19 (t, $J=6.7 \mathrm{~Hz}, 1 \mathrm{H}$ ), 2.38-2.33 (m, 2H), 1.85 (t, $J=7.2 \mathrm{~Hz}, 2 \mathrm{H}$ ), 1.55 (ddd, $J=9.6,6.3,6.0 \mathrm{~Hz}, 1 \mathrm{H}), 1.27-1.22(\mathrm{~m}, 6 \mathrm{H}), 1.00$ (ddd, $J=9.8,6.8,6.0 \mathrm{~Hz}$, $1 \mathrm{H}$ ), 0.83 (t, $J=7.0 \mathrm{~Hz}, 3 \mathrm{H}$ ), 0.68 (ddd, $J=9.6,6.3,4.4 \mathrm{~Hz}, 1 \mathrm{H}$ ), 0.35 (ddd, $J=9.8,6.8,4.4 \mathrm{~Hz}, 1 \mathrm{H}) .{ }^{13} \mathrm{C}$ NMR $\left(101 \mathrm{MHz}, \mathrm{CDCl}_{3}\right): \delta=162.6\left(\mathrm{C}_{\mathrm{q}}\right), 145.1$ $\left(\mathrm{C}_{\mathrm{q}}\right), 144.3\left(\mathrm{C}_{\mathrm{q}}\right), 133.8(\mathrm{CH}), 130.9\left(\mathrm{C}_{\mathrm{q}}\right), 129.2\left(\mathrm{C}_{\mathrm{q}}\right), 129.0\left(\mathrm{q},{ }^{3} \mathrm{~J}_{\mathrm{C}-\mathrm{F}}=3.0 \mathrm{~Hz}\right.$, $\mathrm{CH}), 125.4\left(\mathrm{q},{ }^{3} J_{C-F}=3.9 \mathrm{~Hz}, \mathrm{CH}\right), 124.0\left(\mathrm{q},{ }^{1} J_{C-F}=271.7 \mathrm{~Hz}, \mathrm{C}_{\mathrm{q}}\right), 123.1(\mathrm{CH})$, $122.5(\mathrm{CH}), 118.6\left(\mathrm{CH}_{2}\right), 64.6(\mathrm{CH}), 50.5\left(\mathrm{CH}_{2}\right), 42.0\left(\mathrm{CH}_{2}\right), 38.4\left(\mathrm{CH}_{2}\right), 31.2$ $\left(\mathrm{CH}_{2}\right), 30.3\left(\mathrm{CH}_{2}\right), 26.2\left(\mathrm{CH}_{2}\right), 23.4\left(\mathrm{C}_{\mathrm{q}}\right), 22.5\left(\mathrm{CH}_{2}\right), 19.8\left(\mathrm{CH}_{2}\right), 14.0\left(\mathrm{CH}_{3}\right)$, $10.1\left(\mathrm{CH}_{2}\right) .{ }^{19} \mathrm{~F}$ NMR (565 MHz, $\left.\mathrm{CDCl}_{3}\right): \delta=-62.58$ (s). IR (ATR): 2929, 2860, 1649, 1617, 1469, 1331, 1252, 1160, 1129, $922 \mathrm{~cm}^{-1}$. MS (ESI) $\mathrm{m} / z$ (relative intensity): 447 (45) $[\mathrm{M}+\mathrm{H}]^{+}, 469$ (100) $[\mathrm{M}+\mathrm{Na}]^{+}$. HR-MS (ESI) $\mathrm{m} / z$ calcd for $\mathrm{C}_{24} \mathrm{H}_{30} \mathrm{~F}_{3} \mathrm{~N}_{4} \mathrm{O}[\mathrm{M}+\mathrm{H}]^{+}$447.2366, found 447.2370. 
3-Allyl-4-ethyl-6-(trifluoromethyl)isoquinolin-1(2H)-one (97gg) and 1Butyl-4-(prop-1-en-2-yl)-1H-1,2,3-triazole (119):

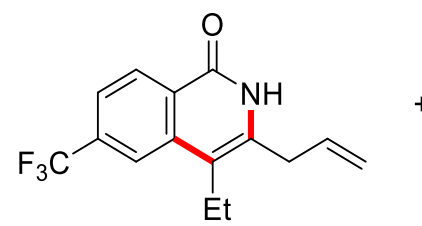

97gg

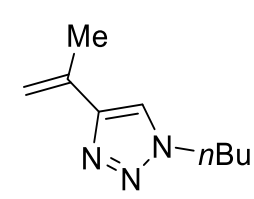

119

The procedure was followed using $\mathbf{3 2 g}$ (106 $\mathrm{mg}, 0.30 \mathrm{mmol})$ and BCP $\mathbf{9 4 g}$ (137 mg, $0.90 \mathrm{mmol})$. Purification by column chromatography ( $n$ hexane/EtOAc/DCM = 3/1/1) yielded $97 \mathrm{gg}(27.2 \mathrm{mg}, 32 \%$ ) as a white solid and 119 (16.4 mg, 33\%) as colourless oil.

\section{3-Allyl-4-ethyl-6-(trifluoromethyl)isoquinolin-1(2H)-one (97gg):}

M.p. $=97-98^{\circ} \mathrm{C} .{ }^{1} \mathrm{H}$ NMR $\left(400 \mathrm{MHz}, \mathrm{CDCl}_{3}\right): \delta=9.76(\mathrm{~s}, 1 \mathrm{H}), 8.62-8.43(\mathrm{~m}$, $1 \mathrm{H}), 7.98(\mathrm{~s}, 1 \mathrm{H}), 7.75-7.58(\mathrm{~m}, 1 \mathrm{H}), 5.96(\mathrm{ddt}, J=16.7,10.1,6.5 \mathrm{~Hz}, 1 \mathrm{H})$, 5.37-5.28 (m, 2H), 3.49 (dt, J=6.5, $1.8 \mathrm{~Hz}, 2 \mathrm{H}), 2.82(\mathrm{q}, J=7.6 \mathrm{~Hz}, 2 \mathrm{H}), 1.25$ $(\mathrm{t}, J=7.6 \mathrm{~Hz}, 3 \mathrm{H}) \cdot{ }^{13} \mathrm{C}$ NMR (126 MHz, $\left.\mathrm{CDCl}_{3}\right): \delta=162.1\left(\mathrm{C}_{\mathrm{q}}\right), 138.1\left(\mathrm{C}_{\mathrm{q}}\right)$, $135.5\left(\mathrm{C}_{\mathrm{q}}\right), 134.4\left(\mathrm{~d},{ }^{2} \mathrm{~J}_{\mathrm{C}-F}=32.0 \mathrm{~Hz}, \mathrm{C}_{\mathrm{q}}\right), 132.8(\mathrm{CH}), 129.2(\mathrm{CH}), 127.8\left(\mathrm{C}_{\mathrm{q}}\right)$, $124.1\left(\mathrm{~d},{ }^{1} J_{C-F}=272.8 \mathrm{~Hz}, \mathrm{C}_{q}\right), 122.1\left(\mathrm{~d},{ }^{3} J_{C-F}=3.9 \mathrm{~Hz}, \mathrm{CH}\right), 120.5\left(\mathrm{~d},{ }^{3} J_{C-F}=\right.$ $4.5 \mathrm{~Hz}, \mathrm{CH}), 119.9\left(\mathrm{CH}_{2}\right), 115.0\left(\mathrm{C}_{\mathrm{q}}\right), 35.3\left(\mathrm{CH}_{2}\right), 19.8\left(\mathrm{CH}_{2}\right), 14.8\left(\mathrm{CH}_{3}\right) .{ }^{19} \mathrm{~F}$ NMR (377 MHz, $\mathrm{CDCl}_{3}$ ): $\delta=-62.90$ (s). IR (ATR): 2963, 2923, 2851, 1651, 1626, 1459, 1300, 1179, 1119, $842 \mathrm{~cm}^{-1}$. MS (ESI) m/z (relative intensity): 282 (86) $[\mathrm{M}+\mathrm{H}]^{+}, 304$ (100). HR-MS (ESI) m/z calcd for $\mathrm{C}_{15} \mathrm{H}_{15} \mathrm{~F}_{3} \mathrm{~N}_{4} \mathrm{O}[\mathrm{M}+\mathrm{H}]^{+}$ 282.1100, found 282.1101.

\section{1-Butyl-4-(prop-1-en-2-yl)-1 H-1,2,3-triazole (119):}

${ }^{1} \mathrm{H}$ NMR $\left(400 \mathrm{MHz}, \mathrm{CDCl}_{3}\right): \delta=7.47(\mathrm{~s}, 1 \mathrm{H}), 5.69(\mathrm{~s}, 1 \mathrm{H}), 5.09(\mathrm{~s}, 1 \mathrm{H}), 4.34(\mathrm{t}$, $J=7.2 \mathrm{~Hz}, 2 \mathrm{H}), 2.14(\mathrm{~d}, J=1.2 \mathrm{~Hz}, 3 \mathrm{H}), 1.89(\mathrm{p}, J=7.4 \mathrm{~Hz}, 2 \mathrm{H}), 1.37$ (h, $J=7.4 \mathrm{~Hz}, 2 \mathrm{H}), 0.96(\mathrm{t}, J=7.4 \mathrm{~Hz}, 3 \mathrm{H}) .{ }^{13} \mathrm{C}$ NMR $\left(101 \mathrm{MHz}, \mathrm{CDCl}_{3}\right): \delta=148.9$ $\left(\mathrm{C}_{\mathrm{q}}\right), 133.9\left(\mathrm{C}_{\mathrm{q}}\right), 119.5(\mathrm{CH}), 112.4\left(\mathrm{CH}_{2}\right), 50.1\left(\mathrm{CH}_{2}\right), 32.5\left(\mathrm{CH}_{2}\right), 20.8\left(\mathrm{CH}_{3}\right)$, 
$19.9\left(\mathrm{CH}_{2}\right), 13.6\left(\mathrm{CH}_{3}\right)$. IR (ATR): 3124, 2959, 2933, 2873, 1640, 1456, 1228 , 1127, 1046, 892, $\mathrm{cm}^{-1}$. MS (ESI) $\mathrm{m} / \mathrm{z}$ (relative intensity): $166(100)[\mathrm{M}+\mathrm{H}]^{+}, 188$ (54) $[\mathrm{M}+\mathrm{Na}]^{+}$. HR-MS (ESI) $\mathrm{m} / z$ calcd for $\mathrm{C}_{9} \mathrm{H}_{16} \mathrm{~N}_{3}[\mathrm{M}+\mathrm{H}]^{+} 166.1339$, found 166.1341 .

\subsubsection{Analytical Data - Substrate Scope with BCP 94}

(E)-4-Ethyl-2-[(1-hexyl-1 H-1,2,3-triazol-4-yl)methyl]-3-(non-2-en-1-yl)isoquinolin-1(2H)-one (95ah):<smiles>[R]O/C=C/Cc1c(CC)c2ccccc2c(=O)n1Cc1cn(CC)nn1</smiles>

The general procedure GPC was followed using $51 \mathrm{a}(85.9 \mathrm{mg}, 0.30 \mathrm{mmol})$ and BCP $94 \mathrm{~h}$ (213 $\mathrm{mg}, 0.90 \mathrm{mmol})$. Purification by column chromatography ( $n$ hexane/EtOAc $=3 / 2)$ yielded $95 \mathrm{ah}(84.8 \mathrm{mg}, 61 \%)$ as colourless oil.

${ }^{1} \mathrm{H}$ NMR $\left(400 \mathrm{MHz}, \mathrm{CDCl}_{3}\right): \delta=8.46(\mathrm{~d}, J=7.5 \mathrm{~Hz}, 1 \mathrm{H}), 7.75(\mathrm{~s}, 1 \mathrm{H}), 7.70$ $7.63(\mathrm{~m}, 2 \mathrm{H}), 7.44$ (ddd, $J=8.1,6.5,1.7 \mathrm{~Hz}, 1 \mathrm{H}), 5.74-5.63(\mathrm{~m}, 1 \mathrm{H}), 5.50-5.40$ (m, $1 \mathrm{H}), 5.37$ (s, 2H), 4.25 (t, $J=7.4 \mathrm{~Hz}, 2 \mathrm{H}$ ), $3.83(\mathrm{~s}, 2 \mathrm{H}), 2.74$ (q, $J=7.5 \mathrm{~Hz}$, 2H), 2.03 (q, $J=6.7 \mathrm{~Hz}, 2 \mathrm{H}), 1.84(\mathrm{p}, J=7.2 \mathrm{~Hz}, 2 \mathrm{H}), 1.29-1.22(\mathrm{~m}, 14 \mathrm{H}), 1.17$ (t, $J=7.5 \mathrm{~Hz}, 3 \mathrm{H}), 0.87-0.81(\mathrm{~m}, 6 \mathrm{H}) .{ }^{13} \mathrm{C}$ NMR $\left(101 \mathrm{MHz}, \mathrm{CDCl}_{3}\right): \delta=162.8$ $\left(\mathrm{C}_{\mathrm{q}}\right), 144.6\left(\mathrm{C}_{\mathrm{q}}\right), 137.5\left(\mathrm{C}_{\mathrm{q}}\right), 136.6\left(\mathrm{C}_{\mathrm{q}}\right), 133.5(\mathrm{CH}), 132.4(\mathrm{CH}), 128.3(\mathrm{CH})$, $125.9(\mathrm{CH}), 125.5(\mathrm{CH}), 125.1\left(\mathrm{C}_{\mathrm{q}}\right), 124.1(\mathrm{CH}), 122.9(\mathrm{CH}), 116.7\left(\mathrm{C}_{\mathrm{q}}\right), 50.4$ $\left(\mathrm{CH}_{2}\right), 39.9\left(\mathrm{CH}_{2}\right), 32.7\left(\mathrm{CH}_{2}\right), 32.0\left(\mathrm{CH}_{2}\right), 31.8\left(\mathrm{CH}_{2}\right), 31.2\left(\mathrm{CH}_{2}\right), 30.2\left(\mathrm{CH}_{2}\right)$, $29.3\left(\mathrm{CH}_{2}\right), 28.9\left(\mathrm{CH}_{2}\right), 26.2\left(\mathrm{CH}_{2}\right), 22.7\left(\mathrm{CH}_{2}\right), 22.5\left(\mathrm{CH}_{2}\right), 20.9\left(\mathrm{CH}_{2}\right), 14.6$ $\left(\mathrm{CH}_{3}\right), 14.2\left(\mathrm{CH}_{3}\right), 14.0\left(\mathrm{CH}_{3}\right)$. IR (ATR): 2955, 2926, 2856, 1643, 1592, 1460, 1337, 1047, 968, $773 \mathrm{~cm}^{-1}$. MS (ESI) $\mathrm{m} / \mathrm{z}$ (relative intensity): 469 (100), 495 (17) $[\mathrm{M}+\mathrm{Na}]^{+}$. HR-MS (ESI) $\mathrm{m} / z$ calcd for $\mathrm{C}_{29} \mathrm{H}_{43} \mathrm{~N}_{4} \mathrm{O}[\mathrm{M}+\mathrm{H}]^{+} 463.3431$, found 463.3426. 
3-Cinnamyl-4-ethyl-2-[(1-hexyl-1 H-1,2,3-triazol-4-yl)methyl]isoquinolin1(2H)-one (95ai):

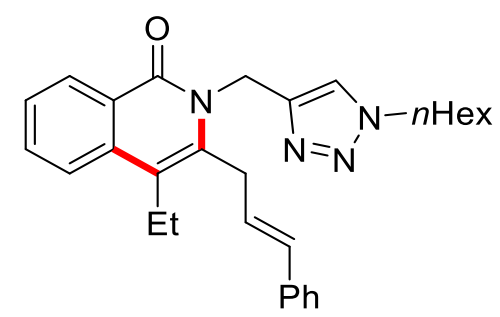

The general procedure GPC was followed using $51 \mathrm{a}(85.9 \mathrm{mg}, 0.30 \mathrm{mmol})$ and BCP 94i (205 mg, $0.90 \mathrm{mmol})$. Purification by column chromatography ( $n$ hexane/EtOAc $=3 / 2)$ yielded 95ai $(72.3 \mathrm{mg}, 53 \%)$ as colourless oil.

${ }^{1} \mathrm{H}$ NMR $\left(400 \mathrm{MHz}, \mathrm{CDCl}_{3}\right): \delta=8.50(\mathrm{~d}, J=6.6 \mathrm{~Hz}, 1 \mathrm{H}), 7.78(\mathrm{~s}, 1 \mathrm{H}), 7.74-7.68$ $(\mathrm{m}, 2 \mathrm{H}), 7.49$ (ddd, $J=8.1,6.6,1.6 \mathrm{~Hz}, 1 \mathrm{H}), 7.39-7.27(\mathrm{~m}, 4 \mathrm{H}), 7.24-7.18(\mathrm{~m}$, $1 \mathrm{H}), 6.50$ (dt, $J=16.1,4.9 \mathrm{~Hz}, 1 \mathrm{H}), 6.37(\mathrm{~d}, J=16.1 \mathrm{~Hz}, 1 \mathrm{H}), 5.40(\mathrm{~s}, 2 \mathrm{H}), 4.25$ (t, $J=7.4 \mathrm{~Hz}, 2 \mathrm{H}), 4.10(\mathrm{~s}, 2 \mathrm{H}), 2.80$ (q, $J=7.5 \mathrm{~Hz}, 2 \mathrm{H}), 1.91-1.80(\mathrm{~m}, 2 \mathrm{H})$, 1.34-1.24 (m, 6H), $1.21(\mathrm{t}, J=7.5 \mathrm{~Hz}, 3 \mathrm{H}), 0.85(\mathrm{t}, J=7.6 \mathrm{~Hz}, 3 \mathrm{H}) .{ }^{13} \mathrm{C}$ NMR $\left(101 \mathrm{MHz}, \mathrm{CDCl}_{3}\right): \delta=162.8\left(\mathrm{C}_{\mathrm{q}}\right), 144.4\left(\mathrm{C}_{\mathrm{q}}\right), 136.9\left(\mathrm{C}_{\mathrm{q}}\right), 136.7\left(\mathrm{C}_{\mathrm{q}}\right), 136.5$ $\left(\mathrm{C}_{\mathrm{q}}\right), 132.5(\mathrm{CH}), 131.9(\mathrm{CH}), 128.7(\mathrm{CH}), 128.3(\mathrm{CH}), 127.6(\mathrm{CH}), 126.3(\mathrm{CH})$, $126.2(\mathrm{CH}), 125.8(\mathrm{CH}), 125.3\left(\mathrm{C}_{\mathrm{q}}\right), 124.1(\mathrm{CH}), 123.0(\mathrm{CH}), 117.2\left(\mathrm{C}_{\mathrm{q}}\right), 50.5$ $\left(\mathrm{CH}_{2}\right), 40.0\left(\mathrm{CH}_{2}\right), 32.3\left(\mathrm{CH}_{2}\right), 31.2\left(\mathrm{CH}_{2}\right), 30.2\left(\mathrm{CH}_{2}\right), 26.2\left(\mathrm{CH}_{2}\right), 22.5\left(\mathrm{CH}_{2}\right)$, $21.1\left(\mathrm{CH}_{2}\right), 14.6\left(\mathrm{CH}_{3}\right), 14.0\left(\mathrm{CH}_{3}\right)$. IR (ATR): 2929, 2869, 1641, 1591, 1459, 1336, 1219, 1048, $773 \mathrm{~cm}^{-1}$. MS (ESI) m/z (relative intensity): 455 (100) $[\mathrm{M}+\mathrm{H}]^{+}, 477(77)[\mathrm{M}+\mathrm{Na}]^{+}, 931$ (62) $[2 \mathrm{M}+\mathrm{Na}]^{+}$. HR-MS (ESI) $\mathrm{m} / \mathrm{z}$ calcd for $\mathrm{C}_{29} \mathrm{H}_{35} \mathrm{~N}_{4} \mathrm{O}[\mathrm{M}+\mathrm{H}]^{+}$455.2805, found 455.2803. 


\subsubsection{Analytical Data - Bispiro-Fused Isoquinolone 96}

2'-[(1-Hexyl-1 H-1,2,3-triazol-4-yl)methyl]dispiro(cyclobutane-1,3'-isoquinoline-4',1"-cyclopropan)-1'(2' H)-one (96aa):

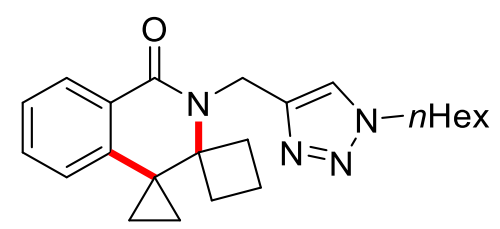

The general procedure GPC was followed using 51 a $(85.9 \mathrm{mg}, 0.30 \mathrm{mmol})$ and BCP 94a (112 mg, $0.90 \mathrm{mmol})$. Purification by column chromatography ( $n$ hexane/EtOAc $=1 / 2)$ yielded 96 aa $(51 \mathrm{mg}, 45 \%)$ as colourless oil.

${ }^{1} \mathrm{H}$ NMR $\left(600 \mathrm{MHz}, \mathrm{CDCl}_{3}\right): \delta=8.02(\mathrm{dd}, J=7.7,1.5 \mathrm{~Hz}, 1 \mathrm{H}), 7.60(\mathrm{~s}, 1 \mathrm{H}), 7.38$ (td, $J=7.7,7.5 \mathrm{~Hz}, 1 \mathrm{H}$ ), 7.27 (dd, $J=7.8,7.6 \mathrm{~Hz}, 1 \mathrm{H}$ ), 6.98 (dd, $J=7.8,1.1$ $\mathrm{Hz}, 1 \mathrm{H}$ ), $5.02(\mathrm{~s}, 2 \mathrm{H}), 4.27(\mathrm{t}, J=7.2 \mathrm{~Hz}, 2 \mathrm{H}), 2.49(\mathrm{~d}, J=11.1 \mathrm{~Hz}, 2 \mathrm{H}), 1.86-$ $1.82(\mathrm{~m}, 4 \mathrm{H}), 1.77(\mathrm{dt}, J=11.5,9.1 \mathrm{~Hz}, 1 \mathrm{H}), 1.56(\mathrm{dt}, J=11.5,9.1 \mathrm{~Hz}, 1 \mathrm{H})$, 1.26-1.23 (m, 6H), 1.05-1.01 (m, 2H), 0.99-0.93 (m, 2H), $0.82(\mathrm{t}, J=6.8 \mathrm{~Hz}$, 3H). ${ }^{13} \mathrm{C}$ NMR $\left(126 \mathrm{MHz}, \mathrm{CDCl}_{3}\right): \delta=164.6\left(\mathrm{C}_{\mathrm{q}}\right), 146.0\left(\mathrm{C}_{\mathrm{q}}\right), 141.4\left(\mathrm{C}_{\mathrm{q}}\right), 132.2$ $(\mathrm{CH}), 130.3\left(\mathrm{C}_{\mathrm{q}}\right), 128.3(\mathrm{CH}), 126.4(\mathrm{CH}), 123.1(\mathrm{CH}), 122.2(\mathrm{CH}), 63.3\left(\mathrm{C}_{q}\right)$, $50.5\left(\mathrm{CH}_{2}\right), 38.2\left(\mathrm{CH}_{2}\right), 31.3\left(\mathrm{CH}_{2}\right), 30.3\left(\mathrm{CH}_{2}\right), 30.1\left(\mathrm{CH}_{2}\right), 26.3\left(\mathrm{CH}_{2}\right), 25.8$ $\left(\mathrm{C}_{\mathrm{q}}\right), 22.6\left(\mathrm{CH}_{2}\right), 14.6\left(\mathrm{CH}_{2}\right), 14.1\left(\mathrm{CH}_{3}\right), 10.3\left(\mathrm{CH}_{2}\right)$. IR (ATR): 2954, 2931, 2858, 1640, 1603, 1461, 1394, 1276, 1045, $757 \mathrm{~cm}^{-1}$. MS (ESI) $\mathrm{m} / \mathrm{z}$ (relative intensity): $379(100)[\mathrm{M}+\mathrm{H}]^{+}, 757(36)[2 \mathrm{M}+\mathrm{H}]^{+}, 779(29)[2 \mathrm{M}+\mathrm{Na}]^{+}$. HR-MS (ESI) $\mathrm{m} / \mathrm{z}$ calcd for $\mathrm{C}_{23} \mathrm{H}_{31} \mathrm{~N}_{4} \mathrm{O}[\mathrm{M}+\mathrm{H}]^{+} 379.2492$, found 379.2490 . 
2'-[(1-Octyl-1H-1,2,3-triazol-4-yl)methyl]dispiro(cyclobutane-1,3'-isoquinoline-4',1"-cyclopropan)-1'(2' H)-one (96ba):

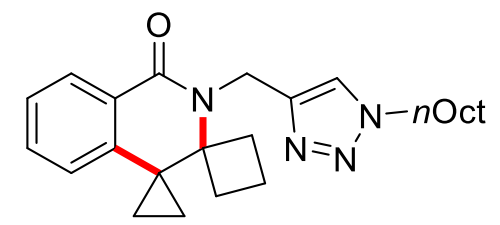

The general procedure GPC was followed using $51 \mathrm{~b}(98.6 \mathrm{mg}, 0.30 \mathrm{mmol})$ and BCP 94a (112 mg, $0.90 \mathrm{mmol})$. Purification by column chromatography ( $n$ hexane/EtOAc $=1 / 2)$ yielded $96 \mathrm{ba}(42.6 \mathrm{mg}, 35 \%)$ as colourless oil.

${ }^{1} \mathrm{H}$ NMR $\left(600 \mathrm{MHz}, \mathrm{CDCl}_{3}\right): \delta=8.03(\mathrm{dd}, J=7.7,1.5 \mathrm{~Hz}, 1 \mathrm{H}), 7.61(\mathrm{~s}, 1 \mathrm{H})$, 7.40 (dd, $J=7.7,7.6 \mathrm{~Hz}, 1 \mathrm{H}$ ), 7.28 (dd, $J=7.8,7.5 \mathrm{~Hz}, 1 \mathrm{H}$ ), 7.00 (dd, $J=7.8$, $1.2 \mathrm{~Hz}, 1 \mathrm{H}), 5.03(\mathrm{~s}, 2 \mathrm{H}), 4.28(\mathrm{t}, J=7.2 \mathrm{~Hz}, 2 \mathrm{H}), 2.56-2.45(\mathrm{~m}, 2 \mathrm{H}), 1.88-1.83$ $(\mathrm{m}, 4 \mathrm{H}), 1.80-1.75(\mathrm{~m}, 1 \mathrm{H}), 1.58(\mathrm{dt}, J=11.6,9.1 \mathrm{~Hz}, 1 \mathrm{H}), 1.26-1.20(\mathrm{~m}, 10 \mathrm{H})$, 1.06-1.03 (m, 2H), 1.00-0.94 (m, 2H), $0.83(\mathrm{t}, J=7.0 \mathrm{~Hz}, 3 \mathrm{H})$. ${ }^{13} \mathrm{C}$ NMR $\left(151 \mathrm{MHz}, \mathrm{CDCl}_{3}\right): \delta=164.8\left(\mathrm{C}_{\mathrm{q}}\right), 146.1\left(\mathrm{C}_{\mathrm{q}}\right), 141.5\left(\mathrm{C}_{\mathrm{q}}\right), 132.3(\mathrm{CH})$, $130.4\left(\mathrm{C}_{\mathrm{q}}\right), 128.4(\mathrm{CH}), 126.5(\mathrm{CH}), 123.2(\mathrm{CH}), 122.3(\mathrm{CH}), 63.3\left(\mathrm{C}_{\mathrm{q}}\right), 50.5$ $\left(\mathrm{CH}_{2}\right)$, $38.2\left(\mathrm{CH}_{2}\right), 31.8\left(\mathrm{CH}_{2}\right), 30.3\left(\mathrm{CH}_{2}\right), 29.9\left(\mathrm{CH}_{2}\right), 29.2\left(\mathrm{CH}_{2}\right), 29.1\left(\mathrm{CH}_{2}\right)$, $26.6\left(\mathrm{CH}_{2}\right), 25.8\left(\mathrm{C}_{\mathrm{q}}\right), 22.7\left(\mathrm{CH}_{2}\right), 14.6\left(\mathrm{CH}_{2}\right), 14.2\left(\mathrm{CH}_{3}\right), 10.2\left(\mathrm{CH}_{2}\right)$. IR (ATR): 2925, 2854, 1642, 1604, 1462, 1395, 1329, 1276, 1047, $769 \mathrm{~cm}^{-1}$. MS (ESI) $\mathrm{m} / \mathrm{z}$ (relative intensity): $407(59)[\mathrm{M}+\mathrm{H}]^{+}, 429(100)[\mathrm{M}+\mathrm{Na}]^{+}, 835(24)[2 \mathrm{M}+\mathrm{Na}]^{+}$. HR-MS (ESI) $m / z$ calcd for $\mathrm{C}_{25} \mathrm{H}_{35} \mathrm{~N}_{4} \mathrm{O}[\mathrm{M}+\mathrm{H}]^{+} 407.2805$, found 407.2809 . 
2'-[(1-Phenyl-1 H-1,2,3-triazol-4-yl)methyl]dispiro(cyclobutane-1,3'-isoquinoline-4',1"-cyclopropan)-1'(2' H)-one (96ya):

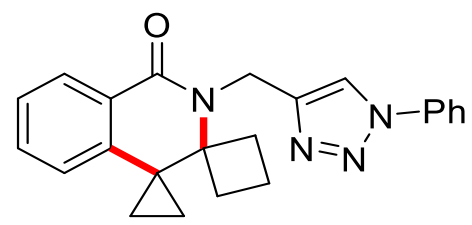

The general procedure GPC was followed using 51 y $(83.5 \mathrm{mg}, 0.30 \mathrm{mmol})$ and BCP 94a (112 mg, $0.90 \mathrm{mmol})$. Purification by column chromatography ( $n$ hexane/EtOAc $=1 / 2)$ yielded 96ya $(33.3 \mathrm{mg}, 30 \%)$ as colourless oil.

${ }^{1} \mathrm{H}$ NMR $\left(400 \mathrm{MHz}, \mathrm{CDCl}_{3}\right): \delta=8.13(\mathrm{~s}, 1 \mathrm{H}), 8.06$ (ddd, $J=7.7,1.5,0.5 \mathrm{~Hz}$, $1 \mathrm{H}), 7.77-7.73(\mathrm{~m}, 2 \mathrm{H}), 7.52-7.48(\mathrm{~m}, 2 \mathrm{H}), 7.45-7.39(\mathrm{~m}, 2 \mathrm{H}), 7.31$ (dd, $J=7.6,7.3 \mathrm{~Hz}, 1 \mathrm{H}), 7.03(\mathrm{dd}, J=8.1,1.1 \mathrm{~Hz}, 1 \mathrm{H}), 5.13(\mathrm{~s}, 2 \mathrm{H}), 2.58(\mathrm{~d}$, $J=11.3 \mathrm{~Hz}, 2 \mathrm{H}), 1.96-1.91(\mathrm{~m}, 2 \mathrm{H}), 1.89-1.83(\mathrm{~m}, 1 \mathrm{H}), 1.65-1.60(\mathrm{~m}, 1 \mathrm{H})$, 1.15-1.07 (m, 2H), 1.06-0.98 (m, 2H). ${ }^{13} \mathrm{C}$ NMR (101 MHz, CDCl 3$): \delta=164.9$ $\left(\mathrm{C}_{\mathrm{q}}\right), 146.8\left(\mathrm{C}_{\mathrm{q}}\right), 141.5\left(\mathrm{C}_{\mathrm{q}}\right), 137.2\left(\mathrm{C}_{\mathrm{q}}\right), 132.4(\mathrm{CH}), 130.4\left(\mathrm{C}_{\mathrm{q}}\right), 129.8(\mathrm{CH})$, $128.8(\mathrm{CH}), 128.4(\mathrm{CH}), 126.6(\mathrm{CH}), 122.4(\mathrm{CH}), 121.6(\mathrm{CH}), 120.5(\mathrm{CH}), 63.4$ $\left(\mathrm{C}_{\mathrm{q}}\right), 38.2\left(\mathrm{CH}_{2}\right), 30.1\left(\mathrm{CH}_{2}\right), 25.8\left(\mathrm{C}_{\mathrm{q}}\right), 14.6\left(\mathrm{CH}_{2}\right), 10.3\left(\mathrm{CH}_{2}\right)$. IR (ATR): 2923, 2853, 1639, 1601, 1502, 1434, 1395, 1280, 1041, $758 \mathrm{~cm}^{-1}$. MS (ESI) $\mathrm{m} / \mathrm{z}$ (relative intensity): $371(48)[\mathrm{M}+\mathrm{H}]^{+}, 393(100)[\mathrm{M}+\mathrm{Na}]^{+}, 763(29)[2 \mathrm{M}+\mathrm{Na}]^{+}$. HR-MS (ESI) $m / z$ calcd for $\mathrm{C}_{23} \mathrm{H}_{23} \mathrm{~N}_{4} \mathrm{O}[\mathrm{M}+\mathrm{H}]^{+} 371.1866$, found 371.1861 . 
2'-\{[1-(3-Chloropropyl)-1 H-1,2,3-triazol-4-yl]methyl\}dispiro(cyclobutane1,3'-isoquinoline-4',1'"-cyclopropan)-1'(2' H)-one (96da):

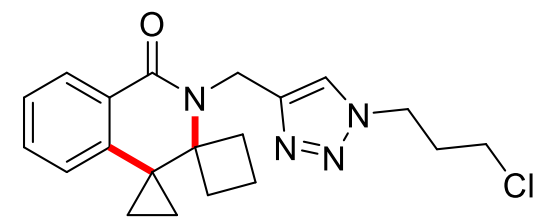

The general procedure GPC was followed using $51 \mathrm{~d}(86.3 \mathrm{mg}, 0.30 \mathrm{mmol})$ and BCP 94a (112 mg, $0.90 \mathrm{mmol})$. Purification by column chromatography ( $n$ hexane/EtOAc $=1 / 2)$ yielded $96 \mathrm{da}(40.0 \mathrm{mg}, 36 \%)$ as colourless oil.

${ }^{1} \mathrm{H}$ NMR $\left(500 \mathrm{MHz}, \mathrm{CDCl}_{3}\right): \delta=8.05(\mathrm{ddd}, J=7.7,1.5,0.5 \mathrm{~Hz}, 1 \mathrm{H}), 7.69(\mathrm{~s}$, 1H), 7.42 (dd, $J=7.7,7.6 \mathrm{~Hz}, 1 \mathrm{H}$ ), 7.31 (dd, $J=7.8,7.6 \mathrm{~Hz}, 1 \mathrm{H}$ ), 7.02 (ddd, $J$ $=7.8,1.2,0.5 \mathrm{~Hz}, 1 \mathrm{H}), 5.05(\mathrm{~s}, 2 \mathrm{H}), 4.51(\mathrm{t}, J=6.7 \mathrm{~Hz}, 2 \mathrm{H}), 3.52-3.48(\mathrm{~m}, 2 \mathrm{H})$, $2.51(\mathrm{~d}, J=11.2 \mathrm{~Hz}, 2 \mathrm{H}), 2.40-2.34(\mathrm{~m}, 2 \mathrm{H}), 1.94-1.87(\mathrm{~m}, 2 \mathrm{H}), 1.84-1.77(\mathrm{~m}$, $1 \mathrm{H}), 1.66-1.60(\mathrm{~m}, 1 \mathrm{H}), 1.11-1.05(\mathrm{~m}, 2 \mathrm{H}), 1.05-0.96(\mathrm{~m}, 2 \mathrm{H}) .{ }^{13} \mathrm{C}$ NMR (126 MHz, $\left.\mathrm{CDCl}_{3}\right): \delta=164.8\left(\mathrm{C}_{\mathrm{q}}\right), 146.3\left(\mathrm{C}_{\mathrm{q}}\right), 141.5\left(\mathrm{C}_{\mathrm{q}}\right), 132.4(\mathrm{CH}), 130.3$ $\left(\mathrm{C}_{\mathrm{q}}\right), 128.4(\mathrm{CH}), 126.6(\mathrm{CH}), 123.9(\mathrm{CH}), 122.3(\mathrm{CH}), 63.3\left(\mathrm{C}_{\mathrm{q}}\right), 47.2\left(\mathrm{CH}_{2}\right)$, $41.2\left(\mathrm{CH}_{2}\right), 38.2\left(\mathrm{CH}_{2}\right), 32.7\left(\mathrm{CH}_{2}\right), 30.0\left(\mathrm{CH}_{2}\right), 25.7\left(\mathrm{C}_{\mathrm{q}}\right), 14.6\left(\mathrm{CH}_{2}\right), 10.2$ (CH2). IR (ATR): 2948, 1639, 1604, 1461, 1406, 1298, 1152, 1044, 758, 557 $\mathrm{cm}^{-1}$. MS (ESI) $\mathrm{m} / \mathrm{z}$ (relative intensity): $371(40)\left[{ }^{35} \mathrm{Cl}, \mathrm{M}+\mathrm{H}\right]^{+}, 393(100)\left[{ }^{35} \mathrm{Cl}\right.$, $\mathrm{M}+\mathrm{Na}]^{+}, 763(13)\left[{ }^{35} \mathrm{Cl}, 2 \mathrm{M}+\mathrm{Na}\right]^{+}$. HR-MS (ESI) $\mathrm{m} / z$ calcd for $\mathrm{C}_{20} \mathrm{H}_{24}{ }^{35} \mathrm{CIN}_{4} \mathrm{O}$ $[\mathrm{M}+\mathrm{H}]^{+} 371.1633$, found 371.1635 . 
2'-[(1-Hexyl-1 H-1,2,3-triazol-4-yl)methyl]-6'-methyldispiro(cyclobutane1,3'-isoquinoline-4',1"-cyclopropan)-1'(2' H)-one (96ea):

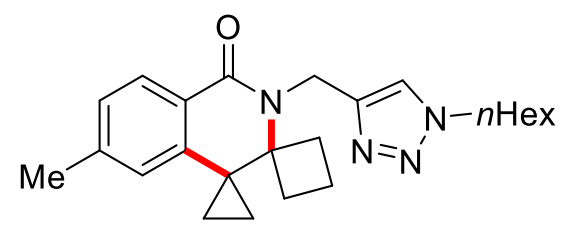

The general procedure GPC was followed using $51 \mathrm{e}(90.1 \mathrm{mg}, 0.30 \mathrm{mmol})$ and BCP 94a (112 mg, $0.90 \mathrm{mmol}$ ). Purification by column chromatography ( $n$ hexane/EtOAc $=1 / 2)$ yielded $96 \mathrm{ea}(37.6 \mathrm{mg}, 32 \%)$ as colourless oil.

${ }^{1} \mathrm{H}$ NMR $\left(600 \mathrm{MHz}, \mathrm{CDCl}_{3}\right): \delta=7.60(\mathrm{~s}, 1 \mathrm{H}), 7.22(\mathrm{~d}, J=7.6 \mathrm{~Hz}, 1 \mathrm{H}), 7.08(\mathrm{~d}$, $J=7.6 \mathrm{~Hz}, 1 \mathrm{H}), 6.86(\mathrm{~s}, 1 \mathrm{H}), 4.99(\mathrm{~s}, 2 \mathrm{H}), 4.28(\mathrm{t}, J=7.2 \mathrm{~Hz}, 2 \mathrm{H}), 2.67(\mathrm{~s}, 3 \mathrm{H})$, 2.61-2.33 (m, 2H), 1.87-1.78 (m, 4H), 1.75 (ddd, $J=11.5,7.3,2.4 \mathrm{~Hz}, 1 \mathrm{H}$ ), $1.56(\mathrm{dt}, J=11.5,9.0 \mathrm{~Hz}, 1 \mathrm{H}), 1.29-1.22(\mathrm{~m}, 6 \mathrm{H}), 0.99-0.80(\mathrm{~m}, 7 \mathrm{H}) .{ }^{13} \mathrm{C} \mathrm{NMR}$ $\left(101 \mathrm{Mz}, \mathrm{CDCl}_{3}\right): \delta=165.3\left(\mathrm{C}_{\mathrm{q}}\right), 146.4\left(\mathrm{C}_{\mathrm{q}}\right), 142.0\left(\mathrm{C}_{\mathrm{q}}\right), 140.4\left(\mathrm{C}_{\mathrm{q}}\right), 131.0(\mathrm{CH})$, $130.6(\mathrm{CH}), 129.2\left(\mathrm{C}_{\mathrm{q}}\right), 123.1(\mathrm{CH}), 120.6(\mathrm{CH}), 62.7\left(\mathrm{C}_{\mathrm{q}}\right), 50.5\left(\mathrm{CH}_{2}\right), 37.9$ $\left(\mathrm{CH}_{2}\right), 31.3\left(\mathrm{CH}_{2}\right), 30.3\left(\mathrm{CH}_{2}\right), 29.9\left(\mathrm{CH}_{2}\right), 26.7\left(\mathrm{CH}_{2}\right), 26.3\left(\mathrm{C}_{\mathrm{q}}\right), 22.6\left(\mathrm{CH}_{2}\right)$, $22.3\left(\mathrm{CH}_{3}\right), 14.7\left(\mathrm{CH}_{2}\right), 14.1\left(\mathrm{CH}_{3}\right), 10.0\left(\mathrm{CH}_{2}\right)$. IR (ATR): 2954, 2929, 2857, $1636,1469,1389,1277,1045,778,705 \mathrm{~cm}^{-1}$. MS (ESI) $\mathrm{m} / \mathrm{z}$ (relative intensity): $393(100)[\mathrm{M}+\mathrm{H}]^{+}, 4415(95)[\mathrm{M}+\mathrm{Na}]^{+}$. HR-MS (ESI) $\mathrm{m} / z$ calcd for $\mathrm{C}_{24} \mathrm{H}_{33} \mathrm{~N}_{4} \mathrm{O}$ $[\mathrm{M}+\mathrm{H}]^{+}$393.2649, found 393.2653. 
2'-[(1-Hexyl-1 H-1,2,3-triazol-4-yl)methyl]-6'-(methylthio)dispiro(cyclobutane-1,3'-isoquinoline-4',1"-cyclopropan)-1'(2' H)-one (96sa):<smiles>CCCCCn1cc(CN2CCC3(CC3)c3cc(OC)ccc32)nn1</smiles>

The general procedure GPC was followed using $51 \mathrm{~s}(99.8 \mathrm{mg}, 0.30 \mathrm{mmol})$ and BCP 94a (112 mg, $0.90 \mathrm{mmol})$. Purification by column chromatography ( $n$ hexane/EtOAc $=1 / 2$ ) yielded $96 \mathrm{sa}(50.8 \mathrm{mg}, 40 \%$ ) as colourless oil.

${ }^{1} \mathrm{H}$ NMR $\left(400 \mathrm{MHz}, \mathrm{CDCl}_{3}\right): \delta=7.93(\mathrm{~d}, J=8.2 \mathrm{~Hz}, 1 \mathrm{H}), 7.60(\mathrm{~s}, 1 \mathrm{H}), 7.10$ (dd, $J=8.2,1.8 \mathrm{~Hz}, 1 \mathrm{H}), 6.82(\mathrm{~s}, 1 \mathrm{H}), 5.00(\mathrm{~s}, 2 \mathrm{H}), 4.27(\mathrm{t}, J=7.2 \mathrm{~Hz}, 2 \mathrm{H}), 2.50-$ $2.44(\mathrm{~m}, 5 \mathrm{H}), 1.88-1.82(\mathrm{~m}, 4 \mathrm{H}), 1.79-1.73(\mathrm{~m}, 1 \mathrm{H}), 1.56(\mathrm{dt}, J=11.5,9.0 \mathrm{~Hz}$, $1 \mathrm{H}), 1.28-1.22(\mathrm{~m}, 6 \mathrm{H}), 1.06-1.02(\mathrm{~m}, 2 \mathrm{H}), 0.99-0.92(\mathrm{~m}, 2 \mathrm{H}), 0.83(\mathrm{t}$, $J=7.0 \mathrm{~Hz}, 3 \mathrm{H}) .{ }^{13} \mathrm{C}$ NMR $\left(101 \mathrm{MHz}, \mathrm{CDCl}_{3}\right): \delta=164.5\left(\mathrm{C}_{\mathrm{q}}\right), 146.1\left(\mathrm{C}_{\mathrm{q}}\right), 144.2$ $\left(\mathrm{C}_{\mathrm{q}}\right), 142.0\left(\mathrm{C}_{\mathrm{q}}\right), 128.9(\mathrm{CH}), 127.0(\mathrm{CH}), 123.1\left(\mathrm{C}_{\mathrm{q}}\right), 123.0(\mathrm{CH}), 119.4(\mathrm{CH})$, $63.2\left(\mathrm{C}_{\mathrm{q}}\right), 50.5\left(\mathrm{CH}_{2}\right), 38.1\left(\mathrm{CH}_{2}\right), 31.2\left(\mathrm{CH}_{2}\right), 30.3\left(\mathrm{CH}_{2}\right), 30.0\left(\mathrm{CH}_{2}\right), 26.2$ $\left(\mathrm{CH}_{2}\right), 25.9\left(\mathrm{C}_{\mathrm{q}}\right), 22.5\left(\mathrm{CH}_{2}\right), 15.1\left(\mathrm{CH}_{3}\right), 14.5\left(\mathrm{CH}_{2}\right), 14.0\left(\mathrm{CH}_{3}\right), 10.2\left(\mathrm{CH}_{2}\right)$. IR (ATR): 2854, 2928, 2857, 1638, 1594, 1435, 1422, 1384, 1046, $784 \mathrm{~cm}^{-1}$. MS (ESI) $m / z$ (relative intensity): $425(100)[\mathrm{M}+\mathrm{H}]^{+}, 447(60)[\mathrm{M}+\mathrm{Na}]^{+}$. HR-MS (ESI) $\mathrm{m} / z$ calcd for $\mathrm{C}_{24} \mathrm{H}_{33} \mathrm{~N}_{4} \mathrm{OS}[\mathrm{M}+\mathrm{H}]+425.2370$, found 425.2374 . 
2'-[(1-Hexyl-1 H-1,2,3-triazol-4-yl)methyl]-6'-(trifluoromethyl)dispiro(cyclobutane-1,3'-isoquinoline-4',1'-cyclopropan)-1'(2' H)-one (96ha):

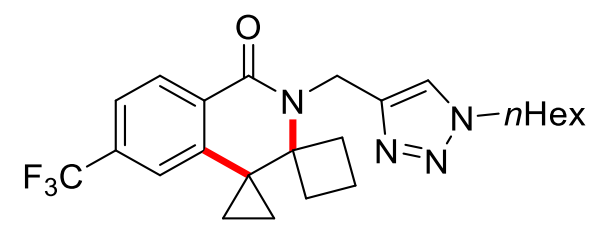

The general procedure GPC was followed using $51 \mathrm{~h}$ (106 $\mathrm{mg}, 0.30 \mathrm{mmol}$ ) and BCP 94a (112 mg, $0.90 \mathrm{mmol}$ ). Purification by column chromatography ( $n$ hexane/EtOAc $=1 / 2)$ yielded $96 \mathrm{ha}(37.5 \mathrm{mg}, 28 \%)$ as colourless oil.

${ }^{1} \mathrm{H}$ NMR $\left(600 \mathrm{MHz}, \mathrm{CDCl}_{3}\right): \delta=8.14(\mathrm{dd}, J=8.0,0.7 \mathrm{~Hz}, 1 \mathrm{H}), 7.61(\mathrm{~s}, 1 \mathrm{H}), 7.54$ (ddd, $J=8.0,1.7,0.8 \mathrm{~Hz}, 1 \mathrm{H}$ ), $7.23(\mathrm{~d}, J=1.6 \mathrm{~Hz}, 1 \mathrm{H}$ ), 5.03 (s, 2H), 4.29 (t, $J=7.2 \mathrm{~Hz}, 2 \mathrm{H}), 2.54(\mathrm{~d}, J=11.9 \mathrm{~Hz}, 2 \mathrm{H}), 1.88-1.83(\mathrm{~m}, 4 \mathrm{H}), 1.83-1.7(\mathrm{~m}, 1 \mathrm{H})$, $1.60(\mathrm{dt}, J=11.6,9.1 \mathrm{~Hz}, 1 \mathrm{H}), 1.32-1.23(\mathrm{~m}, 6 \mathrm{H}), 1.15-1.10(\mathrm{~m}, 2 \mathrm{H}), 1.08-$ $0.99(\mathrm{~m}, 2 \mathrm{H}), 0.83(\mathrm{t}, J=7.0 \mathrm{~Hz}, 3 \mathrm{H}) .{ }^{13} \mathrm{C}$ NMR $\left(151 \mathrm{MHz}, \mathrm{CDCl}_{3}\right): \delta=163.6$ $\left(C_{q}\right), 145.6\left(C_{q}\right), 142.6\left(C_{q}\right), 133.9\left(q,{ }^{2} J_{C-F}=32.3 \mathrm{~Hz}, C_{q}\right), 133.5\left(C_{q}\right), 129.0$ $(\mathrm{CH}), 123.9$ (q, $\left.{ }^{1} J_{C-F}=272.8 \mathrm{~Hz}, \mathrm{C}_{\mathrm{q}}\right), 123.4\left(\mathrm{q},{ }^{3} \mathrm{~J}_{\mathrm{C}-\mathrm{F}}=3.9 \mathrm{~Hz}, \mathrm{CH}\right), 123.0(\mathrm{CH})$, $119.5\left(\mathrm{q},{ }^{3} J_{C-F}=3.9 \mathrm{~Hz}, \mathrm{CH}\right), 63.3\left(\mathrm{C}_{\mathrm{q}}\right), 50.5\left(\mathrm{CH}_{2}\right), 38.3\left(\mathrm{CH}_{2}\right), 31.2\left(\mathrm{CH}_{2}\right)$, $30.3\left(\mathrm{CH}_{2}\right), 30.0\left(\mathrm{CH}_{2}\right), 26.3\left(\mathrm{CH}_{2}\right), 25.9\left(\mathrm{C}_{\mathrm{q}}\right), 22.5\left(\mathrm{CH}_{2}\right), 14.5\left(\mathrm{CH}_{2}\right), 14.0$ $\left(\mathrm{CH}_{3}\right), 10.6\left(\mathrm{CH}_{2}\right) .{ }^{19} \mathrm{~F}$ NMR (565 MHz, $\left.\mathrm{CDCl}_{3}\right): \delta=-62.89$ (s). IR (ATR): 2954 , 2933, 1646, 1443, 1295, 1443, 1295, 1167, 1128, $1048 \mathrm{~cm}^{-1}$. MS (ESI) m/z (relative intensity): $447(45)[\mathrm{M}+\mathrm{H}]^{+}, 469(100)[\mathrm{M}+\mathrm{Na}]^{+}$. HR-MS (ESI) $\mathrm{m} / \mathrm{z}$ calcd for $\mathrm{C}_{24} \mathrm{H}_{30} \mathrm{~F}_{3} \mathrm{~N}_{4} \mathrm{O}[\mathrm{M}+\mathrm{H}]^{+} 447.2366$, found 447.2371 . 


\section{7'-Bromo-2'-[(1-hexyl-1 H-1,2,3-triazol-4-yl)methyl]dispiro(cyclobutane-}

\section{1,3'-isoquinoline-4',1"-cyclopropan)-1'(2' H)-one (96wa):}

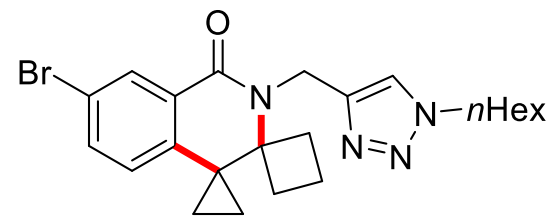

The general procedure GPC was followed using 51 w (110 $\mathrm{mg}, 0.30 \mathrm{mmol})$ and BCP 94a (112 mg, $0.90 \mathrm{mmol}$ ). Purification by column chromatography (nhexane/EtOAc $=1 / 2)$ yielded $96 \mathbf{w a}(42.3 \mathrm{mg}, 31 \%)$ as colourless oil.

${ }^{1} \mathrm{H}$ NMR $\left(500 \mathrm{MHz}, \mathrm{CDCl}_{3}\right): \delta=8.15(\mathrm{~d}, J=2.2 \mathrm{~Hz}, 1 \mathrm{H}), 7.60(\mathrm{~s}, 1 \mathrm{H}), 7.50(\mathrm{~d}$, $J=8.3 \mathrm{~Hz}, 1 \mathrm{H}$ ), $6.87(\mathrm{~d}, J=8.3 \mathrm{~Hz}, 1 \mathrm{H}), 5.00(\mathrm{~s}, 2 \mathrm{H}), 4.28(\mathrm{t}, J=7.2 \mathrm{~Hz}, 2 \mathrm{H})$, $2.50(\mathrm{~d}, J=11.8 \mathrm{~Hz}, 2 \mathrm{H}), 1.88-1.83(\mathrm{~m}, 4 \mathrm{H}), 1.80-1.74(\mathrm{~m}, 1 \mathrm{H}), 1.57$ (dt, $J=11.5,9.1 \mathrm{~Hz}, 1 \mathrm{H}), 1.28-1.23(\mathrm{~m}, 6 \mathrm{H}), 1.09-1.04(\mathrm{~m}, 2 \mathrm{H}), 0.97-0.91(\mathrm{~m}, 2 \mathrm{H})$, $0.83(\mathrm{t}, J=6.9 \mathrm{~Hz}, 3 \mathrm{H}) .{ }^{13} \mathrm{C}$ NMR $\left(126 \mathrm{MHz}, \mathrm{CDCl}_{3}\right): \delta=163.5\left(\mathrm{C}_{\mathrm{q}}\right), 145.7\left(\mathrm{C}_{\mathrm{q}}\right)$, $140.6\left(\mathrm{C}_{\mathrm{q}}\right), 135.1(\mathrm{CH}), 132.2\left(\mathrm{C}_{\mathrm{q}}\right), 131.3(\mathrm{CH}), 124.3(\mathrm{CH}), 123.18(\mathrm{CH}), 120.3$ $\left(\mathrm{C}_{\mathrm{q}}\right)$, $63.2\left(\mathrm{C}_{\mathrm{q}}\right), 50.5\left(\mathrm{CH}_{2}\right), 38.3\left(\mathrm{CH}_{2}\right), 31.2\left(\mathrm{CH}_{2}\right), 30.3\left(\mathrm{CH}_{2}\right), 30.0\left(\mathrm{CH}_{2}\right), 26.2$ $\left(\mathrm{CH}_{2}\right), 25.6\left(\mathrm{C}_{\mathrm{q}}\right), 22.5\left(\mathrm{CH}_{2}\right), 14.5\left(\mathrm{CH}_{2}\right), 14.0\left(\mathrm{CH}_{3}\right), 10.4\left(\mathrm{CH}_{2}\right)$. IR (ATR): 2954, 2930, 1642, 1425, 1374, 1320, 1249, 1132, 1047, $789 \mathrm{~cm}^{-1}$. MS (ESI) $\mathrm{m} / \mathrm{z}$ (relative intensity): $457(47)\left[{ }^{79} \mathrm{Br}, \mathrm{M}+\mathrm{H}\right]^{+}, 479(100)\left[{ }^{79} \mathrm{Br}, \mathrm{M}+\mathrm{Na}\right]^{+}$. HR-MS (ESI) $\mathrm{m} / z$ calcd for $\mathrm{C}_{23} \mathrm{H}_{30}{ }^{79} \mathrm{BrN}{ }_{4} \mathrm{O}[\mathrm{M}+\mathrm{H}]^{+} 457.1598$, found 457.1597 . 
7'-Fluoro-2'-[(1-hexyl-1H-1,2,3-triazol-4-yl)methyl]dispiro(cyclobutane1,3'-isoquinoline-4',1"-cyclopropan)-1'(2' H)-one (96ua):

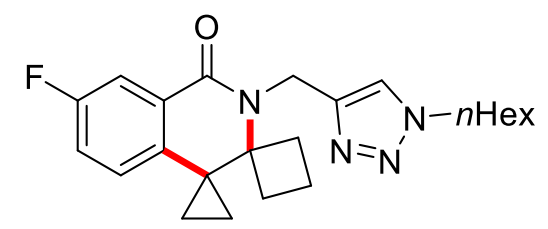

The general procedure GPC was followed using $51 \mathrm{u}(91.3 \mathrm{mg}, 0.30 \mathrm{mmol})$ and BCP 94a (112 mg, $0.90 \mathrm{mmol}$ ). Purification by column chromatography ( $n$ hexane/EtOAc $=1 / 2)$ yielded 96 ua $(34.5 \mathrm{mg}, 29 \%)$ as colourless oil.

${ }^{1} \mathrm{H}$ NMR $\left(400 \mathrm{MHz}, \mathrm{CDCl}_{3}\right): \delta=7.75(\mathrm{dd}, J=9.1,2.8 \mathrm{~Hz}, 1 \mathrm{H}), 7.65(\mathrm{~s}, 1 \mathrm{H}), 7.12$ (dd, $J=8.4,2.8 \mathrm{~Hz}, 1 \mathrm{H}$ ), 7.00 (dd, $J=8.5,4.9 \mathrm{~Hz}, 1 \mathrm{H}$ ), $5.05(\mathrm{~s}, 2 \mathrm{H}), 4.32$ (t, $J=7.2 \mathrm{~Hz}, 2 \mathrm{H}), 2.61-2.48(\mathrm{~m}, 2 \mathrm{H}), 1.92-1.86(\mathrm{~m}, 4 \mathrm{H}), 1.82-1.76(\mathrm{~m}, 1 \mathrm{H}), 1.61$ (dt, $J=11.4,9.1 \mathrm{~Hz}, 1 \mathrm{H}), 1.34-1.24(\mathrm{~m}, 6 \mathrm{H}), 1.12-1.06(\mathrm{~m}, 2 \mathrm{H}), 1.01-0.94(\mathrm{~m}$, $2 \mathrm{H}), 0.87(\mathrm{t}, J=6.9 \mathrm{~Hz}, 3 \mathrm{H}) .{ }^{13} \mathrm{C}$ NMR $\left(101 \mathrm{MHz}, \mathrm{CDCl}_{3}\right): \delta=163.7\left(\mathrm{~d},{ }^{4} J_{\mathrm{C}-\mathrm{F}}=\right.$ $\left.2.6 \mathrm{~Hz}, \mathrm{C}_{\mathrm{q}}\right), 161.6\left(\mathrm{~d},{ }^{1} \mathrm{~J}_{\mathrm{C}-\mathrm{F}}=245.1 \mathrm{~Hz}, \mathrm{C}_{\mathrm{q}}\right), 145.7\left(\mathrm{C}_{\mathrm{q}}\right), 137.2\left(\mathrm{~d},{ }^{4} \mathrm{~J}_{\mathrm{C}-\mathrm{F}}=3.0 \mathrm{~Hz}\right.$, $\left.\mathrm{C}_{\mathrm{q}}\right), 132.3\left(\mathrm{~d},{ }^{3} \mathrm{~J}_{\mathrm{C}-\mathrm{F}}=7.4 \mathrm{~Hz}, \mathrm{CH}\right), 124.3\left(\mathrm{~d},{ }^{3} J_{\mathrm{C}-\mathrm{F}}=7.6 \mathrm{~Hz}, \mathrm{C}_{\mathrm{q}}\right), 123.1(\mathrm{CH})$, $119.1\left(\mathrm{~d},{ }^{2} J_{C-F}=21.9 \mathrm{~Hz}, \mathrm{CH}\right), 115.1\left(\mathrm{~d},{ }^{2} J_{C-F}=23.2 \mathrm{~Hz}, \mathrm{CH}\right), 63.4\left(\mathrm{C}_{\mathrm{q}}\right), 50.5$ $\left(\mathrm{CH}_{2}\right)$, $38.3\left(\mathrm{CH}_{2}\right), 31.2\left(\mathrm{CH}_{2}\right), 30.3\left(\mathrm{CH}_{2}\right), 29.9\left(\mathrm{CH}_{2}\right), 26.2\left(\mathrm{CH}_{2}\right), 25.3\left(\mathrm{C}_{\mathrm{q}}\right)$, $22.5\left(\mathrm{CH}_{2}\right), 14.5\left(\mathrm{CH}_{2}\right), 14.0\left(\mathrm{CH}_{3}\right), 10.2\left(\mathrm{CH}_{2}\right) .{ }^{19} \mathrm{~F} \mathrm{NMR}\left(377 \mathrm{MHz}, \mathrm{CDCl}_{3}\right)$ : $\delta=-115.76$ (td, $J=8.8,5.0 \mathrm{~Hz}$ ). IR (ATR): 2955, 2931, 2858, 1642, 1588, 1443, 1382, 1265, 1047, $825 \mathrm{~cm}^{-1}$. MS (ESI) $\mathrm{m} / \mathrm{z}$ (relative intensity): 397 (44) $[\mathrm{M}+\mathrm{H}]^{+}, 419(100)[\mathrm{M}+\mathrm{Na}]^{+}, 815(20)[2 \mathrm{M}+\mathrm{Na}]^{+}$. HR-MS (ESI) $\mathrm{m} / z$ calcd for $\mathrm{C}_{23} \mathrm{H}_{30} \mathrm{FN} 4 \mathrm{O}[\mathrm{M}+\mathrm{H}]^{+}$397.2398, found 397.2402. 


\subsubsection{Removal of TAH Group}

Dispiro(cyclobutane-1,3'-isoquinoline-4',1"-cyclopropan)-1'(2' H)-one (120):

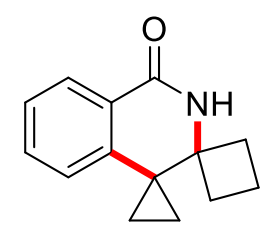

The general procedure GPD was followed using 96aa (114 mg, $0.30 \mathrm{mmol}$ ). Purification by column chromatography ( $n$ hexane/EtOAc $=1 / 2$ ) yielded 120 (42.2 $\mathrm{mg}, 66 \%)$ as a white solid.

M.p. $=188-189^{\circ} \mathrm{C} .{ }^{1} \mathrm{H}$ NMR $\left(400 \mathrm{MHz}, \mathrm{CDCl}_{3}\right): \delta=8.09(\mathrm{dd}, J=7.7,1.6 \mathrm{~Hz}$, 1H), 7.47 (dd, $J=7.7,7.6 \mathrm{~Hz}, 1 \mathrm{H}), 7.33$ (dd, $J=7.8,7.5 \mathrm{~Hz}, 1 \mathrm{H}), 7.02$ (dd, $J=7.8,1.3 \mathrm{~Hz}, 1 \mathrm{H}), 6.41(\mathrm{~s}, 1 \mathrm{H}), 2.18-2.10(\mathrm{~m}, 2 \mathrm{H}), 2.03-1.94(\mathrm{~m}, 3 \mathrm{H}), 1.76-$ $1.66(\mathrm{~m}, 1 \mathrm{H}), 1.19-1.13(\mathrm{~m}, 2 \mathrm{H}), 1.07-1.00(\mathrm{~m}, 2 \mathrm{H}) .{ }^{13} \mathrm{C}$ NMR $(101 \mathrm{MHz}$, $\left.\mathrm{CDCl}_{3}\right): \delta=165.6\left(\mathrm{C}_{\mathrm{q}}\right), 141.8\left(\mathrm{C}_{\mathrm{q}}\right), 132.8(\mathrm{CH}), 129.7\left(\mathrm{C}_{\mathrm{q}}\right), 128.2(\mathrm{CH}), 126.4$ $(\mathrm{CH}), 122.4(\mathrm{CH}), 59.2\left(\mathrm{C}_{\mathrm{q}}\right), 32.5\left(\mathrm{CH}_{2}\right), 25.5\left(\mathrm{C}_{\mathrm{q}}\right), 13.9\left(\mathrm{CH}_{2}\right), 10.6\left(\mathrm{CH}_{2}\right)$. IR (ATR): 2954, 2930, 2857, 1665, 1605, 1465, 1439, 1382, 1052, $759 \mathrm{~cm}^{-1}$. MS (ESI) $m / z$ (relative intensity): $214(100)[\mathrm{M}+\mathrm{H}]^{+}, 256(78)[\mathrm{M}+\mathrm{Na}]^{+}, 449(48)$ $[2 \mathrm{M}+\mathrm{Na}]^{+}$. HR-MS (ESI) $\mathrm{m} / z$ calcd for $\mathrm{C}_{14} \mathrm{H}_{16} \mathrm{NO}[\mathrm{M}+\mathrm{H}]^{+} 214.1226$, found 214.1227. 


\subsubsection{Mechanistic Studies}

\section{Competition Experiments}
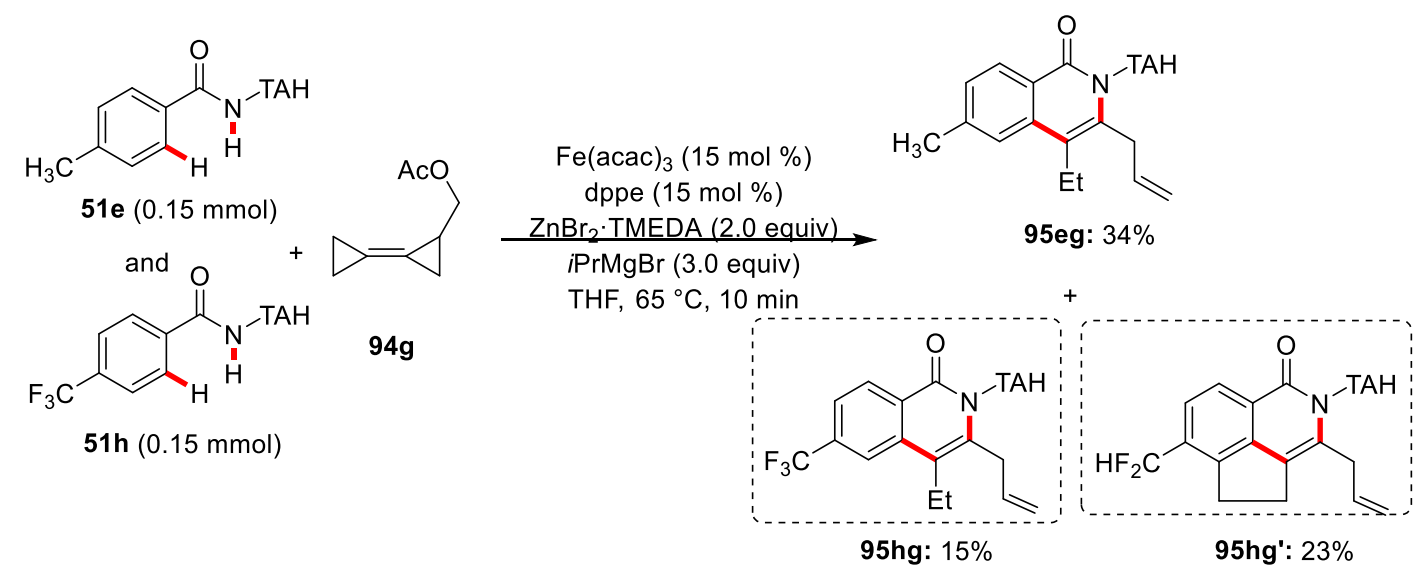

To a stirred solution of $51 \mathrm{e}(45.1 \mathrm{mg}, 0.15 \mathrm{mmol}), 51 \mathrm{~h}(53.2 \mathrm{mg}, 0.15 \mathrm{mmol})$, $\mathrm{ZnBr} 2 \cdot \mathrm{TMEDA}(205 \mathrm{mg}, 0.60 \mathrm{mmol})$ and dppe $(17.9 \mathrm{mg}, 15 \mathrm{~mol} \%)$ in THF $(0.20 \mathrm{~mL}$ ), $\operatorname{PrMgBr}(3.0 \mathrm{M}$ in 2-MeTHF, $300 \mu \mathrm{L}, 0.90 \mathrm{mmol}$ ) was added in one portion and the reaction mixture was stirred for $5 \mathrm{~min}$ at ambient temperature. Then, $\mathrm{Fe}(\mathrm{acac})_{3}(15.9 \mathrm{mg}, 15 \mathrm{~mol} \%)$ was added. After stirring for additional $5 \mathrm{~min}$, a solution of BCP $94 \mathrm{~g}(137 \mathrm{mg}, 0.90 \mathrm{mmol})$ in THF $(0.20 \mathrm{~mL})$ was added in one portion. The reaction mixture was stirred at $65^{\circ} \mathrm{C}$. After $10 \mathrm{~min}$, sat. aqueous $\mathrm{NH}_{4} \mathrm{Cl}(3.0 \mathrm{~mL}$ ) was added and the aqueous phase was extracted with $\mathrm{CH}_{2} \mathrm{Cl}_{2}(3 \times 15 \mathrm{~mL})$. The combined organic phases were dried over $\mathrm{Na}_{2} \mathrm{SO}_{4}$, filtered and concentrated. Purification by column chromatography ( $n$ hexane/EtOAc $=3 / 1$ to $3 / 2$ ) yielded $95 \mathrm{eg}(19.9 \mathrm{mg}, 34 \%)$, 95hg (10.2 mg, $15 \%)$ and 95hg' (15.4 mg, 23\%). 
Intermolecular Kinetic Isotope Effect (KIE) Study

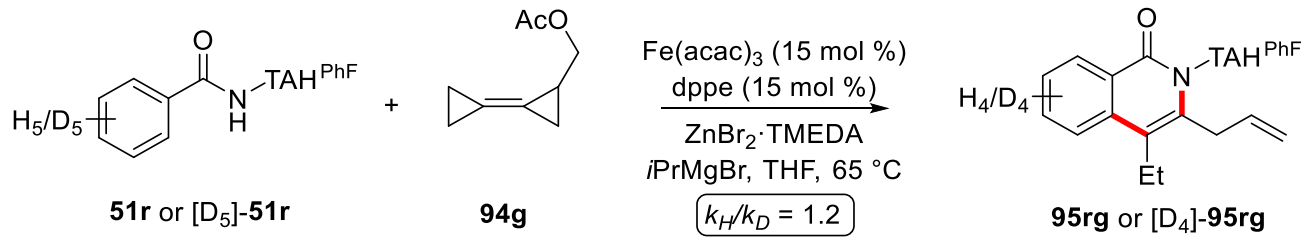

To a stirred solution of $51 \mathrm{r}(29.6 \mathrm{mg}, 0.10 \mathrm{mmol})$ or $\left[\mathrm{D}_{5}\right]-51 \mathrm{r}(30.1 \mathrm{mg}$, $0.10 \mathrm{mmol}), \mathrm{ZnBr}_{2} \cdot \operatorname{TMEDA}(68.3 \mathrm{mg}, 0.20 \mathrm{mmol})$ and dppe $(5.98 \mathrm{mg}$, $15 \mathrm{~mol} \%$ ) in THF (0.1 mL), $\operatorname{PrMgBr}(3.0 \mathrm{M}$ in 2-MeTHF, $0.30 \mathrm{mmol}$ ) was added in one portion and the reaction mixture was stirred for $5 \mathrm{~min}$ at ambient temperature. Then, $\mathrm{Fe}(\mathrm{acac})_{3}(5.29 \mathrm{mg}, 15 \mathrm{~mol} \%)$ in THF $(0.1 \mathrm{~mL})$ was added in a single portion. After stirring for additional $5 \mathrm{~min}$, BCP $94 \mathrm{~g}(30.8 \mathrm{mg}$, $0.2 \mathrm{mmol}$ ) was added in one portion. The reaction mixture was stirred at $65^{\circ} \mathrm{C}$. After the times indicated below, sat. aqueous $\mathrm{NH}_{4} \mathrm{Cl}(3.0 \mathrm{~mL})$ was added and the aqueous phase was extracted with $\mathrm{CH}_{2} \mathrm{Cl}_{2}(3 \times 15 \mathrm{~mL})$. The combined organic phases were dried over $\mathrm{Na}_{2} \mathrm{SO}_{4}$, filtered and concentrated. 1,3,5Triisopropylbenzene (10.2 $\mathrm{mg}, 0.05 \mathrm{mmol}$ ) was added into the reaction mixture then diluted with $\mathrm{CDCl}_{3}(0.7 \mathrm{~mL})$. The yields of product were determined via ${ }^{1} \mathrm{H}$ NMR using $1,3,5$-Triisopropylbenzene $(10.2 \mathrm{mg}, 0.05 \mathrm{mmol})$ as the standard.

\begin{tabular}{cccccccc}
\hline Time [min] & $\mathbf{1}$ & $\mathbf{3}$ & $\mathbf{5}$ & $\mathbf{7}$ & $\mathbf{9}$ & $\mathbf{1 1}$ & $\mathbf{1 3}$ \\
\hline 95rg [\%] & 0.0 & 4.0 & 6.0 & 8.0 & 11.0 & 13.0 & 15.0 \\
\hline $\left.\mathrm{D}_{4}\right]-95 \mathrm{rg}[\%]$ & 1.0 & 3.0 & 5.0 & 7.0 & 10.0 & 11.0 & 13.0 \\
\hline
\end{tabular}




\section{Experimental Part}

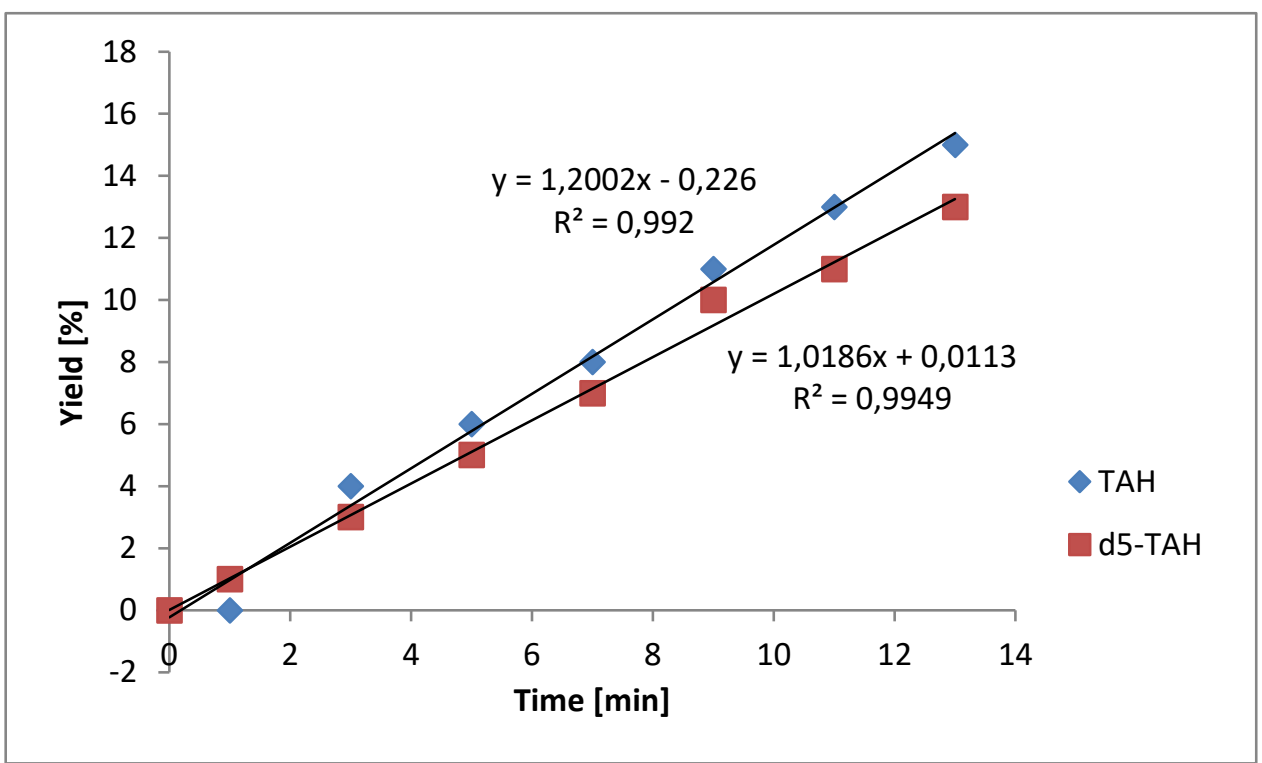

Figure 5.3 Initial rates for the reaction of $51 \mathrm{r}$ or $\left[\mathrm{D}_{5}\right]-\mathbf{5 1 r}$ with $\mathbf{9 4 g}$.

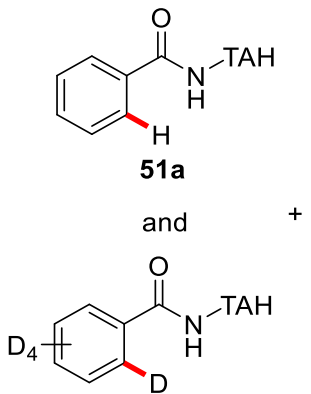

$\left[D_{5}\right]-51 a$

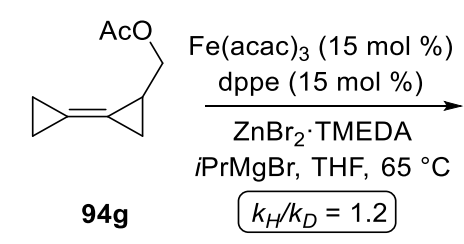

$k_{H} / k_{D}=1.2$

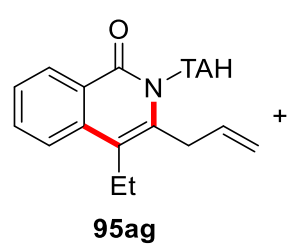

95ag<smiles>C=CCc1c([14CH2])c2ccccc2c(=O)n1[AlH]</smiles>

$\left[D_{4}\right]-95 a g$

To a stirred solution of $51 \mathrm{a}(43.0 \mathrm{mg}, 0.15 \mathrm{mmol})$, [D5]-51a (43.7 mg, $0.15 \mathrm{mmol}$ ) ZnBr $2 \cdot T M E D A ~(205 \mathrm{mg}, 0.60 \mathrm{mmol}$ ) and dppe (17.9 mg, $15 \mathrm{~mol} \%$ ) in THF (0.20 mL), IPrMgBr (3.0 M in 2-MeTHF, $300 \mu \mathrm{L}, 0.90 \mathrm{mmol})$ was added in one portion and the reaction mixture was stirred for $5 \mathrm{~min}$ at ambient temperature. Then, $\mathrm{Fe}(\mathrm{acac}) 3(15.9 \mathrm{mg}, 15 \mathrm{~mol} \%)$ was added. After stirring for additional $5 \mathrm{~min}$, a solution of BCP $94 \mathrm{~g}(137 \mathrm{mg}, 0.90 \mathrm{mmol})$ in THF $(0.2 \mathrm{~mL})$ was added in one portion. After stirring 10 min at $65^{\circ} \mathrm{C}$, sat. aqueous $\mathrm{NH}_{4} \mathrm{Cl}$ $(3.0 \mathrm{~mL})$ was added and aqueous phase was extracted with $\mathrm{CH}_{2} \mathrm{Cl}_{2}$ $(3 \times 15 \mathrm{~mL})$. The combined organic phases were dried over $\mathrm{Na}_{2} \mathrm{SO}_{4}$, filtered and concentrated under reduced pressure. Purification by column 


\section{Experimental Part}

chromatography ( $n$ hexane/EtOAc $=3 / 2$ ) afforded a mixture of both products. The ratio of $95 \mathrm{ag}$ to [D4]-95ag was determined by ${ }^{1} \mathrm{H}$ NMR spectroscopic analysis.

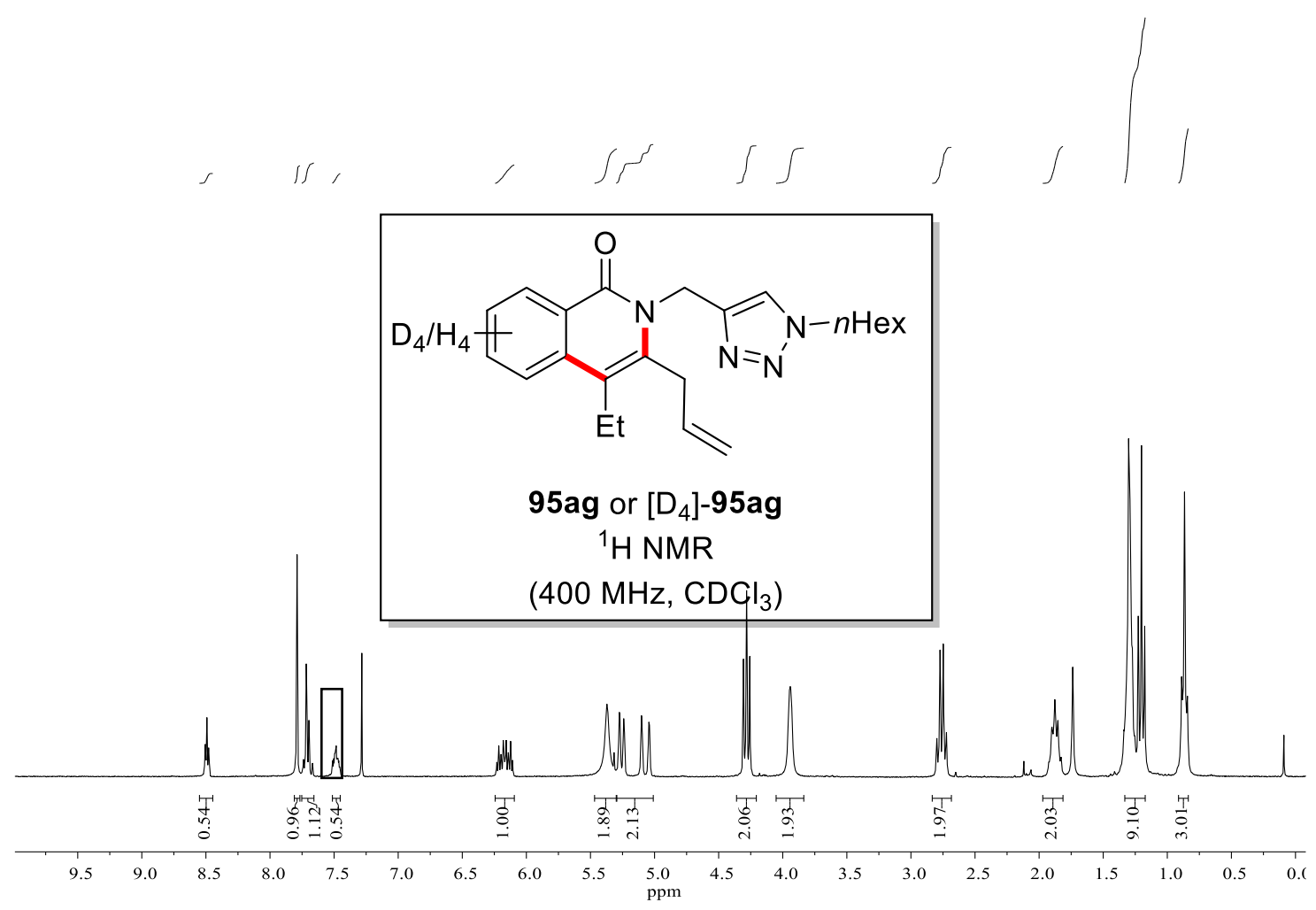

\section{Isotopically-labelled Experiments}

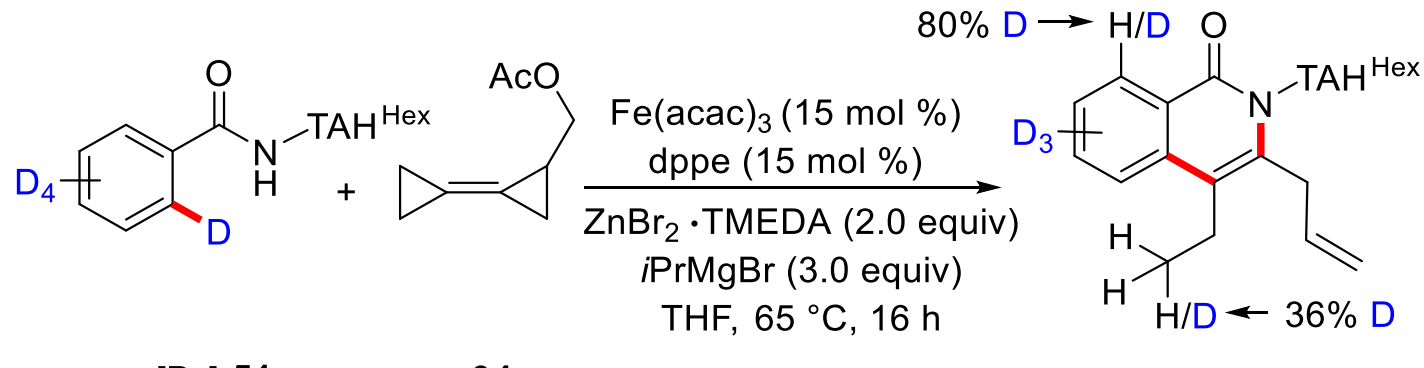

$\left[D_{5}\right]-51 a$

$94 \mathrm{~g}$

$\left[D_{n}\right]-95$ ag: $58 \%$

To a stirred solution of [D5]-51a (87.4 mg, $0.30 \mathrm{mmol}), \mathrm{ZnBr}_{2} \cdot \mathrm{TMEDA}$ (205 mg, $0.60 \mathrm{mmol})$, dppe (17.9 mg, $15 \mathrm{~mol} \%)$ in THF (0.20 mL), $\operatorname{PrMgBr}(3.0 \mathrm{M}$ in 2MeTHF, $300 \mu \mathrm{L}, 0.90 \mathrm{mmol}$ ) was added in one portion and the reaction mixture was stirred for $5 \mathrm{~min}$ at ambient temperature. Then, Fe(acac) 3 (15.9 mg, $15 \mathrm{~mol} \%$ ) was added. After stirring the solution for additional $5 \mathrm{~min}$, a solution of BCP $94 \mathrm{~g}(137 \mathrm{mg}, 0.90 \mathrm{mmol})$ in THF $(0.20 \mathrm{~mL})$ was added in one portion. 


\section{Experimental Part}

The mixture was placed in a pre-heated oil bath at $65^{\circ} \mathrm{C}$. After stirring for $16 \mathrm{~h}$, sat. aqueous $\mathrm{NH}_{4} \mathrm{Cl}(2.0 \mathrm{~mL})$ was added to the reaction mixture and the aqueous phase was extracted with $\mathrm{CH}_{2} \mathrm{Cl}_{2}(3 \times 15 \mathrm{~mL})$. The combined organic phases were dried over $\mathrm{Na}_{2} \mathrm{SO}_{4}$, filtered and concentrated. Purification by column chromatography ( $n$ hexane/EtOAc $=3 / 2)$ yielded $\left[D_{n}\right]-95 a g(66.6 \mathrm{mg}$, $58 \%$ ) as colourless oil.

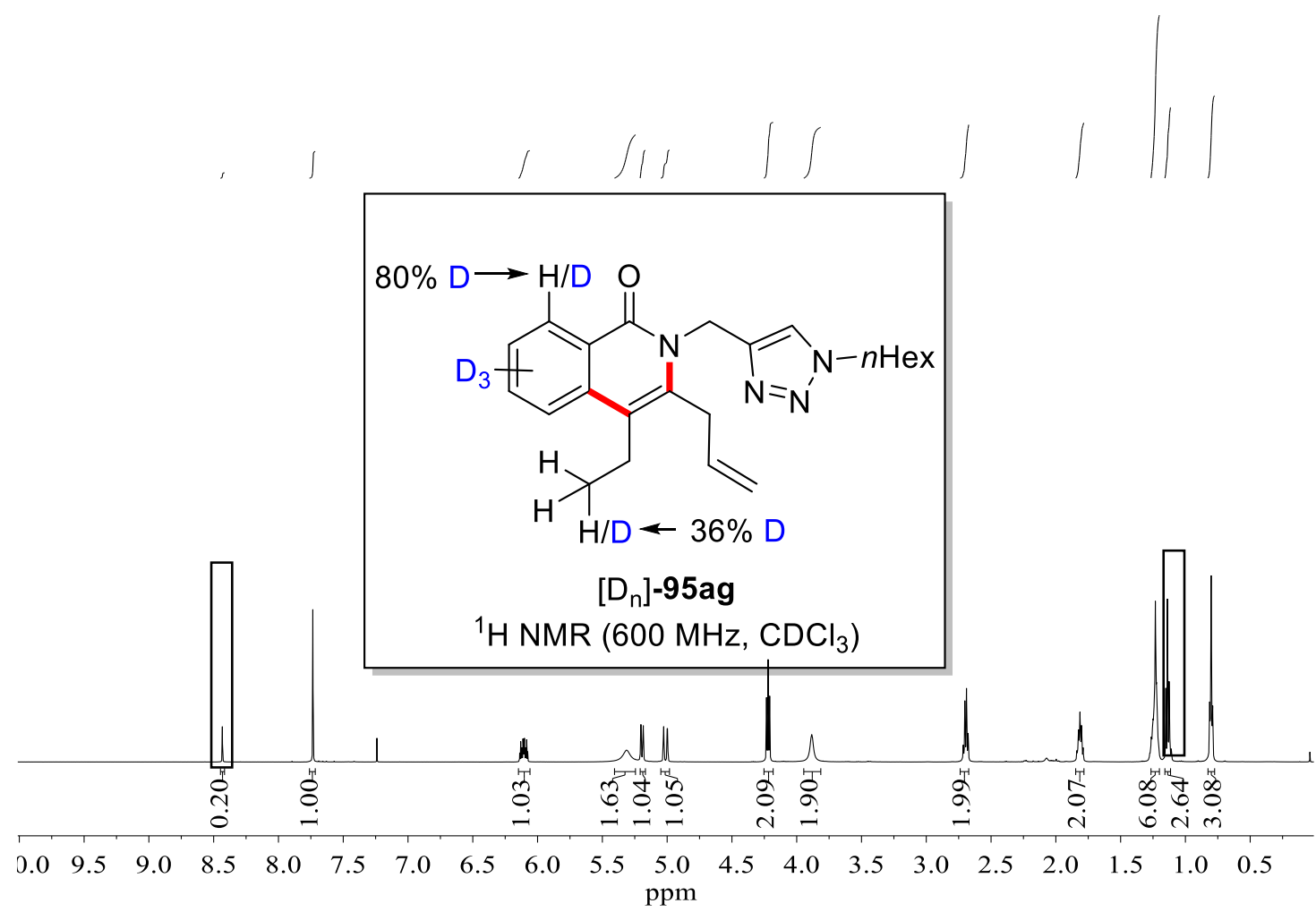


5. Experimental Part

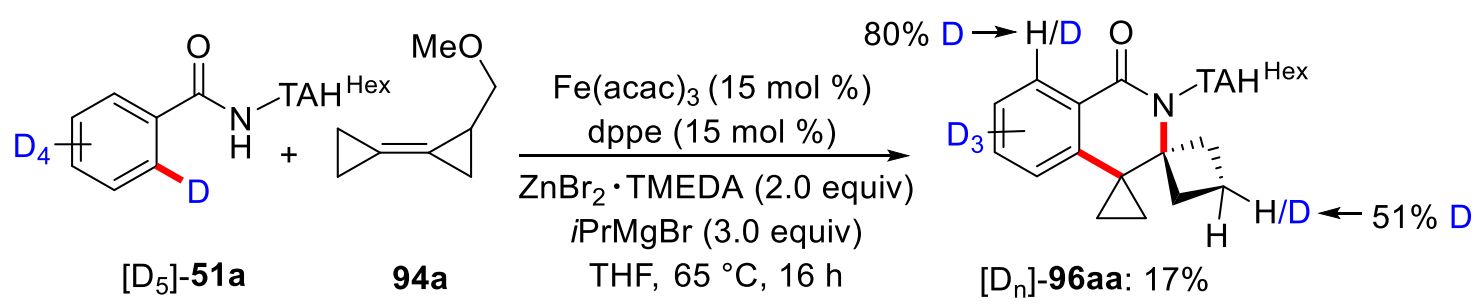

To a stirred solution of [D5]-51a (87.4 mg, $0.30 \mathrm{mmol}), \mathrm{ZnBr}_{2} \cdot \mathrm{TMEDA}$ (205 mg, $0.60 \mathrm{mmol})$, dppe (17.9 mg, $15 \mathrm{~mol} \%)$ in THF $(0.20 \mathrm{~mL}), \operatorname{PrMgBr}(3.0 \mathrm{M}$ in 2MeTHF, $300 \mu \mathrm{L}, 0.90 \mathrm{mmol}$ ) was added in one portion and the reaction mixture was stirred for $5 \mathrm{~min}$ at ambient temperature. Then, $\mathrm{Fe}(\mathrm{acac})_{3}(15.9 \mathrm{mg}$, $15 \mathrm{~mol} \%$ ) was added. After stirring the solution for additional $5 \mathrm{~min}$, a solution of BCP 94a (137 mg, $0.90 \mathrm{mmol})$ in THF $(0.20 \mathrm{~mL})$ was added in one portion. The mixture was placed in a pre-heated oil bath at $65^{\circ} \mathrm{C}$. After stirring for $16 \mathrm{~h}$, sat. aqueous $\mathrm{NH}_{4} \mathrm{Cl}(2.0 \mathrm{~mL})$ was added to the reaction mixture and the aqueous phase was extracted with $\mathrm{CH}_{2} \mathrm{Cl}_{2}(3 \times 15 \mathrm{~mL})$. The combined organic phases were dried over $\mathrm{Na}_{2} \mathrm{SO}_{4}$, filtered and concentrated. Purification by column chromatography $($ nhexane/EtOAc $=1 / 2)$ yielded $\left[\mathrm{D}_{\mathrm{n}}\right]-96 \mathrm{aa}(19.5 \mathrm{mg}$, $17 \%)$ as colourless oil.

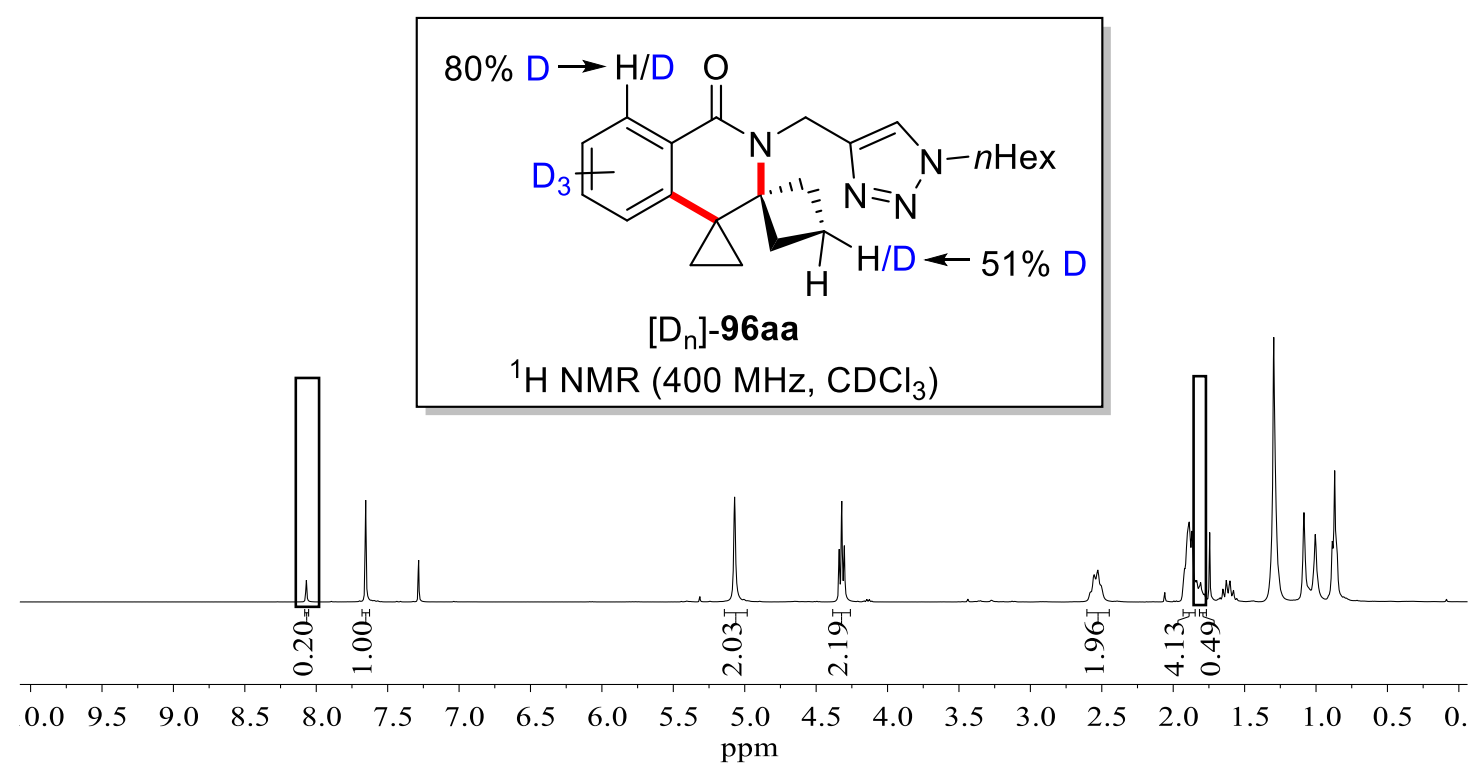




\section{Experimental Part}

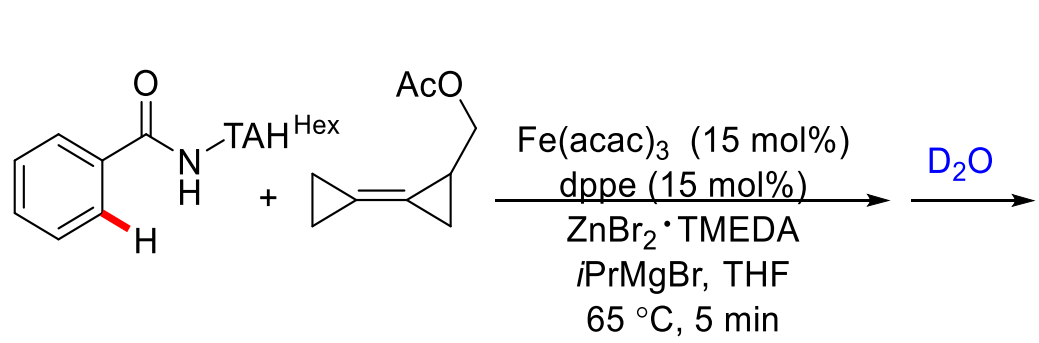

$51 \mathrm{a}$

$94 \mathrm{~g}$

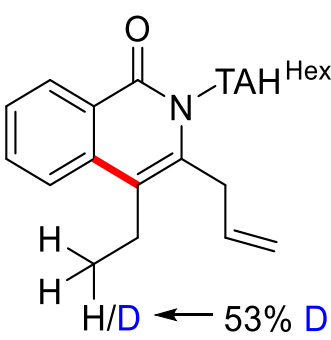

[D]-95ag: $24 \%$

To a stirred solution of 51a ( $85.9 \mathrm{mg}, 0.3 \mathrm{mmol}$ ), $\mathrm{ZnBr} 2 \cdot \mathrm{TMEDA}$ (205 mg, $0.60 \mathrm{mmol})$ and dppe (17.9 mg, $15 \mathrm{~mol} \%)$ in THF (0.2 mL), $\operatorname{PrMgBr}(3.0 \mathrm{M}$ in 2-MeTHF, $300 \mu \mathrm{L}, 0.90 \mathrm{mmol}$ ) was added in one portion and the reaction mixture was stirred for $5 \mathrm{~min}$ at ambient temperature. Then, $\mathrm{Fe}(\mathrm{acac})_{3}$ (15.9 mg, $15 \mathrm{~mol} \%$ ) was added. After stirring for additional $5 \mathrm{~min}$, a solution of BCP $94 \mathrm{~g}$ (137 mg, $0.90 \mathrm{mmol})$ in THF $(0.20 \mathrm{~mL})$ was added in one portion. The reaction mixture was stirred at $65^{\circ} \mathrm{C}$. After $5 \mathrm{~min}, \mathrm{D}_{2} \mathrm{O}(2.0 \mathrm{~mL})$ was added and the aqueous phase was extracted with $\mathrm{CH}_{2} \mathrm{Cl}_{2}(3 \times 15 \mathrm{~mL})$. The combined organic phases were dried over $\mathrm{Na}_{2} \mathrm{SO}_{4}$, filtered and concentrated. Purification by column chromatography ( $n$ hexane/EtOAc $=3 / 2)$ yielded $[D]-95 a g ~(27 \mathrm{mg}$, $24 \%)$ The amount of deuterium incorporation was determined by ${ }^{1} \mathrm{H}$ NMR.

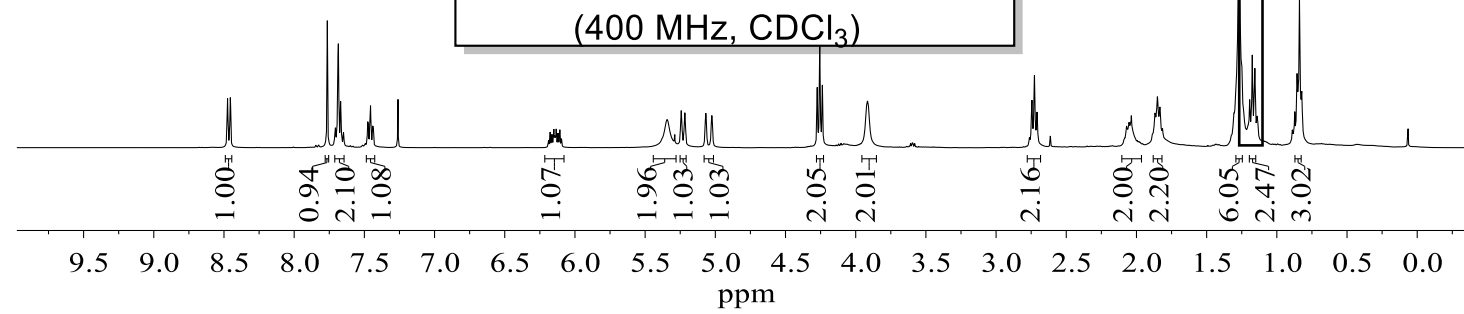




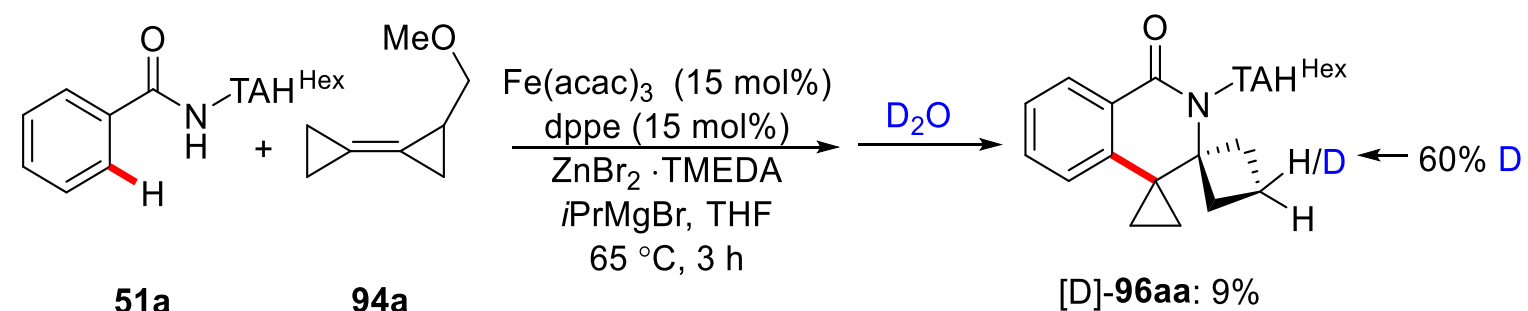

To a stirred solution of $51 \mathrm{a}(85.9 \mathrm{mg}, 0.3 \mathrm{mmol}), \mathrm{ZnBr} \cdot \mathrm{TMEDA}$ (205 mg, $0.60 \mathrm{mmol})$ and dppe (17.9 mg, $15 \mathrm{~mol} \%)$ in THF (0.2 mL), $\operatorname{PrMgBr}(3.0 \mathrm{M}$ in 2-MeTHF, $300 \mu \mathrm{L}, 0.90 \mathrm{mmol}$ ) was added in one portion and the reaction mixture was stirred for $5 \mathrm{~min}$ at ambient temperature. Then, $\mathrm{Fe}(\mathrm{acac})_{3}$ (15.9 mg, $15 \mathrm{~mol} \%$ ) was added. After stirring for additional $5 \mathrm{~min}$, a solution of BCP 94a (112 mg, $0.90 \mathrm{mmol})$ in THF $(0.20 \mathrm{~mL})$ was added in one portion. The reaction mixture was stirred at $65^{\circ} \mathrm{C}$. After $3 \mathrm{~h}, \mathrm{D}_{2} \mathrm{O}(2.0 \mathrm{~mL})$ was added and the aqueous phase was extracted with $\mathrm{CH}_{2} \mathrm{Cl}_{2}(3 \times 15 \mathrm{~mL})$. The combined organic phases were dried over $\mathrm{Na}_{2} \mathrm{SO}_{4}$, filtered and concentrated. Purification by column chromatography ( $n$ hexane/EtOAc $=1 / 2)$ yielded [D]-96aa $(10.2 \mathrm{mg}$, 9\%) The position of deuterium incorporation was determined by ${ }^{1} \mathrm{H}$ NMR.

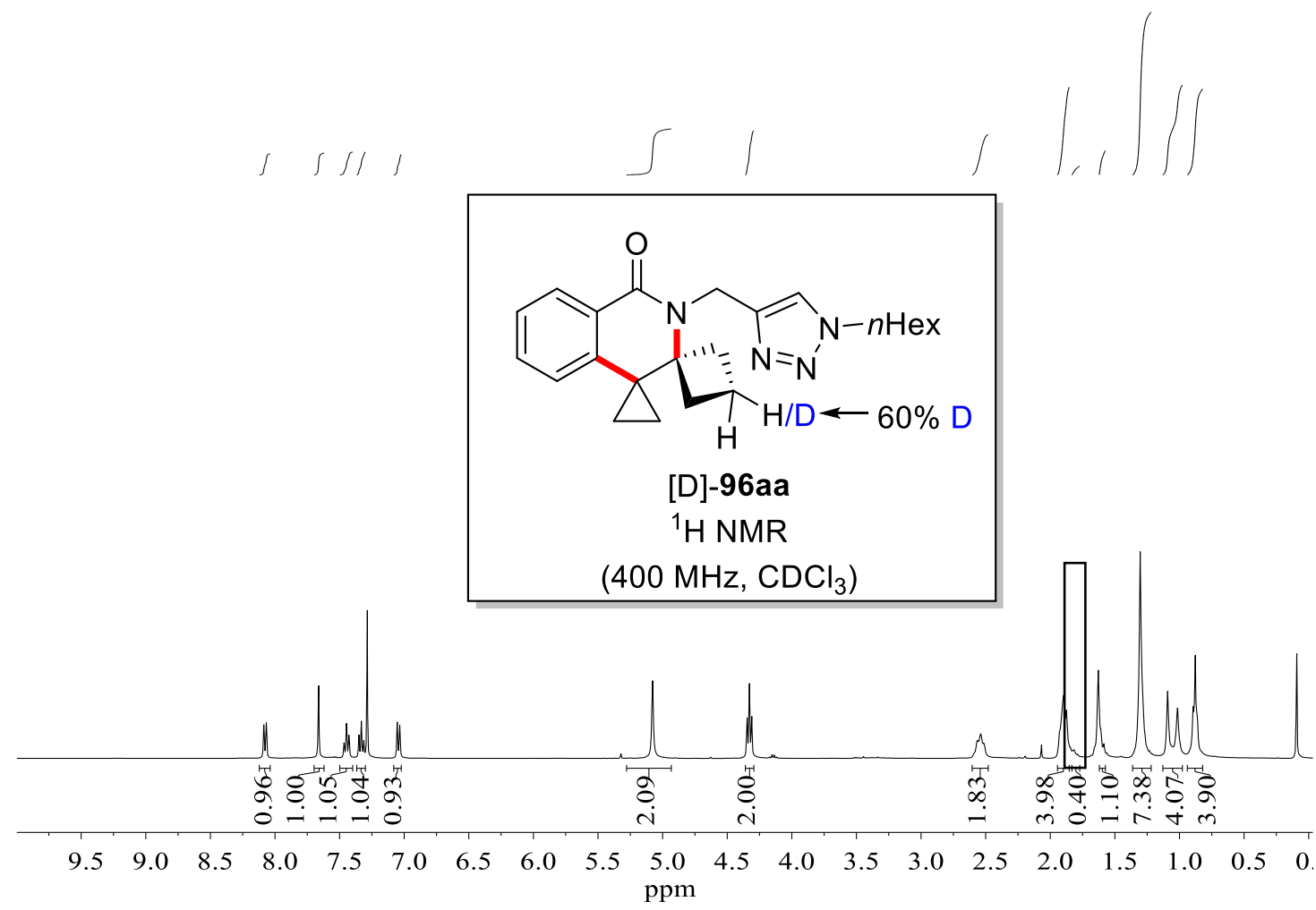


5. Experimental Part

\subsection{Mössbauer Measurement}

After sample preparation, the spectra were recorded and interpreted by Dr. S. Demeshko.

Table 5.1 Mössbauer parameters of reaction mixtures.

\begin{tabular}{|c|c|c|c|c|c|}
\hline Entry & Reaction & $\begin{array}{c}\text { Valence of Iron/ } \\
\text { Spin State }\end{array}$ & $\begin{array}{c}\delta \\
\left(\mathrm{mm} \mathrm{s}^{-1}\right)\end{array}$ & $\begin{array}{c}\Delta E_{Q} \\
\left(\mathrm{~mm} \mathrm{~s}^{-1}\right)\end{array}$ & $\begin{array}{l}\text { rel. int. } \\
\text { (\%) }\end{array}$ \\
\hline 1 & ${ }^{57} \mathrm{FeCl}_{2}+\mathrm{THF}$ & $+2^{\mathrm{HS}}$ & 1.26 & 3.05 & 100 \\
\hline 2 & Entry $1+\mathrm{MeMgBr}$ & $+1.4^{[91]}$ & 0.29 & 0.88 & 100 \\
\hline \multirow[t]{3}{*}{3} & Entry $2+$ & $+2^{\mathrm{HS}}$ & 1.01 & 2.69 & 69 \\
\hline & $\mathrm{ZnBr}_{2} \cdot \mathrm{TMEDA}$ & $+2^{\mathrm{HS}}$ & 1.36 & 2.56 & 31 \\
\hline & & $+2^{\mathrm{HS}}$ & 0.92 & 1.42 & 23 \\
\hline \multirow[t]{2}{*}{4} & Entry $3+$ dppe & $+2^{\mathrm{HS}}$ & 0.98 & 2.57 & 40 \\
\hline & & $+2^{\mathrm{HS}}$ & 1.24 & 2.68 & 37 \\
\hline \multirow[t]{4}{*}{5} & Entry $4+\mathbf{5 1 a}$ & n.a. & 0.26 & 1.01 & 43 \\
\hline & & $+2^{\mathrm{HS}}$ & 1.14 & 2.45 & 36 \\
\hline & & $+2^{\mathrm{HS}}$ & 1.00 & 3.17 & 21 \\
\hline & & $+2^{\mathrm{HS}}$ & 0.89 & 2.05 & 30 \\
\hline \multirow[t]{2}{*}{$6^{[a]}$} & Entry $4+51 a$ & $+2^{\mathrm{HS}}$ & 0.93 & 2.63 & 49 \\
\hline & & $+2^{\mathrm{HS}}$ & 1.02 & 3.07 & 21 \\
\hline \multirow[t]{3}{*}{7} & Entry $5+88 a$ & n.a. & 0.24 & 1.43 & 28 \\
\hline & & $+2^{\mathrm{HS}}$ & 0.68 & 1.94 & 29 \\
\hline & & $+2^{\mathrm{HS}}$ & 1.12 & 2.60 & 43 \\
\hline \multirow[t]{2}{*}{8} & Entry $5+91 a$ & $+2^{\mathrm{HS}}$ & 1.00 & 2.94 & 48 \\
\hline & & $+2^{\mathrm{HS}}$ & 0.95 & 2.29 & 52 \\
\hline
\end{tabular}


5. Experimental Part

\begin{tabular}{|c|c|c|c|c|c|}
\hline \multirow[t]{3}{*}{9} & Entry $6+\mathbf{9 4 g}$ & $+2^{\mathrm{HS}}$ & 0.95 & 2.22 & 33 \\
\hline & & $+2^{\mathrm{HS}}$ & 1.02 & 2.79 & 55 \\
\hline & & $+2^{\mathrm{HS}}$ & 1.05 & 3.13 & 12 \\
\hline \multirow{3}{*}{$10^{[a]}$} & \multirow{3}{*}{ Entry $4+\mathbf{3 2 a}+\mathbf{9 4 g}$} & $+2^{\mathrm{HS}}$ & 0.92 & 2.09 & 44 \\
\hline & & $+2^{\mathrm{HS}}$ & 0.95 & 2.66 & 36 \\
\hline & & $+2^{\mathrm{HS}}$ & 1.03 & 3.00 & 20 \\
\hline \multirow[t]{3}{*}{11} & Entry $6+94 a$ & $+2^{\mathrm{HS}}$ & 0.74 & 2.34 & 13 \\
\hline & & $+2^{\mathrm{HS}}$ & 1.02 & 2.63 & 65 \\
\hline & & $+2^{\mathrm{HS}}$ & 1.03 & 3.09 & 22 \\
\hline
\end{tabular}

[a] used $\mathrm{MeMgBr}$ (3 equiv), $\mathrm{ZnBr}_{2} \cdot \mathrm{TMEDA}$ (2 equiv). n.a. = not assign.

\section{Sample Preparation for Mössbauer Measurements}

\section{Entry $1 .{ }^{57} \mathrm{FeCl}_{2}+$ THF}

Inside a nitrogen-filled glovebox, a suspension of ${ }^{57} \mathrm{FeCl}_{2}(3.2 \mathrm{mg}, 25 \mu \mathrm{mol})$ in THF $(0.80 \mathrm{~mL})$ was stirred at ambient temperature for $5 \mathrm{~min}$. Then, the solution was filtered and added into a sample holder. The sample holder was taken out of the glovebox and frozen in liquid nitrogen immediately.

\section{Entry 2. ${ }^{57} \mathrm{FeCl}_{2}+\mathrm{MeMgBr}+\mathrm{THF}$}

Inside a nitrogen-filled glovebox, a suspension of $\mathrm{MeMgBr}\left(3.0 \mathrm{M}\right.$ in $\mathrm{Et}_{2} \mathrm{O}$, $75 \mu \mathrm{L}, 9.0$ equiv) in THF $(17 \mu \mathrm{L})$ was stirred at ambient temperature for $5 \mathrm{~min}$. Then, ${ }^{57} \mathrm{FeCl}_{2}$ (3.2 mg, $25 \mu \mathrm{mol}$ ) was added. After stirring for additional $5 \mathrm{~min}$, the solution was diluted to $5.0 \mathrm{~mL}$ by adding THF, $0.80 \mathrm{~mL}$ of the solution was filtered and added into a sample holder. The sample holder was taken out of the glovebox and frozen in liquid nitrogen immediately. 


\section{Experimental Part}

\section{Entry 3. ${ }^{57} \mathrm{FeCl}_{2}+\mathrm{MeMgBr}+\mathrm{ZnBr}_{2} \cdot \mathrm{TMEDA}+\mathrm{THF}$}

Inside a nitrogen-filled glovebox, to a stirred solution of $\mathrm{ZnBr}_{2}$.TMEDA (51.6 mg, 6.0 equiv) in THF (17 $\mu \mathrm{L}), \operatorname{MeMgBr}\left(3.0 \mathrm{M}\right.$ in $\mathrm{Et}_{2} \mathrm{O}, 75 \mu \mathrm{L}, 9.0$ equiv) was added in one portion and the reaction mixture was stirred for $5 \mathrm{~min}$ at ambient temperature. Then, ${ }^{57} \mathrm{FeCl}_{2}(3.2 \mathrm{mg}, 25 \mu \mathrm{mol})$ was added. After stirring for additional $5 \mathrm{~min}$, the solution was diluted to $5.0 \mathrm{~mL}$ by adding THF, $0.80 \mathrm{~mL}$ of the solution was filtered and added into a sample holder. The sample holder was taken out of the glovebox and frozen in liquid nitrogen immediately.

\section{Entry 4. ${ }^{57} \mathrm{FeCl}_{2}+\mathrm{MeMgBr}+\mathrm{ZnBr}_{2} \cdot \mathrm{TMEDA}+\mathrm{dppe}+\mathrm{THF}$}

Inside a nitrogen-filled glovebox, to a stirred solution of $\mathrm{ZnBr}_{2}$.TMEDA (51.6 mg, 6.0 equiv) and dppe (10.0 mg, 1.0 equiv) in THF (17 $\mu \mathrm{L}), \mathrm{MeMgBr}$ (3.0 $\mathrm{M}$ in $\mathrm{Et}_{2} \mathrm{O}, 75 \mu \mathrm{L}, 9.0$ equiv) was added in one portion and the reaction mixture was stirred for $5 \mathrm{~min}$ at ambient temperature. Then, ${ }^{57} \mathrm{FeCl}_{2}(3.2 \mathrm{mg}$, $25 \mu \mathrm{mol})$ was added. After stirring for additional $5 \mathrm{~min}$, the solution was diluted to $5.0 \mathrm{~mL}$ by adding THF, $0.80 \mathrm{~mL}$ of the solution was filtered and added into a sample holder. The sample holder was taken out of the glovebox and frozen in liquid nitrogen immediately.

Entry 5. ${ }^{57} \mathrm{FeCl}_{2}+\mathrm{MeMgBr}$ (9 equiv) + $\mathrm{ZnBr}_{2} \cdot$ TMEDA (3 equiv) + dppe + TAH-substrate (51a) + THF

Inside a nitrogen-filled glovebox, to a stirred solution of $51 \mathrm{a}$ (7.2 mg, 1.0 equiv), $\mathrm{ZnBr}_{2} \cdot \mathrm{TMEDA}(51.6 \mathrm{mg}, 6.0$ equiv) and dppe (10.0 mg, 1.0 equiv) in THF $(17 \mu \mathrm{L}), \mathrm{MeMgBr}\left(3.0 \mathrm{M}\right.$ in $\mathrm{Et}_{2} \mathrm{O}, 75 \mu \mathrm{L}, 9.0$ equiv) was added in one portion and the reaction mixture was stirred for $5 \mathrm{~min}$ at ambient temperature. Then, ${ }^{57} \mathrm{FeCl}_{2}(3.2 \mathrm{mg}, 25 \mu \mathrm{mol})$ was added. After stirring for additional $5 \mathrm{~min}$, the solution was diluted to $5.0 \mathrm{~mL}$ by adding THF, $0.80 \mathrm{~mL}$ of the solution was filtered and added into a sample holder. The sample holder was taken out of the glovebox and frozen in liquid nitrogen immediately. 


\section{Experimental Part}

Entry 6. ${ }^{57} \mathrm{FeCl}_{2}+\mathrm{MeMgBr}+\mathrm{ZnBr}_{2} \cdot \mathrm{TMEDA}+$ dppe + TAH-substrate (51a) + THF

Inside a nitrogen-filled glovebox, to a stirred solution of $51 \mathrm{a}(7.2 \mathrm{mg}, 1.0$ equiv), $\mathrm{ZnBr}$-TMEDA (17.2 mg, 2.0 equiv) and dppe (10.0 mg, 1.0 equiv) in THF $(17 \mu \mathrm{L}), \mathrm{MeMgBr}\left(3.0 \mathrm{M}\right.$ in $\mathrm{Et}_{2} \mathrm{O}, 25 \mu \mathrm{L}, 3.0$ equiv) was added in one portion and the reaction mixture was stirred for $5 \mathrm{~min}$ at ambient temperature. Then, ${ }^{57} \mathrm{FeCl}_{2}(3.2 \mathrm{mg}, 25 \mu \mathrm{mol})$ was added. After stirring for additional $5 \mathrm{~min}$, the solution was diluted to $5.0 \mathrm{~mL}$ by adding THF, $0.80 \mathrm{~mL}$ of the solution was filtered and added into a sample holder. The sample holder was taken out of the glovebox and frozen in liquid nitrogen immediately.

Entry 7. ${ }^{57} \mathrm{FeCl}_{2}+\mathrm{MeMgBr}+\mathrm{ZnBr} 2 \cdot \mathrm{TMEDA}+$ dppe + TAH-substrate (51a) + allene (88a) + THF

Inside a nitrogen-filled glovebox, to a stirred solution of $51 \mathrm{a}(7.2 \mathrm{mg}, 1.0$ equiv), $\mathrm{ZnBr}_{2} \cdot \mathrm{TMEDA}(51.6 \mathrm{mg}, 6.0$ equiv) and dppe (10.0 mg, 1.0 equiv) in THF $(17 \mu \mathrm{L}), \mathrm{MeMgBr}\left(3.0 \mathrm{M}\right.$ in $\mathrm{Et}_{2} \mathrm{O}, 75 \mu \mathrm{L}, 9.0$ equiv) was added in one portion and the reaction mixture was stirred for $5 \mathrm{~min}$ at ambient temperature. Then, ${ }^{57} \mathrm{FeCl}_{2}(3.2 \mathrm{mg}, 25 \mu \mathrm{mol})$ was added. After stirring for additional $5 \mathrm{~min}$, allene 88a (13.6 mg, 3.0 equiv) was added as a solution in THF (17 $\mu \mathrm{L})$. After stirring for additional $5 \mathrm{~min}$, the solution was diluted to $5.0 \mathrm{~mL}$ by adding THF, $0.80 \mathrm{~mL}$ of the solution was filtered and added into a sample holder. The sample holder was taken out of the glovebox and frozen in liquid nitrogen immediately.

Entry 8. ${ }^{57} \mathrm{FeCl}_{2}+\mathrm{MeMgBr}+\mathrm{ZnBr} 2 \cdot \mathrm{TMEDA}+$ dppe + TAH-substrate (51a) + alkyne (91a) + THF

Inside a nitrogen-filled glovebox, to a stirred solution of $51 \mathrm{a}$ (7.2 $\mathrm{mg}, 1.0$ equiv), $\mathrm{ZnBr}_{2} \cdot \mathrm{TMEDA}$ (51.6 mg, 6.0 equiv) and dppe (10.0 mg, 1.0 equiv) in THF $(17 \mu \mathrm{L}), \mathrm{MeMgBr}\left(3.0 \mathrm{M}\right.$ in $\mathrm{Et}_{2} \mathrm{O}, 75 \mu \mathrm{L}, 9.0$ equiv) was added in one portion and the reaction mixture was stirred for $5 \mathrm{~min}$ at ambient temperature. Then, 


\section{Experimental Part}

${ }^{57} \mathrm{FeCl}_{2}$ (3.2 mg, $25 \mu \mathrm{mol}$ ) was added. After stirring for additional $5 \mathrm{~min}$, alkyne 91a (16.2 mg, 3.0 equiv) was added as a solution in THF (17 $\mu \mathrm{L})$. After stirring for additional $5 \mathrm{~min}$, the solution was diluted to $5.0 \mathrm{~mL}$ by adding THF, $0.80 \mathrm{~mL}$ of the solution was filtered and added into a sample holder. The sample holder was taken out of the glovebox and frozen in liquid nitrogen immediately.

\section{Entry 9. ${ }^{57} \mathrm{FeCl}_{2}+\mathrm{MeMgBr}+\mathrm{ZnBr}_{2} \cdot \mathrm{TMEDA}+$ dppe + TAH-substrate (51a) + BCP (94g)+ THF}

Inside a nitrogen-filled glovebox, to a stirred solution of $51 \mathrm{a}$ (7.2 $\mathrm{mg}, 1.0$ equiv), $\mathrm{ZnBr}_{2}$.TMEDA (17.2 mg, 2.0 equiv) and dppe (10.0 mg, 1.0 equiv) in THF (17 $\mu \mathrm{L}$ ), $\mathrm{MeMgBr}$ (3.0 $\mathrm{M}$ in $\mathrm{Et}_{2} \mathrm{O}, 25 \mu \mathrm{L}, 3.0$ equiv) was added in one portion and the reaction mixture was stirred for $5 \mathrm{~min}$ at ambient temperature. Then, ${ }^{57} \mathrm{FeCl}_{2}$ (3.2 mg, $\left.25 \mu \mathrm{mol}\right)$ was added. After stirring for additional $5 \mathrm{~min}, \mathrm{BCP}$ 94g (11.4 mg, 3.0 equiv) was added as a solution in THF (17 $\mu \mathrm{L})$. After stirring for additional $5 \mathrm{~min}$, the solution was diluted to $5.0 \mathrm{~mL}$ by adding THF, $0.80 \mathrm{~mL}$ of the solution was filtered and added into a sample holder. The sample holder was taken out of the glovebox and frozen in liquid nitrogen immediately.

\section{Entry 10. ${ }^{57} \mathrm{FeCl}_{2}+\mathrm{MeMgBr}+\mathrm{ZnBr} 2 \cdot \mathrm{TMEDA}+$ dppe + TAM-substrate (32a) + BCP (94g)+ THF}

Inside a nitrogen-filled glovebox, to a stirred solution of $\mathbf{3 2 a}$ ( $7.2 \mathrm{mg}, 1.0$ equiv), $\mathrm{ZnBr}_{2} \cdot$ TMEDA (17.2 mg, 2.0 equiv) and dppe (10.0 mg, 1.0 equiv) in THF $(17 \mu \mathrm{L}), \mathrm{MeMgBr}\left(3.0 \mathrm{M}\right.$ in $\mathrm{Et}_{2} \mathrm{O}, 25 \mu \mathrm{L}, 3.0$ equiv) was added in one portion and the reaction mixture was stirred for $5 \mathrm{~min}$ at ambient temperature. Then, ${ }^{57} \mathrm{FeCl}_{2}(3.2 \mathrm{mg}, 25 \mu \mathrm{mol})$ was added. After stirring for additional $5 \mathrm{~min}, \mathrm{BCP}$ 94g (11.4 mg, 3.0 equiv) was added as a solution in THF (17 $\mu \mathrm{L})$. After stirring for additional $5 \mathrm{~min}$, the solution was diluted to $5.0 \mathrm{~mL}$ by adding THF, $0.80 \mathrm{~mL}$ of the solution was filtered and added into a sample holder. The sample holder was taken out of the glovebox and frozen in liquid nitrogen immediately. 
Entry 11. ${ }^{57} \mathrm{FeCl}_{2}+\mathrm{MeMgBr}+\mathrm{ZnBr}_{2} \cdot \mathrm{TMEDA}+$ dppe + TAH-substrate (51a) + BCP (94a)+ THF

Inside a nitrogen-filled glovebox, to a stirred solution of $51 \mathrm{a}(7.2 \mathrm{mg}, 1.0$ equiv), $\mathrm{ZnBr}$-TMEDA (17.2 mg, 2.0 equiv) and dppe (10.0 mg, 1.0 equiv) in THF $(17 \mu \mathrm{L}), \mathrm{MeMgBr}\left(3.0 \mathrm{M}\right.$ in $\mathrm{Et}_{2} \mathrm{O}, 25 \mu \mathrm{L}, 3.0$ equiv) was added in one portion and the reaction mixture was stirred for $5 \mathrm{~min}$ at ambient temperature. Then, ${ }^{57} \mathrm{FeCl}_{2}(3.2 \mathrm{mg}, 25 \mu \mathrm{mol})$ was added. After stirring for additional $5 \mathrm{~min}$, BCP 94a (9.3 mg, 3.0 equiv) was added as a solution in THF (17 $\mu \mathrm{L})$. After stirring for additional $20 \mathrm{~min}$, the solution was diluted to $5.0 \mathrm{~mL}$ by adding THF, $0.80 \mathrm{~mL}$ of the solution was filtered and added into a sample holder. The sample holder was taken out of the glovebox and frozen in liquid nitrogen immediately. 


\subsection{X-Ray Crystallographic Analysis}

The crystal structures of $\mathbf{8 9 l a}$ and $\mathbf{1 2 0}$ were measured and solved by Dr. Christopher Golz (Prof. Dr. Manuel Alcarazo research group).

\subsubsection{Data Analysis for Crystal Structure of 89la}

The crystal was kept at $99.98 \mathrm{~K}$ during data collection. Using Olex2, ${ }^{[104]}$ the structure was solved with the $\mathrm{XT}^{[105]}$ structure solution program using Intrinsic Phasing and refined with the $\mathrm{XL}^{[106]}$ refinement package using Least Squares minimisation.

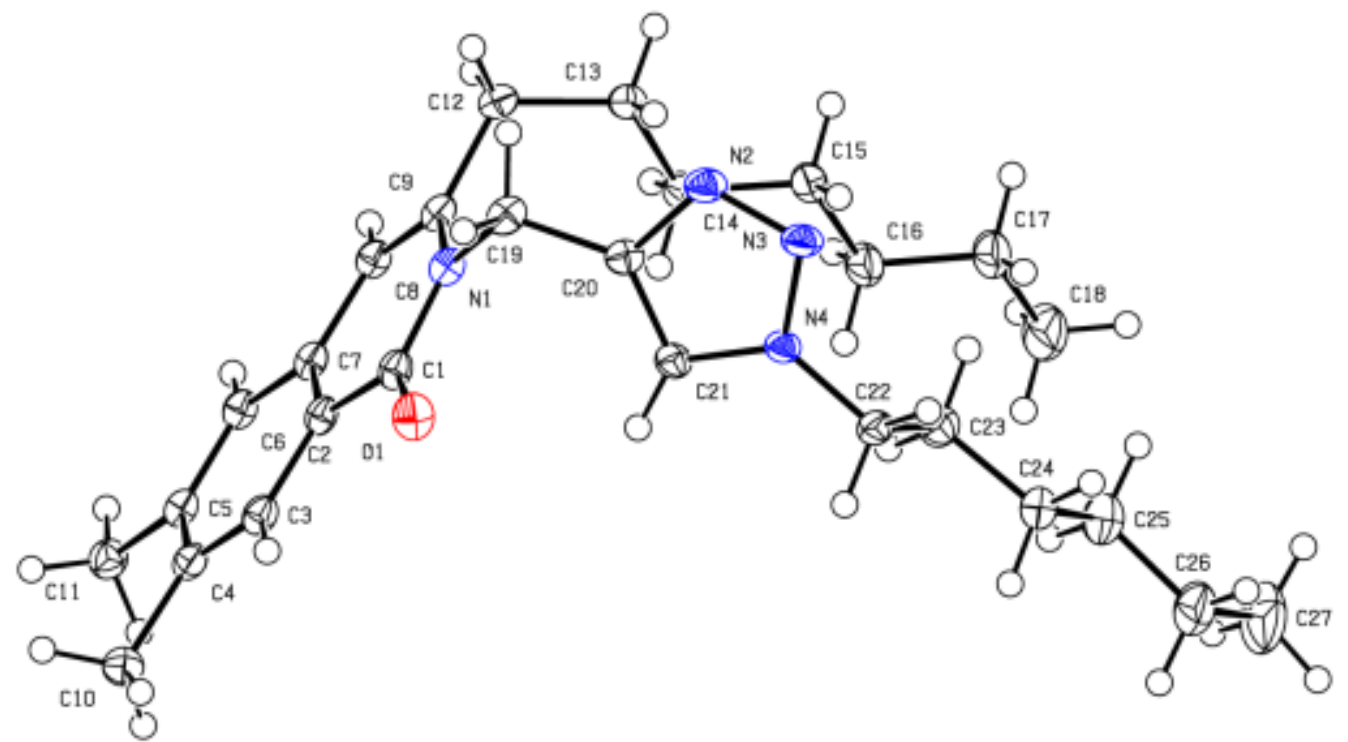

Figure 5.4 Molecular structure of 89 la with thermal ellipoids at $50 \%$ probability level.

Crystal Data for $\mathrm{C}_{27} \mathrm{H}_{40} \mathrm{~N}_{4} \mathrm{O}(M=436.63 \mathrm{~g} / \mathrm{mol}$ ) triclinic, space group P-1 (no. 2), $a=5.6131(13) \AA, b=8.0980(19) \AA, c=27.986(7) \AA, a=87.340(7)^{\circ}$, $\beta=87.040(7)^{\circ}, \quad V=84.035(7)^{\circ}, \quad V=1262.5(5) \AA^{3}, \quad Z=2, \quad T=99.98 \mathrm{~K}$, $\mu($ MoKa $)=0.071 \mathrm{~mm}^{-1}, D c a l c=1.149 \mathrm{~g} / \mathrm{cm}^{3}, 15862$ reflections measured $\left(4.376^{\circ} \leq 2 \Theta \leq 63.042^{\circ}\right), 8285$ unique $\left(R_{\text {int }}=0.0437, R_{\text {sigma }}=0.0624\right)$ which 
were used in all calculations. The final $R_{1}$ was $0.0547(\mathrm{I}>2 \sigma(\mathrm{I}))$ and $w R_{2}$ was 0.1521 (all data).

Table 5.2 Crystal data and structure refinement for 89la.

Compound

Identification code

Empirical formula

Formula weight

Temperature/K

Crystal system

Space group

$\mathrm{a} / \AA ̊ \AA$

$\mathrm{b} / \AA ̊ \AA$

$c / \AA$

$\alpha /^{\circ}$

$\beta /^{\circ}$

$\mathrm{Y}{ }^{\circ}$

Volume/ $/ \AA^{3}$

Z

$\rho_{\text {calc }} / \mathrm{cm}^{3}$

$\mu / \mathrm{mm}^{-1}$

$\mathrm{F}(000)$

Crystal size $/ \mathrm{mm}^{3}$

Radiation
$891 a$

mo_0230_CG_0m

$\mathrm{C}_{27} \mathrm{H}_{40} \mathrm{~N}_{4} \mathrm{O}$

436.63

99.98

triclinic

P-1

5.6131(13)

$8.0980(19)$

27.986(7)

$87.340(7)$

$87.040(7)$

$84.035(7)$

1262.5(5)

2

1.149

0.071

476.0

$0.714 \times 0.391 \times 0.052$

$\operatorname{MoK\alpha }(\lambda=0.71073)$

$2 \Theta$ range for data collection $/{ }^{\circ} 4.376$ to 63.042

Index ranges

Reflections collected

Independent reflections

Data/restraints/parameters

Goodness-of-fit on $\mathrm{F}^{2}$

Final $R$ indexes $[l>=2 \sigma(I)]$

Final $R$ indexes [all data]

Largest diff. peak/hole / $A^{3}$
$-8 \leq \mathrm{h} \leq 8,-11 \leq \mathrm{k} \leq 9,-41 \leq \mathrm{I} \leq 41$

15862

$8285\left[R_{\text {int }}=0.0437, R_{\text {sigma }}=0.0624\right]$

$8285 / 0 / 293$

1.031

$\mathrm{R}_{1}=0.0547, \mathrm{wR}_{2}=0.1421$

$\mathrm{R}_{1}=0.0688, w R_{2}=0.1521$ 
5. Experimental Part

Table 5.3 Bond Lengths $[\AA \AA]$ for 89la.

\begin{tabular}{|c|c|c|c|c|c|}
\hline \multicolumn{2}{|c|}{ Atom Atom } & \multirow{2}{*}{$\begin{array}{c}\text { Length/Å } \\
1.2339(13)\end{array}$} & \multicolumn{2}{|c|}{ Atom Atom } & \multirow{2}{*}{$\begin{array}{l}\text { Length/Å } \\
1.4127(15)\end{array}$} \\
\hline 01 & $\mathrm{C} 1$ & & C6 & C7 & \\
\hline N1 & $\mathrm{C} 1$ & $1.3951(14)$ & C7 & C8 & $1.4337(15)$ \\
\hline N1 & $\mathrm{Cg}$ & $1.4023(14)$ & C8 & C9 & $1.3534(15)$ \\
\hline N1 & C19 & $1.4703(14)$ & C9 & $\mathrm{C} 12$ & $1.5123(15)$ \\
\hline N2 & N3 & $1.3207(14)$ & $\mathrm{C} 12$ & $\mathrm{C} 13$ & $1.5332(16)$ \\
\hline N2 & C20 & $1.3605(14)$ & $\mathrm{C} 13$ & C14 & $1.5216(16)$ \\
\hline N3 & N4 & $1.3428(12)$ & C14 & C15 & $1.5224(16)$ \\
\hline N4 & C21 & $1.3522(13)$ & C15 & C16 & $1.5187(17)$ \\
\hline N4 & C22 & $1.4588(14)$ & C16 & C17 & $1.5173(18)$ \\
\hline C1 & $\mathrm{C} 2$ & $1.4588(15)$ & C17 & C18 & $1.522(2)$ \\
\hline $\mathrm{C} 2$ & C3 & $1.4095(15)$ & C19 & $\mathrm{C} 20$ & $1.4957(15)$ \\
\hline C2 & C7 & $1.4036(15)$ & C20 & C21 & $1.3724(15)$ \\
\hline C3 & $\mathrm{C} 4$ & $1.3820(16)$ & C22 & $\mathrm{C} 23$ & $1.5185(17)$ \\
\hline C4 & $\mathrm{C} 5$ & $1.4213(16)$ & $\mathrm{C} 23$ & $\mathrm{C} 24$ & $1.5230(17)$ \\
\hline C4 & C10 & $1.5062(15)$ & C24 & $\mathrm{C} 25$ & $1.5201(19)$ \\
\hline C5 & C6 & $1.3861(15)$ & $\mathrm{C} 25$ & $\mathrm{C} 26$ & 1.518(2) \\
\hline C5 & C11 & $1.5071(16)$ & C26 & $\mathrm{C} 27$ & $1.523(2)$ \\
\hline
\end{tabular}


Table 5.4 Bond Angles [ $\left.{ }^{\circ}\right]$ for $891 \mathrm{a}$.

\begin{tabular}{|c|c|c|c|c|c|c|c|}
\hline \multicolumn{3}{|c|}{ Atom Atom Atom } & Angle $/^{\circ}$ & \multicolumn{3}{|c|}{ Atom Atom Atom } & \multirow{2}{*}{$\begin{array}{l}\text { Angle }^{\circ} \\
118.76(10)\end{array}$} \\
\hline $\mathrm{C} 1$ & N1 & C9 & 123.33(9) & C2 & $\mathrm{C7}$ & $\mathrm{C} 8$ & \\
\hline $\mathrm{C} 1$ & N1 & C19 & $114.38(9)$ & $\mathrm{C} 6$ & $\mathrm{C7}$ & C8 & 122.78(10) \\
\hline C9 & N1 & C19 & 122.19(9) & C9 & C8 & $\mathrm{C} 7$ & $121.64(10)$ \\
\hline N3 & $\mathrm{N} 2$ & C20 & $108.88(9)$ & N1 & C9 & C12 & $120.19(10)$ \\
\hline N2 & N3 & N4 & $107.19(9)$ & $\mathrm{C} 8$ & C9 & N1 & $119.25(10)$ \\
\hline N3 & N4 & C21 & $110.88(9)$ & C8 & C9 & C12 & $120.53(10)$ \\
\hline N3 & N4 & C22 & 119.81(9) & C9 & C12 & C13 & 117.73(9) \\
\hline C21 & N4 & $\mathrm{C} 22$ & $129.30(9)$ & C14 & $\mathrm{C} 13$ & C12 & $114.42(9)$ \\
\hline O1 & C1 & N1 & $119.83(10)$ & $\mathrm{C} 13$ & C14 & C15 & $112.60(9)$ \\
\hline $\mathrm{O} 1$ & C1 & C2 & $123.75(10)$ & C16 & C15 & C14 & $113.68(10)$ \\
\hline N1 & C1 & C2 & $116.42(9)$ & C17 & C16 & C15 & $113.71(11)$ \\
\hline C3 & $\mathrm{C} 2$ & C1 & $119.47(10)$ & C16 & C17 & C18 & $112.98(12)$ \\
\hline $\mathrm{C7}$ & $\mathrm{C} 2$ & C1 & $120.36(10)$ & $\mathrm{N} 1$ & C19 & $\mathrm{C} 20$ & 113.87(9) \\
\hline $\mathrm{C7}$ & C2 & C3 & $120.17(10)$ & $\mathrm{N} 2$ & C20 & C19 & 119.61(9) \\
\hline C4 & C3 & C2 & $121.04(10)$ & N2 & C20 & C21 & $108.30(10)$ \\
\hline C3 & C4 & C5 & $119.16(10)$ & $\mathrm{C} 21$ & $\mathrm{C} 20$ & C19 & $132.09(10)$ \\
\hline C3 & C4 & C10 & $120.39(10)$ & N4 & $\mathrm{C} 21$ & C20 & 104.74(9) \\
\hline C5 & C4 & C10 & $120.45(10)$ & N4 & C22 & $\mathrm{C} 23$ & 113.18(9) \\
\hline C4 & C5 & C11 & $120.17(10)$ & C22 & $\mathrm{C} 23$ & C24 & $110.42(10)$ \\
\hline C6 & C5 & C4 & $119.88(10)$ & $\mathrm{C} 25$ & $\mathrm{C} 24$ & $\mathrm{C} 23$ & $114.16(11)$ \\
\hline C6 & C5 & C11 & $119.95(10)$ & $\mathrm{C} 26$ & $\mathrm{C} 25$ & $\mathrm{C} 24$ & $112.80(13)$ \\
\hline C5 & C6 & $\mathrm{C} 7$ & $121.27(10)$ & C25 & C26 & $\mathrm{C} 27$ & $113.65(16)$ \\
\hline C2 & $\mathrm{C} 7$ & C6 & $118.46(10)$ & & & & \\
\hline
\end{tabular}




\section{Experimental Part}

\subsubsection{Data Analysis for Crystal Structure of $\mathbf{1 2 0}$}

The crystal was kept at $100.0 \mathrm{~K}$ during data collection. Using Olex2, ${ }^{[104]}$ the structure was solved with the $\mathrm{XT}^{[105]}$ structure solution program using Intrinsic Phasing and refined with the $\mathrm{XL}^{[106]}$ refinement package using Least Squares minimisation.

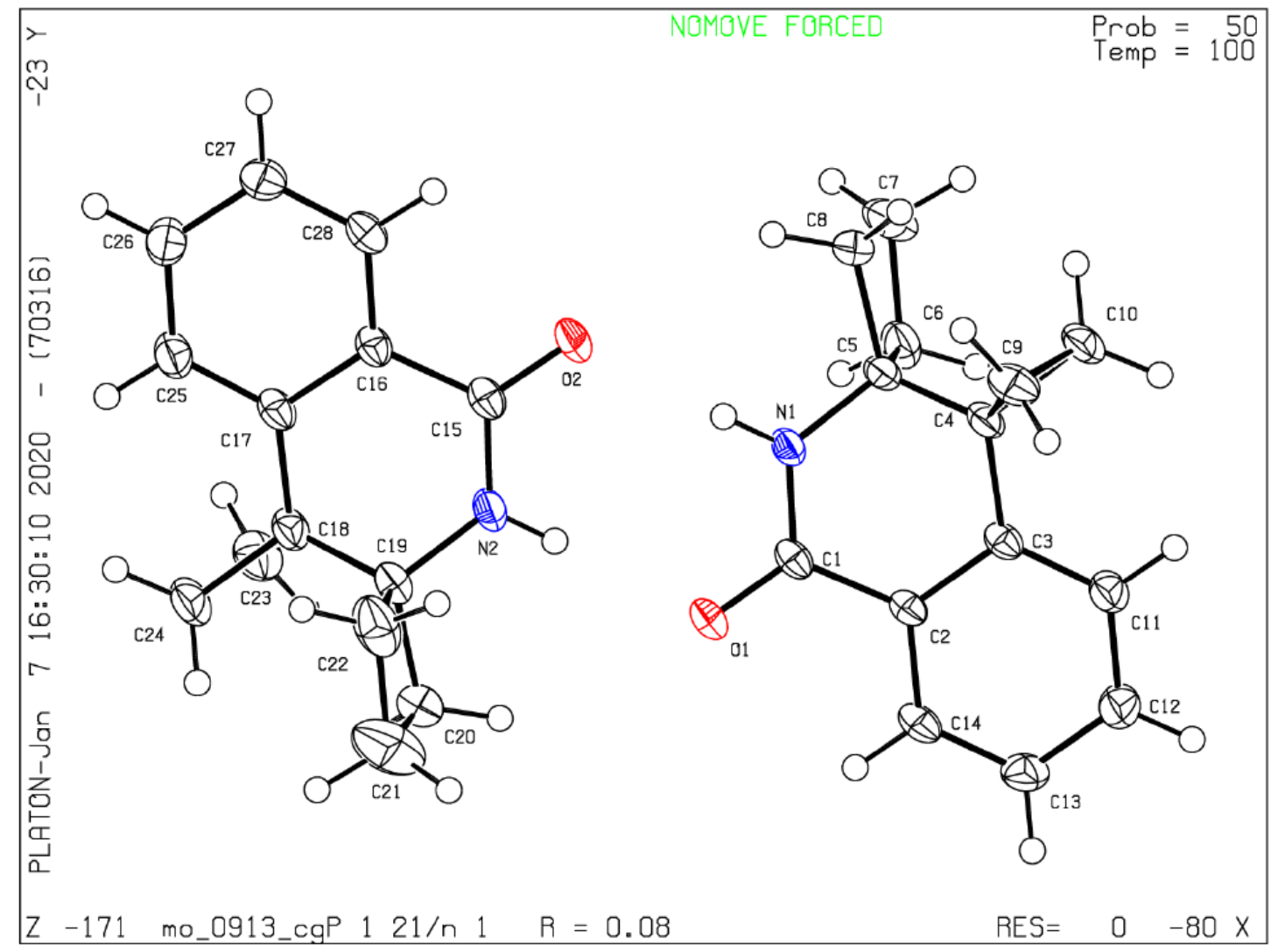

Figure $\mathbf{5 . 5}$ Molecular structure of $\mathbf{1 2 0}$ with thermal ellipoids at $\mathbf{5 0 \%}$ probability level.

Crystal Data for $\mathrm{C}_{14} \mathrm{H}_{15} \mathrm{NO}(M=213.27 \mathrm{~g} / \mathrm{mol})$ : monoclinic, space group P2 $1 / \mathrm{n}$ (no. 14), $a=13.9071(8) \AA, \quad b=9.5864(5) \AA, \quad c=16.9660(10) \AA$, $\beta=100.194(2)^{\circ}, V=2226.2(2) \AA^{3}, Z=8, T=100.0 \mathrm{~K}, \mu(\mathrm{MoK \alpha})=0.080 \mathrm{~mm}^{-1}$, Dcalc $=1.273 \mathrm{~g} / \mathrm{cm}^{3}, 67587$ reflections measured $\left(4.168^{\circ} \leq 2 \Theta \leq 54.268^{\circ}\right)$, 4911 unique $\left(R_{\text {int }}=0.0438, R_{\text {sigma }}=0.0190\right)$ which were used in all calculations. The final $R_{1}$ was $0.0774(\mathrm{I}>2 \sigma(\mathrm{I}))$ and $w R_{2}$ was 0.2170 (all data). 


\section{Experimental Part}

Table 5.5 Crystal data and structure refinement for $\mathbf{1 2 0}$.

CCDC code

Empirical formula

Formula weight

Temperature/K

Crystal system

Space group

a/Å

$b / \AA$

$\mathrm{c} / \AA$

$\alpha /^{\circ}$

$\beta /^{\circ}$

$\mathrm{Y} /{ }^{\circ}$

Volume/ $\AA^{3}$

Z

$\rho_{\text {calc }} \mathrm{g} / \mathrm{cm}^{3}$

$\mu / \mathrm{mm}^{-1}$

$F(000)$

Crystal size $/ \mathrm{mm}^{3}$
2018011

$\mathrm{C}_{14} \mathrm{H}_{15} \mathrm{NO}$

213.27

100.0

monoclinic

$\mathrm{P} 2{ }_{1} / \mathrm{n}$

13.9071(8)

$9.5864(5)$

$16.9660(10)$

90

100.194(2)

90

2226.2(2)

8

1.273

0.080

912.0

$0.247 \times 0.182 \times 0.168$ 


\section{Experimental Part}

Radiation

$$
\operatorname{MoKa}(\lambda=0.71073)
$$

$2 \Theta$ range for data collection $/{ }^{\circ} 4.168$ to 54.268

Index ranges

$-17 \leq h \leq 17,-12 \leq k \leq 12,-21 \leq \mathrm{I} \leq 21$

Reflections collected

67587

Independent reflections

$4911\left[R_{\text {int }}=0.0438, R_{\text {sigma }}=0.0190\right]$

Data/restraints/parameters

$4911 / 0 / 289$

Goodness-of-fit on $F^{2}$

1.087

Final $R$ indexes $[l>=2 \sigma(I)] \quad R_{1}=0.0774, w R_{2}=0.2080$

Final $R$ indexes [all data] $\quad R_{1}=0.0866, w_{2}=0.2170$

Largest diff. peak/hole / e $\AA^{-3} 0.57 /-0.34$ 
5. Experimental Part

Table 5.6 Bond Lengths $[\AA ̊]$ for $\mathbf{1 2 0}$.

\begin{tabular}{|c|c|c|c|c|c|}
\hline \multicolumn{2}{|c|}{ Atom Atom } & \multirow{2}{*}{$\begin{array}{l}\text { Length/A } \\
1.244(2)\end{array}$} & \multicolumn{2}{|c|}{ Atom Atom } & \multirow{2}{*}{$\begin{array}{l}\text { Length/A } \\
1.245(2)\end{array}$} \\
\hline 01 & $\mathrm{C} 1$ & & $\mathrm{O} 2$ & C15 & \\
\hline N1 & C1 & $1.339(2)$ & N2 & C15 & 1.336(3) \\
\hline N1 & C5 & $1.456(2)$ & N2 & C19 & $1.456(2)$ \\
\hline C1 & C2 & $1.486(3)$ & C15 & C16 & $1.489(3)$ \\
\hline C2 & C3 & $1.407(3)$ & C16 & C17 & $1.405(3)$ \\
\hline C2 & C14 & $1.402(3)$ & C16 & C28 & 1.394(3) \\
\hline C3 & C4 & $1.500(3)$ & C17 & C18 & 1.498(3) \\
\hline C3 & C11 & 1.395(3) & C17 & C25 & $1.393(3)$ \\
\hline C4 & C5 & $1.515(3)$ & C18 & C19 & $1.510(3)$ \\
\hline C4 & C9 & $1.513(3)$ & C18 & C23 & $1.519(3)$ \\
\hline C4 & C10 & $1.504(3)$ & C18 & C24 & $1.500(3)$ \\
\hline C5 & C6 & $1.564(3)$ & C19 & C20 & $1.566(3)$ \\
\hline C5 & C8 & $1.550(3)$ & C19 & C22 & $1.551(3)$ \\
\hline C6 & C7 & 1.533(3) & C20 & C21 & $1.510(4)$ \\
\hline C7 & C8 & $1.538(4)$ & C21 & C22 & $1.543(4)$ \\
\hline C9 & C10 & $1.500(3)$ & C23 & C24 & $1.503(4)$ \\
\hline C11 & C12 & 1.392(3) & C25 & C26 & $1.389(3)$ \\
\hline
\end{tabular}


5. Experimental Part

\begin{tabular}{|c|c|c|c|}
\hline C12 C13 & $1.394(3)$ & C26 & C27 \\
\hline C14 & $1.383(3)$ & C27 & $\mathrm{C} 28$ \\
\hline
\end{tabular}

Table 5.7 Bond Angles [] for 120 .

\begin{tabular}{|c|c|c|c|c|c|c|c|}
\hline Aton & Ato & Atom & Angle $^{\circ}$ & Aton & Ator & Atom & Angle $/^{\circ}$ \\
\hline C1 & N1 & C5 & $124.01(17)$ & C15 & N2 & C19 & $124.42(18)$ \\
\hline 01 & C1 & N1 & $122.03(18)$ & $\mathrm{O} 2$ & C15 & N2 & $122.13(19)$ \\
\hline 01 & C1 & C2 & $121.65(17)$ & $\mathrm{O} 2$ & C15 & $\mathrm{C} 16$ & $121.22(18)$ \\
\hline N1 & C1 & C2 & $116.32(16)$ & N2 & C15 & $\mathrm{C} 16$ & $116.64(17)$ \\
\hline C3 & C2 & C1 & $120.44(17)$ & C17 & C16 & C15 & $120.48(18)$ \\
\hline C14 & $\mathrm{C} 2$ & C1 & $119.28(17)$ & $\mathrm{C} 28$ & C16 & C15 & $118.78(17)$ \\
\hline C14 & $\mathrm{C} 2$ & C3 & $120.20(18)$ & C28 & $\mathrm{C} 16$ & C17 & $120.67(19)$ \\
\hline $\mathrm{C} 2$ & C3 & C4 & $117.86(17)$ & C16 & C17 & $\mathrm{C} 18$ & $118.04(18)$ \\
\hline C11 & $\mathrm{C} 3$ & $\mathrm{C} 2$ & $118.41(18)$ & $\mathrm{C} 25$ & C17 & $\mathrm{C} 16$ & $118.01(19)$ \\
\hline C11 & $\mathrm{C} 3$ & $\mathrm{C} 4$ & $123.65(17)$ & $\mathrm{C} 25$ & C17 & $\mathrm{C} 18$ & $123.78(18)$ \\
\hline C3 & $\mathrm{C} 4$ & C5 & $111.78(16)$ & C17 & C18 & C19 & $112.54(17)$ \\
\hline C3 & C4 & C9 & $116.87(18)$ & C17 & C18 & $\mathrm{C} 23$ & $116.04(19)$ \\
\hline C3 & C4 & C10 & $120.92(17)$ & C17 & C18 & $\mathrm{C} 24$ & $121.00(18)$ \\
\hline C9 & C4 & C5 & $119.69(18)$ & C19 & C18 & $\mathrm{C} 23$ & $119.80(19)$ \\
\hline C10 & C4 & C5 & $118.90(17)$ & C24 & C18 & C19 & $118.23(19)$ \\
\hline
\end{tabular}


5. Experimental Part

\begin{tabular}{|c|c|c|c|c|c|c|c|}
\hline C10 & C4 & C9 & $59.62(14)$ & C24 & C18 & $\mathrm{C} 23$ & $59.73(16)$ \\
\hline N1 & C5 & C4 & $108.55(16)$ & N2 & C19 & C18 & $109.74(18)$ \\
\hline N1 & C5 & C6 & $114.59(17)$ & N2 & C19 & C20 & $111.50(18)$ \\
\hline N1 & C5 & C8 & $112.46(17)$ & N2 & C19 & C22 & $114.33(19)$ \\
\hline C4 & C5 & C6 & $113.59(17)$ & C18 & C19 & C20 & $116.56(18)$ \\
\hline C4 & C5 & C8 & $118.06(17)$ & C18 & C19 & C22 & $114.25(19)$ \\
\hline C8 & C5 & C6 & $88.71(17)$ & C22 & C19 & C20 & $89.32(19)$ \\
\hline C7 & C6 & C5 & $89.68(18)$ & C21 & C20 & C19 & $89.4(2)$ \\
\hline C6 & $\mathrm{C} 7$ & C8 & $90.31(17)$ & C20 & C21 & C22 & $91.7(2)$ \\
\hline C7 & C8 & C5 & $89.99(18)$ & C21 & C22 & C19 & $88.7(2)$ \\
\hline C10 & C9 & C4 & $59.90(13)$ & C24 & C23 & C18 & $59.54(15)$ \\
\hline C9 & C10 & C4 & $60.48(14)$ & C18 & C24 & C23 & $60.74(15)$ \\
\hline C12 & C11 & C3 & $120.95(19)$ & C26 & C25 & C17 & $121.29(19)$ \\
\hline C11 & C12 & C13 & $120.5(2)$ & C25 & C26 & C27 & $120.4(2)$ \\
\hline C14 & C13 & C12 & $119.26(19)$ & C28 & C27 & C26 & $118.9(2)$ \\
\hline C13 & C14 & C2 & $120.72(18)$ & C27 & C28 & C16 & $120.77(18)$ \\
\hline
\end{tabular}




\section{References}

\section{References}

[1] a) J.-R. Pouliot, F. Grenier, J. T. Blaskovits, S. Beaupre, M. Leclerc, Chem. Rev. 2016, 116, 14225-14274; b) A. Paun, N. D. Hadade, C. C. Paraschivescua, M. Matache, Mater. Chem. C 2016, 4, 8596-8610; c) D. J. Schipper, K. Fagnou, Chem. Mater. 2011, 23, 1594-1600; d) V. Maman, MiniReviews in Organic Chemistry 2008, 5, 303-312.

[2] a) S. J. Kalita, F. Cheng, Y.-Y. Huang, Adv. Synth. Catal. 2020, 362, 27782800; b) E. R. Welin, A. Ngamnithiporn, M. Klatte, G. Lapointe, G. M. Pototschnig, M. S. J. McDermott, D. Conklin, C. D. Gilmore, P. M. Tadross, C. K. Haley, K. Negoro, E. Glibstrup, C. U. Grünanger, K. M. Allan, S. C. Virgil, D. J. Slamon, B. M. Stoltz, Science 2019, 363, 270-275; c) R. Rossi, F. Bellina, M. Lessi, C. Manzini, G. Marianetti, L. A. Perego, Curr. Org. Chem. 2015, 19, 1302-1409; d) J. Yamaguchi, A. D. Yamaguchi, K. Itami, Angew. Chem. Int. Ed. 2012, 51, 8960-9009: e) K. C. Nicolaou, C. R. H. Hale, C. Nilewski, H. A. Ioannidou, Chem. Soc. Rev. 2012, 41, 5185-5238.

[3] a) S. D. Friis, M. J. Johansson, L. Ackermann, Nat. Chem. 2020, 12, 511-519;

b) T. Cernak, K. D. Dykstra, S. Tyagarajan, P. Vachal, S. W. Krska, Chem. Soc. Rev. 2016, 45, 546-576; c) M. Seki, Org. Process Res. Dev. 2016, 20, 867877; d) L. Ackermann, Org. Process Res. Dev. 2015, 19, 260-269.

[4] a) P. Ruiz-Castillo, S. L. Buchwald, Chem. Rev. 2016, 116, 12564-12649; b) A. V. Bhatia, H. J. Federsel, Q. Chen, Org. Process Res. Dev. 2014, 18, 179179; c) N. Miyaura, A. Suzuki, Chem. Rev. 1995, 95, 2457-2483; d) J.-P. Corbet, G. Mignani, Chem. Rev. 2006, 106, 2651-2710.

[5] a) A. Biffis, P. Centomo, A. D. Zotto, M. Zecca, Chem. Rev. 2018, 118, 2249229; b) C. C. C. J. Seechurn, M. O. Kitching, T. J. Colacot, V. Snieckus, Angew. Chem. Int. Ed. 2012, 51, 5062-5085. 


\section{References}

[6] a) P. T. Anastas, M. M. Kirchhoff, Acc. Chem. Res. 2002, 35, 686-694; b) P. T. Anastas, J. C. Warner, Green chemistry: theory and practice, Oxford University Press, Oxford, 1998.

[7] a) X. Zhang, M. Fevre, G. O. Jones, R. M. Waymouth, Chem. Rev. 2018, 118, 839-885; b) F. E. Celik, B. Peters, M.-O. Coppens, A. McCormick, R. F. Hicks, J. Ekerdt, ACS Catal. 2017, 7, 8628-8640.

[8] a) L. Ackermann, R. Vicente, A. R. Kapdi, Angew. Chem. Int. Ed. 2009, 48, 9792-9826; b) R. G. Bergman, Nature 2007, 446, 391-393.

[9] a) S. Rej, Y. Ano, N. Chatani, Chem. Rev. 2020, 120, 1788-1887; b) S. Rej, N. Chatani, Angew. Chem. Int. Ed. 2019, 58, 8304-8329; c) J. Kalepu, P. Gandeepan, L. Ackermann, L. Pilarski, Chem. Sci. 2018, 9, 4203-4216; d) J. He, M. Wasa, K. S. L. Chan, Q. Shao, J.-Q. Yu, Chem. Rev. 2017, 117, 8754 8786; e) P. H. Dixneuf, H. Doucet, $\mathrm{C}-\mathrm{H}$ Bond Activation and Catalytic Functionalization I, Springer, Cham, 2016; f) J. F. Hartwig, M. A. Larsen, ACS Cent. Sci. 2016, 2, 281-292; g) O. Daugulis, J. Roane, L. D. Tran, Acc. Chem. Res. 2015, 48, 1053-1064; h) A. D. Giuseppe, R. Castarlenas, L. A. Oroac, C. R. Chimie 2015, 18, 713-741; i) G. Rouquet, N. Chatani, Angew. Chem. Int. Ed. 2013, 52, 11726-11743; j) S. R. Neufeldt, M. S. Sanford, Acc. Chem. Res. 2012, 45, 936-946; k) L. McMurray, F. O'Hara, M. J. Gaunt, Chem. Soc. Rev. 2011, 40, 1885-1898; I) T. W. Lyons, M. S. Sanford, Chem. Rev. 2010, 110, 1147-1169; m) O. Daugulis, H.-Q. Do, D. Shabashov, Acc. Chem. Res. 2009, 42, 1074-1086.

[10] a) R. A. Periana, G. Bhalla, W. J. Tenn III, K. J. H. Young, X. Y. Liu, O. Mironov, C. Jones, V. R. Ziatdinov, J. Mol. Catal. A: Chem. 2004, 220, 7-25; b) A. S. Goldman, K. I. Goldberg, ACS Symposium Series 885, Activation and Functionalization of C-HBonds, 2004, 1-43; c) B. A. Arndtsen, R. G. Bergman, T. A. Mobley, T. H. Peterson, Acc. Chem. Res. 1995, 28, 154-162. 


\section{References}

[11] a) The Nobel prize in Chemistry 2010 - Press Release https://www.nobelprize.org/nobel prizes/chemistry/laureates/2010/press.html (accessed on 18.08.2020); b) A. Suzuki, Angew. Chem. Int. Ed. 2011, 50, 6722-6737; c) E.-i. Negishi, Angew. Chem. Int. Ed. 2011, 50, 6738-6764.

[12] S. J. Blanksby, G. B. Ellison, Acc. Chem. Res. 2003, 36, 255-263.

[13] a) L. N. Lewis, J. F. Smith, J. Am. Chem. Soc. 1986, 108, 2728-2735; b) P. Hong, B.-R. Cho, H. Yamazaki, Chem. Lett. 1979, 50, 339-342.

[14] a) H. M. L. Davies, D. Morton, ACS Cent. Sci. 2017, 3, 936-943; b) J. R. Hummel, J. A. Boerth, J. A. Ellman, Chem. Rev. 2017, 117, 9163-9227; c) T. Gensch, M. N. Hopkinson, F. Glorius, Chem. Soc. Rev. 2016, 45, 2900-2936; d) P. Gandeepan, C.-H. Cheng, Chem. Asian J. 2015, 10, 824-838.

[15] I. V. Seregin, V. Gevorgyan, Chem. Soc. Rev. 2007, 36, 1173-1193.

[16] N. Kuhl, M. N. Hopkinson, J. Wencel-Delord, F. Glorius, Angew. Chem. Int. Ed. 2012, 51, 10236-10254.

[17] a) C. Sambiagio, D. Schönbauer, R. Blieck, T. Dao-Huy, G. Pototschnig, P. Schaaf, T. Wiesinger, M. F. Zia, J. Wencel-Delord, T. Besset, B. U. W. Maes, M. Schnürch, Chem. Soc. Rev. 2018, 47, 6603-6743; b) Y. Kuninobu, H. Ida, M. Nishi, M. Kanai, Nat. Chem. 2015, 7, 712-717; c) F. Zhang, D. R. Spring, Chem. Soc. Rev. 2014, 43, 6906-6919; d) L. Ackermann, Top. Organomet. Chem. 2007, 24, 35-60.

[18] S. D. Sarkar, W. Liu, S. I. Kozhushkov, L. Ackermann, Adv. Synth. Catal. 2014, 356, 1461-1479.

[19] W. Ma, P. Gandeepan, J. Li, L. Ackermann, Org. Chem. Front. 2017, 4, 14351467.

[20] P. Gandeepan, L. Ackermann, Chem 2018, 4, 199-222.

[21] a) L. Ackermann, Chem. Rev. 2011, 111, 1315-1345; b) D. Balcells, E. Clot, O. Eisenstein, Chem. Rev. 2010, 110, 749-823. 


\section{References}

[22] D. Lapointe, K. Fagnou, Chem. Lett. 2010, 39, 1118-1126.

[23] a) Y. Boutadla, D. L. Davies, S. A. Macgregor, A. I. Poblador-Bahamonde, Dalton Trans. 2009, 5887-5893; b) Y. Boutadla, D. L. Davies, S. A. Macgregor, A. I. Poblador-Bahamonde, Dalton Trans. 2009, 5820-5831.

[24] a) K. Naksomboon, J. Poater, F. M. Bickelhaupt, M. A. Fernandez-lbanez, J. Am. Chem. Soc. 2019, 141, 6719-6725; b) E. Tan, O. Quinonero, M. E. de Orbe, A. M. Echavarren, ACS Catal. 2018, 8, 2166-2172; c) Y.-F. Liang, V. Müller, W. Liu, A. Münch, D. Stalke, L. Ackermann, Angew. Chem. Int. Ed. 2017, 56, 9415-9419; d) D. Zell, M. Bursch, V. Müller, S. Grimme, L. Ackermann, Angew. Chem. Int. Ed. 2017, 56, 10378-10382; e) H. Wang, M. Moselage, M. J. González, L. Ackermann, ACS Catal. 2016, 6, 2705-2709; f) D. Santrač, S. Cella, W. Wang, L. Ackermann, Eur. J. Org. Chem. 2016, 54295436; g) R. Mei, J. Loup, L. Ackermann, ACS Catal. 2016, 6, 793-797; h) W. Ma, R. Mei, G. Tenti, L. Ackermann, Chem. Eur. J. 2014, 20, 15248-15251.

[25] J. Oxgaard, W. J. Tenn, R. J. Nielsen, R. A. Periana, W. A. Goddard, Organometallics 2007, 26, 1565-1567.

[26] L. Wang, B. P. Carrow, ACS Catal. 2019, 9, 6821-6836.

$[27] \quad$ a) $\quad$ http://www.infomine.com/investment/metal-prices/; $\quad$ b) https://mineralprices.com/.

[28] J. W. Morgan, E. Anders, Proc. Natl. Acad. Sci. USA 1980, 77, 6973-6977.

[29] a) P. B. Tchounwou, C. G. Yedjou, A. K. Patlolla, D. J. Sutton, in Molecular, clinical, and environmental toxicology (Ed.: A. Luch), Springer, Basel, 2009, 133-164; b) S. H. Gilani, Y. Alibhai, J. Toxicol. Environ. Health 1990, 30, 2331.

[30] a) P. Gandeepan, T. Müller, D. Zell, G. Cera, S. Warratz, L. Ackermann, Chem. Rev. 2019, 119, 2192-2452; b) L. Ackermann, T. B. Gunnoe, L. G. Habgood, Catalytic Hydroarylation of Carbon-Carbon Multiple Bonds, Wiley-VCH: 


\section{References}

Weinheim, 2018; c) Y. Hu, B. Zhou, C. Wang, Acc. Chem. Res. 2018, 51, 816827; d) Y. Kommagalla, N. Chatani, Coord. Chem. Rev. 2017, 350, 117-135; e) M. Moselage, J. Li, L. Ackermann, ACS Catal. 2016, 6, 498-525; f) J. Yamaguchi, K. Muto, K. Itami, Top. Curr. Chem. 2016, 374, 157-189; g) L. C. M. Castro, N. Chatani, Chem. Lett. 2015, 44, 410-421; h) E. P. Jackson, H. A. Malik, G. J. Sormunen, R. D. Baxter, P. Liu, H. Wang, A.-R. Shareef, J. Montgomery, Acc. Chem. Res. 2015, 48, 1736-1745; i) K. Gao, N. Yoshikai, Acc. Chem. Res. 2014, 47, 1208-1219; j) A. A. Kulkarni, O. Daugulis, Synthesis 2009, (24), 4087-4109.

[31] a) R. Shang, L. llies, E. Nakamura, Chem. Rev. 2017, 117, 9086-9139; b) G. Cera, L. Ackermann, Top. Curr. Chem. 2016, 374, 191-224.

[32] K. S. Egorova, V. P. Ananikov, Angew. Chem. Int. Ed. 2016, 55, 12150-12162.

[33] a) E. Bisz, M. Szostak, ChemSusChem 2017, 10, 3964-3981; b) A. Fürstner, ACS Cent. Sci. 2016, 2, 778-789; c) I. Bauer, H.-J. Knölker, Chem. Rev. 2015, 115, 3170-3387; d) K. Schröder, K. Junge, B. Bitterlich, M. Beller, Top. Organomet. Chem. 2011, 33, 83-109; e) C.-L. Sun, B.-J. Li, Z.-J. Shi, Chem. Rev. 2011, 111, 1293-1314; f) A. A. O. Sarhan, C. Bolm, Chem. Soc. Rev. 2009, 38, 2730-2744; g) S. Enthaler, K. Junge, M. Beller, Angew. Chem. Int. Ed. 2008, 47, 3317-3321; h) A. Correa, O. G. Mancheno, C. Bolm, Chem. Soc. Rev. 2008, 37, 1108-1117; i) C. Bolm, J. Legros, J. L. Paih, L. Zani, Chem. Rev. 2004, 104, 6217-6254.

[34] a) E. McNeill, T. Ritter, Acc. Chem. Res. 2015, 48, 2330-2343; b) A. Fürstner, R. Martin, K. Majima, J. Am. Chem. Soc. 2005, 127, 12236-12237.

[35] A. Guð̃mundsson, J.-E. Bäckvall, Molecules 2020, 25, 1349.

[36] E. Nakamura, N. Yoshikai, J. Org. Chem. 2010, 75, 6061-6067.

[37] G. Hata, H. Kondo, A. Miyake, J. Am. Chem. Soc. 1968, 90, 2278-2281. 


\section{References}

[38] a) M. V. Baker, L. D. Field, J. Am. Chem. Soc. 1987, 109, 2825-2826; b) J. W. Rathke, E. L. Muetterties, J. Am. Chem. Soc. 1975, 97, 3272-3273; c) H. H. Karsch, H.-F. Klein, H. Schmidbaur, Angew. Chem. Int. Ed. 1975, 14, 637-638.

[39] a) S. Camadanli, R. Beck, U. Flörke, H.-F. Klein, Organometallics 2009, 28, 2300-2310; b) H.-F. Klein, S. Camadanli, R. Beck, D. Leukel, U. Flörke, Angew. Chem. Int. Ed. 2005, 44, 975-977.

[40] W. D. Jones, G. P. Foster, J. M. Putinas, J. Am. Chem. Soc. 1987, 109, 50475048.

[41] E. Nakamura, Two stories of iron https://chemistrycommunity.nature.com/posts/46018-two-stories-of-iron (consulted on 17.09.2020).

[42] J. Norinder, A. Matsumoto, N. Yoshikai, E. Nakamura, J. Am. Chem. Soc. 2008, $130,5858-5859$.

[43] a) W. Xu, N. Yoshikai, ChemSusChem 2019, 12, 3049-3053; b) R. Shang, L. Ilies, E. Nakamura, J. Am. Chem. Soc. 2016, 138, 10132-10135; c) J. J. Sirois, R. Davis, B. DeBoef, Org. Lett. 2014, 16, 868-871; d) S. Asako, J. Norinder, L. Ilies, N. Yoshikai, E. Nakamura, Adv. Synth. Catal. 2014, 356, 1481-1485; e) L. Ilies, M. Kobayashi, A. Matsumoto, N. Yoshikai, E. Nakamura, Adv. Synth. Catal. 2012, 354, 593-596; f) L. Ilies, E. Konno, Q. Chen, E. Nakamura, Asian J. Org. Chem. 2012, 1, 142-145; g) L. Ilies, S. Asako, E. Nakamura, J. Am. Chem. Soc. 2011, 133, 7672-7675; h) N. Yoshikai, S. Asako, T. Yamakawa, L. Ilies, E. Nakamura, Chem. Asian J. 2011, 6, 3059-3065; i) N. Yoshikai, A. Matsumoto, J. Norinder, E. Nakamura, Synlett 2010, (2), 313-316; j) N. Yoshikai, A. Matsumoto, J. Norinder, E. Nakamura, Angew. Chem. Int. Ed. 2009, 48, 2925-2928.

[44] R. Shang, L. Ilies, A. Matsumoto, E. Nakamura, J. Am. Chem. Soc. 2013, 135, 6030-6032. 


\section{References}

[45] Q. Gu, H. H. A. Mamari, K. Graczyk, E. Diers, L. Ackermann, Angew. Chem. Int. Ed. 2014, 53, 3868-3871.

[46] C. Zhu, M. Stangier, J. C. A. Oliveira, L. Massignan, L. Ackermann, Chem. Eur. J. 2019, 25, 16382-16389.

[47] R. Shang, L. llies, S. Asako, E. Nakamura, J. Am. Chem. Soc. 2014, 136, 14349-14352.

[48] L. lies, S. Ichikawa, S. Asako, T. Matsubara, E. Nakamura, Adv. Synth. Catal. 2015, 357, 2175-2179.

[49] R. Shang, L. Ilies, E. Nakamura, J. Am. Chem. Soc. 2015, 137, 7660-7663.

[50] a) Z. Shen, G. Cera, T. Haven, L. Ackermann, Org. Lett. 2017, 19, 3795-3798;

b) K. Graczyk, T. Haven, L. Ackermann, Chem. Eur. J. 2015, 21, 8812-8815.

[51] a) G. Cera, T. Haven, L. Ackermann, Angew. Chem. Int. Ed. 2016, 55, 1484 1488; b) E. R. Fruchey, B. M. Monks, S. P. Cook, J. Am. Chem. Soc. 2014, 136, 13130-13133; c) L. Ilies, T. Matsubara, S. Ichikawa, S. Asako, E. Nakamura, J. Am. Chem. Soc. 2014, 136, 13126-13129; d) B. M. Monks, E. R. Fruchey, S. P. Cook, Angew. Chem. Int. Ed. 2014, 53, 11065-11069.

[52] S. Asako, L. llies, E. Nakamura, J. Am. Chem. Soc. 2013, 135, 17755-17757.

[53] G. Cera, T. Haven, L. Ackermann, Chem. Eur. J. 2017, 23, 3577-3582.

[54] a) B. Plietker, A. Dieskau, K. Möws, A. Jatsch, Angew. Chem. Int. Ed. 2007, 47, 198-201; b) B. Plietker, Angew. Chem. Int. Ed. 2006, 45, 1469-1473.

[55] S. Ito, Y. Fujiwara, E. Nakamura, M. Nakamura, Org. Lett. 2009, 11, 43064309 .

[56] a) M. D. Greenhalgh, A. S. Jones, S. P. Thomas, ChemCatChem 2015, 7, 190222; b) B. D. Sherry, A. Fürstner, Acc. Chem. Res. 2008, 41, 1500-1511.

[57] A. Matsumoto, L. llies, E. Nakamura, J. Am. Chem. Soc. 2011, 133, 65576559 . 


\section{References}

[58] L. Ilies, A. Matsumoto, M. Kobayashi, N. Yoshikai, E. Nakamura, Synlett 2012, 23, 2381-2384.

[59] L. Adak, N. Yoshikai, Tetrahedron 2012, 68, 5167-5171.

[60] T. Matsubara, L. llies, E. Nakamura, Chem. Asian J. 2016, 11, 380-384.

[61] G. Cera, T. Haven, L. Ackermann, Chem. Commun. 2017, 53, 6460-6463.

[62] M. M. Bagga, P. L. Pauson, F. J. Preston, R. I. Reed, Chem. Commun. 1965, $543-544$.

[63] T. Jia, C. Zhao, R. He, H. Chen, C. Wang, Angew. Chem. Int. Ed. 2016, 55, $5268-5271$.

[64] a) S. Yu, S. Ma, Angew. Chem. Int. Ed. 2012, 51, 3074-3112; b) P. RiveraFuentes, F. Diederich, Angew. Chem. Int. Ed. 2012, 51, 2818-2828.

[65] J. Ye, S. Ma, Acc. Chem. Res. 2014, 47, 989-1000.

[66] a) A. Ahlers, T. de Haro, B. Gabor, A. Fürstner, Angew. Chem. Int. Ed. 2016, 55, 1406-1411; b) P. Rivera-Fuentes, F. Diederich, Angew. Chem. Int. Ed. 2012, 51, 2818-2828.

[67] a) Z. Dong, Z. Ren, S. J. Thompson, Y. Xu, G. Dong, Chem. Rev. 2017, 117, 9333-9403; b) G. E. M. Crisenza, J. F. Bower, Chem. Lett. 2016, 45, 2-9; c) S. Pan, T. Shibata, ACS Catal. 2013, 3, 704-712; d) D. A. Colby, R. G. Bergman, J. A. Ellman, Chem. Rev. 2010, 110, 624-655.

[68] a) Z.-J. Jia, C. Merten, R. Gontla, C. G. Daniliuc, A. P. Antonchick, H. Waldmann, Angew. Chem. Int. Ed. 2017, 56, 2429-2434; b) S. Nakanowatari, L. Ackermann, Chem. Eur. J. 2015, 21, 16246-16251; c) X.-F. Xia, Y.-Q. Wang, L.-L. Zhang, X.-R. Song, X.-Y. Liu, Y.-M. Liang, Chem. Eur. J. 2014, 20, 50875091; d) B. Ye, N. Cramer, J. Am. Chem. Soc. 2013, 135, 636-639; e) R. Zeng, J. Ye, C. Fu, S. Ma, Adv. Synth. Catal. 2013, 355, 1963-1970; f) R. Zeng, C. Fu, S. Ma, J. Am. Chem. Soc. 2012, 134, 9597-9600; g) Y. J. Zhang, E. Skucas, M. J. Krische, Org. Lett. 2009, 11, 4248-4250. 


\section{References}

[69] a) A. Brandi, S. Cicchi, F. M. Cordero, A. Goti, Chem. Rev. 2014, 114, 73177420; b) H. Pellissier, Tetrahedron 2010, 66, 8341-8375; c) A. Goti, M. F. Cordero, A. Brandi, Top. Curr. Chem. 2005, 178, 1-97; d) A. Brandi, S. Cicchi, F. M. Cordero, A. Goti, Chem. Rev. 2003, 103, 1213-1270; e) A. de Meijere, S. I. Kozhushkov, Eur. J. Org. Chem. 2000, 3809-3822; f) A. de Meijere, S. I. Kozhushkov, A. F. Khlebnikov, Top. Curr. Chem. 2000, 207, 89-147; g) A. de Meijere, S. I. Kozhushkov, A. F. Khlebnikov, Russ. J. Org. Chem. 1996, 32, 1555-1575.

[70] a) M. Schinkel, J. Wallbaum, S. I. Kozhushkov, I. Marek, L. Ackermann, Org. Lett. 2013, 15, 4482-4484; b) L. Ackermann, S. I. Kozhushkov, D. S. Yufit, Eur. J. Org. Chem. 2012, 12068-12077; c) S. I. Kozhushkov, D. S. Yufit, L. Ackermann, Org. Lett. 2008, 10, 3409-3412.

[71] a) Y. Cohen, A. Cohen, I. Marek, Chem. Rev. 2020, doi: 10.1021/acs.chemrev.0c00167; b) P. H. Chen, B. A. Billett, T. Tsukamoto, G. Dong, ACS Catal. 2017, 7, 1340-1360; c) D. S. Kim, W. J. Park, C. H. Jun, Chem. Rev. 2017, 117, 8977-9015; d) L. Souillart, N. Cramer, Chem. Rev. 2015, 115, 9410-9464; e) T. Xu, A. Dermenci, G. Dong, Top. Curr. Chem. 2014, 346, 233-257; f) K. Ruhland, Eur. J. Org. Chem. 2012, 2683-2706; g) M. Murakami, T. Matsuda, Chem. Commun. 2011, 47, 1100-1105.

[72] M. Murakami, Y. Ito, Top. Organomet. Chem. 1999, 3, 97-127.

[73] Z. Nairoukh, M. Cormier, I. Marek, Nat. Rev. Chem. 2017, 1, 0035.

[74] a) K. Korvorapun, M. Moselage, J. Struwe, T. Rogge, A. M. Messinis, L. Ackermann, Angew. Chem. Int. Ed. 2020, doi: 10.1002/anie.202007144; b) N. Y. P. Kumar, T. Rogge, S. R. Yetra, A. Bechtoldt, E. Clot, L. Ackermann, Chem. Eur. J. 2017, 23, 17449-17453; c) N. Y. P. Kumar; A. Bechtoldt, K. Raghuvanshi, L. Ackermann, Angew. Chem. Int. Ed. 2016, 55, 6929-6932; d) M. P. Drapeau, L. J. Gooßen, Chem. Eur. J. 2016, 22, 18654-18677; e) X.-Y. Shi, X.-F. Dong, J. Fan, K.-Y. Liu, L.-F. Wei, C.-J. Li, Sci. China Chem. 2015, 


\section{References}

58, 1286-1292; f) X.-Y. Shi, K.-Y. Liu, J. Fan, X.-F. Dong, J.-F. Wei, C.-J. Li, Chem. Eur. J. 2014, 20, 1-5; g) W. I. Dzik, P. P. Lange, L. J. Gooßen, Chem. Sci. 2012, 3, 2671-2678; h) J. Cornella, M. Righi, I. Larrosa, Angew. Chem. Int. Ed. 2011, 50, 9429-9432; i) L. J. Gooßen, N. Rodriguez, K. Gooßen, Angew. Chem. Int. Ed. 2008, 47, 3100-3120.

[75] a) A. Dermenci, G. Dong, Sci. China Chem. 2013, 56, 685-701; b) Q. Shuai, L. Yang, X. Guo, O. Baslé, C.-J. Li, J. Am. Chem. Soc. 2010, 132, 1221212213; c) X. Guo, J. Wang, C.-J. Li, J. Am. Chem. Soc. 2009, 131, 1509215093; d) P. Fristrup, M. Kreis, A. Palmelund, P.-O. Norrby, R. Madsen, J. Am. Chem. Soc. 2008, 130, 5206-5215; e) J. Tsuji, K. Ohno, Tetrahedron Lett. 1965, 44, 3969-3971; f) H. E. Eschinazi, H. Pines, J. Org. Chem. 1959, 24, 1369-1369.

[76] a) C. L. Ladd, D. S. Roman, A. B. Charette, Tetrahedron 2013, 69, 4479-4487; b) D. A. Colby, A. S. Tsai, R. G. Bergman, A. J. Ellman, Acc. Chem. Res. 2012, 45, 814-825; c) S. Rousseaux, B. Liégault, K. Fagnou, Chem. Sci. 2012, 3, 244-248.

[77] R. D. Bach, O. Dmitrenko, J. Am. Chem. Soc. 2004, 126, 4444-4452.

[78] a) G. Fumagalli, S. Stanton, J. F. Bower, Chem. Rev. 2017, 117, 9404-9432; b) I. Marek, A. Masarwa, P. O. Delaye, M. Leibeling, Angew. Chem. Int. Ed. 2015, 54, 414-429.

[79] a) R. A. Periana, R. G. Bergman, J. Am. Chem. Soc. 1986, 108, 7346-7355; b) R. A. Periana, R. G. Bergman, J. Am. Chem. Soc. 1984, 106, 7272-7273.

[80] a) X. Zhou, S. Yu, L. Kong, X. Li, ACS Catal. 2016, 6, 647-651; b) X. Zhou, S. Yu, Z. Qi, L. Kong, X. Li, J. Org. Chem. 2016, 81, 4869-4875; c) A. Masarwa, M. Weber, R. Sarpong, J. Am. Chem. Soc. 2015, 137, 6327-6334; d) T. Matsuda, I. Yuihara, Chem. Commun. 2015, 51, 7393-7396; e) A. Vasseur, P. Perrin, O. Eisenstein, I. Marek, Chem. Sci. 2015, 6, 2770-2776; f) A. Masarwa, D. Didier, T. Zabrodski, M. Schinkel, L. Ackermann, I. Marek, Nature 2014, 505, 


\section{References}

199-203; g) D. Rosa, A. Orellana, Chem. Commun. 2012, 48, 1922-1924; h) Z. Chai, T. J. Rainey, J. Am. Chem. Soc. 2012, 134, 3615-3618; i) D. Crépin, J. Dawick, C. Aïssa, Angew. Chem. Int. Ed. 2010, 49, 620-623; j) T. Seiser, O. A. Roth, N. Cramer, Angew. Chem. Int. Ed. 2009, 48, 6320-6323; k) M. Shigeno, T. Yamamoto, M. Murakami, Chem. Eur. J. 2009, 15, 12929-12931; I) C. Aïssa, A. Fürstner, J. Am. Chem. Soc. 2007, 129, 14836-14837; m) T. Matsuda, M. Shigeno, M. Murakami, J. Am. Chem. Soc. 2007, 129, 1208612087.

[81] A. D. Aloise, M. E. Layton, M. D. Shair, J. Am. Chem. Soc. 2000, 122, 12610 12611.

[82] A. Schweinitz, A. Chtchemelinine, A. Orellana, Org. Lett. 2011, 13, 232-235.

[83] a) Q. Li, X. Yuan, B. Li, B. Wang, Chem. Commun. 2020, 56, 1835-1838; b) Q. Wang, L. Shi, S. Liu, C. Zhi, L.-R. Fu, X.-Q. Hao, M.-P. Song, RSC Adv. 2020, 10, 10883-10887; c) Q. Wang, C.-L. Zhi, P.-P. Lu, S. Liu, X. Zhu, X. Q. Hao, M.-P. Song, Adv. Synth. Catal. 2019, 361, 1253-1258; d) Z. Hu, X.-Q. Hu, G. Zhang, L. J. Gooßen, Org. Lett. 2019, 21, 6770-6773; e) Y.-Q. Zhu, Y.X. Niu, L.-W. Hui, J.-L. He, K. Zhu, Adv. Synth. Catal. 2019, 361, 2897-2903; f) J.-Q. Wu, Z.-P. Qiu, S.-S. Zhang, J.-G. Liu, Y.-X. Lao, L.-Q. Gu, Z.-S. Huang, J. Li, H. Wang, Chem. Commun. 2015, 51, 77-80; g) J.-Q. Wu, Z.-P. Qiu, S.S. Zhang, J.-G. Liu, Y.-X. Lao, L.-Q. Gu, Z.-S. Huang, J. Li, H. Wang, Chem. Commun. 2015, 51, 77-80.

[84] S. Cui, Y. Zhang, Q. Wu, Chem. Sci. 2013, 4, 3421-3426.

[85] a) M. Li, F. Y. Kwong, Angew. Chem. Int. Ed. 2018, 57, 6512-6515; b) Q. Lu, F. J. R. Klauck, F. Glorius, Chem. Sci. 2017, 8, 3379-3383; c) T. H. Meyer, W. Liu, M. Feldt, A. Wuttke, R. A. Mata, L. Ackermann, Chem. Eur. J. 2017, 23, 5443-5447; d) D. Zell, Q. Bu, M. Feldt, L. Ackermann, Angew. Chem. Int. Ed. 2016, 55, 7408-7412. 


\section{References}

[86] a) S. Guo, D. I. AbuSalim, S. P. Cook, J. Am. Chem. Soc. 2018, 140, 1237812382; b) N. Yoshikai, Isr. J. Chem. 2017, 57, 1117-1130; c) R. P. Yu, D. Hesk, N. Rivera, I. Pelczer, P. J. Chirik, Nature 2016, 529, 195-199; d) T. J. Osberger, D. C. Rogness, J. T. Kohrt, A. F. Stepan, M. C. White, Nature 2016, 537, 214 219; e) C. Bornschein, S. Werkmeister, B. Wendt, H. Jiao, E. Alberico, W. Baumann, H. Junge, K. Junge, M. Beller, Nat. Commun. 2014, 5, 4111; f) R. V. Jagadeesh, A.-E. Surkus, H. Junge, M.-M. Pohl, J. Radnik, J. Rabeah, H. Huan, V. Schuenemann, A. Brueckner, M. Beller, Science 2013, 342, 10731076.

[87] P. Gandeepan, N. Kaplaneris, S. Santoro, L. Vaccaro, L. Ackermann, ACS Sustainable Chem. Eng. 2019, 7, 8023-8040.

[88] a) S. Tang, O. Eisenstein, Y. Nakao, S. Sakaki, Organometallics 2017, 36, 2761-2771; b) O. Eisenstein, J. Milani, R. N. Perutz, Chem. Rev. 2017, 117, 8710-8753; c) J. Loup, D. Zell, J. C. A. Oliveira, H. Keil, D. Stalke, L. Ackermann, Angew. Chem. Int. Ed. 2017, 56, 14197-14201.

[89] J. Mo, T. Müller, J. C. A. Oliveira, L. Ackermann, Angew. Chem. Int. Ed. 2018, $57,7719-7723$.

[90] a) P. Gütlich, E. Bill, A. X. Trautwein, Mössbauer Spectroscopy and Transition Metal Chemistry, Springer, Heidelberg, 2011; b) P. Gütlich, Z. Anorg. Allg. Chem. 2012, 638, 15-43.

[91] S. B. Munoz III, S. L. Daifuku, W. W. Brennessel, M. L. Neidig, J. Am. Chem. Soc. 2016, 138, 7492-7495.

[92] a) M. Callingham, B. M. Partridge, W. Lewis, H. W. Lam, Angew. Chem. Int. Ed. 2017, 56, 16352-16356; b) B. M. Partridge, M. Callingham, W. Lewis, H. W. Lam, Angew. Chem. Int. Ed. 2017, 56, 7227-7232; c) S. E. Korkis, D. J. Burns, H. W. Lam, J. Am. Chem. Soc. 2016, 138, 12252-12257; d) D. J. Burns, H. W. Lam, Angew. Chem. Int. Ed. 2014, 53, 9931-9935; e) J. Yan, N. Yoshikai, Org. Chem. Front. 2017, 4, 1972-1975; f) J. Yan, N. Yoshikai, ACS 


\section{References}

Catal. 2016, 6, 3738-3742; g) B.-H. Tan, J. Dong, N. Yoshikai, Angew. Chem. Int. Ed. 2012, 51, 9610-9614; h) B. Zhou, H. Sato, L. Ilies, E. Nakamura, ACS Catal. 2018, 8, 8-11.

[93] J. Mo, T. Müller, J. C. A. Oliveira, S. Demeshko, F. Meyer, L. Ackermann, Angew. Chem. Int. Ed. 2019, 58, 12874-12878.

[94] T. E. Boddie, S. H. Carpenter, T. M. Baker, J. C. DeMuth, G. Cera, W. W. Brennessel, L. Ackermann, M. L. Neidig, J. Am. Chem. Soc. 2019, 141, 1233812345.

[95] E. Bill, E. Mfit Program; Max-Planck Institute for Chemical Energy Conversion: Mülheim/Ruhr, Germany, 2008.

[96] a) W. Li, Z. Lin, L. Chen, X. Tian, Y. Wenig, S.-H. Huang, R. Hong, Tetrahedron Lett. 2016, 57, 603-606; b) H. Luo, S. Ma, Eur. J. Org. Chem. 2013, 30413048; c) L. Zhang, X. Li, Y. Liu, D. Zhang, Chem. Commun. 2015, 51, 66336636; d) Q. Li, C. Fu, S. Ma, Angew. Chem. Int. Ed. 2012, 51, 11783-11786.

[97] G. Winter, D. W. Thompson, J. R. Loehe, Inorg. Synth. 2007, 14, 99-104.

[98] T. Schwier, M. Rubin, V. Gevorgyan, Org. Lett. 2004, 6, 1999-2001.

[99] T. Kippo, K. Hamaoka, I. Ryu, J. Am. Chem. Soc. 2013, 135, 632-635.

[100] Anderson H. W. (1972) PhD Thesis, Massachusetts Institute of Technology, Cambridge, Massachusetts.

[101] a) A. de Meijere, S. I. Kozhushkov, T. Späth, Org. Synth. 2002, 78, 142; b) A. de Meijere, S. I. Kozhushkov, N. S. Zefirov, Synthesis 1993, (7), 681-683; c) K. A. Lukin, S. I. Kozhushkov, A. A. Andrievsky, B. I. Ugrak, N. S. Zefirov, J. Org. Chem. 1991, 56, 6176-6179.

[102] H.-P. Guan, M. B. Ksebati, Y.-C. Cheng, J. C. Drach, E. R. Kern, J. Zemlicka, J. Org. Chem. 2000, 65, 1280-1290.

[103] K. Miyazawa, D. S. Yufit, J. A. K. Howard, A. de Meijere, Eur. J. Org. Chem. 2000, 4109-4117. 


\section{References}

[104] O. V. Dolomanov, L. J. Bourhis, R. J. Gildea, J. A. K. Howard, H. Puschmann, J. Appl. Cryst. 2009, 42, 339-341.

[105] G. M. Sheldrick, Acta Cryst. 2015, A71, 3-8.

[106] G. M. Sheldrick, Acta Cryst. 2008, A64, 112-122. 


\section{NMR Spectra}
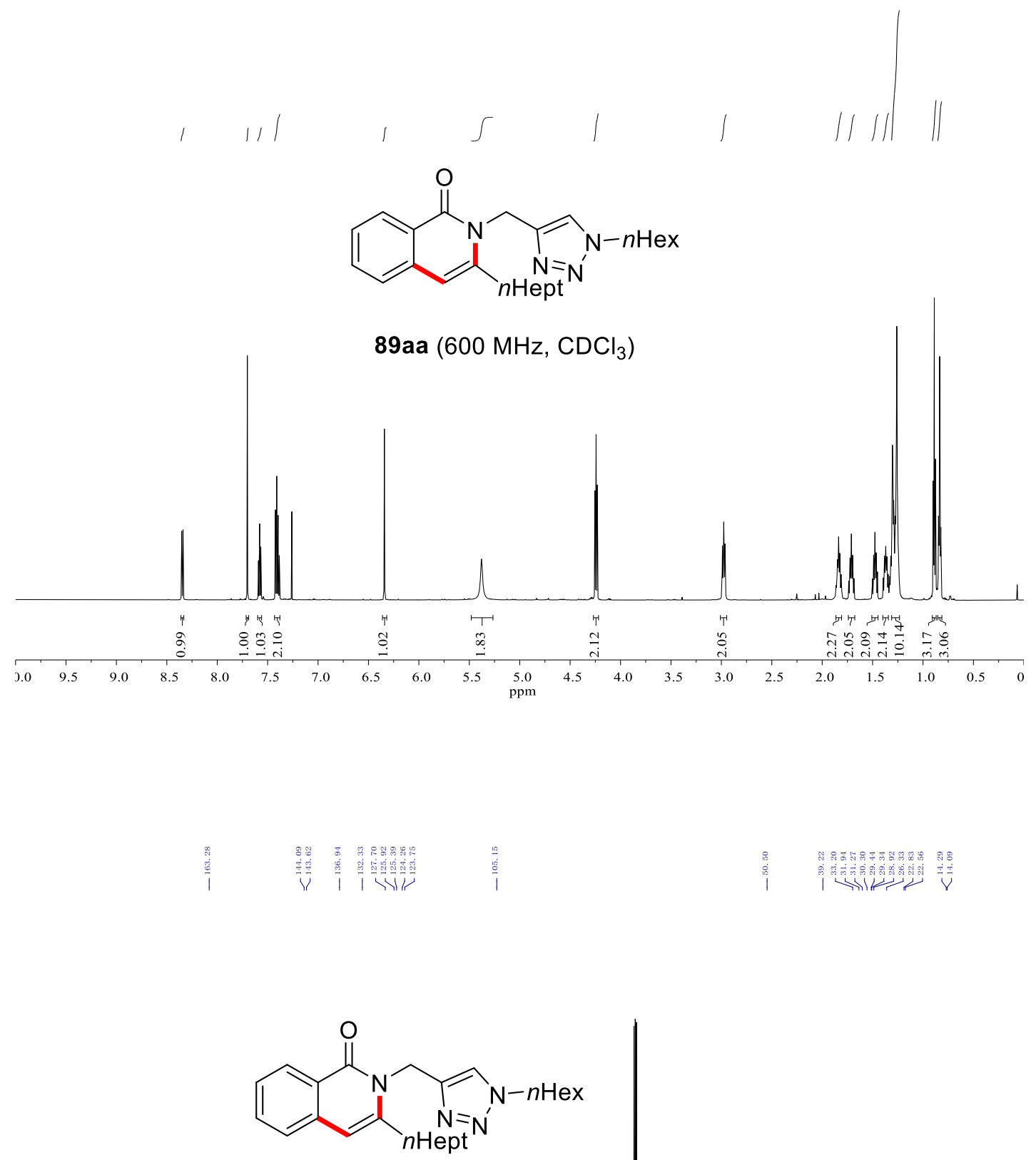

89aa (126 MHz, $\mathrm{CDCl}_{3}$ )

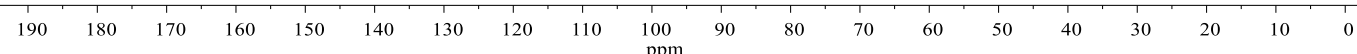




\section{NMR Spectra}
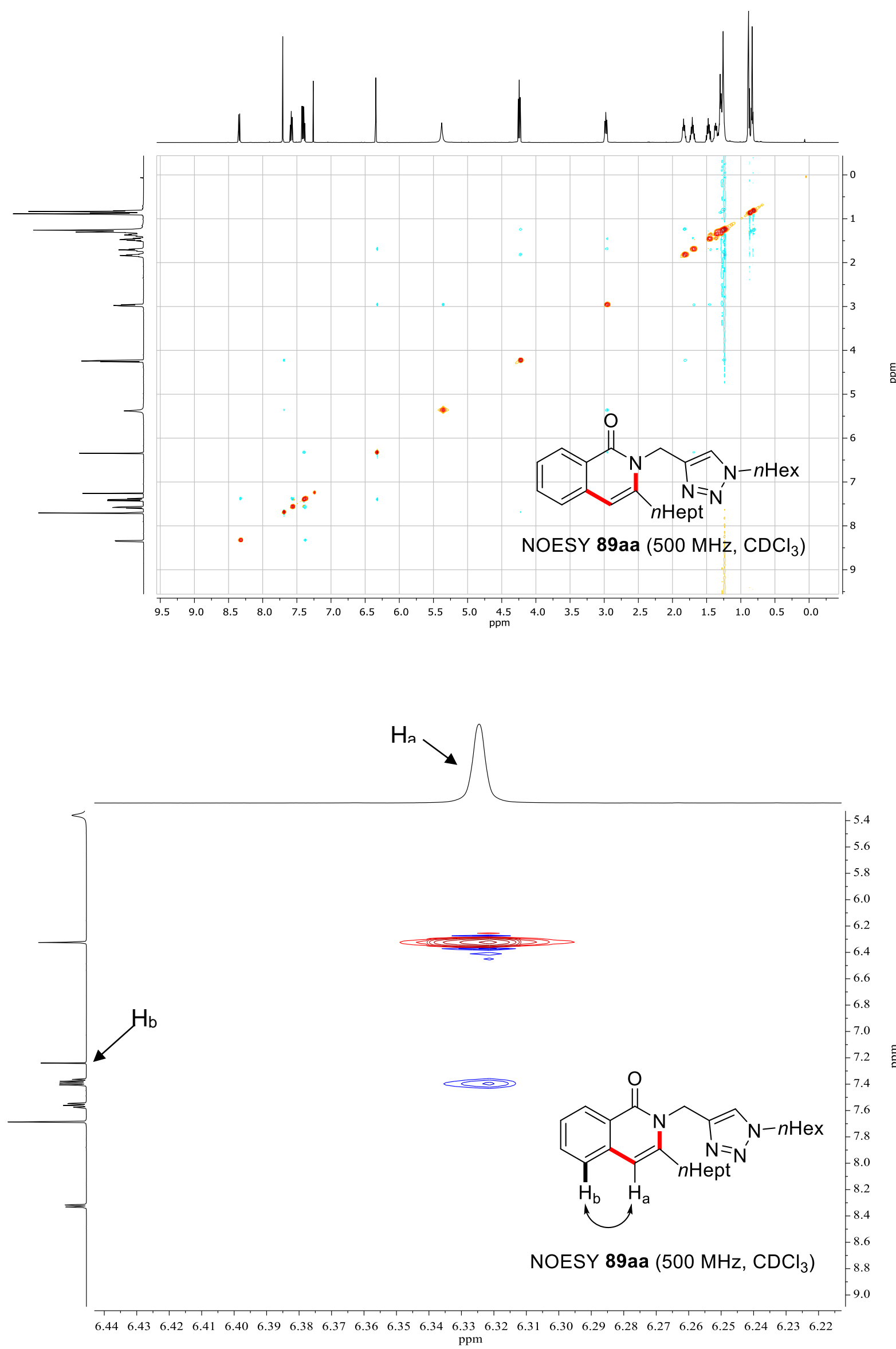


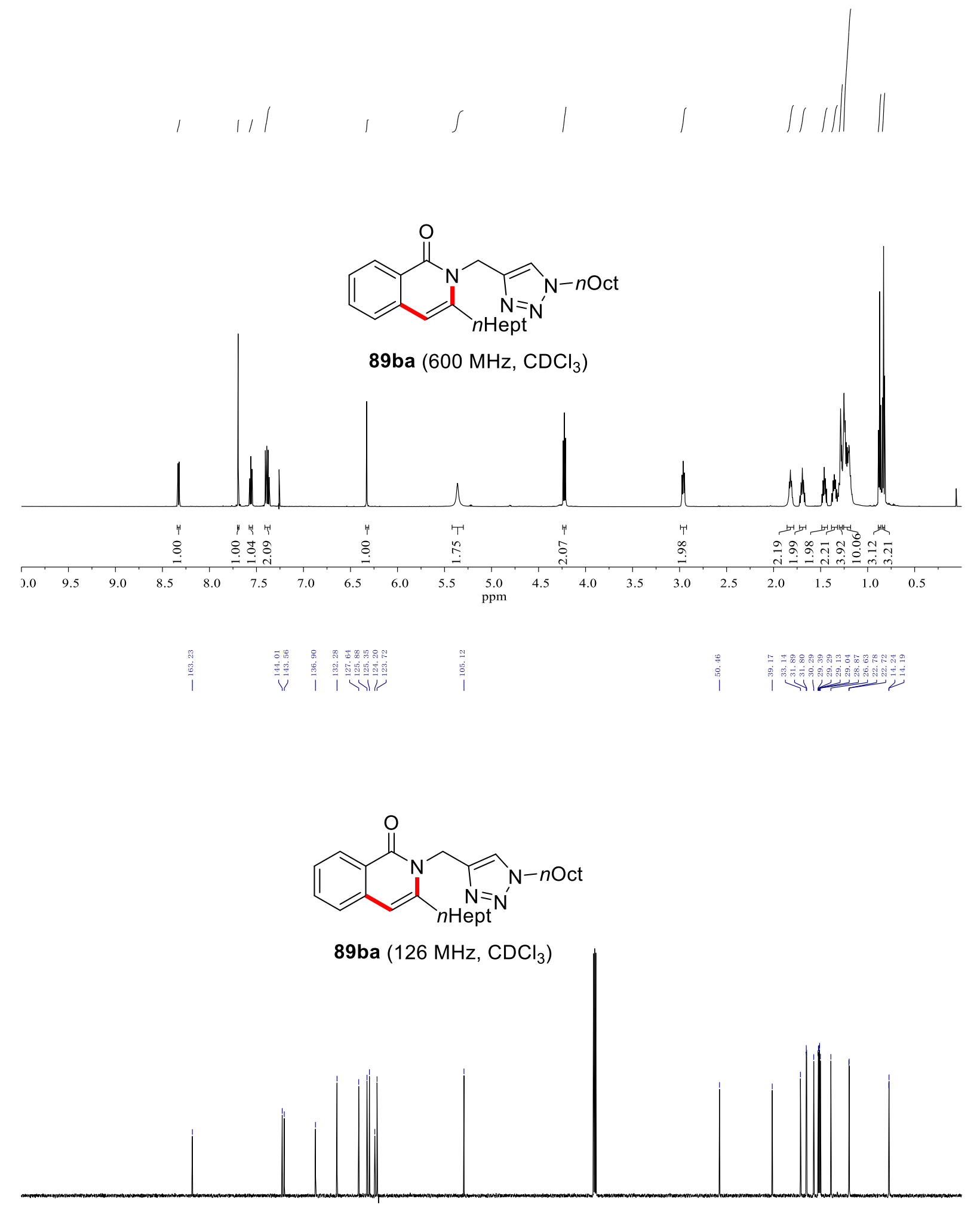

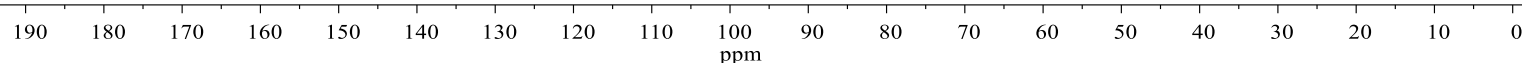




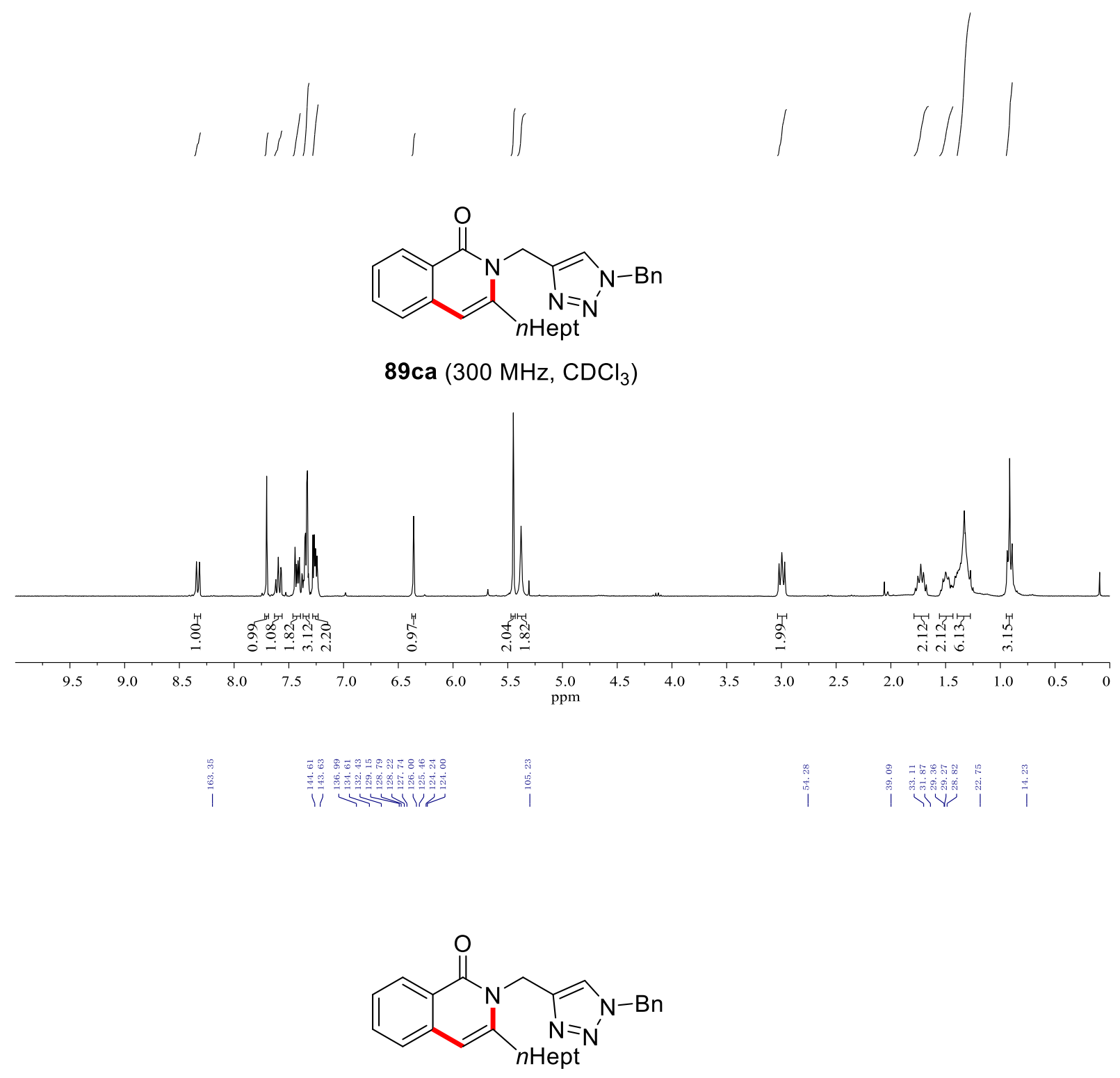

89ca $\left(75 \mathrm{MHz}, \mathrm{CDCl}_{3}\right)$

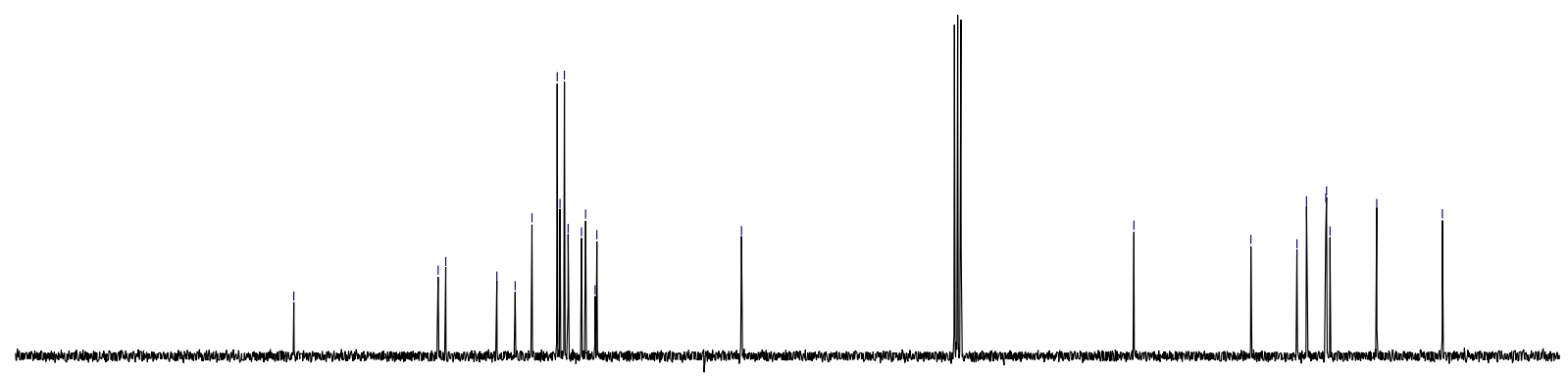

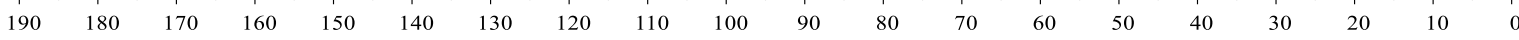


NMR Spectra

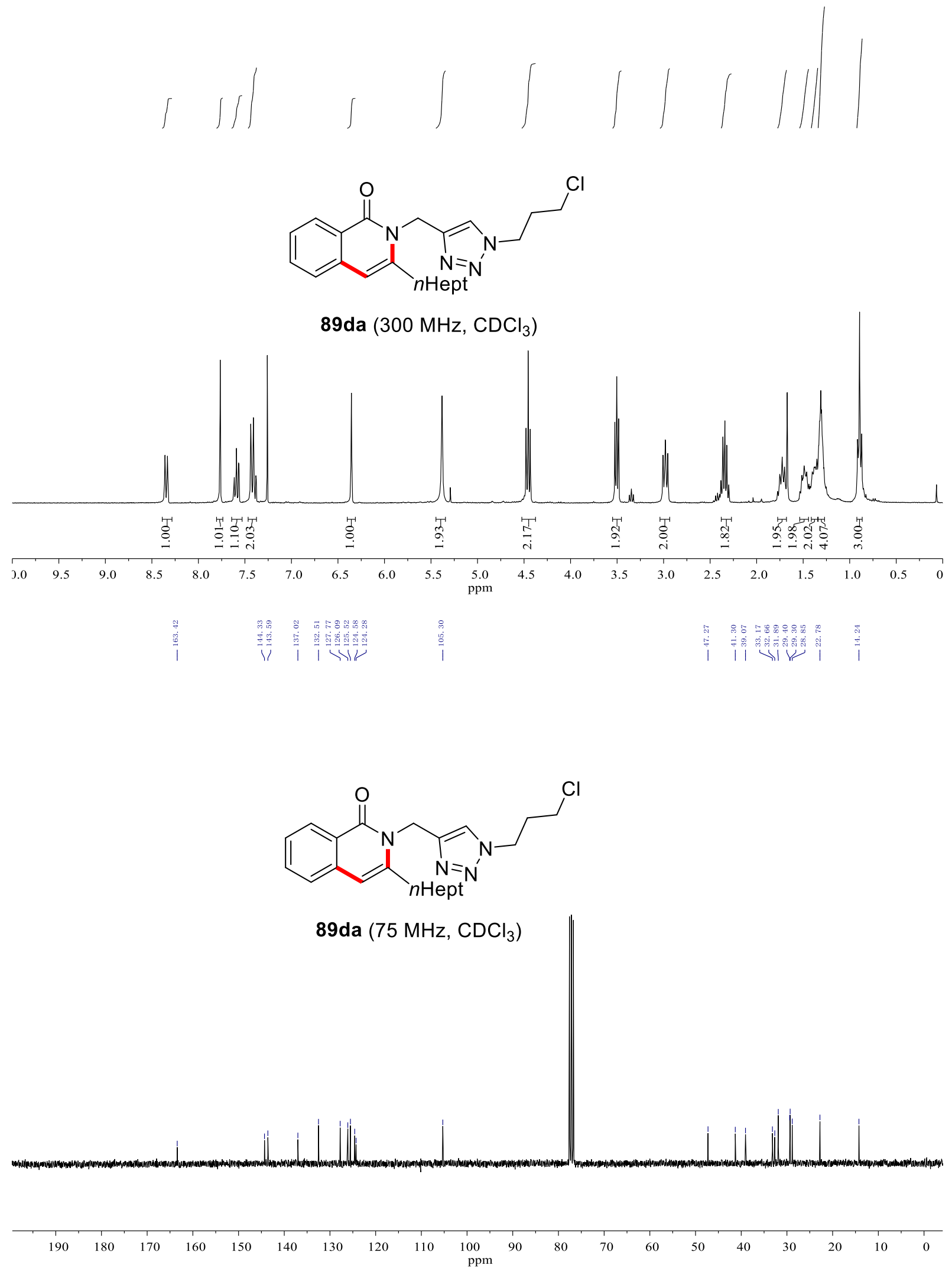



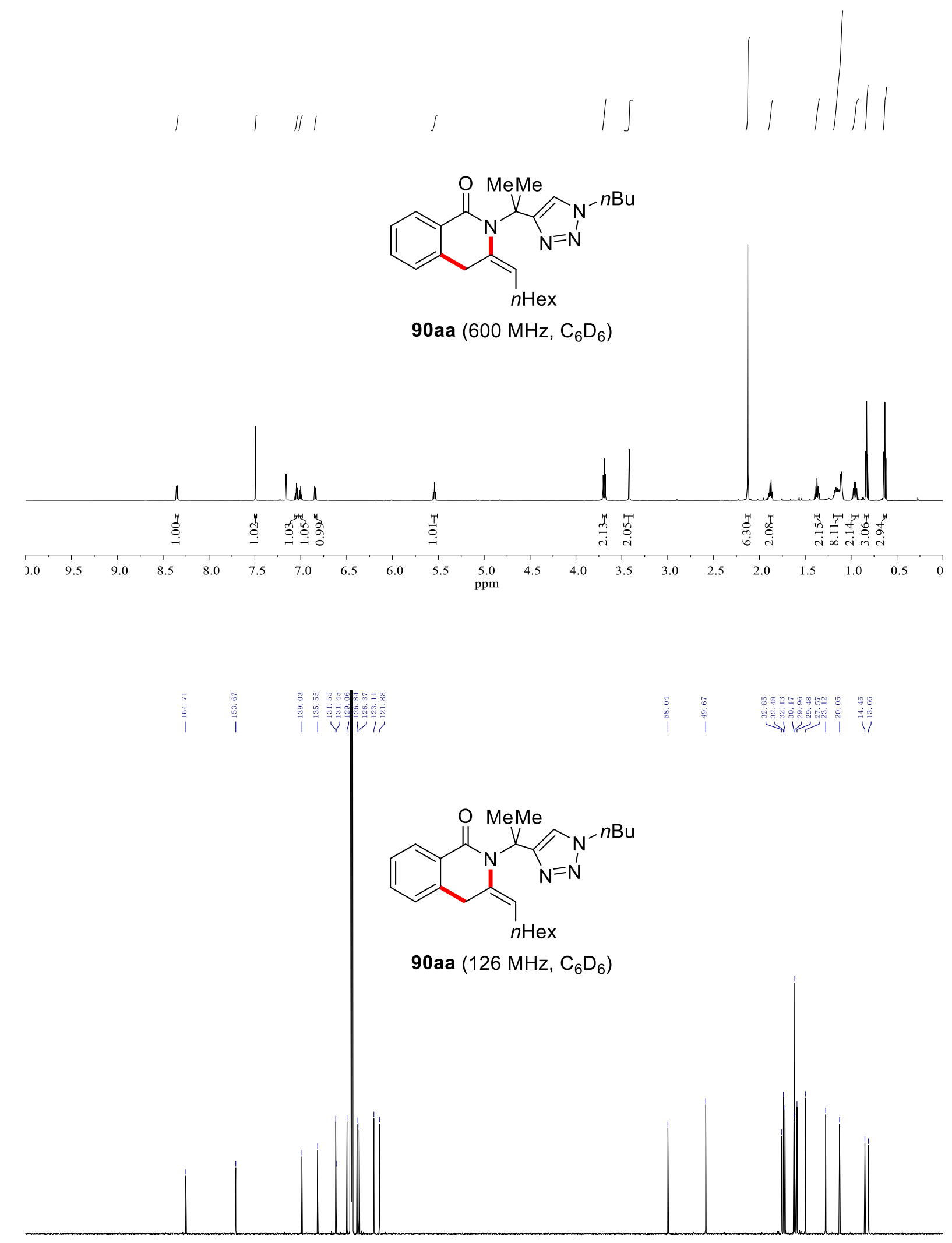

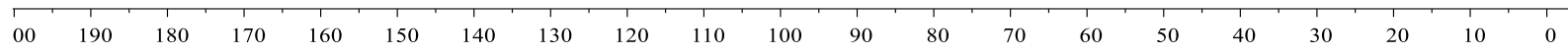


NMR Spectra

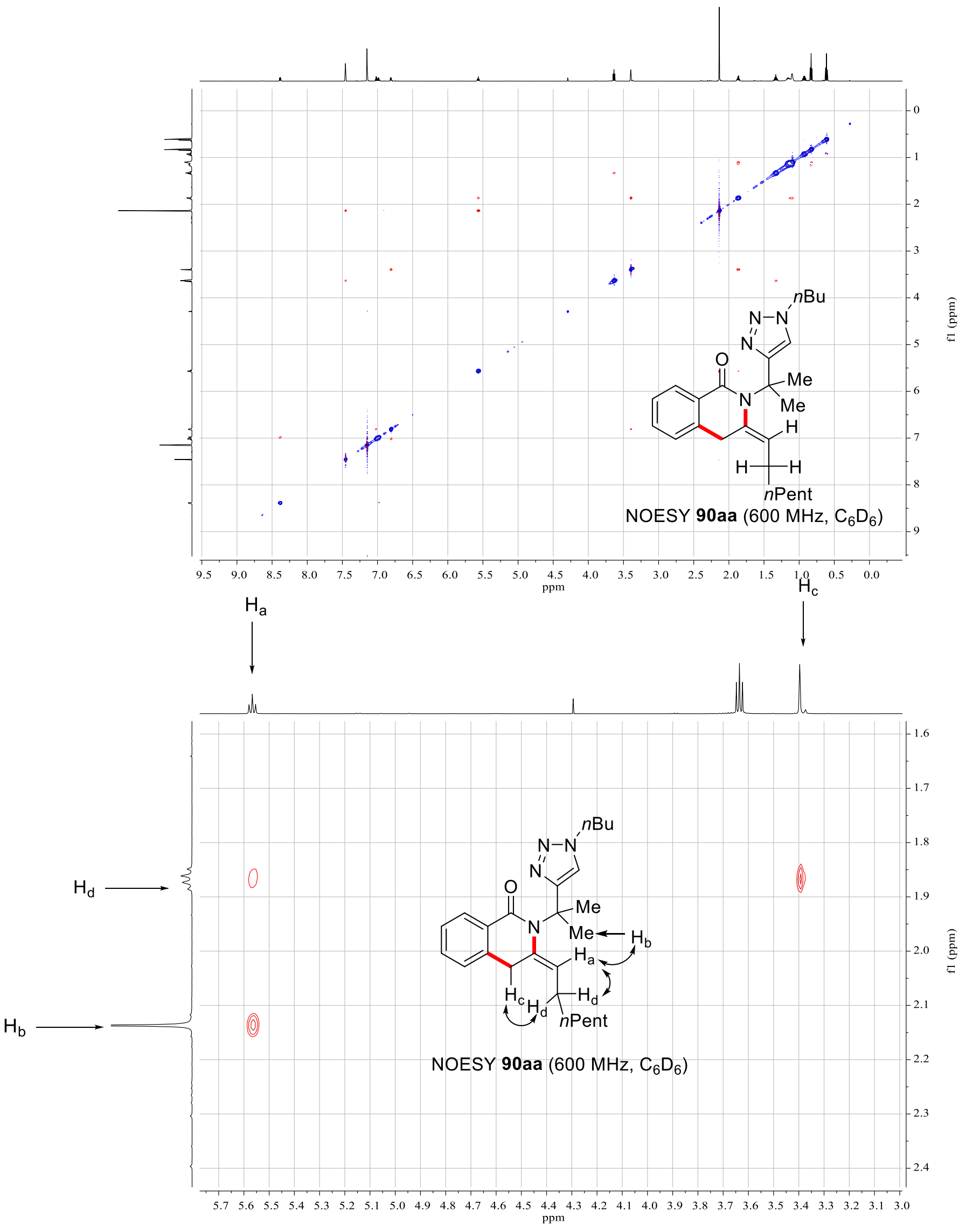


NMR Spectra
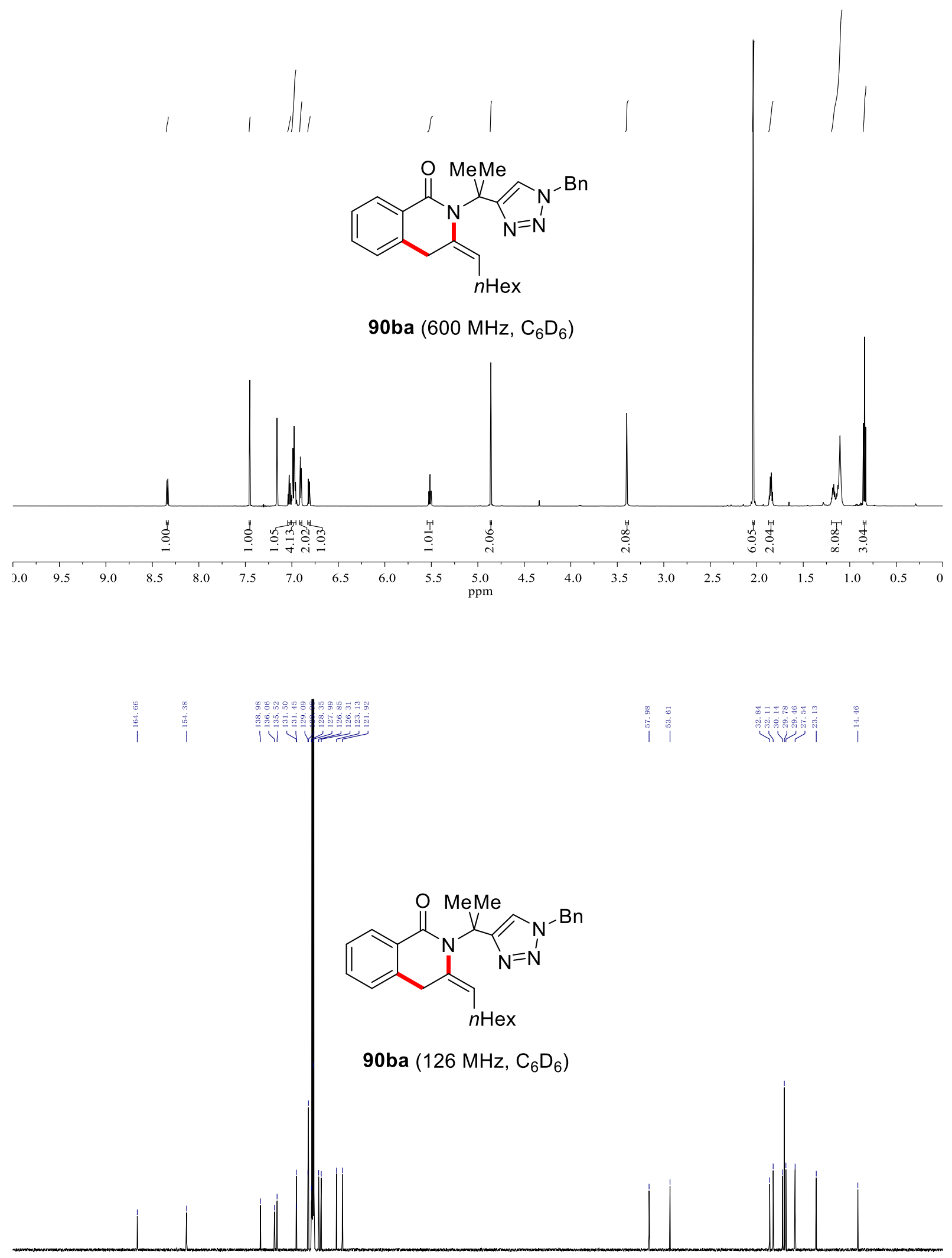

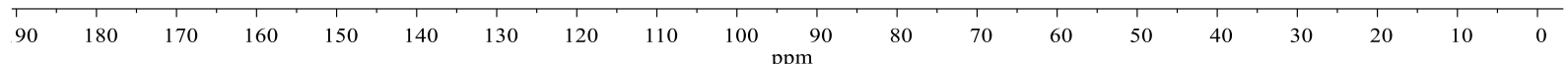



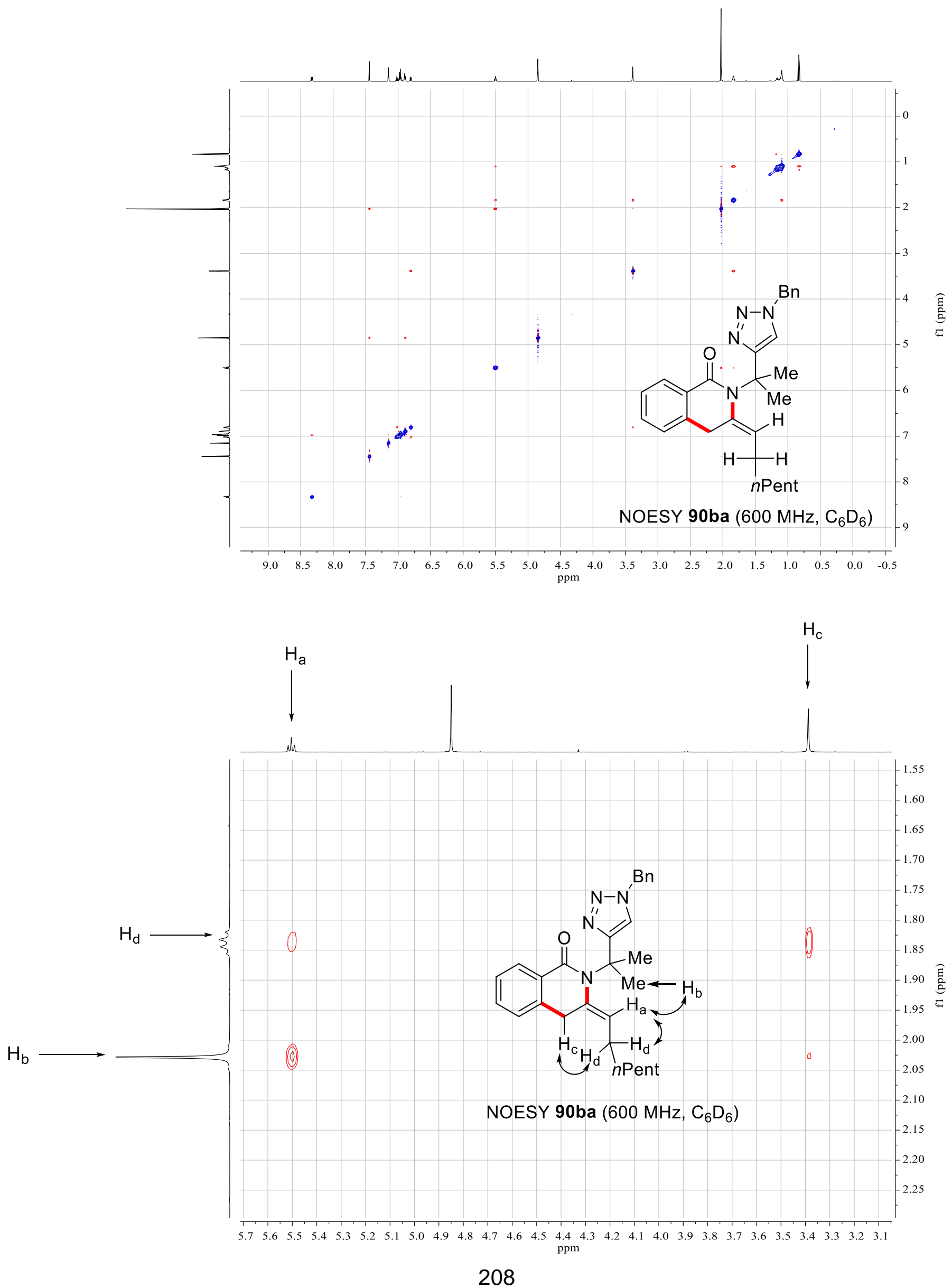

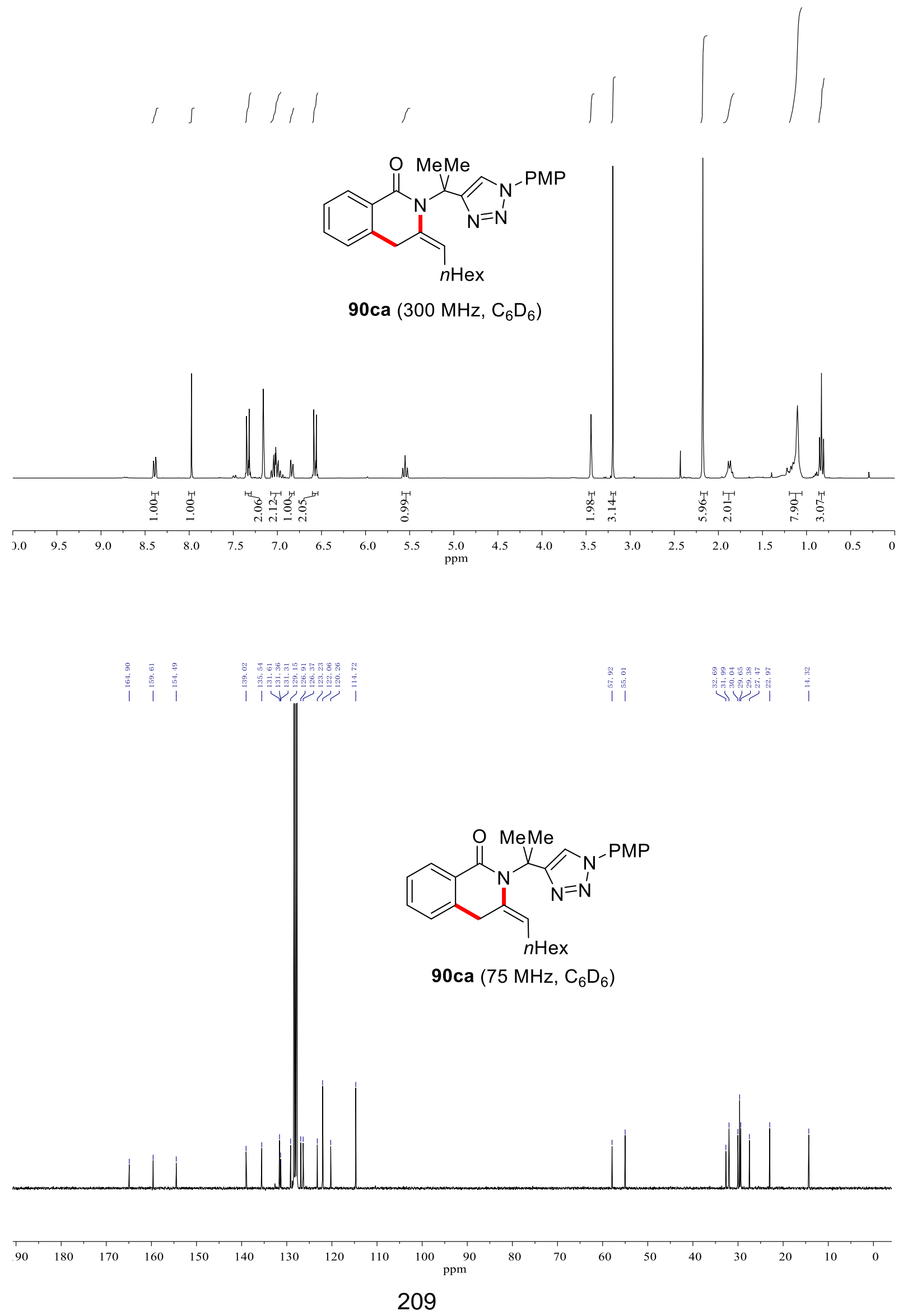
NMR Spectra
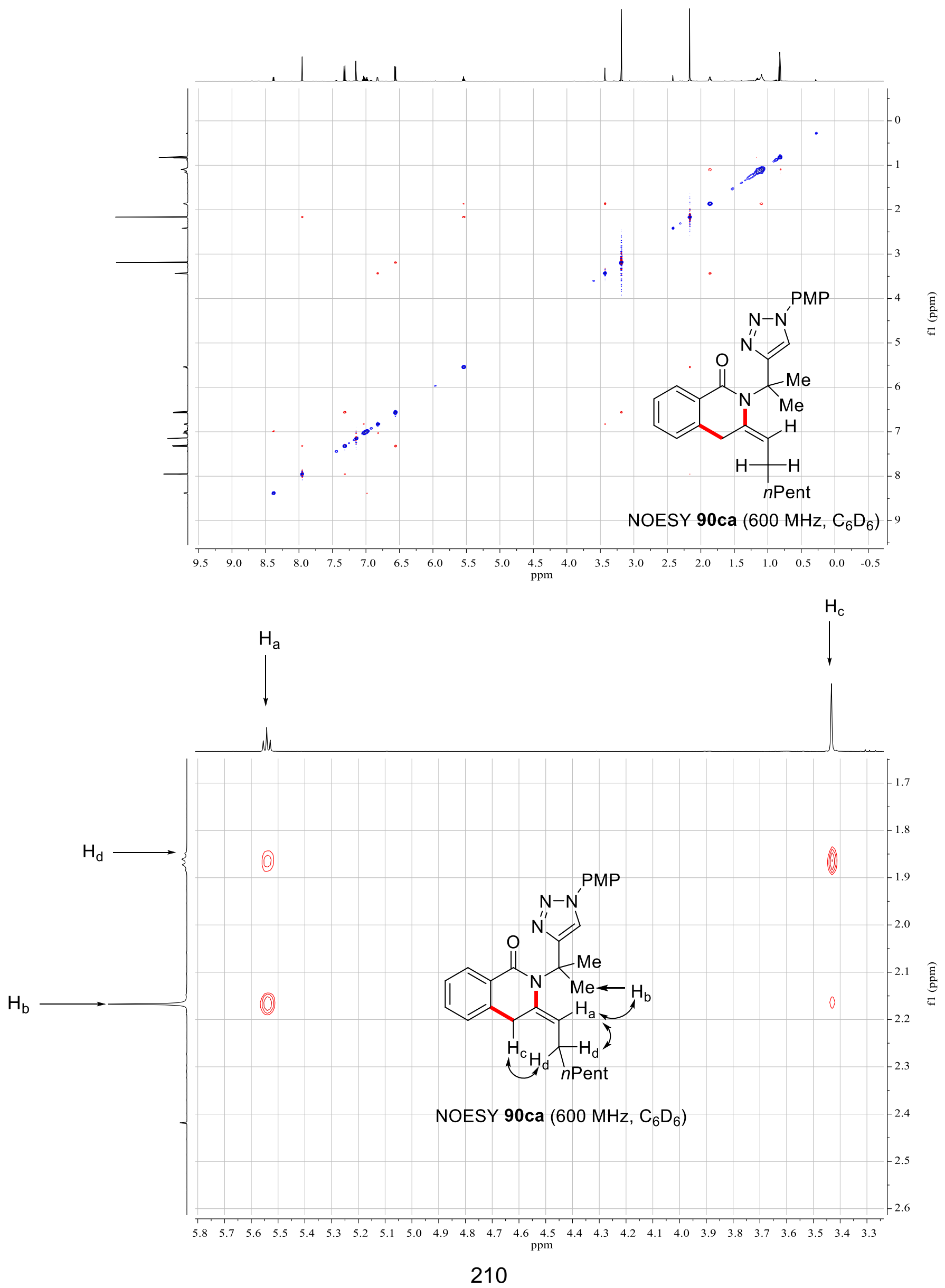


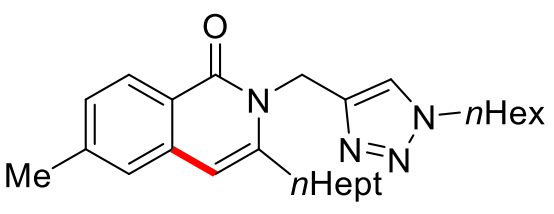

89ea $\left(600 \mathrm{MHz}, \mathrm{CDCl}_{3}\right)$
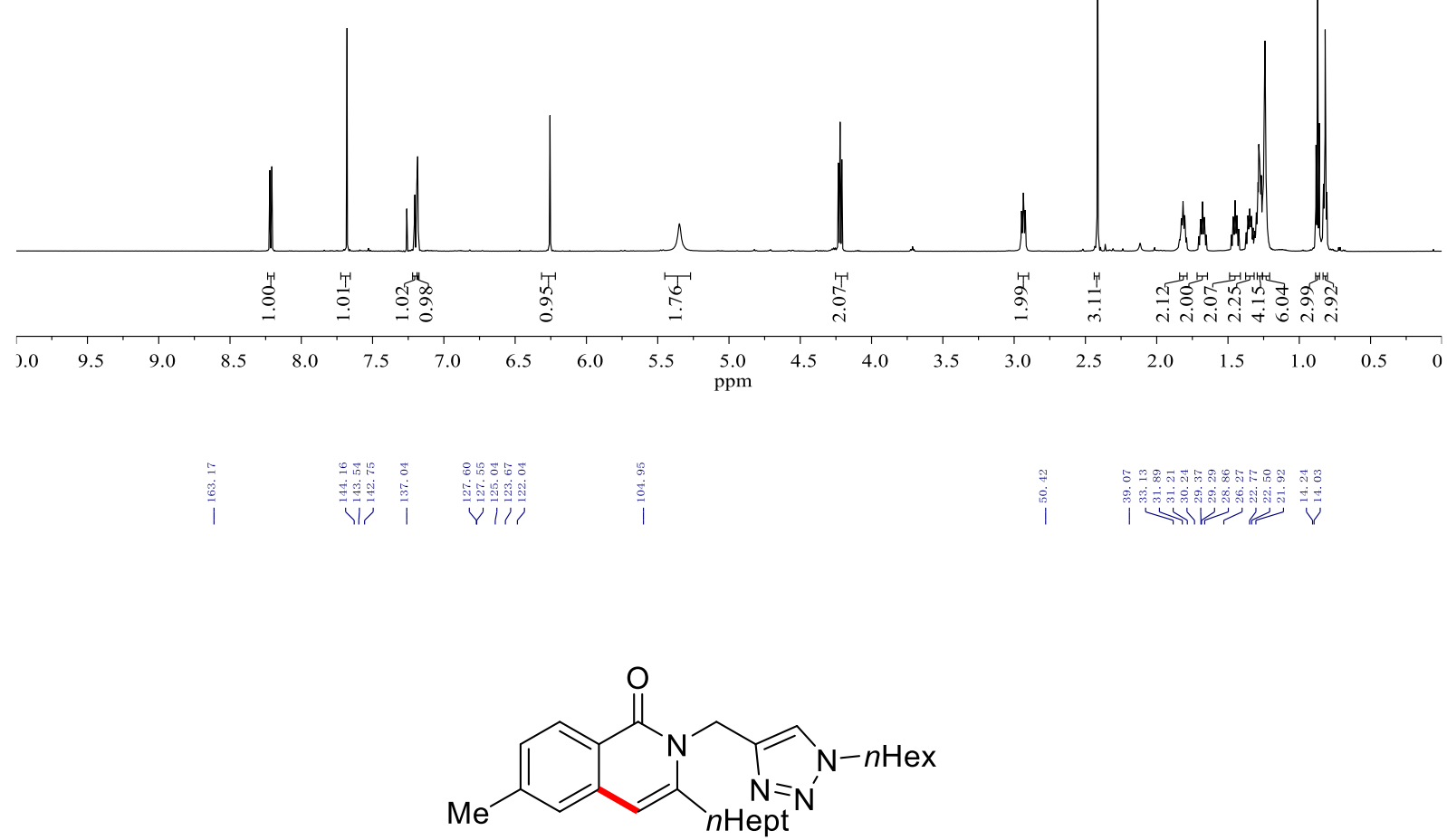

89ea $\left(126 \mathrm{MHz}, \mathrm{CDCl}_{3}\right)$

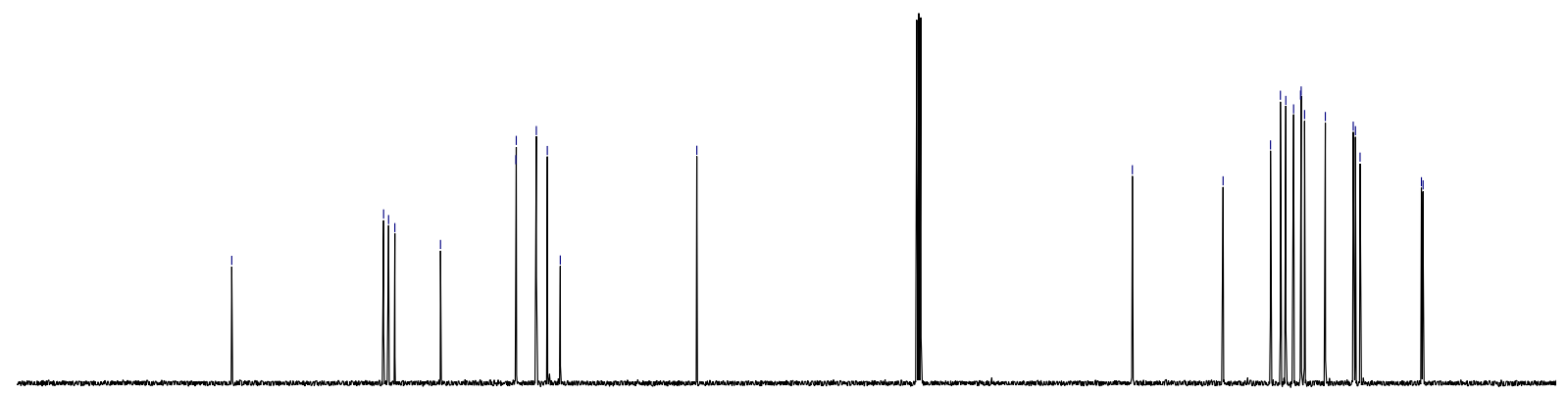

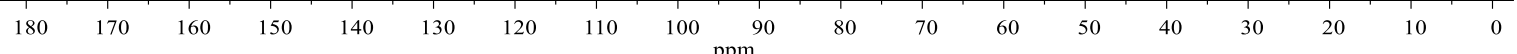




\section{NMR Spectra}
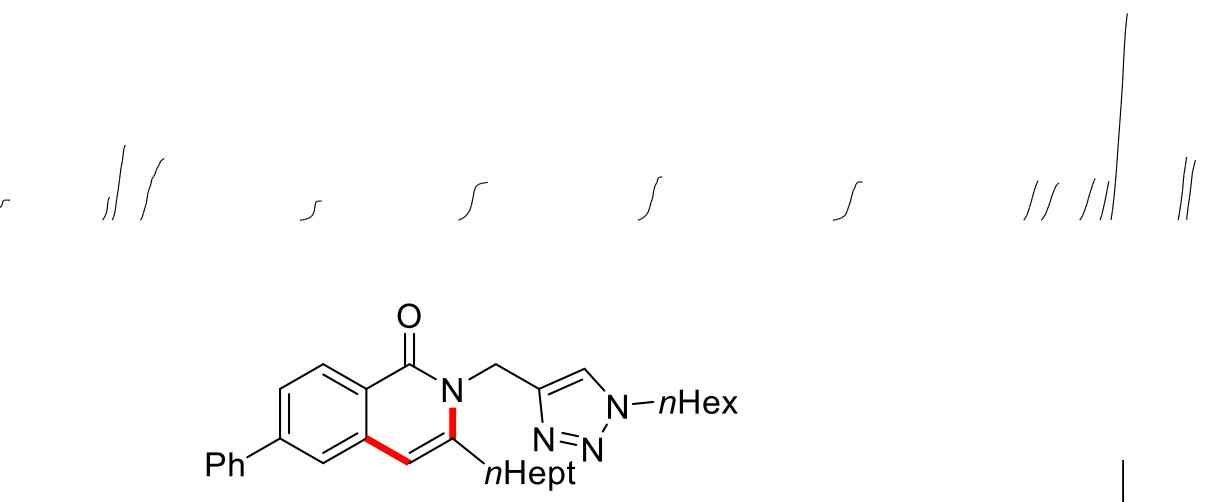

$89 f a\left(300 \mathrm{MHz}, \mathrm{CDCl}_{3}\right)$
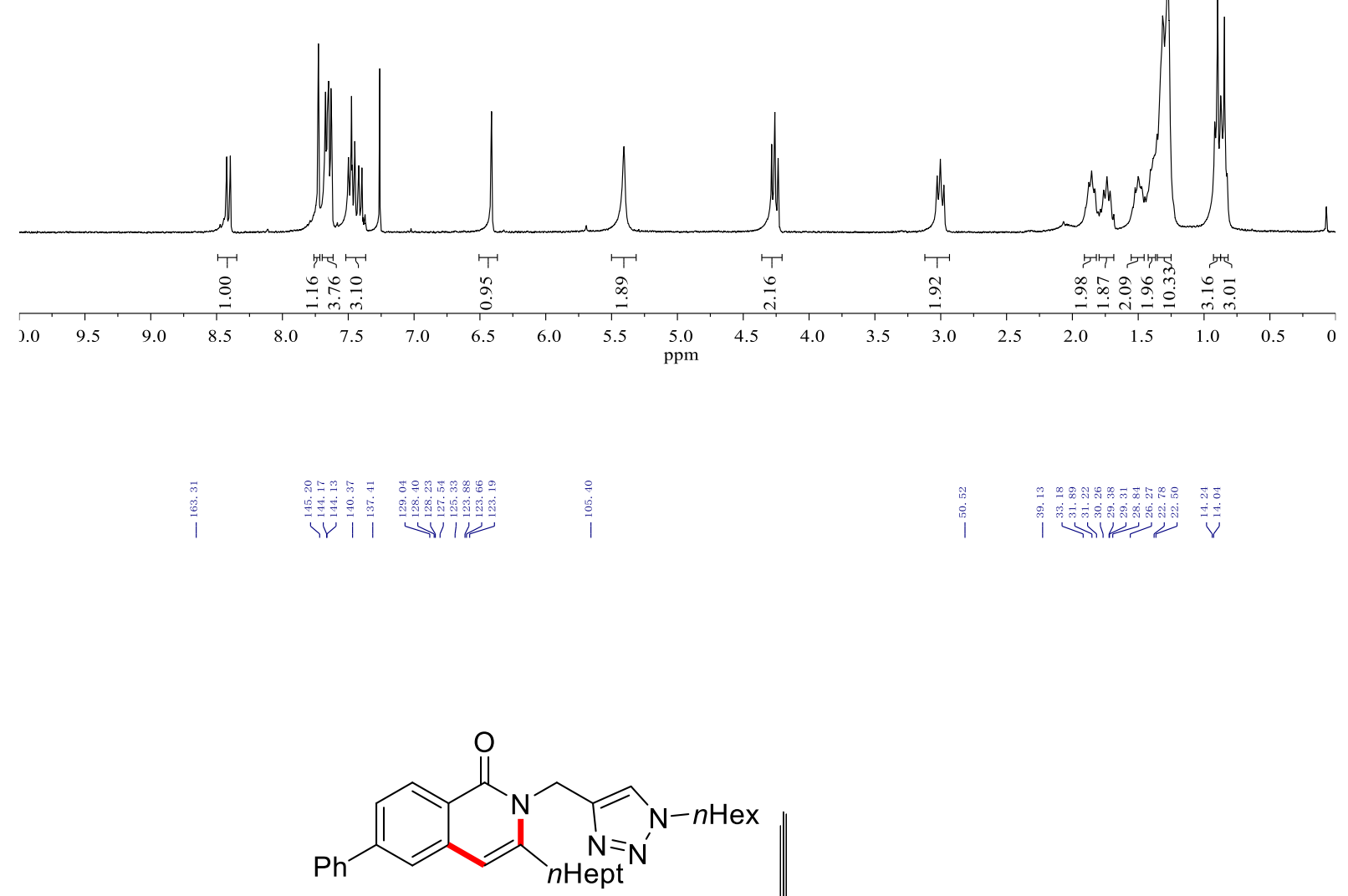

$89 f a\left(75 \mathrm{MHz}, \mathrm{CDCl}_{3}\right)$

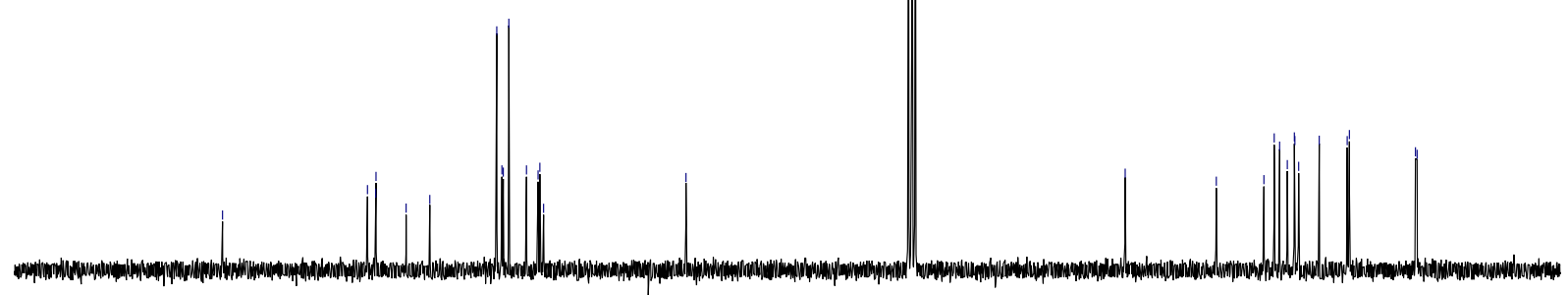

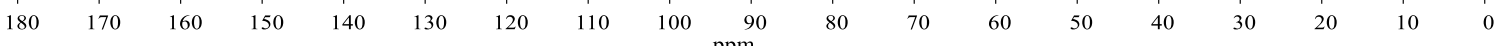



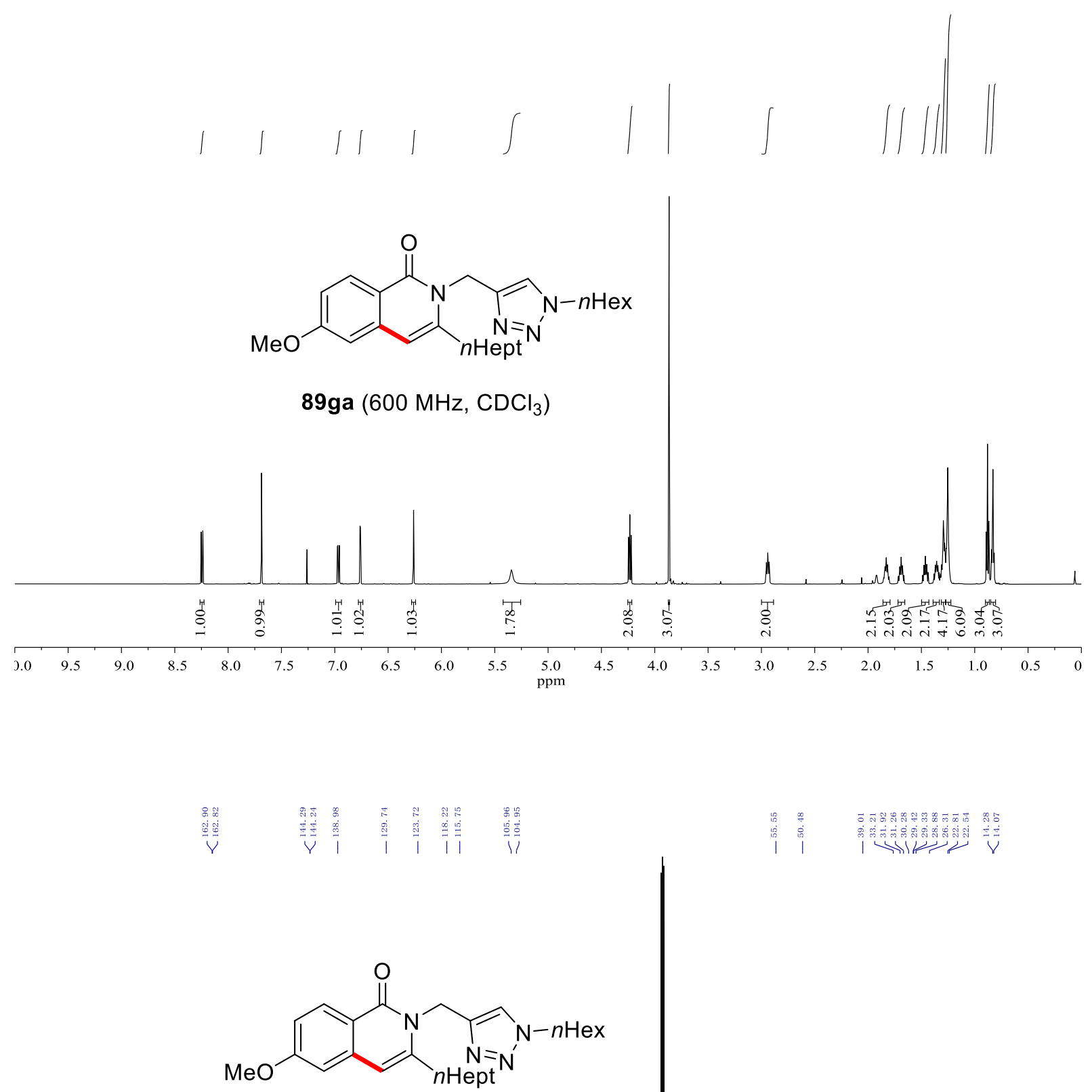

89ga (126 MHz, $\mathrm{CDCl}_{3}$ )

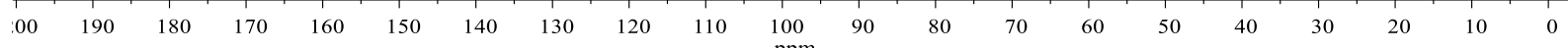



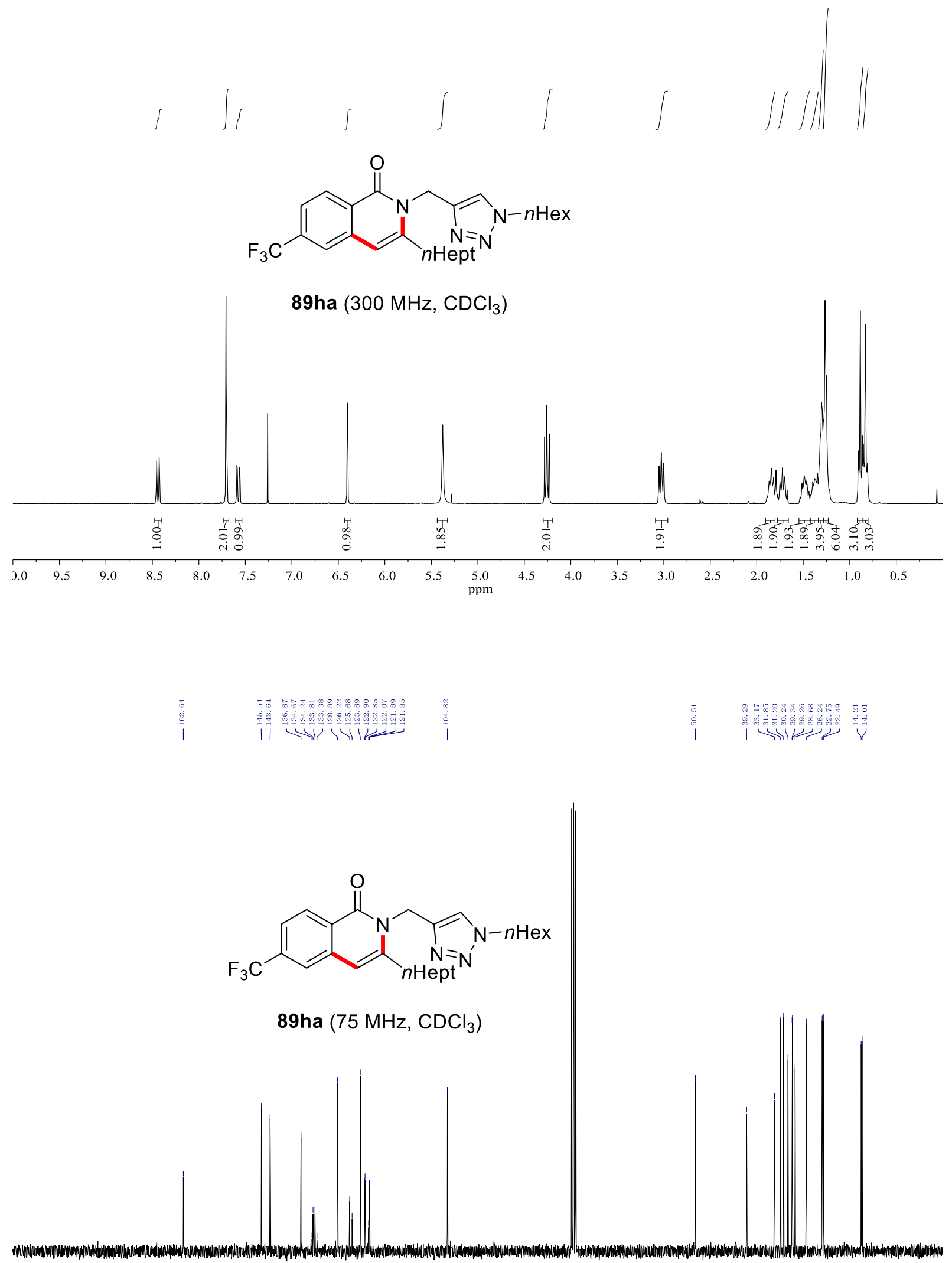

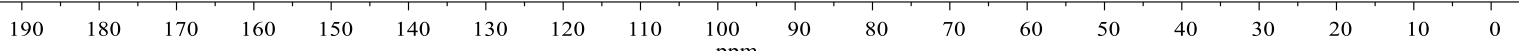




\section{NMR Spectra}

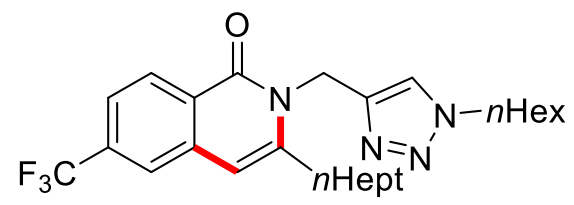

89ha (282 MHz, $\mathrm{CDCl}_{3}$ )

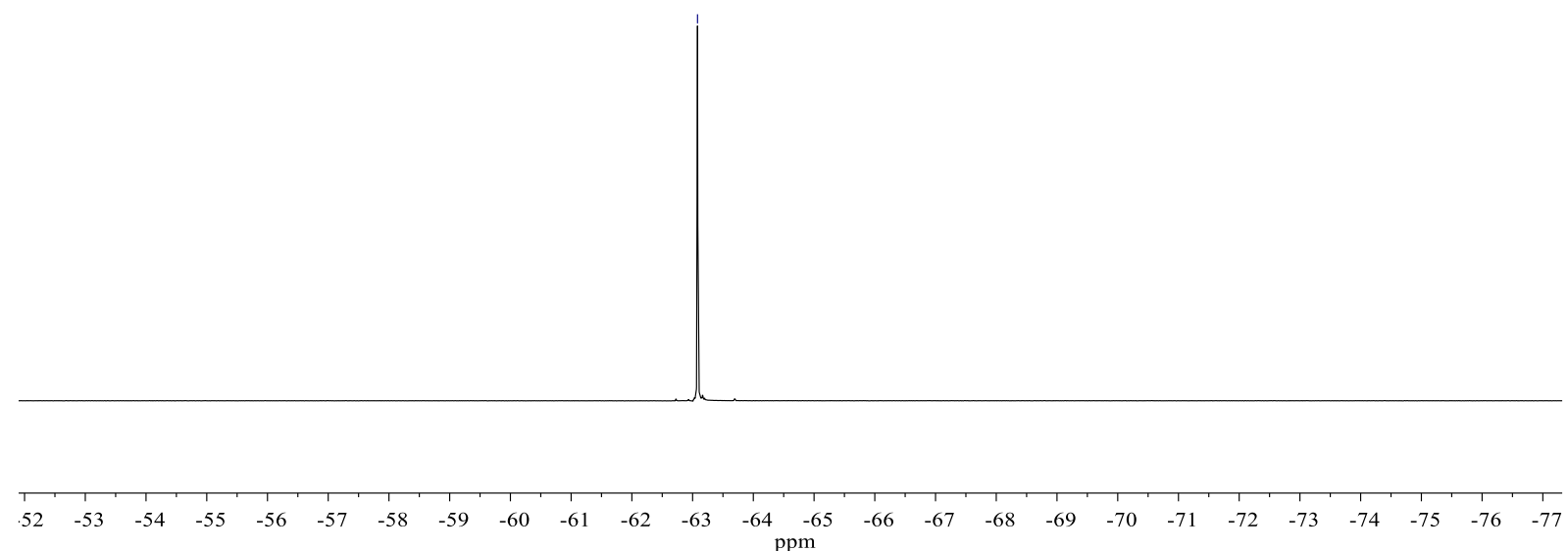


<smiles>O=c1c2ccc(F)cc2cc(O)n1Cc1cn(C[Ga])nn1</smiles>

89ia $\left(300 \mathrm{MHz}, \mathrm{CDCl}_{3}\right)$

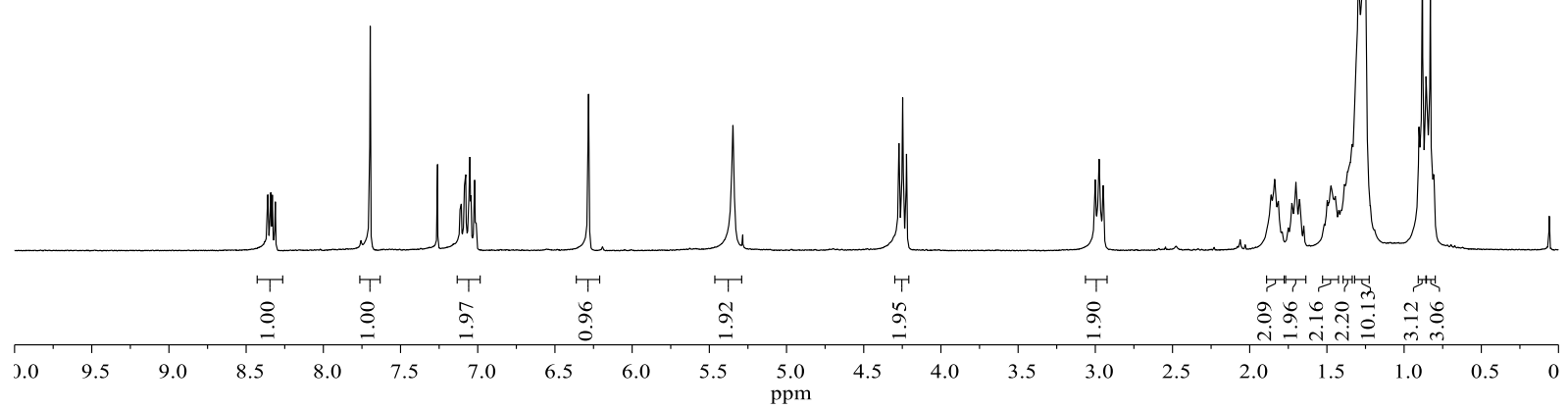

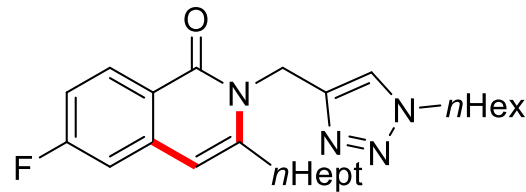

89ia (126 MHz, $\mathrm{CDCl}_{3}$ )

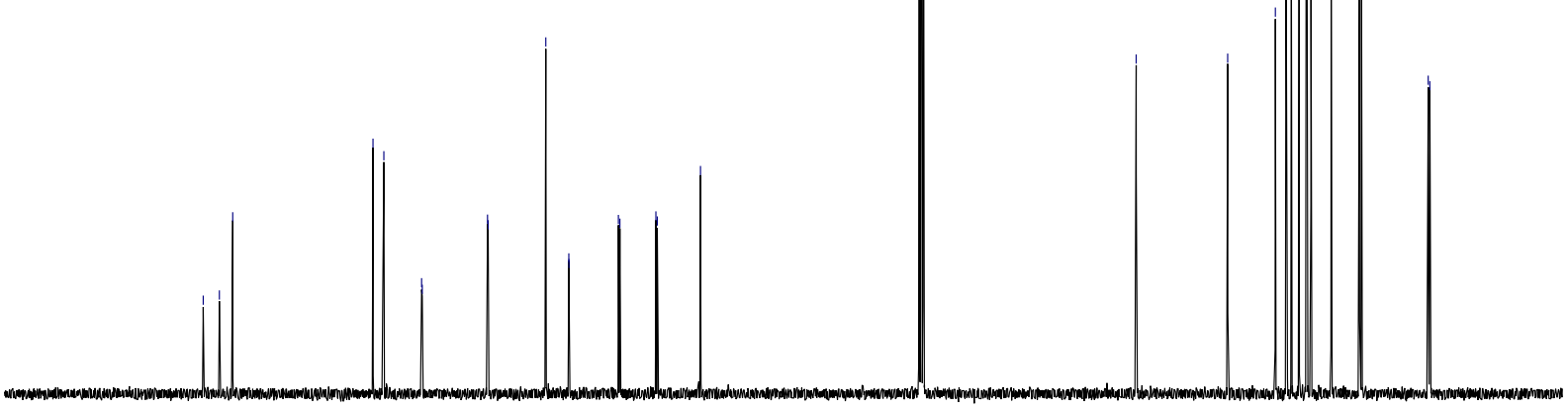

190

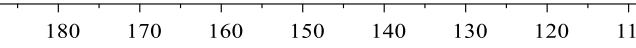

\section{6}


NMR Spectra

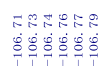

viv<smiles>CCn1cc(Cn2c(C)cc3cc(F)ccc3c2=O)nn1</smiles>

89ia $\left(282 \mathrm{MHz}, \mathrm{CDCl}_{3}\right)$

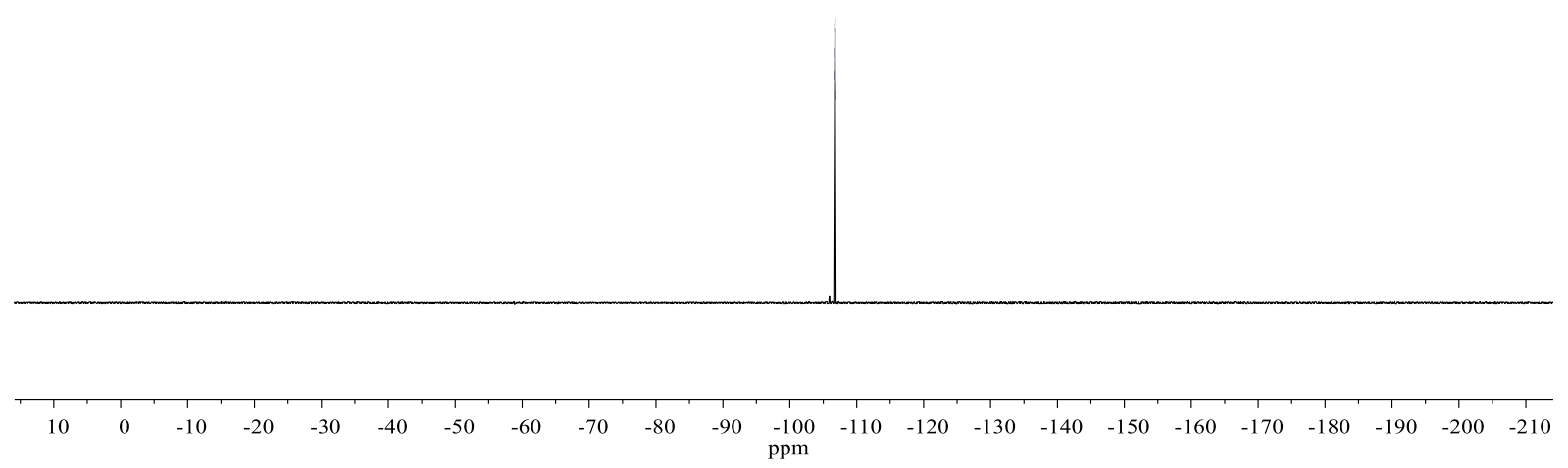




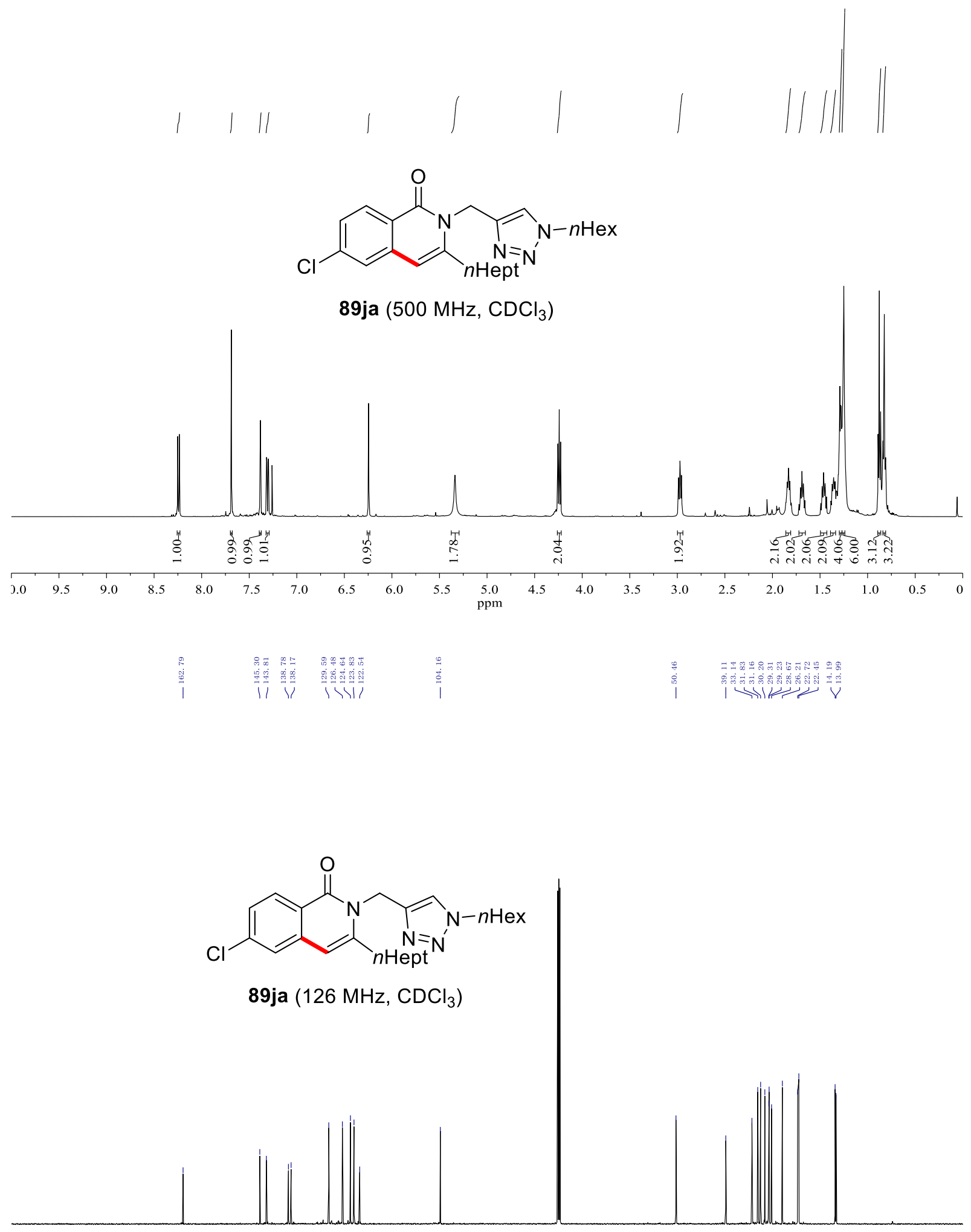

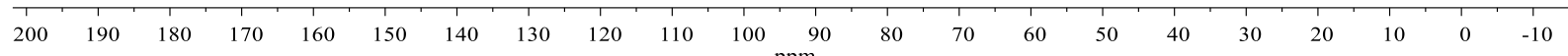



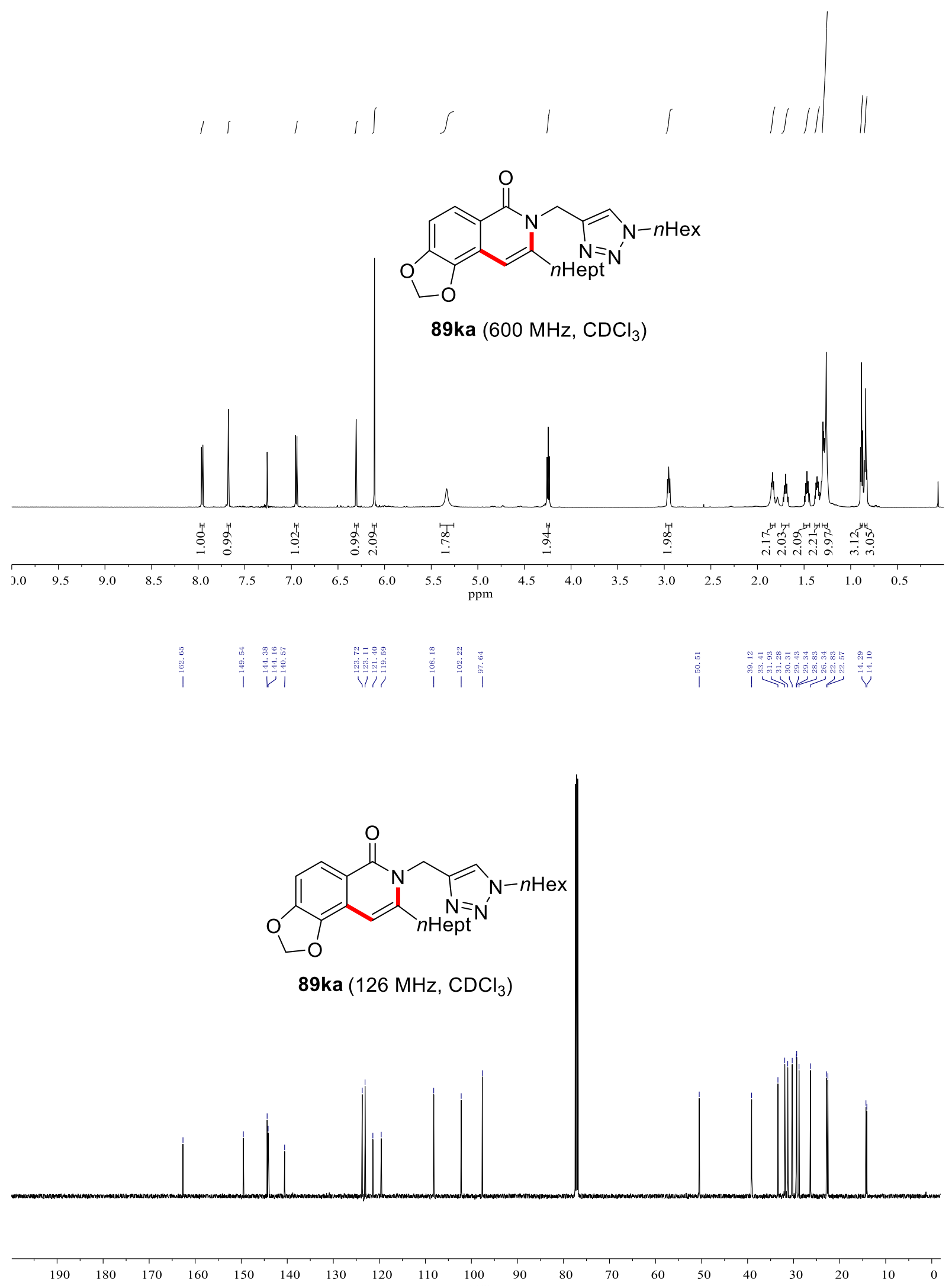

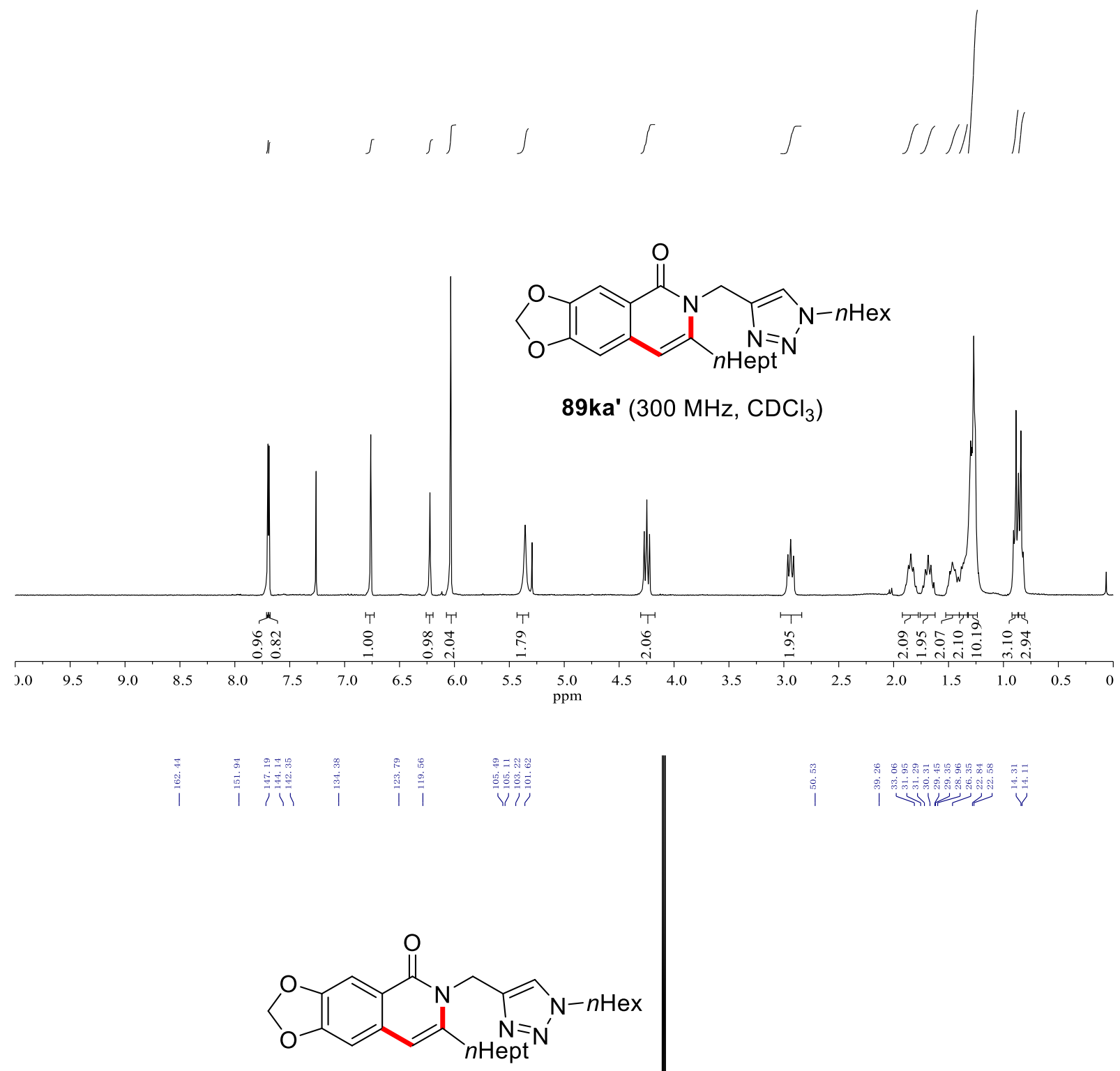

89ka' (126 MHz, $\mathrm{CDCl}_{3}$ )

$\begin{array}{llllllllll}190 & 180 & 170 & 160 & 150 & 140 & 130 & 120 & 110 & 100 \\ \mathrm{ppm}\end{array}$

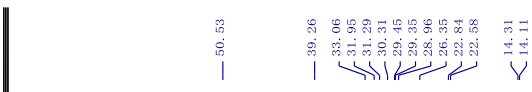



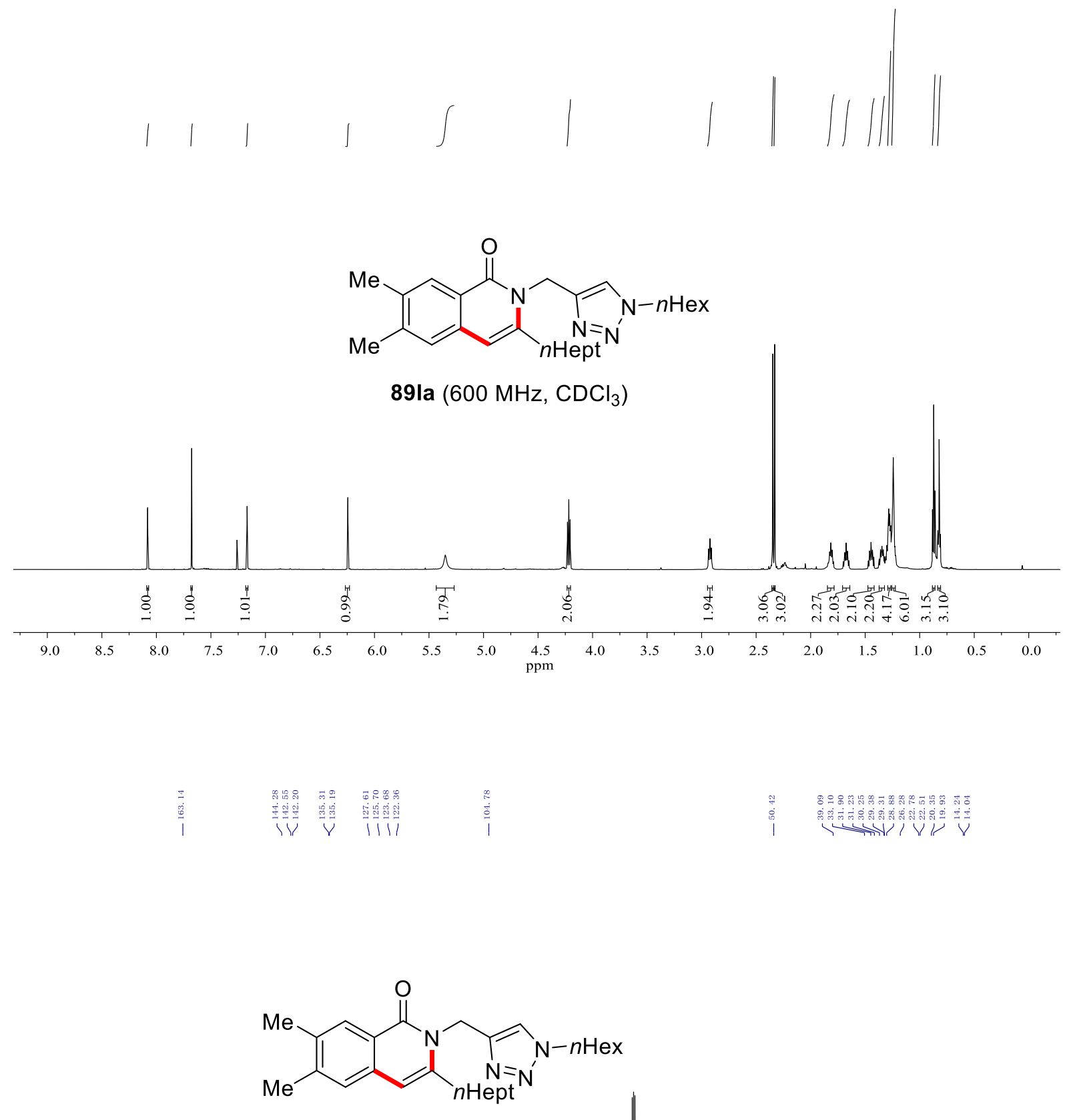

89la (126 MHz, $\left.\mathrm{CDCl}_{3}\right)$

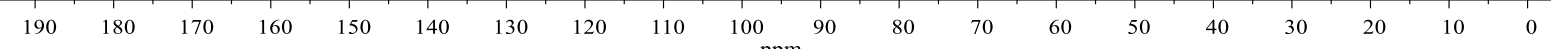



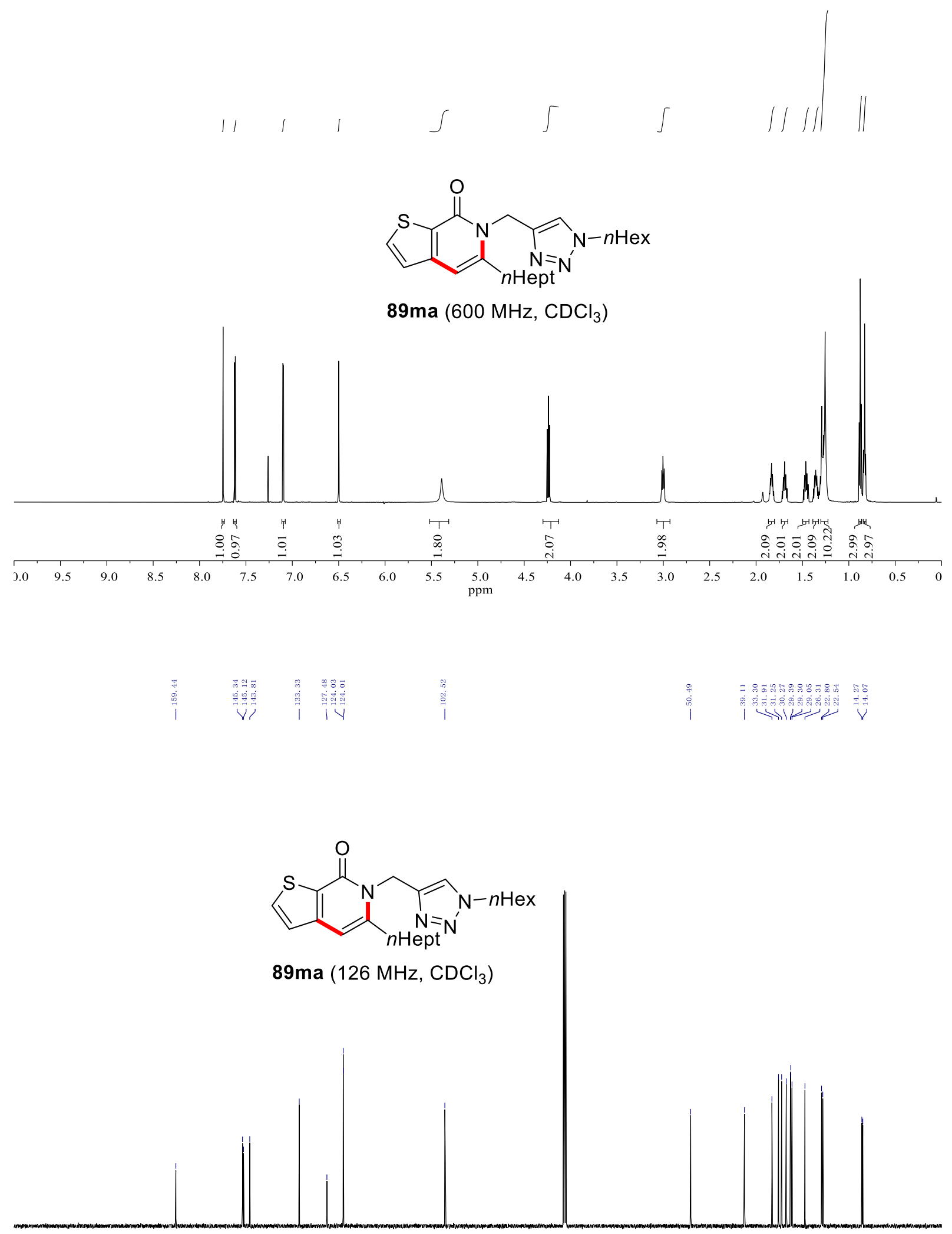

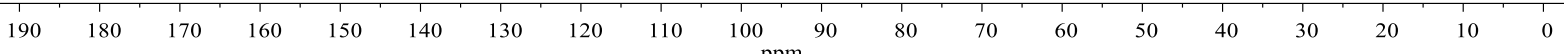




\section{NMR Spectra}

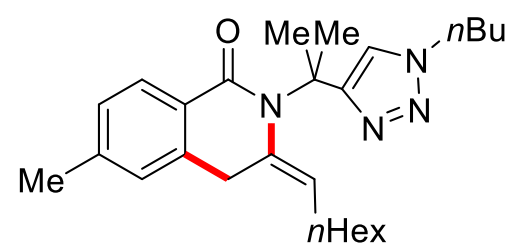

90fa $\left(600 \mathrm{MHz}, \mathrm{C}_{6} \mathrm{D}_{6}\right)$
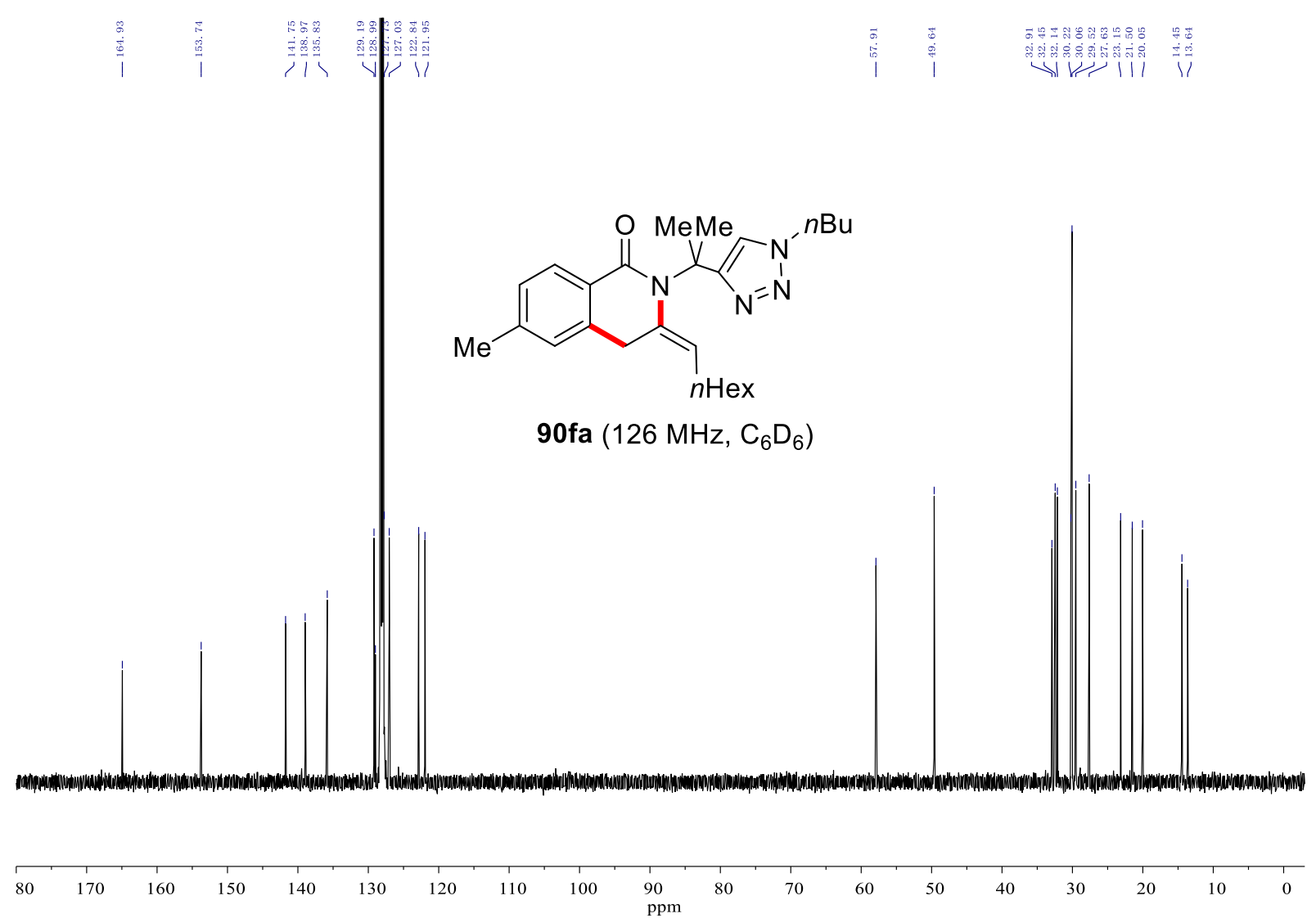

$80 \quad 70 \quad 60$

$\begin{array}{lll}50 & 40 \quad 30\end{array}$

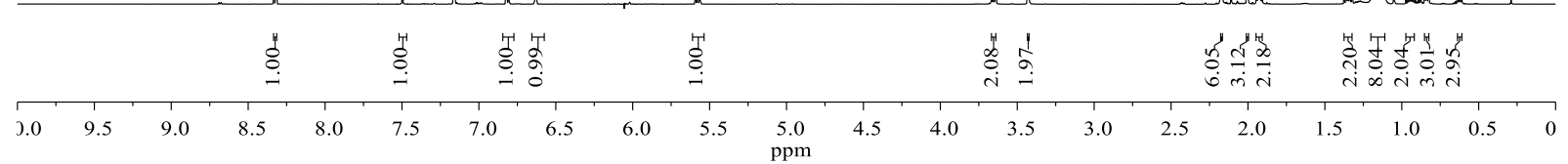




\section{NMR Spectra}

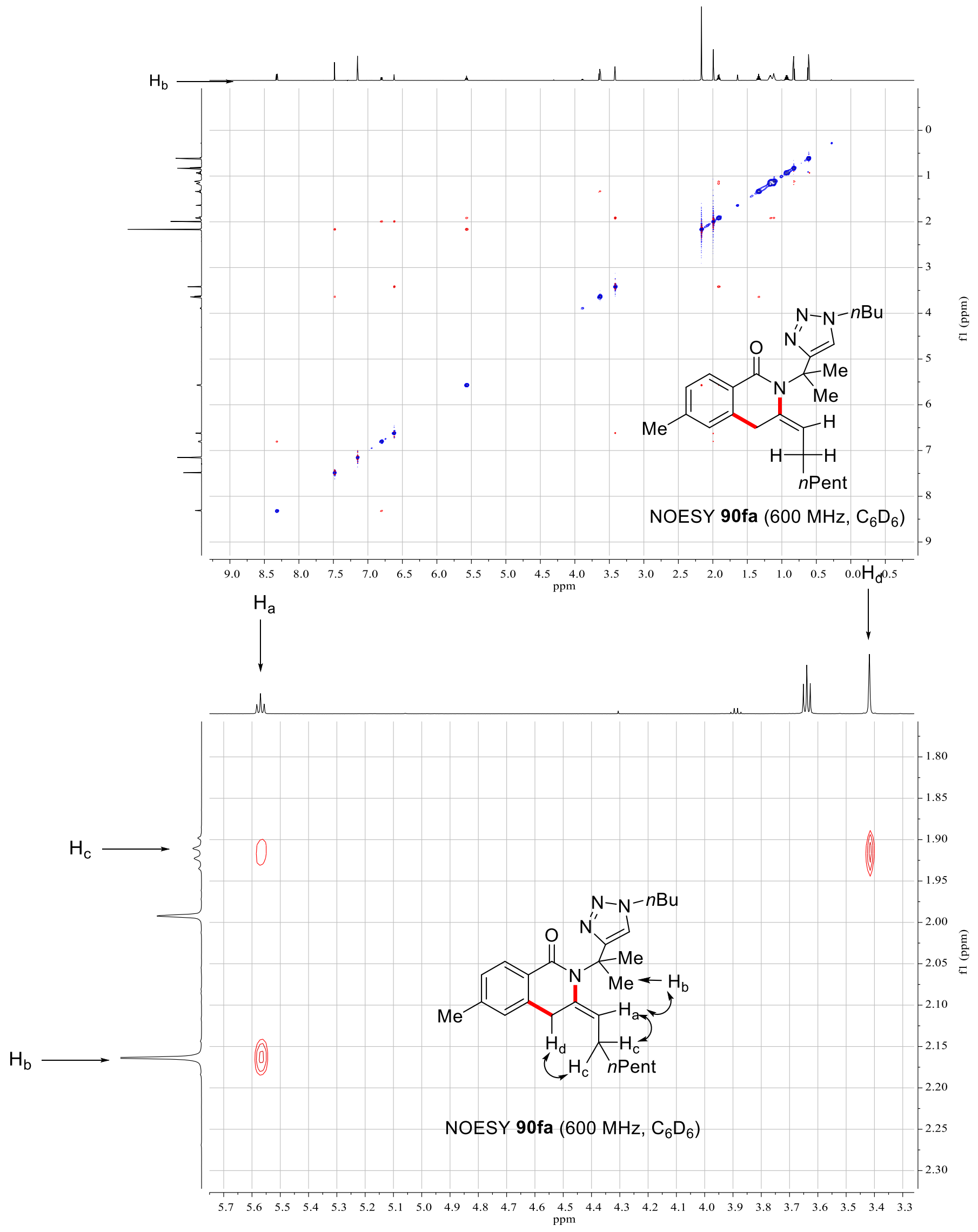




\section{NMR Spectra}

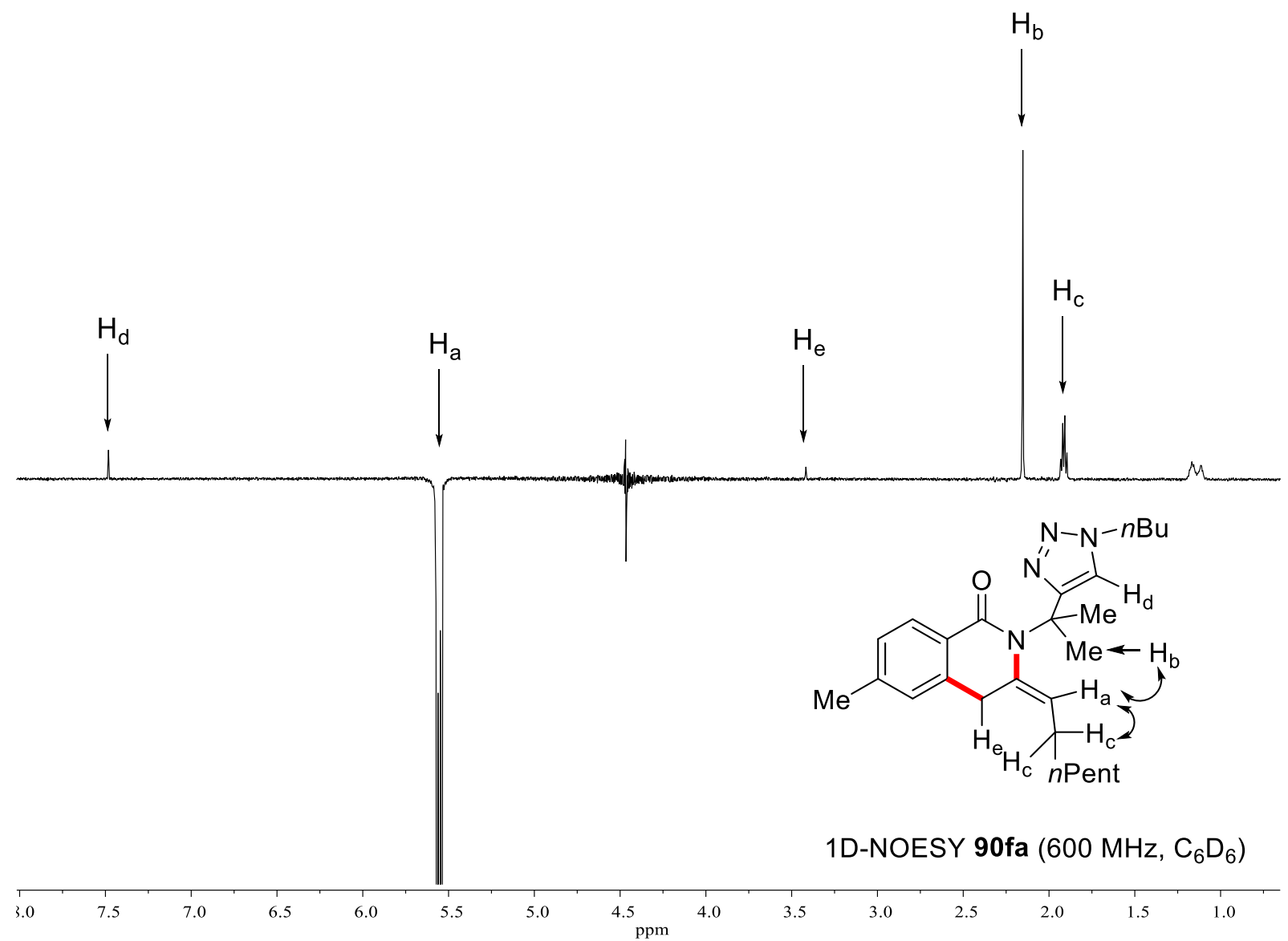


NMR Spectra
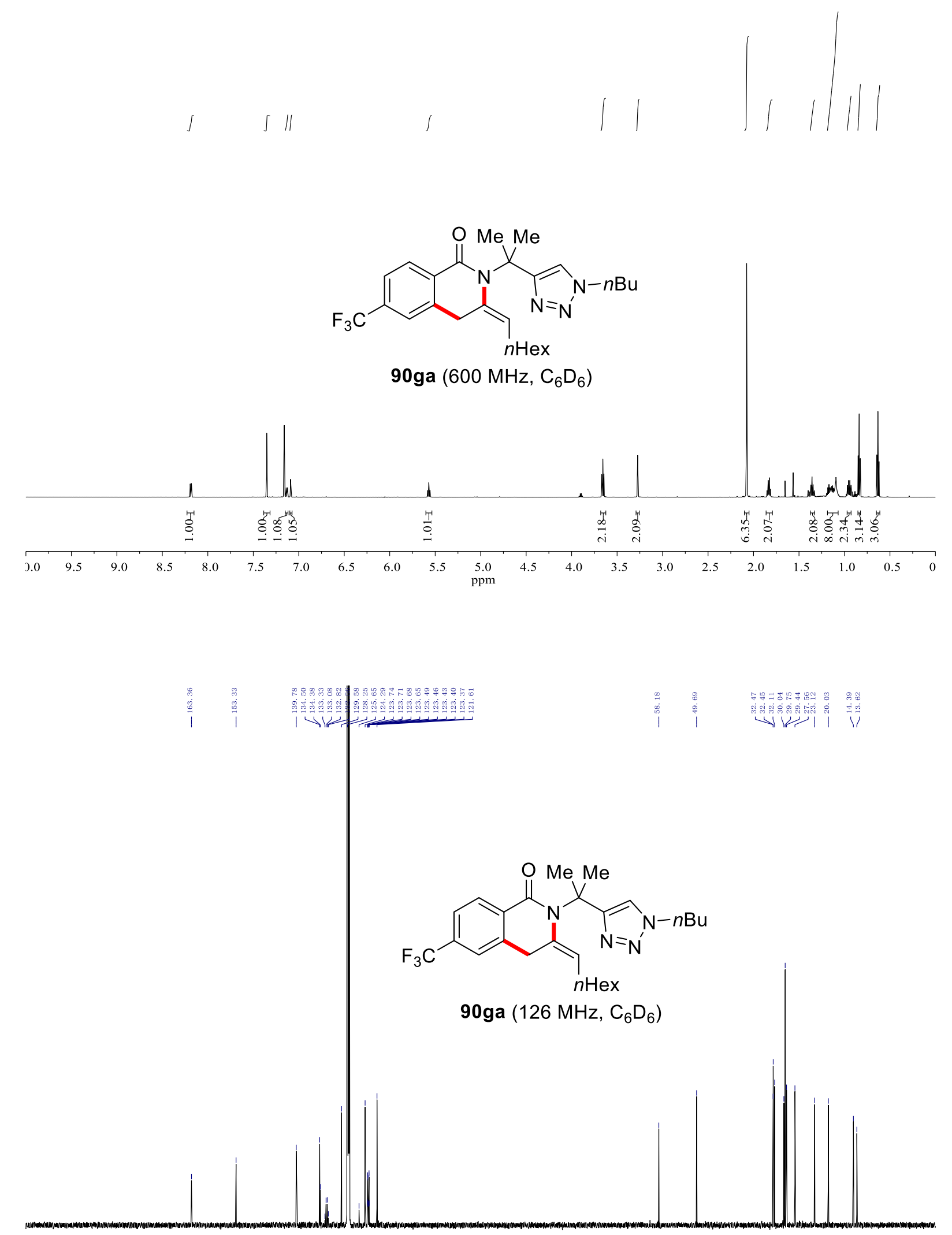

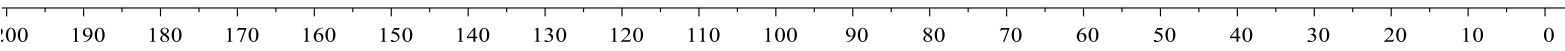




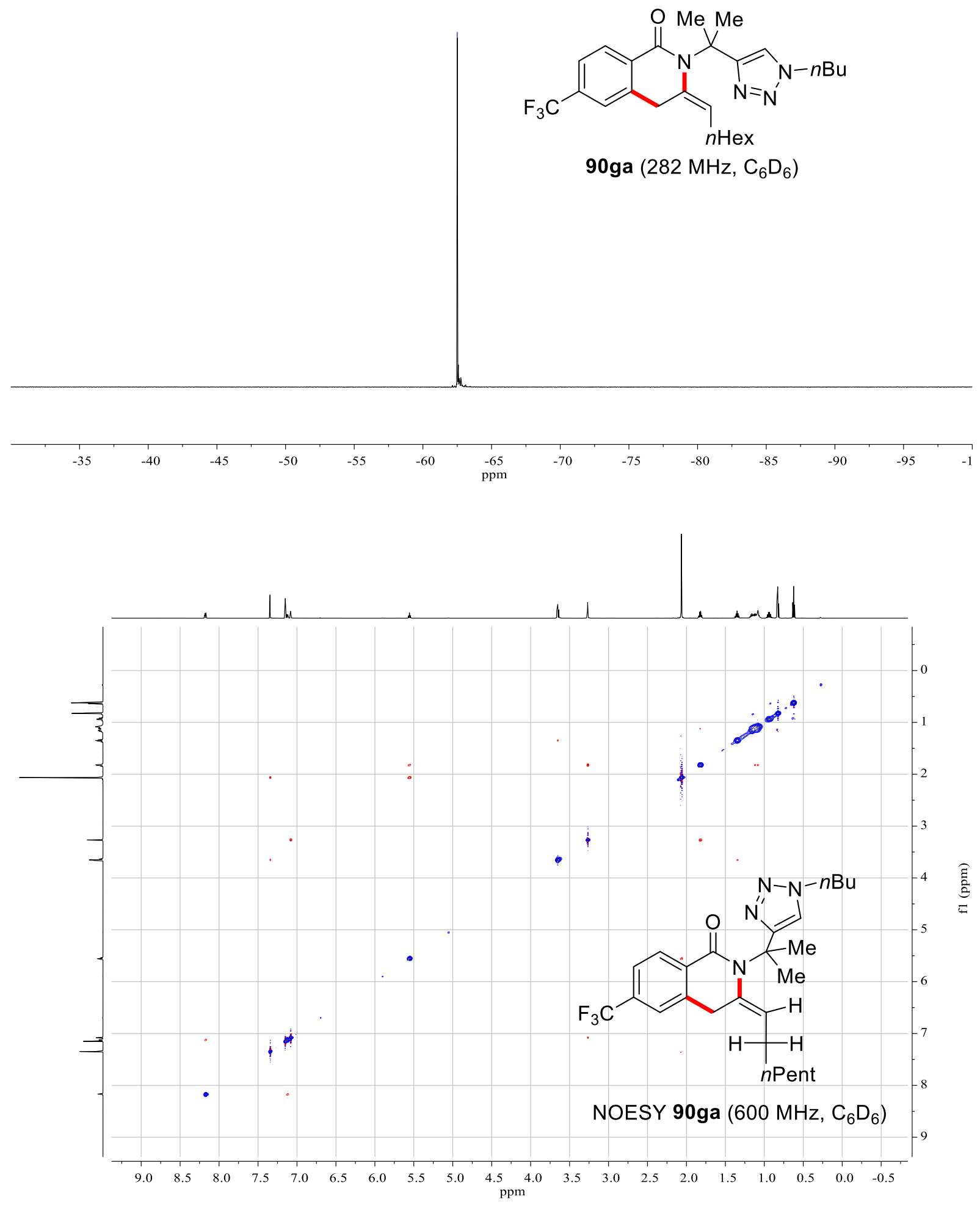



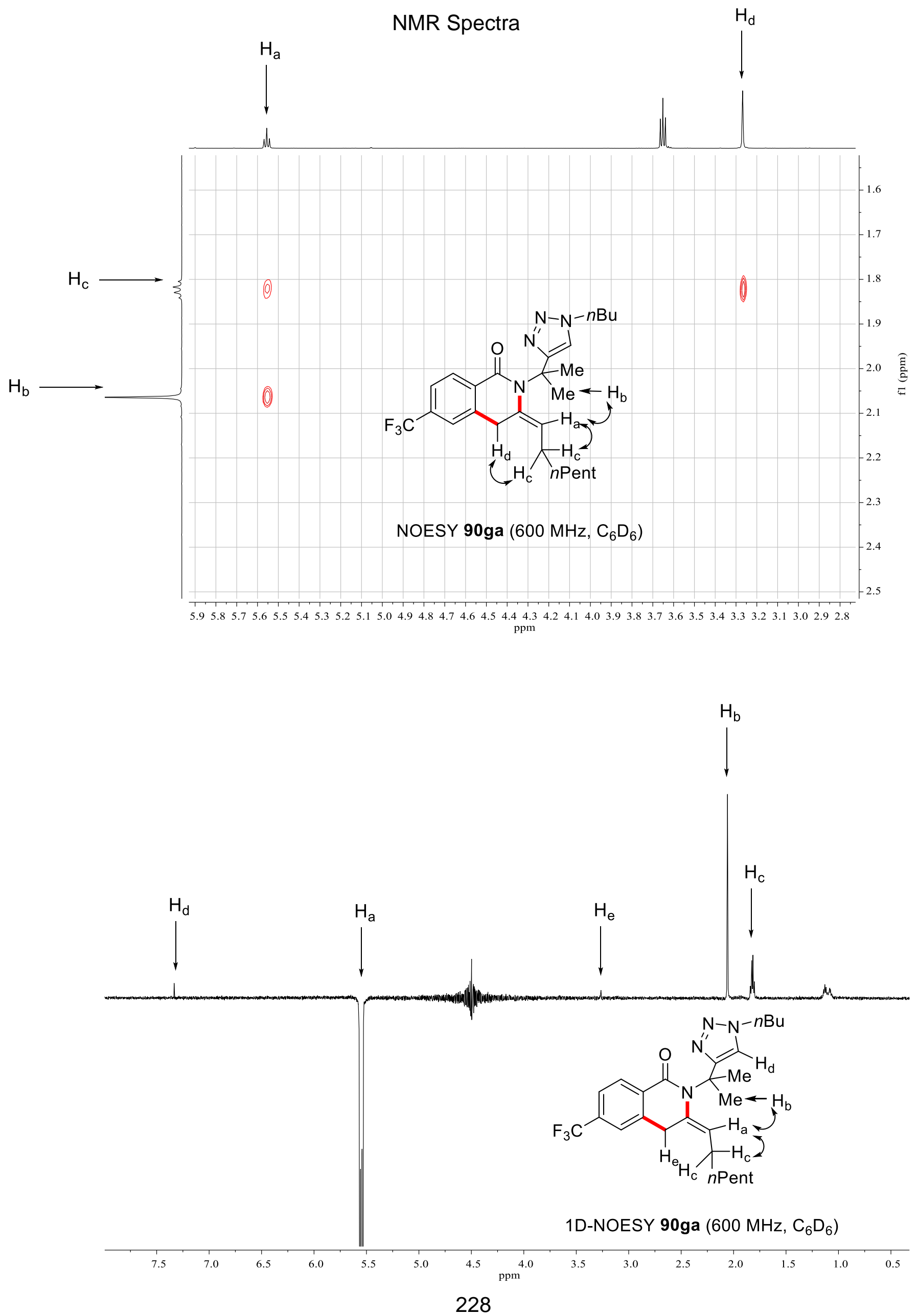

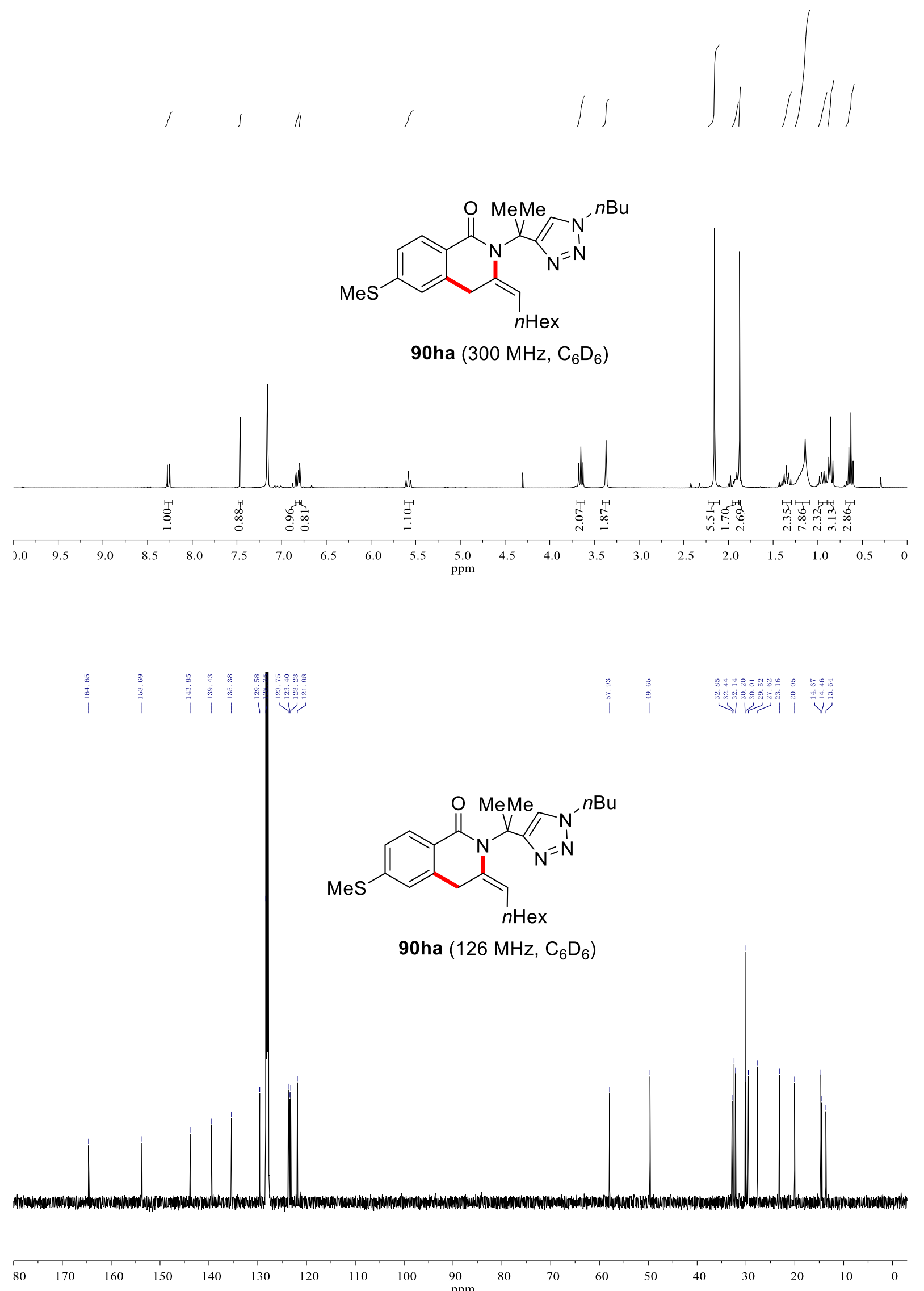

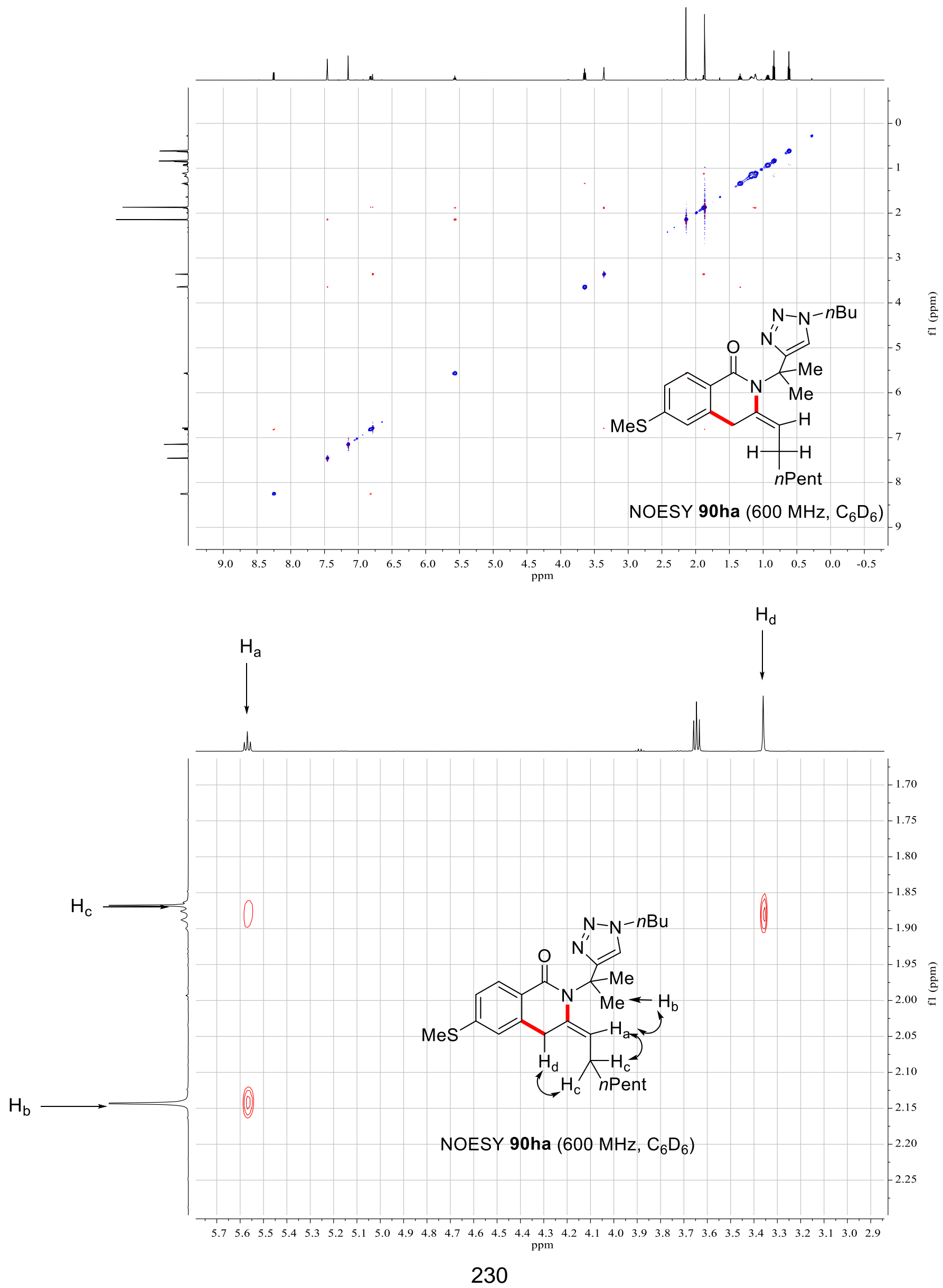


\section{NMR Spectra}

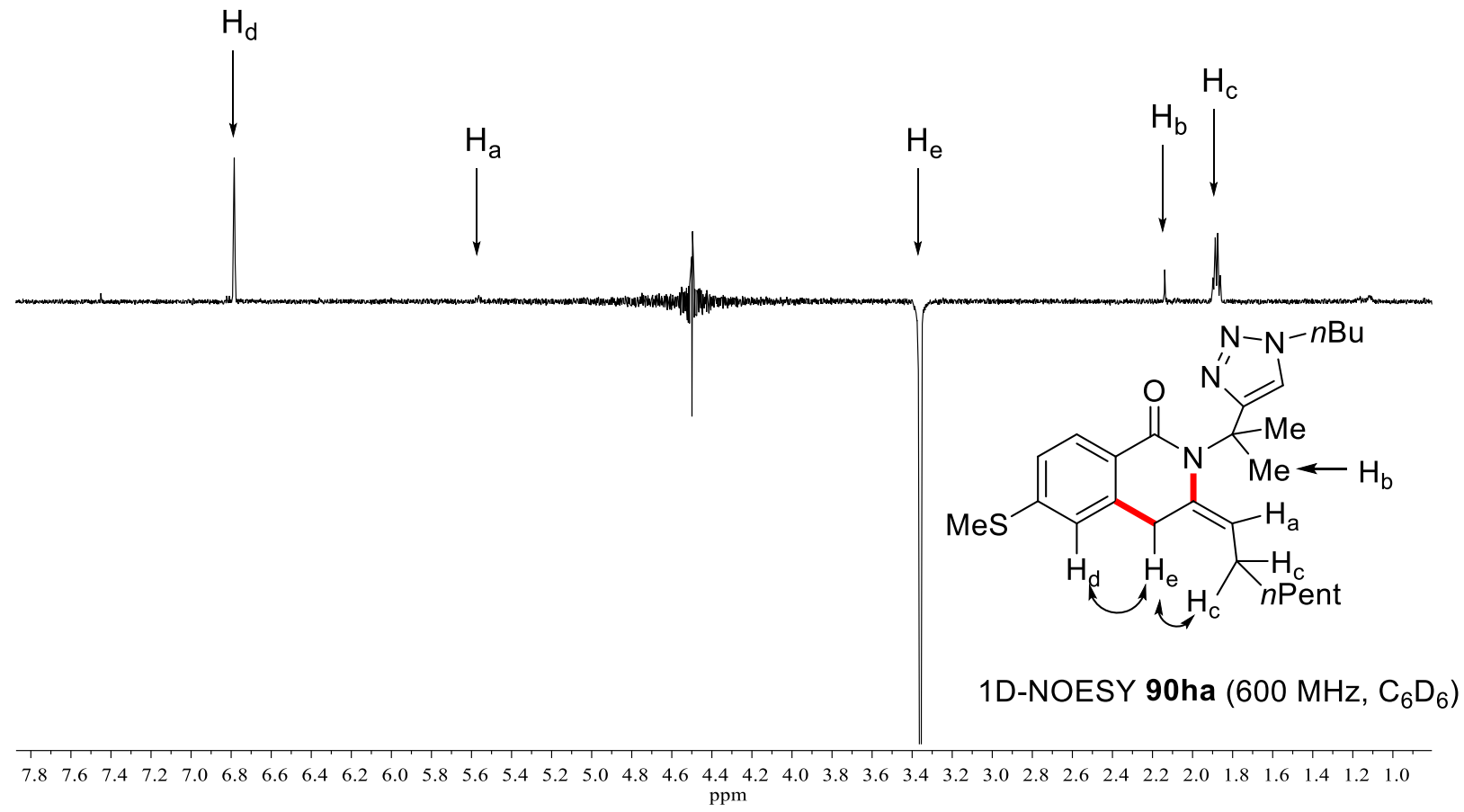



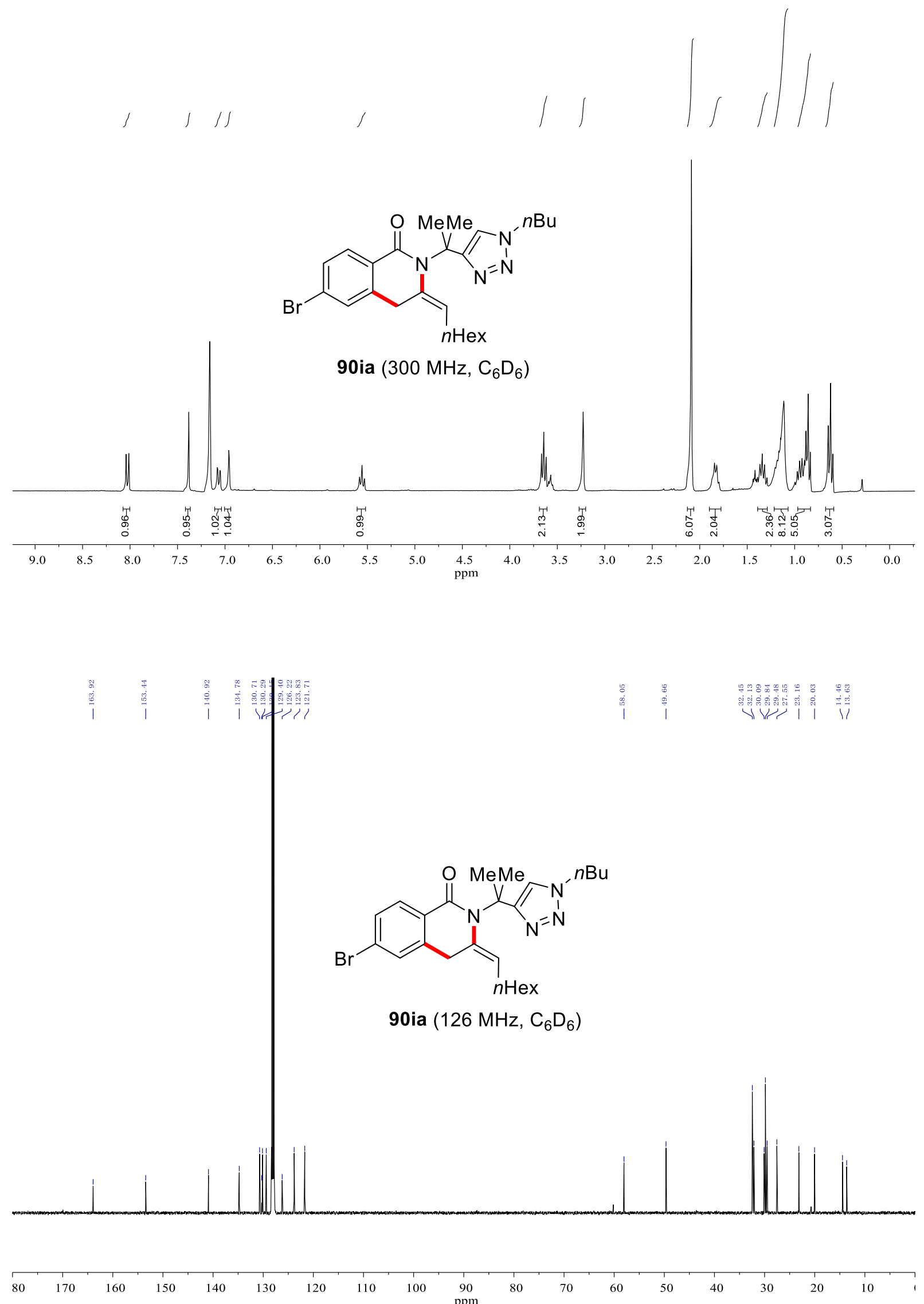


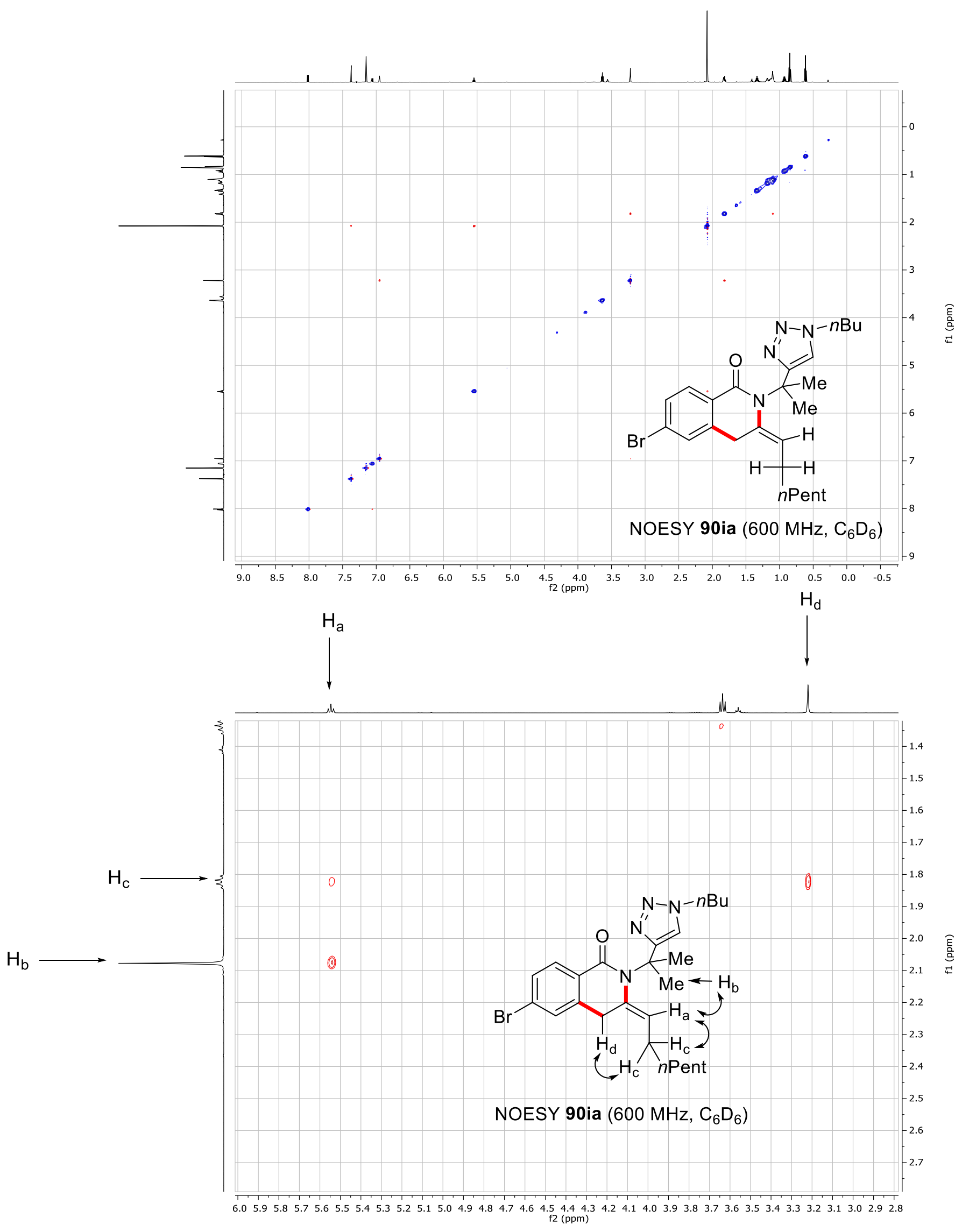



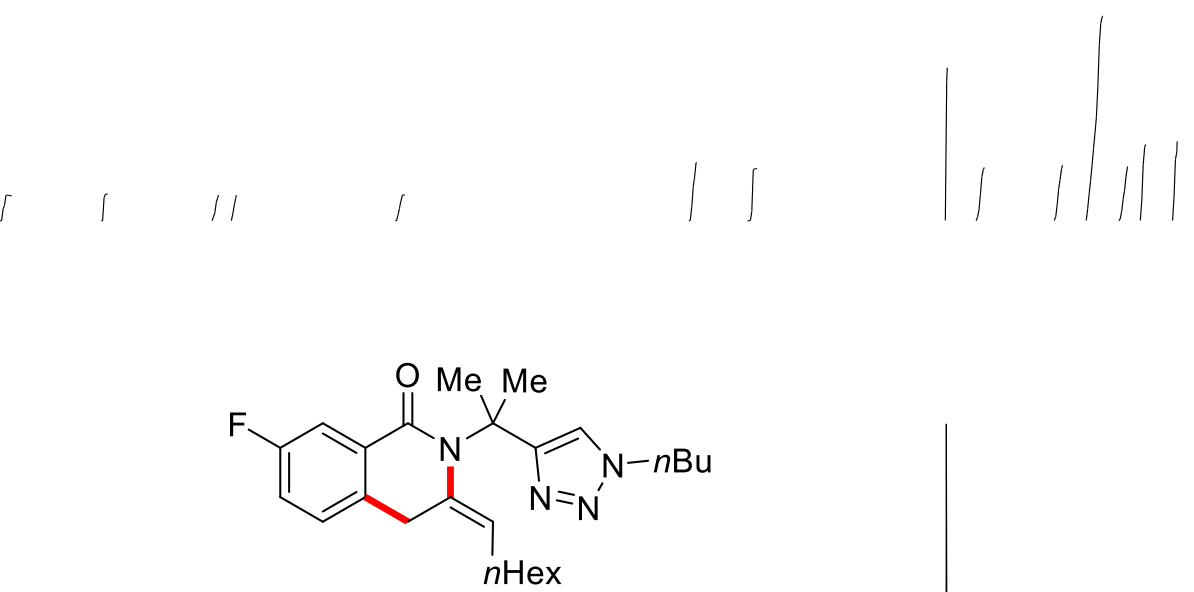

90ja $\left(600 \mathrm{MHz}, \mathrm{C}_{6} \mathrm{D}_{6}\right)$
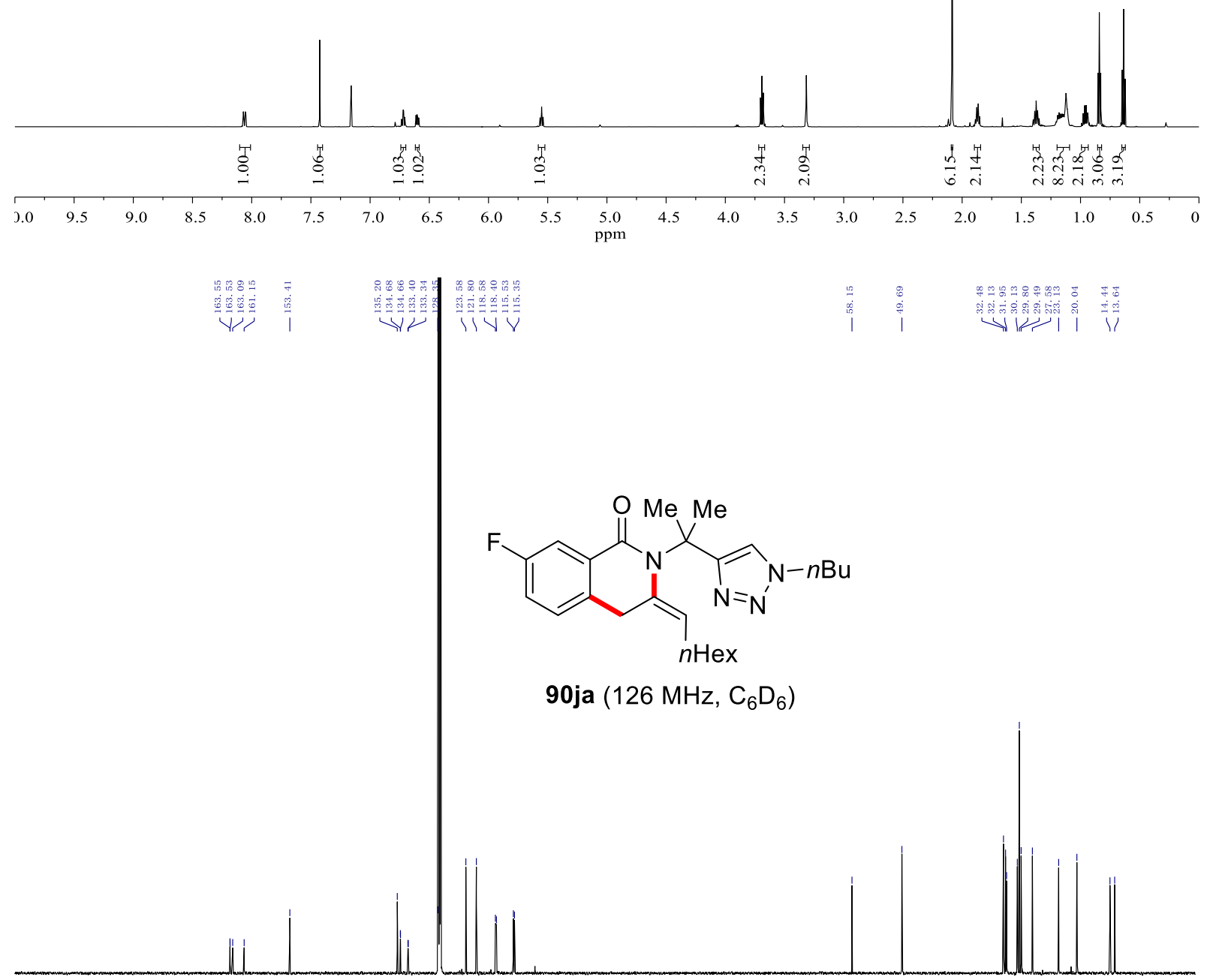

$\begin{array}{llllllllllllllllllllll}00 & 190 & 180 & 170 & 160 & 150 & 140 & 130 & 120 & 110 & 100 & 90 & 80 & 70 & 60 & 50 & 40 & 30 & 20 & 10 & 10\end{array}$ 


\section{NMR Spectra}

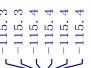

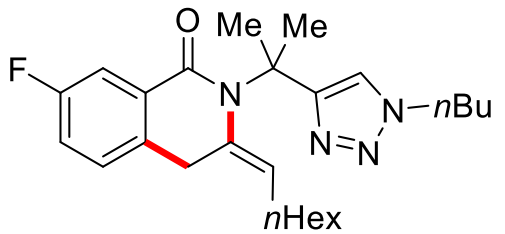

90ja $\left(282 \mathrm{MHz}, \mathrm{C}_{6} \mathrm{D}_{6}\right)$

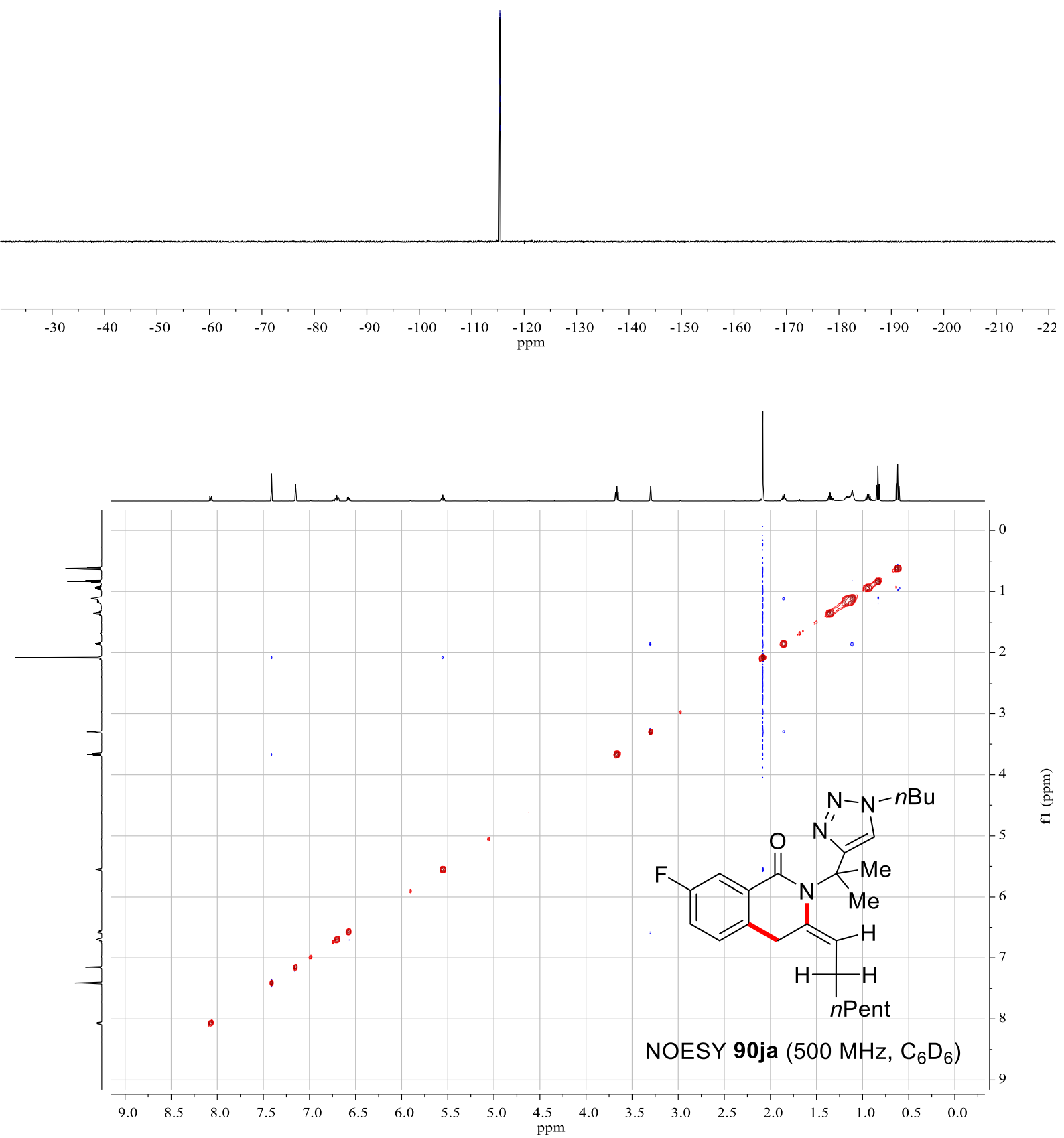




\section{NMR Spectra}
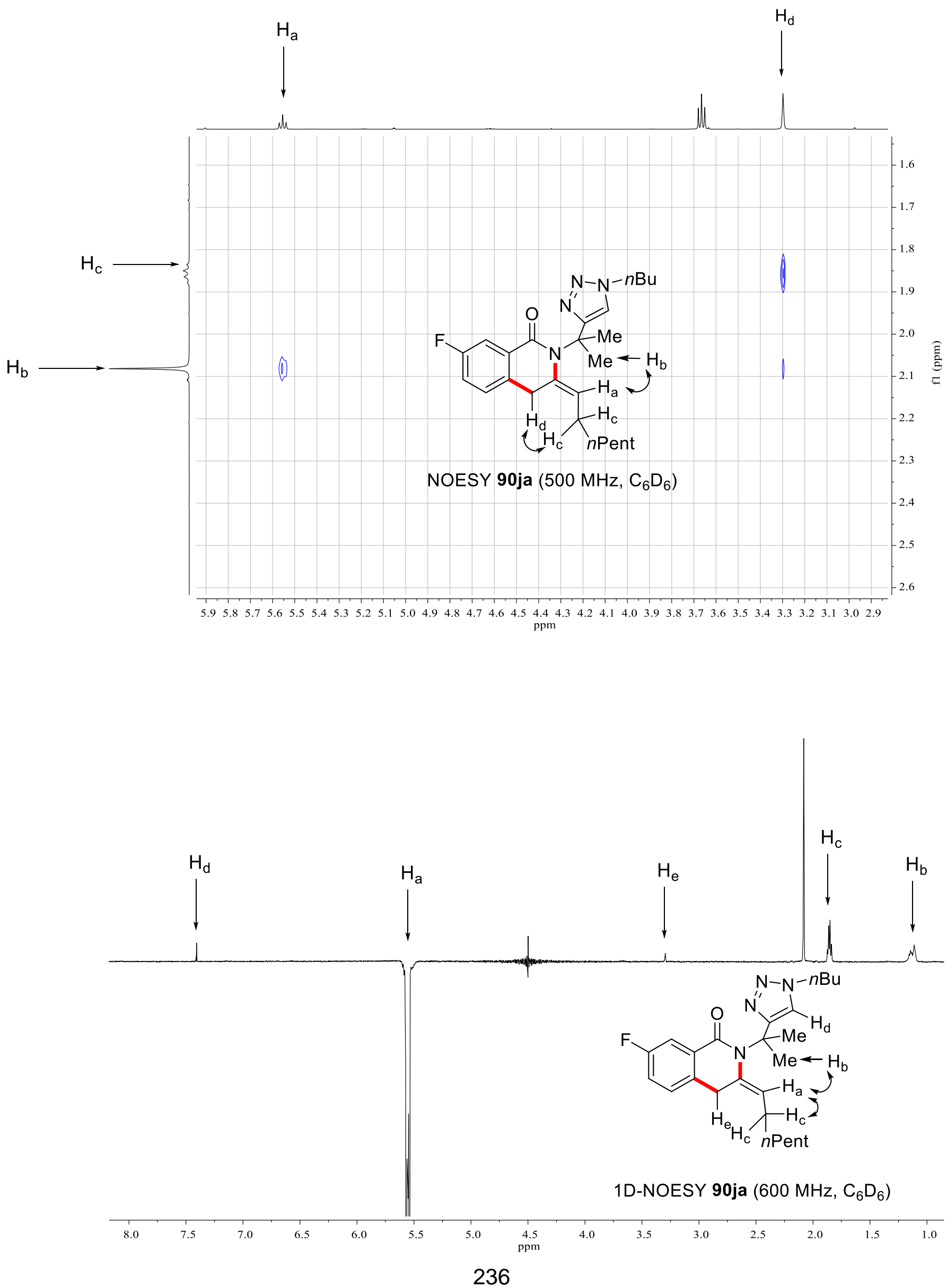
NMR Spectra
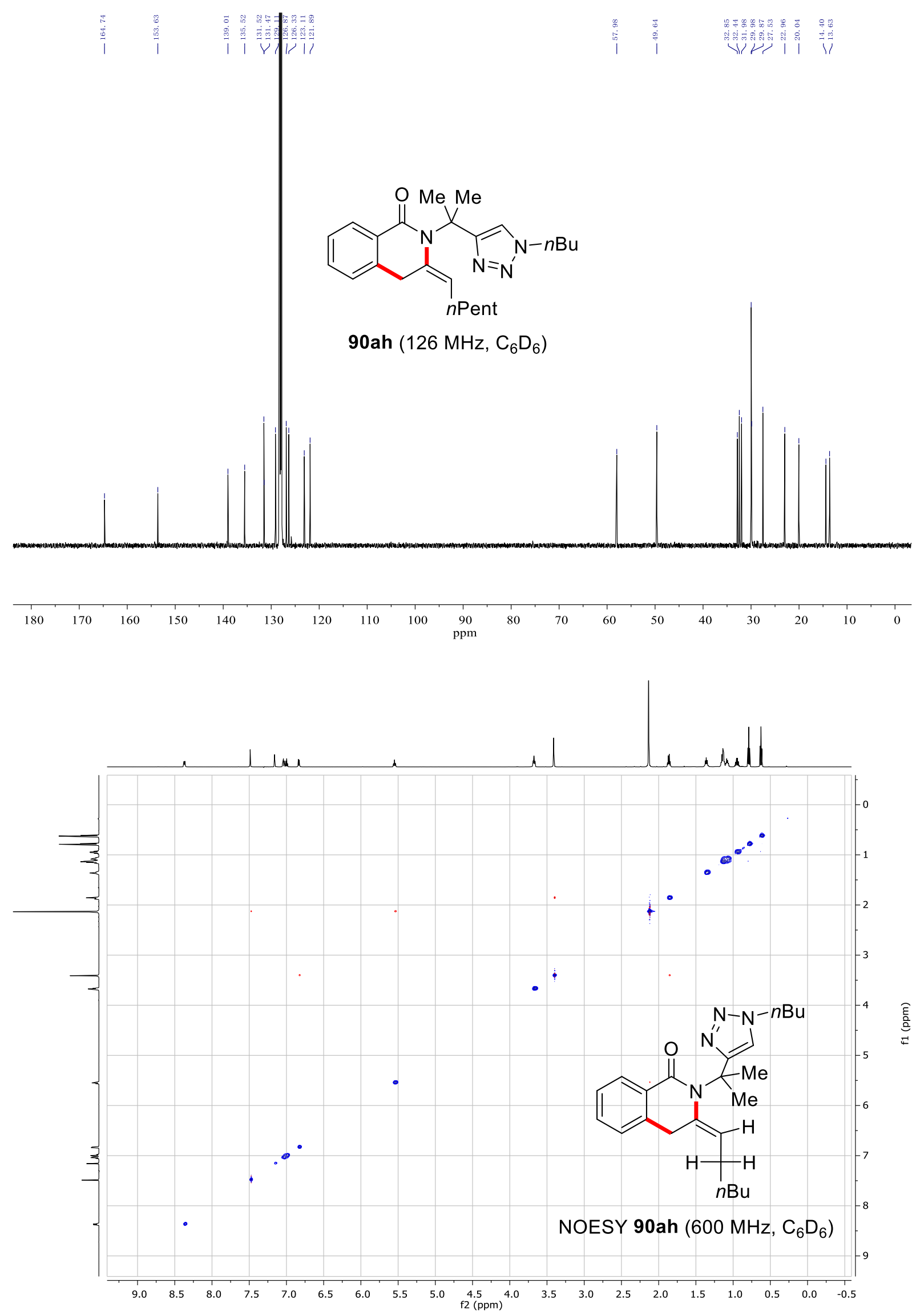


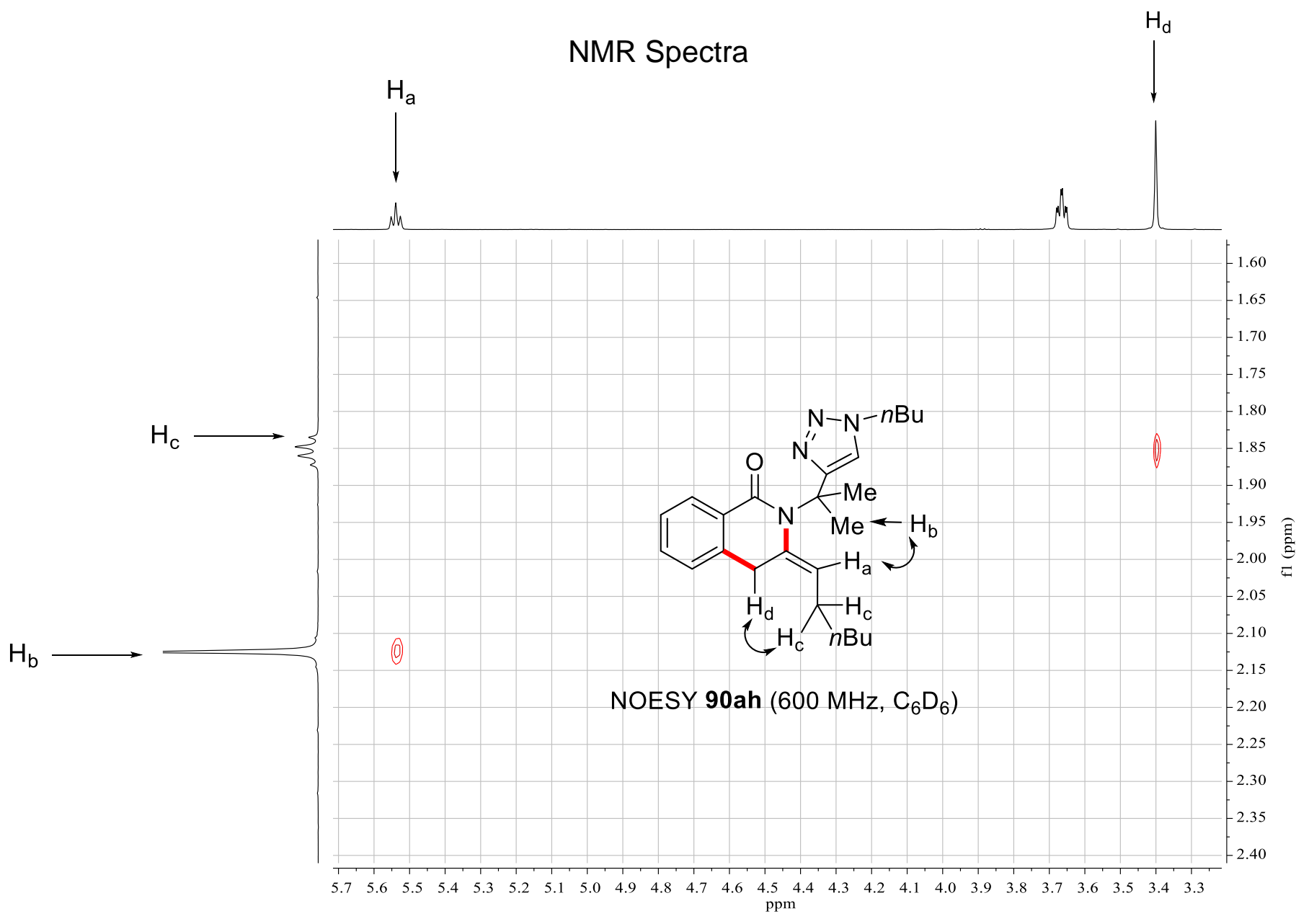


NMR Spectra

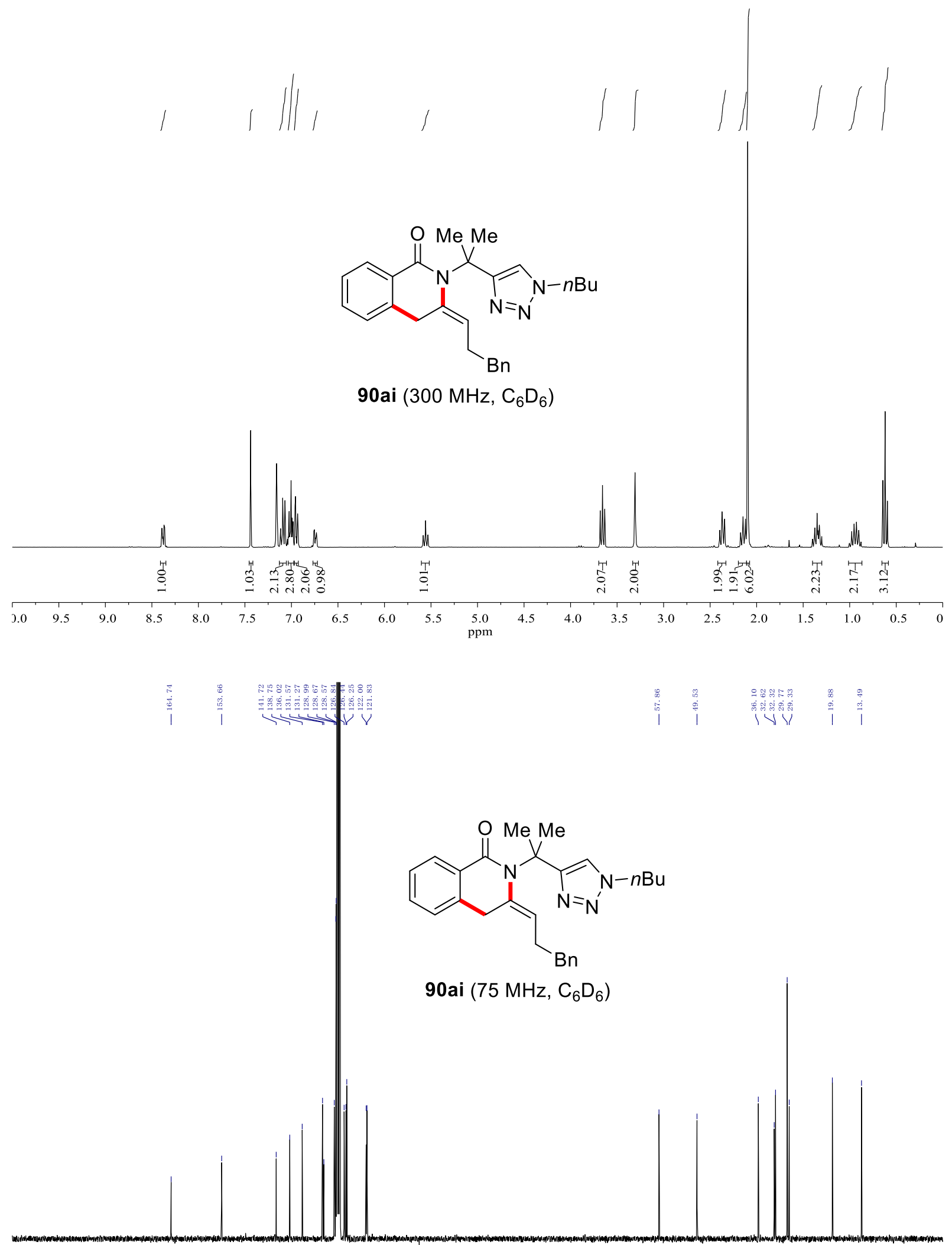

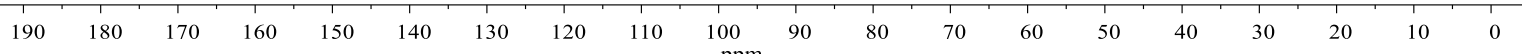



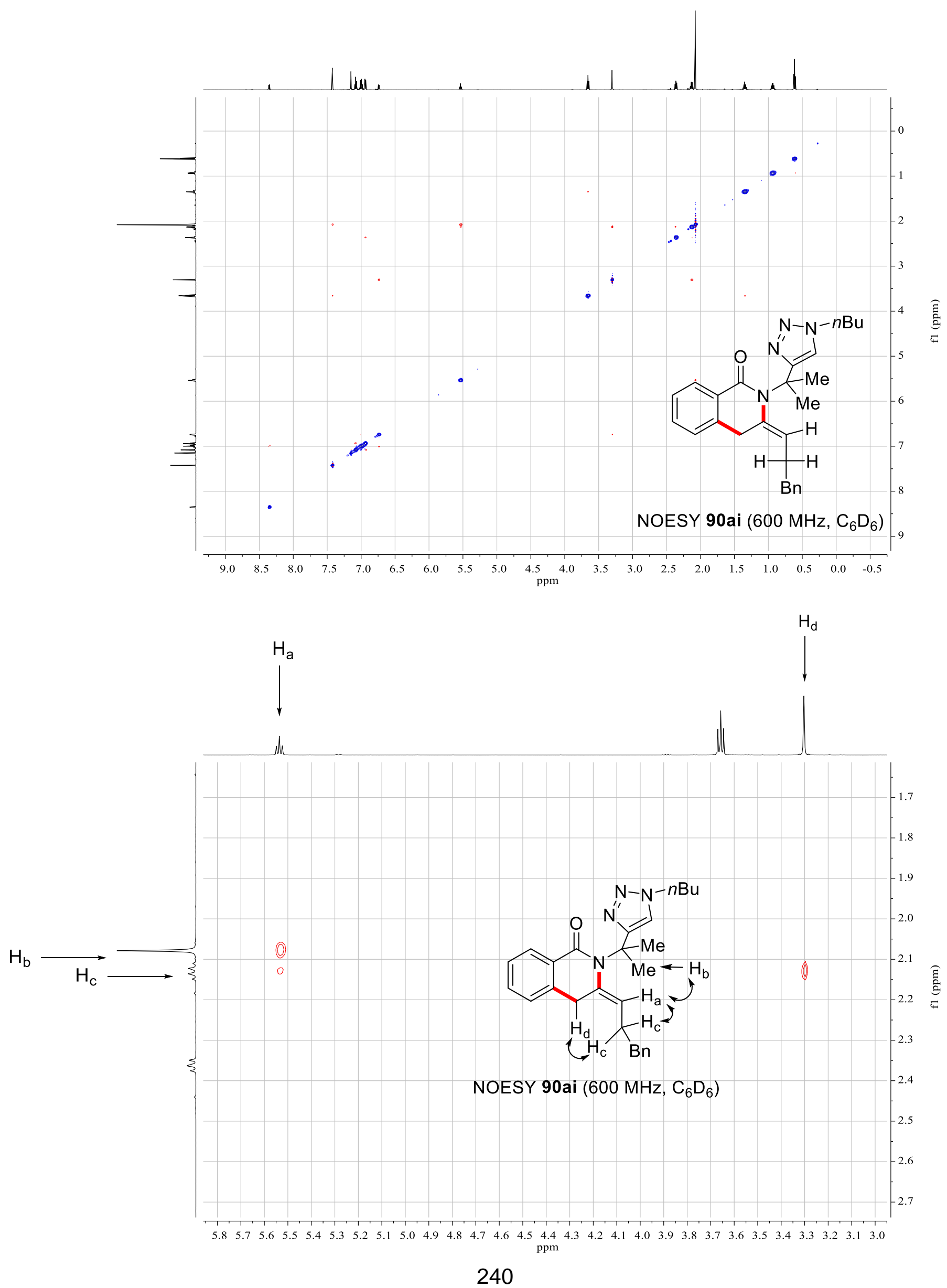
NMR Spectra

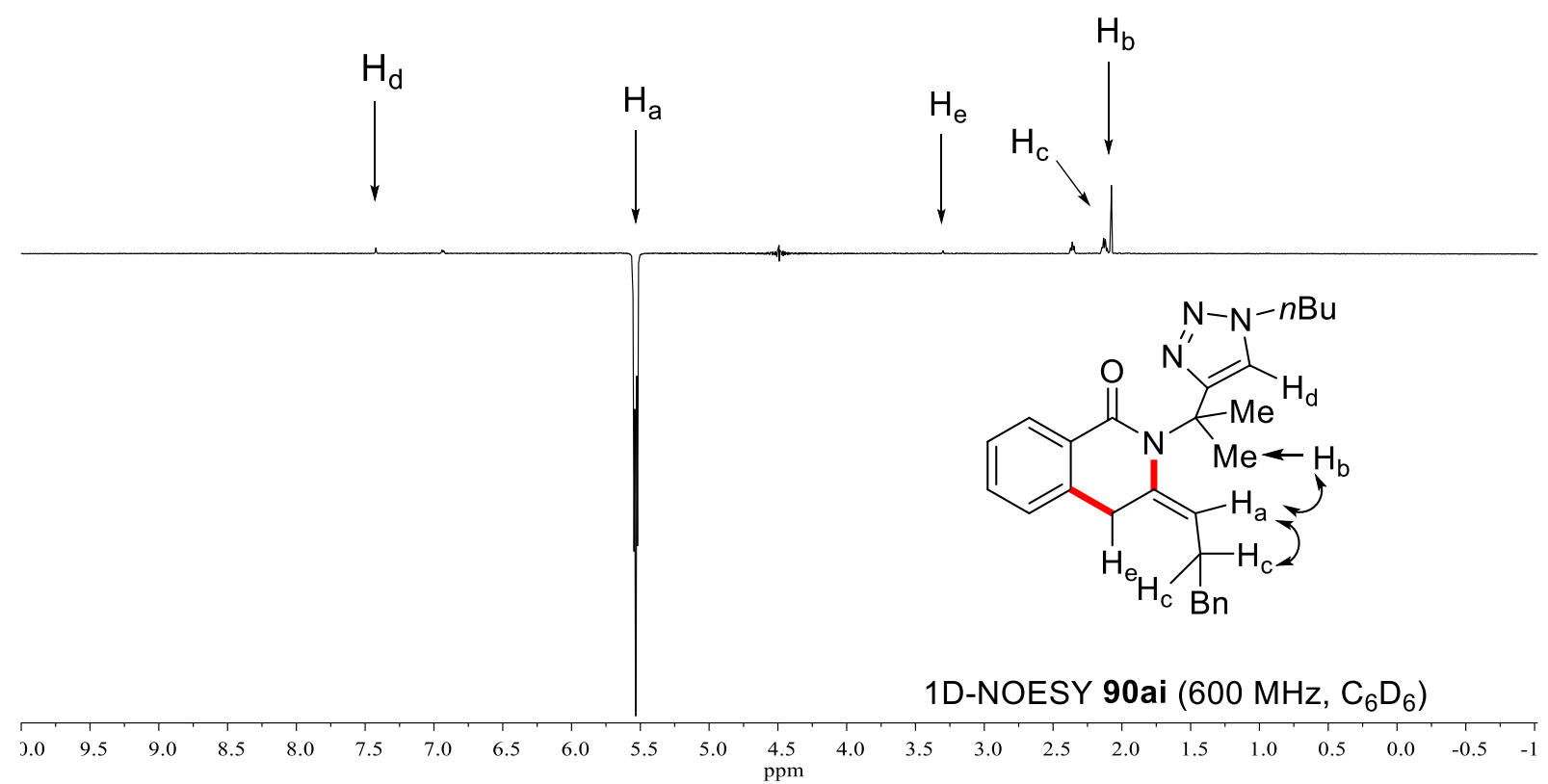


NMR Spectra
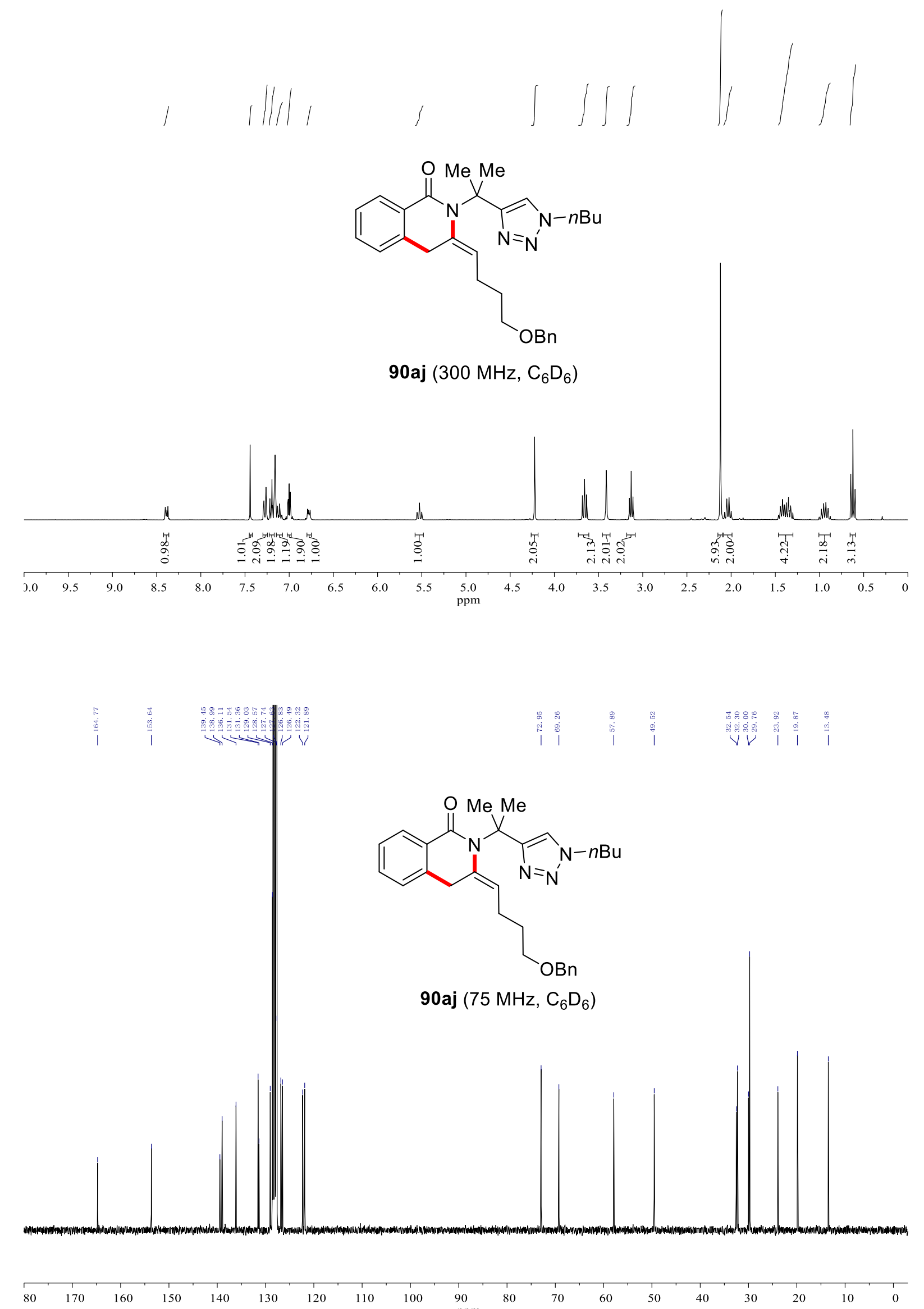


\section{NMR Spectra}

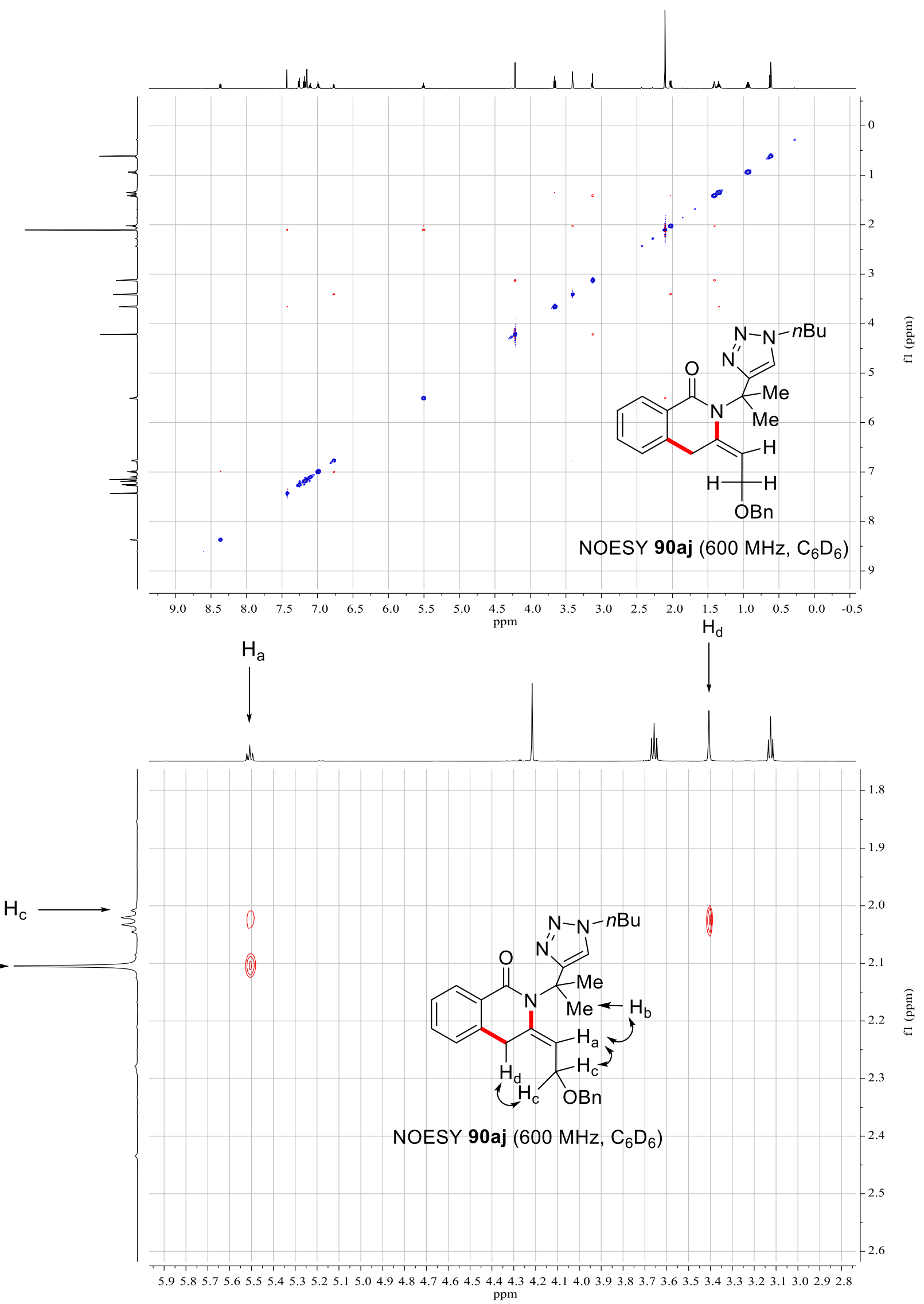


NMR Spectra

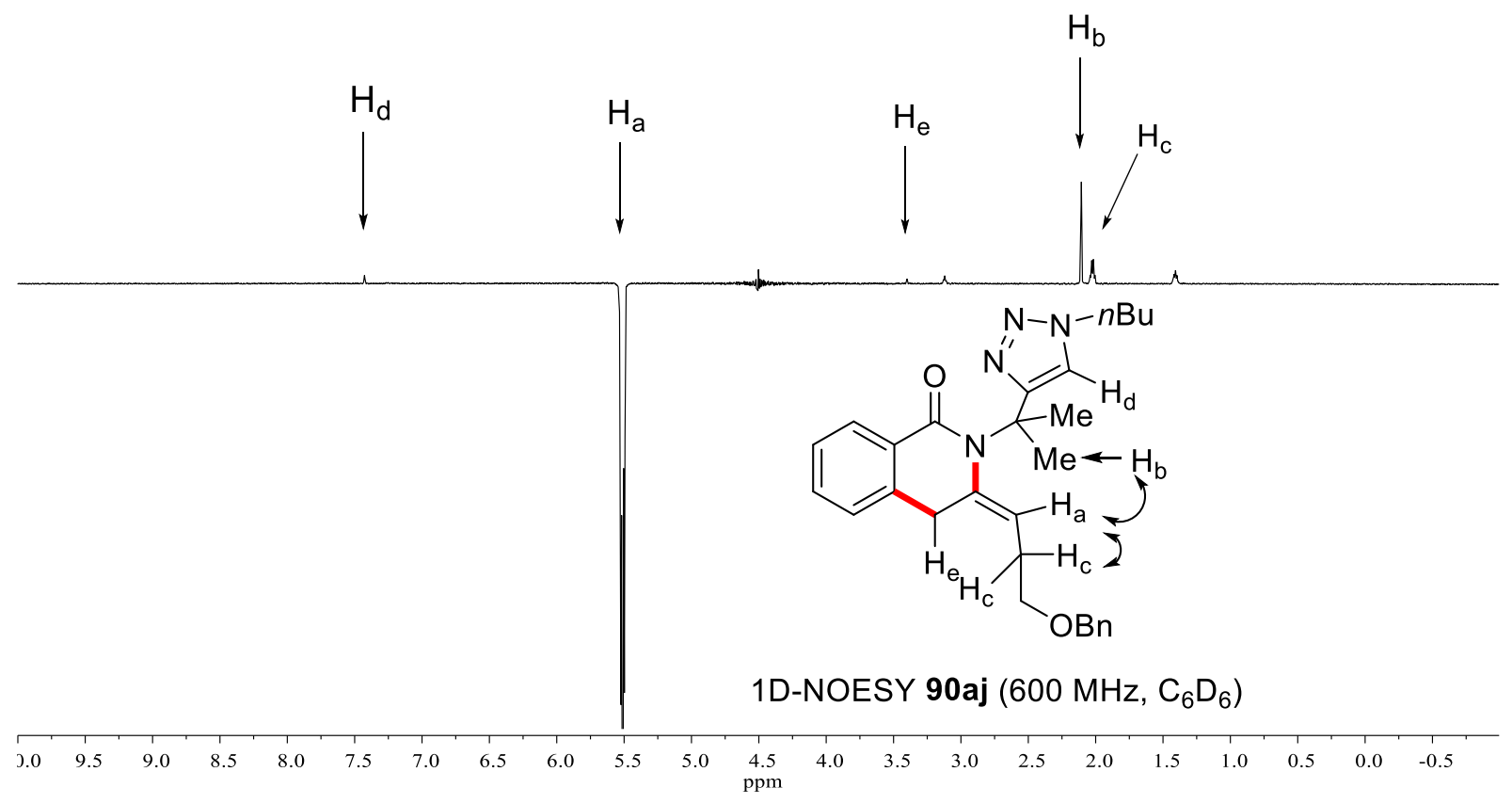



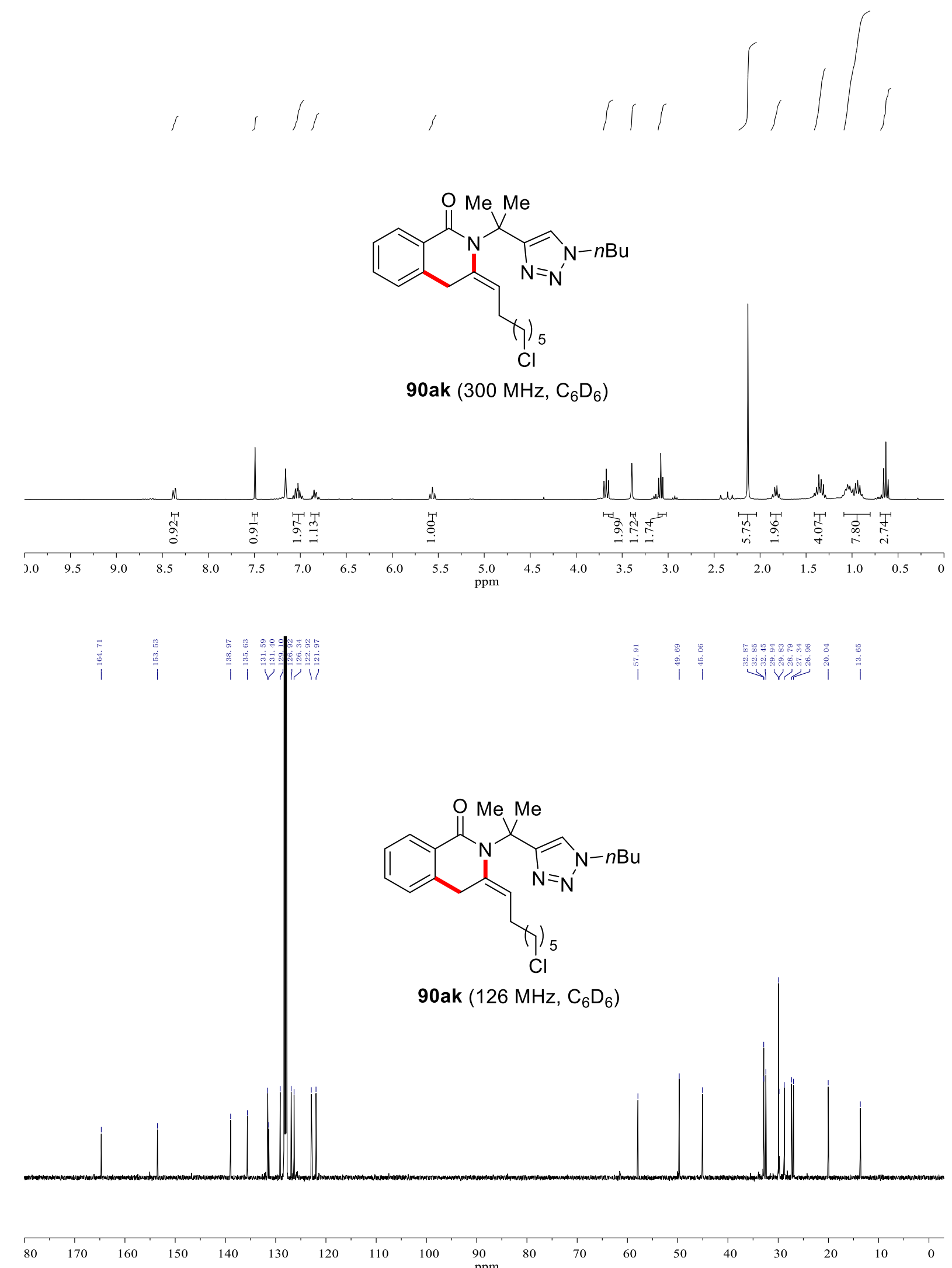
NMR Spectra
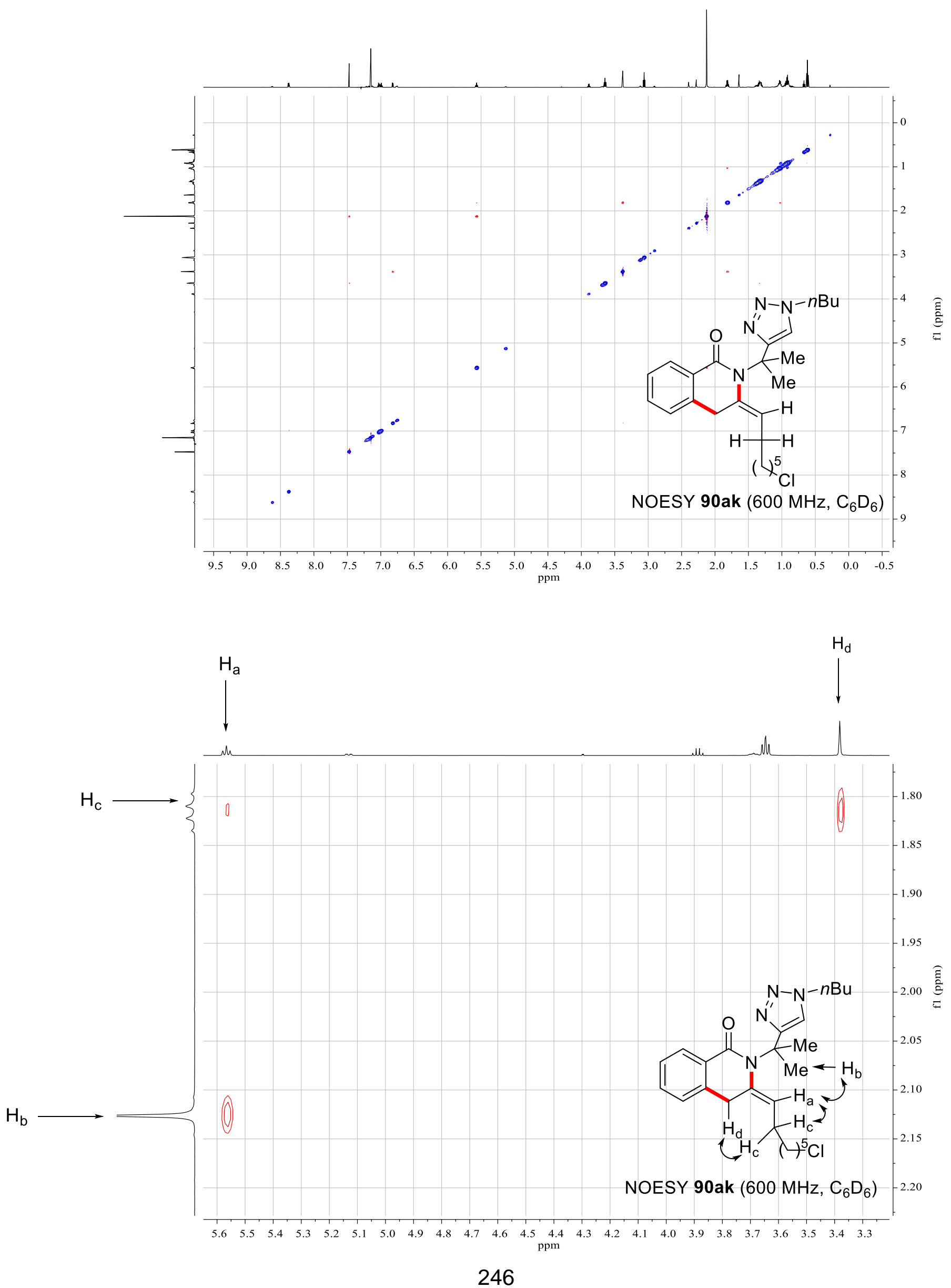
NMR Spectra

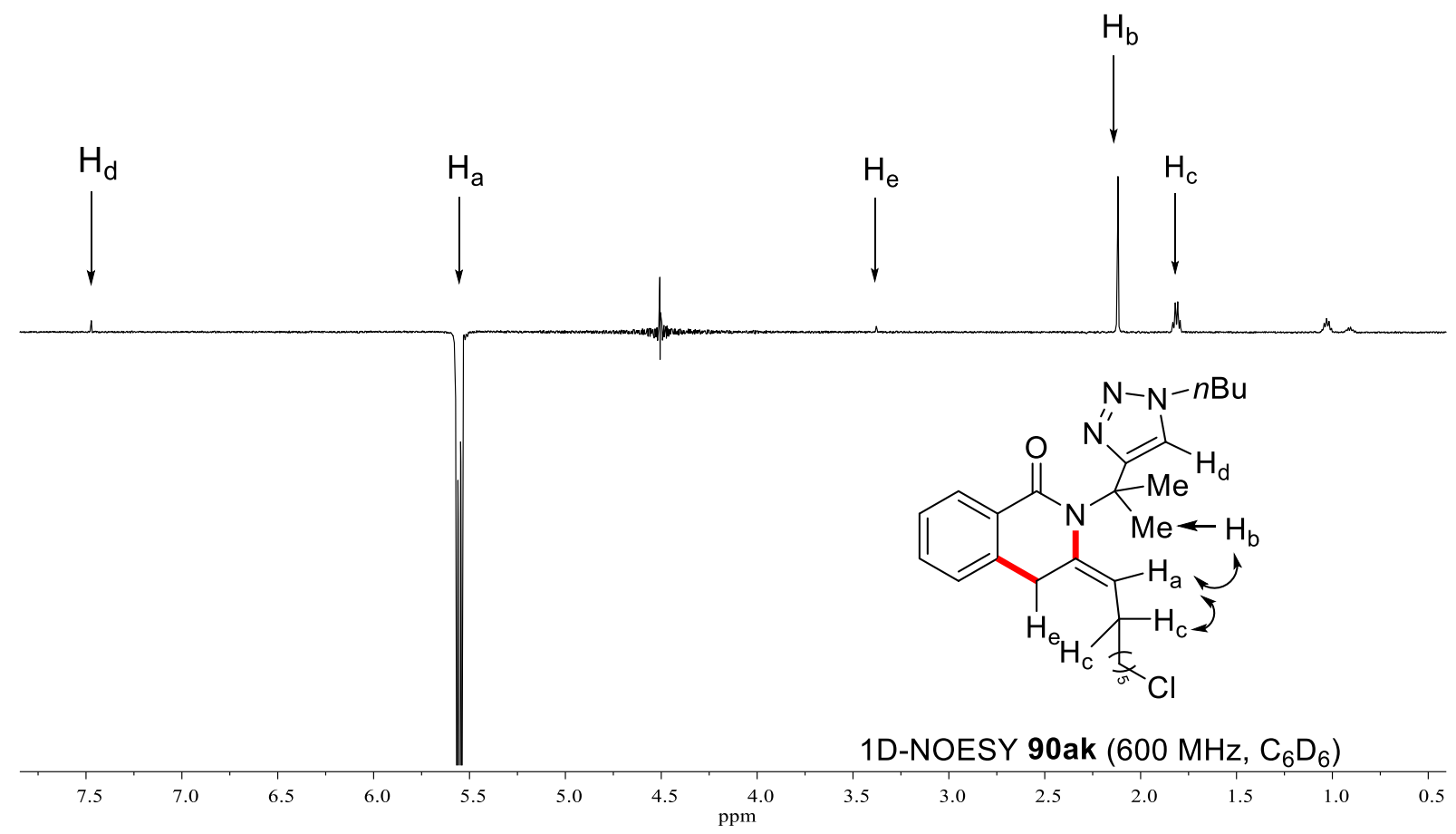




\section{NMR Spectra}

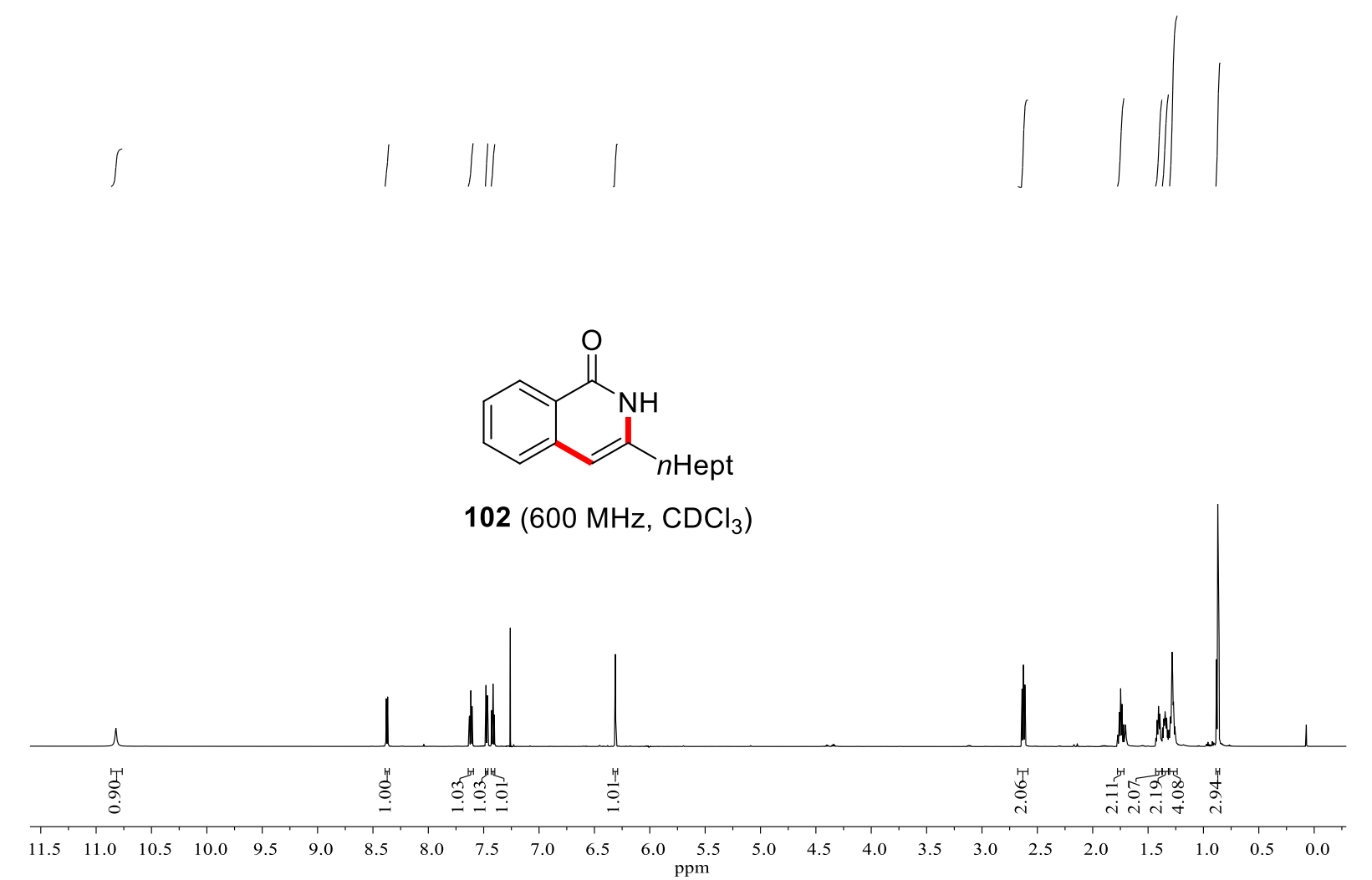

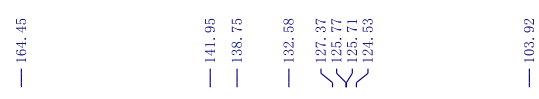

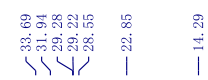

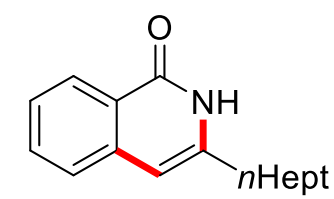

$102\left(126 \mathrm{MHz}, \mathrm{CDCl}_{3}\right)$

$\begin{array}{llllllll}180 & 170 & 160 & 150 & 140 & 130 & 120 & 110\end{array}$

$100 \quad \begin{array}{r}90 \\ \mathrm{ppm}\end{array}$

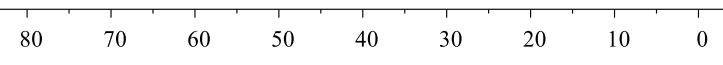


NMR Spectra
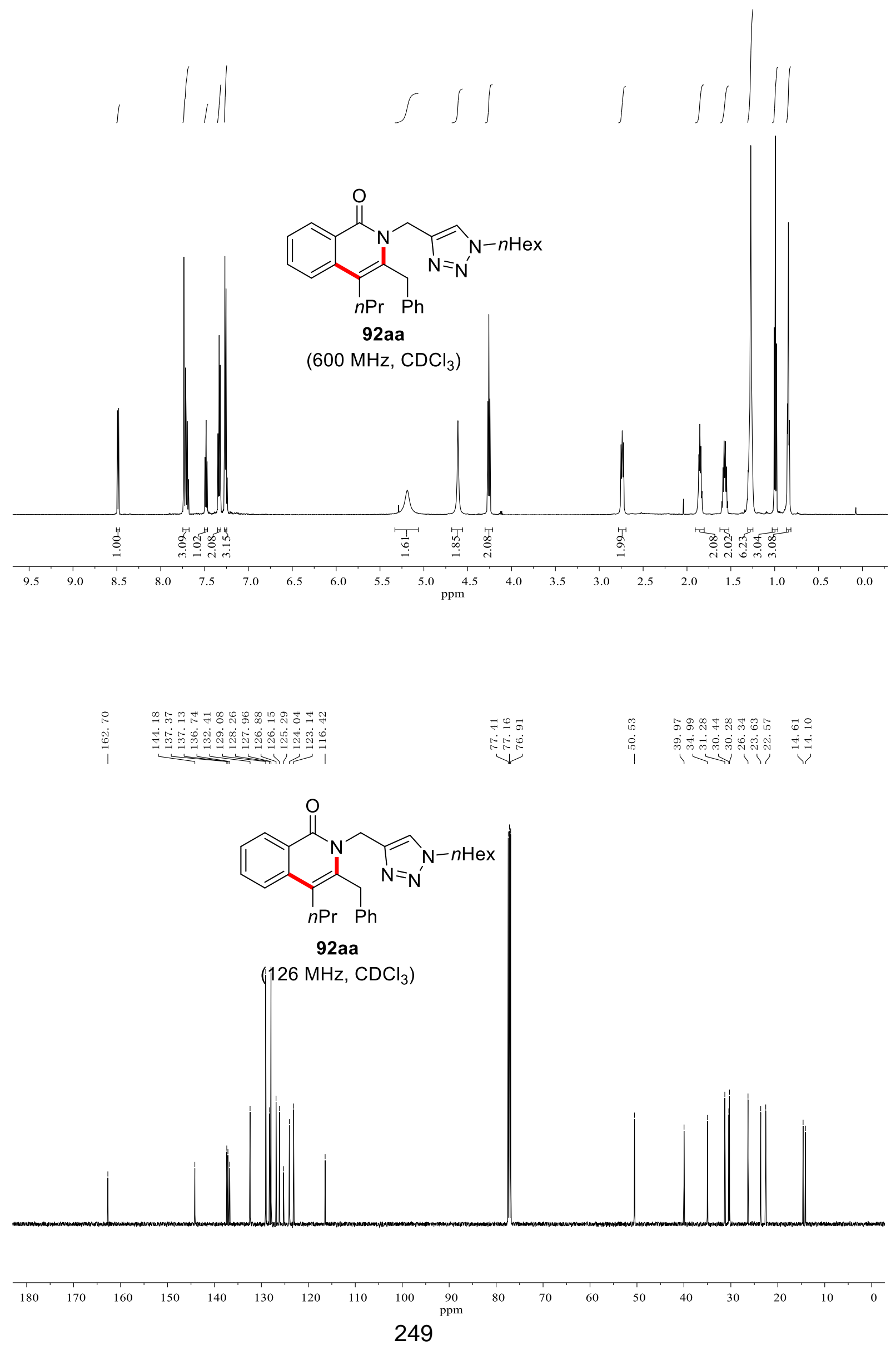

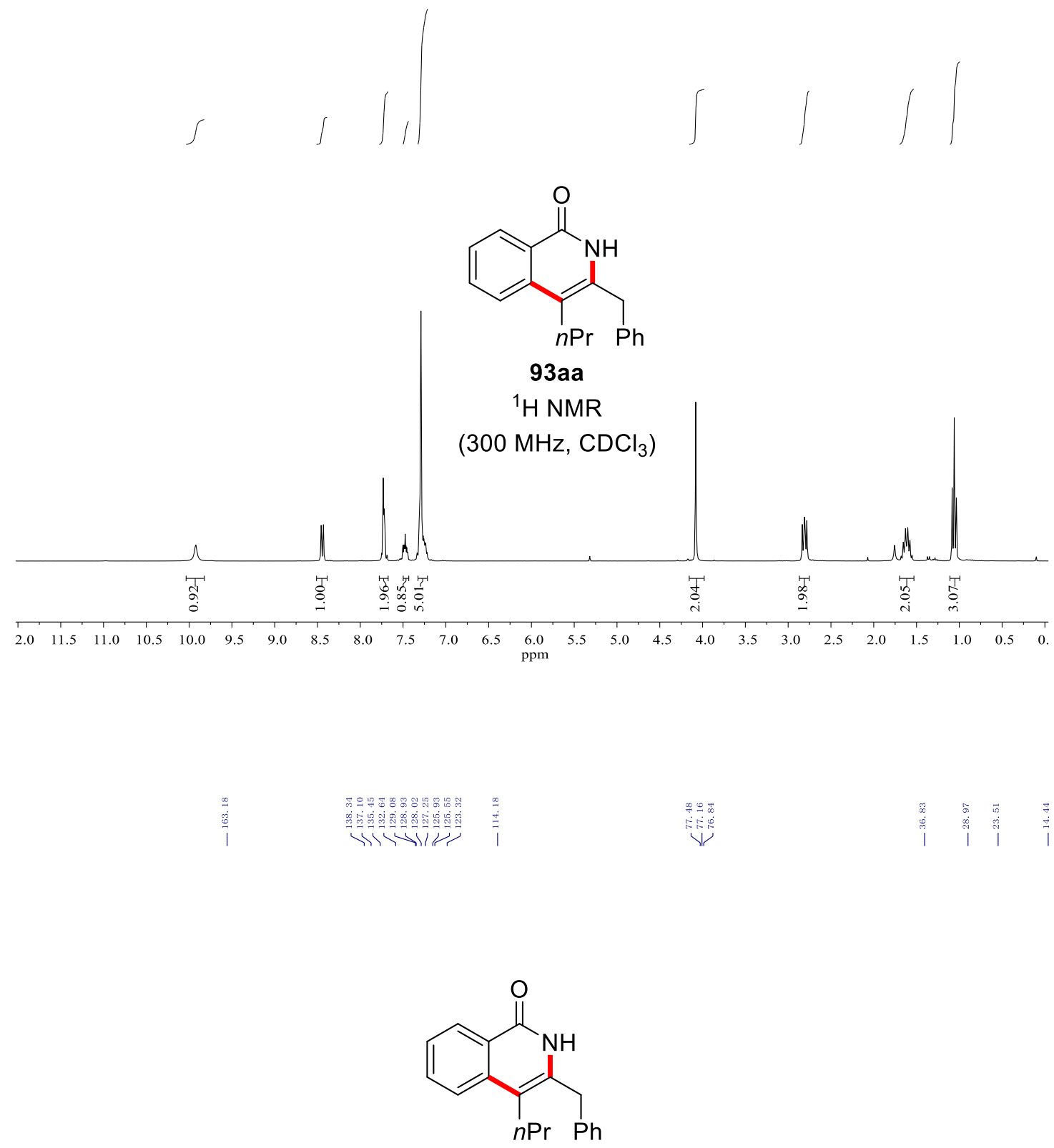

$93 a a$

${ }^{13} \mathrm{C}$ NMR

(126 MHz, $\mathrm{CDCl}_{3}$ )

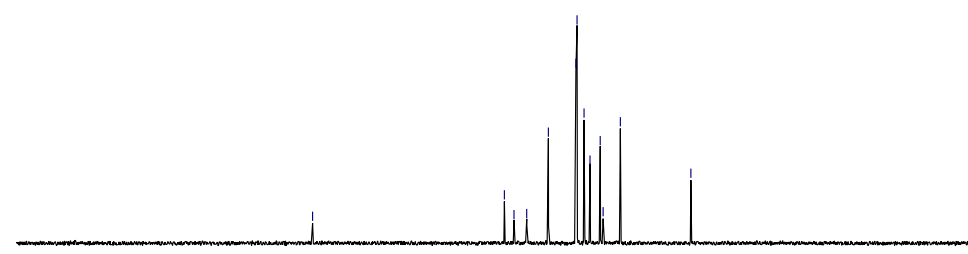

$$
\text { i }
$$


<smiles>[R]Cn1cc(Cn2c(CC=C)c(CC)c3ccccc3c2=O)nn1</smiles>

95ag

${ }^{1} \mathrm{H}$ NMR

(300 $\mathrm{MHz}, \mathrm{CDCl}_{3}$ )

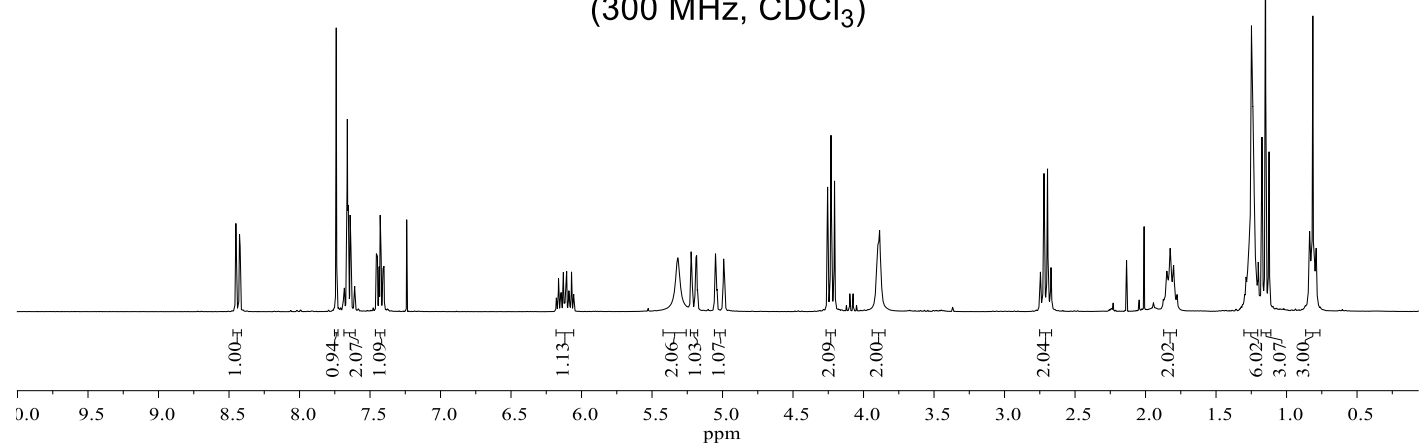

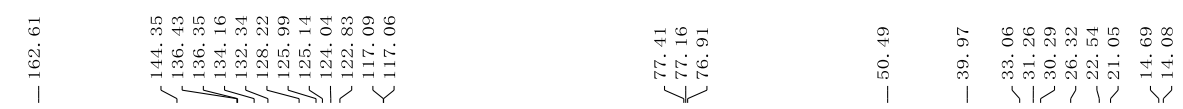<smiles>[R3]Cn1cc(Cn2c(CC=C)c(CC)c3ccccc3c2=O)nn1</smiles>

95ag

${ }^{13} \mathrm{C}$ NMR

$\left(126 \mathrm{MHz} \mathrm{CDCl}_{3}\right.$ )

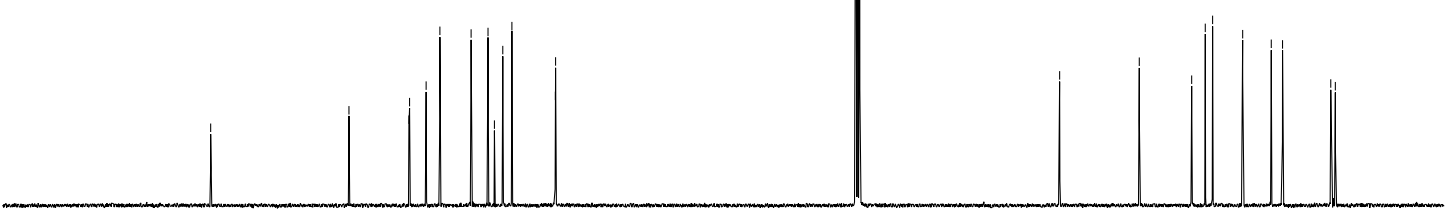

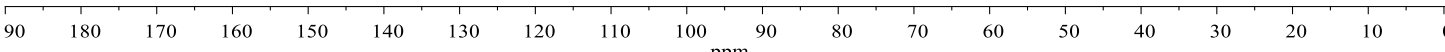




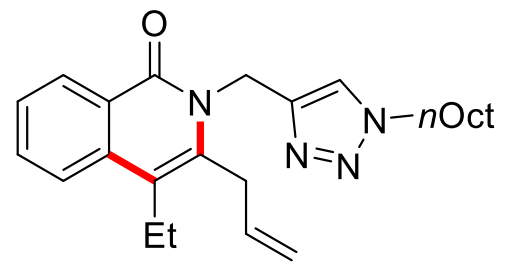

95bg

${ }^{1} \mathrm{H}$ NMR

(400 MHz, $\mathrm{CDCl}_{3}$ )

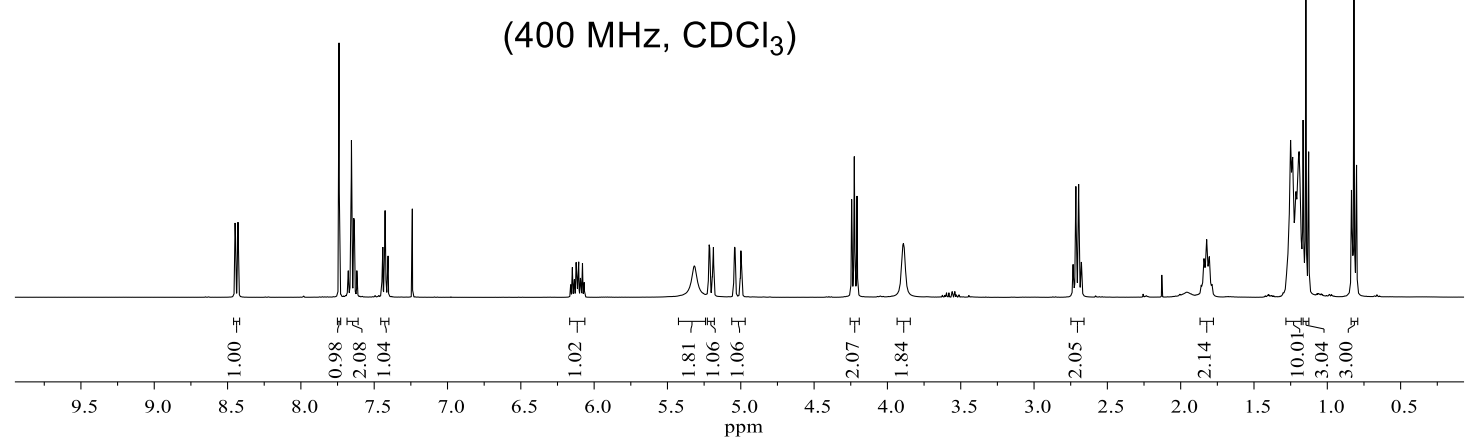

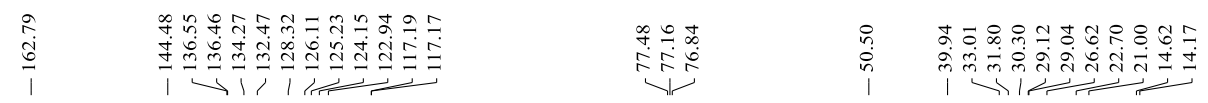<smiles>C=CCc1c(CC)c2ccccc2c(=O)n1Cc1cn(OCC)nn1</smiles>

$95 \mathrm{bg}$

${ }^{13} \mathrm{C}$ NMR

(101 MHz, $\mathrm{CDCl}_{3}$ )

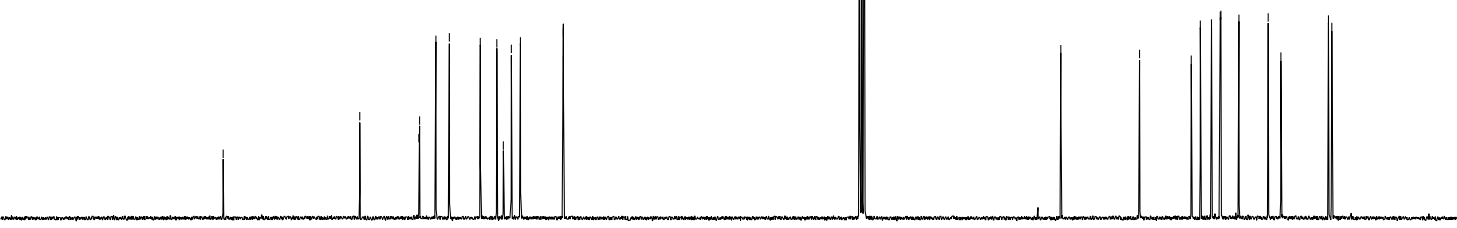

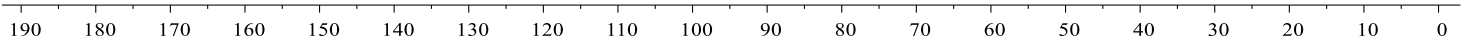


NMR Spectra

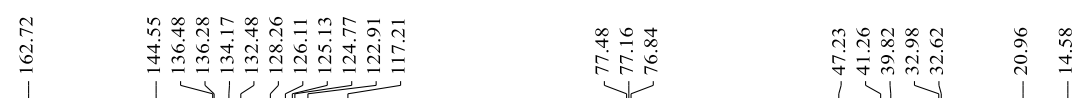

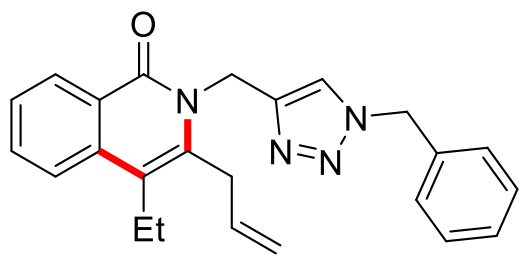

$95 \mathrm{cg}$

${ }^{1} \mathrm{H}$ NMR

(400 MHz, $\mathrm{CDCl}_{3}$ )
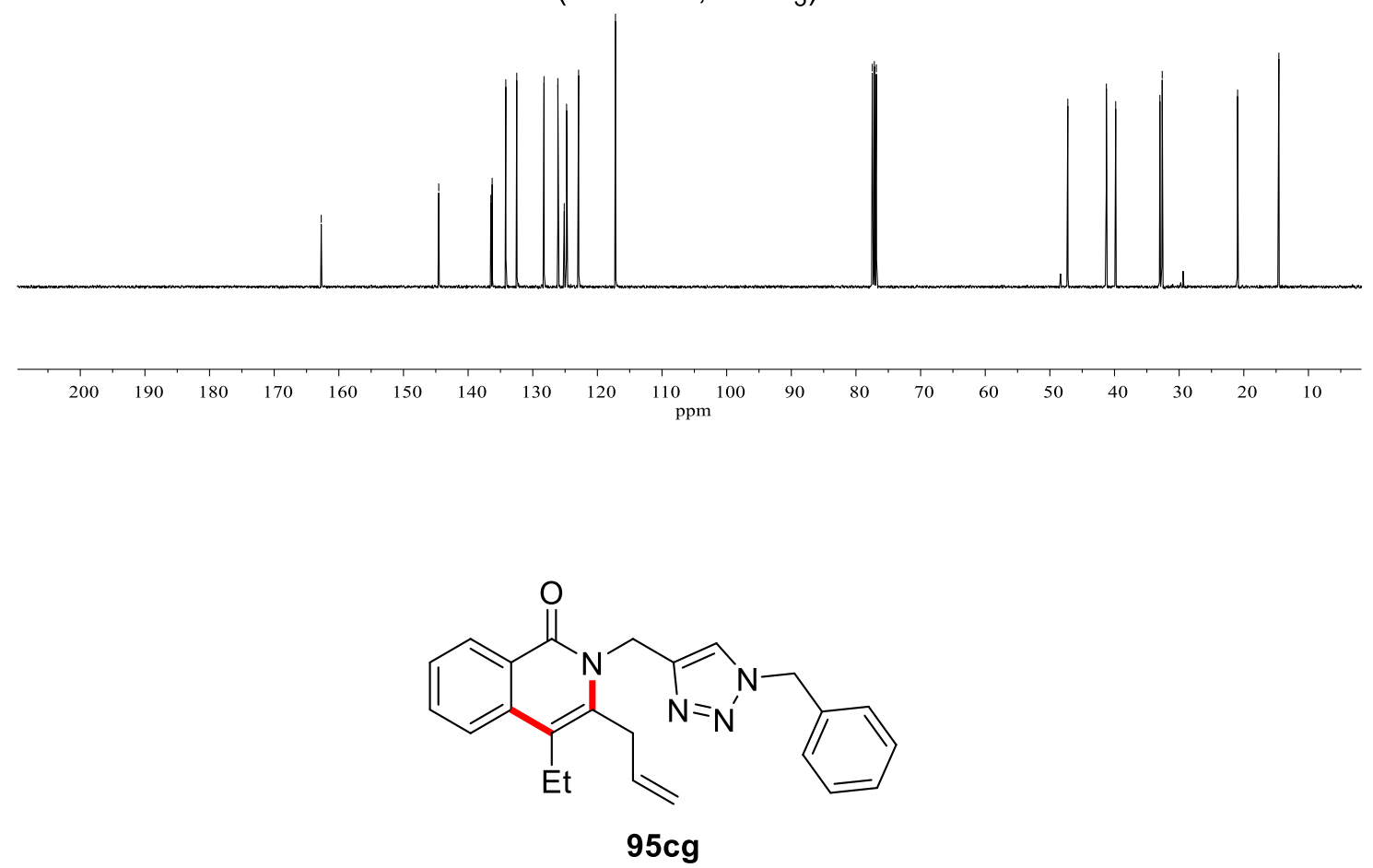

${ }^{13} \mathrm{C}$ NMR

(101 MHz, $\mathrm{CDCl}_{3}$ )

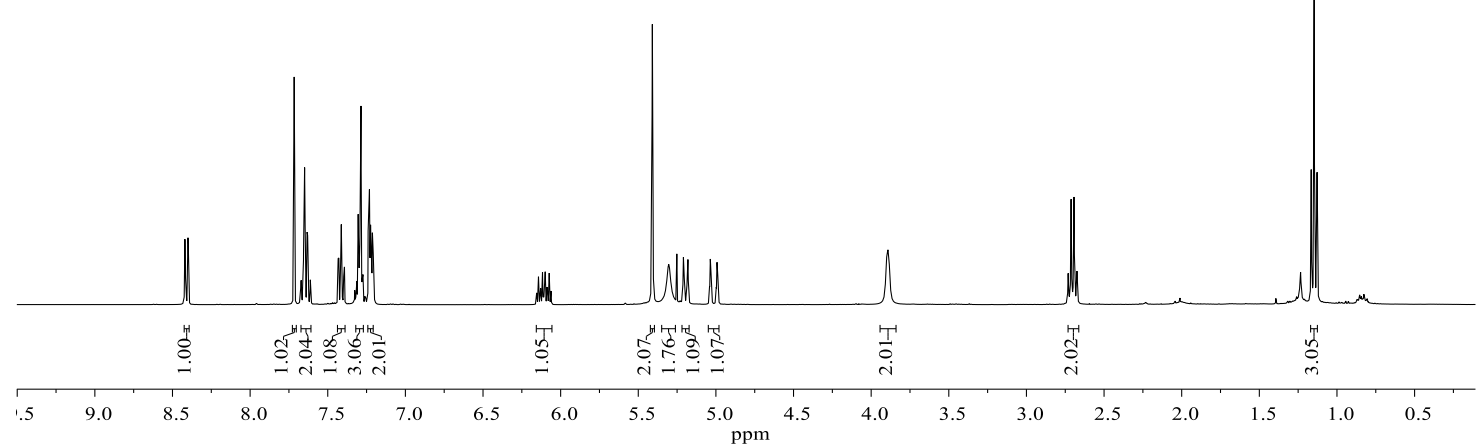




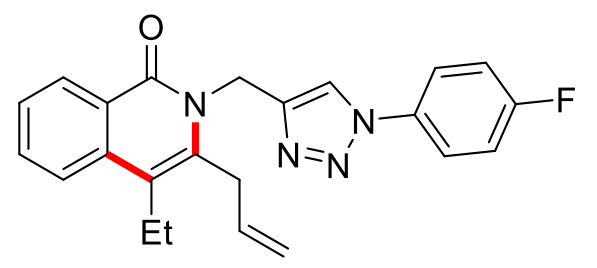

95rg

${ }^{1} \mathrm{H}$ NMR

(400 MHz, $\mathrm{CDCl}_{3}$ )

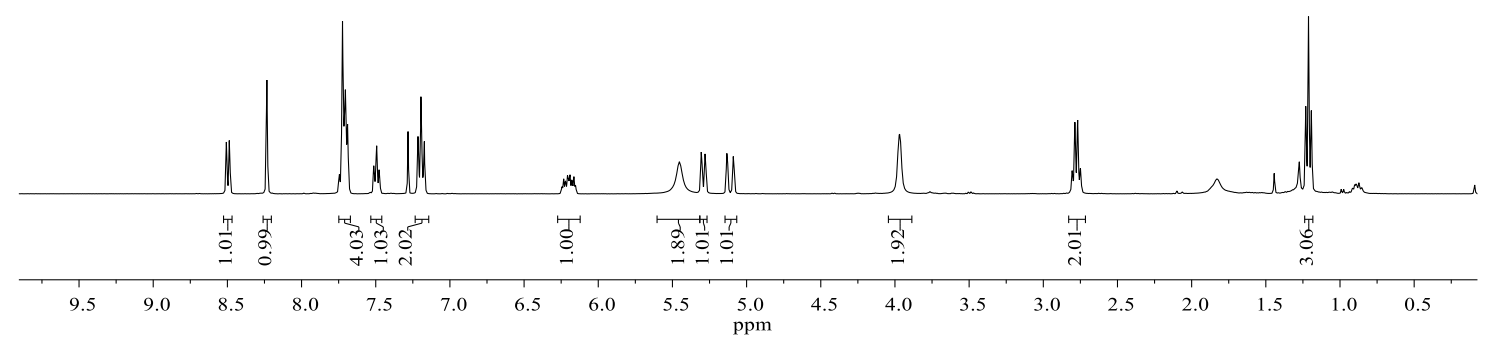

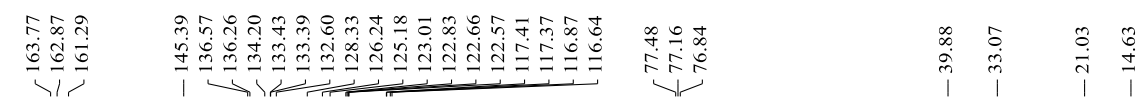

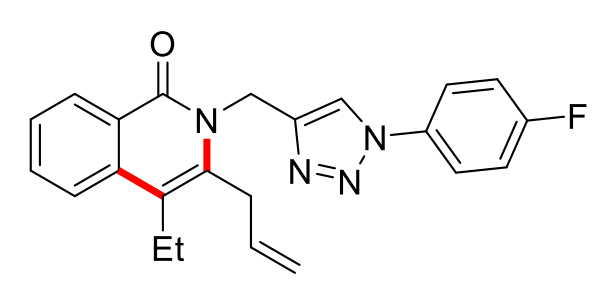

95rg

${ }^{13} \mathrm{C}$ NMR

$\left(101 \mathrm{MHz}, \mathrm{CDCl}_{3}\right)$

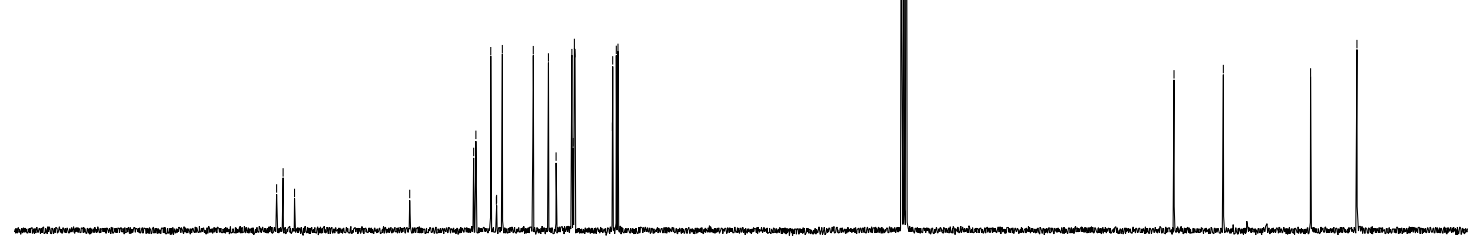

$\begin{array}{llllllllllllllllllll}190 & 180 & 170 & 160 & 150 & 140 & 130 & 120 & 110 & 100 & 90 & 80 & 70 & 60 & 50 & 40 & 30 & 20 & 10 & \mathrm{C}\end{array}$ 


\section{NMR Spectra}

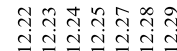 \\ $\exists \exists \exists \exists \exists$}<smiles>C=CCc1c(CC)c2ccccc2c(=O)n1Cc1cn(-c2ccc(F)cc2)nn1</smiles>

95rg

${ }^{19} \mathrm{~F} \mathrm{NMR}$

(377 MHz, $\mathrm{CDCl}_{3}$ )
$\stackrel{\mathcal{J}}{\exists} \stackrel{\mathcal{J}}{\exists} \underset{\exists}{\exists} \stackrel{\mathcal{N}}{\exists}$

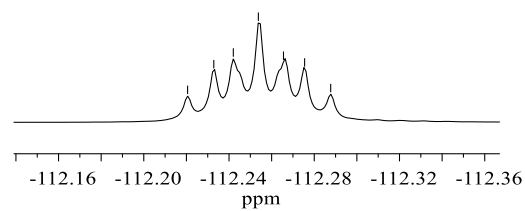




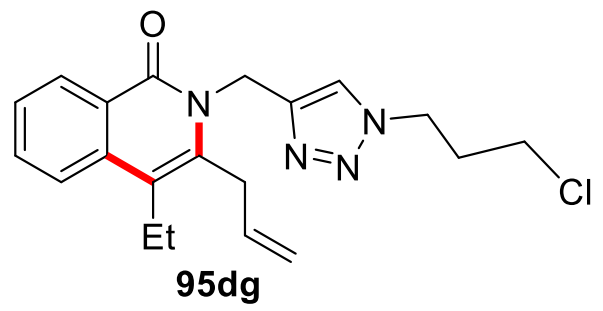

${ }^{1} \mathrm{H}$ NMR

(400 MHz, $\mathrm{CDCl}_{3}$ )

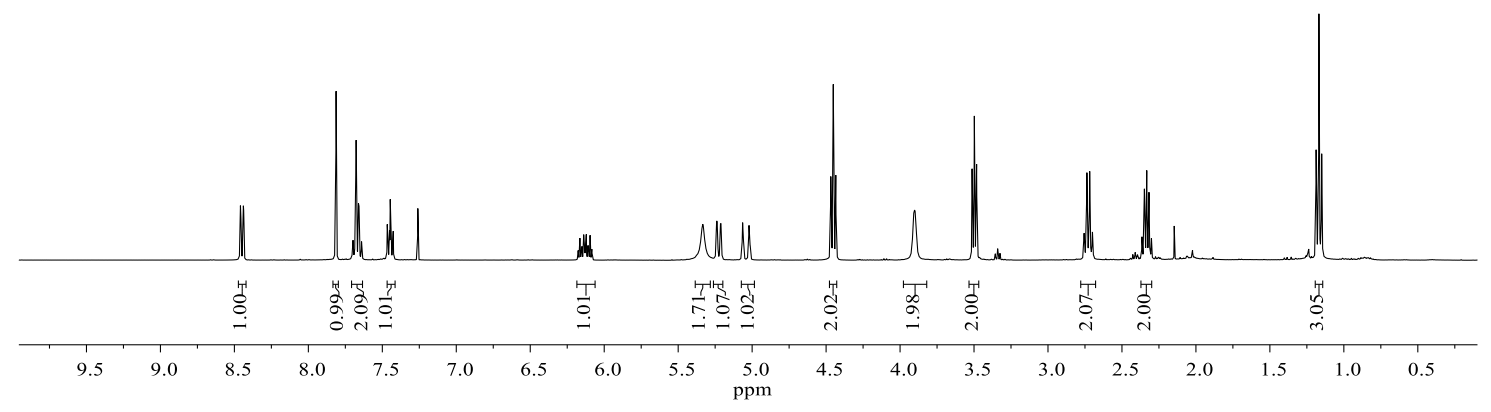

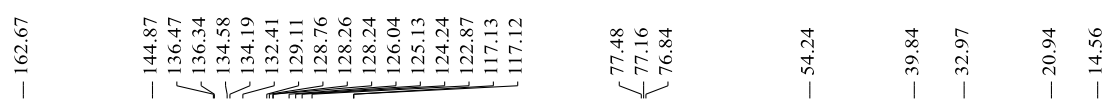

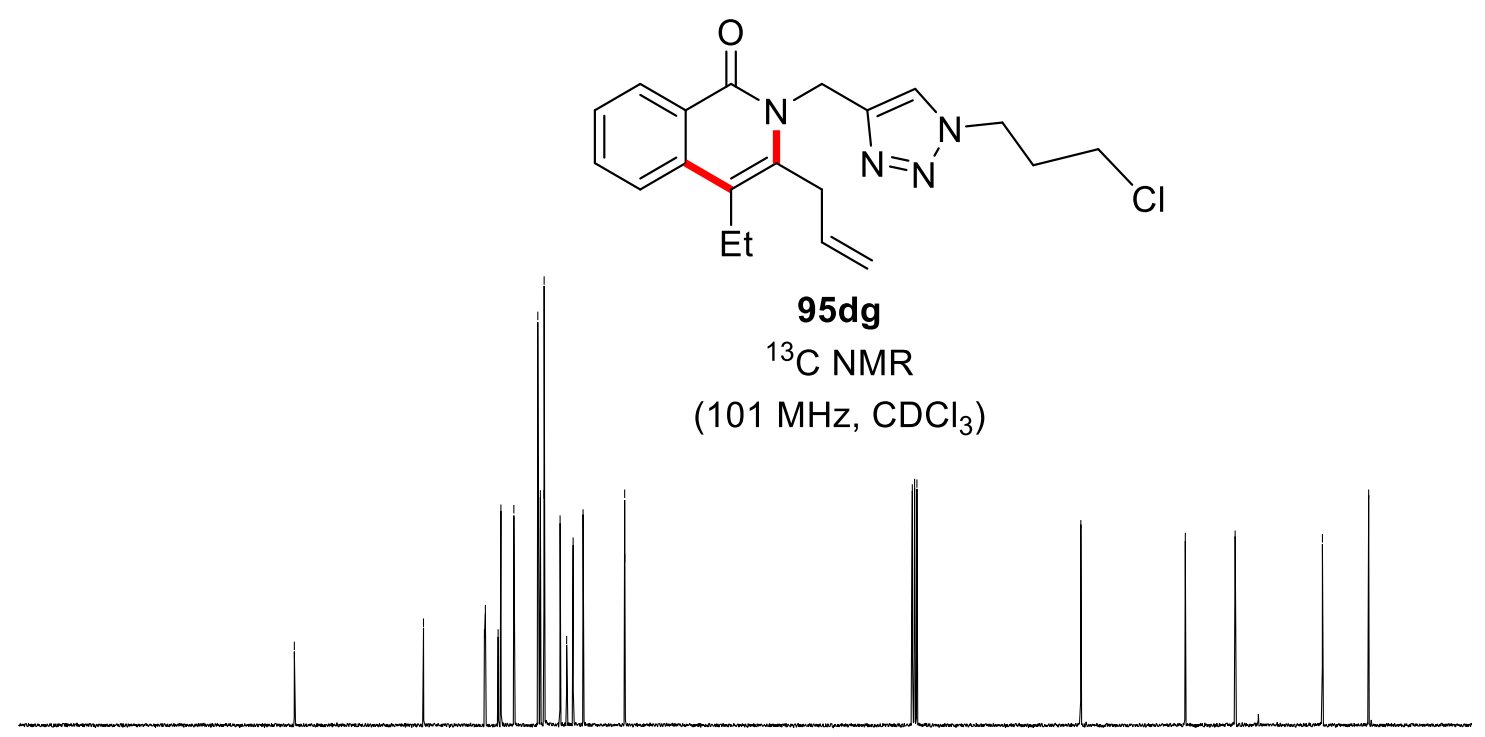

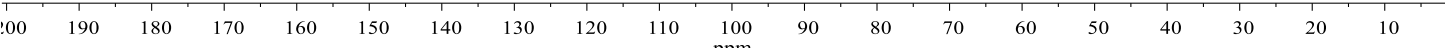



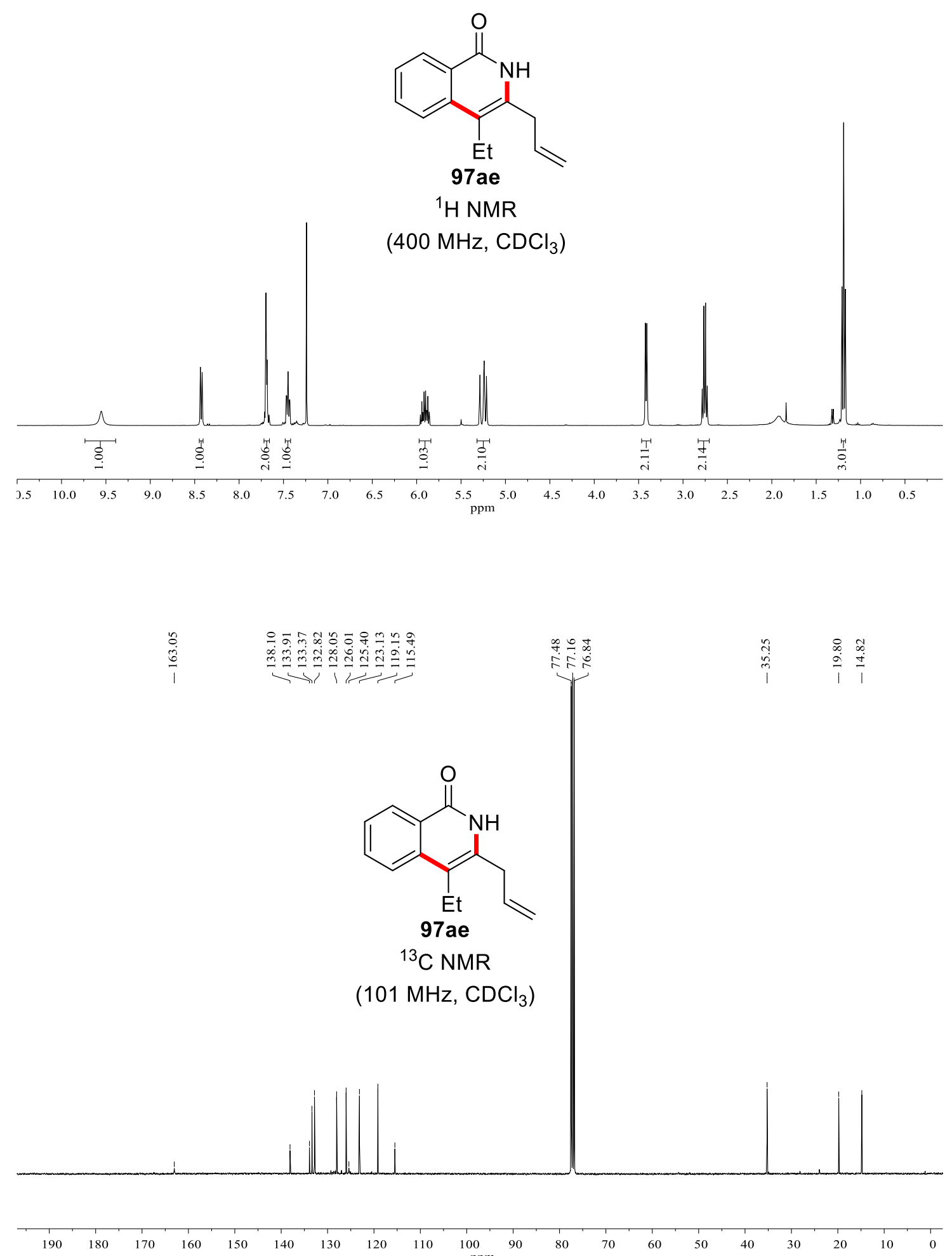
NMR Spectra

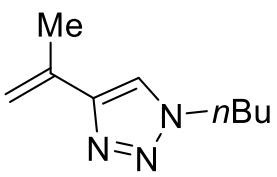

119

${ }^{1} \mathrm{H}$ NMR

$\left(400 \mathrm{MHz}, \mathrm{CDCl}_{3}\right.$ )

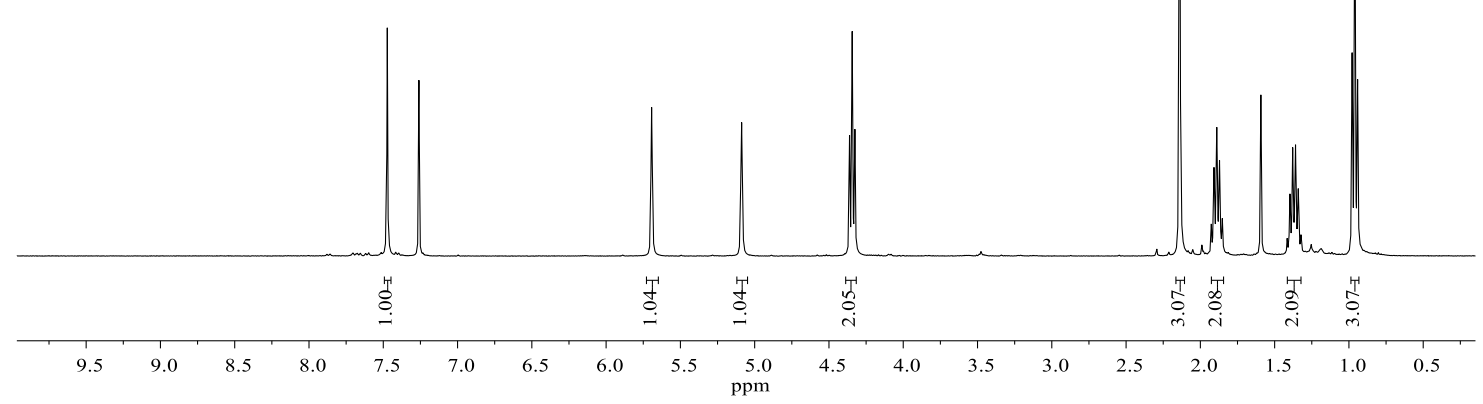

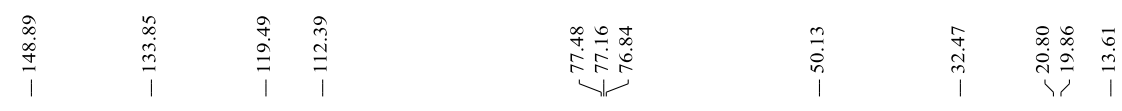<smiles>C=C(C)c1cn(CCCC)nn1</smiles>

119

${ }^{13} \mathrm{C}$ NMR

(101 MHz, $\mathrm{CDCl}_{3}$ )

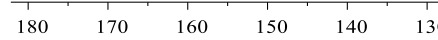

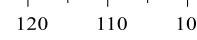

90
$\mathrm{ppm}$ 


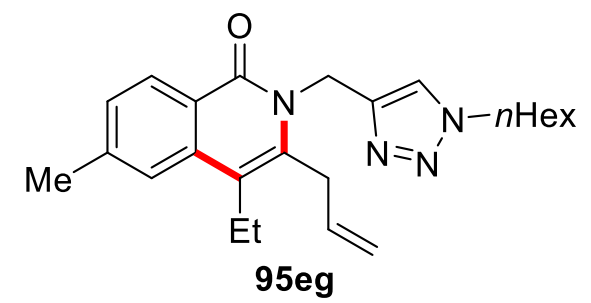

${ }^{13} \mathrm{C}$ NMR

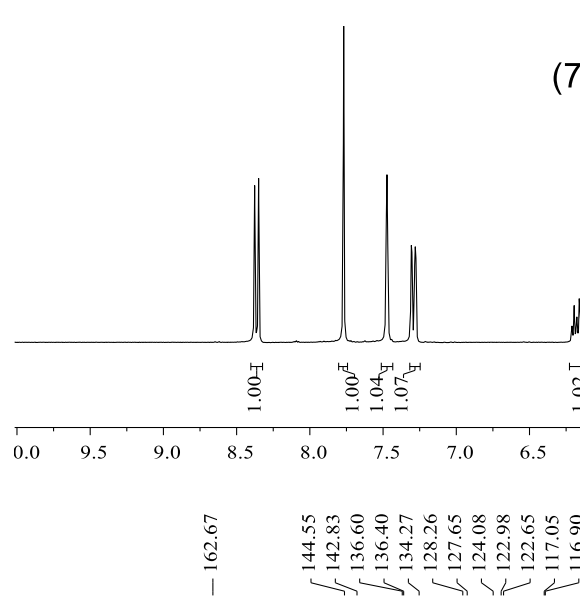

$\left(75 \mathrm{MHz}, \mathrm{CDCl}_{3}\right.$ )
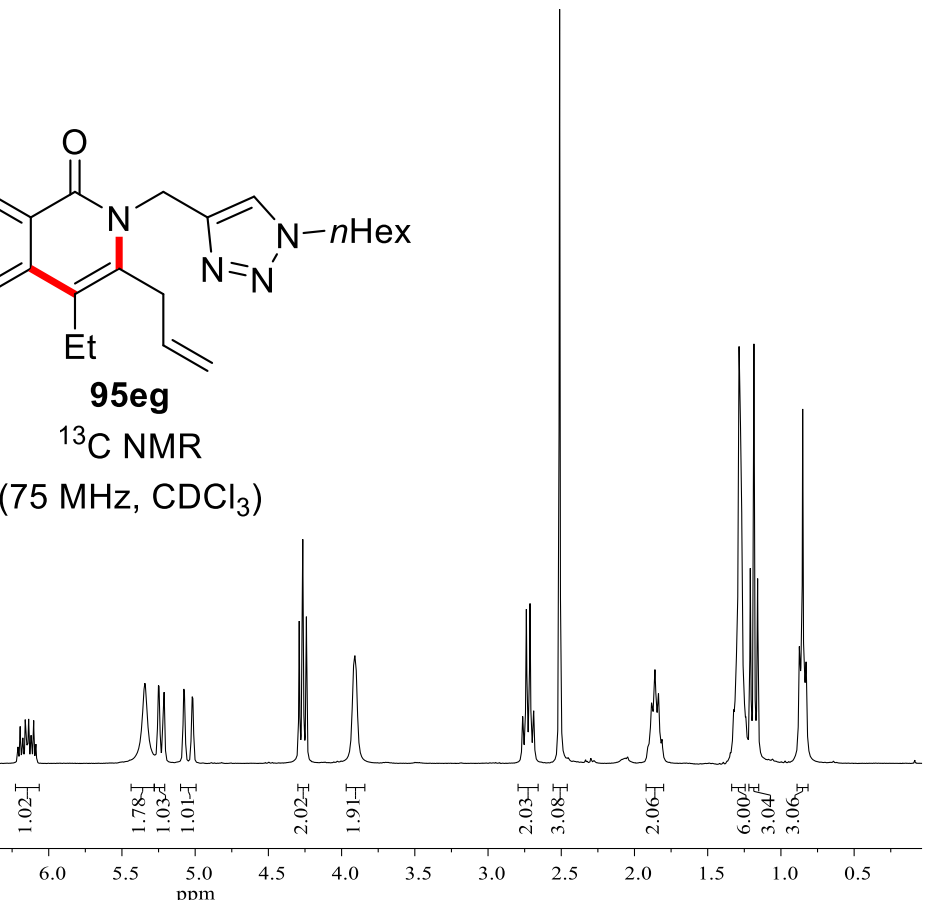<smiles>C=CCc1c(CC)c2cc(C)ccc2c(=O)n1Cc1cn(C=[18O])nn1</smiles>

${ }^{1} \mathrm{H}$ NMR

(300 MHz, $\mathrm{CDCl}_{3}$ )

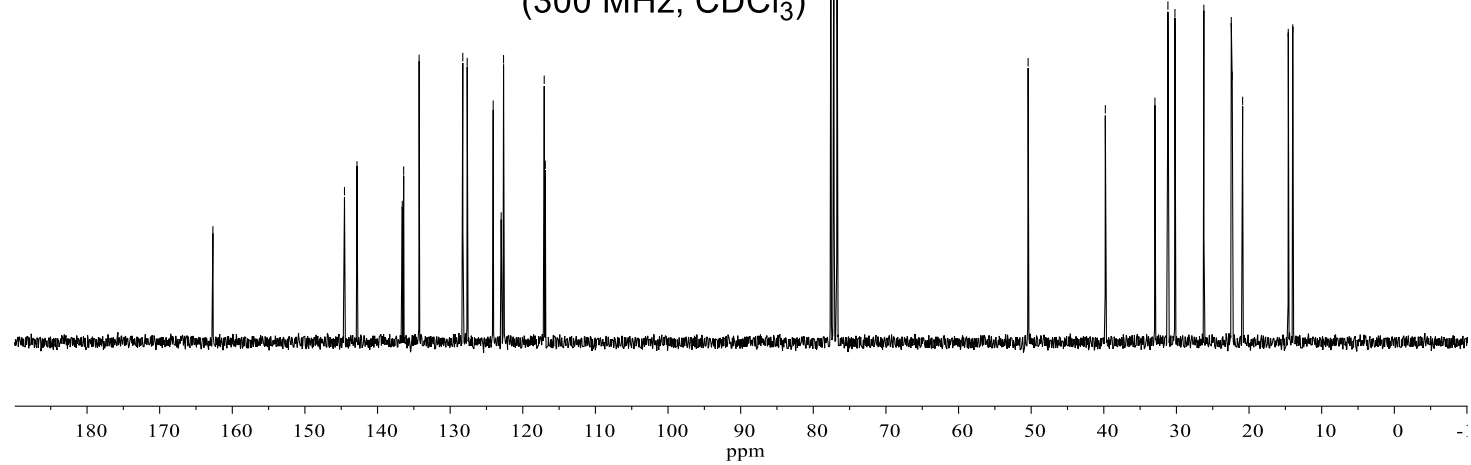


NMR Spectra<smiles>C=CCc1c(CC)c2cc(OC)ccc2c(=O)n1Cc1cn(CC)nn1</smiles>

\section{5gg}

${ }^{1} \mathrm{H}$ NMR

$\left(400 \mathrm{MHz}, \mathrm{CDCl}_{3}\right)$

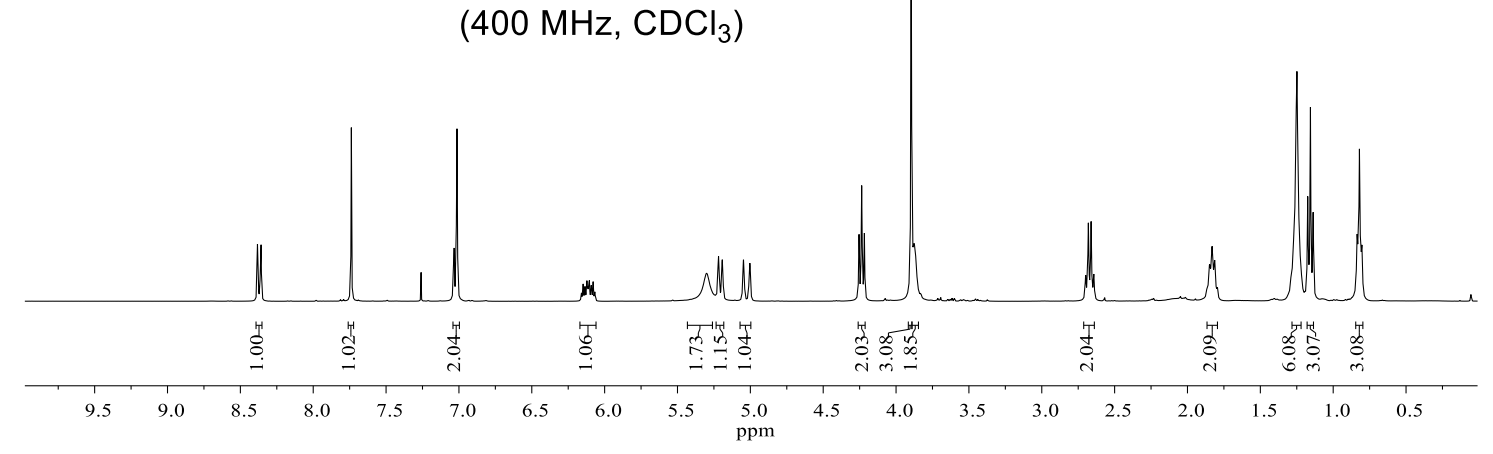

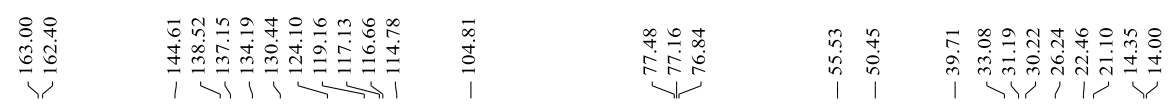<smiles>[R]Cn1cc(Cn2c(CC=C)c(CC)c3cc(OC)ccc3c2=O)nn1</smiles>

\section{5gg}

${ }^{13} \mathrm{C}$ NMR

(101 MHz, $\mathrm{CDCl}_{3}$ )

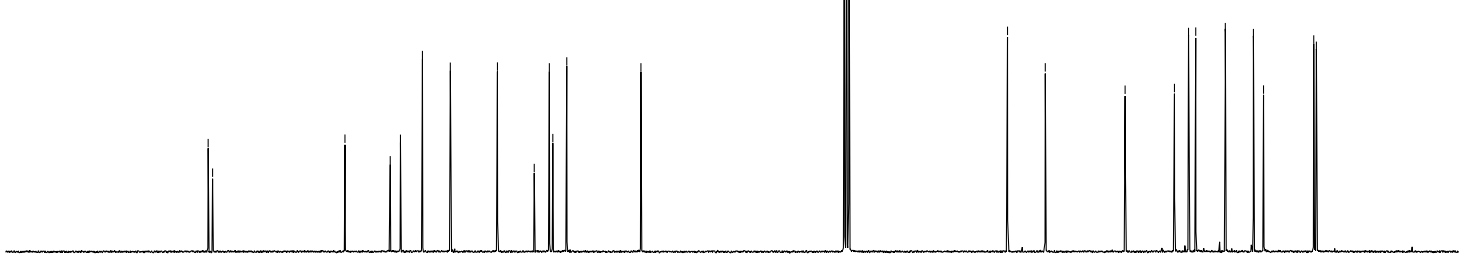

\begin{tabular}{llllllllllllllllllll}
\hline 90 & 180 & 170 & 160 & 150 & 140 & 130 & 120 & 110 & 100 & 90 & 80 & 70 & 60 & 50 & 40 & 30 & 20 & 10 & 0
\end{tabular} 


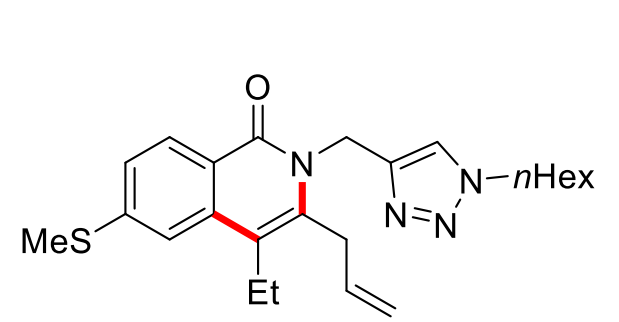

95sg

${ }^{13} \mathrm{C}$ NMR

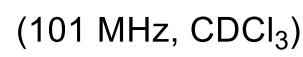

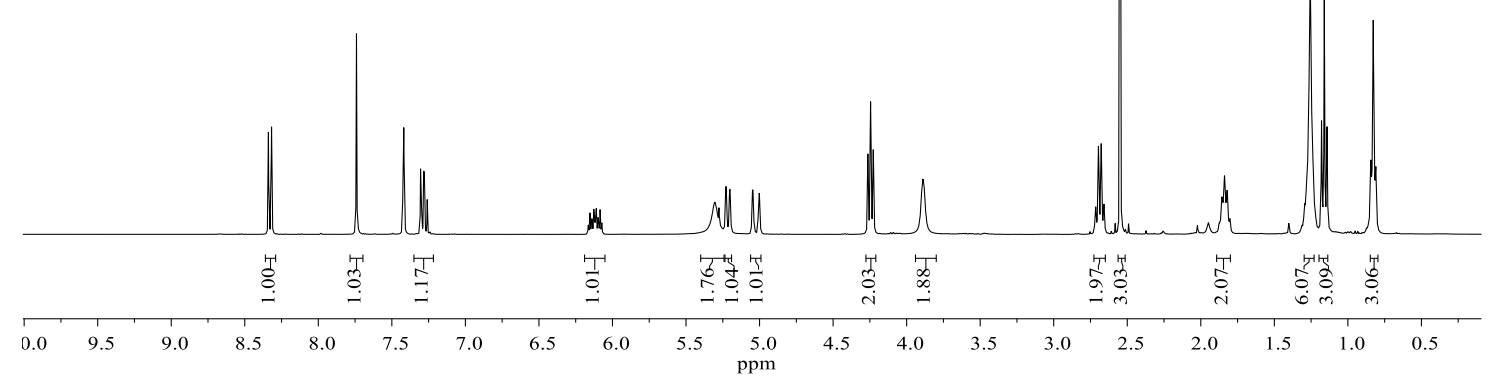

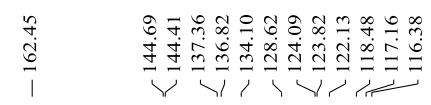<smiles>C=CCc1c(CC)c2cc(S(C)(=O)=O)ccc2c(=O)n1Cc1cn(C[Ga])nn1</smiles>

95sg

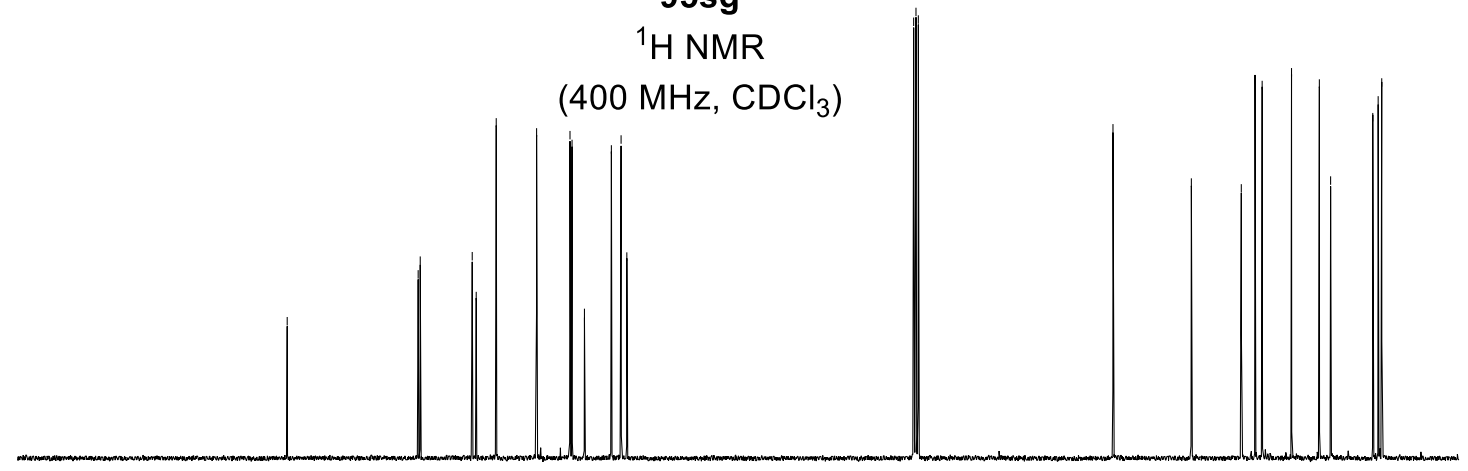

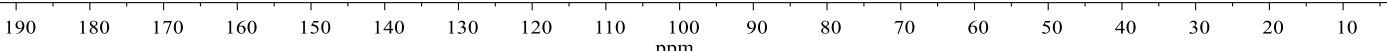




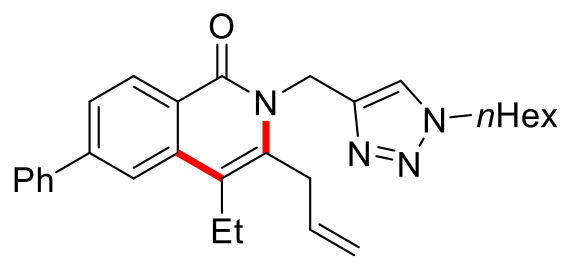

$95 \mathrm{fg}$

${ }^{1} \mathrm{H}$ NMR

(400 MHz, $\mathrm{CDCl}_{3}$ )
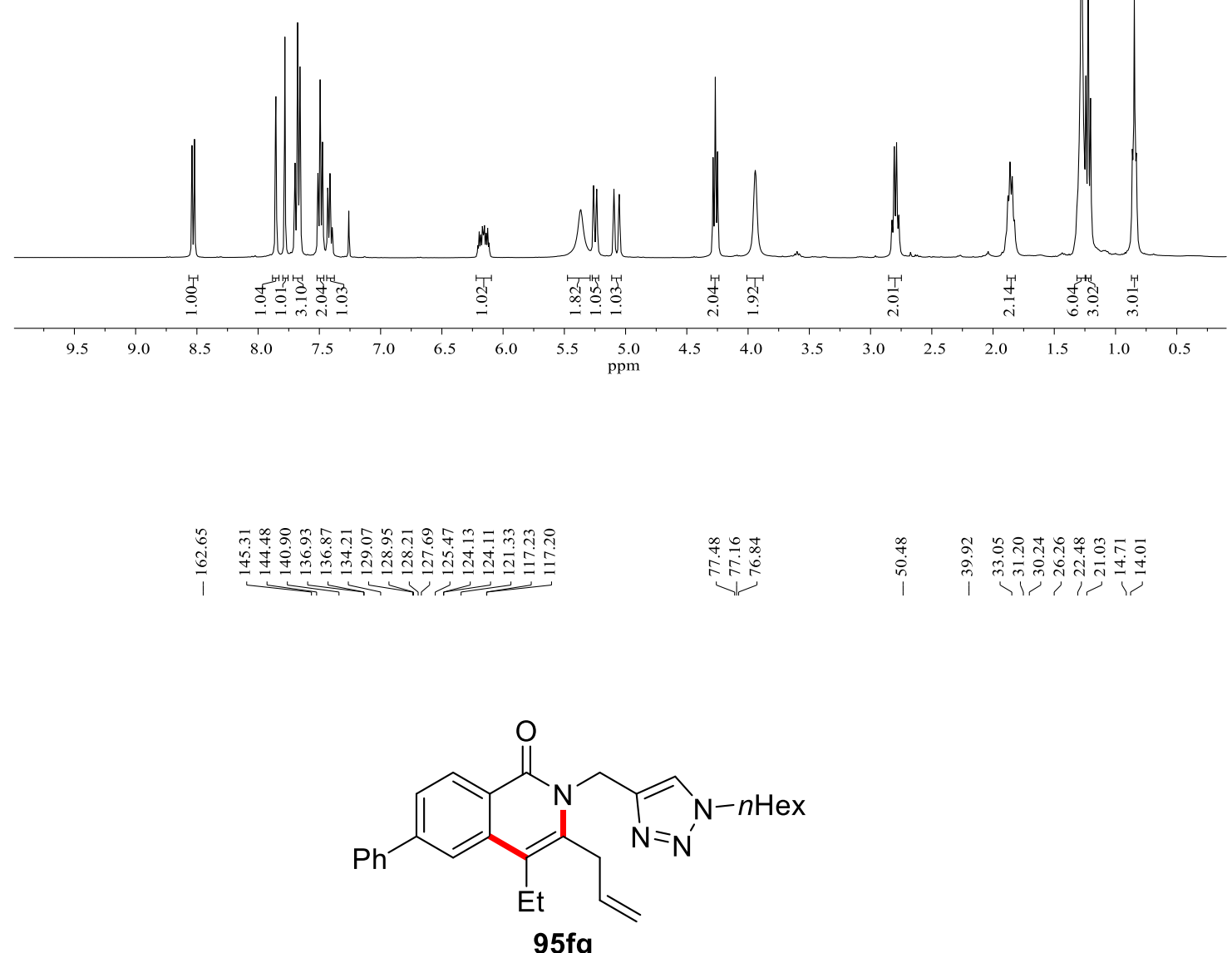

${ }^{13} \mathrm{C}$ NMR

$\left(101 \mathrm{MHz}, \mathrm{CDCl}_{3}\right.$ )
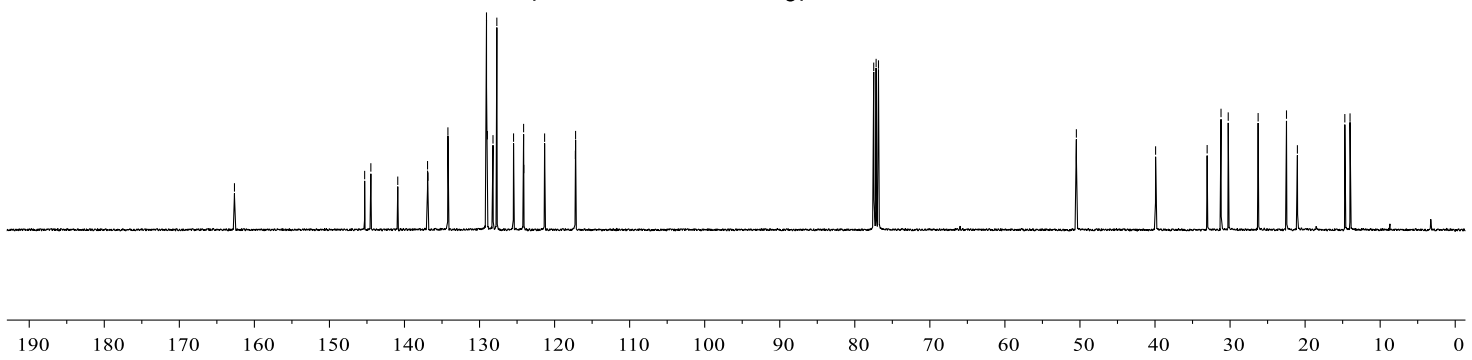
<smiles>[R4]Cn1cc(Cn2c(CC=C)c(CC)c3cc(Cl)ccc3c2=O)nn1</smiles>

95jg

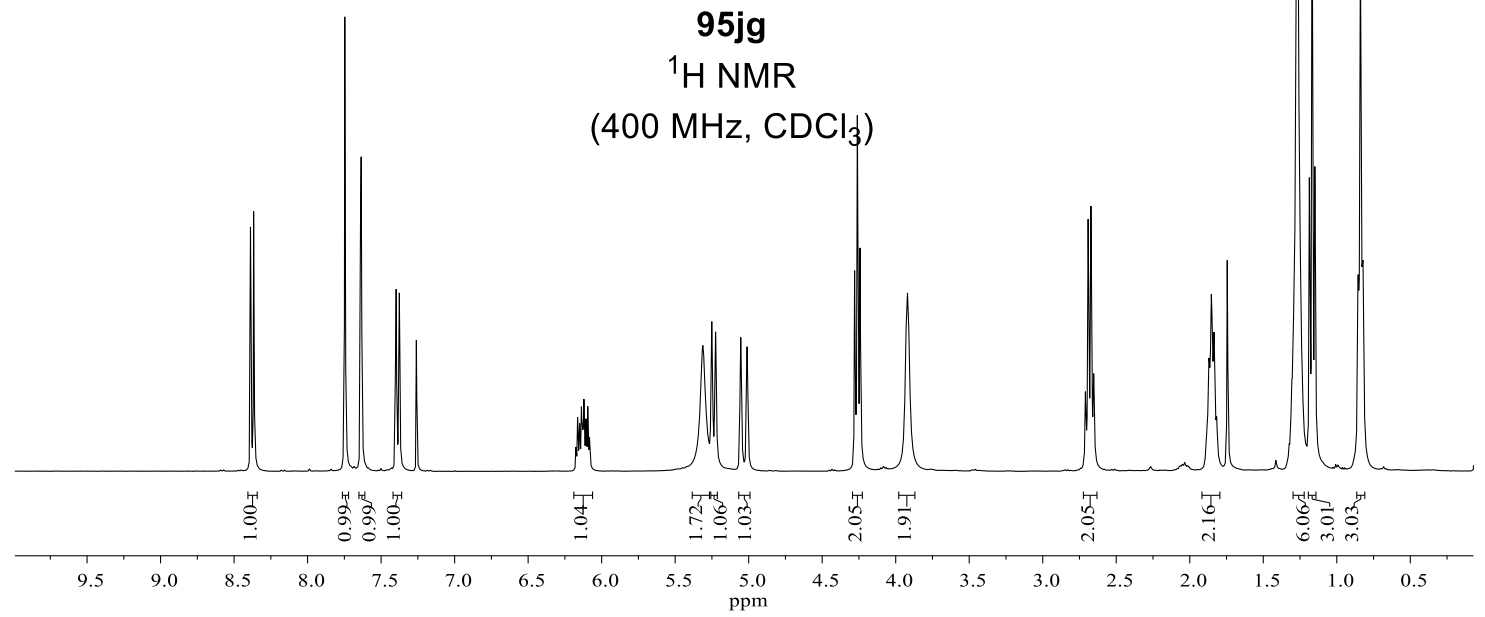

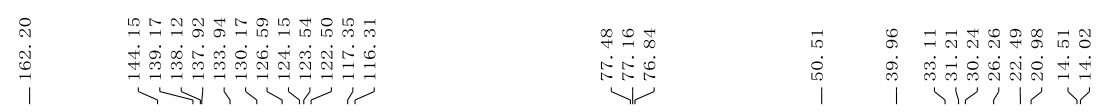<smiles>C=CCc1c(CC)c2cc(Cl)ccc2c(=O)n1Cc1cn(CO)nn1</smiles>

95jg

${ }^{13} \mathrm{C}$ NMR

$\left(101 \mathrm{MHz}, \mathrm{CDCl}_{3}\right)$

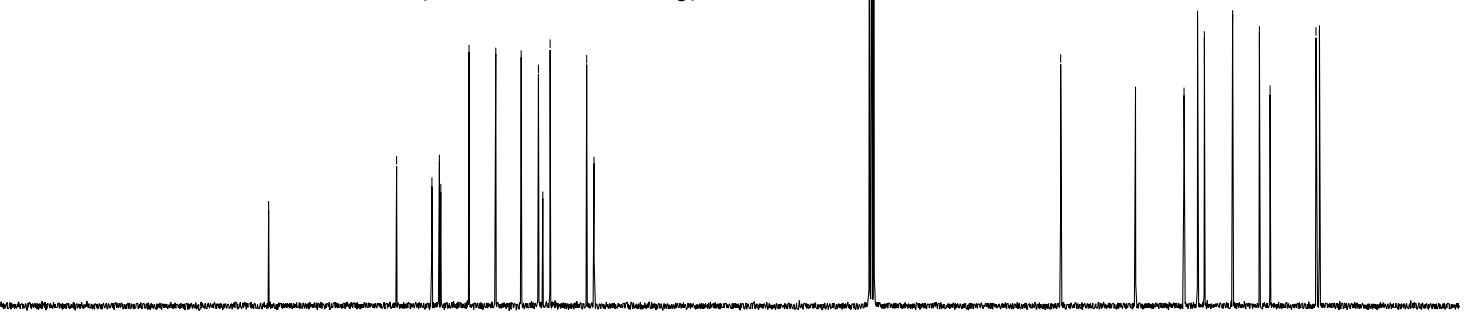

$\begin{array}{llllllllllllllllllll}190 & 180 & 170 & 160 & 150 & 140 & 130 & 120 & 110 & 100 & 90 & 80 & 70 & 60 & 50 & 40 & 30 & 20 & 10 & 0\end{array}$ 
<smiles>[R]Cn1cc(Cn2c(CC=C)c(CC)c3ccc(C)cc3c2=O)nn1</smiles>

95tg

${ }^{1} \mathrm{H}$ NMR

(400 MHz, $\mathrm{CDCl}_{3}$ )

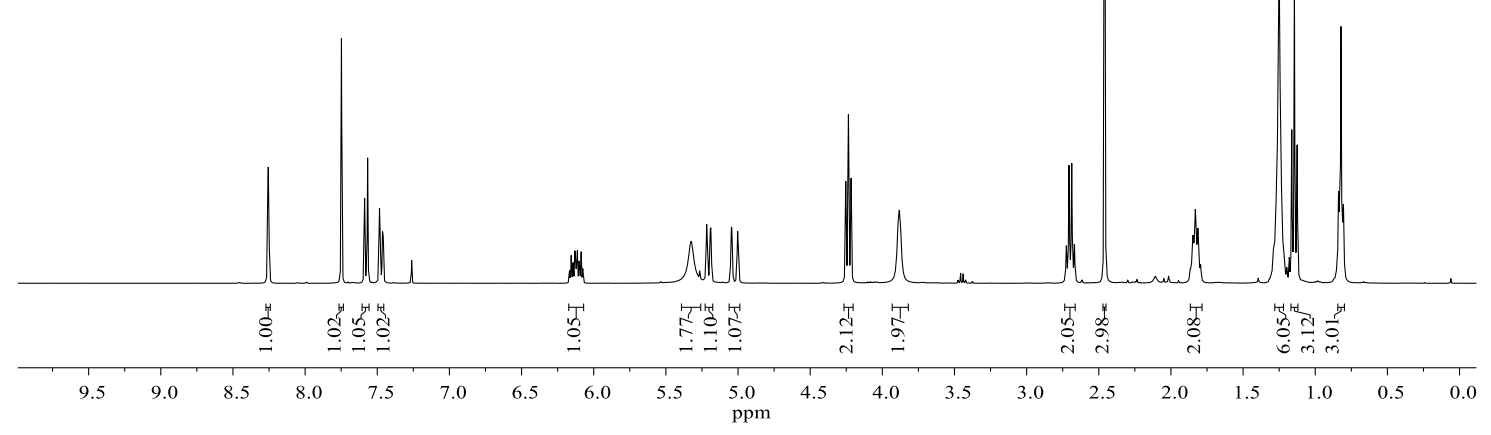

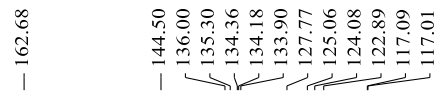

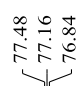

$\infty$
$m$
$m$
0<smiles>[R]Cn1cc(Cn2c(CC=C)c(CC)c3ccc(C)cc3c2=O)nn1</smiles>

95tg

${ }^{13} \mathrm{C}$ NMR

(101 MHz, $\mathrm{CDCl}_{3}$ )

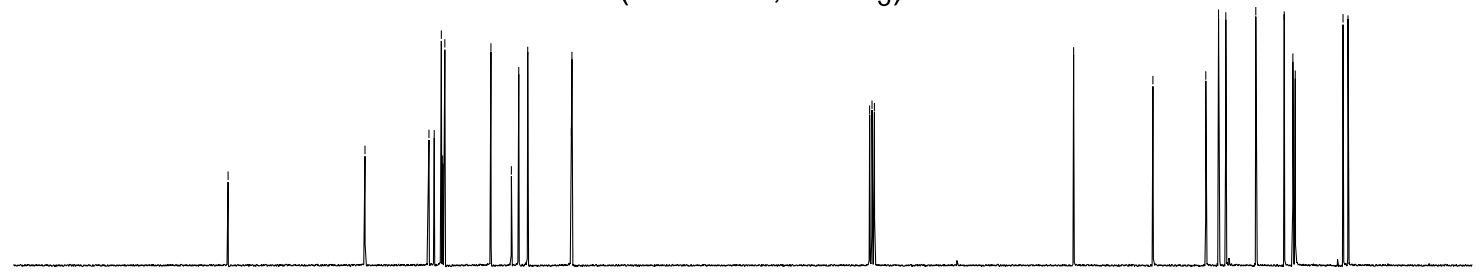

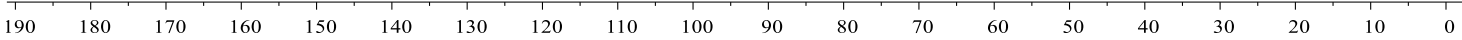




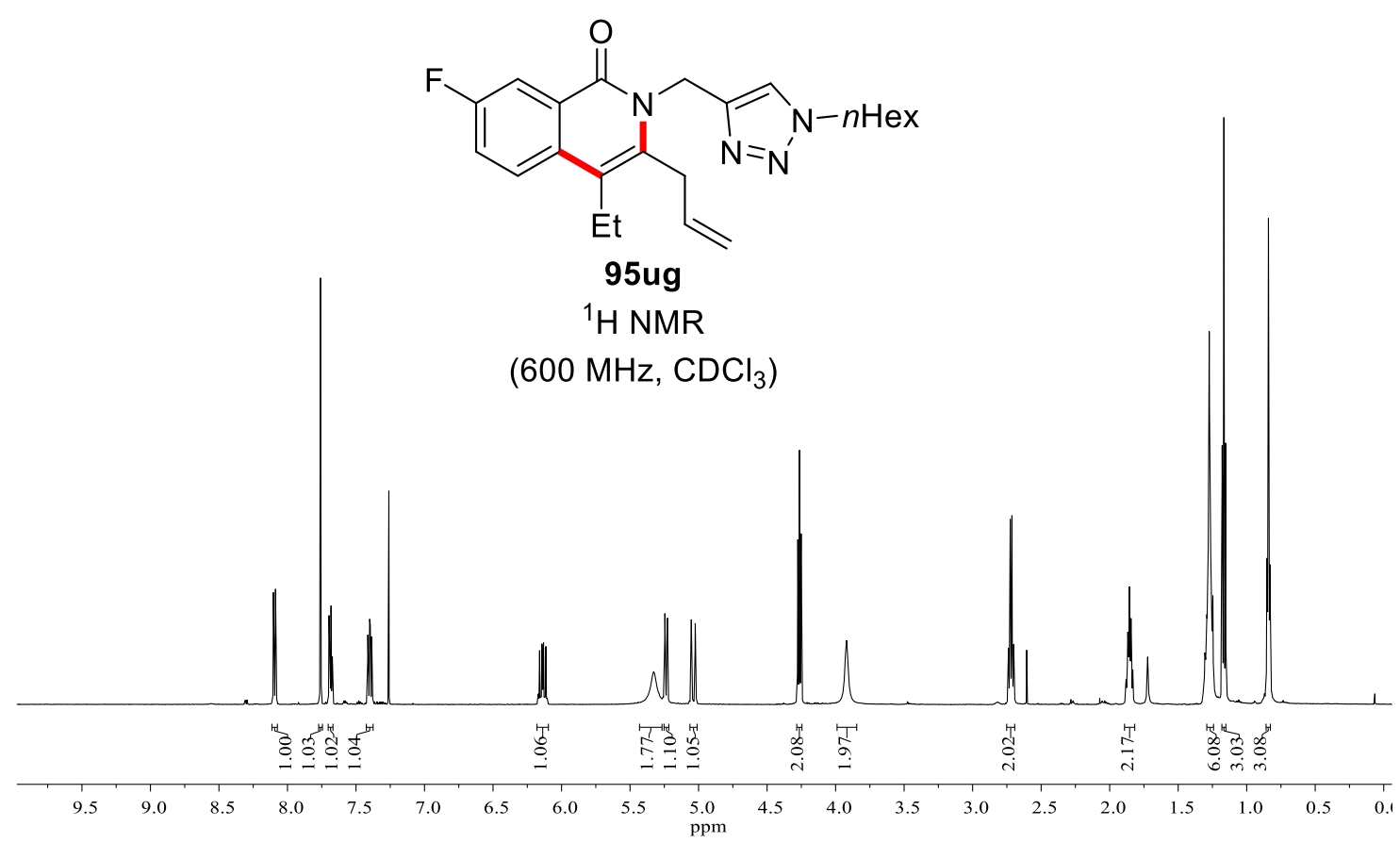

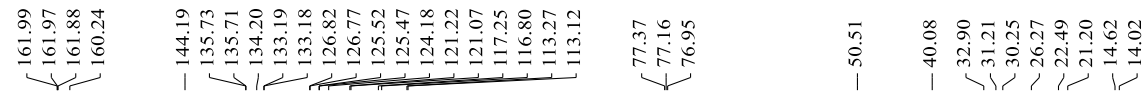<smiles>C=CCc1c(CC)c2ccc(F)cc2c(=O)n1Cc1cn(CCCCC)nn1</smiles>

95ug

${ }^{13} \mathrm{C}$ NMR

(151 MHz, $\mathrm{CDCl}_{3}$ )

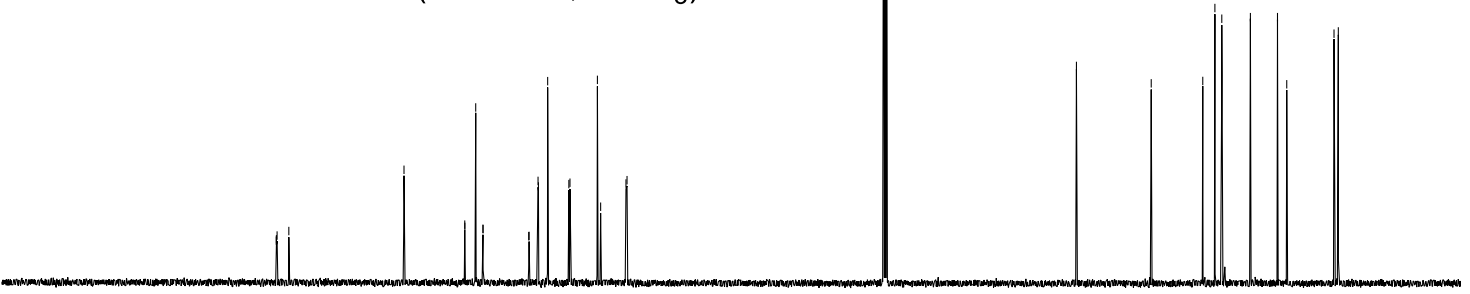

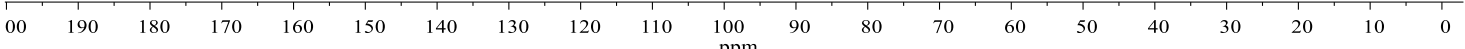




\section{NMR Spectra}

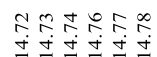

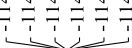<smiles>[R10]Cn1cc(Cn2c(CC=C)c(CC)c3ccc(F)cc3c2=O)nn1</smiles>

95ug

${ }^{19} \mathrm{~F}$ NMR

(377 MHz, $\mathrm{CDCl}_{3}$ )

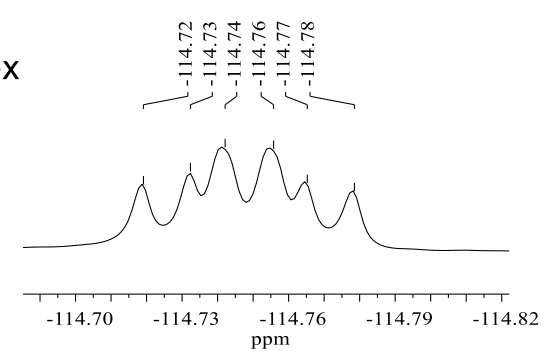

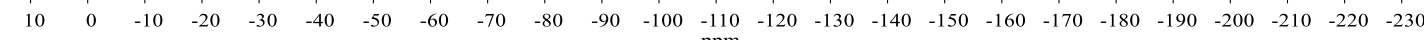



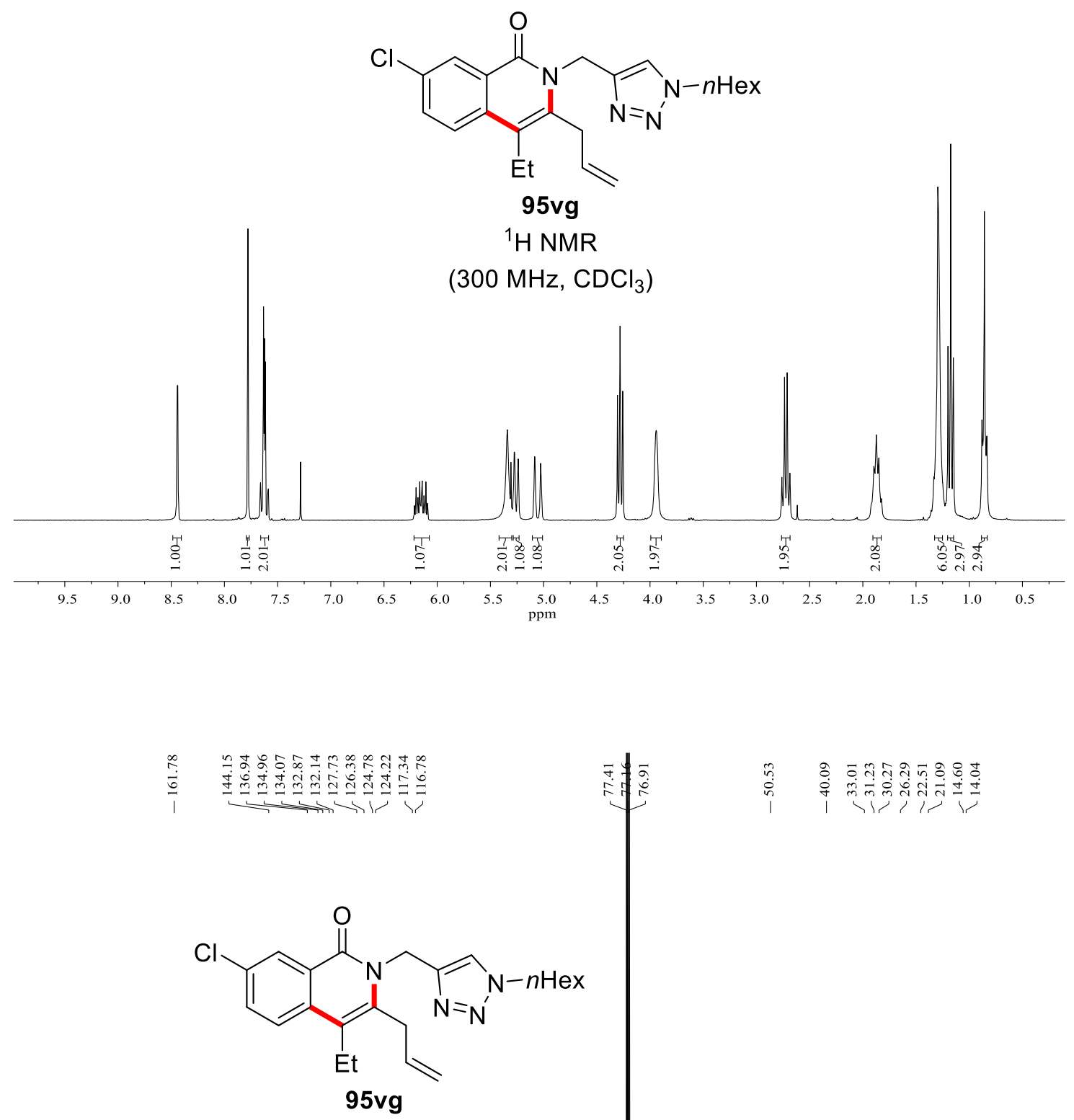

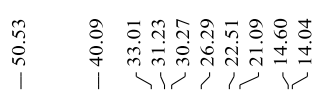

${ }^{13} \mathrm{C}$ NMR

(126 MHz, $\mathrm{CDCl}_{3}$ ) 


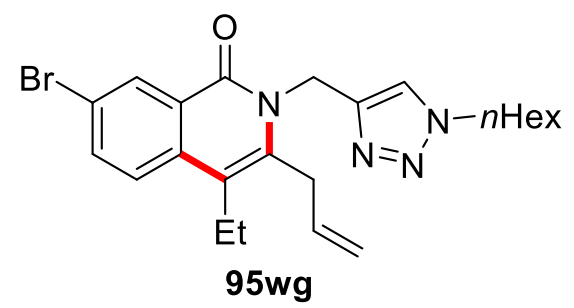

${ }^{1} \mathrm{H}$ NMR

$\left(600 \mathrm{MHz}, \mathrm{CDCl}_{3}\right)$

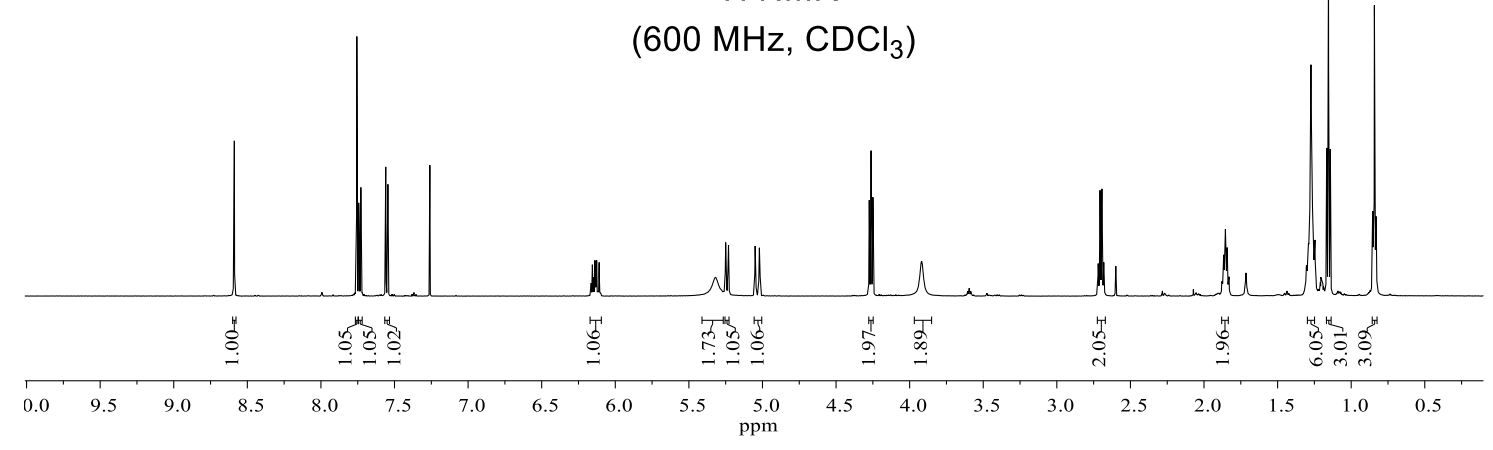

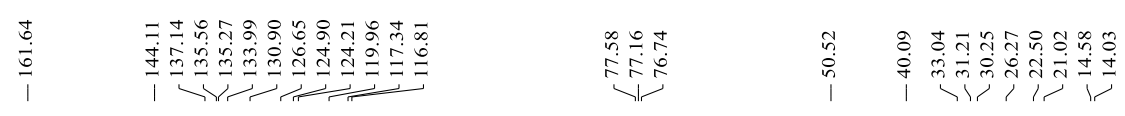<smiles>[R]Cn1cc(Cn2c(CC=C)c(CC)c3ccc(Br)cc3c2=O)nn1</smiles>

95wg

${ }^{13} \mathrm{C}$ NMR

(75 MHz, $\mathrm{CDCl}_{3}$ )

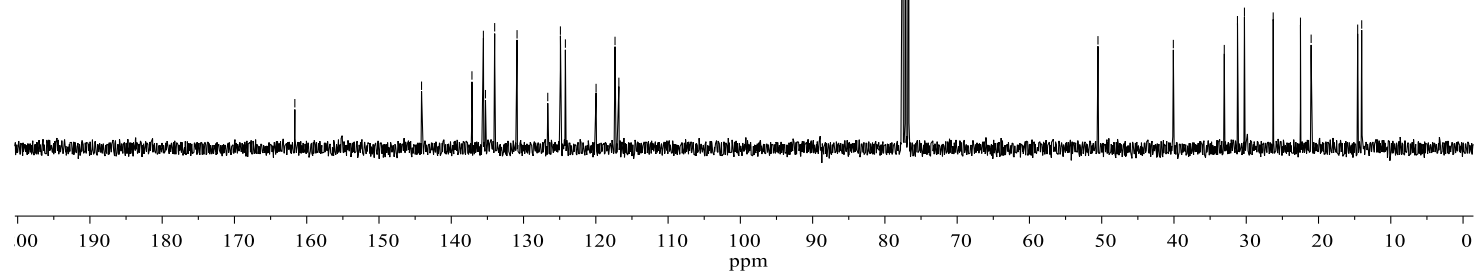




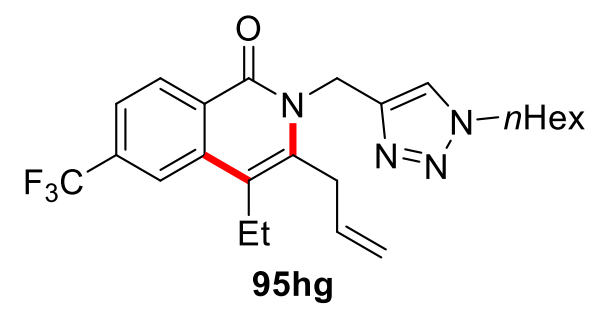

${ }^{1} \mathrm{H}$ NMR

$\left(400 \mathrm{MHz}, \mathrm{CDCl}_{3}\right)$

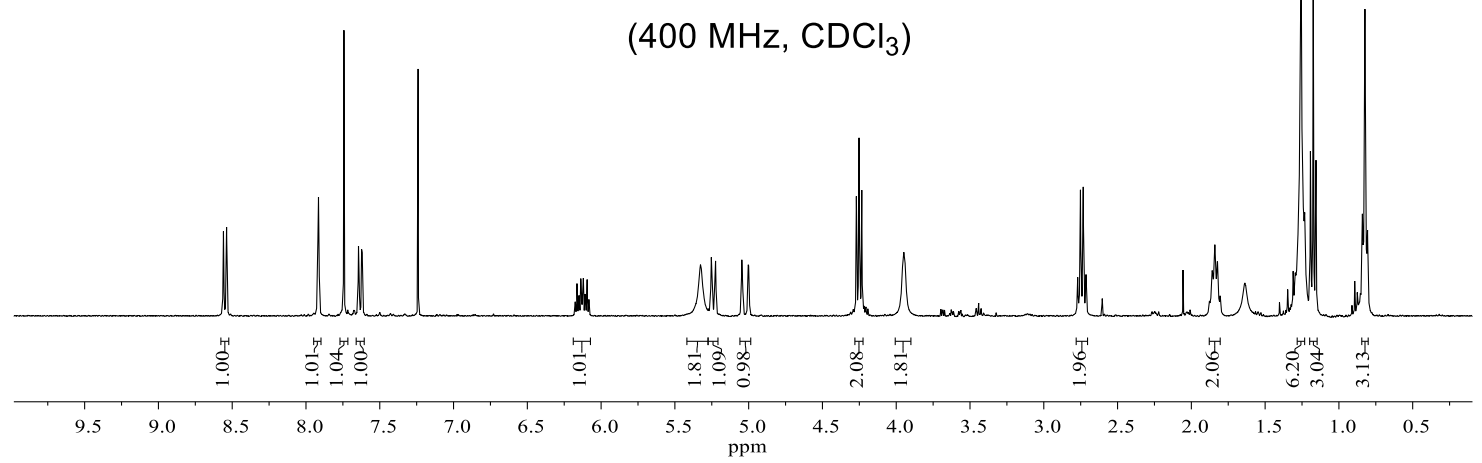

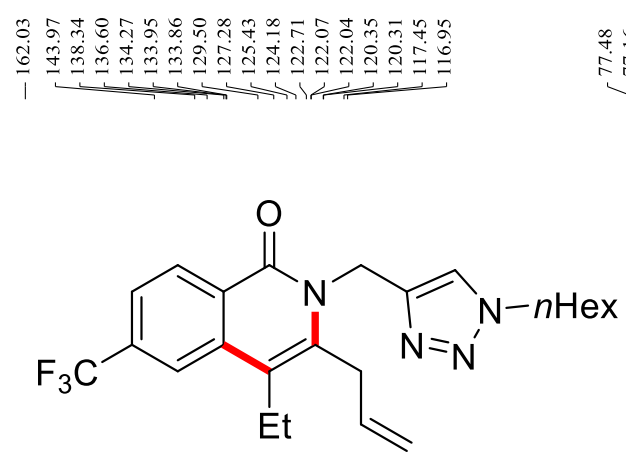

95hg

${ }^{13} \mathrm{C}$ NMR

(101 MHz, $\mathrm{CDCl}_{3}$ ) 
NMR Spectra<smiles>[R]Cn1cc(Cn2c(CC=C)c(CC)c3cc(C(F)(F)F)ccc3c2=O)nn1</smiles>

95hg

${ }^{19} \mathrm{~F}$ NMR

(376 $\mathrm{MHz}, \mathrm{CDCl}_{3}$ )

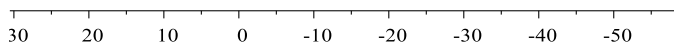

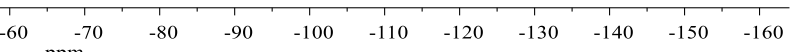




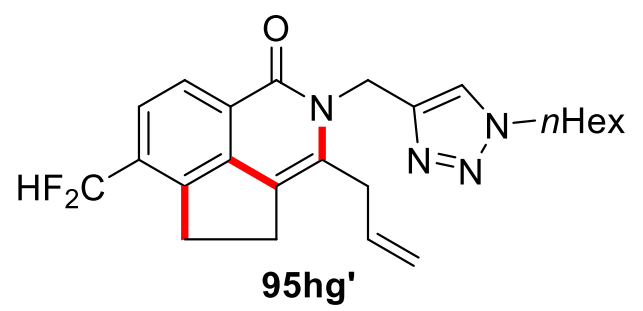

${ }^{1} \mathrm{H}$ NMR

(400 MHz, $\mathrm{CDCl}_{3}$ )

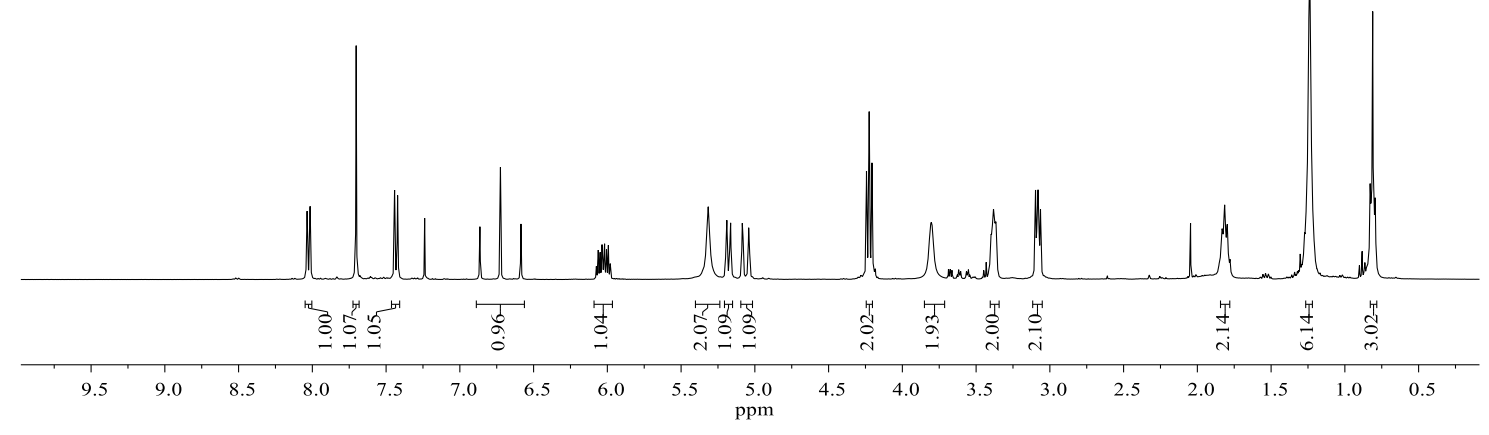

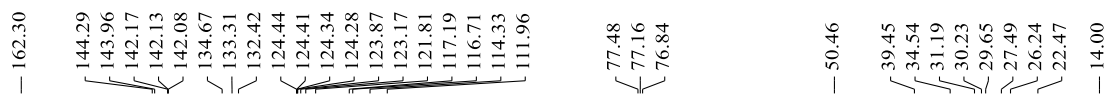<smiles>[R3]Cn1cc(Cn2c(CC=C)c3c4c(c(C(F)(F)F)ccc4c2=O)CC3)nn1</smiles>

${ }^{13} \mathrm{C}$ NMR

$\left(101 \mathrm{MHz}, \mathrm{CDCl}_{3}\right.$ )

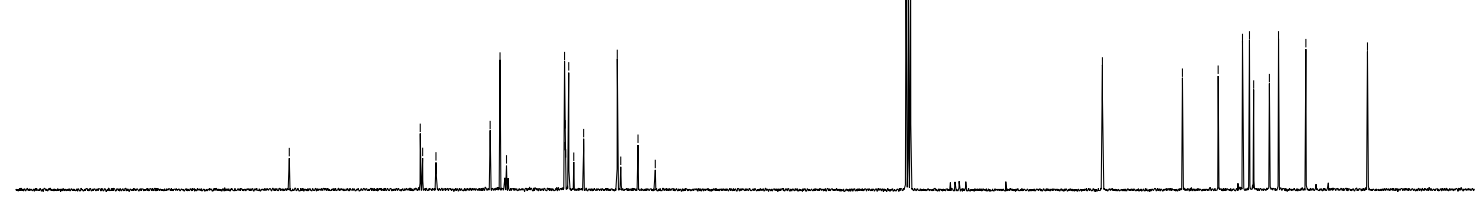

$\begin{array}{llllllllll}190 & 180 & 170 & 160 & 150 & 140 & 130 & 120 & 110 & 100 \\ \mathrm{ppm}\end{array}$ 


\section{NMR Spectra}

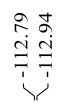<smiles>[R]Cn1cc(Cn2c(CC=C)c3c4c(c(C(F)F)ccc4c2=O)CC3)nn1</smiles>

95hg'

${ }^{19} \mathrm{~F} \mathrm{NMR}$

(377 MHz, $\mathrm{CDCl}_{3}$ ) 


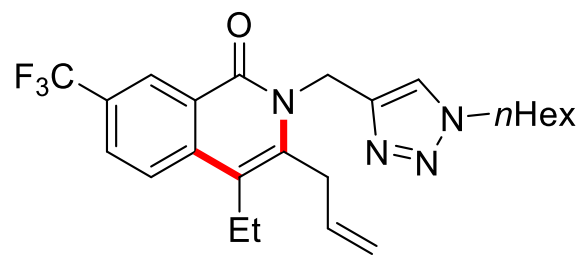

95xg

${ }^{1} \mathrm{H}$ NMR

(400 MHz, $\mathrm{CDCl}_{3}$ )

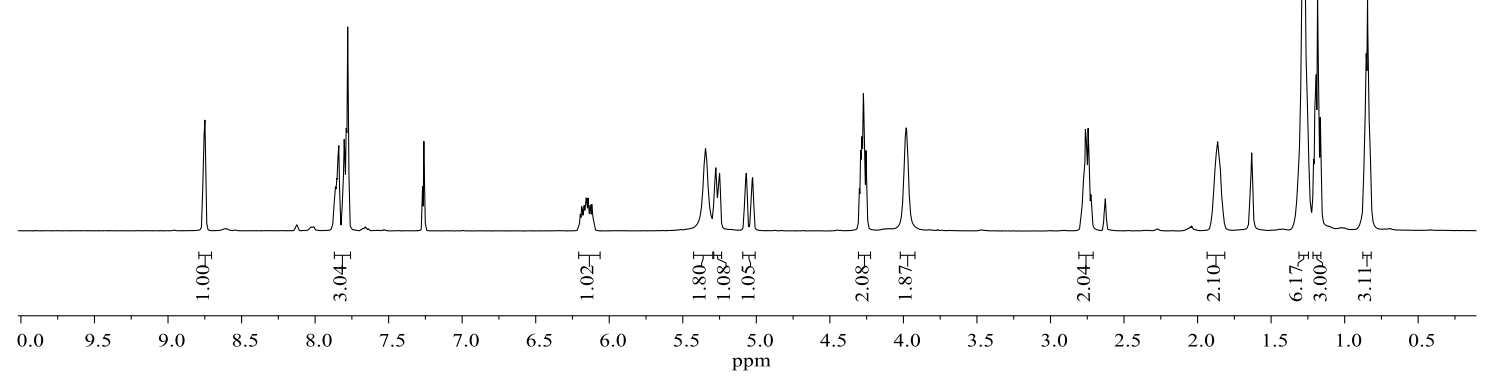<smiles>C=CCc1c(CC)c2ccc(C(F)(F)F)cc2c(=O)n1Cc1cn(C(=O)OCc2ccccc2)nn1</smiles>

${ }^{13} \mathrm{C}$ NMR

(75 MHz, $\mathrm{CDCl}_{3}$ )

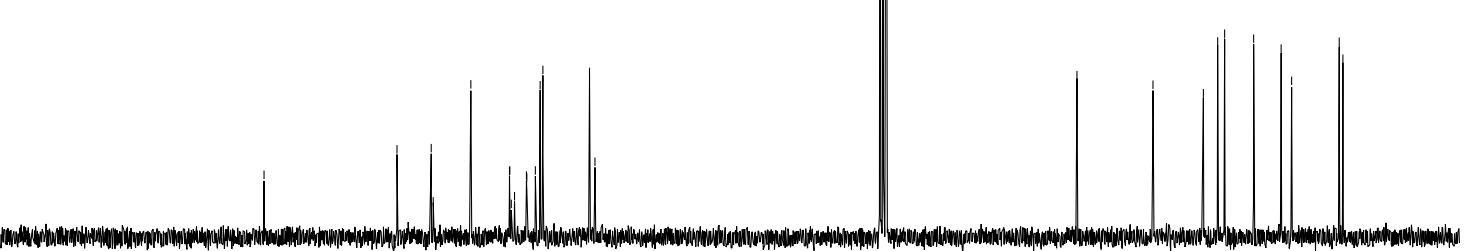

$\begin{array}{llllllllll}190 & 180 & 170 & 160 & 150 & 140 & 130 & 120 & 110 & 100\end{array}$ 
NMR Spectra

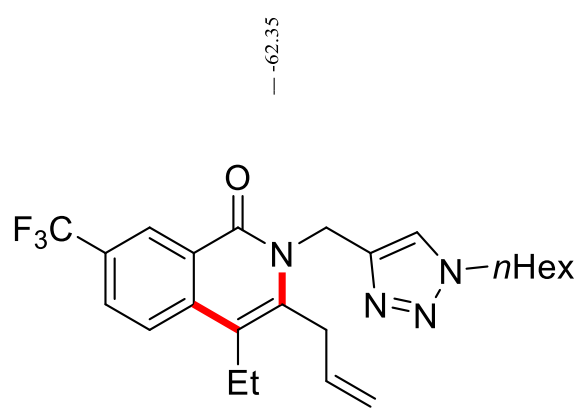

95xg

${ }^{19} \mathrm{~F}$ NMR

(282 MHz, $\mathrm{CDCl}_{3}$ )

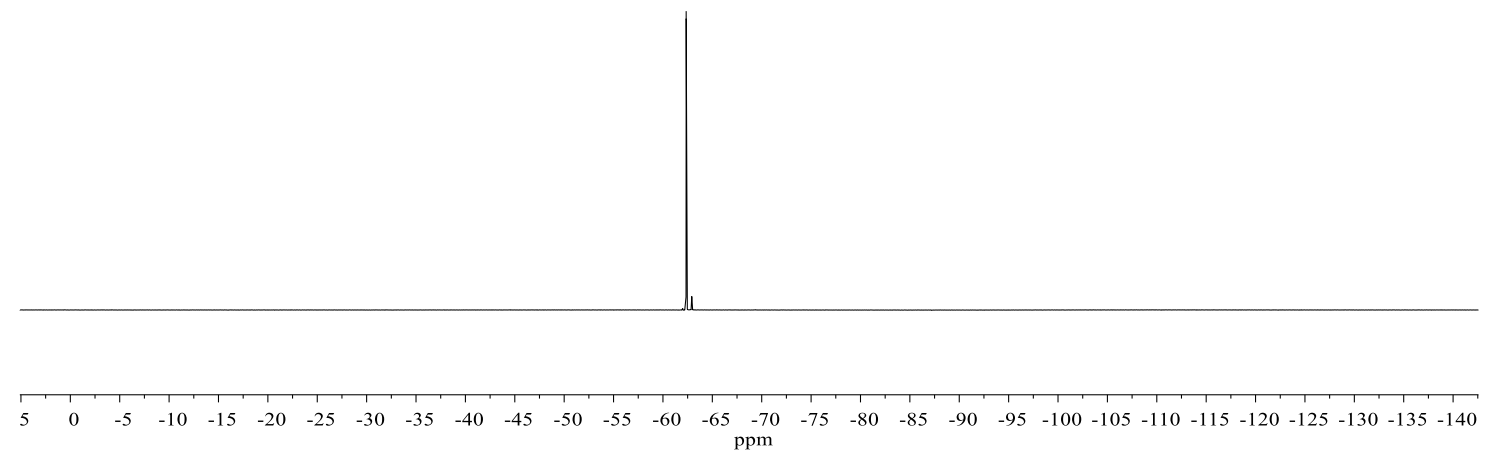




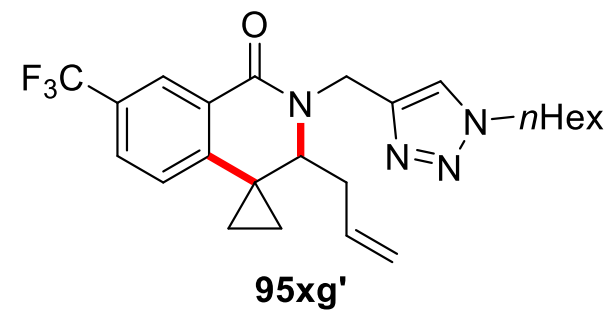

${ }^{1} \mathrm{H} N M R$
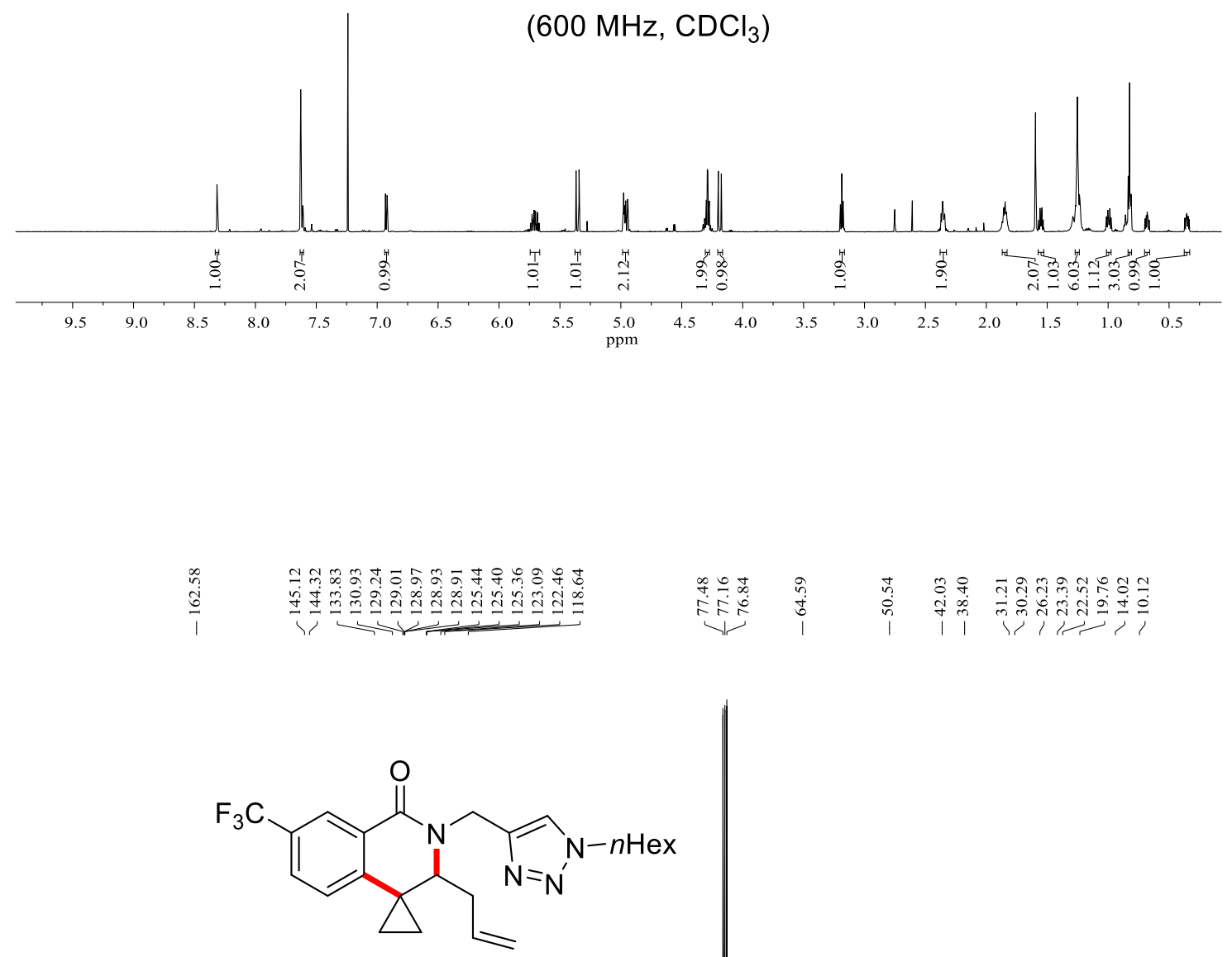

95xg'

${ }^{13} \mathrm{C}$ NMR

(101 MHz, $\mathrm{CDCl}_{3}$ )

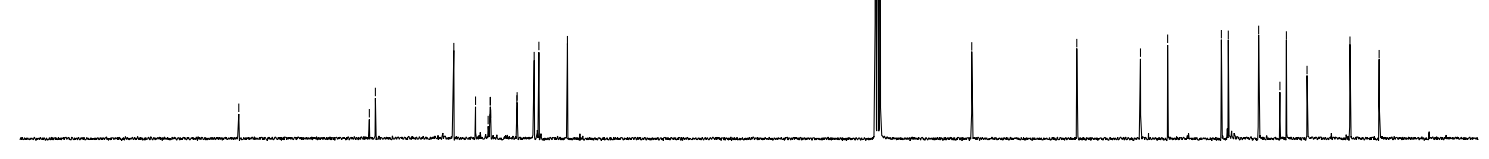

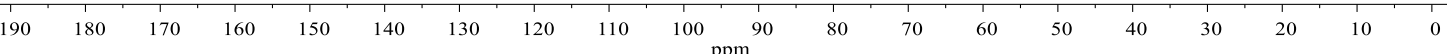


NMR Spectra

in<smiles>C=CCC1N(Cc2cn(C)nn2)C(=O)c2cc(C(F)(F)F)ccc2C12CC2</smiles>

95xg'

${ }^{19} \mathrm{~F}$ NMR

(565 MHz, $\mathrm{CDCl}_{3}$ )

$\begin{array}{lllllllllllllllllllllllllllllllllll}10 & 5 & 0 & -5 & -10 & -15 & -20 & -25 & -30 & -35 & -40 & -45 & -50 & -55 & -60 & -65 & -70 & -75 & -80 & -85 & -90 & -95 & -100 & -105 & -110 & -115 & -120 & -125 & -130 & -135\end{array}$ 
<smiles>C=CCc1[nH]c(=O)c2ccc(C(F)(F)F)cc2c1CC</smiles>

97gg

${ }^{1} \mathrm{H}$ NMR

(400 MHz, $\mathrm{CDCl}_{3}$ )

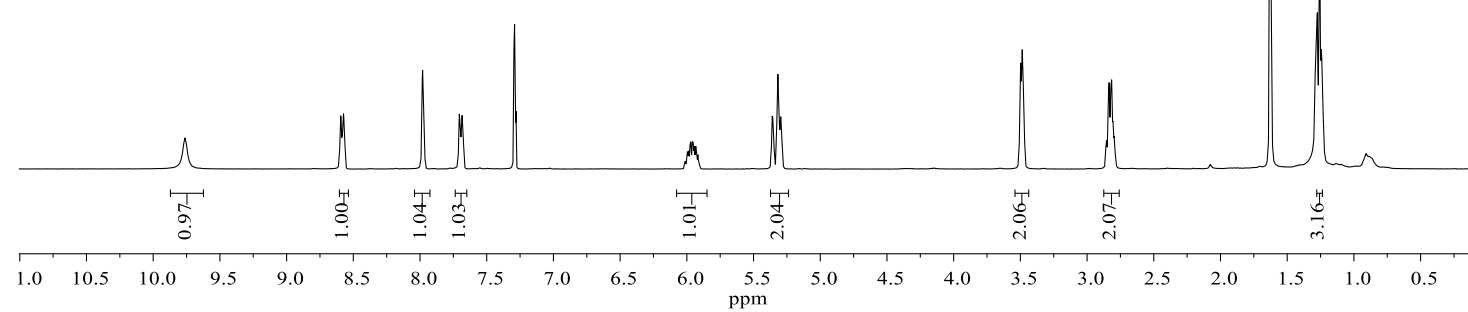<smiles>C=CCc1[nH]c(=O)c2ccc(C(F)(F)F)cc2c1CC</smiles>

97gg

${ }^{1} \mathrm{C}$ NMR

(126 MHz, $\mathrm{CDCl}_{3}$ )

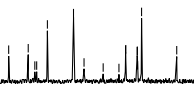


NMR Spectra

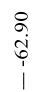<smiles>C=CCc1[nH]c(=O)c2ccc(C(F)(F)F)cc2c1CC</smiles>

97gg

${ }^{19} \mathrm{~F}$ NMR

(377 MHz, $\mathrm{CDCl}_{3}$ )

\begin{tabular}{llllllllllllllllllllllllll}
\hline-5 & -10 & -15 & -20 & -25 & -30 & -35 & -40 & -45 & -50 & -55 & -60 & -65 & -70 & -75 & -80 & -85 & -90 & -95 & -100 & -105 & -110 & -115
\end{tabular} 

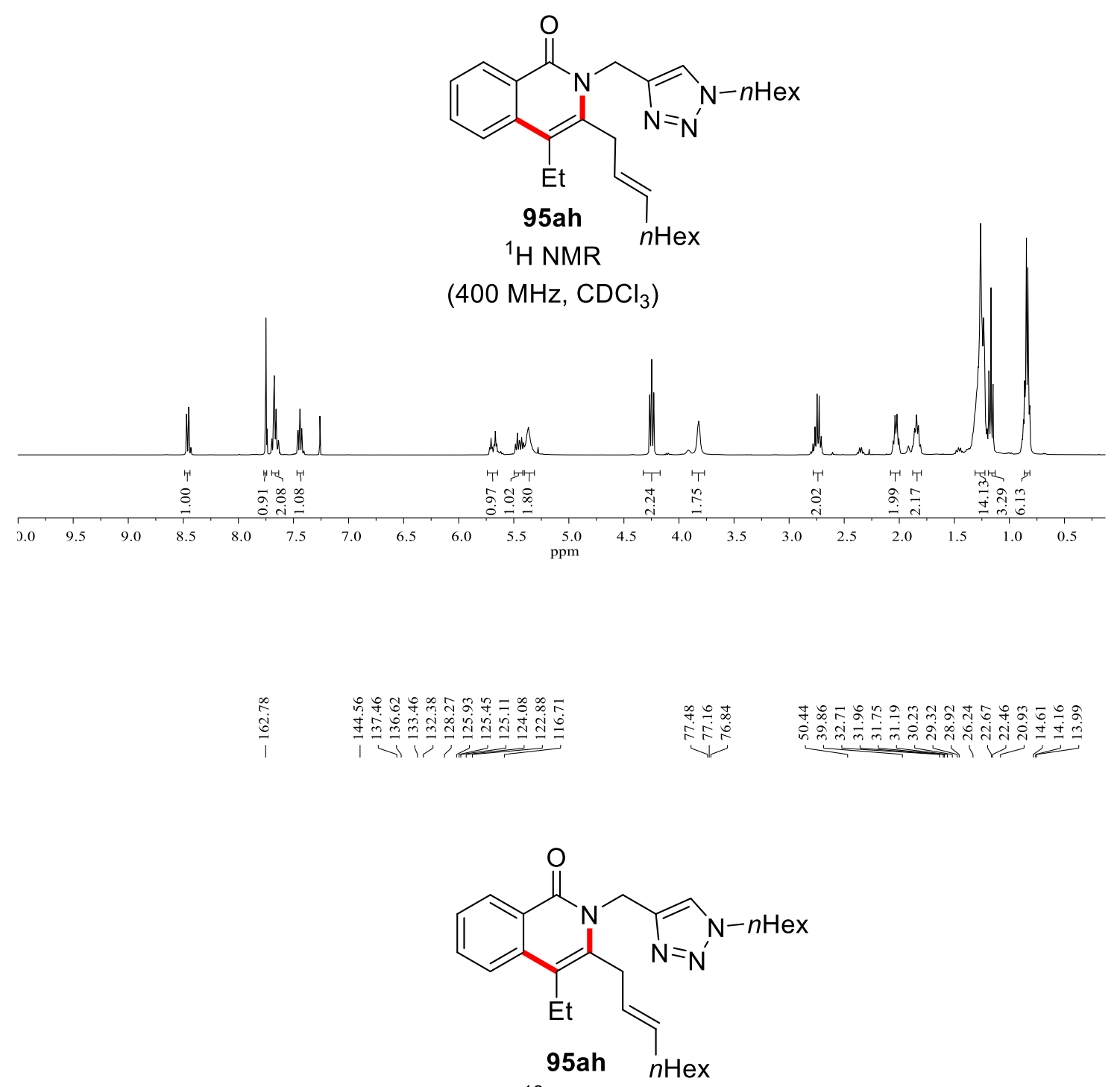

${ }^{13} \mathrm{C}$ NMR

(101 MHz, $\mathrm{CDCl}_{3}$ )

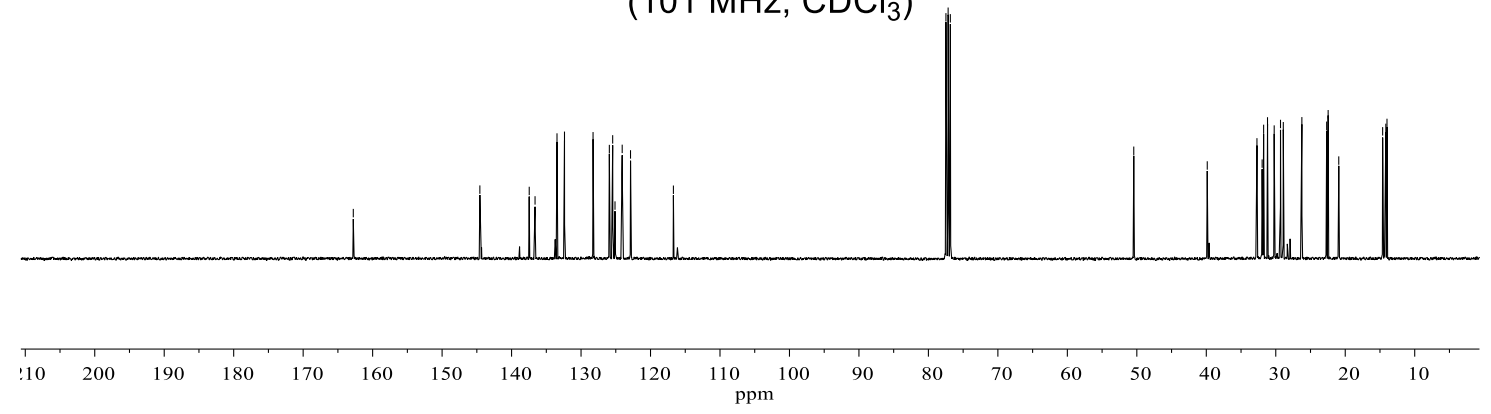



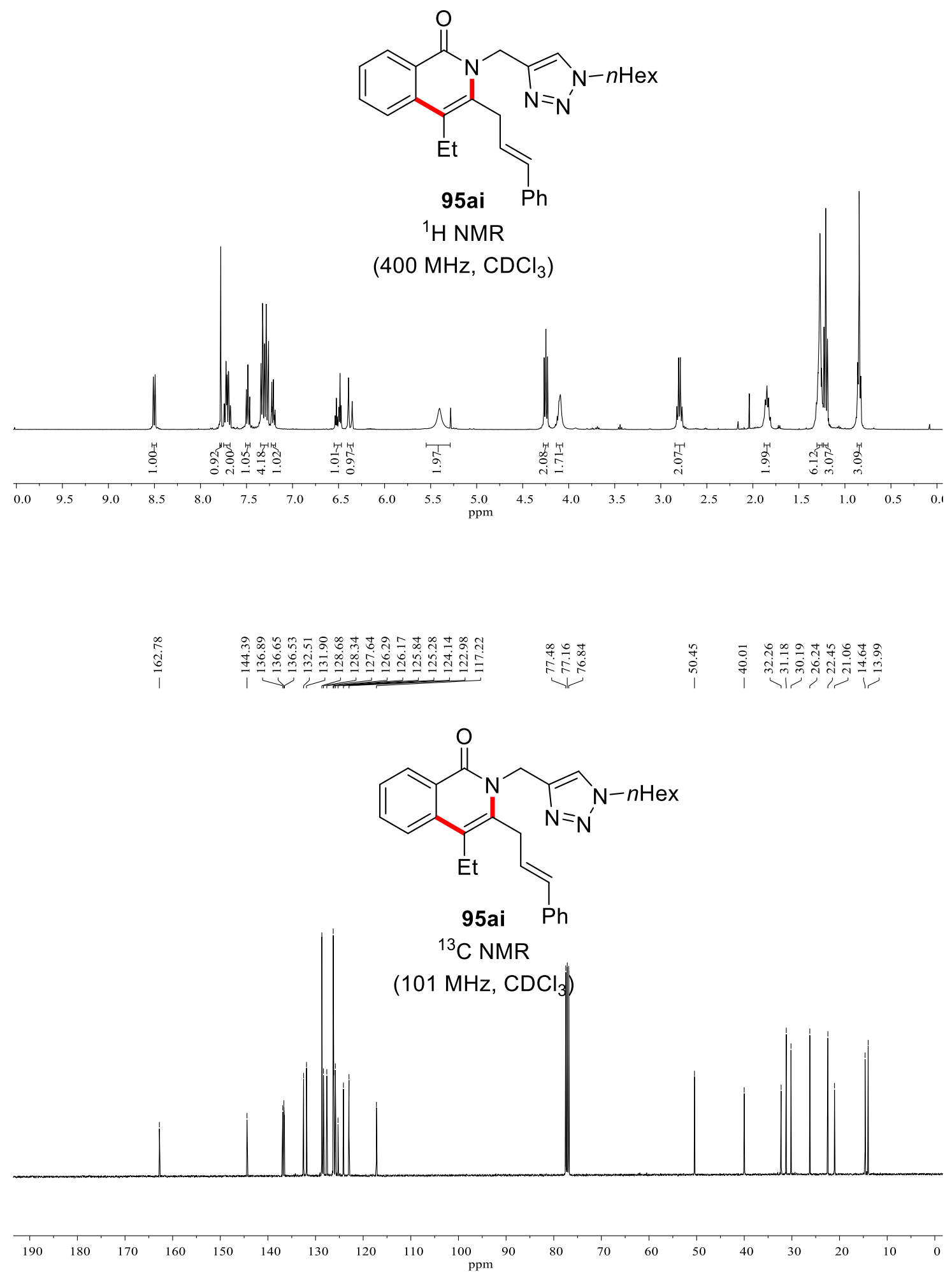


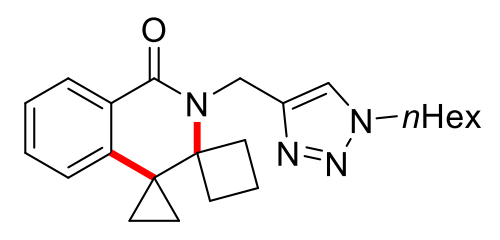

96aa

${ }^{1} \mathrm{H}$ NMR

(600 MHz, $\mathrm{CDCl}_{3}$ )

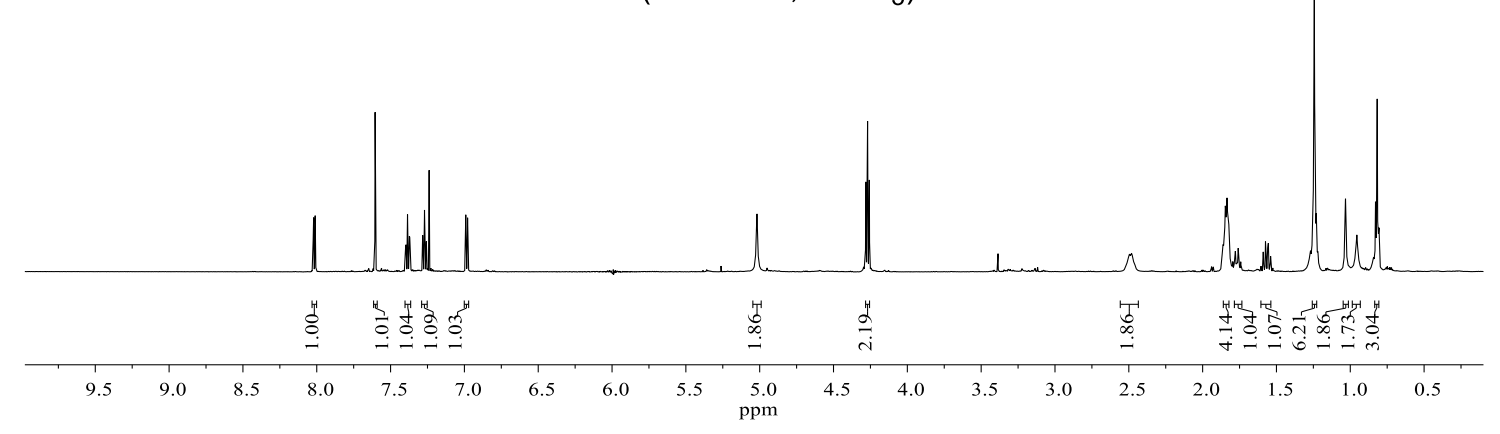

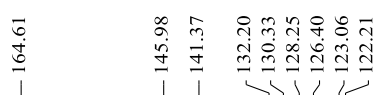

曶<smiles>O=C1C(=O)N(Cc2cn(C=[W])nn2)C2(CCC2)C2(CC2)c2ccccc21</smiles>

96aa

${ }^{13} \mathrm{C}$ NMR

(126 MHz, $\mathrm{CDCl}_{3}$ )

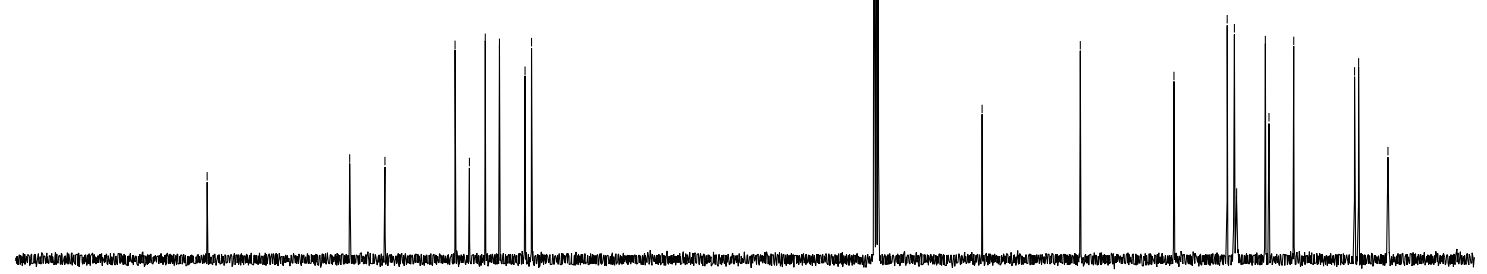

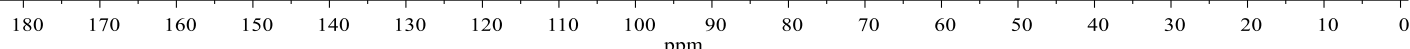



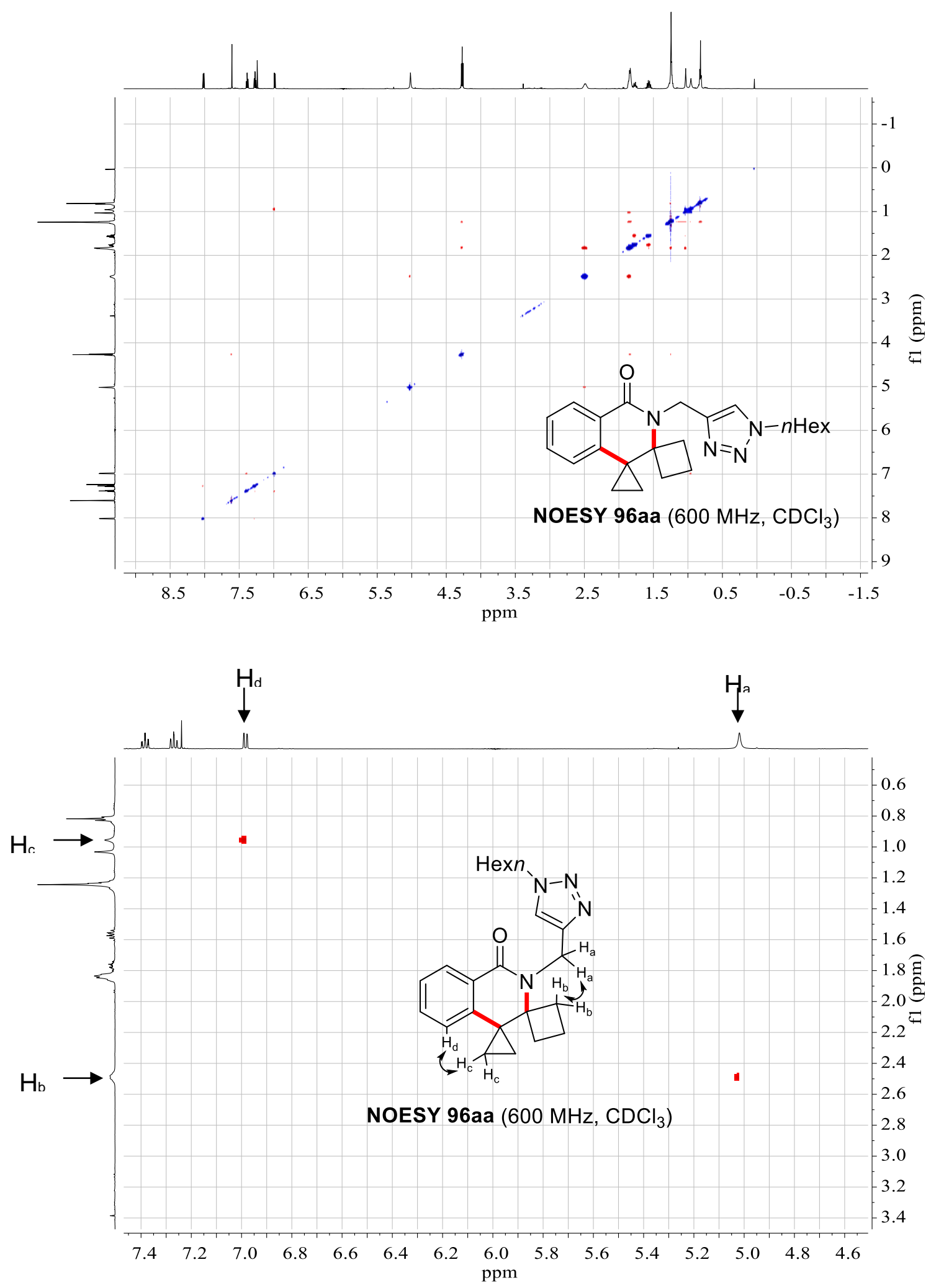


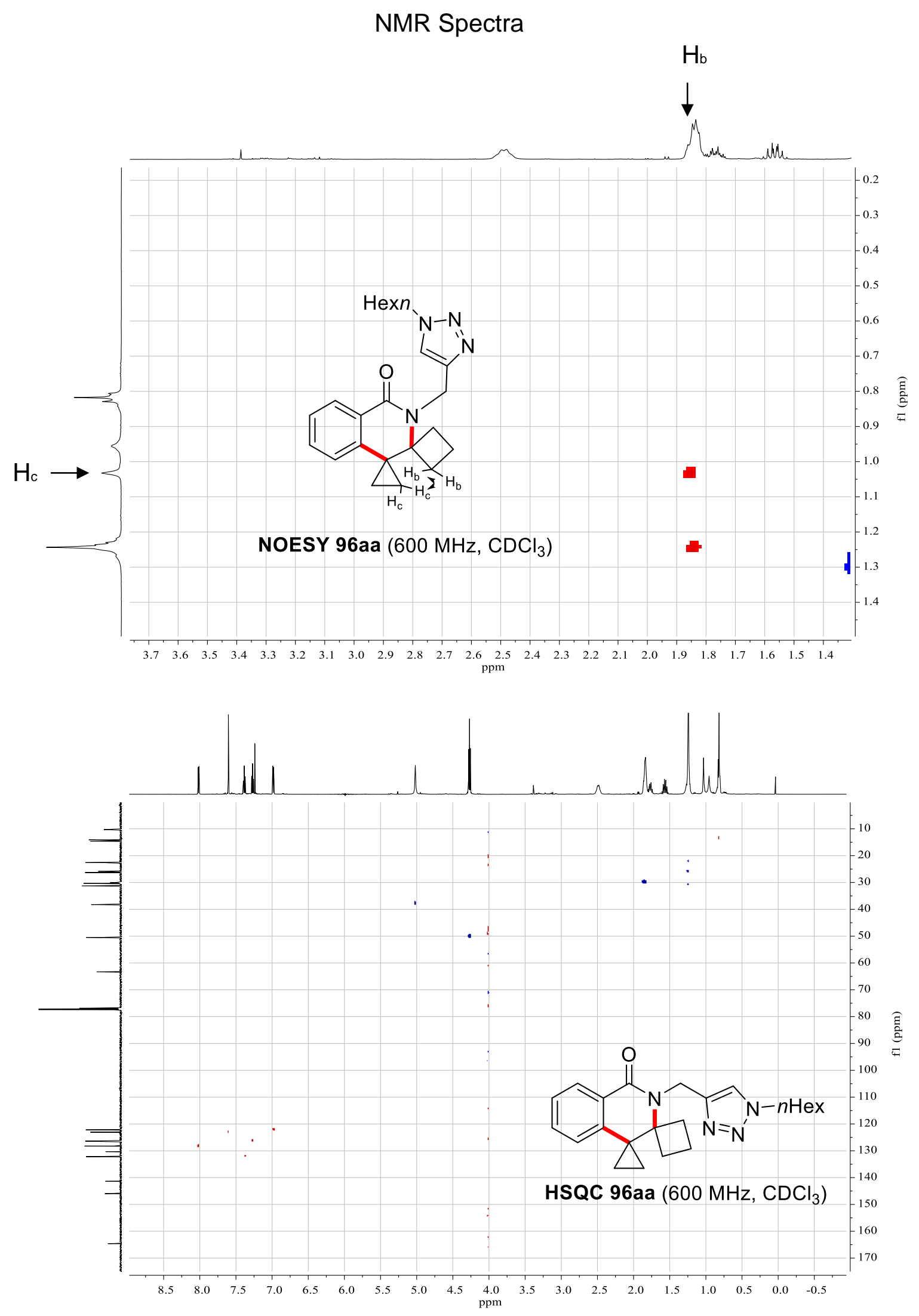



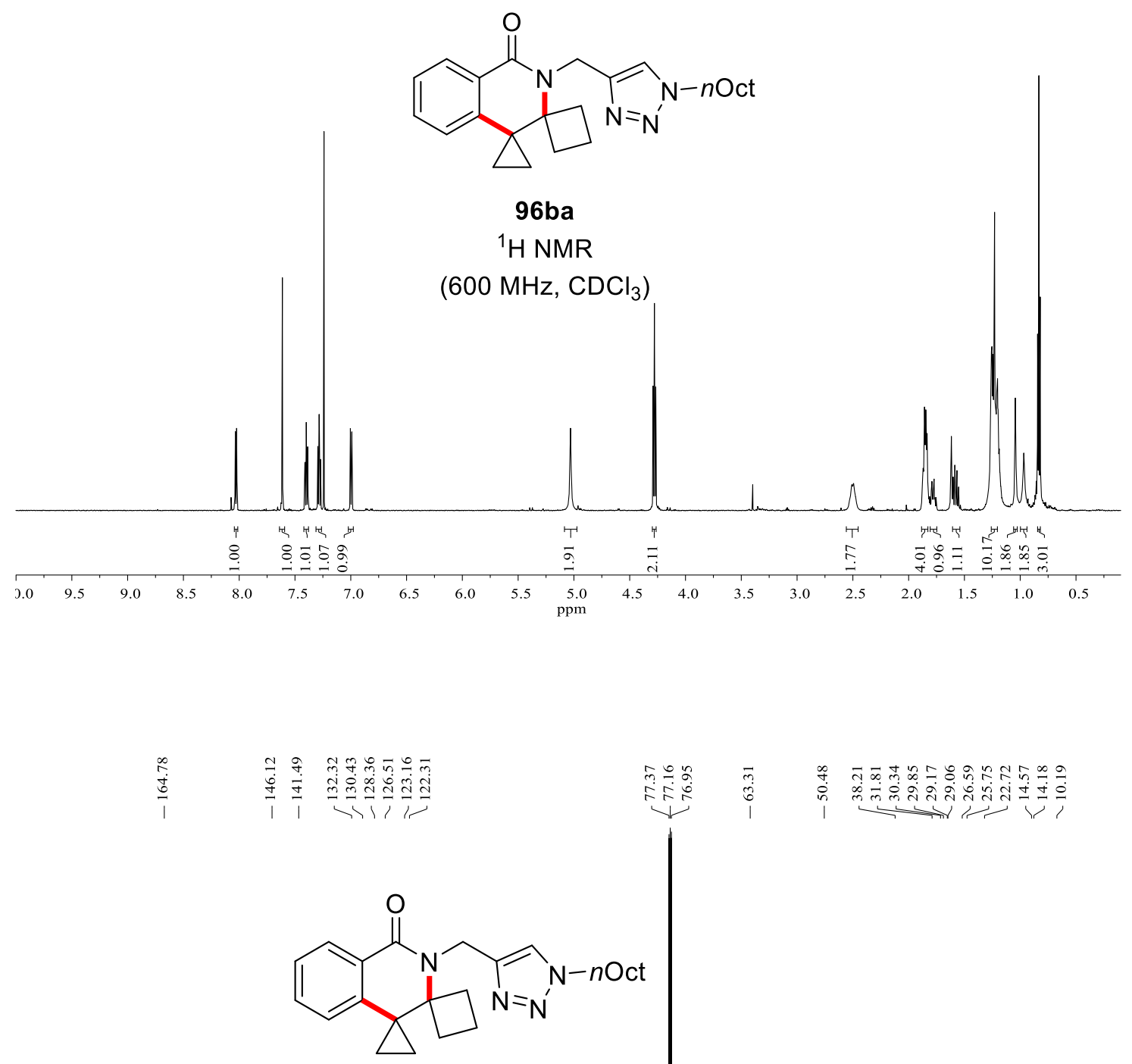

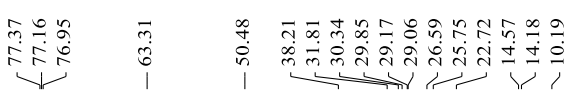

$96 \mathrm{ba}$

${ }^{13} \mathrm{C}$ NMR

(151 MHz, $\mathrm{CDCl}_{3}$ )

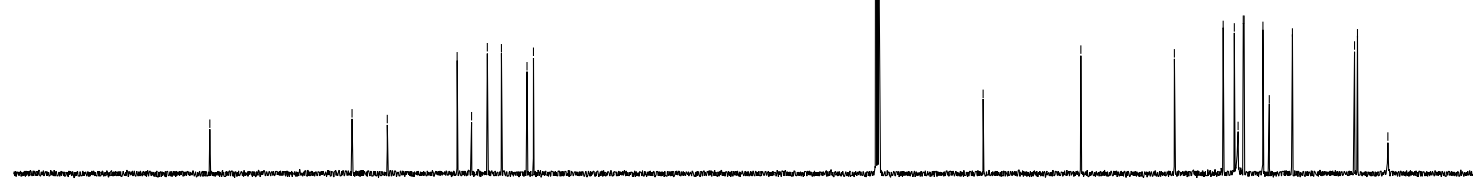

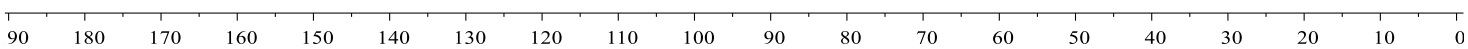




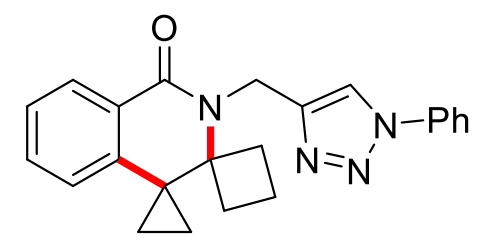

96ya

${ }^{1} \mathrm{H}$ NMR

(400 MHz, $\mathrm{CDCl}_{3}$ )

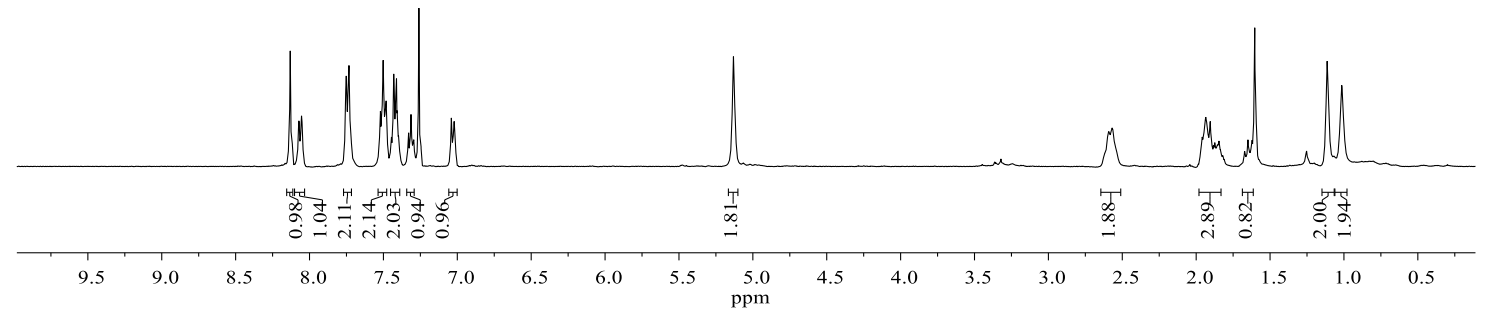

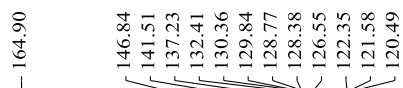

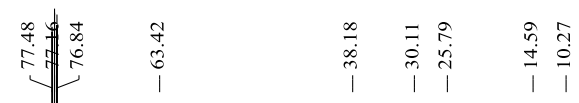

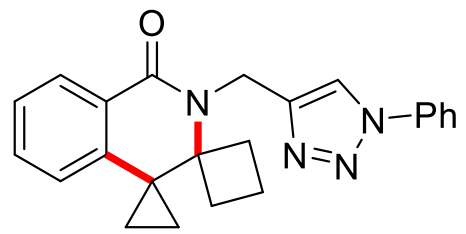

96ya

${ }^{13} \mathrm{C}$ NMR

(101 MHz, $\mathrm{CDCl}_{3}$ )

$\begin{array}{lllllllllll}90 & 180 & 170 & 160 & 150 & 140 & 130 & 120 & 110 & 100 & 90\end{array}$ 

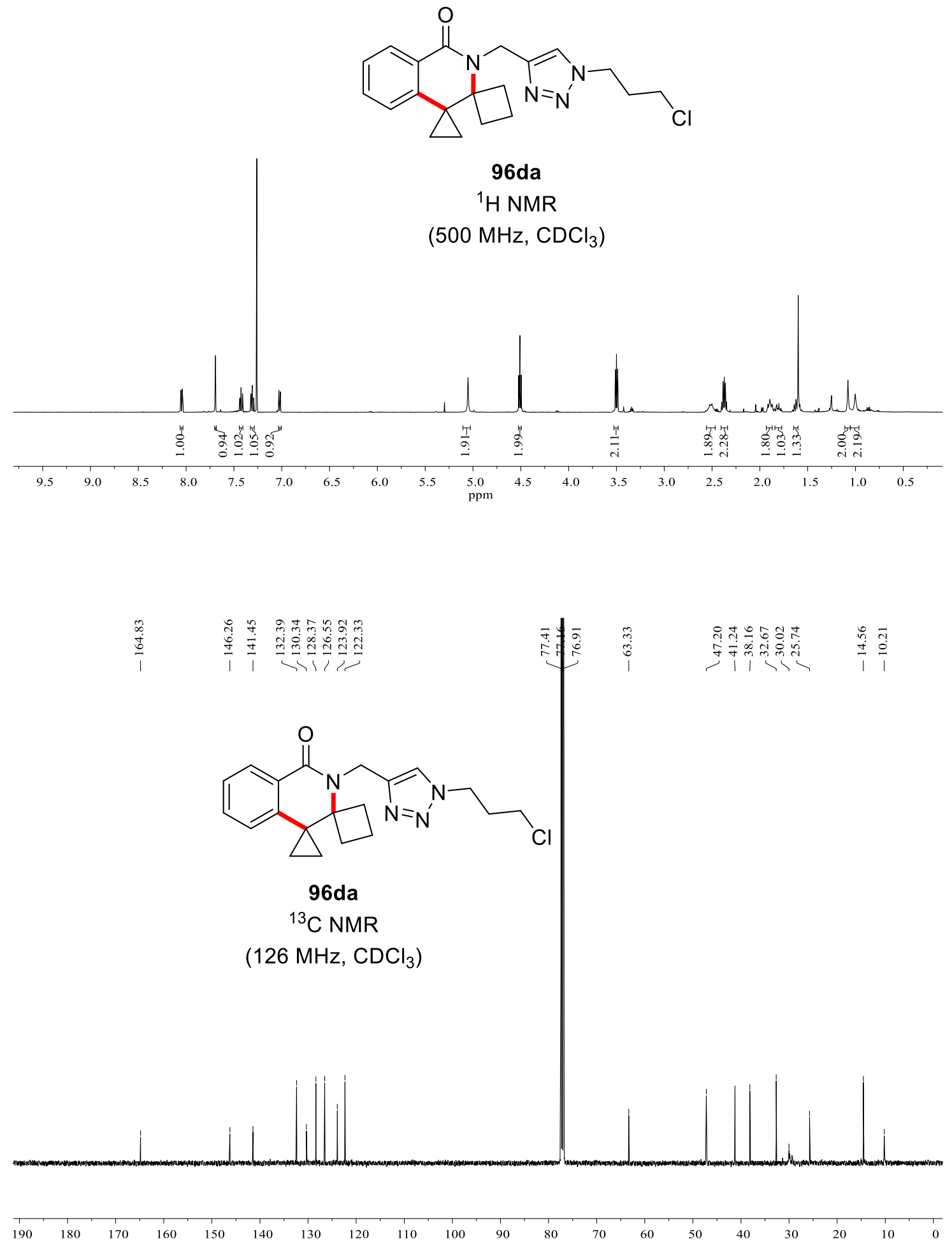

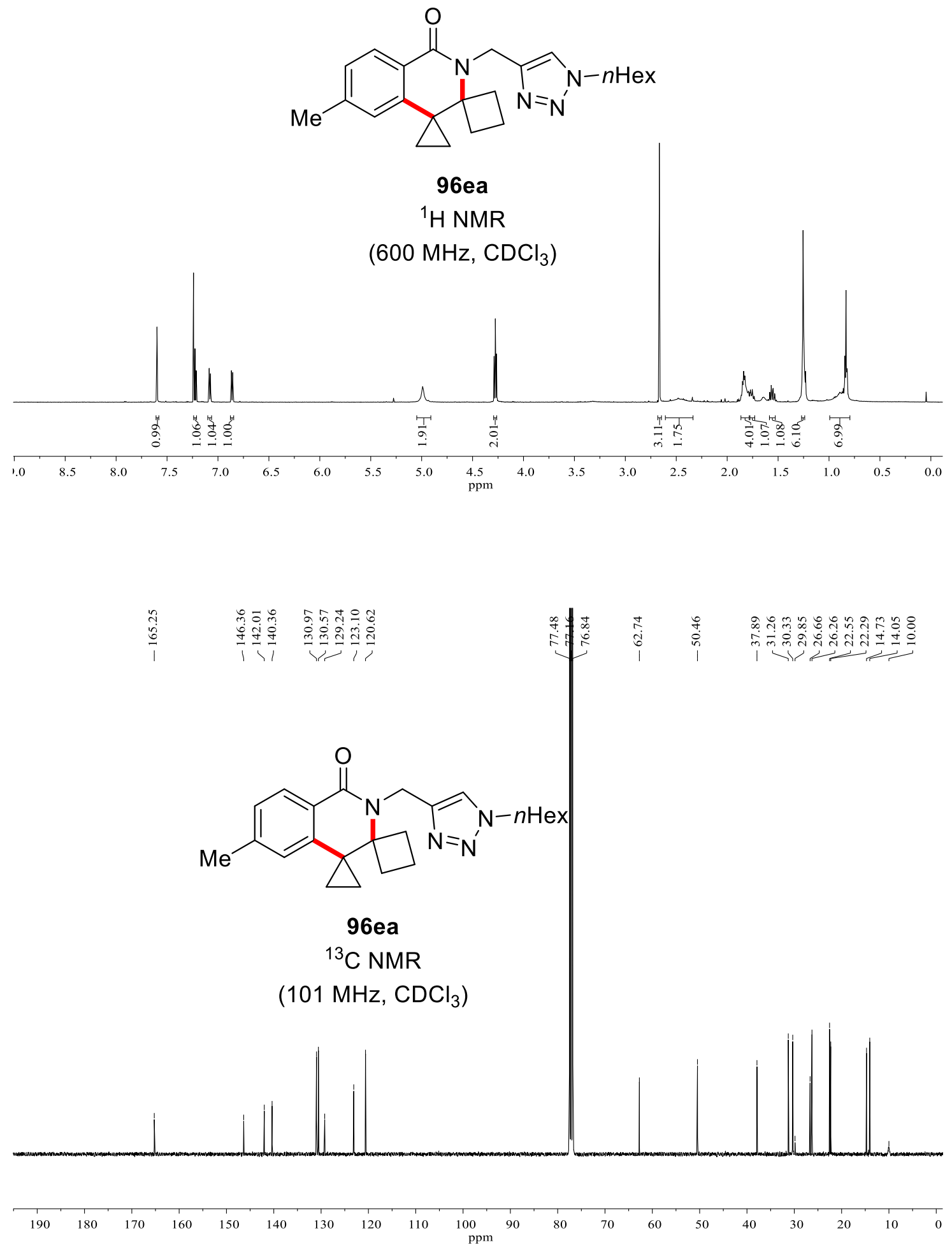


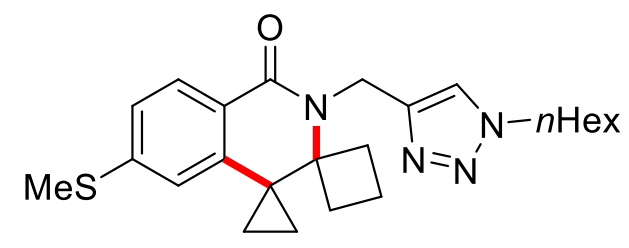

96sa

${ }^{1} \mathrm{H}$ NMR

$\left(400 \mathrm{MHz}, \mathrm{CDCl}_{3}\right)$

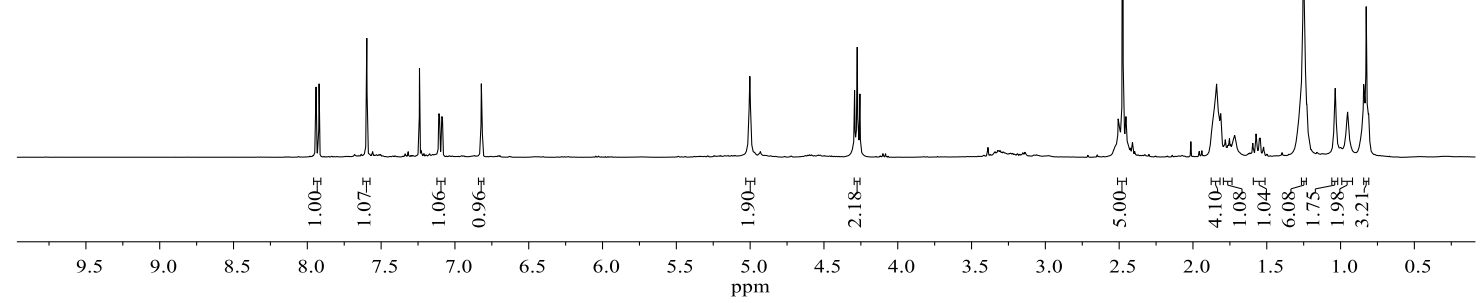<smiles>CCCCCCn1cc(CN2C(=O)c3ccc(SC)cc3C3(CC3)C23CCC3)nn1</smiles>

96sa

${ }^{13} \mathrm{C}$ NMR $\left(101 \mathrm{MHz}, \mathrm{CDCl}_{3}\right)$

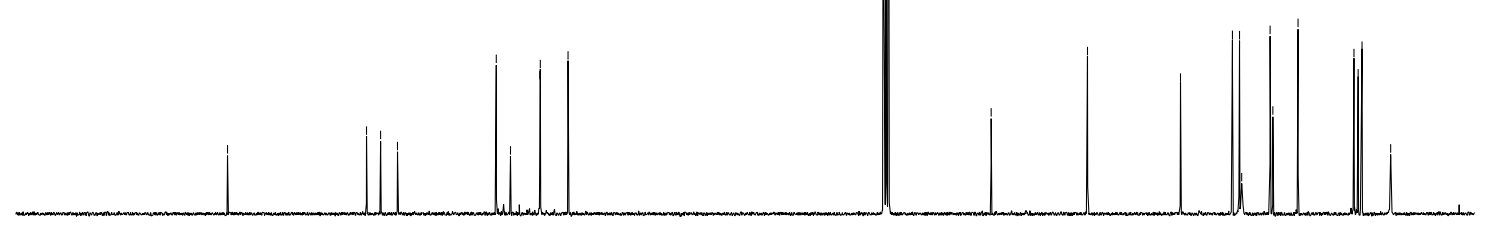

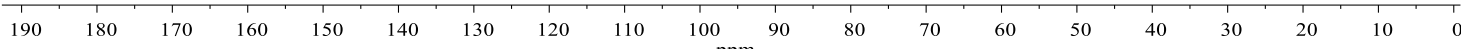




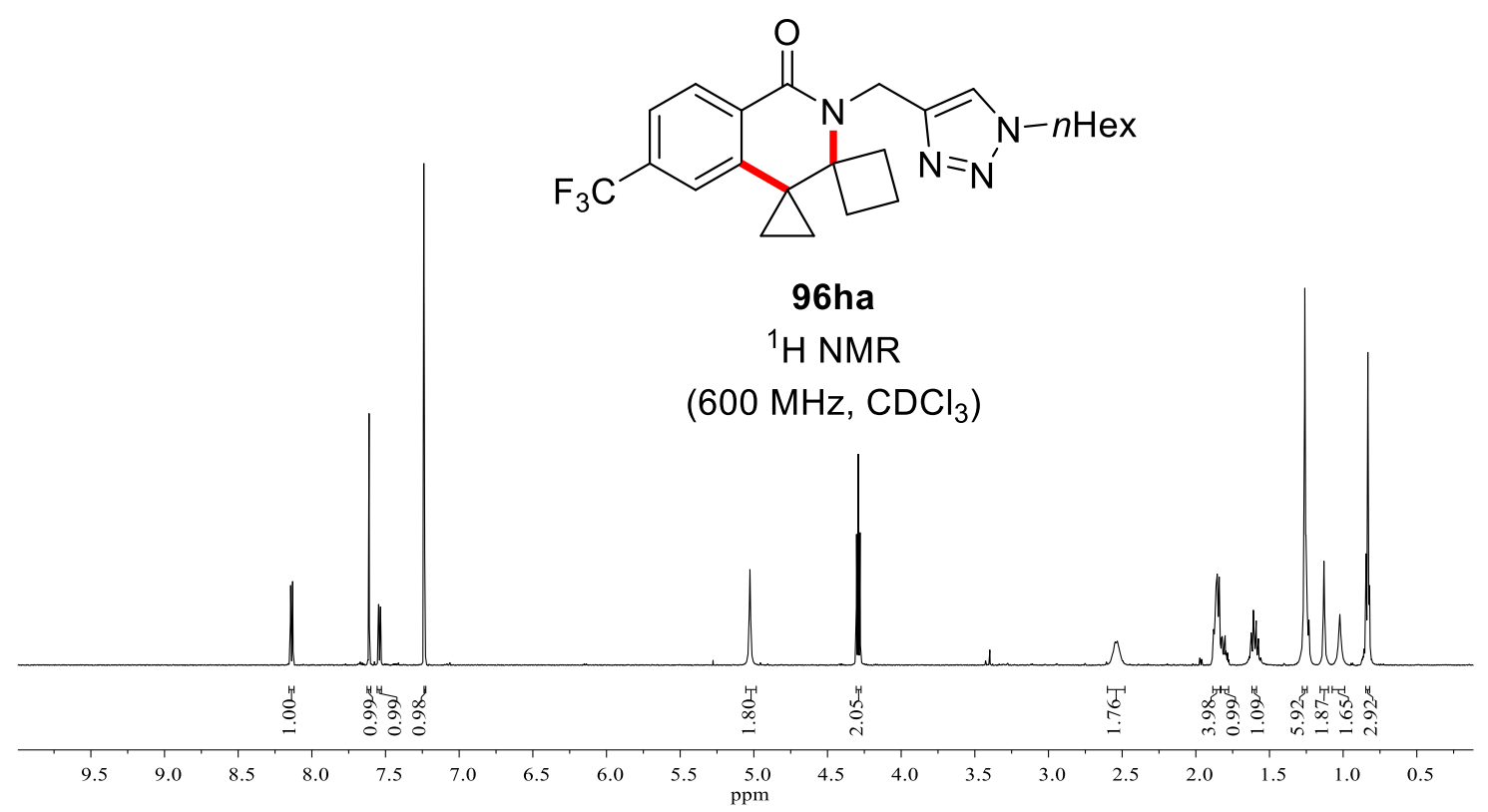<smiles>CCOCn1cc(CN2CC(=O)c3ccc(C(F)(F)F)cc3C3(CC3)C23CCC3)nn1</smiles>

96ha

${ }^{13} \mathrm{C}$ NMR

(151 MHz, $\mathrm{CDCl}_{3}$ )

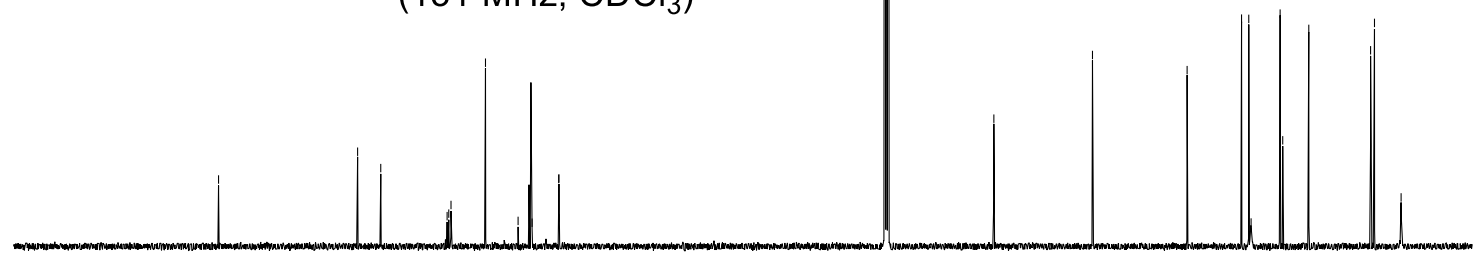

90

$\begin{array}{lllllllll}180 & 170 & 160 & 150 & 140 & 130 & 120 & 110 & 100\end{array}$ 


\section{NMR Spectra}

$a$
$\infty$
$\mathbb{C}$
1<smiles>[R4]Cn1cc(CN2C(=O)c3ccc(C(F)(F)F)cc3C3(CC3)C23CCC3)nn1</smiles>

96ha

${ }^{19} \mathrm{~F}$ NMR

(565 MHz, $\mathrm{CDCl}_{3}$ )

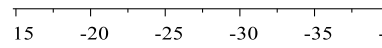

$-60 \quad-65$
$\mathrm{ppm}$ 


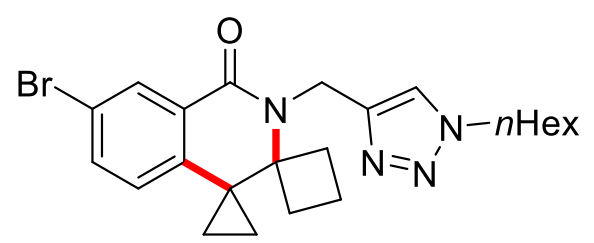

96wa

${ }^{1} \mathrm{H}$ NMR

$\left(500 \mathrm{MHz}, \mathrm{CDCl}_{3}\right)$

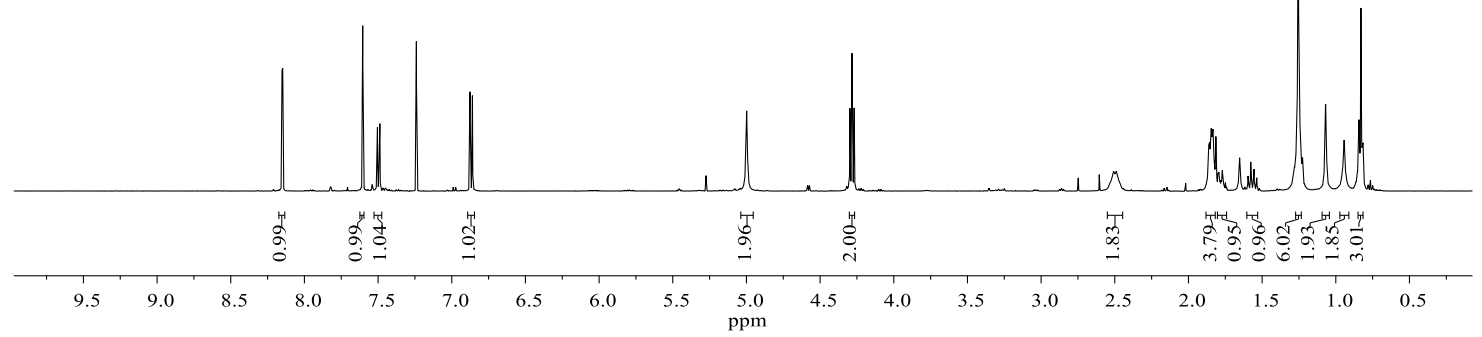

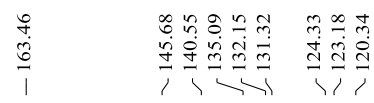

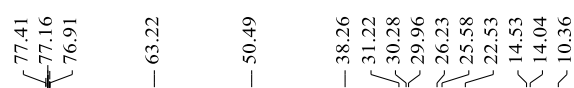

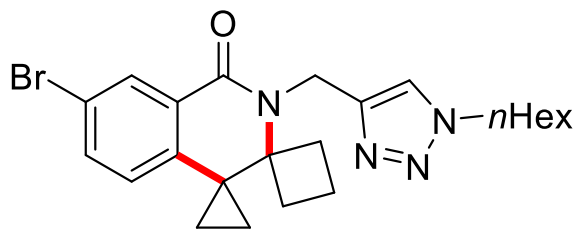

96wa

${ }^{13} \mathrm{C}$ NMR

$\left(126 \mathrm{MHz}, \mathrm{CDCl}_{3}\right)$

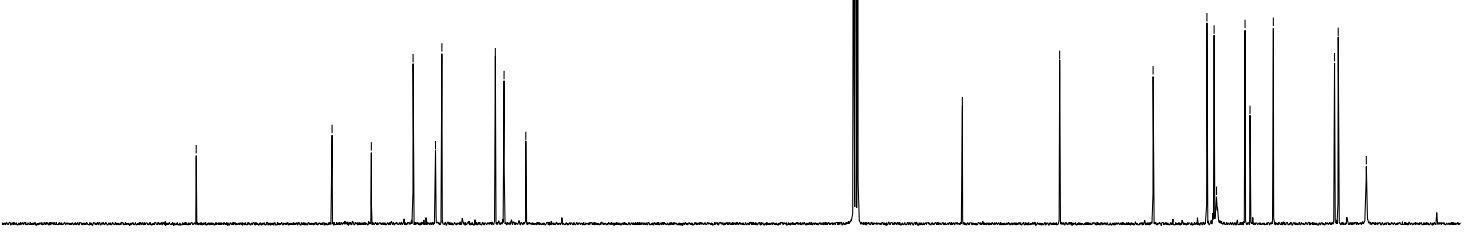

$\begin{array}{lllllllll}180 & 170 & 160 & 150 & 140 & 130 & 120 & 110 & 100\end{array}$ 


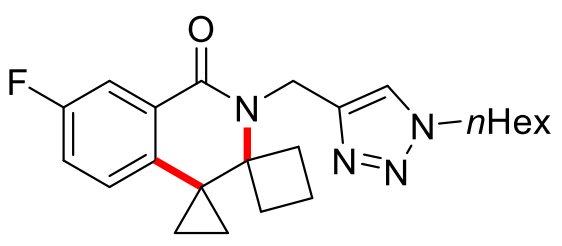

96ua

${ }^{13} \mathrm{H}$ NMR

(400 MHz, $\mathrm{CDCl}_{3}$ )

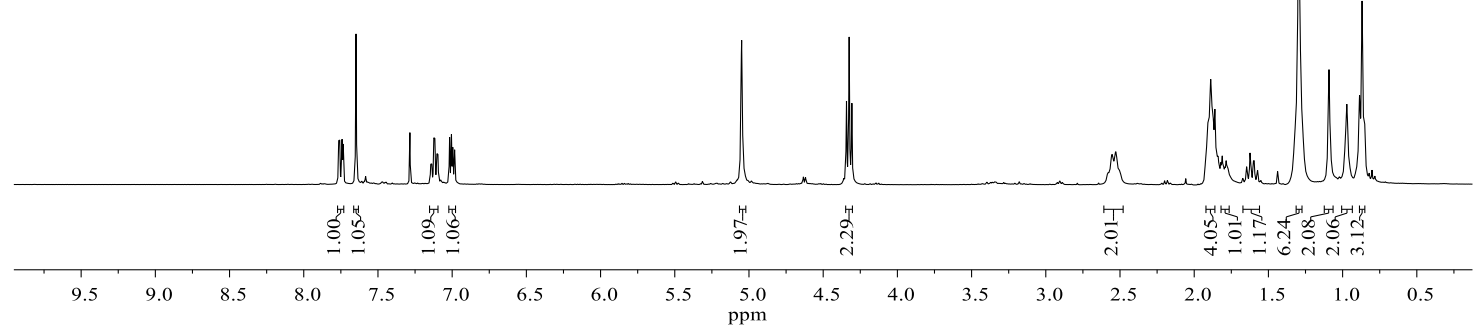

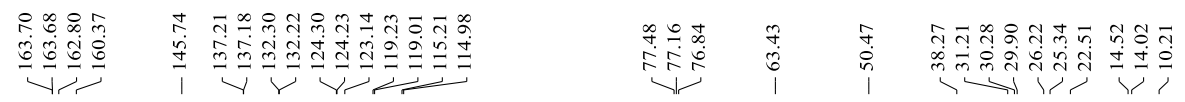<smiles>[R4]Cn1cc(CN2C(=O)c3cc(F)ccc3C3(CC3)C23CCC3)nn1</smiles>

96ua

${ }^{13} \mathrm{C}$ NMR

$\left(101 \mathrm{MHz}, \mathrm{CDCl}_{3}\right.$ )

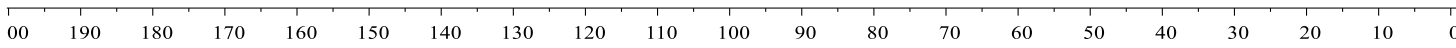




\section{NMR Spectra}

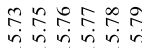 \\ 7777}<smiles>[R10]Cn1cc(CN2C(=O)c3cc(F)ccc3C3(CC3)C23CCC3)nn1</smiles>

96ua

${ }^{19} \mathrm{~F}$ NMR

(377 MHz, $\mathrm{CDCl}_{3}$ )

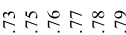

政气

iji 


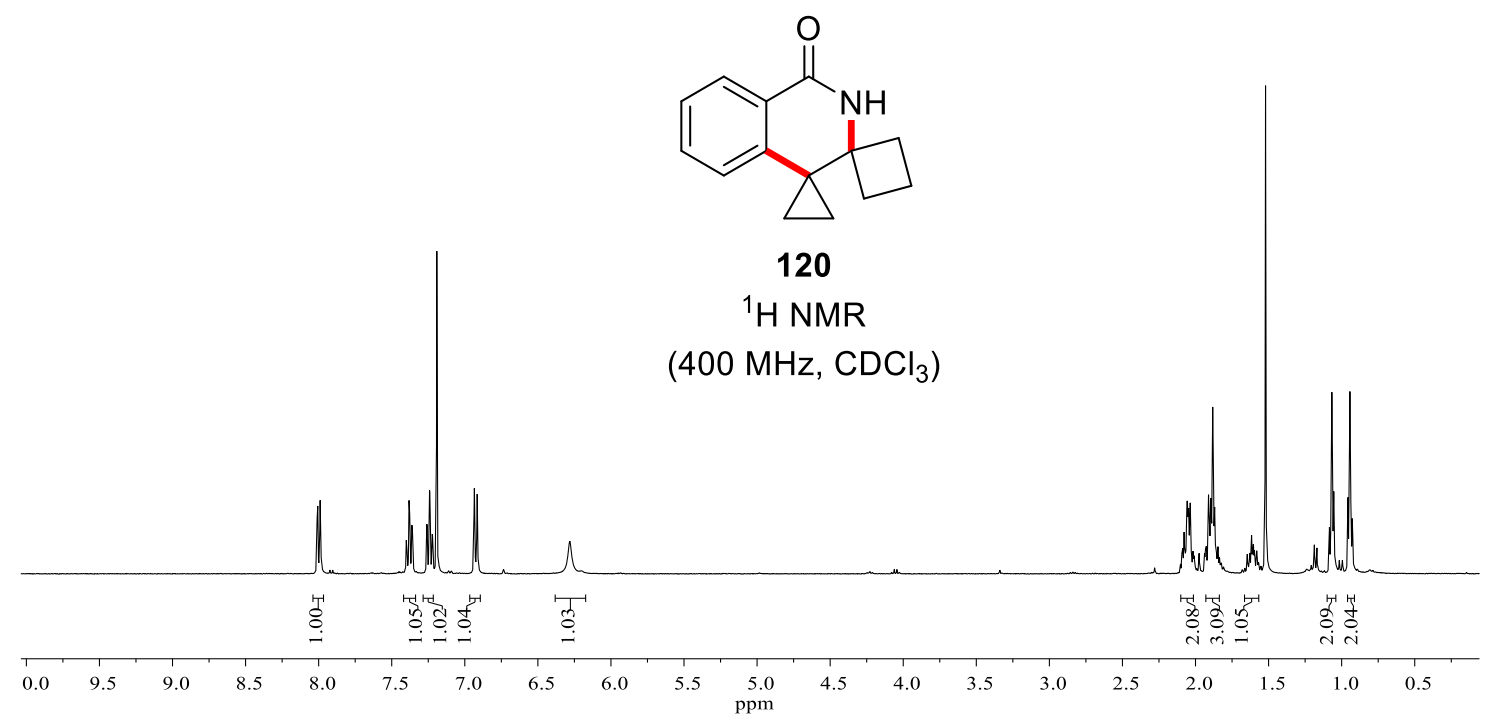

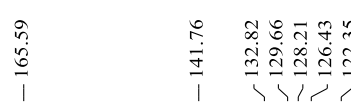

\begin{tabular}{|c|c|c|c|c|}
\hline 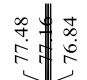 & $\begin{array}{l}\text { N̦ } \\
\text { in }\end{array}$ & 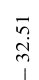 & $\begin{array}{l}+ \\
\dot{y} \\
\text { ì }\end{array}$ & $\begin{array}{ll}0 & n \\
\infty & n \\
m & 0 \\
1 & 0\end{array}$ \\
\hline
\end{tabular}

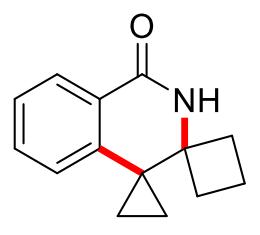

120

${ }^{13} \mathrm{C}$ NMR

$\left(101 \mathrm{MHz}, \mathrm{CDCl}_{3}\right)$

$\begin{array}{lllllllllll}00 & 190 & 180 & 170 & 160 & 150 & 140 & 130 & 120 & 110 & 100\end{array}$ 


\section{Erklärung}

Ich versichere, dass ich die vorliegende Dissertation in dem Zeitraum von Oktober 2016 bis Oktober 2020 am Institut für Organische und Biomolekulare Chemie der Georg-August-Universität Göttingen

auf Anregung und unter Anleitung von

\section{Herrn Prof. Dr. Lutz Ackermann}

selbstständig durchgeführt und keine anderen als die angegebenen Hilfsmittel und Quellen verwendet habe.

Göttingen, den 05.11.2020 